

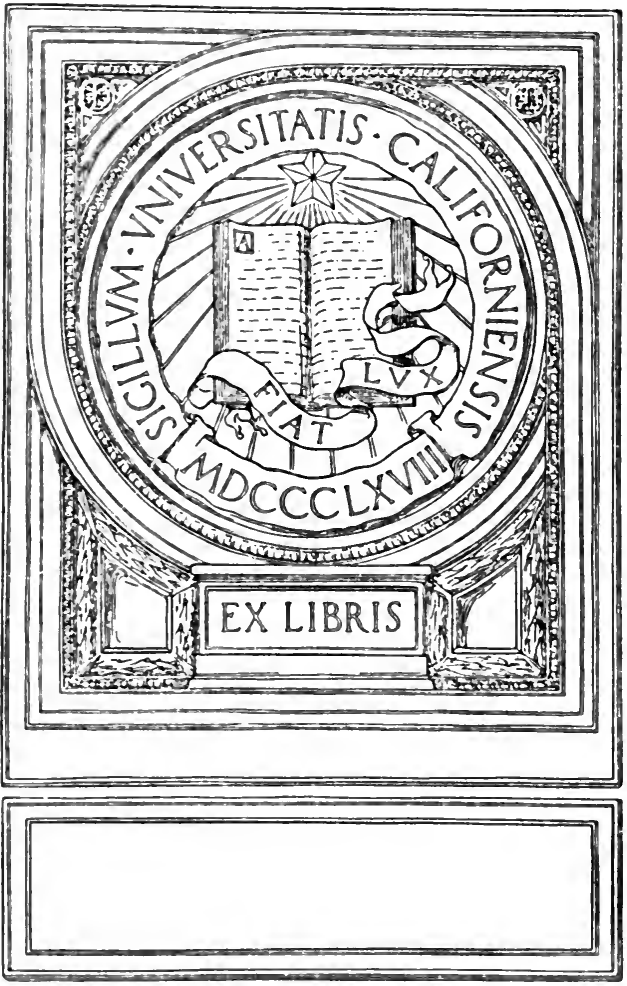






\section{Digitized by the Internet Archive in 2007 with funding from Microsoft Corporation}





\title{
. OUTLINES
}

\section{OF}

\section{ANCIENT HISTORY。}

\author{
FOR THE USE OF
}

HIGH. SCHOOLS AND ACADEMIES

BY

WILLIAM C. MOREY, Pн.D., D.C.L. PROFESSOR OF History AND POLITICAL SCIENCE, UNIVERSity OF ROCHESTER

AUTHOR OF "OUTLINES OF ROMAN HISTORY," "OUTLINES OF ROMAN LAW,"

"OUTLINES OF GREEK HISTORY," ETC.

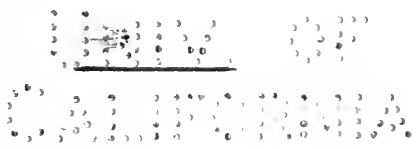

NEW YORK • : • CINCINNATI • : CHICAGO 


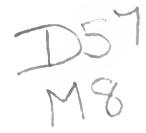

Copyrigrt, 1906, вy

WILLIAM C. MOIEY

ANCIENT HIBTORY

W. P. 3

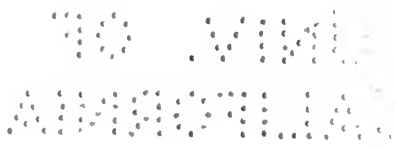




\section{PREFACE}

THIs book has been prepared to meet the wants of those teachers who have expressed the desire for a text-book of ancient history in a single volume, constructed on the plan of the author's "Outlines of Greek History" and "Outlines of Roman History." Such a text-book, of course, requires something more than the mere bringing together of separate accounts of the different countries of the old world. It should be so arranged as to indicate the historical relation of these countries to one another, and the contributions which each has made to the progress of mankind. The significance of each country should be estimated by the permanent elements of its civilization, or those elements which have survived after the nation has passed away. The purpose of this book is, therefore, not simply to describe the growth of separate countries, but to indicate in a general way the continuity of ancient history. The subject-matter contained in the author's previous volumes has been used so far as it is available for this purpose.

The usual division of ancient history into Oriental, Greek, and Roman, has been followed not only as the most convenient arrangement, but as affording the means to illustrate in a satisfactory way the progressive stages in the growth of ancient civilization. The Oriental countries are described to show the beginnings of man's industrial life and the initial stages in the development of government, literature, art, science, and religion. The Greek world is viewed as the historical field especially distinguished for the growth of political liberty and the development of a high intellectual and æsthetic culture. In describing the Roman world, the attempt has been made to keep clearly in view that which has given to Rome its distinctive place in the world's history-the genius for organization, 
the growtn of an imperial dominion, and the development of a universal system of government and law.

It has been especially the desire of the author to reduce history to the simplest terms consistent with the importance of the subject-matter. But it has also been his desire to develop in the pupil's mind a scientific spirit, not only by emphasizing the continuity of history, but by indicating the relation of special facts to general movements, and the relation of these general movements to the growth of the national character and institutions, as well as the relation of each nation's career to the general progress of mankind. Irrelevant matter has been excluded; and facts have been selected and arranged with reference to their historical significance. The attention of the teacher is called to the "Progressive Maps," which are intended to indicate in outline the most important changes in the geographical history of the ancient world. Each chapter is followed by a "Synopsis for Review" which presents at a glance the order of the general and special topics treated in the text. This is followed by a list of "References for Reading." The attempt has been made not to collate an extensive bibliography, which can be of little practical value to the ordinary pupil, but rather to direct attention to certain chapters-with their exact titles-in books which are readily accessible. The classified list of books in the Appendix will give to the teacher and advanced student further bibliographical aid.

W. C. M.

UNIVERSITY OF ROCHESTER,

Rochester, N. Y. 


\section{CONTEN'TS}

I. Introduction-General Character of Ancient History . 7

\section{THE ORIEN'TAL WORLD}

II. The First Empires-Early Babylonia and Egypt 19

III. The Syrian States-Phœnicia and Judea _ . . 41

IV. The New Semitic Empires-Assyria and Later Babylonia 51

V. The Aryan Empires-Media and Persia . . . . 61

\section{THE GREEK WORLD}

Period I. The Beginnings of Greece (-776 B. c.)

VI. Greece, its People and Early Legends . . . . 75

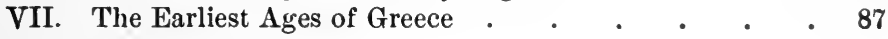

Period II. Development of the Greek City States (776-500 B. c.)

VIII. Political Growth and Expansion of Greece . . 102

IX. The Typical City States-Sparta and Athens . 114

X. The Beginnings of Hellenic Culture $\quad$ • $\quad$ • $\quad$ • $\quad$. 129

Period III. The Athenian Ascendency; its Growth ANd Decline (500-359 B. C.)

XI. The Persian Wars-Growing Power of Athens . . 143

XII. The Athenian Empire; Age of Pericles . • . $\quad$. 160

XIII. The Struggles for Supremacy in Greece . . . . 178

XIV. The Attic Period of Hellenic Culture . . . . 197

PERIOD IV. 'The Union of Greece and the Orient (359-146 в. C.)

XV. Macedonia and the Empire of Alexander . . . 225

XVI. The New Græco-Oriental, or Hellenistic, Culture . . 245 


\section{THE ROMAN WORLD}

PERIOD I. Beginnings of the Roman State (753-343 B. C.)

CHAPTER

XVII. Italy and the Traditional Origin of Rome . .

XVIII. The Early City State-Regal Rome . . . . 271

XIX. The Development of the Republican Constitution . 286

Period II. The Expansion of the Roman Republic (343-133 B. c.)

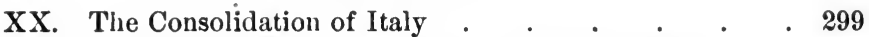

XXI. The Struggles with Carthage : the Punic Wars . . 315

XXII. The Conquest of the Mediterranean Lands . • . 332

XXIII. Rome as a World Power . . . . . . 344

Period III. Transition from the Republic to the EMPIRE (133-31 B. C.)

XXIV. The Revolution under the Gracchi . 354

XXV. The Leadership of Marius and Sulla . . . . . 364

XXVI. The Growth of Imperialism-Pompey and Cæsar $\quad$. 375

XXVII. The Last Struggle for the Empire--Antony and Octavius . . . . . . . . . . 393

PERIOD IV. The Roman World under the Empire (31 B. C. -395 A. D.)

XXVIII. The Empire under Augustus _ . . . . 407

XXIX. The Development of the Early Empire . . . 4419

XXX. The Later Empire of Diocletian and Constantine $\quad 455$

XXXI. Distinctive Features of the Roman Empire . . $\quad 470$

PERIOD V. The Dissolution of the Roman Empike (395-800 A. D.)

XXXII. The German Occupation of the West . . . 482

XXXIII. The Roman Empire in the East . . . . . 498

XXXIV. The Growth of the Carolingian Empire . . . 508

Appendix - A Classified List of Books on Ancient History . . 525

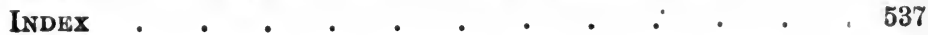




\section{A NCIENT HISTORY}

\section{CHAP'TER I}

\section{INTRODUCTION-GENERAL CHARACTER OF ANCIENT HISTORY}

\section{OF History in General}

Meaning of History.-We may perhaps define history in the briefest way by saying that it is the record of human progress. The study of history enables us to see how the world in which we live to-day has come to be what it is. By this study we learn that the ideas, the customs, and the institutions which we possess in the present, have grown out of what men already possessed in the past. Hence we study the ages which have gone before us, in order that we may understand the age in which we live. It has been said that "to know what man is we must know what man has been." History, therefore, in the broadest sense of the word, deals with the progress of mankind-the successive stages of human development. We must not think that it is chiefly a story of wars and battles; it is rather a record of the steps by which men have advanced from barbarism to eivilization-by which they have been raised from a lower to a higher plane of existence.

Sources of Historical Knowledge.-As we begin our study of history, we may ask the question, How can we know the past-how can we find out anything about the men who lived ages ago? We may perhaps best answer this question by first 
asking a simpler one. How, for example, do we know anything about our own ancestors, whom no person now living has ever seen? In the first place, we may have heard stories about them, which have been handed down from generation to generation. In the next place, we may have pictures or heirlooms or other relics which they once possessed and which reveal sumething regarding their looks, their tastes, and their character. Finally, we may have in our possession letters or other documents which they themselves have written, or which others have written about them. By such means we are able to learn something about the persons who have lived in the past and whom we have never seen. It is in fact by methods quite similar to these that we get our knowledge of the past ages of mankind. We may in a similar way group the sources of our historical knowledge as follows:

(1) Oral traditions, or stories, myths, folklore, and legends which have been handed down from generation to generation. These are valuable as evidences of what people have believed; although we cannot place much reliance upon them as evidence of what has really happened.

(2) Material remains, or relics of the past, such as stone and metal weapons and other implements, buildings, sculptures, vases, coins, and other works of art which bear the impress of the character of the people that produced them.

(3) Written records, such as inscriptions, manuscripts, and books, written either by those living at the time of the events described. or by those living at a later period but having knowledge of such events.

Stages of Human Progress.-From the study of such sources it has been found that mankind has passed through various stages of development-from savagery to barbarism, and from barbarism to civilization. Our knowledge of the earliest stage of human progress is derived somewhat from traditions, but more largely from material relics. These reveal a very primitive condition, in which men evidently lived in caves or in the 
shelter of rocks and trees; in which they obtained their food by hunting and fishing, and made their implements from rough or polished stone. This primitive stage has been called the Age of Savagery, or the Age of Stone.

The discovery and use of the metals-such as copper, tin, silver, gold, and iron-mark a higher stage of progress. Now men began to show greater mechanical skill, to manufacture many new articles, both for use and for ornament, which added to their comfort and happiness. They began to live in artificial dwellings, such as tents and hovels of wood or clay, and to obtain their living by the domestication of animals and the
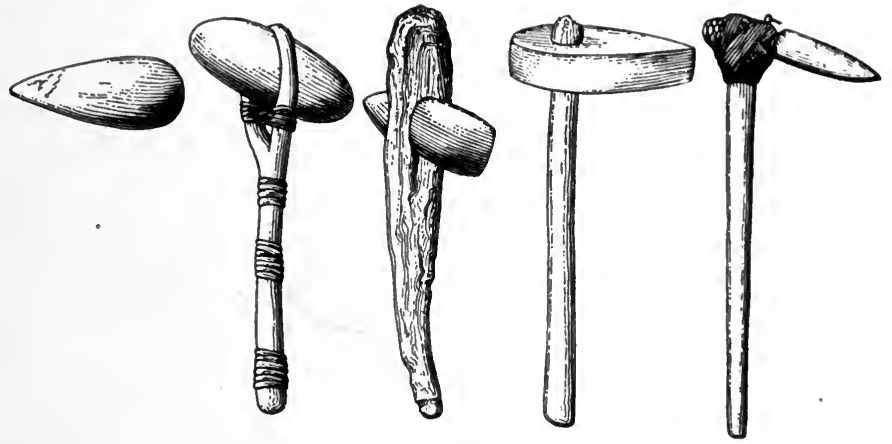

EARLY STONE IMPLEMENTS

cultivation of the soil. This stage has been called the Age of Barbarism, or the Age of Metals-including the Bronze Age and the Iron Age.

The use of a well-defined written language may be said to mark the dawn of civilization. From this time men have gradually advanced in industry and commerce. in the arts and sciences, in language and literature, in government and laws, and in all those things which belong to the higher physical, intellectual, and social life.

Divisions of General History.-In studying the facts and movements of history, it is customary to arrange them in cer- 
PROGIRFSSIVF MAP No.1.

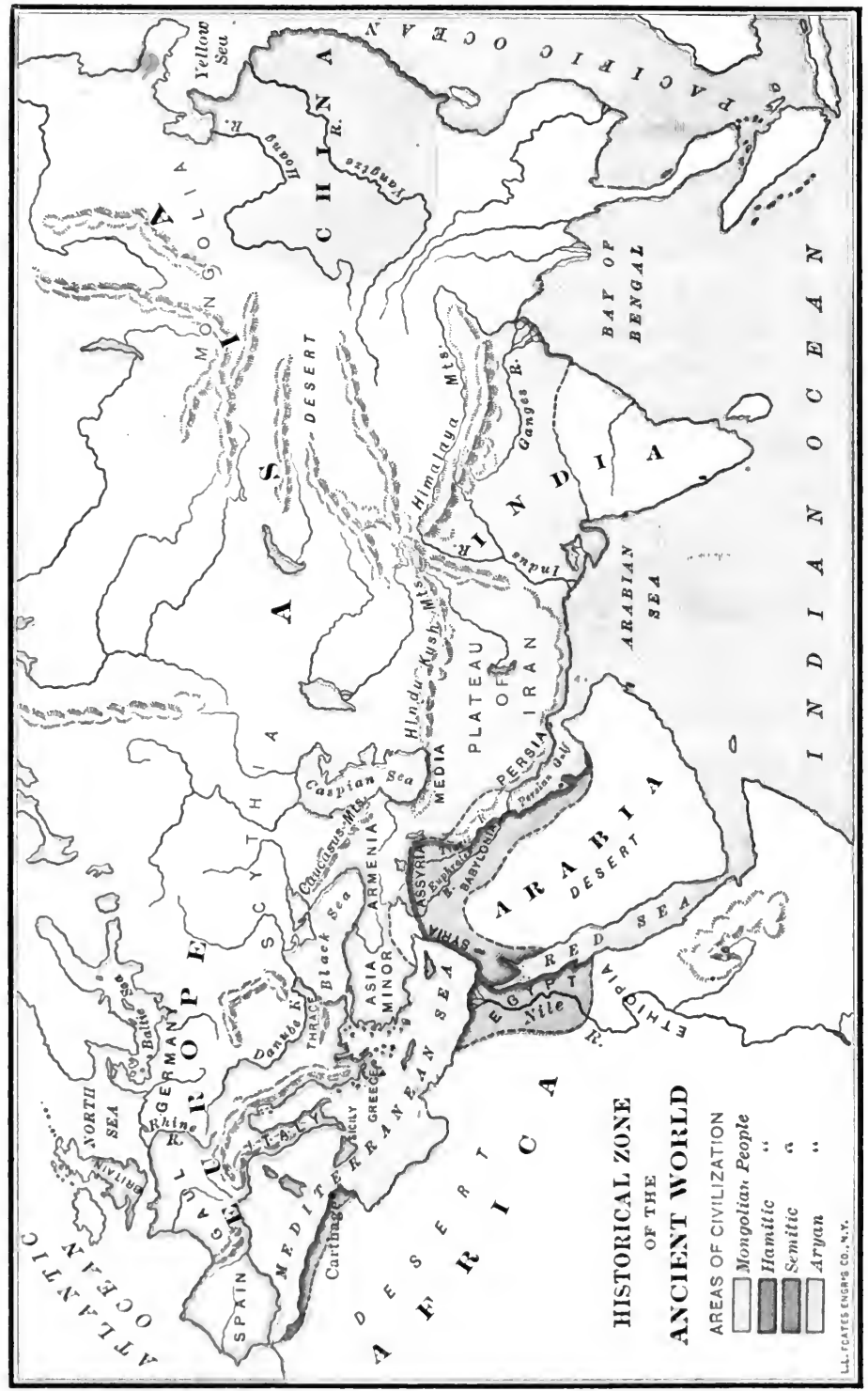


tain divisions or periods. This is well enough, if we do not suppose that there is any sharp dividing line which separates one period from another. In spite of revolutions and the rise and fall of nations, the course of history has been continuous. The "periods" of history are not separated by gaps or breaks, but rather are successive phases of development merging gradually one into another. Bearing this in mind, we may first arrange the general history of the world into two great divisions-ancient and modern. Ancient history begins with the dawn of civilization, and traces the progress of mankind among those nations which have now ceased to exist-or at least have ceased to contribute anything to the world's progress. Modern history, on the other hand, deals with the origin and growth of those nations which still exist and are still working out the problems of a higher world life. ${ }^{1}$

In making this division between ancient and modern history we must remember that these two great periods of history are closely related to each other. Indeed, the great interest which we have in ancient history is due to the fact that a large part of our present ideas, customs, and institutions have descended to us from the peoples who flourished in ancient times.

\section{The Field of Ancient History}

Geography and History.-It is a fact familiar to us all that men are influenced to a large extent by their surroundings-that is, by the localities in which they are placed. One of the conditions, therefore, of human progress is a favorable environment. Hence the study of geography is closely related to the study of history. We know, for example, that men are greatly affected by the climate in which they live. Too much

1 The term "mediæval history," or the "middle ages," is often applied to the formative period of modern nations, extending from the fall of the Western Roman Empire in the fifth century, or from the establishment of the Empire of Charlemagne in the eighth century, down to the fifteentil or the sixteenth century, 
heat, or too much cold, tends to weaken or benumb their powers. A temperate climate is most favorable to progress. Moreover, men are most likely to advance in those places where they can obtain the best means of living-where the soil is most fertile, and where the earth furnishes the largest amount of natural resources, and also where peoples can most easily exchange their products with one another by land or by water routes.

On the other hand, the progress of man may be obstructed by unfavorable surroundings. A barren soil tends to keep men in poverty and misery. Mountain barriers often hem them in and narrow their lives. And so in the early periods of history, especially, man is largely the creature of his environment. But with the growth of a higher civilization he may rise above nature, and become to a certain extent its master.

The Historical Zone of the Ancient World.-It is in the old World that we find the first traces of civilization; and the field of ancient history comprises those parts of Africa, Asia, and Europe that have temperate climates and are drained by great rivers or border upon the sea. To bring more clearly before our minds the geographical limits of ancient history, let us mark out on the map that strip of territory which was hest fitted for human progress and upon which the old civilizations flourished. This strip we may call " the historical zone of the ancient world" (see colored portions of the map on page 10). Beginning at the Yellow Sea on the coast of China, let us follow along the line of the Hoang River, then westward along the mountain chains of the Hima'layas, the Hindu-Kush, and the Cau'casus, and finally along the banks of the Danube and the Rhine rivers to the North Sea-and the line thus traced will mark the northern boundary of this historical zone. Its southern boundaries are, in general, the shores of the Indian Ocean and the deserts of Arabia and Africa. The lands within this zone, in respect to climate and soil. present the conditions most favorable for human development; and 
they became in ancient times the homes of civilized peoples. These peoples, however, were not equally progressive, and they did not reach the civilized stage at the same time.

The Centers of Ancient Civilization.-This strip of territory, stretching from the Pacific to the Atlantic, we may separate into different areas, which formed to a certain extent distinct centers of civilization. Farthest to the east is China, drained by two great rivers, the Hoang and the Yangtze. Its remote situation and the barriers on the west formed by the spurs of the Himalayas, combined to make this land the most isolated of the civilized lands of the Old World. To the west of China lies India, also drained by two great rivers, the Indus and the Ganges, which rise among the slopes of the Himalayas and flow in different directions to the sea. These two countries-China and India_stood nearly alone in ancient times, separated from the peoples of western Asia by the wide, dry plateau of Iran', and hence these countries did not exercise a great influence upon the ancient world.

As we leave the Far East and pass to the West we come to two of the most remarkable valleys of the world-that formed by the Tigris and Euphra'tes rivers and that formed by the river Nile- the one pouring its waters into the Persian Gulf and the other into the Mediterranean Sea. Both of these valleys were gifted with a rich alluvial soil, which favored the early development of industry among the inhabitants. These two centers were at first separated from each other by the intervening desert of Arabia, but after a time their inhabitants were brought into contact by way of Syria, so that the currents of their history often flowed together.

But the most important center of ancient civilization was the Mediterranean Sea. This body of water formed the world's greatest highway. It was taken possession of successively by the Phœni'cians, the Greeks, and the Romans, and became an important factor in the development of a wider world commerce and a higher world culture. 


\section{Races and Peoples of the Old World}

Race Characteristics.-The progress of mankind has been influenced not only by geographical conditions; it has also been influenced by the traits and qualities which peoples have inherited from their ancestors. 'The physical and mental peculiarities, the ideas and customs, which are transmitted from age to age, have contributed much to human progress. These inherited qualities we may call "race characteristics."

There have been many attempts to find a scientific distinction among the different races of mankind. They have, for example, been classified according to color, into the white or Caucasian race, the black or Negro race, and the yellow or Mongolian race. They have also been classified according to the shape of the head, the texture of the hair, and other physical features. Science has attempted in this way to discover the pure, or original, races of mankind. But, as a matter of fact, the various peoples of the world have become so intermingled that it is difficult to determine what are the pure, or original, races, and to distinguish them from the mixed, or secondary, races. History deals not simply with the original races, but with the secondary races as well. It looks upon a "race" as any people, whether pure or mixed, having the same inherited characteristics-a common language, common customs and institutions, which are transmitted from generation to generation, and which furnish the basis of a distinct type of civilization.

Classification by Color and Language.-The most usual and perhaps convenient way of classifying the various peoples of the world is to group them first by color. Thus we have (1) the black or Negro race, (2.) the yellow or Mongolian race, and (3) the white or Caucasian race. The black race, which is found chiefly in Africa. in Australia. and in the neighboring islands, stands lowest in the scale of human beings and 
has made no real contributions to the civilization of the world. The yellow or Mongolian race, which has occupied the central and eastern parts of Asia, has made some advance in the arts of civilized life. But it early became stationary and its contributions to human progress have been few. Of this race the most important in ancient times were the Chinese. The most progressive peoples of the world have belonged to the white or Caucasian race. These peoples in ancient times occupied the most farored lands of the Old World-the valleys of the Euphrates and the Nile, and the coasts of the Mediterranean Sea. Ancient history is, for the most part, the record of the progress of these peoples.

When we attempt to arrange the Caucasian peoples into distinet groups, we find it difficult, because they came into contact with one another and were often intermingled, so as to form mixed or secondary races. It is, therefore, usual to group these peoples, not according to their physical characteristics, but according to their language. The study of language, or philology, thus becomes an aid to the study of history. Peoples who speak the same language, although they may be "mixed," are closely related to one another in their culture and their historical development. By the study of their different languages, we are able to group the white peoples in subdivisions which are not only convenient but also useful for historical purposes. The Caucasian race is thus subdivided into the Hamit'ic, the Semit'ic, and the Ar'yan or Indo-European peoples-or "races," as they are sometimes called.

The Hamitic Race.-In early times, the Ham'ites probably occupied all the northern coasts of Africa. But it was only in Egypt, on the fertile banks of the Nile, that they found the conditions most favorable to their development. In this restricted habitat they put to the highest use the resources of nature and attained to a high place among the nations of antiquity. 
The Semitic Peoples.-The original home of the Sem'ites was probably in Arabia. This remarkable race furnished some of the most important historical peoples of the ancient world. The Babylonians and the Assyrians settled in the TigrisEuphrates valley; and the Hebrews and the Phœnicians found a home on the eastern shores of the Mediterranean. From the Phœnicians sprang the Carthaginians, who founded a commercial empire on the northern coasts of Africa. In later times, the Arabians built up a great Mohammedan empire, which covered the western part of Asia and the northern part of Africa and encroached upon the southern countries of Europe.

The Aryan or Indo-European Peoples.-The people that carried ancient civilization to its highest stage were the Aryans, or Indo-Europeans. Where was the original home of this people is a matter of doubt-perhaps in central Asia, but quite as likely somewhere in Europe. In ancient times they spread to the east and to the west until they extended from the Ganges River to the Atlantic Ocean. In their progress they mingled with other peoples whom they conquered and absorbed. But wherever they went they preserved the marks of their common language and of their common primitive culture. To this people belong the Hindus of India, the Medes and Persians of central Asia, and the Greeks and the Romans of southern Europe. The Indo-European peoples also include the Slavs, the Germans, and the Celts of northern and western Europe, whose history, however, is not so important in the ancient period. ${ }^{1}$

Phases of Ancient Culture.-We have thus pointed out the various lands in the ancient world most favorable to progress, and the chief races and peoples which occupied these lands. Now, as we look over the development of these various peoples, we may distinguish three great types or phases of civilization,

${ }^{1}$ We must not suppose that all the Indo-European, or Aryan-speaking, peoples have descended from the same stock-an opinion once held, but now disproved by recent Investigations. It must be kept in mind that identity of language does not necessarily involve identity of race. 
namely, the Oriental, the Greek, and the Roman. ${ }^{1}$ By studying these phases of ancient culture, we shall see the successive steps by which men emerged from barbarism and entered upon a higher physical and intellectual existence.

In the Oriental world we shall see the beginnings of civilized life - the first successful efforts of man to subdue the earth and to utilize the resources of nature; the beginnings of science and of a well-defined written language; the first evidences of architectural skill in the construction of great buildings; and the first marked tendency in the direction of great empires and of centralized governments.

In the Greek world we shall see a finer type of humanity: a versatile intellect, expressed in exalted works of philosophy and literature; a refined rsthetic taste, embodied in the most beautiful specimens of architecture and sculpture; and a strong love of freedom, shown in the development of democratic institutions.

In the Roman world we shall see a more practical genius and a more vigorous manhood; a great capacity for military and political organization; a broad sense of civil justice, expressed in an enduring system of law; a wide cosmopolitan spirit, capable of appropriating the ideas of other peoples-in short, a civilization which expressed the highest unity and broadest culture of the ancient world.

\section{SYNOPSIS FOR REVIEW}

I. OF History in General.-Meaning of History.-Sources of Historical Knowledge.-Stages of Human Progress.-Divisions of General History.

II. The Field of Ancient History.-Geography and History.The Historical Zone of the Ancient World.-The Centers of Ancient Civilization.

1 These successive phases of civilization furnish the basis of our divisions of ancient history. Other divisions, however, might be adopted. For example, since the earliest civilization was developed by the Oriental nations, and this was taken up by the classical nations of Greece and Rome, whose culture was afterward transmitted to the German peoples, we might divide ancient history into the Oriental, classical, and Germanic periods. 
III. Races and Peoples of the Old World.-Race Characteristics.-Classification by Color and Language.-The Hamitic Race.-The Semitic Peoples.-The Aryan or Indo-European Peoples.-Phases of Ancient Culture.

\section{REFERENCES FOR READING}

Fisher, pp. 1-16, "Introduction" (1).

Bourne, Ch. 5, "The Value of History" (3).

Diesterweg, Ch. 1, "Meaning of History"; Ch. 2, "Uses of History" (3).

Ducoudray, Ancient Civilization, Ch. 1, "The Beginnings of Civilization" (1).

Hoernes, Sec. 3, "Characteristies of Human Culture" (2).

Tylor, Anthropology, Ch. 1, "Man, Ancient and Modern" (2).

Keary, Ch. 5, "The Nations of the Old World" (2).

Taylor, Ch. 1, "The Aryan Controversy" (2).

Starr, Ch. 3, "Food-Getting" (2).

Joly, Part II., "Primitive Civilization" (2).

Encyclopædia Britannica, Art. "Geography" (for geographical ideas of the ancients).

Rawlinson, Ancient History, pp. 24-35, "The Geography of Asia" (1).

${ }^{1}$ The figure in parenthesis refers to the number of the topic in the Appendix, where a fuller title of the book will be found. 


\section{THE ORIEN'TAL WORLD}

\section{CHAPTER II}

THE FIRST EMPIRES-EARLY BABYLONIA AND EGYPT

\section{The Early Babylonian Empire}

The First Centers of Civilization.-In beginning our study of the Oriental world, we may ask, In what part of the East did men first rise from barbarism to a civilized life-in other words, where did civilization first appear? We cannot answer this question with certainty. We may be quite sure, however, that it was either in Babylonia in the lower Euphrates valley, or in Egypt in the valley of the Nile. It has long been supposed that Egypt was the oldest civilized country. But the most recent excavations have brought to light some indications that the people who lived in the Euphrates valley used a written language and reached a condition which might be called civilized, even before these results were attained by the Egyptians. However this may be, these two valleys - that of the Euphrates and that of the Nile-formed at first two distinct centers of civilization. Separated as they were by an intervening desert, the Egyptian and Babylonian peoples took the first steps in the direction of a more civilized life, each unaided by the other. For a long period of time they were isolated from each other. It was only when they had each broken through their early boundaries and extended their conquests along the 
PROGIRHASIVE MAT NO.?.

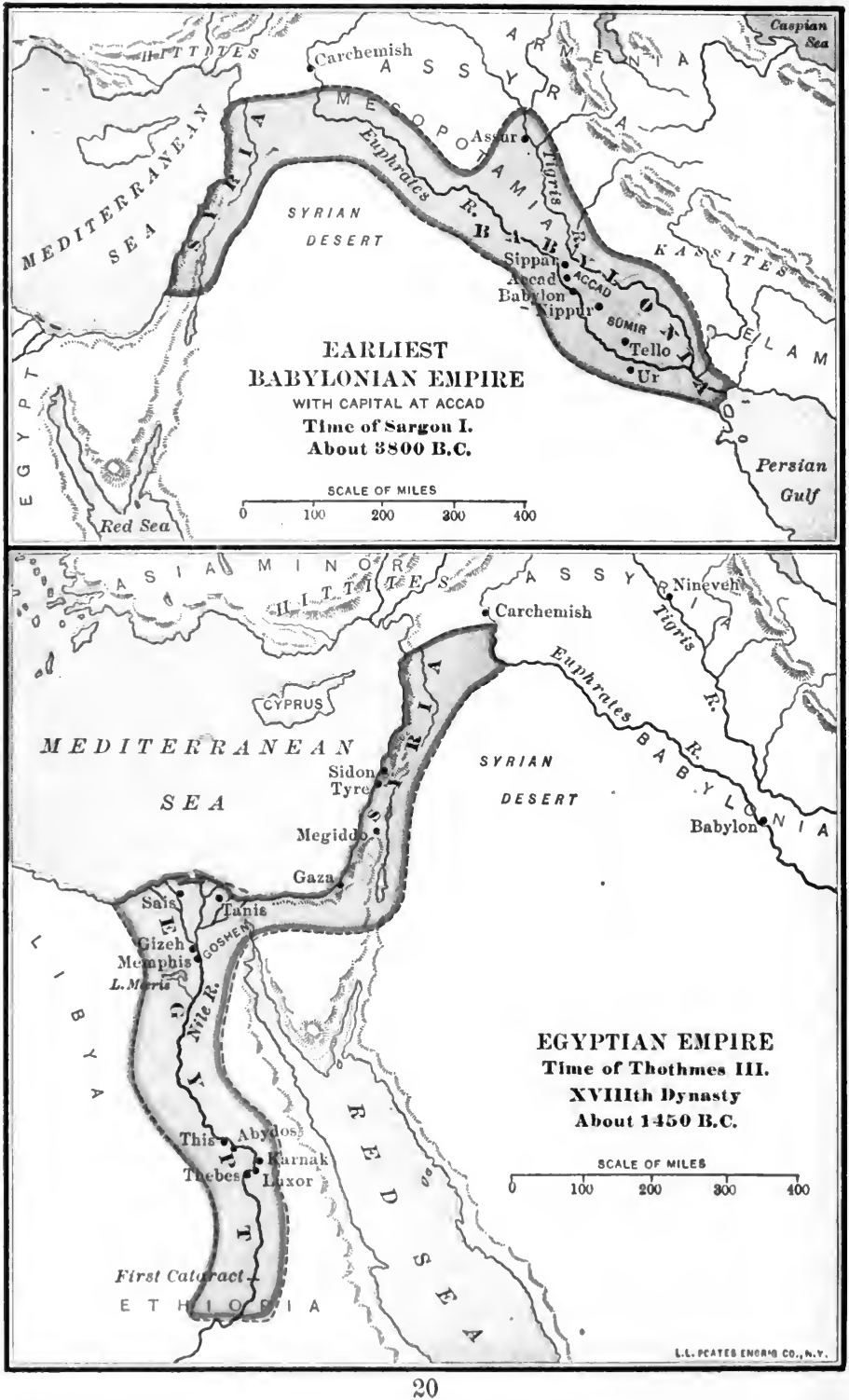


eastern coast of the Mediterranean Sea-that is, in Syriathat their civilizations met and were mingled together. 'The first to extend their conquests to this middle land of Syria were the Babylonians. Whether or not they were the first to emerge from barbarism, the Babylonians, or the peoples of the 'l'igrisEuphrates valley, were the first to extend their culture to lands beyond their own, and to obtain importance as a civilizing people.

The Tigris-Euphrates Valley.-The Tigris and Euphrates rivers, rising in the mountains of Armenia, flow southward and pour their united waters into the Persian Gulf. 'The valley formed by these rivers may be divided into two partsthe southern or the lowlands, and the northern or the highlands. The southern part, which has received the name of Babylonia, has its chief historical center at Bab'ylon on the Euphrates. Its most marked features are its soft climate and its rich alluvial soil. The northern part of the valley, called Assyria, had its chief center first at Assur on the Tigris, and afterward at Nin'eveh on the same river. Its climate was more rugged than that of the south; and its land, though less fertile, furnished large supplies of minerals and precious stones.

It was the people who found their way into the southern part, or the lower valley, that first developed a civilized state. It is probable that this lower valley was in very ancient times settled by an earlier, non-Semitic race-usually known as the Acca'dians - who laid the basis of the Babylonian culture. But the territory became at last the home of a Semitic people, who probably came from Arabia, who conquered and absorbed the earlier peoples, taking up their customs and institutions, and becoming the dominant race. It is this mixed people that we call the Babylonians. The date of the earliest occupation of this country by the Semites cannot be accurately fixed; but it can hardly be later than 5000 B. c.

Not many years ago our knowledge of this ancient people was derived chiefly from the Greek historian Herod'otus and 
the Chaldæ'an priest Bero'sus. The accounts of these writers, so far as the earliest history was concerned, were based upon traditions, which were of course not very trustworthy. In recent years, however, our knowledge has been greatly increased and made more definite by the large number of excavations made among the ruins of ancient cities. The remains of palaces and temples have been brought to light, and inscriptions have been deciphered which show the great antiquity of this people, and reveal much regarding their history, their arts, and their institutions.

The Early City States: Sargon I.-The first light that falls upon the Euphrates valley reveals the existence of many cities of more or less importance, each under its own government and ruled by its own king. ${ }^{1}$ At a very early day the rulers of some of these cities sought to establish something like an imperial government, by bringing other cities under their power. So far as we know the first successful attempt to ereate an empire was made by Sargon I., king of Acead (or Agade), who flourished in 3800 в. c.- the first authentic date, it is said, in the world's history. With Acead as his capital Sargon extended his authority to the upper part of the Mesopotamian valley and. as far west as the Mediterranean Sea. Other cities, like Ur and Babylon, afterward vied with one another in taking the lead. But the early cities of Babylonia finally (about 2300 в. c.) passed under the foreign dominion of the E'lamites-a people who eame from east of the Tigris.

\section{Hammurabi and the Old Babylonian Empire. ${ }^{2}-$ Although} the earliest empire of Babylonia was really established by Sar-

1 A few of these ancient cities were Sippar, Accad, Babylon, Nippur, Tello (ancient Lagash), and Ur (see map, p. 20).

2 The old Babylonian emplre is sometimes called the "Chaldxan," because it arose in the lower valley, near the home of the Chaldrans. But it is quite certain that the Chaldxans (Kaldi) did not appear in Babylonia until after the fall of the old empire, and durlng the time of the Assyrian ascendency. Siee fioodspeed. History of the Babylonians and Assyians, pl. 181, 211, 2:36, 351; also Phllip Smlth, Ancient History of the East, p. 242 . 
gon I., the most prosperous period of what is usually called the "Old Babylonian Empire" began with Hammura'bi, one of the greatest of ancient kings. He not only drove out the Elamites, but he again brought the whole territory under a single rule (about 2250 B. c.). He made the city of Babylon his capital, and labored for the welfare of his people. He constructed dikes to prevent the overflow of the Euphrates, and built a network of canals to irrigate the arid lands. 'The most remarkable monument of this king is the "Code of Hammurabi,". which has been but recently discovered, and is regarded as the oldest code of laws in the world. During this most prosperous period of its history, the early Babylonian empire was not devoted to the arts of war so much as to the arts of peace. The people were more active in subduing nature than in conquering their neighbors; and hence we find that they made great progress in the development of a civilized life.

The Kassite Conquest.-In later years (about $1 \% 00$ в. с.) Babylonia fell under the foreign rule of the Kassites-a barbarous people from the east of the Tigris, of a race kindred to the Elamites. During the long period in which Babylonia was ruled by foreign kings, it is well to notice that the civilization already developed was not destroyed. On the contrary, the Kassites adopted the culture which they found in the Euphrates valley, and became themselves civilized. They took up the customs of the Babylonians, their laws, their religion, their science and arts, and preserved them for future generations.

Babylonian Industry and Art.-The life and progress of the Babylonians were greatly influenced by the country in which they lived. Their civilization was based upon the character of their soil, which was made fertile by the waters of the Euphrates. They were primarily a pastoral and agricultural people, grazing their flocks and herds upon the natural pastures of the valley, or raising by artificial means the grains and fruits necessary for food. They dug canals to irrigate the out- 
lying fields. In the absence of stone and timber they built their houses of clay which became hardened in the sun. They soon learned to manufacture bricks burned in the kiln, from which they constructed their more important buildings. The wool shorn from their flocks they wove into cloths and rugs. As they extended their territory up the valley they obtained

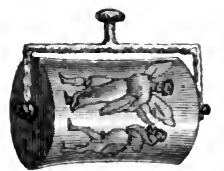

A Cylinder supplies of wood, metals, and precious stones, and from these they wrought new articles for use as well as for ornament. There thus arose a class of traders and merchants, who exchanged the native products of the lower $\mathrm{Eu}$ phrates with the products of other lands. The Babylonians developed remarkable skill in the working of clay and metals, and also in the carving of precious stones-which acquired the character of a fine art. This is seen in their vases of alabaster, of terra-cotta, and of silver, their statuettes of copper and bronze, and especially in their fine intaglio work cut in onyx, jasper, and other precious stones. The intaglio work was often cut upon cylinder seals, which revolved upon a metallic axis and were used to authenticate legal documents.

Babylonian Government and Laws.-The government of Babylonia centered about the king. From the time of the early city kings to the imperial monarchy of Hammurabi we do not find that the people had any share in the government. The king was the source of all authority. He was supposed to derive his authority from the gods. He was the one to determine what was necessary for the welfare of the people. It was under his direction that the wars were earried on, the public works were constructed, the lands were irrigated, the palaces and temples were built, and the laws were administered.

'The character of the Babylonian laws is seen not only in the recently discovered code of Hammurabi, which we have referred to, but also in the legal documents inseribed on brick tablets. These show the rules relating to marriage and divorce, property 
and inheritance, partnership and loans, and also the penalties for theft, assault, housebreaking, and other crimes. The advanced character of these laws is evident from the fact that nearly all business transactions required the use of written contracts.

\section{Babylonian Writing and Litera-} ture.-The writing employed by the Babylonians was peculiar to this part of the Orient. It is what is called "cune'iform," because expressed in wedge-shaped characters (from cuneus, a wedge). The writing took this shape because the only writing material of the lower valley was the clay tablet, and because the instrument used in writing was a three-cornered stylus, a sort of gouge, which made a

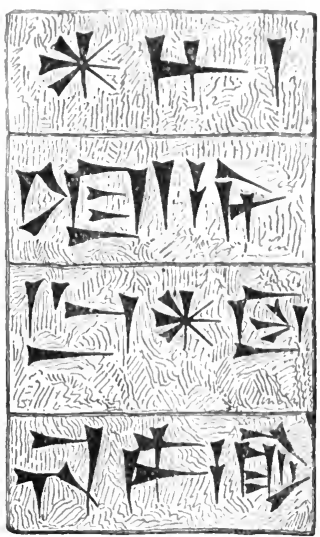

An TAschiption in CUNEIFOKM wedge-shaped mark on the surface of the moistened clay. The cuneiform characters were probably first used by the Accadians; but they were employed by all the peoples of the middle Orient: not only by the Babylonians, but afterward by the Assyrians, and by the Medes and the Persians.

The clay tablets, thus inscribed with cuneiform characters,

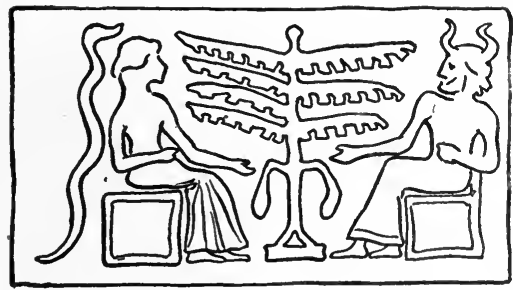

Babylonian Cylinder

(Supposed to represent "The Fall.") were baked in a peculiar way, making them almost indestructible. Thousands of the tablets have been unearthed, revealing the thought and spirit of this ancient people. They contain writings on religion and science, history and law, also hymns, penitential psalms, and epic poems. They show the beliefs of the people in the form of myths and 
legends. Some of these stories bear a striking likeness to the stories preserved in the Hebrew Scriptures-such as the ac-

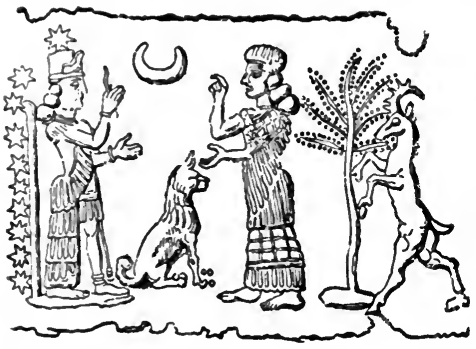

Babyloxian Goddess, Ishtar (From an Assyrian cylinder) counts of the Garden of $\mathrm{Eden}$, the Deluge, the Tower of Babel, and the confusion of tongues.

Babylonian Religion and Science.-The Babylonians were deeply imbued with a religious spirit, tainted with a large amount of superstition. Their religion was a complicated form of nature worship. Their supreme deities were the gods of the heaven, the earth, and the sea (Anu, Bel, and $E a)$. Other objects of worship were the sun, the moon, and the several planets. Ishtar, who corresponded to the planet Venus, was the favorite goddess, and was sometimes called "the Queen of Babylon." The people believed that every object has its spirit, good or evil, and that these spirits can be appeased only by the priests and sorcerers through charms and magic rites. The future life, according to their belief, is in a dark and gloomy abode, without happiness or hope.

As the greater gods were supposed to dwell in the heavens, the temples (which were constructed of brick) were built in the form of towers, with a number of receding stories, reaching toward the sky. Upon the summit of the temple tower was an image of the god to whom the

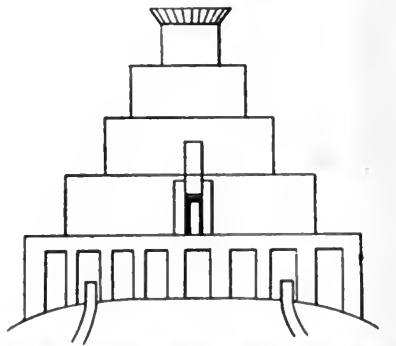

Fonm of the Temple Tower temple was dedicated. The temples were presided over by the priests, who, on account of their supposed nearness to the gods. were able to exercise a great influence over the people. 
The science of the Babylonians was closely connected with their religion. As the gods were supposed to preside over the movement of the heavenly bodies, the position and motion of these bodies were matters of deep concern. From their observations the priests developed a system of astrology, by which it was thought that the will of the gods could be determined and human events could be predicted. As they discovered the regular movement of the heavenly bodies, they acquired some knowledge of astronomical science. They marked out the constellations and the signs of the zodiac. They divided the year into months, weeks, days, hours, minutes, and seconds. They measured the hours of the day by the sundial, and the hours of the night by the water clock. In their mathematics they adopted the decimal notation; but they also introduced the "sexagesimal" system, that is, the system based on the number sixty, which we have inherited from them in our division of the hour and the minute into sixty parts. The accompanying diagram shows the Babylonian numerals from one to ten, expressed in cuneiform characters. Besides acquiring considerable knowledge of mathematics, this people were the first to devise a regular system of weights and measures.

The progress made by the early Babylonians in architecture, science, and the mechanic arts exercised a great influence upon later nations. In- Numerais deed, it would be difficult to overestimate the importance of these early steps in the world's civilization.

\section{Ancient Egrpt}

The Valley of the Nile.-The second great people of the Oriental world were the Egyptians. Although far removed from the Babylonians, and for a long time unacquainted with 
them, the aneient Egyptians were not behind their distant rivals in developing the arts of civilized life. The early progress of Egypt was due to the favorable conditions furnished by the river Nile. What the Euphrates was to Babylonia, the Nile was to Egypt.

The Nile is one of the longest rivers of the world; rising in the distant lakes of central Africa, it pursues a course of about 4000 miles on its way to the sea. But the part of the valley occupied by the Egyptian people extended only about six hundred miles from the mouth of the river-to the rapids called the "first cataract," on the borders of Ethiopia. The valley is inclosed on either side by low ranges of mountains, which furnish stone suitable for building; and it is well to notice that this abundant supply of stone gave to the Egyptians a great advantage over the Babylonians, who were obliged to use the less durable materials, clay and brick, for building. The valley of the Nile is only about seven or eight miles in width-except at the Delta, where it spreads out into an open plain. Not only has this valley been eut by the Nile, but its fertility is due to the annual overflow of the river, for the climate is dry and rain rarely falls. This river is also the great highway of Egypt, affording a ready means of communication from one part of the country to another. The fertile soil of Egypt was especially suitable for the raising of vegetables and grain. Rice. oats, bärley. and wheat grew there in great abundance, so that the country became the granary of the ancient world.

Egypt may be divided into two principal parts. (1) The lower, or northern, part includes the extended plain about the Delta, where the soil is most fertile, and where the earliest civilization was developed. It was here that the first empire was established, with its center at Memphis. (2) The upper, or southern, part includes the rest of the valley as far as the "first cataract." This formed a second area of civilization, with its center at Thelses. In either direction from these two 
centers the banks of the Nile became dotted with a multitude of towns and villages, each one of which was a seat of industry and art.

The People of the Nile.-As to the origin of the Egyptian people we have very little definite knowledge, except that they belonged for the most part to the Hamitic race. It is supposed that in the earliest times-during the Stone Age-the land was inhabited by an uncivilized black people, who were conquered by the Hamites coming from the lands along the southern coasts of the Red Sea, either from eastern Africa or from southwestern Arabia. It is also supposed by some writers that the early Hamites, before coming into Egypt, were acquainted with the primitive culture of the people living in the TigrisEuphrates valley. But whatever may be said regarding the origin of the Egyptian people is very largely a matter of conjecture.

Periods of Egyptian History.-Formerly the chief sources of our knowledge of Egypt were, first, the Greek historians, especially Herodotus, who visited Egypt in the fifth century B. c. ; and, second, the Egyptian priest Man'etho, who lived in the third century B. c., and who wrote a history containing a list of the various dynasties and kings, but whose work has reached us only in fragments. Since the beginning of the nineteenth century, however, a vast amount of additional information regarding Egypt has been derived from the inscriptions which have been deciphered and the monuments which have been brought to light. With these sources many attempts have been made to reconstruct the chronological history of Egypt. But scholars do not yet agree in regard to the dates of the early Egyptian history. The general divisions of Egyptian history and the most important dynasties may be briefly indicated as follows:

(1) The Old Empire (about 4000-2\%00 B. c.) extended from the first dynasty to the tenth inclusive. with the capital at Memphis. 'The founder of the first dynasty was Me'nes, who 
is supposed to be the first monarch to bring the whole country under a single government. During the time of the old empire the most important dynasty was the fourth, when the great pyramids and the sphinx were built at Gizeh, and the vast

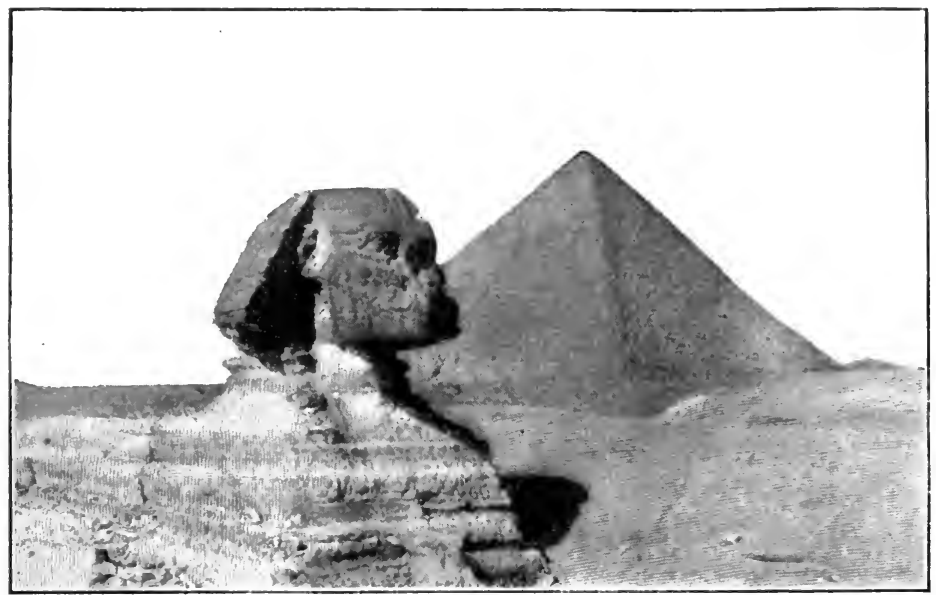

SPHINx and P'yramid at Gizeh

necropolis, or rock cemetery, was laid out at Sakka'rah, near Memphis. The kings of the fourth dynasty are known as the "pyramid builders," the most noted of whom was Khufu (or Cheops).

(2) The Middle Empire (about 2700-16\%0 в. c.) extended from the eleventh to the seventeenth dynasty, with the capital first at Thebes and afterward at Tanis. The most important dynasty was the twelfth, when Egypt reached a high degree of prosperity and many important public works were constructed, like reservoirs and canals for irrigating the lands not reached by the overflow of the Nile. This dynasty was followed by the conquest of Egypt by foreign barbarian kings, called the "Hyksos" or Shepherd Kings, who probably came from Asia. The rule of the shepherd Kings extended from the thirteenth 
to the seventeenth dynasty, and this was the darkest period of Egyptian history.

(3) The New Empire $(16 \% 0-525$ B. c.) extended from the eighteenth to the twenty-sixth dynasty (to the time of the Persian conquest), the capital being again at 'Thebes and afterward at Tanis and Saïs. During the eighteenth dynasty Egypt recovered her independence by driving out the shepherd Kings. Under Thothmes III. she extended her power over Ethiopia and over Syria as far as the Euphrates and the borders of Asia Minor. 'This period marks the greatest extent of the Egyptian empire (map, p. 20). By these conquests Egypt was brought into contact with the culture of the Euphrates valley, and derived from the Babylonians a taste for the finer mechanical arts, for Oriental luxury, and for a more palatial architecture. ${ }^{1}$ During the nineteenth dynasty, under the renowned kings Seti I. and his son Rame'ses II., Egypt reaped the glorious results of her previous conquests and reached the highest stage of her civilization. From this time Egypt began to decline. In the twenty-fifth dynasty she was conquered by the Ethiopians and afterward by the Assyrians. In the twenty-sixth dynasty she recovered her independence under the king Psam-

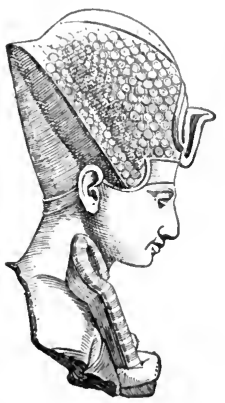

RAMESES II. met'ichus I., but after a century she was finally reduced to the condition of a Persian province.

Egyptian Society and Government.-Egypt, at the dawn of history, had already become a united empire. There is evidence that this first empire, under Menes, had grown

1 The great influence of Babyionia upon Egypt during the eighteenth dynasty is shown in the now famous Tel-el-Amarna Tablets discovered near the Nile in 1887-about three hundred in all, written in Babylonian characters-containing correspondence between the Egyptian king (Amenho'tep IV., the "heretic king") and the kings of Assyria and Babylonia; also letters between Egyptian officials, showing that the Babylonian was the official diplomatic language in Egypt at the time. See Goodspeed, Babjlonians and Assyrians, p. 134. 
up from a union of towns and villages which were previously independent, each under its own ruler and priests. 'These towns became grouped into districts, or " nomes," under local governors; and these in turn were gradually brought under the common authority of a king who ruled over the whole country. The people were not equal, but were divided into classes. The upper classes included the priests, whose office was hereditary, and the warriors, who were devoted exclusively to military pursuits. The lower classes comprised the common people, including the artisans, the farmers, and the herdsmen. The land was generally owned by the upper classes, and let out to the peasants, who paid their rent in the products of the soil. Above all these classes was the king, or Pha'raoh. who was looked upon as a divine person. He was the fountain of all authority; and the labor, the property, and the lives of the people were at his disposal. The king was assisted in his government by a body of councilors, who carried out his will. The highest offices of the state were held by the priests, who were exempted from all taxes and held the best parts of the

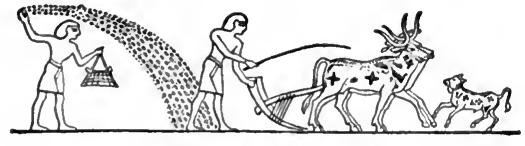

Egyptans Sowixg

land. The government was supported by the army, or warrior class, which was also exempt from taxes and held large landed estates. The great body of government officials preyed upon the common people, who were obliged to furnish their tribute and labor. The government of such a body of taxgatherers and taskmasters necessarily became corrupt and oppressive. We read of workmen, goaded by tyrannical masters, rising in revolt in the manner of a modern "strike" and refusing to continue their work. Sometimes their tasks were lightened, but quite as often they were made more heavy-as in the case of the Israelites in the time of Moses.

Egyptian Industry and Industrial Arts.-The Egyptians, like the Babylonians, were first of all an agricultural people. 
For regulating and distributing the water supply of the Nile they built canals and reservoirs. The most remarkable of these artificial reservoirs was Lake Mœris, by which a large outlying district was transformed from a desert waste into fertile fields. After their contact with the Babylo-

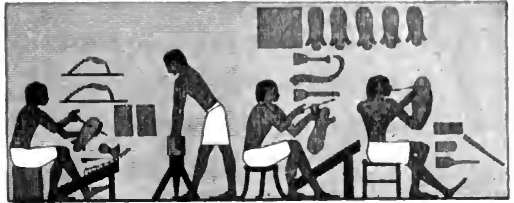

GGYP'TIAN SHOEMAKER's SHOP nians, the Egyptians acquired great skill in the industrial arts, working in clay, stone, and glass; in wood, ivory, leather, and the textile fabrics; in the coarser metals bronze, lead, and iron; and in the precious metals gold and silver. They exchanged these products with one another, by boats plying the waters of the Nile, which became an artery of commerce. Their commerce with foreign countries, however, was small.

Egyptian Religion and Science.-The religion of Egypt was a strange mixture of various kinds of worship. The lowest

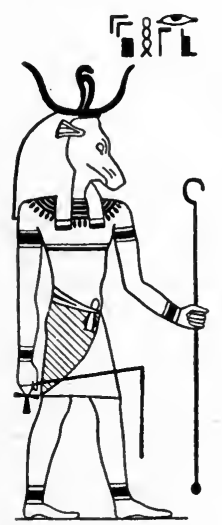

SERAPIS form of religion was animal worship, such as was prevalent among the primitive tribes of Africa. The crocodile, the serpent, the hawk, the cow, the cat, and many other animals were held as sacred. For many centuries the bull Apis was worshiped as an important god at Memphis. This low form of worship survived in Egypt even after the development of higher religious ideas. Besides this animal worship we find a complex form of nature worship. The forces of nature were worshiped as gods, and represented in human forms. The mixture of these two forms of religion-animal worship and nature worship-is seen in the representation of the gods with human bodies and the heads of animals. The animal features came afterward to be regarded as simply symbolical of spiritual qualities. In the higher 


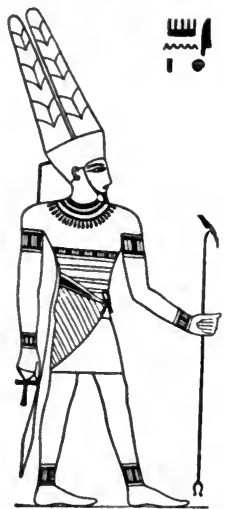

AMUN

gods, however, human heads were joined to human bodies.

The chief object of nature worship was the sun, the source of light and life, whose journey through the heavens was the cause of day and night and an emblem of life and death. The sun god was worshiped under different names at different places-as Ptah at Memphis, as Amun-Ra at Thebes, as Osi'ris at certain other eities. The gods were often joined in "triads" -

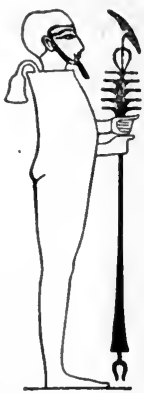

PTAII

the most noted of which was that of Osiris the father, Isis the mother, and Horus the son. With the recognition of a supreme god, the most learned men of Egypt attained an idea which approached that of monotheism. We sometimes find in the old records such statements as this: "Before all things which

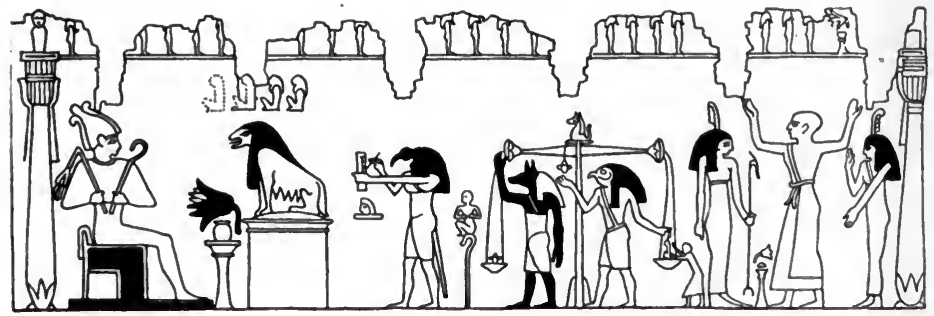

JudgMent of the Soul Before OSIRIS

actually exist, and before all beginnings, there is one God, unmoved in the singleness of his own Unity."

The Egyptians believed in the continued existence of the soul after death. This belief led to the practice of embalming the body of the deceased, that the mummy might be preserved 
for the return of the spirit. The Egyptians also believed in a system of future rewards and punishments, and that every soul must be judged before Osiris for the deeds done in the body. The priests of Egypt, who had charge of the religion, were also the learned class. They cultivated philosophy and the various sciences-astronomy, geometry, arithmetic, and medicinewhich here attained a considerable degree of development.

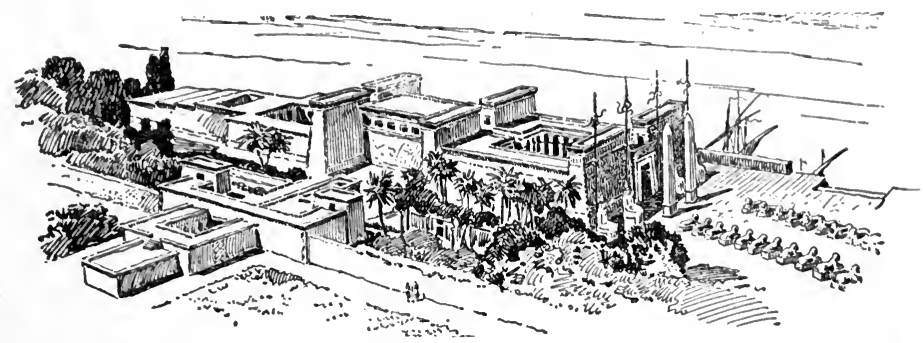

An Egyptian Temple

Egyptian Architecture and Monuments.-The religious spirit of the Egyptians was strongly impressed upon their architecture, which consisted mainly of tombs and temples. The buildings for the dead are seen in the rock-sepulchers cut in the sides of the hills which flanked the Nile-for example, the extensive necropolis at Sakkarah (near Memphis). Separate monumental tombs took the form of pyramids, and reached the most gigantic proportions at Gizeh. In these artificial mountains of stone rested the remains of kings. The most impressive specimens of architecture are seen in the massive temples, which were often made up of a combination of columns and sculptured walls. Noted examples of these temples were those of Luxor and Karnak and the Ramesse'um near Thebes, the ruins of which are among the most imposing in the world. Egyptian architecture is distinguished by simplicity of general design, but especially by grandeur of proportions and great elaborateness of decoration. It is also distin- 
guished, in some eases, by the use of columns as a means of supporting the roof-a feature which was afterward adopted by the Cireeks.

Egyptian Sculpture, Painting, and Music.-The other arts were also cultivated by the Egyptians. This people was probably the first to make sculpture an independent art,- that is, not joined to architecture. Some of the best of their statues belong to a very early periol. 'Tlue colossal sphinx is perhaps the most anciont example of independent sculpture existing

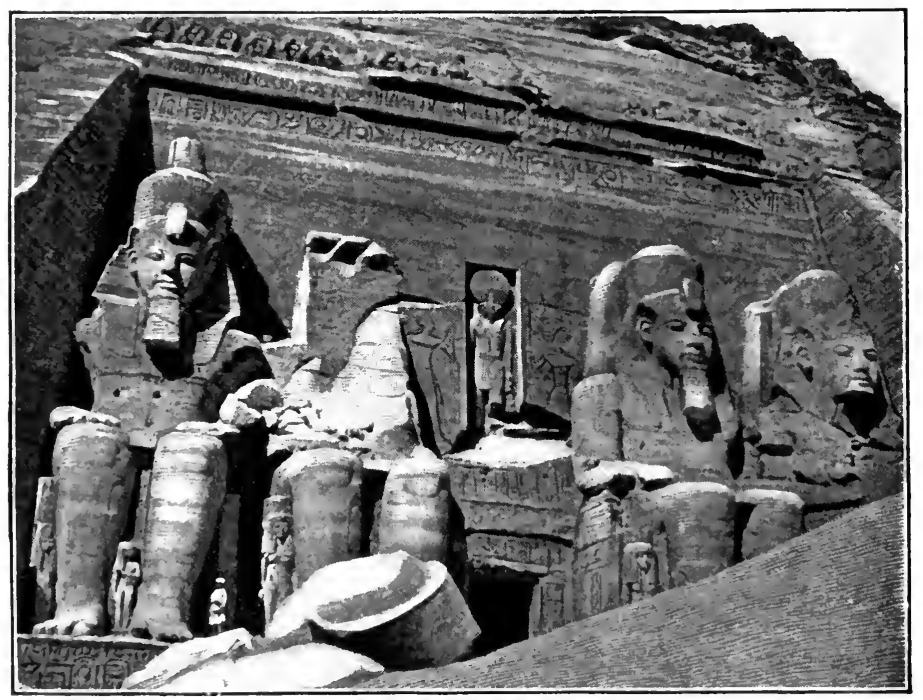

Colossal Statues of Rameses 11 .

in the world. But a less pretentious form of statuary grew up in the form of portrait statues, which were placed in the tombs to preserve the image of the deceased. Many of these portrait statues show a considerable degree of artistie skill. But Egyptian sculpture came to lose its independent eharacter and to be userl for the decoration of buildings. It appears in immense figures affixed to tombs and temples, and also in the multitude 
of bas-reliefs which adorned the walls of buildings. 'These sculptured designs were almost always colored; and this addition of color to carving was probably the earliest step in the growth of painting. 'The subjects of these paintings are almost infinite in variety, from the representation of the gods to scenes of domestic life. The Egyptians also attained some skill in music; they possessed such instruments as the guitar, the harp, and the pipe, and the drum and the trumpet inspired the Egyptian soldier on his march.

Egyptian Writing and Literature.-The great number of inscriptions cut upon the buildings and monuments indicate the peculiar character of the Egyptian writing, and one of the ways in which records were kept. On account of these inscriptions and designs the buildings are veritable books in stone. But. they remained practically sealed books until a key was found by which the inscriptions could be deciphered. The "Roset'ta stone," discovered near one of the mouths of the Nile (1799), contained a royal decree written in three kinds of characters, the hieroglyphic, the demotic, and the Greek. With this key the French scholar Champollion deciphered the language (1821), and may be said to have unlocked the treasurehouse of Egyptian learning. This line gives an example of the hieroglyphic characters: ${ }^{1}$

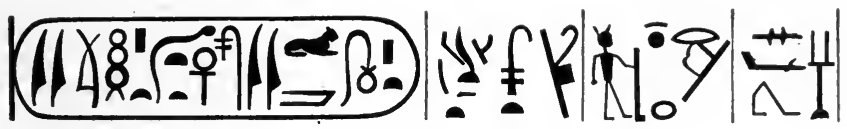

The written language of Egypt had its origin in picture writing. The most ancient form is the hieroglyphic, made up of pictures of things and symbols of ideas. The next form is the hieratic, which was used by the priests for executing long records, and hence is a more cursive, or running, form. The final form is called the demotic because it was used by the

1 The line is read from right to left, and is translated thus: "Raising | statue | of king of Egypt | Ptolemy eternal beloved of Ptah." 
people. The Egyptian writing contains not only ideographic but also phonetic elements, - that is, the symbols represent not only ideas but sounds, containing the germs of a phonetic alphabet by which words could be represented. The Egyptians did not confine their writing to stone; they also used a kind of paper prepared from the papyrus plant. Their literature contained many books upon science and religion; the most re-

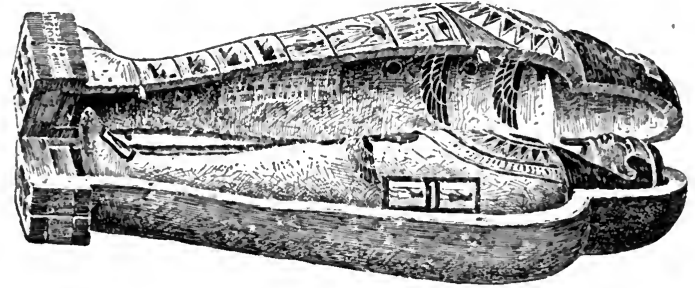

Mummy and Mummy Case

markable of these is the so-called "Book of the Dead," which contains descriptions of the future life.

The Influence of Egypt.-Egypt held a place in the valley of the Nile somewhat similar to that held by Babylonia in the Tigris-Euphrates valley. They both represent the early stages in the world's civilization, and contributed much to the progress of later nations. But the culture of Egypt was not at first so widely diffused as was that of Babylonia. Egypt, however, formed one of the great sources of Oriental culture, from which Europe and modern countries have received valuable materials. Egypt taught the world the principles of a durable architecture. It is true that the Babylonians built elaborate structures of brick, but these have well-nigh perished, while the stone buildings of Egypt have withstood in a wonderful manner the destructive influences of time. Indeed, we might say that one great difference between the material civilization of Babylonia and that of Egypt was the fact that one was wrought in clay and the other in stone. The 
Greeks, no doubt, derived much of their early knowledge of architecture from the Egyptians. 'The Egyptians have also exercised a strong intellectual influence upon the world. 'T'he progress made by them in some of the sciences-especially in geometry and astronomy-was appreciated by later nations, and formed a basis for further seientific achievements. Their higher religious ideas-for example, their idea of a Supreme Being and of a future life-may have had some inflnence upon the religion of the Hebrews and even upon that of Christian nations. We may, therefore, look upon Egypt as one of the sources of modern thought and culture.

\section{SYNOPSIS FOR REVIEW}

I. The Early Babylonian Empine.-The First Centers of Civilization.-The Tigris-Euphrates Valley.-The Larly City States; Sargon I.- Ilammurabi and the Old Babylonian Enpire.-The Kassite Conquest.-Babylonian Industry and Art.Babylonian Government and Laws.-Babylonian Writing ard Literature-Babylonian Religion and science.

II. Ancient EgYpt.-The Valley of the Nile.-The People of the Nile.-Periods of Egyptian History.-Egyptian Society and Government.-Egyptian Industry and Industrial $\Lambda$ rts.-Fgyptian Religion and Science.-Egyptian Architecture and Monuments.Egyptian Sculpture, Painting, and Music--Egyptian Writing and Literature.-The Influence of Egypt.

\section{REFERENCES FOR READING}

Murison, Babylonia, Ch. 1, "Ancient Babylonia"; Ch. 2, "Tnited Babylonia" (5). ${ }^{\mathrm{i}}$

Egypt, Ch. 1, "Introductory"; Ch. 2. "The Ancient Kingdom"; Ch. 3, "The Niddle "Kingdom": Ch. 4, "Eighteenth Dynasty"; Ch. 12. "The Book of the Dead" (6).

Goodspeed, Introduction, Ch. 2, "Excavations in Babylonia and Assyria"; p. 64 (Ur of the "Chaldees"); also Index, "Vr" (5). Encyclopædia Britannica, Tenth Ed., Vol. 29, "Irrigation" (ancient and modern).

Rawlinson, Vol. I., pp. 67-69, 70-73, 82, 86, 279, 340, 384 (uses of clay and brick in the Tigris-Euphrates valley) (4).

Ragozin, Chaldea, Ch. 5. "Babylonian Religion" (5).

Ducoudray, Ch. s, "The Nonuments and Arts of Egypt" (1).

${ }^{1}$ The figure in narenthes:s refers to the numbar of the topic in the $\mathbf{A p}$. pendix, where a fullẹ title of the book will be found. 


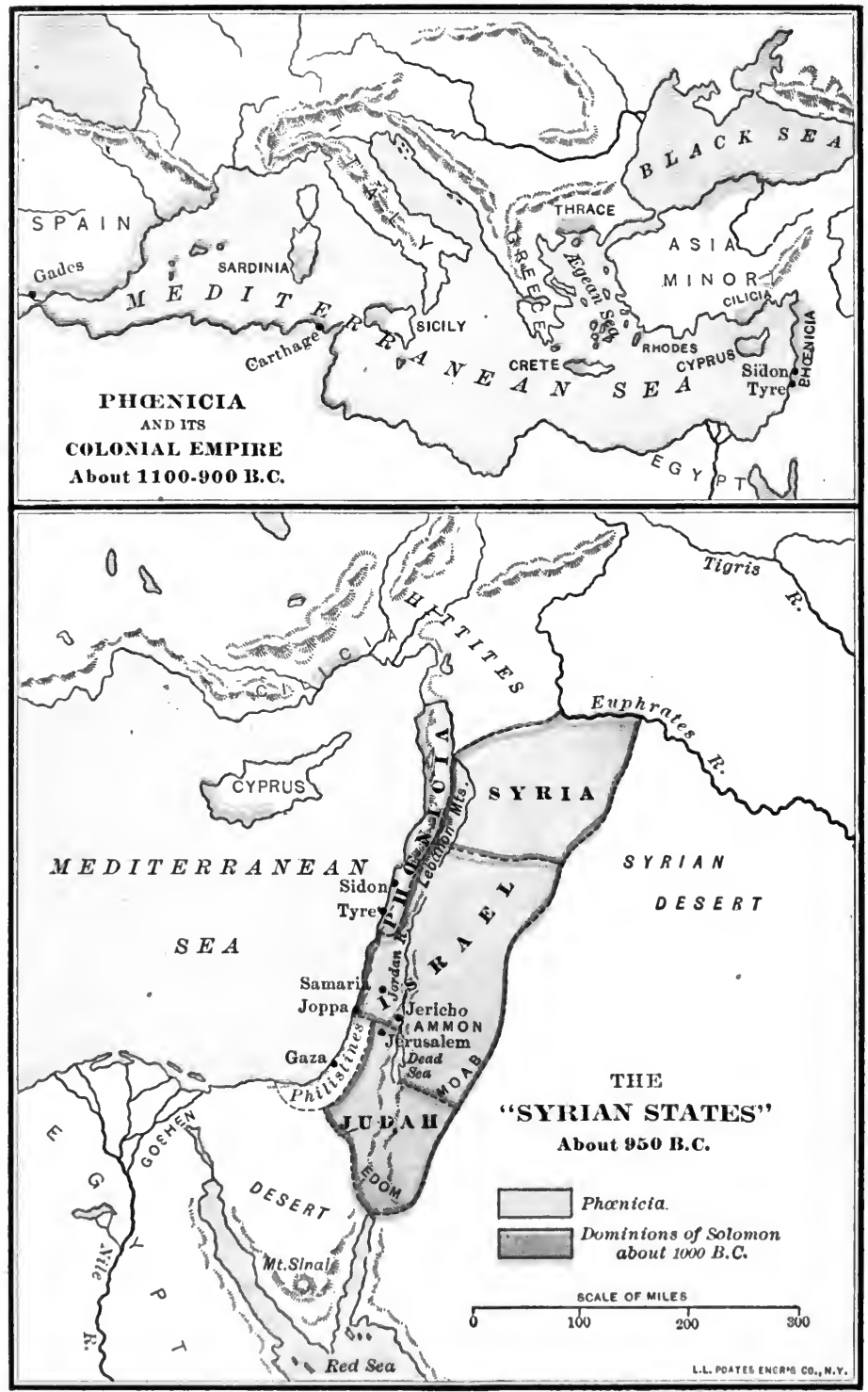


Lenormant, Vol. I., Bk. III., Ch. 5, "Civilization, Manners, and Monuments of Egypt" (4).

Boughton, pp. 211-250, "The New Empire-XVIIIth and XIXth

Dynasties"; pp. 428-450, "The Mesopotamians" (t).

Rawlinson, Story of Egypt, Ch. 4, "The Pyramid Builders" (6). Sayce, Ancient Empires, l'art I., "Egypt" (4).

Maspero, Egyptian Arehæoology, Ch. 5, "The Industrial Arts" (6). Smith, P., Ch. 1, ss. 3, 8 (sources and inundations of the Nile);

Ch. 2 (authorities for the history of Egypt); ('h. 3, s. 9 (the sphinx); Ch. 9, "Industry, Religion, and Arts of Egypt" (4).

Newberry and Garstang, Ch. 2, "The Arehaic Period [of Egypt]” (6).

Breasted, Ch. 3, "Earliest Egypt"; see also Index, "Obelisk" (6). Herodotus, Bk. II., Chs. 35-99 (manners and customs of the Egyptians); Bk. III., Chs. 147-152 (accession of P'sammetichus) (17).

\section{GHAPTER III}

\section{THE SYRIAN STATES-PHGENICIA AND JUDEA}

\section{Phenicia and Ancient Commerce}

Phœnicia and its People.-On the eastern coast of the Mediterranean Sea was a land which, as we have seen, was the meeting ground of the Babylonians and the Egyptians. For the want of any other common name we call this land Syria. The most important peoples living here were the Phœnicians and the Hebrews, both of whom belonged to the Semitic race." Of these the first to reach an important position in the Oriental world were the Phœnicians. Their home was a narrow strip of territory bordering on the shores of the sea, about one hundred and fifty miles long and from ten to fifteen miles in width, and shut off from the interior of the country by the range of the Leb'anon Mountains. This country, having been conquered in succession by Babylonia and Egypt, became the common heir of the two older civ- 
ilizations. For example, the religion of the Phœnicians was a form of nature worship quite similar to that of the Babylonians. Their architecture was, in its main features, modeled upon that of the Egyptians. In their mechanic arts they also showed the same refined skill as their older neighbors. The Phœnicians were distinguished for their glass and metal work, their pottery, their textile fabries, and especially for their purple dyes, which they obtained from a sea snail that was found along the Mediterranean coasts. Besides obtaining many scientific ideas from Babylonia and Egypt, they are said to have discovered the relation. between the tides of the sea and the motions of the moon. In their limited territory they had no passion for military glory or political dominion; they preferred to pay tribute to others, and pursue their industry. Their government was mainly government of separate
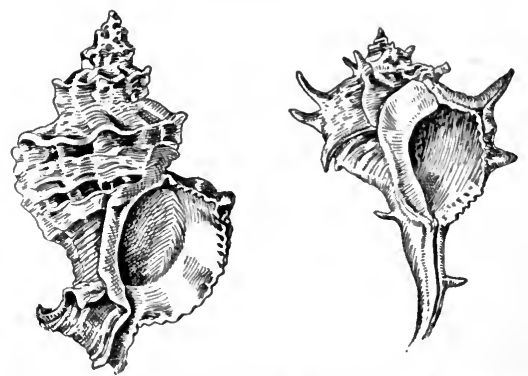
cities, but sometimes these were grouped into loose confederacies. Their greatest cities were Sidon and Tyre, which were in succession the chief seats of Phœnician civilization.

Phœnician Commerce.-The great distinction of this people was their genius for trade and commerce. Upon the sea the Phonicians established an empire perhaps equal in importance to that which any other Oriental people had established upon the land. The cedars of Lebanon furnished timber for their ships; and with these they became the first masters of the Mediterranean, and the greatest commercial nation of ancient times. Their fleets estallisher the first commercial intercourse between Europe, Asia, and $\triangle$ frica. They not only exported their own products to other countries, but they became the common 
carriers for the known world. From India they brought ivory, jewels, spices, and scented wood. From Arabia they brought gold, precious stones, incense, and myrrh. From the coasts of Ethiopia they added to their cargoes of gold and ivory supplies of ebony and ostrich feathers. 'They brought from the shores of the Baltic yellow amber; from Spain, silver, iron, lead, and copper; from Africa the precious metals; and from Britain tin. Thus the different parts of the world were brought into relation with one another by the Phœnician mariners and merchants.

Phœnician Colonies.-To aid in extending their commerce the Phœnicians established trading posts, or colonies, in all the countries visited by their ships and merchants. Not only were these established in the civilized countries of the East for the purchase and exchange of wares; they were also established among the uncivilized peoples of the West for the development of the resources of new lands. The coasts of

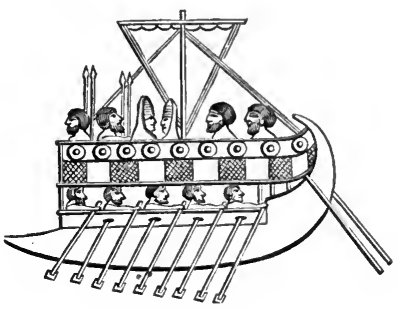

A Phonician Bireme the Mediterranean became dotted with Phœnician colonics. The most famous of these colonies was Carthage (founded. about 850 в. с.), which itself established a commercial empire on the northern coast of Africa, and which in later times came into a bitter conflict with Rome. The colonies on the Mediterranean were largely mining stations, where the metals were extracted from the earth for the use of eastern factories. By thus coming into contact with the barbarous people on the European coasts, the Phœnicians diffused among them a taste for the arts of civilized life. They carried not only commodities but culture. They have on this account been called the first " missionaries of civilization."

The Phœnician Alphabet.-Perhaps the greatest gift of the Phœnicians to the world was a true phonetic alphabet. It is said that the Phœnicians invented their alphabetical writing as 


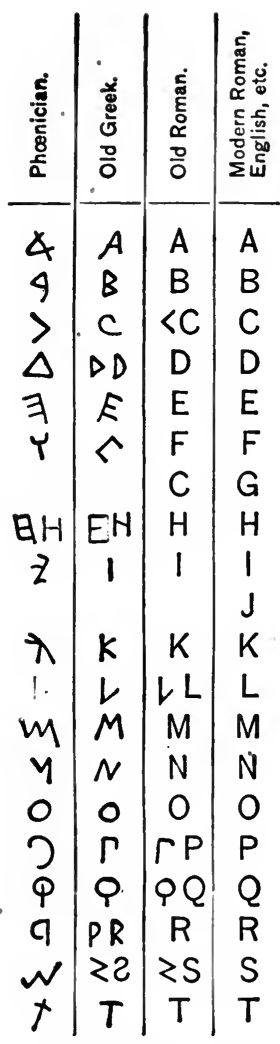

Growtil OF THE

ALPHABET

a common language of commerce. Wherever they sailed and carried their cargoes, they.also carried their alphabet, which Renan aptly calls one of their "exports." The alphabet was, however, the result of a long process of growth. The earliest writing was in the form of pictures to represent material objects, and then in the form of symbols to represent abstract ideas. The Egyptians made great progress by using signs to represent syllables, and afterward to represent elementary sounds (p. 38). This was the beginning of alphabetic writing; but the signs used by the Egyptians were very indefinite and largely pictorial; for example, the sound of $A$ was represented by the picture of a feather or by that of an eagle. It was reserved for the Phœnicians to develop a true phonetic alphabet, in which the chief elementary sounds were represented by separated and well-defined characters. This alphabet was adopted by many peoples, especially by the Greeks, who gave it to the Romans, by whom it was given to modern nations. Thus the Phœnicians, by the development of commerce and the invention of a true phonetic alphabet, and also by their diffusion of Oriental culture over the Mediterranean coasts, must be regarded as one of the most important of ancient nations.

\section{Judea and the Hebrews}

The Hebrew Nation.-Not far from Phonicia in Palestine there grew up another Semitic nation, which was in many re- 
spects different from every other Oriental people (see map, p. 40). This was the Hebrew nation. Having no great river like that of the Egyptians and that of the Babylonians, and not taking to the sea like the Phœnicians, they did not attain distinetion in the industrial or eommercial arts. Their greatness did not depend upon art or science, or upon their eapacity for political organization. Yet they have perhaps done for civilization as much as any other people of the East, for they became the moral and religious teachers of the world.

Periods of Jewish History.-No other ancient nation possessed so complete a record as did the Hebrews of the way in which a people has passed from the primitive to the civilized stage. From these records, we learn that their ancestor, Abram, was a Babylonian, that he came (about 2000 в. c.) from Ur, a "city of the Chaldees," that he visited Egypt, and finally settled in Jude'a. His descendants, in the time of a famine, took refuge in Egypt, and became subject to the Shepherd Kings, who assigned to them a home in lower Egypt (Goshen). Being oppressed by a king of a subsequent dynasty, they were delivered from their bondage by their great leader and lawgiver, Moses, a man skilled in all the learning of Egypt. From this time the history of the Jews may be divided into the following periods:

(1) From the Exodus to the Establishment of the Monarchy (1300-1095 в. c.).-During this time the people were welded into a nation, with a national law and a national religion, under the statesmanship of Moses. They crossed the Jordan under their leader Joshua, eaptured Jer'icho, conquered the surrounding country in Palestine (or Canaan, as they called it), and established a theocratic commonwealth under the rule of officers called "judges."

(2) From the Establishment of the Monarchy to the Division of the Kingdom (1095-975 B. C.).-During this period the nation was ruled by three distinguished kings. The first of these was Saul, who carried on war with the neighboring tribes, 
the Am'monites, the Philis'tines, and others. The second king was David, who captured Jerusalem and made it the capital of the kingdom, building a royal palace, with the aid of Phœnician architects. By his conquests he established an empire extending from the Euphrates on the north to the Red Sea on the south. The third and last king of the united monarchy was Solomon, who gave to the kingdom an air of Oriental magnificence. He built a splendid temple at Jerusalem, and

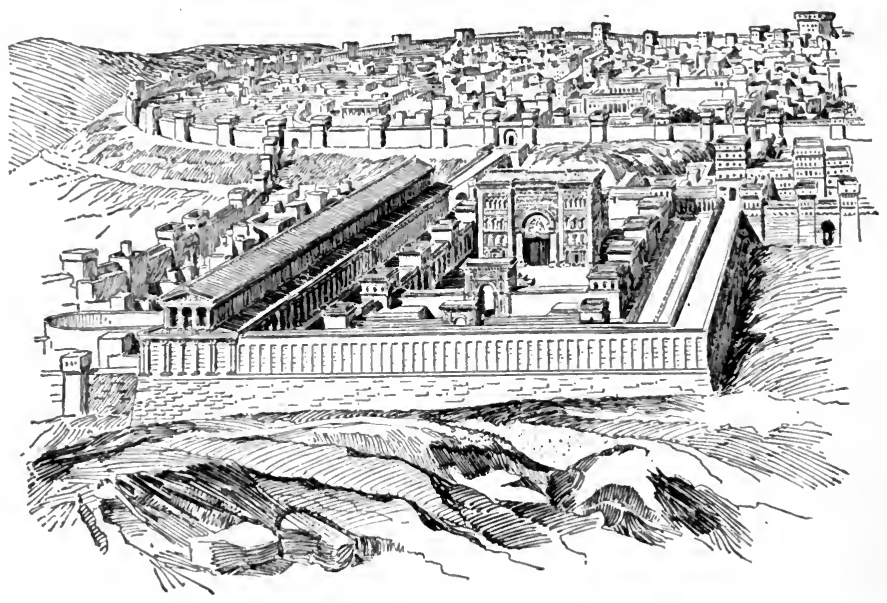

Temple at Jerusalem (Restoration)

adorned the city with sumptuous palaces. He formed an alliance with the kings of 'Tyre, and carried on an extensive commerce with Egypt and the East. He amassed enormous wealth and surrounded his throne with pomp and splendor. He married an Egyptian princess, and established a luxurious court like that of the eastern kings. But his glory was purchased at the expense of justice and his nation's honor. He laid heavy burden upon his subjects and impoverished them. He disregarded the laws of Moses, and the Hebrew kingdom became practically an Oriental monarchy like that of Babylon. 
(3) From the Division of the Kingdom to the Babylonish Captivity (975-586 в. c.).-During this time the Hebrew nation formed two distinet kingdoms. 'Ten tribes revolted and formed the kingdom of Israel, with its capital at Sama'ria; the remaining two tribes formed the kingdom of Judah, with its capital at Jerusalem. The kingdom of Israel was finally conquered by the Assyrian king Sargon II. (7\%\% B. c.), and the people were removed to Nineveh, where they were "lost" as a separate people (see p. 53). The kingdom of Judah was destroyed by the Babylonian king Nebuchadnezzar (586 в. с.), and the inhabitants were carried away as captives to Babylon (see p. 58); but they were afterward allowed to return to Jerusalem (53\% в. c.) as subjects of Cyrus, the Persian king.

The Hebrew Commonwealth.-Before the Hebrew nation passed under a monarchical form of government, their society is of special interest to us, because it was patterned upon a pure democratic type. The Hebrew commonwealth presents the best, and perhaps the only, example of a true democracy among ancient civilized nations before the time of the Greeks. The society was based upon the patriarchal family. The father was head of the family group and priest of the family worship. Parental, marital, and filial duties were the sacred ties of social life. The families were grouped into tribes, each under a patriarchal chief, a council of elders, and a general assembly. The tribes were united into a larger federal commonwealth, with its judge, who was a patriarchal and military chieftain; its san'hedrim, which was a national senate, or federal council; and its "congregation," which was a popular assembly of the tribes. Each tribe retained the right of local self-government, and all its people were equal before the lawexcept the slaves, who were, however, generally well treated. The decay of the Hebrew commonwealth was due to the influx of Oriental ideas, and to the breaking down of the primitive customs of the Hebrew nation. 
The Hebrew Religion; Monotheism.-In spite of the fact that the people and the rulers were often led astray by the influence of foreign religious ideas, still the highest and most distinctive feature of the Jewish civilization was the growth of monotheism. We must judge of the real character of the Jewish religion, not by, the practices of those who departed from it, but by the teachings of those who were its highest expounders-Moses and the prophets. In these great teachers we find the true idea of monotheism. This is not simply the idea of the Egyptians, that there is one god higher than other

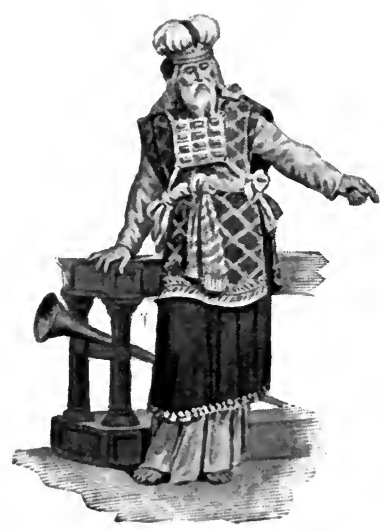

High Priest gods; it is the idea that there is only one Supreme God. Another feature of the Jewish religion was the fact that it was closely linked to morality. Religious worship and moral duty were regarded as two sides of a complete life. The history of the nation was a constant struggle against false ideas of religion and false ideas of morality. When the priests were carried away with the idea that religion consisted simply in rites and ceremonies, and the kings were seeking the pomp and luxury of the East, and the people were falling into wickedness and idolatry, it was left to the later prophets to become the true expounders of religion and the moral law.

The Hebrew Literature; the Bible.- The idea of monotheism was the inspiring idea of the Hebrew literature, as it was of the Hebrew religion. This literature is contained in what we call the Old 'Testament, and comprises (1) the Pentateuch, or the legal hooks; (2) the historical hooks; (3) the poetical books: and (4) the books of the prophets. In their literary genius the Hobrews surpassed all other Oriental nations. In the writings of their poets and prophets we find the highest 
examples of religious fervor and imaginative description. The Psalms of David, the Book of Job, and the Propheey of Isaiah, considered merely as literary compositions, are unsurpassed in the literature of any people. When we consider the writings of the Hebrews and their religious influence upon the rivilized world, we must assign to this nation a high place among the historical peoples of ancient times.

\section{SYNOPSIS FOR REVIEW}

I. Phenicia and Ancient Commerce.-Phœnicia and its People.-Phøuician Commerce.-Phœnician Colonies.-The Phœnician Alphabet.

II. Judea and the Herrews.-The Hebrew Nation.-Periods of Jewish History.-The Hebrew Commonwealth.-The Hebrew Religion; Monotheism.-The Hebrew Literature; the Bible.

\section{REFERENCES FOR READING}

Encyclopædia Britannica. Art. "Phœenicia."

Rawlinson, History of Phœnicia, Ch. 18, "Phœnician Manufactures" (7). ${ }^{1}$

Lenormant, Vol. II., Bk. VI., Ch. 4, "Civilization and Influence of the Phœnicians" (4).

Sayce, Ancient Empires, Part II., "Phœnicia" (4).

Ducoudray, "Ch. 4, "Religion and Social State of the Jews"; Ch. 5, "Phœnician Commerce" (1).

Boughton, pp. 291-344, "The Phœenicians"; pp. 393-406, "Israelitish Institutions" (4).

Souttar, pp. 191-276, "The Hebrews"; pp. 277-306, "Phœnicia" (1). Milman, History of the Jews, Bk. III.. "The Desert" (en passant, idolatry among the Jews); Bk. VII., "The Monarchy" (with its Oriental features) (7).

Edersheim, Ch. 12, "Sickness and Death" (sanitary features of the Mosaic law) (7).

Josephus, Wars, Bk. VI. (siege of Jerusalem by Titus) (9).

The Bible, Numbers, Ch. 4 (the Levites and their duties); Ezekiel, Chs. 26-28 (exaltation of Tyre).

${ }^{1}$ The figure in parenthesis refers to the number of the topic in the Appendix, where a fuller title of the book will be found. 


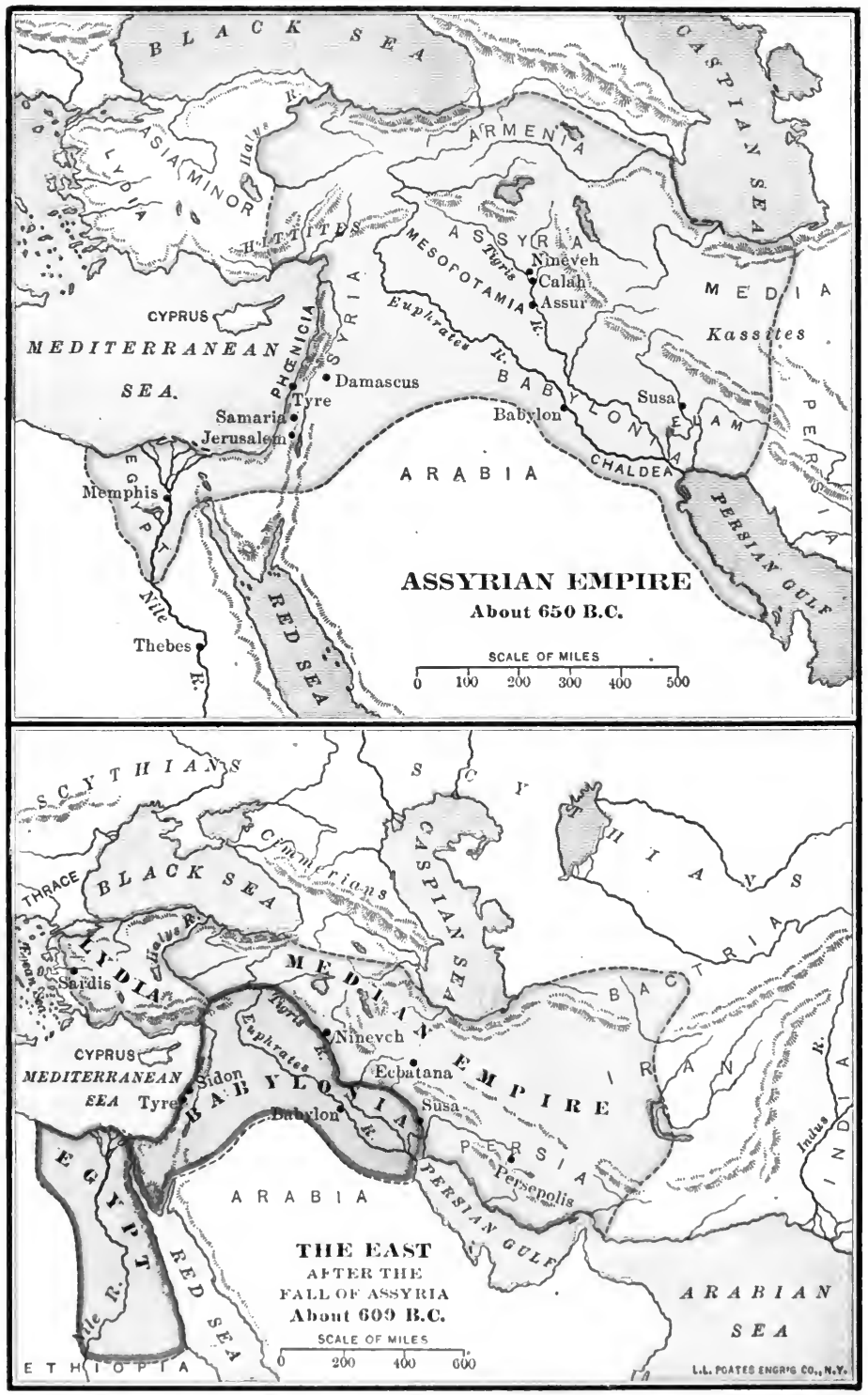




\section{CHAPTER IV}

\section{THE NEW SEMITIC EMPIRES-ASSYRIA AND IAATER BABYLONIA}

\section{Assyria, the First World Empire}

The Rise of Assyria.-We are now brought to a new period in Oriental history, in which all the previous nations of the East-not only the Phønicians and the Hebrews, but also the Babylonians and the Egyptians-lose their independence, and become parts of one great world empire. The people who established this empire were the Assyrians. They belonged to the Semitic race, like the Babylonians, and dwelt in the upper part of the Tigris-Euphrates, or Mesopotamian, valley. In the rugged climate of the north they developed a hardy and warlike character. The Assyrians have been compared to the Romans as a military and conquering people. They cultivated the arts of war; having well organized bodies of infantry, cavalry, and war chariots.

The center of Assyrian power was at first the city of Assur; this was a colony of Babylonia situated on the upper Tigris River and the seat of the worship of the god Assur. The city obtained its independence from Babylonia, and gave the name "Assyria" to the whole surrounding country. After a timé, the Assyrian capital was transferred from Assur to Nineveh (by Shalmane'ser I., 1320 в. c.); and this new capital became the permanent seat of the empire. The external history of Assyria is a history of almost continual wars, resulting in the partial success of the Assyrian arms under the first empire, and the final triumph of the Assyrian power under the second empire. 
The First Assyrian Empire (1120-745 B. c.).-The founder of the first Assyrian empire was the great warrior 'king of Nineveh, 'Tiglath-Pile'ser I. (1120 B. c.), who subdued the surrounding cities, and carried his arms to the west until after many wars he finally reached the coasts of the Mediterranean. That he looked with satisfaction upon his own achievements is evident from his inscription (now pre-

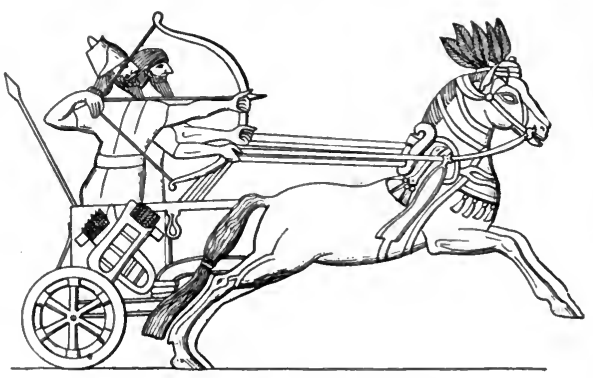

Assyrian War Cilariot served in the British Museum), in which he calls himself " the king of kings, the lord of lords, the ever victorious hero." 'The

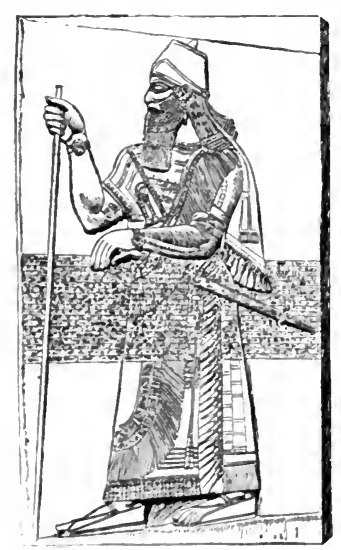

Assur-NAZIR-PAL Relief in British Museum merciless character of Assyrian warfare is seen in the career of another noted king, Assur-nazir-pal (885 B. c.), whom, in spite of his fame, we may regard as one of the most cruel of conquerors. The lands which he conquered, he desolated, ravaging the fields and killing the people. In his own words, which have come down to us, we may read his boasting of the pyranids he has built of human heads, of the captives flayed alive, and of the children burned to death. The conquests of these early kings were continued by Shalmaneser II. ( 860 B. c. $)$, whose deeds. are recorded on the famous "black obelisk," which he built. On one side of this obelisk we may see a procession of subjects bringing their gifts and tribute to the king. 'The many wars of the period were intended 
to bring into subjection the neighboring countries-especially Babylonia to the south, and Syria to the west. But these conquests were not permanent, and the first empire fell into a state of decline.

The Second Assyrian Empire (745606 в. с.).-The failure of the first empire was due to the lack of an efficient mode of governing the subjects. When a people were once conquered and made tributary, they were left to themselves; and consequently they were tempted to rise in rebellion against the king when he demanded further tribute. This policy was changed by a distinguished king who is regarded as the founder of the second Assyrian empire-Tiglath-Pileser III. (745 в. C.). This king adopted the policy of organizing the conquered cities into districts, or provinces, each subject to a governor of his own appointment. He also adopted the practice of "deportation"-that is, of scattering rebellious

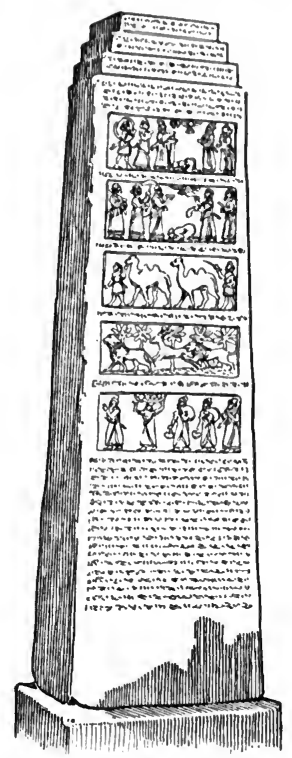

BLACK OBELISK of Shalmaneser II. peoples into different parts of the empire, thus preventing any united efforts at revolt. In accordance with this practice, the

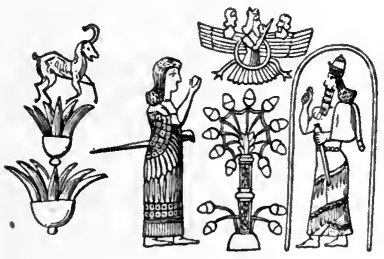

Seal of Sennacherib next king, Sargon II. (722 в. с.), when he had conquered Samaria, carried away the "Ten Tribes" of Israel into captivity and scattered them among the towns of Media, where they were forever "lost" as a separate people. The success which attended the campaigns of Sargon in Israel led his successor, the more famous King Sennach'erib (705 B. c.), to continue these expeditions. He accordingly subdued the cities 
of Phœnicia; but his efforts against the city of Jerusalem failed, and his armies, smitten by a pestilence, were led back to Nineveh. The last years of this king were devoted to wars with Babylonia, resulting finally in the total destruction of the city of Babylon (688 B. c.). The conquests of the three kings just mentioned resulted in bringing nearly the whole of western Asia under the Assyrian power. The completion of the empire was effected by the two following kings-Esarhad'don (681 в. c.), who brought Egypt under his control, and As-

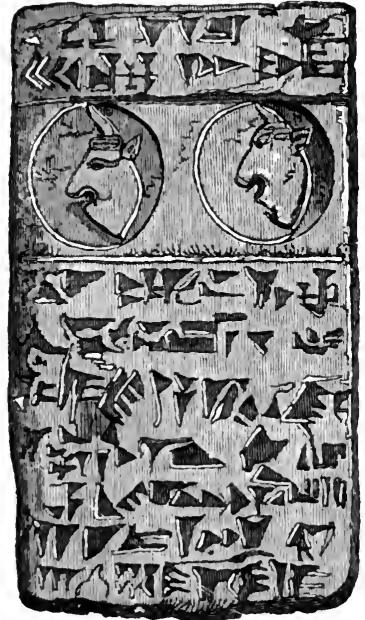

Assyrian Clay Tablet sur-bani-pal (668 в. c.), who reduced the rebellious city of Tyre. Under these two monarchs the Assyrian empire reached its greatest extent and its greatest glory, and became, in fact, what we may call the first world empire. One of the most remarkable monuments of this period is the Royal Library of Assur-bani-pal, which may be regarded as the first great library of the world. It was gathered from various conquered cities, a considerable part of it being plundered from Babylon. It contained about 30,000 tablets, which have been brought to light in recent years, and have revealed to modern scholars the history and civilization of a people who flourished more than twenty-five centuries ago.

Assyria the Heir of Babylonia.-A great part of the civilization of the Assyrians was inherited from the early Babylonians. It is true that these two peoples belonged to the same race; yet they were quite different in spirit. "The Babylonians were peaceful in disposition, given to agriculture, fond of literature. well educated and comparatively humane in the conduct of their wars. The Assyrians cared little for agricul- 
ture, their wars were undertaken for plunder and were conducted with ferocity." Still, many of the arts of peace developed by the Babylonians were taken up by the Assyrians. 'The Assyrians, for example, adopted the method of writing used by their older neighbors, and showed something of the same taste for literature. They acquired the same, if not superior, skill in the mechanic arts, and adopted the same scientific ideas. Their religion was in all essential matters the same as that of the Babylonians; and they generally adopted the same strict methods in their legal transactions. The' advancement which they made upon the Babylonians was principally in the direction of a more highly developed imperial government, a more palatial style of architecture, and a greater appreciation of sculpture as a decorative art.

The Assyrian Government.-The Assyrians seem to have been the first great people to develop a systematic government based upon the imperial idea. The monarch was the supreme source of all authority. He was surrounded by a court composed of officers of his household, such as the grand vizier, the royal cupbearer, the royal treasurer, the eaptain of the guards, etc. These officers served the king and executed his commands. The provinces of the empire received a definite organization. They were divided into two classesthose under governors, or satraps, appointed by the king, and those under native rulers approved by the king and subject to him. The provinces were all alike obliged to furnish trib-

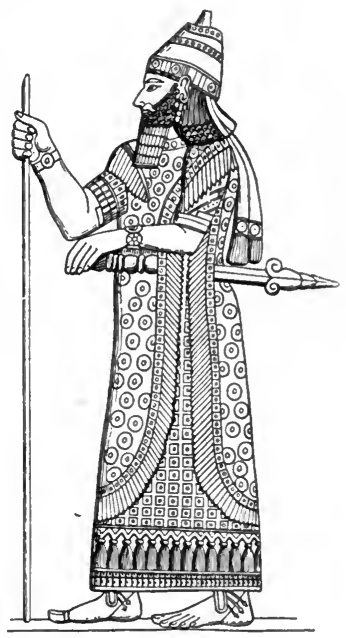

Assyrian KING IN Royal Robes ute for the royal treasury and troops for the royal army. Except the priestly class, the subjects of the king possessed a cer- 
tain degree of equality, there being no caste system, and no established aristocracy. 'There was, however, a class of slaves composed of captives taken in war and of persons unable to pay their debts.

Assyrian Architecture; Royal Palaces.-The influence of the imperial idea, and the great dignity attached to the king, are seen in the character of the Assyrian architecture. The most important buildings were not the temples, as in Babylonia, but the royal palaces, upon which the wealth of the empire was expended. The temple was merely accessory to the palace, and was still built in the form of a terraced tower.

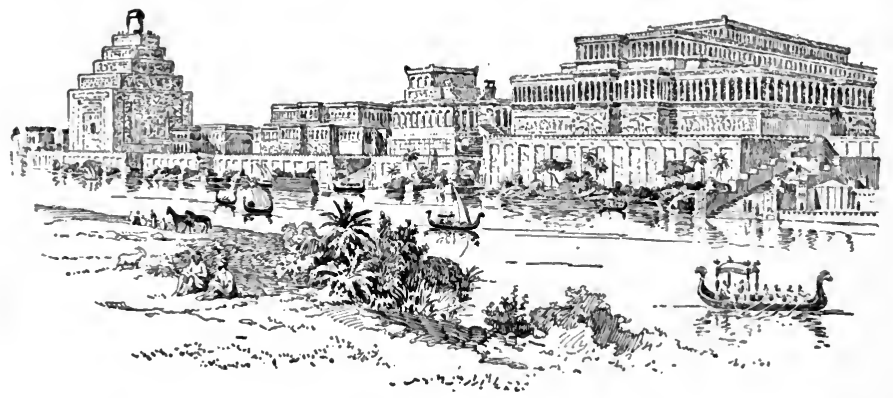

Assyrian Palace at Ninevei (Restoration)

But the palace assumed another form, and was built over an extended area upon the flat surface of an artificial hill or elevation overlooking a plain or river. Although this country furnished stone suitable for building, the Assyrians continued, like the Babylonians, to use brick for architectural purposes. 'The royal palace consisted of a vast system of courts, corridors, and galleries. In spite of the fact that the Assyrians used the arch in sewers, the roof of the palace was generally supported by wooden heams placed upon massive brick walls. Slender columns, made of stone or of wood covered with metal, were often used for ornamental purposes; and these were sometimes surmounted with capitals of artistic designs. 
Assyrian Sculpture and Painting.-The Assyrians acquired considerable skill and proficiency in the art of sculpture. 'This was chiefly employed in the way of ornamentation for the royal palaces. The most conspicuous, but not the most pleasing, examples of Assyrian sculpture are seen in the enormous and grotesque figures which were usually placed at the entrance of the palace. They consisted of winged bulls or lions with human heads, — symbolizing perhaps strength, swiftness, and intelligence,-and were sup-

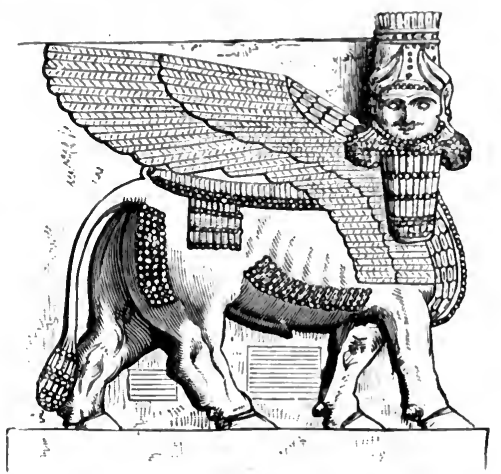

Winged Bull with Human Heal) posed to guard the palace from the intrusion of evil spirits. The highest examples of Assyrian art are seen in the basreliefs, cut on alabaster slabs and adorning the interior of the royal palaces. Here are represented scenes of war and events

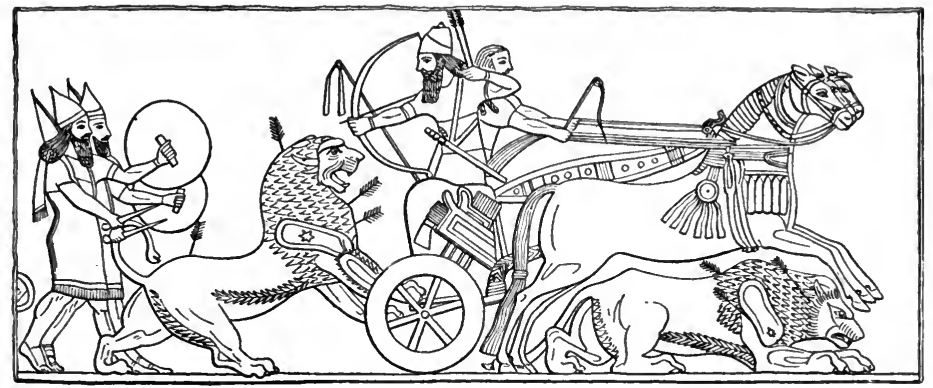

AsSYRIAN BAS-RELIEF

in the life of the king. In these sculptured reliefs are exhibited the best specimens of ancient drawing before the time of the Greeks. From the large number of these reliefs 
we have obtained much of our knowledge of Assyrian life and customs. The flat and strong colors-often a brilliant vermilion-which are placed upon the reliefs (as upon the Egyptian bas-reliefs), show the first steps in painting, which had not yet reached the dignity of an independent art.

\section{The Later Babylonian Empire}

Recovery of the Empire by Babylon.-During the supremacy of Assyria, Babylon remained in the position of a dependent kingdom; but throughout this reriod she had preserved the memory of her former greatness, and frequently revolted against the Assyrian monarch. But in these attempts she was doomed to failure, until she found an ally in a people living east of the 'Tigris. This people was the Medes, who had themselves been subject to Assyria for more than a century; they had now recovered their independence and established an empire of their own. With the aid of the Medes, the Babylonians succeeded in destroying Nineveh and overthrowing the Assyrian monarchy (606 в. с.). The dominions of Assyria were divided between the conquerors,-Media ruling the countries to the east of the Tigris, and Babylon the countries to the west.

Babylon under Nebuchadnezzar.-In this way Babylon recovered her ancient power, and ruled with increased splendor.

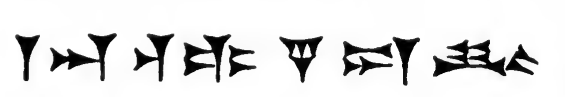

The Name Nebuchadnezzar in CUNEIFORM

The great king Nebuchadnez'zar

$(605-561$ B. c.) restored her fallen eities, and made her for a short time the center of Eastern eivilization. His dominions extended over the valley of the Euphrates and the countries of Syria to the borders of Egypt (see map, p. 50). The Jews who refused to respect his authority were treated with severity. Jerusalem was taken and sacked: and the tribes of Judah were carried away into captivity. The great king rebuilt the city of Babylon, sur- 
rounded it with massive walls, and adorned it with sumptuous palaces. To rival the beauties of nature and to please his queen, a Median princess, he built the famous "hanging gardens," which were artificial hills built in the form of immense terraces and covered with luxuriant shrubs and flowers. During this brief period of her later supremacy Babylon attained, in the highest degree, all the luxury and pomp peeuliar to Oriental civilization. But Babylon the Great finally fell before the rising power of Persia (538 в. c.), which absorbed all the countries of western Asia.

The Assyrio-Babylonian Civilization.-We have seen that the Tigris-Euphrates valley was the seat of three successive empires; but in their culture these empires may be looked upon as presenting three successive phases of one and the same civilization. The early Babylonians had developed a form of religion, science, and art which showed the evidence of intellectual growth and a certain degree of refinement. The Assyrians took up the culture of the Babylonians, and impressed upon it a political and imperial stamp, such as was naturally derived from a great and conquering people. And this imperial character was transferred back to Babylon with the establishment of the later empire. So the culture which was finally developed in the Mesopotamian valley was a mingling of Babylonian and Assyrian elements.

From this brief review we can see that the Tigris-Euphrates valley was one of the great centers of ancient civilization. By its commercial and political relations its culture was extended to the shores of the Mediterranean Sea. The religious ideas of its people became the common property of the Last; and their notions regarding the origin of the world and the early condition of mankind became entwined with the Hebrew account of creation. Their progress in certain branches of science, especially in astronomy, formed a contribution to the intellectual development of the ancient world Their skill in some of the industrial arts, such as weaving and the cutting of 
intaglios, has scarcely been equaled by modern nations. Their political organization formed the basis of the later imperial systems of the East, which were afterward transferred to Europe under the later Roman empire.

\section{SYNOPSIS FOR REVIEW}

I. Assyria, the Finst World EMPIRE.-The Rise of Assyria.'The First Assyrian Empire.-The Second Assyrian Empire. - Issyria the Heir of Babylon.-The Assyrian Government.Assyrian Architecture; Royal Palaces.-Assyrian Sculpture and l'ainting.

II. The Later Babylonian Empire.-Recovery of the Empire by Babylon.-Babylon under Nebuchadnezzar.-The AssyrioBabylonian Civilization.

\section{REFERENCES FOR READING}

Murison, Babylonia and Assyria, Ch. 5, "Consolidation of the Assyrian Empire"; Ch. 14, "Writing and Literature"; Ch. 15, "Civilization"; pp. 18-20, "The Tel-el-Amarna Tablets" (5). Ducoudray, Ch. 3. "The Babylonians and Assyrians" (1).

Sayce, Ancient Empires, Ch. 2, "Babylonia and Assyria" (4).

Goodspeed, Part II., Ch. 5. "Early Conflicts of Babylonia and Assyria"; Part III., Ch. 5, "The Assyrian Empire at its Height"; Part 1V., Ch. 2, "Nebuchadrezzar and his Successors" (5).

Lenormant, Vol. II., pp. 417-467, "Civilization, Manners and Monuments of Assyria" (4).

Boughton, pp. 493-508, "Mesopotamian Institutions and Progress" (4).

Smith, P., Ch. 17, "The Cuneiform Writing and Literature" (4). Maspero, Life, Ch. 16, "Assurbanipal's Library" (4).

Rawlinson, Monarchies, Vol. II., pp. 516-520, 553 (the hanging gardens and walls of Babylon) (4).

. Josephus, Antiquities, Bk. X., Ch. 8 (capture of Jerusalem by Nebuchalnezzar): Bk. XI., Ch. 1 (return of the Hebrews from captivity) (9).

Herodotus, Bk. I., Chs. 131-140 (Persian manners and customs); ('hs. 178-183 (description of Babylon); Chs. 190, 191 (capture of Babylon by Cyrus) (17).

The Bible, II Kings. ('hs. 18, 19 (Sennacherib and Hezekiah); Daniel, ('hs. 1-4 (Nebuchadnezzar and Daniel); Ch. 5 (Feast of Belshaz:ar).

${ }^{1}$ The figure in marenthesis refers to the number of the toplc in the $\mathbf{A p}$ pendix, where a fuller title of the book will be found. 


\section{CHAPTER V}

\section{THE ARYAN EMPIRES-MEDTA AND PERSIA}

\section{The Aryans and the Median Empire}

Beginnings of Aryan Civilization.-We have thus far seen the beginnings and growth of civilization among the Hamitic people in Egypt, and also among the Semitic people who lived in the Tigris-Euphrates valley and on the eastern shores of the Mediterranean Sea. We have noticed the rise and fall of the great empires estabtablished by these peoplesthe early Babylonian, the Egyptian, the Assyrian, and the later Babylonian. The time has now come when the dominion of the Orient passes from the Hamites and the Semites into the hands of Aryan

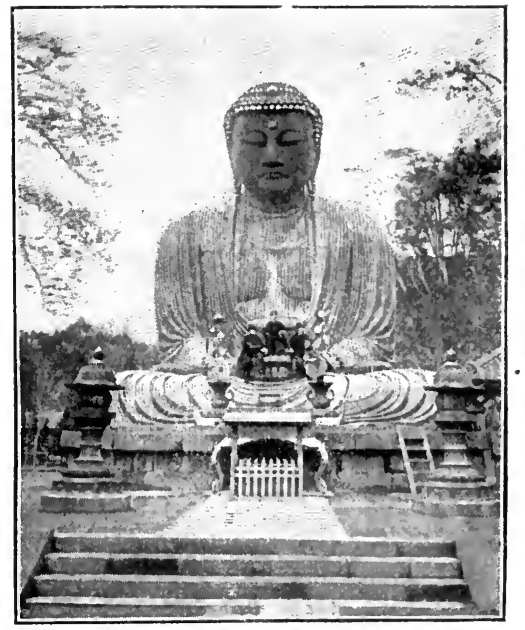

Statue of the Hindu Budiha peoples, who are henceforth to become the masters of the civilized world.

It is true that a part of the Aryan people had already entered India, had settled upon the banks of the Indus and the Ganges, and had made some progress in civilization. These Aryans in India were called Hindus. They had developed the simple nature worship of their ancestors into a highly philosophical religion called Brahmanism. This was followed by 
another and simpler form of religion called Buddhism, founded by the great religious reformer Buddha. 'The Aryan Hindus had also produced a literature in the so-called "Vedas" and in certain epic poems which show strong feeling and imagination. Finally, they had obtained some scientific ideas in astronomy and mathematics, which indicate a certain degree of intellectual progress. But the Aryan Hindus, in spite of their progress in certain directions, were still a contemplative people, lacking the activity and vigor necessary for great political achievements; and hence they exercised little influence upon the general progress of the East.

The Medes and the Persians.-The first Aryan peoples who became a real factor in the progress of the ancient world were the Medes and the Persians. They were inspired with the imperial spirit of the East, and changed the face of the Oriental world. These two peoples were closely related to each other, although they found homes in different regions. They both settled upon the western part of the great plateau of Iran, which lies between the Indus and Tigris rivers; but the home of the Medes was among the higher lands toward the north and west, while that of the Persians was farther south near the shores of the Persian Gulf. In the early periods of their history they had both struggled against the aboriginal peoples of the plain and succeeded in establishing their dominion. Of these two peoples, the Medes were the first to obtain prominence by throwing off the yoke of the Assyrians, to whom they had been subject. Fighting for existence against the continual eneroachments of Assyria on the west and of the barbarous Scythians on the north, they not only maintained their national life, but developed the military strength which enabled them to conquer their neighbors and to establish an empire.

The Median Empire; Cyaxares.-The founder, and in fact the only great ruler, of the Median empire was Cyax'ares (625585) в. с.). IIe organized the seattered tribes of the country and completed the work begun by previous princes. His mili- 
tary ability is shown by the fact that he formed his army into regular divisions, each made up of those who were armed with the same kind of weapons. He first drove back the barbarians who were pressing upon his kingdom from the north, and delivered western Asia from these invaders. He then formed an alliance with the king of Babylonia, as the result of which Nineveh was destroyed and the empire of Assyria was overthrown (see p. 58). While Nebuchadnezzar was ruling in splendor at Babylon, Cyaxares was extending his dominions. He invaded $\Lambda$ sia Minor and pushed his arms to the river Halys, which became the dividing line between his empire and that of Lydia (see map, p. 50). The Median empire, though extensive in its territory, was the shortest-lived of all the great Oriental monarchies. Its chief significance lies in the fact that it prepared the way for the greater empire of the Persians.

\section{Persia, the Second World Empire}

The East before the Persian Conquests.-At the death of Cyaxares in the beginning of the sixth century (585 в. C.), there were four principal nations of the Oriental world, which we should keep in mind if we would understand the growth of the Persian empire (maps, pp. 50, 66). These were: (1) the Median empire, which had been built up by the prince Cyaxares, and which extended to the IIalys River on the west, to the Caspian Sea on the north, to the Persian Gulf on the south, and to an indefinite boundary line on the east toward the Indus River; (2) the Later Babylonian empire, which, with the aid of the Medes, had been formed from the dissolution of the empire of Assyria, and which extended from the Tigris River to the shores of the Mediterranean; (3) the Lydian empire, which covered the western part of Asia Minor from the Halys River alınost to the Agean Sea, on the coasts of which had grown up a number of Greek cities; and (4) Egypt, which had recovered its independence under Psammetichus and occu- 
pied its original territory if the valley of the Nile. We. are now to see how these different countries became absorbed into the one great world empire of Persia.

Rise of Persia under Cyfus (558-529 B. c.).-Persia had been a small province of the Median empire situated on the Persian Gulf. About the middle of the sixth century B. c.

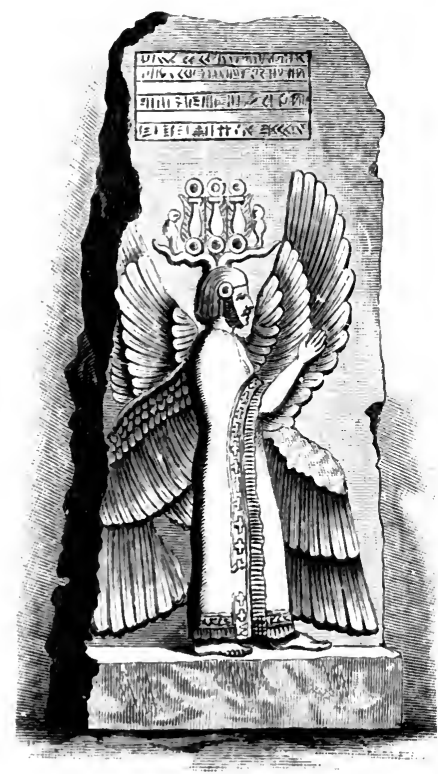

Bas-reifef of Cyrus

a prince, whom we know as Cyrus the Great, revolted from Media and succeeded in reducing that state to his own authority. Many stories are told about the birth and early life of this great man; but they are largely mythical, and need not be rehearsed. His chief significance for us is in the fact that he created the most powerful empire that the world had yet seen, and established a policy which was destined to bring Asia into conflict with Europe. The growth of this empire resulted from the conquests made by three kingsCyrus, its founder, and his successors, Camby'ses and Dari'us.

Conquest of Lydia.-With the overthrow of the Median empire, Cyrus proceeded to extend his kingdom to the west. This required the conquest of Babylonia west of the Tigris, and of Lydia west of the Halys River. Iydia was especially alive to the dangers of Persian aggression. Her energetic king, Crœsus, who had now under his control all of Asia Minor west of the Halys, assumed the part of defender of western $\Lambda$ sia. He is said to have consulted the oracle of Apollo at Delphi (p. 130), and to have received the response that " if he crossed the Halys 
he would destroy a great empire." Not thinking that this might apply to his own empire, as well as to that of Cyrus, he crossed the river, and after an indecisive battle retreated into his own territory. Without delay Cyrus invaded Lydia and captured Sardis. Asia Minor now beeame a part of the Persian empire.

Conquest of Babylonia and Egypt.-After the conquest of Lydia Cyrus turned his attention to his next great rival, Babylonia. With the fall of Babylon (538 в. с.), this empire also became a part of his dominions. It is to the credit of Cyrus that he permitted the Jews, who had been held in captivity since the days of Nebuchadnezzar (see page 4i), to return to their home in Jerusalem. After the death of Cyrus, his son Cambyses (529-522 в. c.) extended the Persian authority over Phœnicia, Cyprus, and Egypt. But an army sent into Ethiopia perished in the sands of the desert; and an expedition planned against Carthage failed, because the Phœnician sailors refused to serve against their kinsfolk. The rule of Cambyses was oppressive and often cruel, and was marked by frequent revolts in different parts of the empire.

Conquests in Europe under Darius.-The insurrections which attended the death of Cambyses were quelled by Darius (521-484 в. с.), who was, next to Cyrus, the greatest king of Persia. He has a special interest for us, because he was the first to extend the Persian authority into Europe-which fact paved the way for the subsequent invasion of Greece. The purpose of Darius in entering Europe was, according to Herodotus, to send an expedition against the barbarous Scythians. So far as the Scythians were concerned, this expodition proved a failure. But on his return to Asia, Darius left in Europe an army which subdued Thrace and the Greek cities to the north of the Fgean Sea, and even compelled Macedonia to acknowledge the supremacy of the great king. The Persian empire was thus extended into Europe to the boundary of Greece itself. 
PROGRESSTVE MAP No.5.

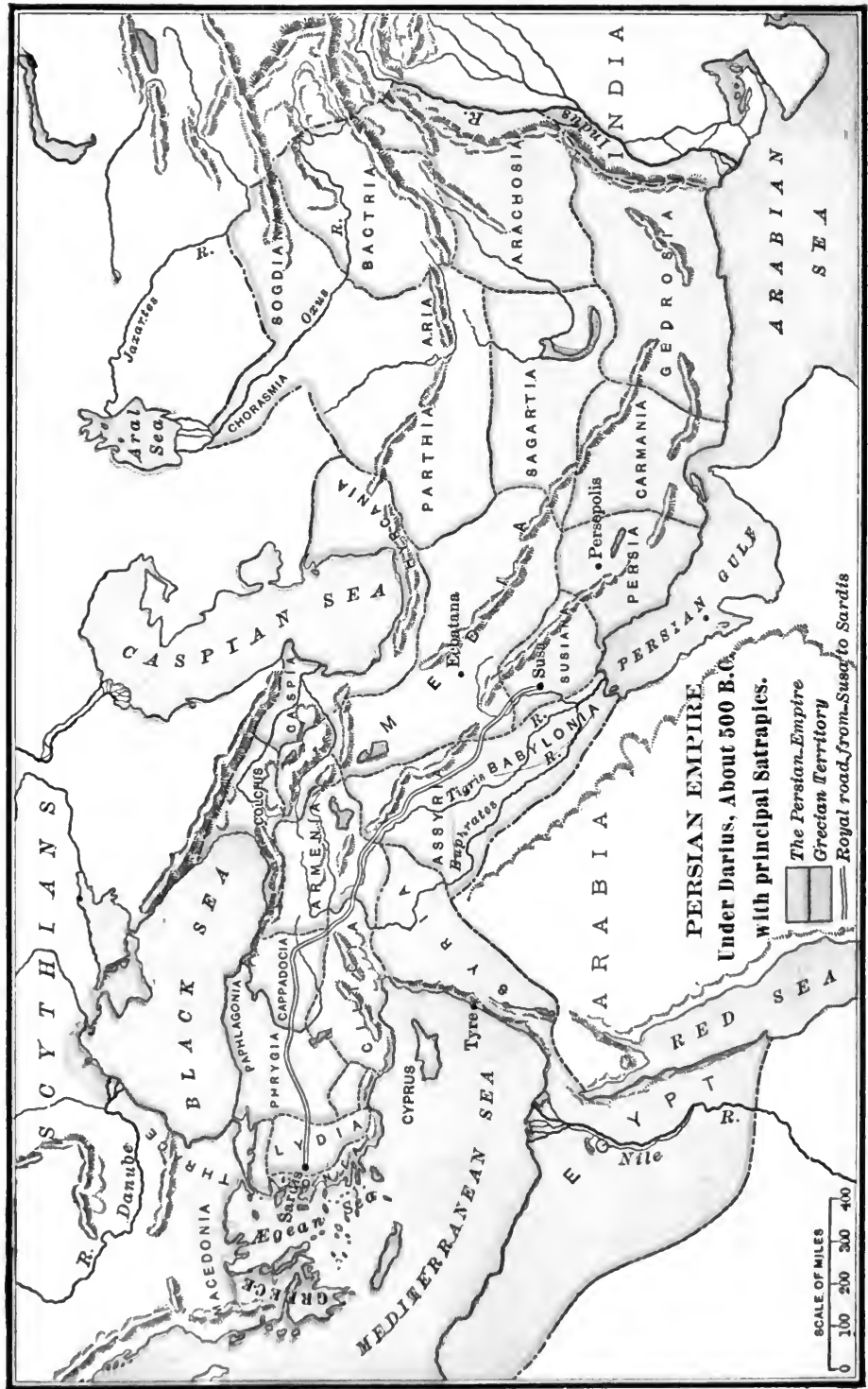


The subsequent history of Persia was closely related to that of Greece, which had by this time developed a distinct civilization of its own and had become the center of a new world culture. We shall hereafter see how Persia came into conflict with the Greek states, and how it was finally overthrown by Alexander the Great (331 в. c.).

\section{The Government anj Civilization of Persia}

Political Organization of the Empire.-In its geographical extent Persia surpassed all the previous empires of the East. It not only covered all the lands hitherto occupied by Assyria, Babylonia, Media, Lydia, and Egypt, but added to them other territory not included in these older empires. It extended from the Indus River to the Agean Sea, a distance of about three thousand miles. It comprised, in fact, the whole civilized world except India and China in the Far East, and Greeee and Carthage in the West.

The form of government established over this vast domain was patterned after that of the Assyrians, but strengthened and perfected by the genius of Darius. For the purposes of administration the territory was divided into a number of provinces, or "satrapies," each under a provincial governor, or satrap, appointed by the king. The provinces were divided into distriets, each under a deputy of the satrap. The provinces were subject to the satraps, and the satraps were subject to the king. The duties of the provincial subjects were to furnish men for the royal army, ships for the royal navy, and money for the royal treasury. The provinces were joined to the capital, Susa, by military roads, the most important of which was the great royal road from Susa to Sardis, fifteen hundred miles long. The person of the king was exalted above that of other men. He sat upon a throne made of gold, silver. and ivory. His garments were of richest silk. To serve him was the highest mark of nobility. To minister to his comfort, 
one dignitary was chosen to carry the royal parasol, another the royal fan, while other officers were appointed to perform

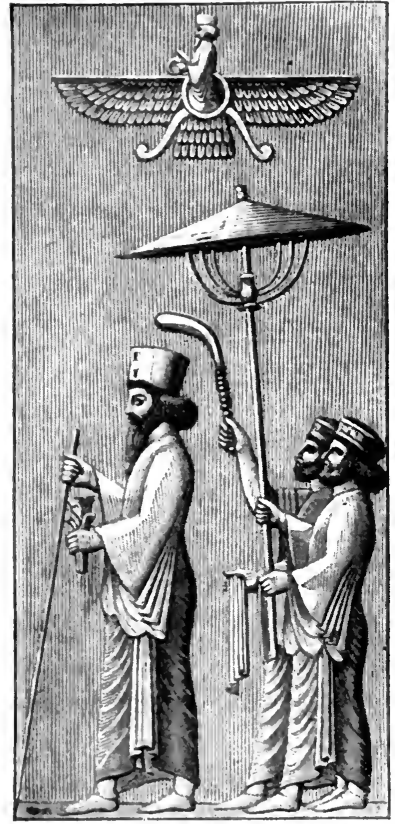

The Persian King (with attendants) other equally honorable duties.

\section{Persian Army and Navy.-} The chief support of the royal authority was the army drawn from the different provinces. When called together, it was marshaled by nations, each with its own costume and subject to royal officers. The footmen were armed with the sword, the spear, and their favorite weapon, the bow, in the use of which they were expert. The cavalry was an important branch of the army, and was very effective when fighting upon an open plain. The ehoicest part of the Persian army was the "Ten Thousand Immortals," so called because their numbers were perpetually maintained. On the sea the Persians were able to gather from their subjects a large number of ships, mostly triremes (ships with three banks of oars) armed with iron prows. With such an army and navy the Persians had already conquered Asia, and hoped to conquer Greece and Europe.

Persian Art and Literature.-As the Persians were chiefly a conquering and ruling people, they were not distinguished for their intellectual achievements. Whatever art they possessed was mostly a mere reproduction of that of Assyria and Babylon. Their architecture and sculpture, as seen in the ruins at Persep'olis and other places, show no evidences of 
marked originality. While using an Aryan speech, the l'ersians adopted for writing the wedge-shaped characters of their predecessors. 'They made no contributions to science; and for many generations they possessed no literature worthy of notice except the "Aves'ta," which was the Persian Bible.

Persian Religion and Morality.-The most distinetive feature of the Persian civilization was its religion. 'The religion of Persia was doubtless an outgrowth of a lower polytheistie nature worship; but it seems to have reached its highest de-

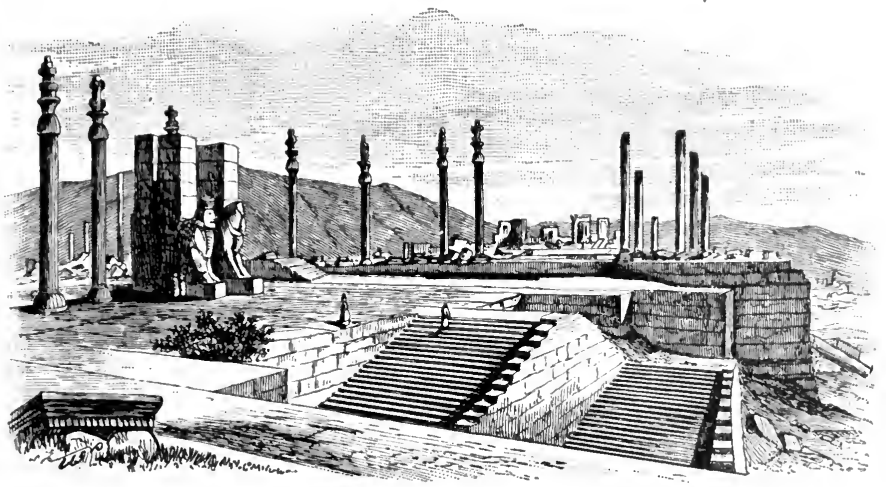

Ruins of Persepolis

velopment under the influence of Zoroas'ter. This religious reformer is supposed to have lived in Bactria about the middle of the seventh century B. c. Some scholars are inclined to believe that his name stands merely for a mythical person; while others strongly assert that "we must aeeept the historical reality of Zoroaster" (Sayce). He considered the powers of nature as separated into the powers of light and the powers of darkness - the one under the control of the great god of light (Ormuzd), who is the creator of all that is good; and the other under the control of the god of darkness (Ah'riman), who is the father of all that is evil. This is a system of religion which we call Dualism. The whole universe is looked upon as 
a struggle between light and darkness, between the good and the evil, in other words, between Ormuzd ${ }^{1}$ and Ahriman. Human life in the same way is regarded as a perpetual struggle between good and evil; and the duty of man is to cleave to that which is good and to shun that which is evil. Morality was closely related to religion. The Persians believed in truthfulness as a high moral virtue, and despised lying and deceit. The higher elements of the Persian religion were corrupted under the influence of a priestly class, the Magi, who were inclined to worship the symbol of fire in place of the god of light, and to regard the performance of religious rites and ceremonies as the chief duty of life.

Historical Significance of Persia.-The Persian empire represents the highest unity attained by the ancient Oriental world before the time of Alexander the Great. Of all the great monarchies hitherto established-the early Babylonian, the Egyptian, the Assyrian, the Median, and the later Babylonian-no one except Assyria can be regarded as properly a "world empire." Persia carried to a still higher stage of development the military and political system of Assyria. Although she made no contributions to the finer arts of life, she surpassed all her predecessors as a conquering and ruling power. She is, on this account, the prototype in Asia of Rome in Europe. She withstood the rude barbarians of the north-the Scythians-in their inroads into the civilized south. She developed a more permanent system of provincial government than had before existed-which furnished the model of that of the later Roman empire. Her religion was perhaps the nearest approach to Jewish monotheism of all the religions of western Asia. But with all her achievements she represented an old and decaying civilization, which appears in its true light when we see it brought into contact, and placed in contrast with the new and growing civilization of Greece.

\footnotetext{
1 The upper part of the picture on page 68 shows the symbol of Ormuzd, copied from the Assyrian god Assur.
} 


\section{Review of Oriental Nations}

The Beginnings of Civilization.-In reviewing the history of the Oriental world there are certain general facts which should be impressed upon our minds. In the first place, we see that it is from the Orient that the world received the rudiments of its civilization. It is here that men first passed out of the tribal state and developed a higher form of government, by the erection of cities, kingdoms, and great empires. It is here, also, that we see the early development of religion, which passed from crude forms of animal or ancestral worship to a polytheistic nature worship and finally to a monotheistic religion, like that of the Hebrews. We also find here a great advancement in man's economic life, which began with hunting and fishing or the tending of flocks and herds, and passed to the cultivation of the soil, the growth of manufactures, and the development of commerce. Moreover, the people of the Orient gave to the world the rudiments of some of the important sciences, especially astronomy and mathematics. Still further, we see a remarkable progress made in the art of writing, which began with the expression of ideas in the form of pictures, then advancing to the use of symbolic signs, and at last to the use of a phonetic alphabet such as we use to-day. Finally these ancient peoples acquired great ability, if not taste, in the art of building, beginning with huts made of sticks or clay, and passing to the use of brick among the Babylonians, and stone among the Egyptians. So thoroughly were they acquainted with the principles of architecture that many of their buildings have remained to the present time as monumients of their skill and as permanent evidences of that early civilization which we have inherited from the East.

The Course of Oriental History.-Our review of the Oriental world will enable us to distinguish certain periods, or successive stages, which mark the course of its historical development. We may briefly characterize these periods as follows: 
(1) During the first period the rudiments of civilization appeared in two separate and independent centers,-Babylonia and Egypt,- - each having a peculiar culture of its own, and each being unaffected, so far as we know, by any influences derived from the other (about 5000-3800 B. c.). ${ }^{1}$

(2) The second period is the time of the Babylonian ascendeney, when Babylonia extended its authority to the Mediterranean coast, and its culture to the lands of Syria (about 38001600 B. C.).

(3) Then followed the period of the Egyptian ascendency, when the authority of Egypt superseded that of Babylonia in the Syrian lands and the Egyptian culture became extended to this territory (about 1600-1100 в. с.).

(4) With the decline of the Egyptian power, we come to the period of Syrian independenee, which continued for two centuries, during which time the influence of Phœnicia became predominant over the Mediterranean coasts, and the Hebrew kingdom reached its height under David and Solomon (about 1100-900 B. C.).

(5) This was followed by the ascendency of Assyria as the first world empire, bringing under its control all the previously mentioned countries of the East,-Babylonia, Egypt, Phœnicia, and .Judea,- - the period of the Assyrian ascendency closing with the independence of Egypt and the division of the remaining territory between the short-lived empires of later Babylonia and Media (about 900-550 B. c.).

(ii) Lastly appeared the second great world empire of Persia, which consolidated under one supreme authority all the countries of" the Orient west of the Indus, comprising not only the nations alrearly noticed, but also the country of the Hittites and Lydia in 1 -ia Minor (about 550-331 в. c.).

The Blending of Culture by Conquest and Commerce.-In connection with the rise and fall of the different Oriental na-

\footnotetext{
${ }^{1}$ These dates are only approximate, and are substantially those adopted by I'rofessor Goodspeed.
} 
tions it is important to notice the fact that the culture of different countries became blended by means of conquests. For example, the successive conquests of Syria by Babylonia and Egypt led to that composite form of culture which marked the Phonicians, preserving both Babylonian and Egyptian f'atures, as seen in the Syrian religion and industrial arts. So the conquest of Egypt by Assyria did not destroy the existing civilization of Egypt, but rather brought the civilization of the Tigris-Euphrates valley into relation with that of the valley of the Nile. And by the extensive conquests of Persia the various centers of culture throughout the Orient were brought into communication with one another. Again, the civilizations of different peoples became mingled by means of commercial intercourse. Commerce tended to bring about the exchange not only of the products, but of the ideas of various peoples. 'This we have seen in the case of the Phœnicians, who became the common carriers not only of commodities but also of culture. Hence, by means of conquests and commerce, the different peoples of the Orient were brought together; and their civilizations became blended into a composite culture, which we may characterize in general as Oriental.

Transmission of Oriental Culture to the West.-The culture of the Eastern world was destined to overflow the boundaries of the Orient and to find its way into the Occident. There were two principal means of communication between the East and the West: the one was by the sea traffic of the Phœnicians, the other was by the land traffic of the peoples of Asia Minor. We can readily see how the Phœnicians, through their commerce ard colonies, brought the culture of Asia to the ports of Europe. The peoples of Asia Minor who furnished some means of communication between the Fast and the West. were the Hittites and the Lydians (map, p. 50). Concerning the Hittites little is definitely known; but that they at one time formed a powerful and influential nation, seems quite certain. They are said to have done much for civilization by 
taking up the arts and culture of Assyria, Egypt, and Phœnicia, and passing them on to their western neighbors. The Lydians lived on the western frontiers of the Orient and joined hands with the Greeks on the Egean Sea. It is believed that they received much of the culture of the East, not only through the Phœnicians, but also through their neighbors the Hittites. If this is so, we may conclude that the peoples of Asia Minor, as well as the Phœnicians, furnished a means for the transmission of the ancient culture of the East to the West.

\section{SYNOPSIS FOR REVIEW}

I. The Aryans and the Median Empire.-Beginnings of Aryan Civilization.-The Medes and the Persians.-The Median Empire; Cyaxares.

II. Persia, the Second World Empire.-The East before the Persian Conquests.-Rise of Persia under Cyrus.-Conquest of Lydia.-Conquest of Babylonia and Egypt.-Conquests in Europe under Darius.

HII. The Government and Crvilization of Persia.-Political Organization of the Empire.-Persian Army and Navy.-Persian Art and Literature.--Persian Religion and Morality.-Historical Significance of Persia.

IV. Review of Oriental Nations.-The Beginnings of Civilization.-The Course of Oriental History.-The Blending of Culture by Conquest and Commerce.-Transmission of Oriental Culture to the West.

\section{REFERENCES FOR READING}

Ducoudray, Ch. 6, "Civilization of the Aryans, Hindoos and Persians" (1). ${ }^{1}$

Tenormant, Vol. II., Bk. V., "The Medes and the Persians" (4). Benjamin, Ch. 7, "Cyrus"; Ch. 8, "From Cyrus to Darius" (8). Vaux, Ch. 1, "Cyrus, Cambyses and Darius"; Ch. 4, "Monuments of Persia" (8).

Clarke, Ch. 5, "Zoroaster and the Zend-Vesta" (3).

Souttar, pp. 145-190, "Medes and Persians" (1).

Bury, Ch. 6, "Advance of the Persians to the Agean" (10).

Cox, History, Bk. II., Chs. 1, 2, "The Persian Einpire" (10).

Smith. P., Ch. 28, "Decline and Fall of the Persian Empire" (t). Encyclopsedia Britannica, Art. "Hittites" (the "Forgotten Empire"): Art. "Lydia" (for coinage of Lydia).

Herodotus, 13k. I., Chs. 131-140 (Persian manners and customs); Pk. IV., Chs. 1-8, 28-100 (the Seythians) (17).

'The figure in parenthesis refers to the number of the topic in the Appendix, where a fuller title of the book will be found. 


\section{THE GREEK WORLD}

\section{PERIOD I. THE BEGINNINGS OF GREECE (-776 B. O.)}

\section{CHAPTER VI \\ GREECE, ITS PEOPLE AND EARLY LEGENDS}

\section{Hellas, the Land of the Greeks}

Greece and the 0rient.-As we approach the study of Greece we must first of all notice the close relation of this land to the Oriental countries which we have already considered. Of the three peninsulas of Europe which project into the Mediterranean Sea, Greece lies nearest to the East. Hence it would naturally be the first of European countries to feel the influence of Oriental culture and the first to develop a civilization of its own. The Aggean Sea, which lies between its coasts and those of Asia Minor, can be regarded not as a barrier, but rather as a highway uniting the East and the West. The numerous islands scattered over this sea aided the early mariners to find their way across its waters; so that these islands have been aptly called the "stepping stones" of the Egean. Greece was also open to the early commerce of the Phœnicians, who had obtained a foothold upon some of the Egean islands. Since the culture of Babylonia and Egypt had been taken up by Phœnicia and the countries of Asia Minor, the drift of Oriental civilization was in the direction of the Grecian peninsula. For these reasons we may see that Greece 
was in a certain sense the heir of the Orient, receiving in some degree the stimulating influence of Eastern culture.

Geographical Features of Greece.-The Grecian peninsula presents a striking contrast to the great countries of the East, with their broad plains and fertile valleys. Greece was a very

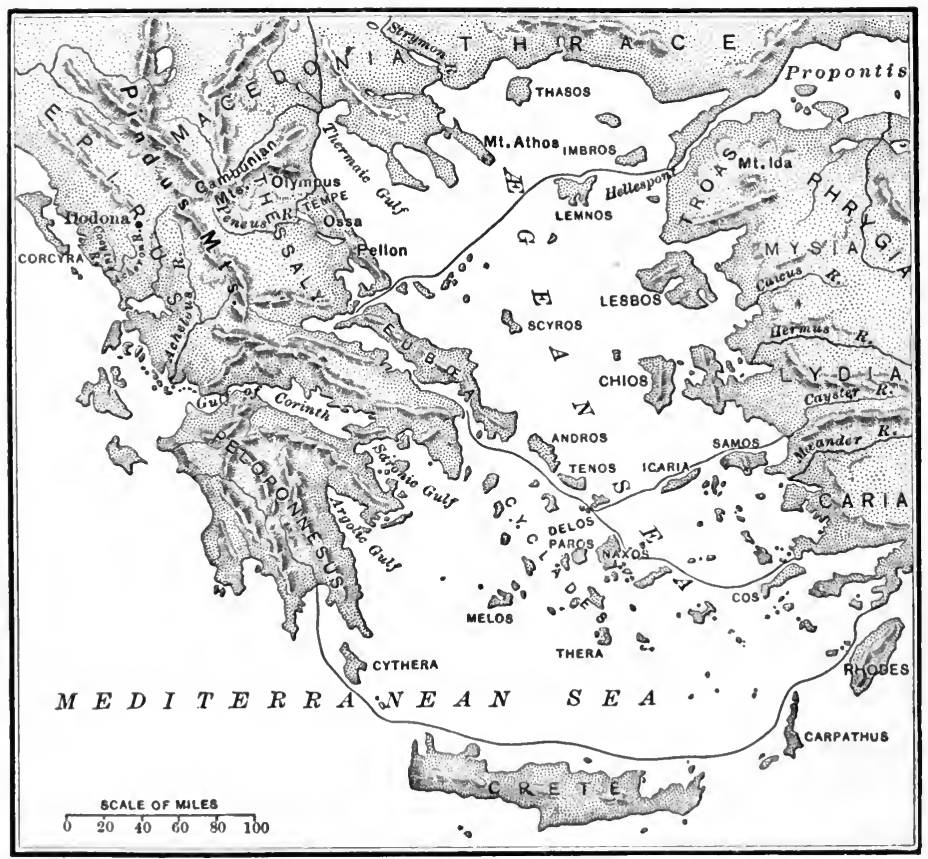

Hellas: the Fgfan Land

Routes across the Egean Sea

small country (smaller than the present state of Florida). Its surface is broken by mountain ranges and small valleys, and drained by innumerable small streams. The outlines of the country are as irregular and diversified as its surface. There is no other country of the world of the same area with such an extensive and irregular coast line. It has been called 
"the most European of European countries." It is said that there is no point in Greece more than forty miles from the coast. The many bays, gulfs, and inlets which indent its shores form the navigable waters of Greece. The climate is generally mild and temperate, but changeable with the seasons and also quite different in different localities. The soil is not very fertile; but under ordinary cultivation, it produced in ancient times wheat, barley, flax, wine, and oil. The trees vary from the pine and oak forests in the north to the lemons, oranges, and date palms in the south.

The geographical features of Greece exercised an important influence upon the character of the people and upon their history. The face of nature, with its brilliant skies and beautiful landscapes, tended to give the people a cheerful temper and a fine asthetic taste. The broken relief of the country separated the people into distinct communities, and led to the growth of many small states and to the development of a spirit of freedom and local independence. Moreover, the irregular coast line furnished an opportunity for ports and harbors, and thus promoted the commercial spirit of the people. $\Lambda \mathrm{s}$ the bays and gulfs lay mostly upon the eastern coast, Greece may be said to have "faced" toward the Orient, and thus to have been fitted by nature to receive the gifts of her more civilized neighbors.

Divisions of Greece.-To obtain a more definite idea of the peninsula of Greece and of its most noted places, we may glance at its principal divisions.

(1) Northern Greece is separated from the main part of Europe by the Cambu'nian Mountains. It comprised two provinces, Epi'rus and Thes'saly, divided by the range of the Pindus. The most famous spot in Epirus was Dodo'na, where was located an ancient oracle of Zeus. Thessaly, to the east of the Pindus, was a fertile plain, drained by the river Pene'us; this stream flows through the beautiful vale of Tempe into the Egean Sea. To the north rises Mt. Olym'pus, the highest 
peak in Greece (nearly 10,000 feet), upon whose summit the gods were supposed to dwell.

(2) Central Greece comprised a number of states of varied historical interest. Toward the west were the two provinces of Acarna'nia and of Eto'lia. In the middle of central Greece were several small provinces separated from one another by

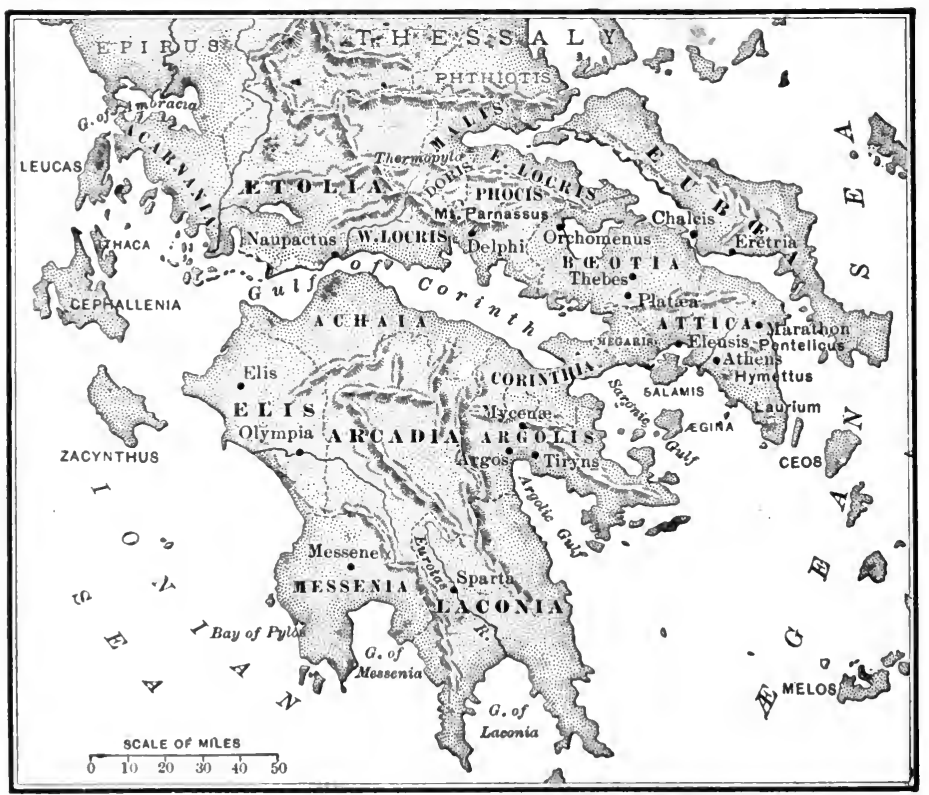

Central Greece and the Peloponnesus

mountain harriers. Of these Phocis claimed the highest renown, for it contained the celebrated oracle of Apollo at Delphi, near which rose the mount of Parnas'sus, the favorite haunt of the Muses. In the eastern part of central Greece were the three provinces of Boso'tia, At'tica, and Meg'aris. Bootia contained the cities of Orchom'enus and 'Thebes, one of which was an early seat of civilization, and the other took an 
active part in later Greek politics. East of Bootia lay the triangular province of Attica, the most noted country of Hellas. Its most famous point was the Acrop'olis, about which grew up the city of Athens, the most cultivated spot of the world. Other heights were the Pentel'icus, famous for its marble, and Hymet'tus, noted for its honey. 'The soil of Attica is not well suited for agriculture. 'The people of the rural districts were therefore compelled to live mostly upon their flocks and herds, while those near the sea engaged in commerce.

(3) Southern Greece received the name of the Peloponne'sus, । or the "Isle of Pelops." It is separated from the rest of Greece by the Gulf of Corinth and the Saron'ic Gulf, having as a bond of union the narrow Isthmus of Corinth. 'The central country of the Peloponnesus was Arca'dia; this was surrounded by a wall of mountains, the only country of Greece (with the exception of Doris) without a seaboard. To the west and north of Arcadia were the three provinces of Elis, Acha'ia, and Corin'thia. The most famous locality in these states was Olym'pia in Elis, the seat of the "Olympian games." Finally, to the east and south of Arcadia were also three provinces-Ar'golis, Laco'nia, and Messe'nia. Argolis was distinguished for the prehistoric cities of Myce'næ and Ti'ryns, and the historic city of Argos. Laconia was the home of the Spartans, who became the ruling power of the Peloponnesus, conquering Messenia and other states, and whose chief city, Sparta, became the greatest rival of Athens.

(4) The Islands of Greece are also worthy of notice. The largest of these was the island of Eubo'a, which stretches along the eastern coast from Thessaly to Attica, and contained the historic cities of Chalcis and Ere'tria. In the Saronic Gulf are the islands of Sal'amis and Agi'na, the former of which gave the name to a decisive naval battle between the Greeks and the Persians. Off the eastern coast of the Peloponnesus was a group of islands called the Cyc'lades (map. p. $\% 6$ ), the most noted of the group being the tiny island of Delos, the seat of a 
celebrated shrine of $\Lambda$ pollo. The most important island off the southern coast was Crete, which was a center of the oldest civilization of the Agean.

Greater Hellas.-The home of the Greeks, which they called Hellas, was not confined to the European peninsula and the neighboring islands. It included also the western coasts of Asia Minor. These coasts were from very early times occupied by a Greek people, and afterward received emigrants from the European peninsula. This part of the Greek world, which we may call "Asiatic Greece," comprised three divisions, named respectively from the north to the south Eo'lia, Io'nia, and Doris (see map, p. 94). Besides these Asiatic lands, Hellas, in the larger sense, came to include other lands, which we may call "Western Greece." These comprised the eastern and southern part of the island of Sicily, as well as certain territory in the southern part of Italy, known as "Magna Græcia." In fact, by the word Hellas the Greeks meant all the lands inhabited by the Greek people-the Helle'nes, as they called themselves-and these lands were continually widening with the growth of Greek commerce and colonization.

\section{The Hellenes, the People of Greece}

The Earliest Inhabitants of Greece.-It would be interesting to know precisely when, and how, and by whom all these lands about the Egean were first settled. But this is a subject concerning which we have no very extensive or definite knowledge. What we do know is that the dominant people who inhabited Greece in historical times, were people who spoke an Aryan, or Indo-European, language. But it is very likely that, before the Aryan settlements, the Aigean lands were already inhabited by an older people. We have left to us the names of some very ancient tribes which were probably pre-Aryan. Chiof among these were the people whom the Greeks called the "Pelasgians," about whom much has been 
written and little is known. 'Their name is found on both sides of the Aigean-in Asia Minor, where they are said to have fought on the side of the Trojans; in Attiea, where they were supposed by some to have been the ancestors of the Athe'nian people; and in Epirus, where they possessed at 1)odona an altar to Zeus. To this people are attributed the massive stone walls found in different parts of Greece, and often described as "Cyclope'an."

The Coming of the Hellenes.-Whatever we may think eoncerning the primitive people of Greece, we may be confident that the Hellenes, the Greeks in whom we are especially interested, and who ereated the eivilization which we have inherited, spoke a language

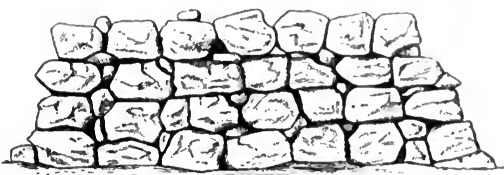

ANCIENT "CYCLOPAAN" WALL which belonged to the same family (Aryan) as that to which our own language belongs. This people probably came into Greece not by a sudden conquest but by "successive waves," becoming fused with the earlier tribes already there; but still they preserved their own speech and their own eustoms, and developed a civilization peculiarly their own.

It is now believed by scholars that the Hellenes made very early settlements upon both shores of the Agean Sea; and that "the coast of Asia Minor is just as much ancient Greek soil as European Greece" (Holm). If this is so, we ean readily imagine the general course of the ancient settlements. Moving from their earlier home,-wherever this may have been,- - the Hellenes first came into Thrace. A part of them then crossed the Hel'lespont, and, passing along the eastern shore of the Egean Sea, found new homes in Asia Minor. Another part, pushing to the west, along the northern and western shores of the Aigean, occupied Thessaly, Bœotia. Attica, and other Grecian lands. At the time of their settlement, the early Greek tribes on either side of the sea were 
scarcely advanced beyond the stage of barbarism. They worshiped their ancestors and the gods of nature; chief among these gods was Zeus, the god of the heavens. They lived upon their flocks and herds and were beginning to acquire a knowledge of agriculture, cultivating the cereals and perhaps the vine. They fought with spears and with the bow and arrow, and made their implements of stone, beginning perhaps to use some of the metals. They were acquainted with the art of navigation, certainly with the use of boats and oars; but the use of sailing vessels was probably acquired after they settled upon the Agean. With the aid of these vessels, the people of the different shores were able to communicate with one another, to occupy the intervening islands, and thus to preserve the sense of their original kinship.

Divisions of the Hellenic People.-The Greeks called themselves "Hellenes" because they professed to believe that they were descended from a common ancestor, Hellen. From this common ancestor they traced four lines of descendants, or tribes-the Achrans, the Ionians, the Dorians, and the Aolians. Their mythical relationship is indicated as follows:

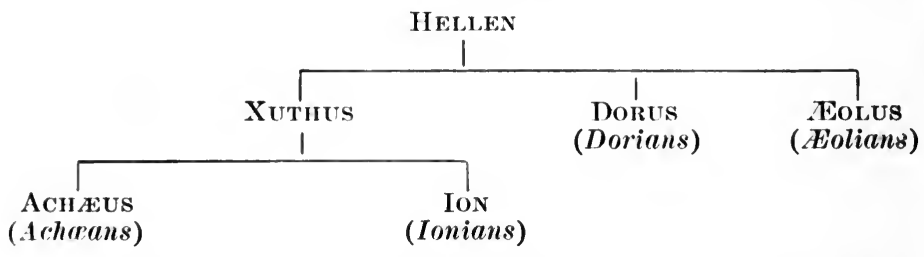

The $\Lambda$ chæans were in very early times the leading race of the Peloponnesus, being regarded by some as the founders of the kingdoms of Tiryns, Mycenæ, and Argos. The early home of the Ionians is placed on the northern coast of the Peloponnesus, also in Megaris, Attica, and the island of Eubœa. 'The Dorians are supposed to have occupied in very early times the plains of Thessaly. The name Eolian was used to cover the rest of the Hellenic people. 
The most important of these tribes during the historical period were the Dorians and the Ionians. The Dorians were a simple, practical, and warlike race, represented by the Spartans. The Ionians were a versatile, enterprising, and artistic people, represented by the Athenians. The history of these two peoples forms, in large part, the history of Greece.

General Characteristics of the Greek People.-There were certain qualities which, though especially marked in the Ionians, may be said to characterize the Greek people as a whole, and which distinguished them from the peoples of the Orient. In the first place, they possessed a strong love of freedom, which would brook no restraint except that which they imposed upon themselves, and which made them independent, wideawake, and original. In the next place, they had a political instinct, which resulted in the development of self-governing communities, and which made the Greek city something far different from the cities of the East. Moreover, they were characterized by simplicity and moderation, which were revealed not only in their art, but in their life, and which led them to shun all forms of Oriental ostentation and extravagance. Still further, they possessed great intellectual activity, which showed itself in literary productions and philosophical speculations. Finally, they were gifted with a fine æsthetic sense, a taste for beauty for its own sake, which made them the creators of a new form of art. These qualities gave to the world a new type of culture.

\section{The Early Legends of Greece}

Importance of the Legends.-The eharacter of the Greek people is strikingly set forth in their early legends- the myths and stories by which they sought in a fanciful way to explain the mysteries of nature and the origin of their own institutions. It was principally by means of these legends that the Greeks 
attempted to reconstruct their early history. ${ }^{1}$ The importance which we attach to these stories will depend very much upon our point of view. If we look at them as giving an account of actual and well-defined events, they have of course little historical value. But if we look at them as indicating the ideas and beliefs of the people, they have a great deal of significance. The nature of the early Greek mind is revealed in these traditional stories. In them we see the early fancy of a people who afterward became the masters of imaginative thought. Without a knowledge of these legends much of the literature and art of a later period would be unintelligible to us.

Legends of the Founders of Cities.- The Greeks surrounded every locaility, every mountain, stream, and vale with a halo of song and story. An important group of legends referred to the founders of cities. The foundation of Athens, for example, was ascribed to Cecrops, regarded by some as a native of Egypt; he is said to have introduced into Attica the arts of civilized life, and from him the Acropolis was first called Cecro'pia. Argos was believed to have been founded by another Egyptian, named Dan'aus, who fled to Greece with his fifty daughters, and who was elected by the people as their king, and from whom some of the Greeks received the name of Danaï. Thebes, in Bootia, looked to Cadmus, a Phœnician, as its founder; he was believed to have brought into Greece the art of writing, and from him the eitadel of Thebes received the name of Cadme'a. 'The Peloponnesus was said to have been settled by, and to have reeeived its name from. Pelops, a man from Phrygia in Asia; he became the king of Mycenæ, and was the father of $\mathrm{A}^{\prime}$ treus, and the grandfather of Agamem'non and Menela'us, chieftains in the Trojan war. Such traditions as these show that the early Greeks had some notion of their dependence upon the Eastern nations.

'Many of the early myths and legends, as narrated by Homer and preserved by IJe'siod (in his Theog'ony), were gathered into somewhat systematic form to explain the genealogy of the llellenic tribes, their suldivisions, and the origin of Greek cities. See Bury, II istory of (ireece, pp. 79-84. 
Legends of Grecian Heroes.-'That the early Greeks had an admiration of personal prowess and valiant exploits is evident from the legends which they wove about the names of their great heroes. In these fanciful stories we may see the early materials of Grecian poetry. In them we read of philanthropic deeds, of superhuman courage, and of romantic adventures. We read of Per'seus, the slayer of the horrid Medu'sa, whose locks were coiling serpents, and whose looks turned every object to stone. We read of Beller'ophon, who slew the monster Chimæ'ra, and captured the winged steed Peg'asus, on whose back he

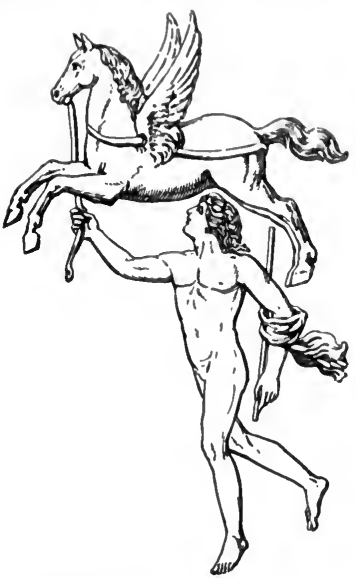

Belleropiton and Pegasus tried to ascend to heaven. We read of Minos, the king of

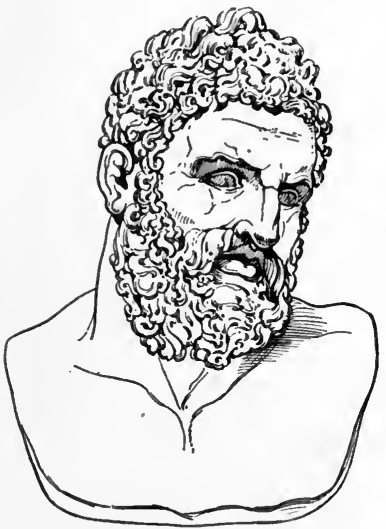

Heracles Crete, who rid the sea of pirates, and gave to his subjects a code of laws received from Zeus. We read of The'seus, who rid the land of robbers, and who delivered Athens from the terrible tribute imposed by the king of Crete-a tribute which required the periodical sacrifice of seven youths and seven maidens to the monster Min'otaur. But the greatest of Grecian heroes was Her'acles (Her'cules). Strange stories were told of the "twelve labors" of this famous giant, the prodigious tasks imposed upon him by the king of Mycenæ with the consent of Zeus. The prototype of the Greek Heracles may be found in Oriental countries-in Egypt, in Phœnicia, 
and in Asia Minor. In these countries his power was related to that of the sun. But the fancy of the Greeks turned the sun god of the East into a national hero, and conferred upon him a human character.

Legends of National Exploits.-The legends are not only grouped about particular places and individual heroes, but have for their subjects national deeds, marked by courage and fortitude. One of these stories describes the so-called "Argonautic expedition"-an adventurous voyage of fifty heroes, who set sail from Bœotia under the leadership of Jason, in the ship Argo, for the purpose of recovering a "golden fleece" which had been carried away to Colchis, a far distant land on the shores of the Euxine (map, p. 111). Another legend-the "Seven against Thebes"-narrates the tragic story of CEd'ipus, who unwittingly slew his own father and married his own mother and was banished from Thebes for his crimes, after having been made king; and whose sons quarreled for the vacant throne, one of them with the aid of other chieftains making war upon his native city. But the most famous of the legendary stories of Greece was that which described the Trojan war-the military expedition of the Greeks to Troy, in order to rescue Helen, who was the beautiful wife of Menelaus, king of Sparta, and who had been stolen away by Paris, son of the Trojan king. The details of this story - the wrath of Achil'les, the battles of the Greeks and the Trojans, the destruction of Troy, and the return of the Grecian heroesare the subject of the great epic poems ascribed to Homer. All these legends, whether derived from a foreign source, or produced upon native soil, received the impress of the Greek mind. They form one of the legacies from the prehistoric age, and reveal some of the features of the early Greek character.

\section{SYNOPSIS FOR REVIEW}

I. Hellas, the LaNd of the Greeks.-Greece and the Orient.Geographical Features of Greece.-Divisions of Greece.-Greater Hellas. 
II. The Hellenes, the People of Greece.-The larliest Inhabitants of Greece.-The Coming of the Hellenes.-Divisions of the Hellenic People.-Characteristies of the Greek P'eople.

III. The Early Legends of Greece.-Importance of the Legends.-Legends of the Founders of Cities.-Legends of Grecian Heroes.-Legends of National Exploits.

\section{REFERENCES FOR READING}

Smith, Wm., "Introduction, Outlines of Grecian Geography"; Ch. I, "Earliest Inhabitants of Greece"; Ch. "2, "Grecian Heroes" (10). . $^{2}$

Oman, Ch. 1, "Geography of Greece" (10).

Bury, Introduction, "Greece and the Agean" (10).

Cox, History, Bk. I., Ch. 1, "Physical Geography of Continental Hellas"; Ch. 3, "Mythology and Tribal Legends of the Greeks" (10).

Abbott, Vol. I., Ch. 1, "Hellas"; Ch. 2, "The Earliest Inhabitants"; Ch. 3, "Migrations and Legendary History" (10).

Curtius, Vol. I., Bk. I., Ch. 1, "Land and People" (10).

Grote, Part II., Ch. 16, "Grecian Myths as Understood, Felt and Interpreted by the Greeks Themselves" (10).

Holm, Voì. I., Ch. 1, "The Country"; Ch. 4, "The Earliest Traditional History"; Ch. 10, "Most Important Legends of Greece" (10).

Herodotus, Bk. I., Chs. 52-58 (Pelasgians and Hellenes) (17). Thucydides, Bk. I., Chs. 2-12 (early peoples of Greece) (17).

\section{CHAPTER VII}

\section{THE EARLIEST AGES OF GREECE}

\section{The Mycenæan Age}

Recent Excavations in Hellas.-Not many years ago our knowledge of the early ages of Greece was derived almost entirely from the old legends-especially those contained in the Homeric poems. These were at one time accepted as giving real historical facts, but were afterward rejected as purely

${ }^{1}$ The figure in parenthesis refers to the number of the topic in the Appendix, where a fuller title of the book will be found. 
imaginary. But recent excavations have thrown a new light upon these early ages, and opened a new world to the student of Greek history. 'The story of these diggings among the ruins of the old cities of the Egean has an almost romantic interest. 'The name most closely connected with them is that of Dr. Schliemann, the German archæologist. It was his childlike faith in Homer and the tale of Troy that led him to seek for the 'Trojan eity and the palace of Agamemnon,king of Myeenæ. The excavations made by him (beginning in 18\%1), together with the work of his successors, have not only given us new ideas regarding the poems of Homer, but have also presented many new and difficult problems regarding the early ages of Greece. We ean do no more here than to refer briefly to the most important of these exeavations, and the relics they have disclosed.

Hissarlik and the City of Troy.-The hill of Hissar'lik, situated in 'Tro'as, in northern Asia Minor, was believed by Dr.

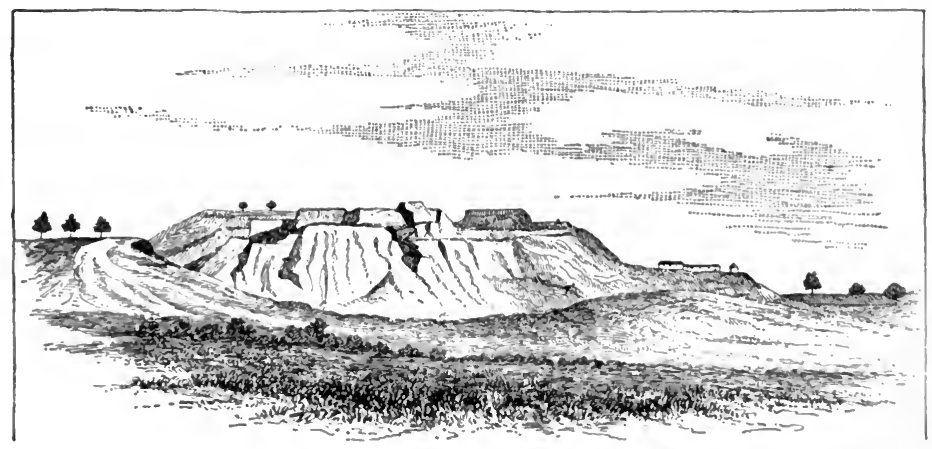

The Hill of Hissarlik

Schliemann to be the site of 'Troy. But instead of finding here a single city, he found the ruins of nine cities. lying one above another and representing different stages of human progress. The lowest eity contained relies of the stone age-stone axes, 
flint knives, earthen vessels covered with rude decorations. The second eity-evidently destroyed by a conflagration and hence called the "burnt city" - was surrounded by walls built of brick and placed upon rough stone foundations. It contained a palace surrounding a court. Among the ruins were found battle-axes, spearheads, and daggers made of copper, showing that its inhabitants belonged to what we call the "age of bronze." 'There were found also articles of fine workmanship, showing an Eastern influence-cups of silver, diadems, bracelets, earrings made of gold, and also articles of ivory and jade which could have come only from central Asia. This "burnt eity" was believed by Dr. Schliemann to have been the Troy of Homer. But the later work of Dr. Dörpfeld, the distinguished colleague of Schliemann, has shown that the sixth city-with its great circuit walls, its stately houses of well-dressed stone, and its finely wrought vases-is more likely to be the city described in the Homeric poems.

The Citadel of Tiryns.-But the most important remains of this prehistoric age have been found, not in Asia Minor, but in European Greece, especially in two cities of ArgolisTiryns and Mycenæ. Tiryns is the older of these, and its walls, too, are better preserved. The citadel of Tiryns was surrounded by massive walls. The palace consisted of a complicated system of courts, halls, and corridors, suggesting an Oriental palace rather than any building in historic Greece. The most artistic features of the palace were alabaster friezes, earved in rich patterns of rosettes and spirals, such as are described in the Homeric poems (Odyssey, Bk. VII.).

The Ruins and Relics of Mycenæ.-The prehistoric culture of Greece probably reached its highest development at Mycenæ. One of the most conspicuous objects here was the well-known "lion gate" (p. 92). through which the citadel was entered, and which had been an object of interest to the later Greeks. The form of these rampant lions has often been compared to similar designs in the East, especially in Assyria and Phrygia. 
Within the walls near the gate was found a cirele of upright slabs inclosing a number of graves. These contained human bodies and a wealth of art treasures-articles of gold, silver, copper, bronze, terra cotta, glass, ivory, and precious stones; articles of ornament, such as dirdems. pendants and rings of artistic design; articles of use, such as bowls, pitehers, cups, ladles, spoons, ete. 'These articles show a high degree of mechanical skill and artistic taste. Some of them may have been brought from the East, and some of them may have been the products of native industry. Below the citadel was found another type

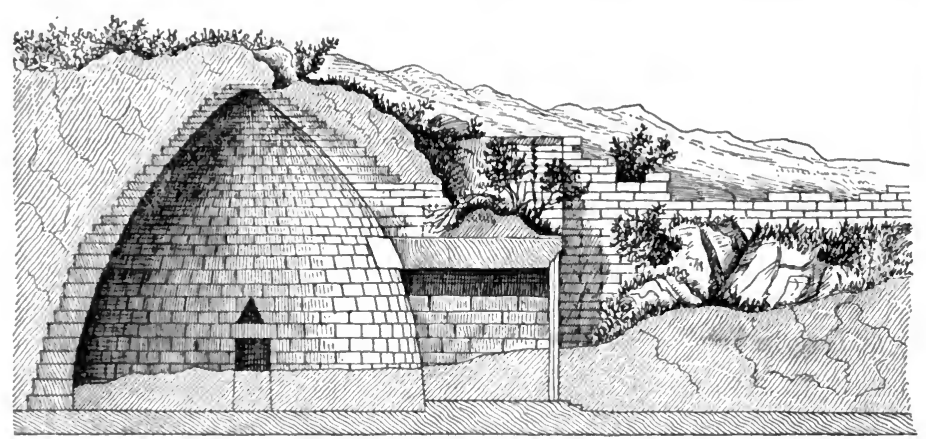

The So-called "Treasury of Atreus"

of sepulchers, called from their peculiar form "bee-hive tombs." one of which the archæologists have called the "Treasury of Atreus." 1

0ther Sites of Prehistoric Remains.-Recent excavations have shown that the kind of culture which existed in the prehistoric cities of Tiryns and Mycenæ prevailed in many other parts of Greece, and in many islands of the Egrean. At Orchomenus, in Boeotia, was discovered an elaborate and beauti-

${ }^{2}$ Such structures were at first supposed to be places where the kings kept their treasures. The ancient writer Iausanias mentions at Mycena "underground structures of Atreus and his sons where they kept their treasuries." IBut archrologists are now agreed that these structures were not treisure-homses but tombs. See Tsountas and Manatt, Mycensan Age, p. 117 . 


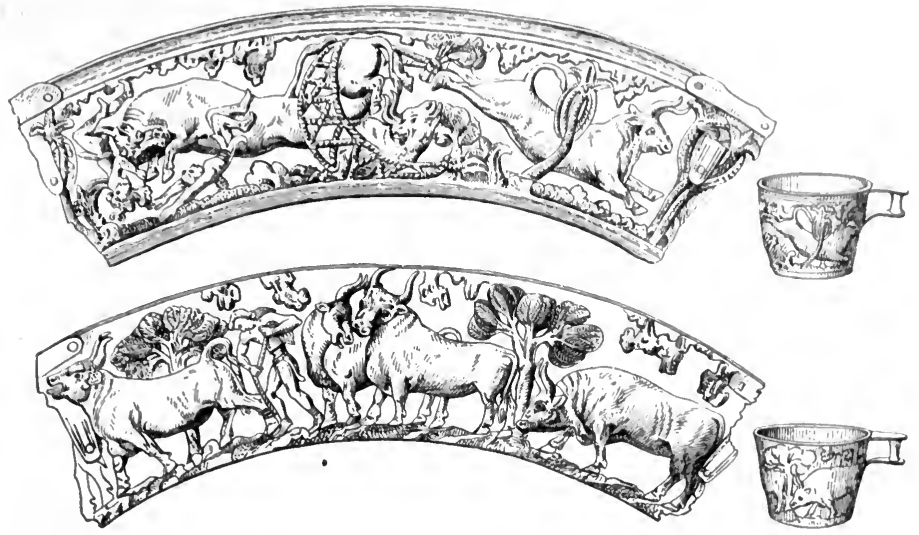

The Vaphio Gold Cups

ful ceiling said to be of a pure Egyptian pattern. At Vaphi's (near Sparta) were found two remarkable gold cups covered with finely wrought relief work, and regarded by some as the most artistic work of the prehistoric age. In Crete has been discovered a crude and curious form of hieroglyphic writing. But a strange feature of these remarkable discoveries is not the presence of writing in Crete, but the almost total absence of writing and inscriptions

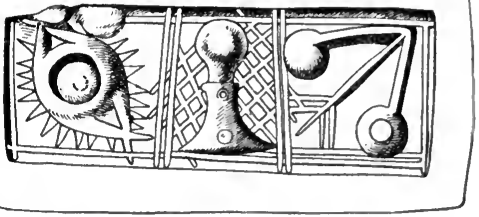

Preinstoric Writing from C'rete everywhere else among a people who possessed so many of the evidences of civilization.

Character of the Mycenæan Culture.-The type of civilization brought to light by these discoveries has been called by some "Mycenæan," from the city in Argolis where its remains are most conspicuous; and by others it has been called "Agean," from the fact that it seems to have extended over a large part of the Agean basin. It is supposed to have reached 
its culmination perhaps between the years 1500 B. c. and 1200 B. c. But there is reason to believe that in its earlier stages it may have extended back as far as 2000 B. C., or even to an earlier date. Its last and deelining stage was evidently closed by the I orian migration about $1000 \mathrm{~B}$. C., when it was swept from Creece, its memory still lingering in the minds of those

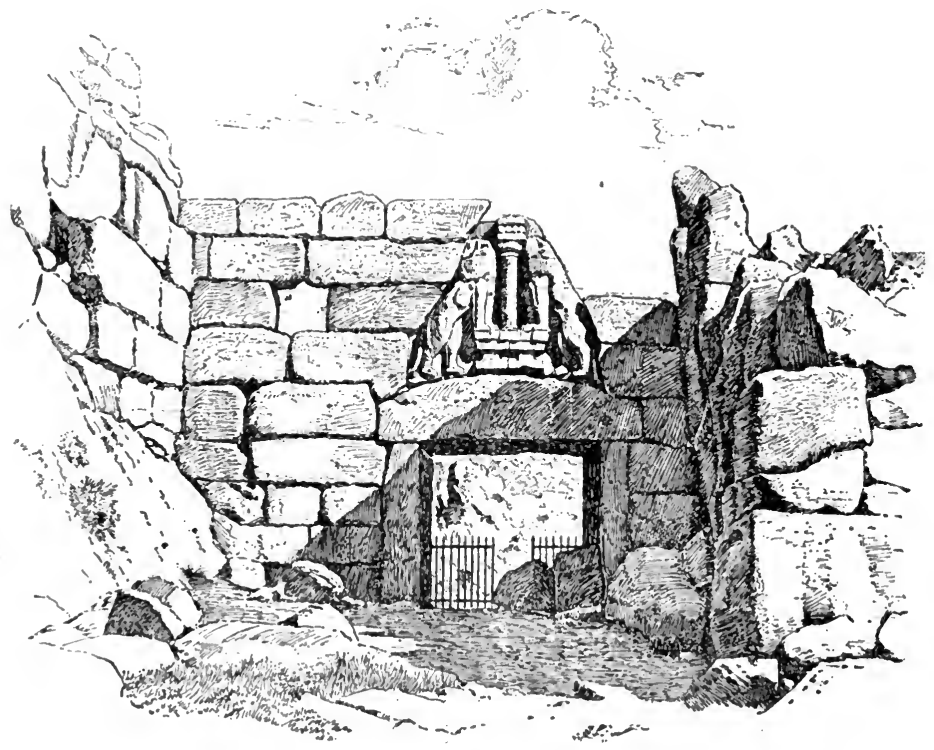

The "Lion Gate" at Mycena

tribes that migrated to the coasts of Asia Minor. Regarding the origin of this ancient eulture of Greece we have no right to speak with confidence, since scholars are by no means agreed upon the question. We may venture the opinion that this culture-with its strange mingling of crude art, of massive walls, of palatial buildings. of Oriental designs, and of objects showing a high mechanical skiil and eastern taste-may have been developed by the early people of Greee who were brought 
into close commercial and intellectual relation with the people of the Orient. Whatever we may think of its character and origin, we know that it exereised but slight influence upon the classic art of Greece, but passed away, leaving scarcely more than monuments and memories. These memories, however, furnished an inspiration to the poets and minstrels of the Homeric age.

\section{Transition to the Homeric Age}

The So-called Dorian Migration.-The brilliant period of ancient Greece which we call the Mycenæan age, was evidently brought to a close by a great movement which affected practically a large part of the Greek world. It seems quite certain that about the year 1000 в. c. there was a general disturbance of the population throughout Greece. This was due to the movement of the northern tribes into the south, resulting in the displacement of the old inhabitants and the destruction of the old civilization. This movement is called the "Dorian migration." It is known in the traditional history as the "Return of the Heracli'dæ"-being mixed up with stories regarding the descendants of Heracles. Notwithstanding the myths connected with it, it must be regarded as a real movement, which affected nearly all the tribes of Greece, and which may have extended over many generations. As a result of this movement, we find the Dorians, who formerly occupied Thessaly, now the leading race of the Peloponnesus.

The Migrations to Asia Minor.-The invasion of the Peloponnesus by the Dorians resulted not only in rearranging the tribes in Greece proper, but also in bringing about a closer union between Greece and Asia Minor. The people who had been dispossessed of their old homes in Greece, or who were not satisfied with their new ones, sought other settlements across the sea. The coasts of Asia Minor, already peopled by an ancient Greek race (p. 81), now received a new population 
PROGRTRSIVF MAP No.6.

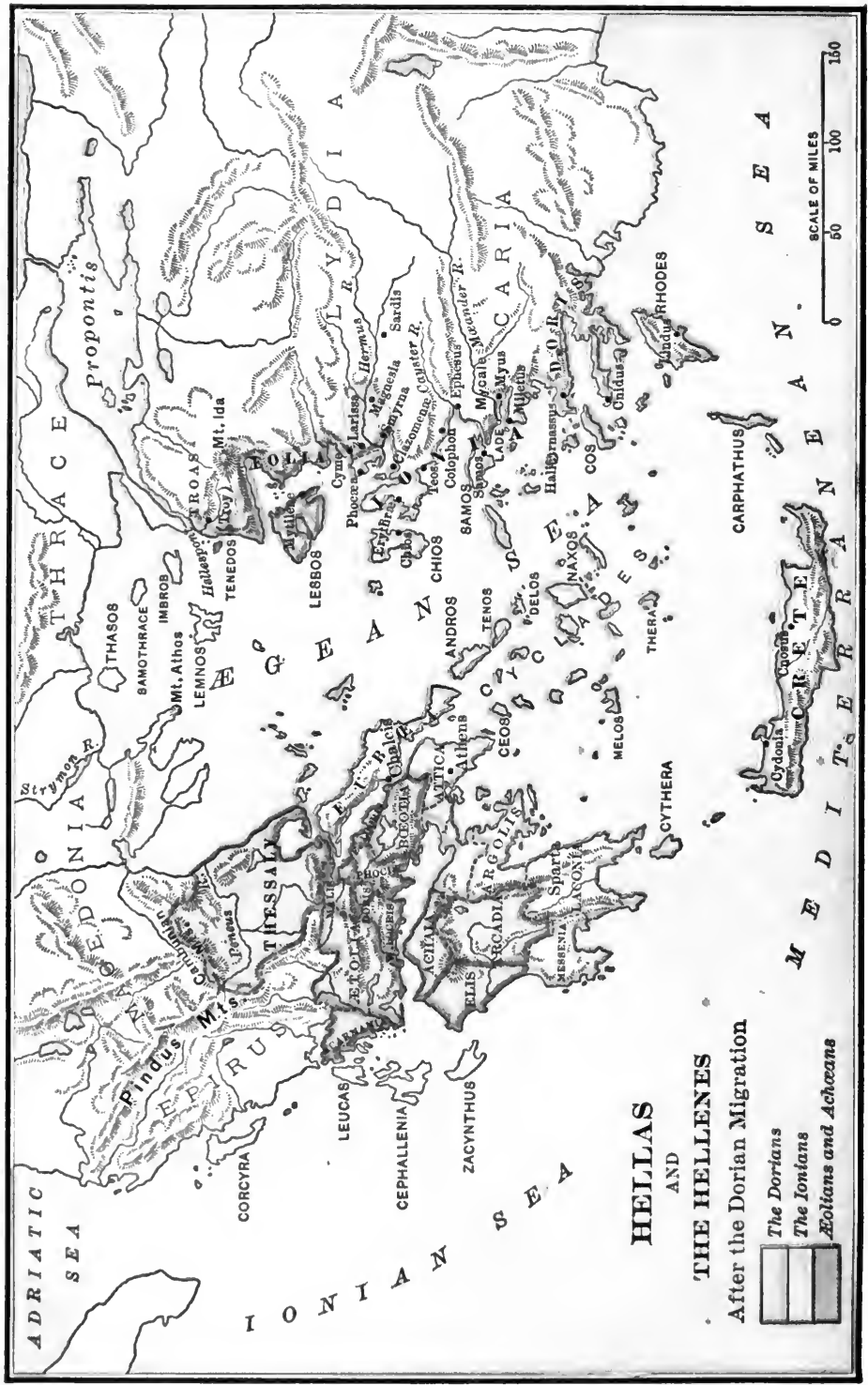


from the European peninsula. There were, in fact, three streams of migration from Greece to Asia Minor.

(1) One stream of migration was made up of the Erolians, -which name came to be a general term applied to all who were not Ionians or Dorians, including even the Achwans. 'This mixed people took possession of the northern part of the western coast of Asia Minor. They occupied the island of Lesbos and founded the important city of Mytile'ne. Their settlements upon the coast extended nearly as far north as the Hellespont, and as far south as the river Hermus. But the settlements upon the mainland had less historical importance than those upon the island of Lesbos, where the people became noted for their culture, especially in music and poetry.

(2) A second stream of migration comprised the Ionians, who settled upon the central part of the coast. They took a course across the sea by way of the Cyclades, leaving on these islands colonies of their own people. They took possession of the islands of Chios and Samos. They occupied the coast land from Phocæ'a to Mile'tus, and the latter city became especially noted for its commerce and its colonies.

(3) A third stream was that of the Dorians, who took a southern course by way of Crete, where they left their colonies. They also occupied Rhodes and Cos, and on the mainland they established Halicarnas'sus and other less important towns.

The New Culture of Asia Minor.-The invasion of the Dorians and the migrations to Asia Minor mark the decline of the old Mycenæan age. But these movements also mark the transition to a new phase of culture in Asia Minor. We shall find that during this transitional period the cities of Asia Minor became the chief centers of intellectual life and activity. But the new culture of Asia Minor did not consist in reproducing the works of Mycenæan art; it consisted rather in rehearsing the traditional glories of that golden age. The bards of Ionia recounted the mythical stories of the gods, the legends of ancient heroes, and the traditions of Troy and 
Mycenæ. They accompanied their words with regular strokes upon the lyre; and their fanciful stories fell into rhythm and took the form of the hexameter verse. The group of Ionian bards in Asia Minor received the name of the "cyclic poets"; and the group of narrative poems which they produced is known as the "epic cycle." These lays were descriptive in character and inspired with an heroic spirit; they were full of imagination, reciting the deeds of gods and men and throwing a halo about the past.

\section{The Homeric Poems and the Homeric Age}

The Iliad and the 0dyssey.-From the cycle of poems that sprang up in Asia Minor there emerged two great epics, known as the "Il'iad" and the "Od'yssey." Being the fittest expressions of the popular thought and feeling, they survived. 'They are, in fact, regarded by many critics as the greatest epic poems in the world's literature. 'The Iliad is a poem of war, and the

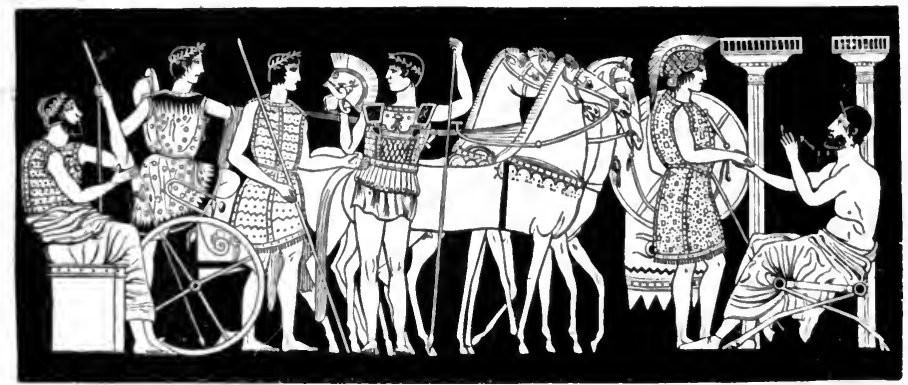

Departure of Achilles (From an ancient vase)

Odyssey is a poem of peace. The former describes the closing scenes of the Trojan war, and revolves about the wrath of Achilles, the warlike son of the king of 'Thessaly. 'The leader of the Grecian armies was Agamemnon, king of Mycenae. and hence we find many traditions which reach back to the Myconxan age. 'The Odyssey narrates events which were 
supposed to follow the Trojan war, especially the wanderings of Odys'seus (Ulysses) on his return to his home.

The Homeric Question.-These poems stand out prominently from an otherwise dark and obscure period. 'They have naturally been made the subject of the most searching inquiries. Was there ever such a poet as Homer? Were the Iliad and Odyssey both produced by the same person? Was either poem originally a single production? Was not each one rather a collection of separate ballads, afterward brought together' by some skillful hand? These queries comprise the chief points in what is called the "Homeric question." The ancients generally believed that the two epics were produced by the same poet, and that this poet was Homer. Certain critics of Alexandria, observing the difference between the two poems, declared that they were pro-

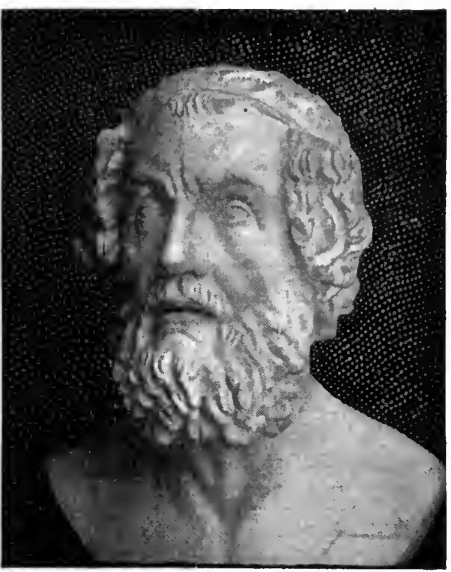

HOMER duced by two different poets. Modern critics have submitted the theory that each poem was a collection of lays, originally distinct, but collected into a coherent form during the historical period. This question will perhaps never be settled to the satisfaction of every one.

Historical Value of the Homeric Poems.-Whether the Iliad and Odyssey were the product of one poet or not, they were evidently produced in the transitional period (probably about 850 в. c.) between the prehistoric age of Tiryns and Mycenæ, and the historic age of Sparta and Athens. They are made up largely of legends and traditions, and so far are no more valuable than any other legends and traditions. But traditions 
are not necessarily false. The recently discovered relies of the prehistoric age show how faithfully the memories of "golden Mycenæ" were preserved by the people who migrated to Asia Minor and were expressed in the Homeric poems. But the great historieal value of these poems does not consist merely in the narrative of traditional events and the pictures of past glories. It consists rather in the great number of allusions made to the life and customs of the early Greek people. Homer painted the past in the colors of his own time. From the numerous allusions made to industry and art, to society and government, to religion and morality, we can get a comprehensive view of that early culture which existed among the prehistoric Greeks of $\Lambda$ sia Minor, and which was bequeathed to the Greeks of historical times. It has been foreibly said that " while the pre-Doric art in Europe was not continued in later times, and the later genuine Greek art followed other paths than those of Myeenæ and Orchomenus, the earliest poetry of Asia Minor is still the truest expression of Greek life that exists" (IIolm).

\section{The Homeric Society and Government.-In the Homeric} poems we see the picture of a simple and primitive society, such as we find among other early $\Lambda$ ryan peoples. Its primary element was the family, conprising the household father, the mother, the children, and the slaves. The families were grouped into clans, and these into tribes. The tribe was governed by a king (bas'ileus), who performed the religious rites of the tribe, settled disputes, and commanded the people in time of war. He was assisted by a council (bou'lé), made up of the chiefs of the clans. Matters of great importance, like the declaration of war or the distribution of plunder, might be left to the assembly (ag'ora), which comprised all the people capable of bearing arms. In times of war several tribes might unite under a common chieftain; for example, in the expedition against 'l'roy, the (ireck tribes were united under the leadership of Agamemnon, king of Mycenæ. 
Homeric Industry and Art.-We may also obtain from the Homeric poems an idea of the degree of progress made by the early Greeks in the art of living. They obtained their fool, not only by hunting and fishing, but also by the domestication of animals and by the cultivation of the soil. They had the use of at least six metals,-gold, silver, iron, lead, copper, and tin,-which they obtained mostly from other lands. They worked the metals in a simple way, and did not possess the fine mechanical skill seen in the more ancient works of the Mycenæan and Oriental art. The descriptions, contained in the poems, of princely palaces with their rich decorations and furniture, are based upon the traditions of an age which had passed away, but which had not been forgotten.

Homeric Religion and Morality.-The religion of the Homeric age was evidently derived from the nature worship of the early Aryans. The Greeks coupled with their nature worship an elaborate and beautiful mythology; and they saw in their gods beings like themselves, with human feelings and foibles, with human likes and dislikes. The gods were supposed to dwell about the top of Mit. Olympus, where they feasted and held their couneils. They took part in the battles of the Trojan war, and assisted the Greeks

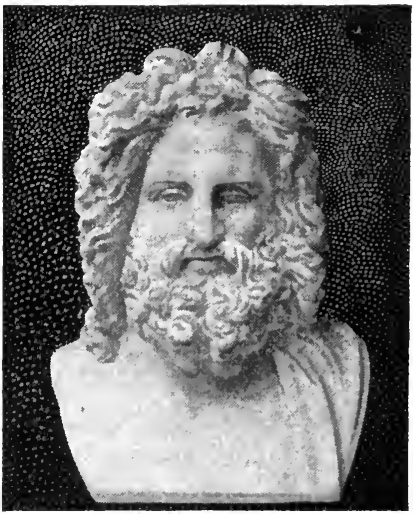

Zeus or the Trojans according to their preferences for either party. At the head of the divine cirele was Zeus, the god of the heavens and the father of gods and men. Around him were gathered the other Olympian deities. The Olympian circle consisted of the greater deities, comprising six gods and six goddesses. The six gods were: (1) Zeus (Jupiter), the supreme 
god of the heavens, the king and father of mankind; (2) A pollo, god of light and of prophecy; (3) Ares (Mars), god of war; (4) Hermes (Mercury), the messenger of the gods, the patron of commerce, and the master of cunning; (5) Posei'don (Neptune), god of the sea; and (6) Hephas'tus (Vulean), god of fire. The six goddesses were:(1) Hera (Juno), the wife

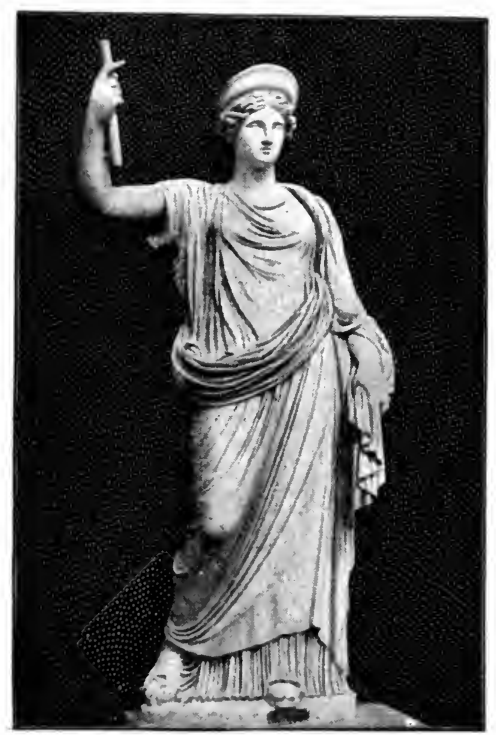

IIERA of Zeus and the queen of heaven ; (2) Athe'na (Minerva), goddess of wisdom, who was born from the forehead of Zeus; (3) Ar'temis (Dian'a), goddess of the chase; (4) Aphrodi'te (Venus), goddess of love and beauty; (5) Deméter (Ceres), goddess of the harvest; and (6) Hestia (Vesta), goddess of the hearth. Besides these superior deities there were a large number of inferior gods, as well as mythical beings, with which the Greekimagination peopled the sky, the earth, and the sea. The Greeks believed that the favor of the gods may be obtained by prayers and sacrifices, and that their will may be discovered by means of signs and oracles. They also believed in a future life, where those who had found favor with the gods would receive a place in Elys'ium, the field of the blest; and those who had incurred their anger would be condemned to 'Tar'tarus, the gulf of torment. The people of Homeric Greece were probably no better and no worse than the early people of other countries. They lived a bright and cheerful life. In peace they were hospitable to the stranger; in war 
they were vindictive and cruel to their fallen foes. 'i'hoy had a high respect for women; but they were often deceitful in their commercial dealings and regarded piracy as an honorable calling. Their highest motive of life was to obtain the approval of the gods.

\section{SYNOPSIS FOR REVIEW}

I. The Mrcendean AgE.-Recent Excavations in Hellas.-IIissarlik and the City of Troy.-The Citadel of Tiryns.-The Ruins and Relics of Mycenæ.-Other Sites of Prehistoric Remains.Character of the Mycenæan Culture.

II. Transition to the Homerfc Age.-The So-called Dorian Migration.-The Migrations to Asia Minor.-The New Culture of Asia Minor.

III. The Homeric Pofms and the Homeric Age.-The Iliad and the Odyssey.-The Homeric Question.-Historical Value of the Homeric Poems.-Homeric Society and Government.Homeric Industry and Art.-Homeric Religion and Morality.

\section{REFERENCES FOR READING}

Bury, Ch. 1, "Beginnings of Greece and the Heroic Age" (10).

Oman, Ch. 2, "Agean Civilization"; Ch. 3, "The Homeric Poems and the Greeks of the Heroic Age"; Ch. 5, "The Great Migrations" (10).

Hall, Ch. 7, "Mycenæ's Place in History" (13).

Schuchhardt, Ch. 1, "Life of Dr. Schliemann"; Ch. 2, "Troy"; Ch. 3, "Tiryns"; Ch. 4, "Mycenæ" (13).

Smith, Wm., Ch. 3, "State of Society of the Heroic Age"; Ch. 5, "The Poems of Homer" (10).

Abbott, Vol. I., Ch. 5, "The Homeric Poems" (10).

Grote, Part I., Ch. 21, "Grecian Epic-Homeric Poems" (10).

Warr, Ch. 2, "The Homeric Poetry" (14).

Mahaffy, Survey, Ch. 2, "The Homeric Age" (10).

Fowler, Ch. 3, "The Homeric Question" (15).

Freeman, Essay, "Homer and the Homeric Age" (3).

Holm, Vol. I., Ch. 13, "Civilization of the Asiatic Greek-Homeric Poetry"; Ch. 14, "Institutions and Mode of Life of the Early Greeks, Especially as Described by Homer" (10).

Jebb, Homer, Ch. 2, "The Homeric World" (14).

Keller, Ch. 3, "Religious Ideas and Usages"; Ch. 5, "Narriage and the Family"; Ch. 6, "Government," etc. (14).

Homer, Iliad, Bk. I. (contention of Achilles and Agamemnon); Odyssey, Bk. VT. (the palace of Alcinouis) (17).

See also $\Lambda$ ppendix (13) Mycenrean Age and (14) Homer and the Homeric Age.

${ }^{1 T h e}$ figure in parenthesis refers to the number of the topic in the Appendix, where a fuller title of the book will be found. 


\title{
PERIOD II. DEVELOPMENT OF THE GREEK OITY STATES $(776-500$ B. O.)
}

\author{
CHAPTER VIII \\ POLITICAL GROWTH AND EXPANSION OF GREECE
}

\section{The Early City State}

Importance of the Greek Cities.-We have already seen among the early Greeks some evidences of their political life. The cities of the Mycenæan age were evidently ruled by kings of the Oriental type, with their sumptuous palaces and their subject population. Next, in the Homeric period, we have seen a simpler form of political life, in which the government was divided between the king, the council, and the assembly. This form of government was very primitive in character, but from it sprang the eity states of historical Greece. It is in these city states that we are to find the beginnings of political freedom, and in fact the germs of modern eonstitutional liberty. As we study the growth of the cities we must observe the striking contrast between them and the cities of the East. The Oriental cities were governed solely by the king, or by viceroys subject to the king; and this resulted in the growth of autocratic and despotic governments, in which the people had no part. In the Greek eities, on the other hand, the people obtained a certain share in the government; and this resulted in the growth of institutions more or less democratic in character. Even at the beginning of the historical period we find many centers of city 
life in different parts of Greece. 'These cities were in a more or' less flourishing condition and could already boast of great age. 'Their origin is hidden in the mists of tradition; and we must form our ideas of their early development chiefly by studying the elements of which they were composed. ${ }^{1}$

The Elements of the City State.-The early Greek state was no doubt the result of a slow process of growth. We may trace its gradual development from the family, the primitive element of Greek society. The family was governed by the father, who presided over the family worship, and controlled all its members. The family expanded naturally into the clan, or gens, which was essentially the larger body of family relatives, held together by a common worship and by a common feeling of kinship. The clan was governed by a council of the household fathers, and by a chief man selected to preside over the common worship, to settle disputes, and to lead the people in time of war. In times of great danger the different clans would be induced to unite in a larger body, called a brotherhood or "phratry." This, too, had its own chief and council, and its armed men might be called together in an assembly to decide on questions of war. To repel a common peril the phratries would league themselves into a still larger body called the "tribe," which would also have its own leader, council, and assembly. By these successive unions was gradually developed the tribal state such as we find in Homeric times (compare p. 98); and this grew into the city state of the historical -period. The elements which entered into the city state were thus the family, the gens, the phratry, and the tribe.

The Government of the City State.- The city was generally formed by a union of tribes. The people sought a common

1 Among the most important of these cities were the following: in central Greece, Athens, Eleu'sis, Platæ'a, Thebes, Orchomenus, Delphi, Naupactus; in the northern Peloponnesus, Mycenæ, Tiryns, Argos, Ne'mea, Corinth, Sic'yon (sish'i-on), Elis, Olympia; in the southern Peloponnesus, Sparta, Amv'clæ, Heios, Mantine'a, Te'gea, Pylos. (For the location of these cities, cee maps, pp. 78, 119). 
center of defense on some elevated spot-like the Acropolis of Athens-which could be fortified, and to which they might retreat in times of danger. They were held together by the worship of some common deity, whom they regarded as their protector. The city population comprised not simply the people who lived within the city walls but also those who lived in the surrounding country -in fact, all those who shared in the common city worship and were subject to the common city government. This government in early times was patterned after that of the tribe, and consisted of the king, the council, and the assembly.

(1) The city king (basileus) was, like the older tribal chief, the leader of the people in time of war, the priest of the common city religion, and the judge to settle disputes between the citizens. He governed by no written laws, but tried to uphold the existing customs of the people and what he supposed to be the will of the gods.

(2) The city council (boulé) was, like the council of the tribe, made up of the leading men of the community. They formed a sort of advisory body, which was called together whenever the king desired. On account of their influence they might guide or restrain the power of the king; and on account of their superior birth or position, they came to be an aristocratic class, or what we might call a body of nobles.

(3) The city assembly (agora), like the tribal assembly, was composed of all citizens capable of bearing arms. As the state was formed originally for the purpose of protection, and as it thus had primarily a military character, the people were generally consulted only on questions relating to war. But as the state acquired more and more a civil character, the assembly of the people came to be a more important element in the government.

Independence of the City States.-The Greek world was made up of a large number of these little city states, which for the most part preserved their local independence. This was 
due largely to the broken nature of the territory, which kept the different communities separated from one another. It was due also to the independent spirit of the people themselves. The national life of Greece thus became localized in the cities. The spirit of patriotism consisted in the love of one's own city; and the great achievements of the Greeks were made to glorify the city. This spirit of independence had both a good and a bad effect. On the one hand, it tended to foster free institutions and the forms of local self-government. On the other hand, it prevented the permanent union of Greece and the development of a national state.

Amphictyonies or City Leagues.-Although the Greek cities were politically independent of one another, they sometimes united themselves into leagues or confederacies, called "amphictyonies." These leagues were often formed to maintain the worship of some common deity, or to promote common commercial interests, or to protect the cities against a common foe. The members of these associations often professed to believe that they were descended from some common ancestor, and were under the protection of the same god. Sometimes one city obtained the leadership, or " hegemony," over the rest; but if such a leadership became oppressive, it generally provoked a revolt on the part of the subject cities. In the course of our study we shall have our attention called to a number of these Greek confederacies, like the Amphictyon'ic League with its center at Delphi, the Peloponnesian League under Sparta. the Bœotian League under Thebes, the Delian Confederacy under Athens, and in later times the Achæan and Atolian leagues organized against Macedonia.

\section{Political Development in Greece}

Tendency to Revolution.-When we consider the political organization of the Greek city states, we must not suppose that they always remained in the simple and primitive condition 
which we have just described. Their political life, on the contrary, was one of continual activity and change. One form of government succeeded another as the king, or the nobles, or the people gained the upper hand. Although the different cities presented a great diversity in their political life, we can trace a general tendency in the direction of more democratic ideas and freer institutions.

From Monarchy to Aristocracy.-In the earliest times, the king was the most prominent figure in the government. This supremacy of the king and the royal family is what constitutes a monarchy. When the rule of the king became oppressive, the political power passed into the hands of the nobles. The supremacy of such a class of influential men in the state is what constitutes an aristocracy. If the power is restricted to a very few persons, the government is called an oligarchy. At an early period the political authority in the cities passed from the hands of the king to the hands of the nobles; that is, there was a transition from monarchy to aristocracy or oligarchy.

From Aristocracy to Tyranny.-When the nobles obtained the supreme power in the city, they were tempted to use it for their own interests, at the expense of the people in general. The city population thus came to be divided into two parties, the aristocratic and democratic parties-the former striving to maintain their own power and privileges, and the latter struggling to obtain an equality of rights. In the midst of these popular discontents there appeared certain men whom the Greeks called "tyrants." The so-called tyrant was not necessarily a despotic ruler, but a man who had seized the power of the state in an irregular way. He might be a patriot, working for the interests of the people, or he might be a demagogue, working for his own interests. In either case, he was an enemy to the oligarchy, and his triumph meant the overthrow of the aristocratic power. The tyrants were in fact "the means of breaking down the oligarchies in the interests of the people" (Abbott). 
From Tyranny to Democracy.-The one-man power was established in many of the cities of Greece. As long as the tyrants looked after the interests of the people, their rule was tolerated. But whenever and wherever they became selfish, ambitious, and oppressive, they were detested. While in some cases the city might revert to an oligarchy, the tyranny more often led to democracy. 'The so-called "age of tyrants" thus formed, generally speaking, a period of transition to the democratic form of government; and democracy came to be more highly developed in Greece than in any other part of the ancient world.

The many different states of Greece, however, were not equally successful in obtaining a democratic government. In some states we see the power remaining in the hands of a small part of the people, resulting in the permanent establishment of an aristocracy or oligarchy. Such aristocratic governments were developed in Sparta; in Thebes of Bœotia; in Chalcis and Eretria on the island of Eubœa; and also in Corinth, Meg'ara, and Sicyon on or near the isthmus of Corinth. In other cities, we see the political power transferred to the great body of citizens, resulting in the growth of a well-organized democratic state. The most important democratic cities were Athens, Argos, and Elis. Of these various cities we may look upon Sparta and Athens as the most important, for they represented the two extreme tendencies in the political development of Greece-the former showing the tendency toward oligarchy, and the latter the tendency toward democracy.

\section{Expansion of Greece by Colonization}

Causes of Colonial Expansion.- $-A$ t the same time that the cities of Hellas were working out the problem of free government, the boundaries of the Hellenic world were widening by the establishment of colonies. The causes leading to the colonial expansion of Greece were various. In the first place, the 
growth of population required the formation of new settlements; and these could be formed only in the unoccupied lands which bordered upon the adjoining seas. In the next place, the political discontent resulting from aristocratic oppression led many people to seek greater freedom in new settlements; hence we find a large number of colonies established by cities subject to aristocratic rule. Finally, the growing spirit of commerce furnished a strong impulse to colonization. The coasts of the Egean were indented with natural harbors; and the Greeks early derived from the Phœnicians the spirit of commerce and shared with them the trade routes of the sea. With the decline of the Phœnician power, the Greeks became the leading commercial people of the East. Like the Phœnicians, they dotted the shores of the Mediterranean with their trading posts. Greece thus became the mother of colonies, and from the eighth to the sixth century (750-550 в. с.) the territory of Hellas was continually growing wider and wider.

Character of the Greek Colony.-The Greek colony was a community of Greek citizens transported to a new land. It was generally the offshoot of a single city, although one colony might sometimes be formed by the people of different cities. The Greek colony carried with it the traditions, the customs, the language, and the religion of the parent city. Wherever it might be planted, it bore the blossoms and fruits of Greek culture. The founding of a colony was a matter of so much importance that it was customary to consult the oracle at Delphi to ascertain whether the undertaking would meet with the divine sanction. If the response was favorable, a "founder" was appointed to lead the colonists to their new home. The sacred fire taken from the altar of the parent eity was carried with the colonists as a symbol of their filial devotion. The infant colony worshiped the same gods as the parent eity, and in every way showed the sacred reverence due from a daughter to a mother. But in its political life the colony was entirely independent of the parent state. 'Though bound by filial affection, 
it was not subject to parental authority. It formed its own government, made its own laws, and was expected to work out its own destiny. ${ }^{1}$

The Colonizing Cities.-The cities of Greece were not equally zealous in the planting of colonies. Of the chicf cities, Athens was one of the least conspicuous in this movement. This may have been due to the fact that she was at first more devoted to politics than to commerce, or to the fact that her citizens were less discontented than those of other cities. Sparta, on account of her distance from the sea, was also not important as a colonizing state. But her subjects-especially the Messenians-were sometimes driven by her oppressive government to seek a refuge beyond her dominion. Of the cities of Greece proper the foremost in the colonizing movement was Chalcis, situated on the island of Eubœe. This city had a favorable seaboard. It commanded the copper trade of the East, and its aristocratic government was a cause of popular discontent. These facts are sufficient to explain its colonizing spirit. Next after

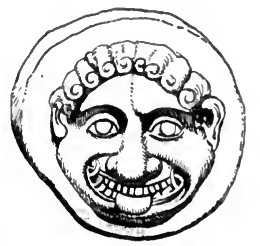

Coin of Eretria

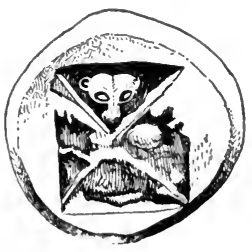
(1)

Chalcis should be mentioned the neighboring city of Eretria; and then Megara and Corinth, both of which were favorably situated for commerce, and were often misruled by an oppressive oligarchy. But the eity which surpassed all others as a colonizing center was situated not in Europe, but in Asia. This was Miletus, the most celebrated city of Ionia. It possessed four large harbors, and seems to have fallen heir to the commercial enterprise of the Phœnicians. Miletus is said to have been the mother of eighty colonies. Other cities of Ionia

1 This statement does not apply to the subject colonies, or "cle'ruchies," sent out by Athens as a means of maintaining her influence in a foreign land. In this case the settlers retained their political relations and rights as members of the parent state. 
PIROGIRHEST

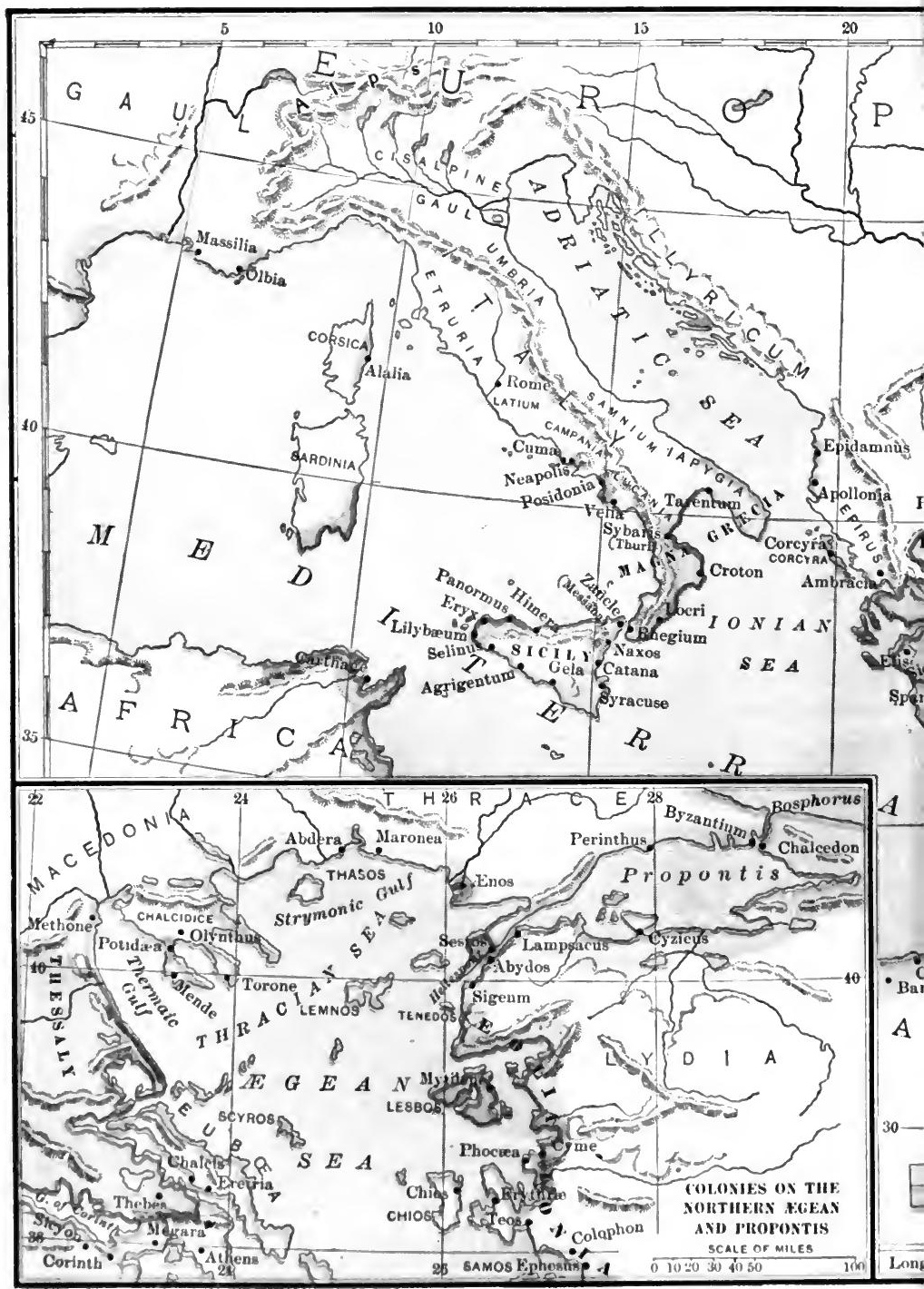




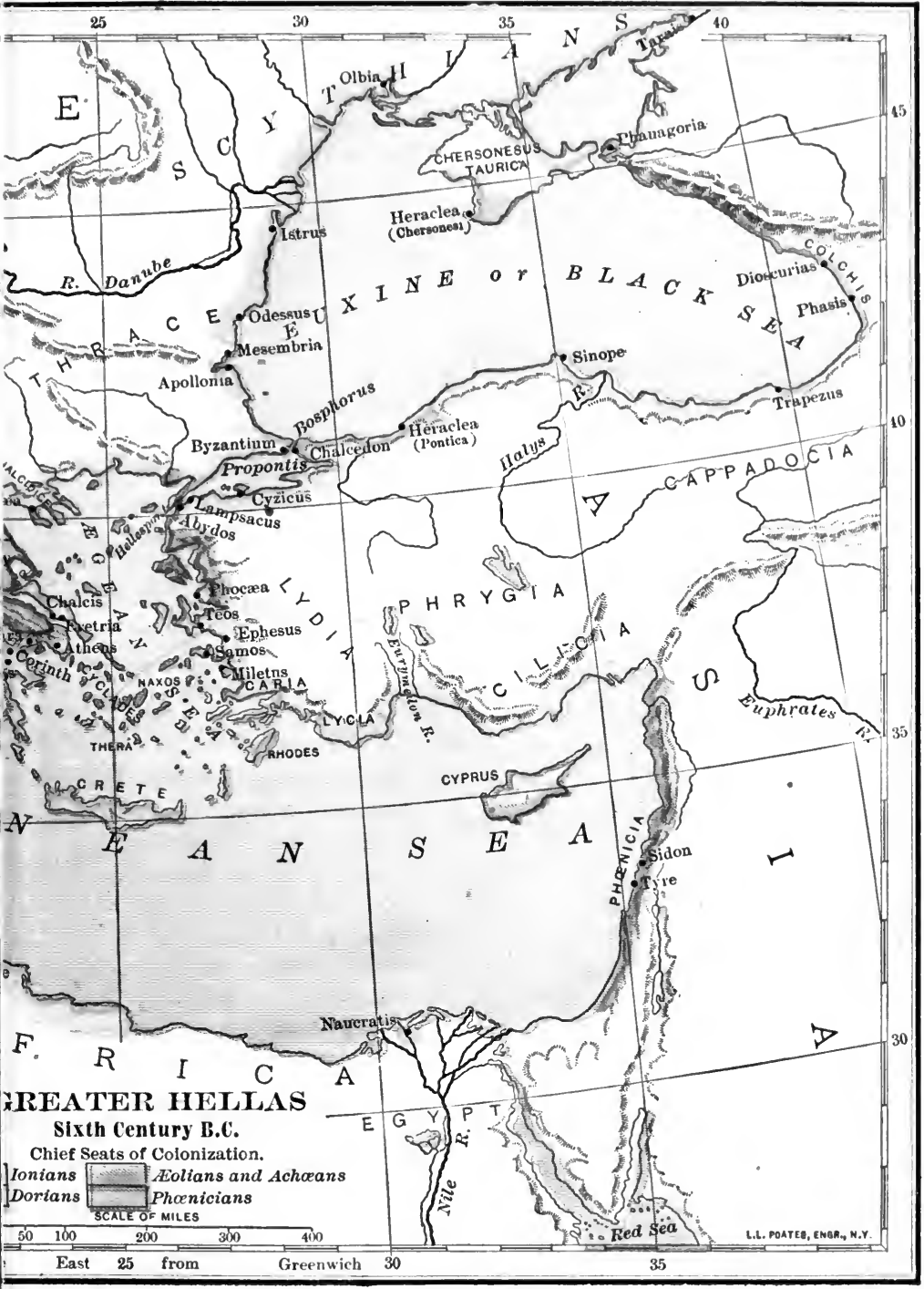




\section{LIST OF PRINCIPAL GREEK COLONIES}

The name of the parent colony is placed in parenthesis, together with the date of settlement when known. These dates can be regarded as only approximate, and are variously given by different authorities; the dates below are generally those accepted by Grote.

\section{Eastern Colonies.}

1. Northern Egean.

Methone (Eretria, 720 B.c.).

Mende (Eretria).

Torone (Chalcis).

Olynthus (Chalcis, 480 в.c.).

Potidea (Corinth).

Abdera (Teos, 553 в.c.).

Maronea (Chios).

Anos (Eolia).

2. Propontis.

Abydos (Miletus).

Lampsacus (Miletus, 650 B.c.).

Cyzicus (Miletus, 7.56 в.c.).

Chalcedon (Megara, 674 в.c.).

Byzantium (Megara, 657 в.c.).

Perinthus (Samos, 600 в.c.).

Sestos (Folia).

3. Euxine or Black Sea.

(a) Southern and Eastern Coast. Heraclea (Megara, 560 в.c.).

Sinope (Miletus, 770 в.c.).

Trapezus (Sinope).

Phasis (Miletus).

Dioscurias (Miletus).

(b) Western and Northern Coast. Apollonia (Miletus).

Mesembria (Megara).

Odessus (Miletus).

Istrus (Miletus).

Olbia (Miletus).

Heraclea (Heraclea Pontica).

'Tanais (Miletus?).

Phanagoria (Miletus).

4. Africa.

Naucratis (Miletus, 650 в.c.).

Cyrene (Thera).

Barca (Cyrene).
II. Western Colonies.

1. Adriatic Coast.

Corcyra (Corinth, 730 B.c.).

Ambracia (Corinth, 650 B.c.).

Apollonia (Corinth, 600 B.c.).

Epidamnus (Corcyra, 625 B.c.).

2. Italy.

(a) Southern Coast.

Tarentum (Sparta, 707 B.c.).

Sybaris (Achaia, 720 в.c.).

Croton (Achaia, 710 B.c.).

Locri (Locris, 683 B.c.).

Rhegium (Chalcis, 720 B.c.).

(b) Western Coast.

Cumæ (Chalcis, 1050 в.c. ?).

Neapolis (Cumæ).

Posidonia (Achaia).

Velia (Phocæa, 550 в.c.).

3. Sicily.

(a) Ionian Colonies.

Naxos (Chalcis, 735 в.c.).

Catana (Naxos, 729 B.c.).

Zancle (Chalcis, 728 в.c.).

Himera (Zancle, 648 B.c.).

(b) Dorian Colonies.

Syracuse (Corinth, 734 B.c.).

Gela (Rhodes, 690 B.c.).

Agrigentum (Gela, 582 в.c.).

Selinus (Megara, 630 в.c.).

4. Gaul.

Massilia (Phocæa, 597 B.c.).

Olbia (Massilia). 
also sent out some colonies. A few colonies were estahlished by the Eolian eities of the north, and a still less number by the Dorian eities of the south of Asia Minor.

Areas of Colonization.-The lands open to Greek colonization were the unoccupied coasts of the Mediterranean and Black seas. Some of these lands had already been held by Phœnician colonists; but the decline of Phonicia gave an opportunity to the Greeks, either to take possession of the old Phœnician sites, or to establish new settlements. The new lands were generally inhabited by a barbarous people; but the native products of these lands afforded a strong inducement ${ }^{t}$ to Grecian traders. There were two general areas open to colonization, which we may distinguish as the eastern and western. The eastern area comprised the northern coasts of the Agean Sea; the shores of the Propon'tis with its tributary straits, the Hellespont and the Bosphorus; the extensive coast of the Euxine or Black Sea; and also the northeastern coast of Africa. The western area comprised the western coasts of Illyr'icum and Epirus; the coasts of southern Italy (Magna Græcia) and Sicily; and the seaboards of the western Mediterranean, including southern Gaul, and extending along the shores of Spain. For the most important colonies study pages 110-112.

\section{SYNOPSIS FOR REVIEW}

I. The Early City State.-Importance of the Greek Cities.Elements of the City State.-Government of the City State.-Independence of the City States.-Amphictyonies or City Leagues.

II. Political Development in Greece.-Tendeney to Revolution.-From Monarchy to Aristocracy.-From Aristocracy to Tyranny.-From Tyranny to Democracy.

iII. Expansion of Greece by Colonization.-Causes of Colonial Expansion.-Character of the Greek Colony.-The Colonizing Cities.-Areas of Colonization.

\section{REFERENCES FOR READING}

Cox, History, Ch. 2, "Origin and Growth of Hellenic Civilization" (10). ${ }^{1}$

${ }^{1}$ The figure in parenthesis refers to the number of the topis in the Appendix, where a fuller title of the book will be found. 
Allcroft, Vol. I., Ch. 9, "Evolution of Governments"; Ch. 10, "Age of Tyrants" (10).

Abbott, Vol. II., Introduction, "Sketch of Constitutional History"; Ch. 11, "The Greek Colonies"' (10).

Holm, Vol. I., Ch. 20, "Political Development of the Greek States"; Ch. 21, "Greek Colonization" (10).

Whibley, Greek Oligarchies, Ch. 3, "Historical Development of Constitution", (11).

Greenidge, Ch. 2, "Early Development of the Greek Constitutions; Monarchy, Aristocracy, Tyranny to Constitutional Government"; Ch. 3, "Colonization" (11).

Fowler, W. W., Ch. 2, "Genesis of the City State"; Ch. 4, "Rise of Aristocratic Government"; Ch. 5, "Transition from Aristocracy to Democracy" (11).

Oman, Ch. 9, "The Age of Colonization" (10).

Smith, Wm., Ch. 12, "History of the Greek Colonies" (10).

Curtius, Vol. I., Bk. II., Ch. 3, "The Hellenes beyond the Archipelago" (10).

Bury, Ch. 2, "The Expansion of Greece"; pp. 95-102 (Sicily); p. 115 (Naucratis); pp. 116, 117 (Cyrene) (10).

Herodotus, Bk. III., Chs. 39-56, 120-125 (Polycrates, tyrant of Samos) (17).

\section{CHAPTER IX}

\section{THE TYPICAL CITY STATES-SPARTA AND ATHENS}

\section{The Aristocratic City State; Sparta}

The Dorians and Sparta.-In their conquest of the Peloponnesus (p. 93), the Dorians took possession of three important countries-Argolis, Laconia, and Messenia. Their first important cities arose in Argolis; chief of them was Argos. One
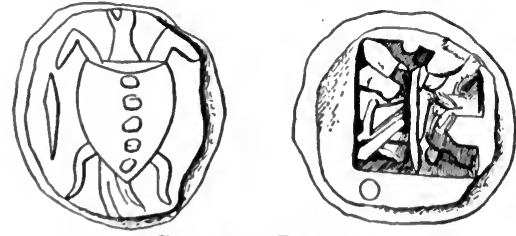

CoIn of PiInon of the rulers of Argos, Phi'don by name, was especially noted as the man who introduced a system of weights and measures, and who established a mint for the coinage of money. From the city of Argos as a center, the Dorians sub. dued the neighboring towns of Corinth, Megara, and Sicyon. 
But all the Dorian eities were at last overshadowed by Sparta, a town of Laconia, which we may study as the typical eity state of the Dorian race. Situated on the Euro'tas River, it was at first a mere military garrison, struggling to maintain itself against a hostile people. By degrees it gained in strength until it became the center of the Dorian civilization. 'This remarkable city owed its success to its peculiar organization and discipline, said to have been established by Lyeur'gus. 'The stories which are told of Lycurgus are largely mythical. It is said that he reorganized, with the approval of the Delphic oracle, the whole social and political system of Sparta; and that, having obtained from the people a solemn oath to make no changes in his laws during his absence, he left the city and never returned. Without attempting to criticise the

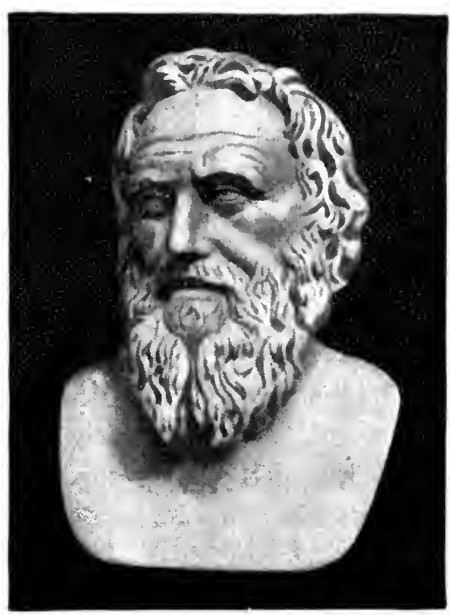

Lycurgus (So-called) "myth of Lycurgus," which is told by Plutarch, let us review the Spartan institutions as they existed in historical times.

Divisions of the People in Sparta.-The first thing we notice in Sparta is the division of the whole population into three classes-which had evidently resulted from the Dorian conquest of the Peloponnesus.

(1) The upper class consisted of the Spartans themselves, the descendants of the Dorian conquerors. They were the free inhabitants of the Spartan city, and were the sole possessors of political rights and privileges. They formed a comparatively small part of the entire population-not more than ten thousand men capable of bearing arms. They received the best portions of the land; but they were forbidden themselves to 
till the soil, or to do the work of artisans or traders. 'Their sole oceupation was war and service to the state.

(2) The next class comprised the Perioe'ci (dwellers around), who formed a large part of the conquered people. They lived in the neighboring towns, farmed the lands of the state, and engaged in manufactures and commerce. 'They were personally free; but were forced to pay tribute to Sparta. 'They were, moreover, called upon to serve in the Spartan army in time of war, and were even assigned to posts of command.

(3) The lowest class were the Helots, or serfs. who tilled the soil allotted to the citizens. They belonged to the state, and could not be sold by their Spartan masters. They formed the largest part of the population. They had no rights, and their condition was wretched.

The Spartan Government.- The form of the government of Sparta was an outgrowth of the system which prevailed in the tribal state of Homeric times. This we see in the three branches of the early government, the kingship, the senate, and the assembly.

(1) At the head of the state were two kings, members of distinct royal families. The origin of this double kingship it is difficult to determine. The kings acted as a restraint upon each other, and this tended to weaken the royal power.

(2) A more important element of the state was the senate (gerou'sia), composed of thirty of the leading citizens, including the two kings. In early times the members of the senate were no doubt the chiefs of the clans which had united to form the state. But in historical times they were elected by the assembly. 'They were at least sixty years of age, and held their position for life. Originally the senators were simply the advisers of the kings; but they came to be the sharers of the royal power. 'They not only determined largely the policy of the kings, but were jurlges in criminal eases, and prepared the matters which came before the assembly.

(3) 'The assembly (apel'la) consisted of all Spartan citizens 
above thirty years of age. It not only elected the senators, but decided upon the most important matters of state. It ratified the laws, determined questions of war and peace, and settled disputes regarding the royal succession. The highest power thus rested in the body of Spartan citizens; and in this respect. the state might be called a democracy. But when we consider the fact that the body of citizens formed but a small part of the whole population, the government can more properly be regarded as an aristocracy.

(4) We should not have a complete view of the Spartan constitution if we failed to notice the ephors (watchers), who were officers peculiar to Sparta. They were five in number, and formed a kind of supervisory board. They were elected by the assembly each year to protect the interests of the people against the encroachments of the kings and the senate. They came in time to be the "guardians of the constitution" and the real rulers of the state.

Spartan Education and Discipline.-The Spartans evidently believed that the character of a nation depends upon the training of its children. If the state is to be prepared for war. the children must be physically strong and inured to hardships akin to those of war. The Spartan elders decided whether each child, at birth, was sufficiently strong to be reared, or whether he should be exposed to the wild beasts. At the age of seven the boy was taken from his mother's care and placed in the hands of the public trainers. From this time he was subject to a training which was severe, and which to us seems brutal; but to the Spartans it.seemed the necessary education for a soldier's life. The boy was obliged to prepare his own meals; to wear the same clothing summer and winter; to sleep on a bed of rushes; to be hardened by the lash that he might better endure the hardships of the camp. To develop his physical strength and agility, he was trained in gymnastic exercises, in running, wrestling, and throwing the javelin.

The supervision of the state was exercised not only over the 
training of the young, but over the lives of all citizens. Every form of luxury was discouraged. The dress was simple. The houses were humble and unadorned. Money was not lavished upon public buildings and works of art. The temptations to a life of luxury were withstood, especially by the institution of public meals (syssitia). The men were organized in companies, and each one contributed to the common meal. They were withdrawn from their families, and lived in public barracks. Home life was thus destroyed in the interest of the state. 'The men were carefully organized, and trained in military evolutions; the simple and severe discipline of the camp was maintained in peace as well as in war; and as a result of this the Spartans came to have the most efficient army of Greece, and, as a matter of fact, of the world at that time.

The Conquests of Sparta; the Peloponnesian League.With such military training and discipline Sparta was able to extend and maintain her authority over the Peloponnesus. She first gained possession of the valley of the Eurotas, subduing the cities of Amyclæ and Helos. The territory of Cynuria was then wrested from Argos, which brought the whole of Laconia under Spartan authority. After two long and severe warseach one lasting about twenty years-Sparta subdued the neighboring district of Messenia, west of the 'Taÿg'etus mountains. These conflicts are known as the "Messenian Wars," and belong to the most heroic period of Spartan history (about $750-650$ B. c.). I Later the city of Tegea with the surrounding territory of Arcadia was subdued. Finally, Sparta gained a controlling influence in Elis, especially in the management of the national games at Olympia.

All the cities of the Peloponnesus (except Argos and the towns of A(haia) were joined in a confederacy known as the "Peloponnesian League." Each city was allowed to retain its loeal independence, but was joined to Sparta by a treaty, in which the eity agreed to furnish to Sparta a certain number of troops in time of war. Every eity of the league had 


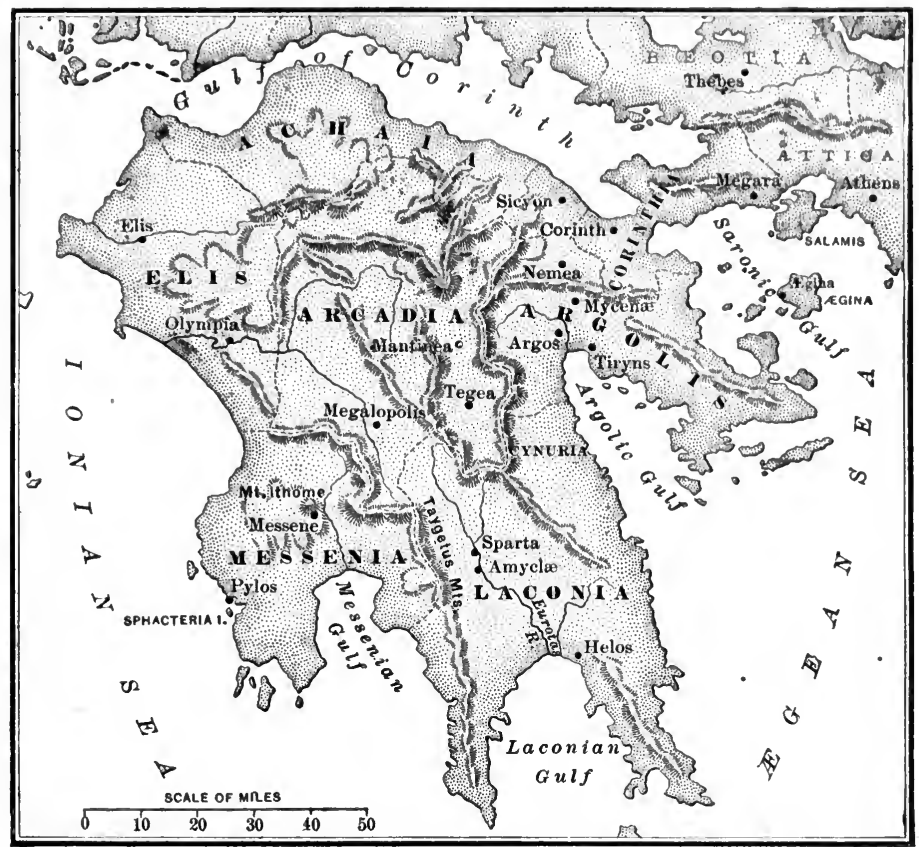

The Peloponnesus

an equal voice in a federal council, which met at Sparta and which was supposed to regulate matters of general interest. In this confederacy Sparta was the leader; and she exercised her influence in striving to extend her aristocratic institutions throughout Greece.

Position of Sparta in Greece.-While there are many things that we might criticise in the narrow government, the austere training, and the domineering policy of Sparta, we must confess that she contributed much to the future greatness of Greece. She set an example of simplicity in life, of self-control, of patriotic devotion, of respect for existing institutions. She showed the importance of physical education, of healthy, strong, and symmetrical bodies; and she gave Greece an ideal 
of physical manhood which furnished an inspiration to Greek sculpture. She also set a pattern of military organization by which in the subsequent period of foreign invasions Greece was saved from destruction. Although Sparta did not represent the highest culture of Greece, she did much to make that highest culture possible.

\section{The Democratic City State, Athens}

The Ancient Monarchy of Athens.-In marked contrast to Sparta, the aristocratic and military center of the Peloponnesus, stood Athens, which came to be the democratic and intellectual center of all Greece. As Sparta represented the Dorians, $\Delta$ thens was the chief representative of the Ionian people. The city state which grew up about Athens comprised all the towns of Attica, which were united under a common government. The union of these towns was ascribed to the mythical king Theseus. Our knowledge of this early period is based almost entirely upon traditions; but we may be quite certain that the earliest government of $\Lambda$ thens was a monarchy of the IIomeric type-with a king, a council. and an assembly.

Divisions of the People in Attica.-In each of the Ionian towns of Attica there were certain divisions of the people which remained after the towns were united under the common monarchy. In the first place, there were the four Ionian tribes which bore distinct names (Geleon'tes, IIople'tes, Egic'ores, and $A r^{\prime}$ gades) and which were each made up of phratries and clans. In the next place, there were three class divisions, upon which were based social rank and political privileges: (1) the well-born, or nobles (Eupat'rida). (2) the farmers (Geom'ori), and (3) the artisans (Demiur'gi). Of these classes the Eu'patrids stood nearest to the king. 'They were the only persons who had political privileges; and from them the king chose the members of his council. If the freemen were ever called together in an assembly, it was only on rare occasions. 
The Growth of the Archonship: Eupatrid Rule.-The first important changes in the Athenian govermment were due to the decline of the power of the king, resulting in the appointment of three archons to take his place. One was the chief archon, after whom the year was named; another was the war archon (called the polemarch), who commanded the army; the third was the king-arehon, who represented the old king as priest of the common religion. Afterward, there came to be appointed in addition six junior archons, called by way of distinction the thesmoth'etce, or guardians of the law. The nine archons thus gradually took the place of the old kings as the chief rulers of the state. As these new officers were chosen by, and from, the body of nobles, or Eupatrids, Athens came to have a real aristocratic government. The archons were chosen for a year; and after their term of office had expired, they became members of the council for life. This council took the place of the old council of the king. It was accustomed to meet on the hill of Ares (Mars), and was hence called the "Council of the Areop'agus." The people (farmers and artisans) at this time had practically no share in the government. The Eupatrids were the state. The political history of Athens, from this time, is most interesting to us, because it shows the successive changes by which the Athenian government was transformed from an aristocracy into a democracy. It is also interesting because it presents to us some of the most noted men of Athens-Draco, Solon, Pisis'tratus, and Clis'thenes.

The Laws of Draco (about 621 B. c.).-The rule of the nobles was often harsh and oppressive, and led to many disturbances. ${ }^{1}$ The laws of this time existed only in the form of unwritten customs, which were practically unknown to the common people and which the nobles could interpret as they

${ }^{1}$ The conspiracy of Cylon which took place about this time was an incident in these disturbances; but it has no special significance except as being the first attempt at a "tyranny," and as being the occasion of the "accursing" of the family of the Alcmxon'idx. Cylon was not assisted by the people, and his conspiracy only indlrectly led to a better state of things. 
saw fit. Draco, one of the archons, was authorized to put these laws into a written form, so that they might be known to all. The harsh character of the laws became evident as soon as they were published; so that it was afterward said that the laws of Draco were "written not in ink but in blood." If Draco made any change in the existing laws, it was a beneficial change relating to the law of homicide. Hitherto, if a man had slain another, whether accidentally or willfully, he might be pursued and killed by the relatives of the deceased-and that without trial. But Draco made a distinction between accidental and willful homicide, and this was to be determined by a trial before a court.

It is probable that Draco made some political changes in the way of extending the franchise-so that all Ionian tribesmen who were wealthy enough to furnish themselves with heavy armor received the right to vote. This tended to make wealth, as well as blood, a basis of political rights. It is also probable that Draco established-in addition to the old council of the Areopagus-a new council of four hundred and one members, to be elected by lot from all those who possessed the franchise. The legislation and reforms of Draco did not, however, relieve to any extent the condition of the common people, for they did not strike at the root of the existing evils.

The Reforms of Solon (about 594 B. c.).-The government was now in the hands of the high-born Eupatrids and of those who were rich enough to furnish heavy armor. The poorer classes were not only excluded from the government, but were held in a state of practical bondage to the rich. "The whole country," says Aristotle, "was in the hands of a few persons; and if the poor tenants failed to pay their rent, they were liable to be redueed to slavery, and their children with them" (Athenian Constitution, Ch. 2). Solon, who was regarded as

iOn these disputed points and the apparent discrepancy between Aristotle's "Politics" and the "Athenian Constitution," see Gustav Gillert, Constitutional Antiquities of Sparta and Athens, Eng. Ed., 1895, pp. xxxili-xxxix, and p. 119 , note. 
one of the seven wise men of Greece, was elected to the archonship, with full authority to remedy the evils of the state. He made three important reforms.

(1) The first of these reforms was to remove the burdens resting upon the poorer classes. He freed all those who had been sold into slavery for debt, and called back all those who had fled into exile to escape the cruelty of their masters. He canceled the old debts, and abolished the practice of reducing men to slavery on account of debt.

(2) His next reform was to extend the franchise to the poorer classes. There had already been established (at some time not exactly known) four "census classes," in

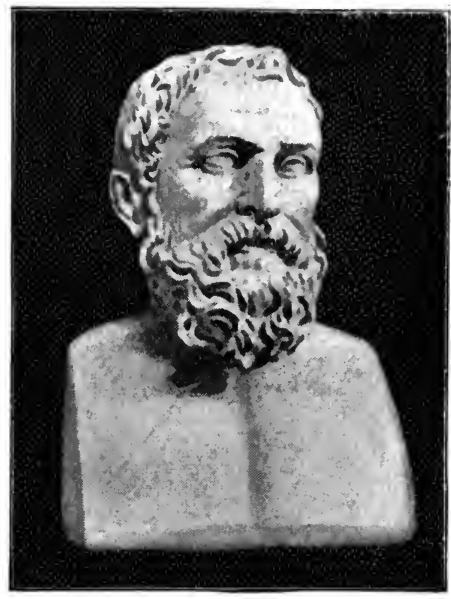

Solon (So-called) which the members of the Ionian tribes were arranged according to the amount of income which persons received. These classes had previously been used as a basis for the apportionment of the taxes. Solon now used these classes as a basis for the distribution of political rights. For example, the archons were to be elected from the first class only; and all the inferior officers were to be chosen from the first, second, or third class. But all the classes-including the fourth, called the The'tesreceived the right to vote in the assembly for all officers. This gave to the assembly a democratic character, although it was at this time chiefly a voting or election body, having little to do with the actual making of the laws. Solon also established a popular court (helice'a), in which all citizens, including the Thetes, could sit as jurors.

(3) The third important reform of Solon was the reorgani- 
zation of the council. He retained the old council of the Areopagus, which continued to hold its dignified position as "guardian of the constitution." But in place of the council of four hundred and one established by Draco, he created a new council of four hundred members-one hundred members being chosen by lot from each of the four Ionian tribes. This council prepared the laws, which might or might not be submitted to the assembly of the people.

The reforms of Solon were guided by wisdom and moderation. Although he did not destroy the aristocratic element of the state, he did give a greater importance to the popular element, and paved the way for a more democratic government.

The Tyranny of Pisistratus (560-527 B. C.).-It is said that Solon bound the people by an oath to observe his laws for ten years, and then departed from the city. But during his absence bitter strifes arose among the various classes of citizens who had different interests. These were: (1) the wealthy landowners, who held their estates on the lowlands, and were called the Men of the Plain; (2) the shepherds and peasants, who lived in the highlands, and were called the Men of the Hill; and (3) the merchants and traders who lived along the coast, and were called the Men of the Shore. In the struggles between these parties, the cause of the common people was espoused by an able leader, Pisistratus, who seized the government in a manner not sanctioned by law. To such a man the Greeks gave the name of "tyrant," whether his rule was good or bad. Although twice expelled from the city by his enemies, he each time recovered his power, and ruled in the interests of the people. "His administration," says Aristotle, "was more like a constitutional government than the rule of a tyrant." He retained the political forms established by Solon. only taking care that his own supporters should be elected to the archonship. He advanced money to the poorer people to aid them in obtaining a livelihood. He appointed local judges in the country, so that the rights of the lower classes might be 
protected without their being obliged to come to the city for justice. He adorned Athens with public buildings, not only to satisfy his own love of art, but to give work to the unemployed. 5 He was a patron of literature and collected a library which he threw open to the public. He is said to have made the first collection of Homer's poems. (He gathered about him the poets and artists of Greece. THe also encouraged commerce and formed alliances with foreign states. He favored in every way the worship of the gods, and instituted splendid festivals in their honor. Although a tyrant in name, he was one of the greatest of Athenian rulers, and began the policy that later made Athens the literary and art center of Greece.

At the death of Pisistratus the power passed into the hands of his two sons, Hip'pias and Hippar'chus, ${ }^{1}$ who began their rule by following their father's worthy example. But when Hipparchus was killed as the result of a private quarrel, his brother Hippias was embittered, and by his despotic rule he made the name of tyrant forever odious to the Athenian people. With the aid of the Spartans, who were directed by the Delphic oracle to help the Athenians, Hippias was overthrown and banished from the city. The

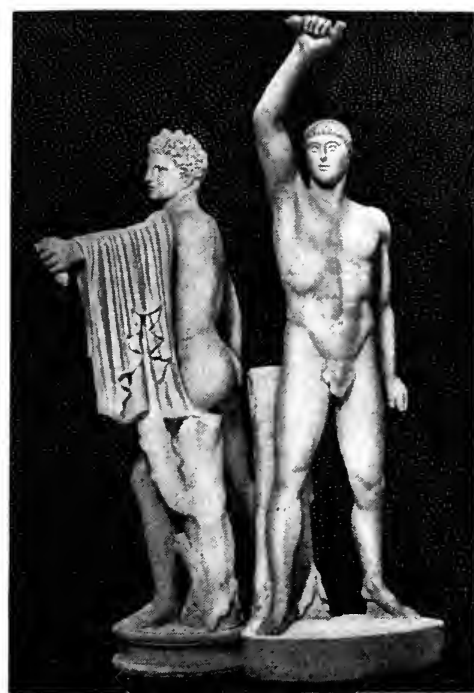

The Tyrannicides (Copies) tyrannicides, Harmo'dius and Aristogi'ton, who had previously killed Hipparchus, were hailed as the deliverers of their country, and statues of bronze were erected in their honor.

2 Called the Pisistrat'idæ, or sons of Pisistratus. 


\section{The New Constitution of Clisthenes (508 в. c.).-The man} who now appeared as the friend of the people was Clisthenes, who had taken part in overthrowing the recent tyranny. He was an able and far-seeing statesman, and one of the greatest reformers that Greece ever produced. He reorganized the government by placing it upon a new and more democratic basis.

(1) In the first place, he made a new division of the people, so as to include persons who were not members of the four old Ionian tribes, - such as enfranchised slaves and resident foreigners. To take the place of the Ionian tribes, which were based upon blood relationship, he divided the whole territory of Attica into ten districts, or "local tribes." Each local tribe was made up of three smaller districts (called trittyes) - one of which was situated in or near the city, another near the shore, and the third in the intermediate territory. The trittys was simply a group of three or four villages or townships, which were called demes. The deme was thus the smallest unit in the state; and every person enrolled in a deme was a citizen of the Athenian state and entitled to political rights. This arrangement tended not only to broaden the basis of citizenship, but to break down the old strife between the Men of the Plain, the Hill, and the Shore; since the members of each tribe would be inclined to act together for their common interests.

(2) In the next place, the government was changed so as to rest upon this new arrangement of the people. For example, the assembly (eccle'sia) -instead of being composed simply of members of the old Ionian tribes-was now made up of all the people of Attica who were enrolled in the various demes. So too, the council, or senate (boulé) -instead of consisting of four hundred members, one hundred from each of the four Ionian tribes-was now made to consist of five hundred members, fifty of whom were selected hy lot from each of the ten new tribes. ${ }^{1}$

${ }^{1}$ The old council of the Areopagus still remained as a time-honored and perfunctory branch of the government. It represented the conservative spirit of Athens, but practically lost its importance-except for a time during the progress of the Persian wars. 
The chief magistrates of the state continued to be the nine archons, who were chosen by lot, not now from the upper classes, but from candidates presented by all the demes. The military organization was also based upon the new tribal division, ten generals (strate'gi) being elected to command the ten tribal regiments, and forming a war council under the pole'march, who was still the nominal commander in chief.

(3) Clisthenes also introduced a method to protect the state from the danger of tyranny, or the undue prominence of a party leader. If six thousand votes were cast against any man thought to be dangerous to the state, that man was obliged to withdraw from the city for ten years. As these votes were written upon pieces of earthenware (ostraca) this process was called ostracism. Although intended as a safeguard to the state, it was yet capable of being abused and used for partisan purposes.

The Triumph of Democracy.-From this review we can see how the ancient monarchy of Athens was gradually transformed into a well-organized democracy. The old king, who held his office by hereditary right, was displaced by the archons, chosen at first from the nobles, and finally from the whole body of the people. The ancient council of elders, or war chiefs, passed into the council of the Areopagus, which consisted of the ex-archons, and which was supplemented by new councils, -at first, the council of four hundred and one, established by Draco, and chosen from the wealthy classes; afterward, the council of four hundred, established by Solon, and chosen from the four Ionian tribes; and, finally, the council of five hundred, established by Clisthenes, and chosen from the members of the ten new Attic tribes. The assembly had passed through somewhat similar changes, until it had come to be composed of the whole body of citizens, and to hold the sovereign power of the state. As Athens came to represent the principle of democracy, she incurred the enmity of the Spartans, as the chief defenders of the aristocratic principle. 
Under their king, Cleom'enes, they even invaded Attiea and attempted to overthrow the new Athenian eonstitution; but this effort proved a failure. With her democratic institutions firmly established, Athens continued to grow in strength until she became the chief eity of Hellas and the champion of Greek liberty.

\section{SYNOPSIS FOR REVIEW}

I. The Aristocratic City State, Sparta.-The Dorians and Sparta.-Divisions of the People in Sparta.-The Spartan Government.-Spartan Erlucation and Discipline.-The Conquests of Sparta; the Peloponnesian League.-Position of Sparta in Greece.

II. The Demockatic City S'rate, Atuess.-The Ancient Monarchy of Athens.-Divisions of the People in Attica.-The Growth of the Archonship; Eupatrid Rule.--The Laws of Draco.-The Reforms of Solon.-The Tyranny of Pisistratus.-The New Constitution of Clisthenes.-The Triumph of Democracy.

\section{REFERENCES FOR READING}

Smith, Wm., Ch. 7, "Early History of the Peloponnesus"; Ch. 10, "Early History of $\Lambda$ thens" (10).'

Bury, Ch. 3, "Growth of Sparta"; Ch. 5, "Growth of Athens" (10). Oman, Ch. $\tau$, "The Dorians in Peloponnesus"; Ch. 12, "Solon and Peisistratus"; Ch. 16, "The Constitution of Cleisthenes" (10). Cox, History, (h. 5. "Constitution and Early History of Sparta"; Ch. 9, "Early Constitutional History of Athens"; Ch. 12, "Reforms of Kleisthenes" (10).

Cox, Greek Statesmen, "Solon." "Pisistratus," "Kleisthenes" (26). Abbott, Vol. T., Ch. 6, "The Spartan State"; Ch. 15, "Pisistratus and Cleisthenes"' (10).

Curtius, Vol. T.. Bk. II., Ch. 1, "IIistory of the Peloponnesus"; Ch. 2, "History of Attiea" (10).

Greenidge, Ch. 5, "Mixed Constitutions" (11).

Gilbert, pp. 81-91. "The Lacedremonian League" (11).

Fowler, pp. 64, 65 (war songs of Tyrtaeus) (15).

Abbott, Vol. I., pp. 212, 213, "Spartan Women" (10).

Plutarch, "Tseurgus." "Solon" (26).

Aristotle, Athenian Constitution, Chs. 3-21 (growth of the constitution) (17).

Herodotus, Bk. I., Chs. 29-33 (Solon and Crosus); Bk. VT.. Chs. 126-131 (the wooing of $\Lambda$ gariste, the daughter of Clisthenes, tyrant of Sicyon, and mother of Clisthenes, the Athenian statesman) (17).

${ }^{2}$ The figure in parenthesis refers to the number of the topic in the Appendlx, where a fuller title of the book will be found. 


\section{CHAPTER $\mathrm{X}$}

\section{THE BEGINNINGS OF HELLENIC CULTURE}

\section{The Greek Religion and Religious Institutions}

General Character of Hellenic Culture.-We have considered in the two previous chapters the political growth of the Greek people during the early historical period-especially as seen in the development of their most important city states. We have seen a growing tendency in the direction of free institutions, and of a political life far different from that which marked the great empires and despotic governments of the East. We shall now see that during the same period there was also growing up a new form of culture, not only different from that of the Oriental world but also different from that of the Mycenæan age in Greece. It is true that the Greeks derived many of their ideas from the East; but it is also true that they gave to these ideas a new expression, and added to them many original features. To this distinctive and superior type of culture, developed by the historic Greeks, we may apply the name "Hellenic." If we should try to describe its general character, we might call it, for the want of a better word, humanisticthat is, based upon human nature, and pervaded by a human sympathy. The Greeks believed in the dignity of man. They had high ideals of human life-physical, intellectual, and æsthetic. They were especially distinguished for their refined taste; and this refinement of taste was opposed to everything that was excessive, extravagant, or meretricious. This Hellenic spirit and type of culture came to be the possession of all Greeks, and gave to them a common national character. 
Religion as an Element of Greek Culture.-The most fundamental element of the culture of the Greeks was no doubt their religion. The religious ideas of the common people, their conceptions of the gods and the future life, were essentially the same as those contained in the Homeric poems (p. 99), and were imbued with a thoroughly Greek spirit. The stories of the gods and goddesses were woren into a beautiful mythology in harmony with the Greek taste. The deities were inspired with the same feelings as were the Greeks themselves. The Greek religion was, in fact, a reflection of the Greek character. The religion was also the most powerful inspiration of Greek life and thought. It influenced the acts of the warrior and the statesman, and furnished the theme of the poet and the sculptor. Another important feature to be noticed is the fact that it was the strongest bond of union between the different branches of the Greek race. However much they might be embittered by jealonsy and war, the Greeks found in their religion a common tie of sympathy.

The Delphic Oracle.-One of the most important centers of the religious and national life of the Greeks was the orncle of Apollo at Delphi, situated in Phocis at the foot of Mt. Parnassus. The Greeks looked upon Apollo as preëminently the god of revelation, the god of light, of inspiration, and of prophecy. He had many oracles, but no other so renowned as that at Delphi. Here was his most illustrious temple, rich with costly gifts bestowed by his worshipers. Here his breath was supposed to issue from a cleft in the rock, over which stood a tripod-the seat of the Pyth'ia, or priestess, who uttered his will. 'The inspired words of the Pythia were taken down by the attendant priests, and delivered to the people. 'The oracle was consulted by private persons and by the envoys of cities from every part of Hellas. Answers were given to questions relating to religion and polities, to national disputes, to wars, and to colonization. Although these answers often had a double meaning and were difficult to interpret, 
still the Delphic priests were able by means of this sacred oracle to exercise a great and generally a bencficial influence upon the Greek people.

The Amphictyonic League.-The influence of the Greek religion, as a bond of union, is also seen in the associations of cities called amphictyonies, which were leagues bound together by some common interest, religious, commercial, or political (see p. 10J). The most important of these in early times was the famous Amphictyonic League organized for the protection of the temple of Apollo at Delphi. It was made up of twelve states of central and northern Greece, which sent to Delphi a number of delegates forming the Amphictyonic council. Although religious in its origin, the league also had a political influence in binding the cities together under a kind of legal code. The cities were bound, not only to protect the temple of the god, but to respect one another's rights in time of war-not to cut off the running water which supplied a city, and not to destroy any Amphictyonic town. The punishment inflicted upon the Phocian towns of Crissa and Cirrha for molesting the pilgrims to Delphi-when these cities were razed to the ground, in the so-called first "Sacred war"-shows the jealousy with which the league guarded the shrine of Apollo.

The Panhellenic Games.-The religious institutions which perhaps more than all others tended to promote a national unity and a national type of culture, were the great public games. These were celebrated in honor of the gods; and they show how closely religion was connected with all the phases of human life,-with art and literature, and even with athletic sports. Chief among these games were those held every four years at Olympia in Elis. The physical contests consisted in running, jumping, throwing the discus or quoit, casting the javelin, wrestling, boxing, and sometimes in chariot racing. These games were not barbarous sports, but were subject to strict rules, intended to promote the restraints. of discipline 


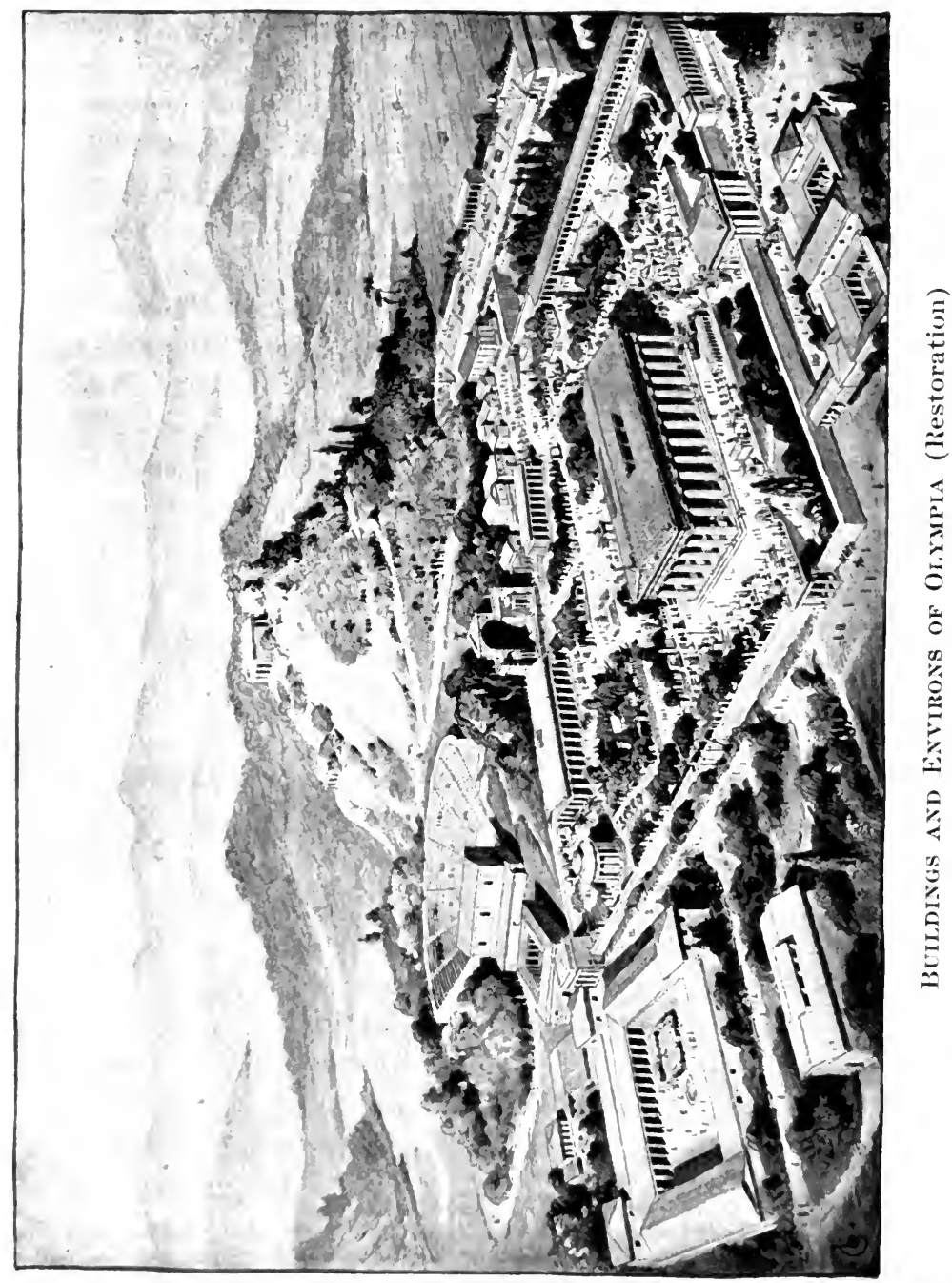


and the sense of honor. The competition was restricted to Greeks of good character, well trained and unblemished by any physical or moral taint. The reward of the victor was a wreath of olive leaves, and high honors were paid him. 'The games also furnished a field for intellectual culture. Here poets reeited their verses, painters displayed their pietures, and men of science explained their discoveries. Olympia became adorned with noble buildings-especially the temple of Zeus. The multitude which gathered here from every part of Hellas carried back to their homes the feeling of a common kinship, and the love of Greek ideals.

Other, less noted, games were the Pythian, given in honor of Apollo near his shrine at Delphi; the Nemean, in honor of Zeus at Nemea in Argolis; and the Isthmian, in honor of Poseidon on the Isthmus of Corinth.

Special Religious Festivals.-Besides these general celebrations which belonged to the whole of Greece, there were special festivals which were more local in their character. These were holiday entertainments given in honor of certain deities, and for the sake of social recreation. They consisted of processions, singing, dancing, games, and other diversions in which the people took part. There were a number of . these festivals in Attica. The most important of them were: the Panathenæ'a, given in honor of Athena; the Dionys'ia, in honor of the god of wine, Diony'sus; and the Eleusin'ia, in honor of the goddess Deme-

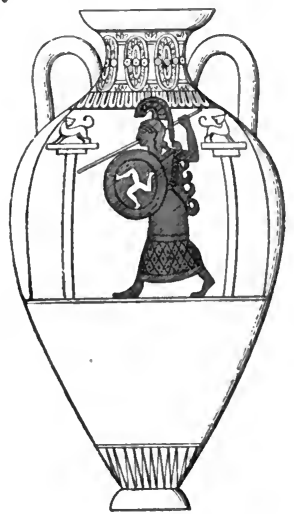

Panathenaic Vase ( 6 th century B. C.) ter. The last-named festival was of peculiar interest, especially to those who had been initiated into the secret rites of this worship. It consisted of a solemn procession in which every one might take part, from Athens by the "sacred way" to the city of Eleusis, the seat of the mysterious worship of the god- 
dess. The secret ceremonies and doctrines attending this worship were called the "Eleusinian mysteries," of which no one was supposed to have any knowledge except the initiated.

\section{The Beginnings of Greek Art}

Character of Greek Art.-The art of Greece, like that of the Orient, was closely related to religion. But Greek art was as different from Oriental art as the Greek religion was different from the Oriental religion. The gods of Babylon, who dwelt among the stars, conld be approached only by lofty temples, towering toward the sky. The grim religion of Egypt produced imposing structures which were gigantic and awe-inspiring. But the Greek religion appealed more strongly to human sympathy and revealed a finer sense of beauty. It produced an art which showed the marks of taste and reason. of moderation, of symmetry, and proper proportion. Some of the early features of Greek art were no doubt derived from the East; but its distinctive character was due to the refined taste of the Greeks themselves. That which we most admire in a Greek temple or a Greek statue is that combination of artistic qualities-simplicity of design, grace of form, symmetry of structure, and sincerity of expression-which we can find in no earlier people.

The Greek Temple.-For the highest expression of Greek art we must look to the temple. During the historical period we find in Greece no royal palaces like those in Assyria or Egypt, or even like those previously built on Greek soil at Tiryns and Mycenæ. The reverence for royalty passed away with the growth of political freedom; and so the architectural skill and taste of the Greeks were devoted almost entirely to the service of the gods. In every eity the temple was the most beautiful and conspicuous object.

In its design the Greek temple was a simple roof supported by columns and covering a space inclosed by four walls. It 
is supposed that this design grew out of the form of a dwelling house, made of wood, with a front porch. At first the building had two columns in front (in antis), and then four columns (pro'style); afterward it had also four columns in the rear (amphip'rostyle), and finally the whole building was sur-

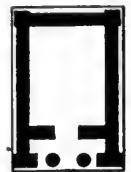

1

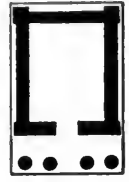

2

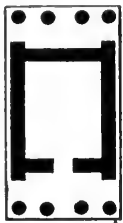

3

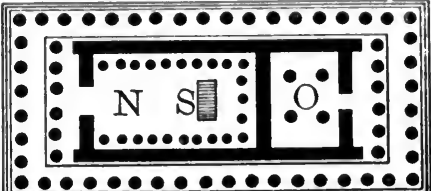

(East)

(West)

Types of The Greek Temple

1 , in antis ; 2 , prostyle ; 3 , amphiprostyle ; 4 , peristyle (the Parthenon) ; N, naos ; O, opisthodomus ; S, statue

rounded by a colonnade (per'istyle). 'The inclosed space in the largest temples gencrally consisted of a principal part ( $n a^{\prime} o s$ or cella), in which was placed the statue of the deity, and a rear part (opisthod'omus), which contained the treasures of the temple.

Orders of Greek Architecture.-As the Greeks broke away from the conventional architecture of the Eastern peoples, they developed styles of architecture of their own. 'These styles, or orders, are distinguished chiefly by the forms of the columns and the surmounting capitals. The earliest style was the Doric, so called because it was supposed to have its origin among the Dorian people of the Peloponnesus. This was the simplest and most dignified style. The column had no distinct base, and the capital consisted simply of a circular band surmounted by a square slab. This style was used mostly during this early period, but it was always greatly admired by the Greeks. A later style was the Ionic, in which the column was more slender and rested upon a distinct base, and the eapital was adorned with a spiral roll, or volute. A third style, developed still later, was called the Corinthian, which was a mere modification 
of the Ionic-the capital being somewhat more ornate and embellished with designs taken from the leaves of the acanthus plant. While the architecture of the Greeks did not reach its highest development during this period, it yet acquired a dis-
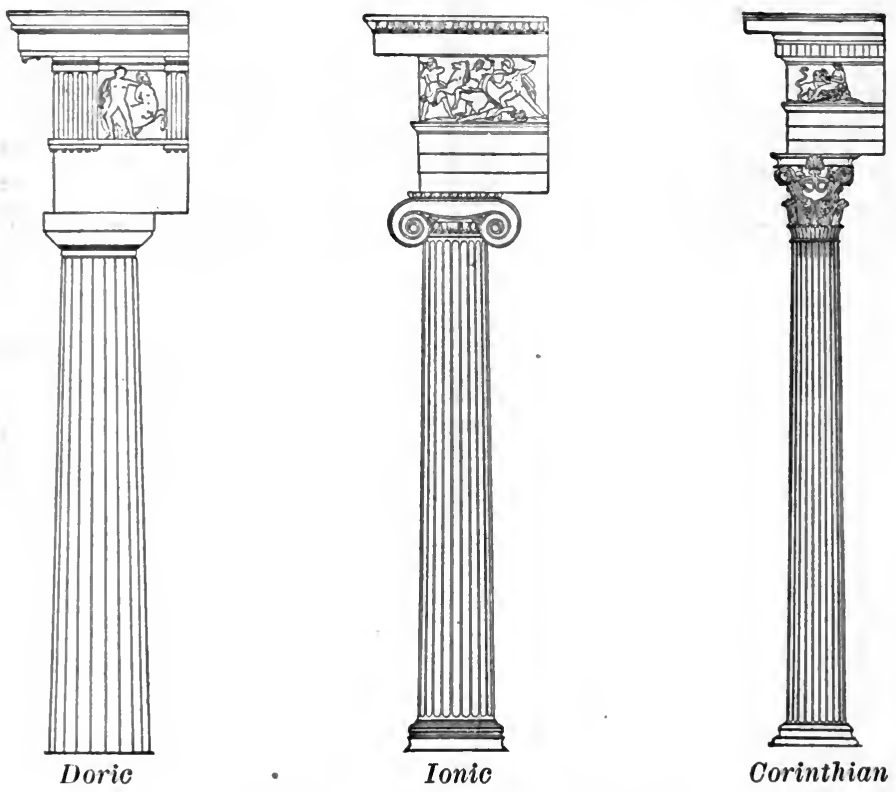

Orders of Greek Architecture

tinctly Hellenic character and showed the Greek taste for simplicity and symmetry.

Early Greek Sculpture.-The art of sculpture did not make as rapid progress in this period as did architecture. In fact, most of the examples which are left to us are crude and archaic. We ean see the first feeble efforts to break away from the stiff and conventional forms of the East. and to give to stone the features of life. The influence of religion is seen in the early. attempts to represent the gods in the form of men; but these attempts are suggestive of idols rather than statues. The credit 
of giving to statues a more lifelike appearance is ascribed to the mythical Dæd'alus, who was said to be a native of $\Lambda$ thens. Schools of sculpture grew up in the eities of Samos and Chios in Asiatic Greece; at Argos, Asgina, and Athens, in European Greece; and especially at Seli'nus, in Sicily. We have preserved to us some of the sculptured reliefs from the temple at Selinus. These consist of small groups of figures representing mythological scenes, and are carved in a very rude fashion. But they are interesting, as they show the early way in which sculpture was used for temple decoration. Among the strongest influences which led to the improvement of sculpture

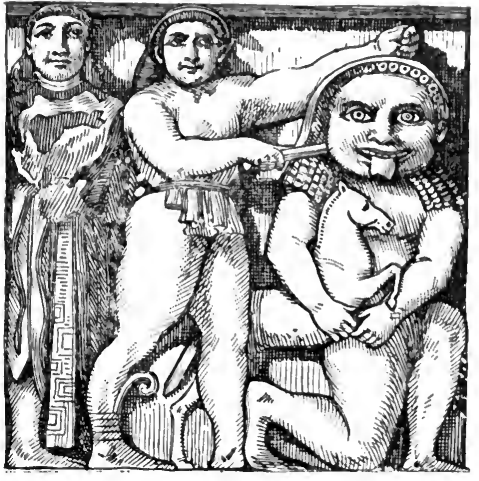

Relief from Temple of Selinus (Perseus slaying Medusa, see p. 85) during this time were the encouragement given to physical training and the custom of erecting at Olympia statues to successful athletes. But it is not until the close of this period that we see the sculpture beginning to acquire some of those artistic qualities which we have noticed in the architecture.

\section{The Greek Language and Early Literature}

The Greek Language.-Another strong bond which united the various branches of the Greek people was their language. This gave them a common means of communication, and preserved among them the feeling of kinship. It also separated them from the outside "barbarian" world, and contributed to the growth of a distinct Hellenic culture. Although a branch of the great Aryan or Indo-European family. the Greek early surpassed the other languages of this group as an instrument 
of thought and expression. By means of this remarkable language the Greeks produced a literature which has given them a high place among the most civilized peoples of the world. We can here take only a hasty glance at the growth of the literature during this formative period.

Decline of Epic Poetry.-At the beginning of the period the Greeks already possessed the "poems of Homer." 'These poems pictured in matchless verse the glories of the past, and recounted the deeds of gods and heroes. The epic was thus the poetry of action, and as such the Homeric epic could not be equaled. It was feebly imitated by a class of poets called the Homer'idæ, who still sang of the legends of 'Troy and of mythical heroes. A new and lower kind of epic was introduced by Hesiod, who is said to have been a nătive of Bœotia. This kind of epic was didactic in its character; that is, written for purposes of instruction. "The "Theogony" of Hesiod is a sort of theological treatise containing a description of the gods and the religious faith of the ancient Greeks. The "Works and Days" is a poem of common life, deseribing the labors of the farmer and interspersed with wholesome moral advice.

Transition to Lyric Poetry.-With the decline of the epic, or the poetry of action, there arose a new kind of poetry more closely related to human thoughts and feelings. This is shown in what are called the elegiac, the iambic, and finally the lyric verse. The elegiac and the iambic poetry, like the older epie, made their first appearance among the Ionians. The elegy was serious in its character, sometimes used to express feelings of sadness, and sometimes patriotic in its appeals. The chief elegiae poets were Calli'nus of Ephesus, and 'Tyrte'us of $\Lambda$ thens. It is said that Tyrtæus was sent to Sparta during the Messenian wars to inspire the Spartan soldiers with an heroic spirit. The iambic poetry, differing from the elegy, was the poetry of wit and satire, and devoted to raillery and invective. Its chief representative was Archil'ochus, a native of the island of Paros. 'These two forms of poetry-the elegiac and the iambic 
- prepared the way for the higher and more cultivated form of the lyric.

The Eolian Lyric Poetry.-The first form of lyric poetry appeared on the Lolian island of Lesbos in Asia Minor. It consisted of songs intended to be sung by a single voice accompanied by the lyre. The chief poets of Aolia were Alca'us, who sang of patriotism and war; Sappho, who sang of love; and Ana'creon, who sang of the pleasures of life. Of these Sappho is preëminent. To the Greeks

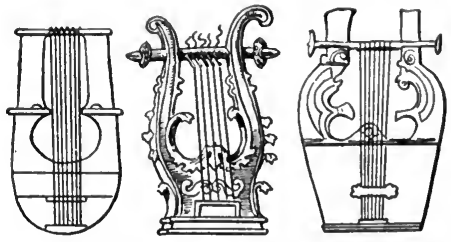

Greek Lyres she was " the poetess," as Homer was "the poet." Of the few fragments of her work which remain to us, modern critics can hardly express their admiration. Says one, "Of all the illustrious artists of all literature, Sappho is the one whose every word has a peculiar and unmistakable perfume, a seal of absolute perfection and inimitable grace" (Symonds).

The Dorian Lyric Poetry.-Another form of lyric poetry was cultivated by the Dorians. It comprised hymns, or choruses, to be sung by a number of voices at the public worship of the gods, or at public festivals. The chorus, accompanied by dances or processional marches, was not a new thing in Greece. But it was reduced to a more regular form under the influence of three poets-Alcman, Stesich'orus, and Ari'on.

Alcman regulated the rhythmic movement of the persons singing the chorus. The movement of the singers from right to left before the altar, and the part of the hymn, or ode, sung during this movement, were called the "strophe"; the movement from left to right, and the corresponding part of the hymn, were called the " antis'trophe."

Stesichorus added an after-part, sung after these movements were completed, by the chorus when standing still, and called the "ep'ode." 
Arion is said to have given a special form to the chorus in the worship of Dionysus, the wine god. 'The chorus of fifty singers was arranged about the altar in the form of a circle, and the hymns were accompanied with dancing, gestures, and mimetic features. This choral hymn was known as the "dith'yramb," and from it sprang the later drama.

\section{Early Greek Philosophy}

The Early Ionic School.-While the poets were singing the praises of the gods, there arose a class of thinkers who were not inclined to accept the old mythological stories. These men first appeared at Miletus, an Ionian city in Asia Minor. Here they came into contact with the scientific notions of the East; and these ideas furnished a kind of starting point for Greek philosophy. 'The Egyptians and the Assyrians had made considerable progress in mathematies and astronomy; and their scientific ideas had been taken up by the Phœnicians and the people of Asia Minor.

The first of the Greek philosophers was Tha'les, who was born at Miletus and was of Phœnician descent. He was first of all a mathematician and astronomer. He is said to have measured the height of the Egyptian pyramids by their shadows and to have predicted an eclipse. As he studied the universe he was led to believe that everything has been evolved from one substance, and that that substance was water, or some form of moisture.

Other philosophers of Miletus were Anaxim'ines and Anaximan'der-the former believing that the primitive substance was air, and the latter that it was some kind of unknown matter without definite qualities. Another philosopher appeared a little later in the Ionian city of Eph'esus; this was Heracli'tus, who believed that the original substance was fire, and that evervthing is in a state of perpetual movement, or, as he said, "all things flow." 
The Philosophy of Pythagoras.-Another school of philosophy was founded by Pythag'oras, who was a native of Samos, an Ionian city of Asia Minor. He is said to have traveled in Egypt, and perhaps in Phœnicia and in Babylon, and to have absorbed the wisdom of these countries. At any rate, he was called the most learned man of his time. He finally settled at Croton in southern Italy, and his philosophy exereised a great influence in Magna Grecia. Pythagoras was first of all a mathematician; and he looked at everything through mathematical eyes. He saw that everything possesses number, either one or many; and hence he reasoned that number is the principle of everything. He was also a religious and moral teacher, and he organized a secret fraternity, the purpose of which was to cultivate the highest virtue among its members.

The Eleatic Philosophy.-Still another school of philosophy arose in $E^{\prime} l e a$ (Ve'lia), on the western coast of Italy, called the Eleat'ic school. This was also connected, like the others, with Ionia in Asia Minor; since its founder, whose name was Xenoph'anes, originally came from that part of Hellas. This philosopher embodied his ideas in a poem "On Nature." As he looked at the world, he saw that all things are parts of one complete and harmonious whole; and hence to express his idea in a brief form he used this phrase, "The All is One." He also affirmed that the one universal principle which comprehends and controls everything else, is God. The greatest philosopher of this school was Parmen'ides. He distinguished between the world of sense, which is only appearance, and the world of reason, which is reality. If by the aid of the reason we look below the surface of things, we shall find, he says, an ultimate principle which does not change-an absolute Being, ever the same, yesterday, to-day, and forever.

Such ideas were opposed to the old mythological notions contained in Homer and Hesiod, and show that the philosophy of the Greeks was tending to elevate and purify the old religious ideas. 
We can thus see in the Greek religion, art, literature, and philosophy the evidences of the growing refinement, versatility, and power of the Greek mind, which was gradually expressing itself in a distinctive Hellenic culture, different from that of any other ancient people. The growth of such a common culture shows that the Greeks, although broken up into many small city states, were yet bound together in thought and feeling as one great nation, which extended from the coasts of Asia Minor to the shores of Sicily.

\section{SYNOPSIS FOR REVIEW}

I. The Greek Religion and Reifgiousinstitutions.-General Character of Hellenic Culture.-Religion as an Element of Greek Culture.-The Delphic Oracle.-The Amphictyonic League.-The Panhellenic Games.-Special Religious Festivals.

II. The Beginsings of Greek ART.-Character of Greek Art.-The Greek Temple.-Orders of Greek Architecture.-Early Greek Sculpture. .

iII. The Greek Language and Early Literature.-The Greek Language.-Deoline of Epic Poetry.-Transition to Lyric Poetry.-A Eolian Lyric Poetry.-Dorian Lyric Poetry.

IV. Early Greek Philosophy.-'The Early Ionic School.-The Philosophy of Pythagoras.-The Eleatic Philosophy.

\section{REFERENCES FOR READING}

Cox, History, Ch. 7, "Intellectual Education of the Greeks" (10)." Smith, Wm., Ch. 13, "History of Literature"; Ch. 14, "History of Art” (10).

Mahaffy, Survey, Ch. 3, "First Two Centuries of Historic Development" (10).

Curtius, Vol. II., Bk. II., Ch. 4, "The Unity of Greece" (10).

Holm, Vol. I., Ch. 24, "Growth of Greek Philosophy, Literature and Art in Asia Minor" (10).

Symonds, (ireek Poets, Ch. 5, "The Iyric Poets" (15).

Veller, First Period, Part I., "The Three Earliest Schools" (15).

Tarbell, Ch. 2, "Prehistoric $\mathrm{Art}$ in Greece"; Ch. 3, "Greek Architecture" (1:).

Collignon, l3k. I., "Origin of Greek Art" (12).

Grote, Part II.. ('h. 2s, "Pan-Hellenic Festivals" (en passant, the first Silcred war) (10).

Harper"s Dictionary, "Oracula" ((ireek oracles); "Religio" (the religion of IIomer and of later times); "Eleusinia" (Eleusis and its mysteries); "Delphi" (and its priesthood) (11).

'The figure in parenthesis refers to the number of the topic in the Appendix, where a fuller title of the book will be found. 


\section{FERIOD III. THE ATHENIAN ASCENDENCY; ITS GROWTH AND DECLINE (500-359 B. O.)}

\section{CHAPTER X.I}

\section{THE PERSIAN WARS-GROWING POWER OF ATHENS}

\section{The First Persian Invasion, under Darius}

Greece and Persia.-We have thus far traced the beginnings of the Greek political system, and the first steps in the growth of a common Hellenic culture. We have seen how the Greeks broke away from the old monarchical ideas of the East, and laid the basis of freer and more democratic institutions. We have also seeh how they began to develop a higher intellectual life and a finer æsthetic taste than had hitherto existed among the peoples of the Orient. With the extension of the colonies, the influence of this new civilization was beginning to be felt on nearly every shore of the Mediterranean-in Asia Minor, in Thrace, in southern Italy and Sicily. But now came a great crisis in the history of the Greek people, when they were called upon to defend their very existence. Their cities, their colonies, their commerce, their free institutions, and their new culture were all threatened with destruction by the encroachments of Persia. This great world empire, having absorbed all the monarchies of the East, was now brought into contact with the city states of Greece. Persia had extended her power to the shores of the Aggean. Her armies had already crossed the Hellespont into Europe, and held lands extending to the very borders of 
Thessaly. ${ }^{1}$ We are now about to witness a conflict which is perhaps to decide the fate of the world; it will certainly decide the question whether Greek civilization is to survive, or whether Europe is to become a province of the Orient.

The Asiatic Cities and the Ionian Revolt.-This great struggle between the East, represented by Persia, and the West, represented by Greece, began with the revolt of the Greek cities in Asia Minor. We remember that these cities grew up as

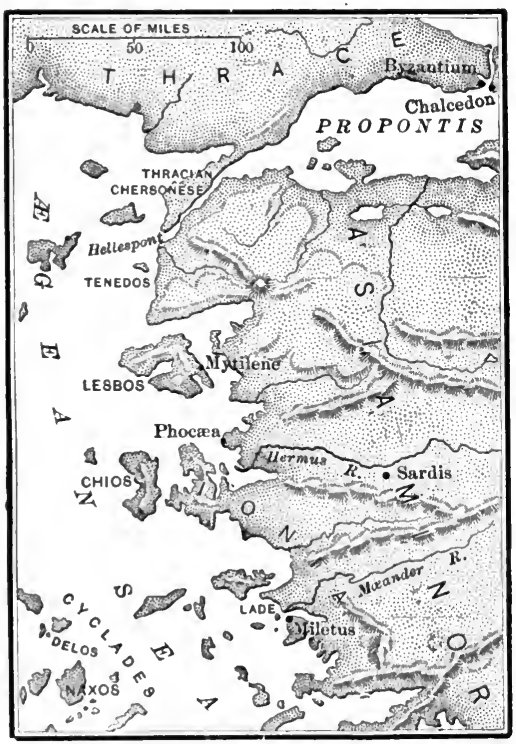

Seat of the Ionian Revolt the result of the early migrations of the Greeks across the Egean Sea. The most important of these cities were in Ionia; and the most influential of the Ionian cities was Miletus. Thes e cities maintained their independence for a long time. But when the new empire of Lydia arose in Asia Minor, they passed under the control of the Lydian kings, the most noted of whom was Crœsus (560546 в. c.). Under the Iydian rule, the Greeks were well treated and their rights respected. A great change, however, occurred when Lydia was conquered by Persia, and the Asiatic Greeks became subject to the Persian empire. They were now ruled by tyrants under the control of the Persian satrap whose capital was at Sardis. The revolt against Persia began at the city of Miletus (500 13. C.); it soon spread to the other cities of

1 For the I'ersian conquest of Iydia, the Scythian expedition of Darius, and his encroachment upon Europe, see pp. 64, 65. 
Asia Minor, and also to the Greek colonies on the coast of Thrace.

In their extremity the cities appealed to European Greece for assistance. Sparta refused to give any help. But $A$ thens voted to send a fleet of twenty ships to aid their "kin beyond the sea." Tho this was added a small squadron of five ships sent by Eretria, a city friendly to Miletus. With this aid the Ionians captured and burned the Persian capital Sardis. On their retreat from the eity the Athenians suffered a severe defeat; and disheartened they returned to Greece. The Asiatic cities continued their resistance; but on account of their relative weakness, and especially their lack of union, they could not cope with the forces of Persia. The Persians gained a decisive naval battle off the little island of La'de, near Miletus. Miletus was then captured and burned; and the remaining cities of Asia Minor were soon reduced to submission (49:3 B. c.). This revolt furnished an example of the lack of strength that results from a too great love of liberty and the failure to unite in a common cause.

Plans of Darius against Greece.-Whether or not the Persian king, Darius, had up to this time thought of conquering Greece, he was now determined at least to punish the cities of Athens and Eretria for interfering in the affairs of Asia. For this purpose he organized an expedition (492 B. C.), consisting of land and naval forces, and placed it under the command of his son-in-law Mardo'nius. This expedition was to invade Greece by way of the Hellespont and the coasts of Thrace and Macedonia. But this first attempt to invade Greece was a complete failure; for the fleet of Mardonius was wrecked off the rocky point of Mt. Athos (see map, p. 152). This failure, however, did not discourage the Persian king. He now determined not simply to punish Athens and Eretria, but to subdue all the cities of Greece which would not recognize his authority. To test their loyalty, he sent his heralds among them, demanding "earth and water" as a token of their submission. Most of 
the island states, fearing attacks from the Persian fleet, yielded -including Egina, off the coast of Attica. Many of the cities of the peninsula hesitated; but Athens and Sparta stood firm, and even treated the royal heralds with indignity. The stand taken by these leading states was a good omen; for it showed that Greece might yet be united in the face of a common danger.

Persian Invasion under Datis and Artaphernes.-The new expedition of Darius was placed in the hands of a Median general, Datis, and the king's nephew Artapher'nes. Instead of following the previous course of Mardonius and risking another disaster at Mt. Athos, the new generals proceeded directly across the sea. 'Their fleet consisted, it is said, of six hundred triremes. On their way they captured Naxos and reduced its inhabitants to slavery. But

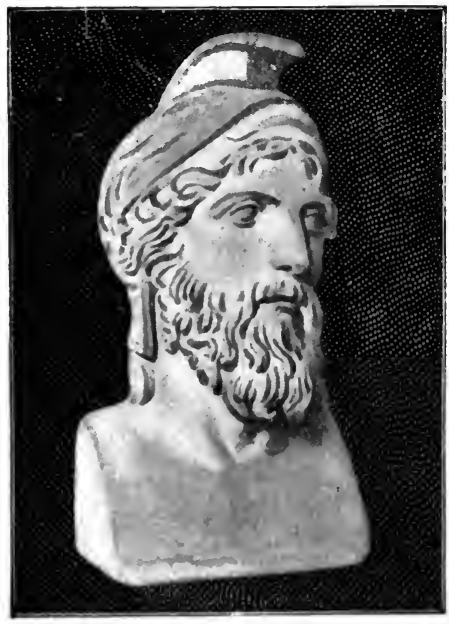

Mrutianes (So-called) they spared Delos, the seat of the shrine of Apollo. They soon landed on the island of Eubœa, and attacked the city of Eretria. After a gallant defense, the city fell by the treachery of two of its citizens. It was burned and its people were enslaved. The Persians now crossed over to Attica to mete out a similar punishment to Athens. By the advice of Hippias, the banished Athenian tyrant (p. 125) now in the enemy's service, the Persians landed on the shore of Attica near the plain of Mar'athon.

Miltiades and the Battle of Marathon (490 B. C.).-Upon Athens now rested the ehief duty of defending Greece. She collected an army and sent it to meet the invaders. It was 
led by the ten strategi, or generals, who usually commanded the army each in his own turn. One of the generals was Milti'ades. 'To him it seemed necessary to attack the Persians on the plain of Marathon. The other generals were divided in their opinions, but finally decided to yield to the advice of Miltiades and to give to him the chief command. A swift runner was dispatched to Sparta with a request to that city for aid. This aid was promised; but it was delayed on account of a Spartan superstition that an army should not be sent away before the time of the full moon. The only assistance which the Athenians received was from the friendly city uf Platæa, which sent its entire

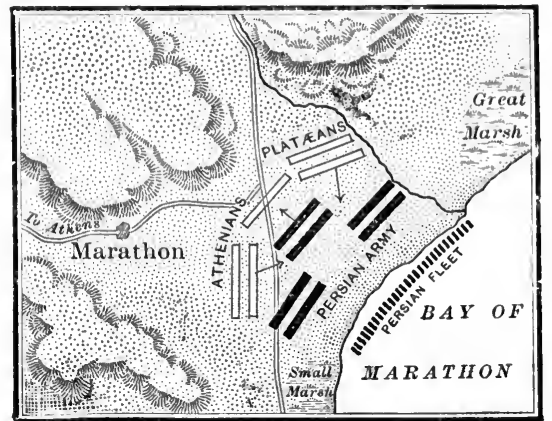

Battle of Marathon, 490 B. C. ariny, a thousand fighting men, raising the total force to ten or eleven thousand. The Greeks were drawn up in front of the town of Marathon. Opposite them the Persians were stationed nearer the sea and supported by their fleet. The battle line of the Greeks was equal in length to that of the Persians; but the center was made weak in order to strengthen the wings. At a given signal, the Greeks, heedless of superior numbers and the terrible shower of arrows, rushed upon the enemy. The battle was long and obstinate. The Persians drove back the weak center of the Athenians and pressed forward in the intervening space. But the strong wings of the Greek army closed upon the enemy and routed them with great slaughter. The Persians were pursued to their ships, and with great difficulty embarked and sought refuge upon the open sea. Not entirely discouraged, the Persians sailed directly to Athens, hoping to find the city unguarded. But Miltiades made a 
forced march to Athens; and the Persians, when they arrived, found the eity protected by the victorious army of Miltiades. Foiled at every point, Datis and Artaphernes sailed with their defeated forces back to Asia. When the full moon was passed, the Spartan army arrived to find that Marathon had been won.

The Athenians were entitled to look upon Marathon as their own battlefield. The Spartans paid the highest tribute to their valor. 'The poets of Greee vied with one another in singing the praises of the dead heroes. A monumental mound was thrown up in their honor, which remains to the present day. Two statues were ereeted to Miltiades, one at $A$ thens and the other at Delphi. While the battle of Marathon did not end the struggle between the East and the West, it marked an important step toward the ascendency of Athens in Greece, and of Greece in the civilization of the world.

\section{Athens during the Tex Years' Respite (490-480 B. c.)}

Democratic Progress at Athens. - After the battle of Marathon there was an interval of ten years before the next Persian invasion. During this time Athens was striving to maintain her democratic institutions, and to strengthen her power for the next attack. As Miltiades was looked upon as a friend of the oligarchical party, he was called upon to answer a charge of deceiving the people. He had induced them to fit out for him a naval expedition, which had failed. This furnished to the popular party a pretext for condemning him; this was done, and the hero of Marathon died in disgrace. The people also drove into exile all the friends of Hippias, the banished tyrant who had aided the Persians in the recent invasion. The popular party overcame all opposition, until they held completely the reins of government. All political questions were now redueed to the one problem. how best to maintain and strengthen the Athenian democracy. 
Aristides and Themistocles. - But even in the popular party there were different views as to the best way of developing the power of Athens. The conservative view was held by Aristi'des; the progressive view by 'Themis'toeles. Aristides was highly esteemed by the people, so that they called him "the Just." He had supported the democratic reforms of Clisthenes, and had commanded the Greek center at Marathon. He believed that the strength of Athens depended upon preserving the institutions and maintaining the policy that had already made her great, and that no change would improve her condition. Themistocles, on the other hand, believed that the state should not rest entirely upon the past, but should prepare itself for the future. 'The suecess which Athens had already attained should not blind. her eyes to the need of new achievements. These two states-

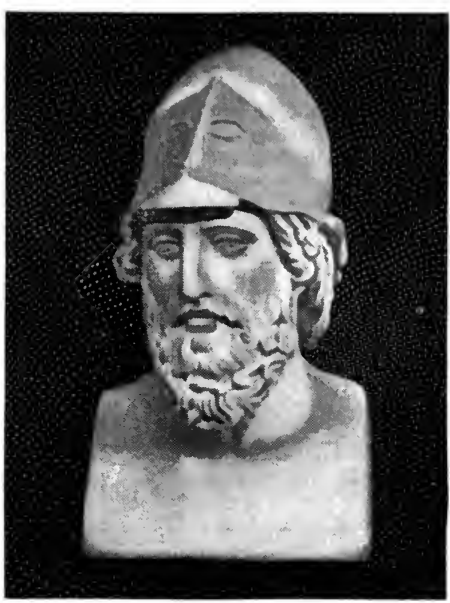

Themistocles (So-called) men, though differing widely in their character and views, were equally conscientious and devoted to the interests of their country.

The Naval Programme of Themistocles.-Themistocles no doubt saw more clearly than Aristides the need of preparing for a new struggle with Persia. He also saw that in the coming confliet Athens, the chief object of Persia's hatred, must again bear the brunt of Persia's attack. Persia was both a great military and a great naval power. In any future conflict, if Sparta was to be recognized as the chief military power of Greece, Athens should be recognized as its chief maritime power. There was also another consideration in 
favor of the policy of Themistocles. Athens was now embroiled in a war with Ligina, the neighboring island state which had shown a sympathy with Persia. Ligina had already a strong fleet. The only hope of winning in this war was by meeting ships with ships. With arguments such as these Themistocles enforced upon the people the need of a strong navy. That the new naval project might be carried through without hindrance, Aristides was ostracized; and Themistocles became the leader at Athens without a rival.

Athens Becomes a Maritime Power.-Through the building of a strong fleet and the construction of an adequate harbor, Athens soon became the greatest naval power in Greece. The fleet was built with the aid of the silver mines recently opened at Laurium in the south of Attica. It was at first proposed that the product of these mines, which belonged to the state, should be divided among the eitizens. But Themistocles appealed to the patriotism of the people and induced them to devote the proceeds of the mines to the building of war ships. In a short time Athens possessed a fleet of two hundred triremes, far outnumbering that of Egina or of any other Greek city. About this time-perhaps earlier-Themistocles also transferred the harbor of $A$ thens from the bay of Phale'rum, which was exposed alike to storms and to enemies, to the Piræ'us, which was far better adapted for a naval station. This new port was surrounded by natural defenses, but was now further strengthened by fortifications. On account of these works Themistocles may properly be regarded as the founder of the maritime greatness of $A$ thens.

The Congress of Corinth (481 B. c.).-But Themistocles saw that $\Lambda$ thens alone, even with her new navy. could not withstand the power of Persia. He saw that the safety of Greece depended upon the union of her states. At his suggestion a congress was called at Corinth to consider the means of a common defense. The principal continental states responded favorably to this call-except Argos and Thebes, who were 
jealous, the former of Sparta and the latter of $\Lambda$ thens. The Greeks in their conference at Corinth agreed to lay aside all internal strife, and act together against the common foe. It was decided to punish any city that should "Medize"- that is, aid the cause of Persia. It was also decided that of the three possible lines of defense-namely, the vale of Tempe, the pass of Thermop'ylæ, and the isthmus of Corinth-the best place to meet the invader was at the pass of Thermopylæ. The leadership of the new confederation of Greek states was given to Sparta, which was already the head of the Peloponnesian League. At no other period did Greece ever come so near to being one nation as it did at this time under the influence of the great Athenian statesman Themistocles. It was by his foresight and genius that not only Athens, but Greece as well, was made ready for the next great war with Persia.

\section{The Second Persian Invasion, under Xerxes}

Preparations and Advance of Xerxes.-While the Greeks were thus preparing to defend themselves against Persia, the Persians were making the most formidable preparations for their next invasion. These preparations had been begun by Darius, but were interrupted by a revolt in Egypt and were finally cut short by the death of the king himself. Darius was succeeded by his son Xerxes, a man of far greater pretensions and of far less ability than his father. Prompted to take up the task left unfinished by Darius, he called together his nobles and announced his purpose. "As Cyrus, Cambyses, and Darius," he said, "have each enlarged the empire, I wish to do the same. I propose to bridge the Hellespont and march through Europe, and fire Athens for burning Sardis and opposing Datis and Artaphernes. By reducing Attica and Greece, the sky will be the only boundary of Persia" (Herodotus, VII., 8). Four years he spent in preparing for his great expedition. Infantry, cavalry, horse transports, provisions, long 
ships for bridges, and war ships for battles were collected from various Asiatic nations. Three years were spent in cutting a channel through the isthmus of Athos, to avoid the promontory near which the fleet of Mardonius had been wrecked.

After collecting his forces at Sardis, Nerxes marched to the Hellespont. Crossing into Thrace, the army was reënforced

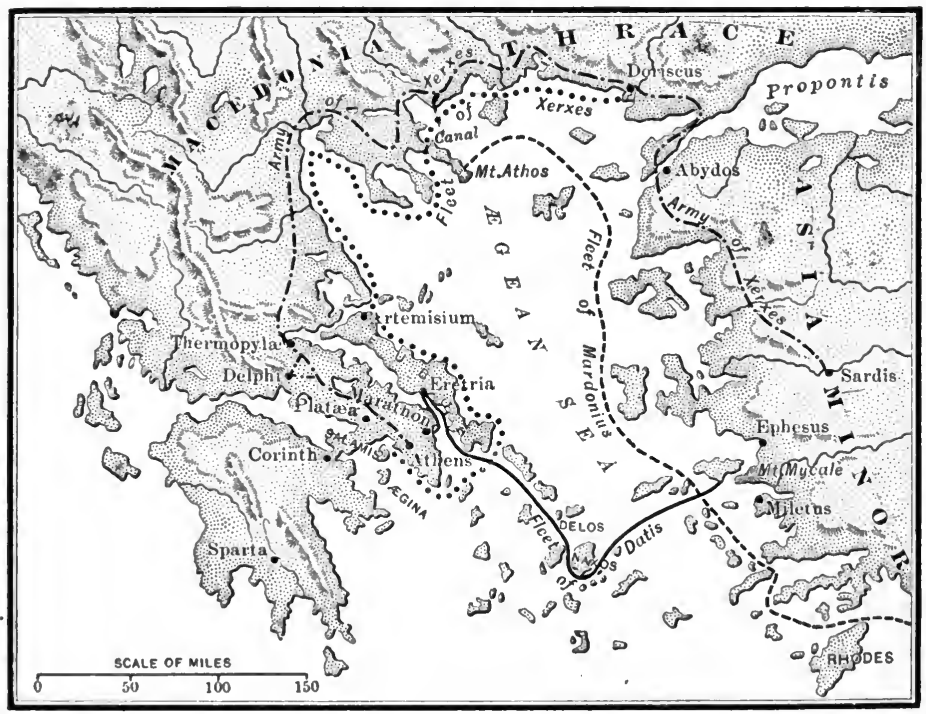

Routes of P'ersian Ixvasions

by the fleet, which had followed by way of the coast. Here the great king reviewed his immense armament, gathered, it is said, from forty-six different nations. Here were Persians clad in corselets and armed with great bows and short javelins. Here were Ethiopians covered with the skins of beasts and having arrows tipped with sharp stones. Here were the savages from central Asia, and the more civilized warriors from Assyria and Media. According to Herodotus the whole army amounted to more than a million of men. 'The fleet consisted 
of more than twelve hundred ships eolleeted from Phœnicia, Egypt, Ionia, Cyprus, and other maritime states. With this prodigious armament Xerxes hoped to appall and overwhelm the little armies and fleets of Greece. He advaneed by way of Thrace and Macedonia to the pass at 'Tempe, and was surprised to find this point abandoned. He then pushed through Thessaly and approached the pass of Thermopylx.

Battles at Thermopylæ and Artemisium.-It was at this pass that the Greeks had decided to resist the Persian advanee. This was no doubt the strongest defensive point in Greece. The pass itself was a very narrow roadway between the mountains and the sea, and could be easily defended by a small force; it was also proteeted from an attack from the sea by the long island of Eubeea, so that it eould be approached from the north only through the strait at Artemis'ium (see map, p. 152). The defense of the pass was intrusted to the brave Spartan king Leon'idas; while the strait was guarded by the Grecian fleet under a Spartan admiral-the Athenian division being commanded

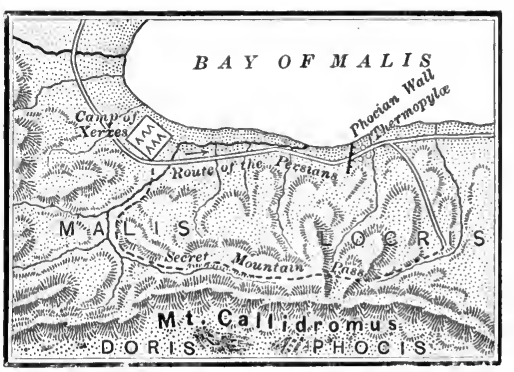

Pass of Thermopyla by Themistocles. Leonidas had with him about four thousand men, including three hundred Spartans, whom he stationed behind an old wall once built by the Phocians. That the whole Spartan army was not hurried to the defense of this most important position, was due to a superstition similar to that which had before delayed the arrival of the Spartan troops at Marathon. But with his small force Leonidas determined to hold the pass. For two days Xerxes hurled against him as large detachments of his army as he was able-but in vain. Even the "Ten Thousand Immortals" were repulsed. Then a citizen of Malis, who has been branded as the "Judas of Greece," 
Ephial'tes by name, revealed to Xerxes a secret path over the mountains, by which a force could be thrown in the rear of the Spartan position. By this act of treachery Thermopylw was lost. Leonidas and his Spartan band preferred death to dishonor, and perished-examples for all time of courage and patriotic devotion.

At Artemisium the Grecian fleet was held to its duty by the inspiring influence of Themistocles. The fleet comprised

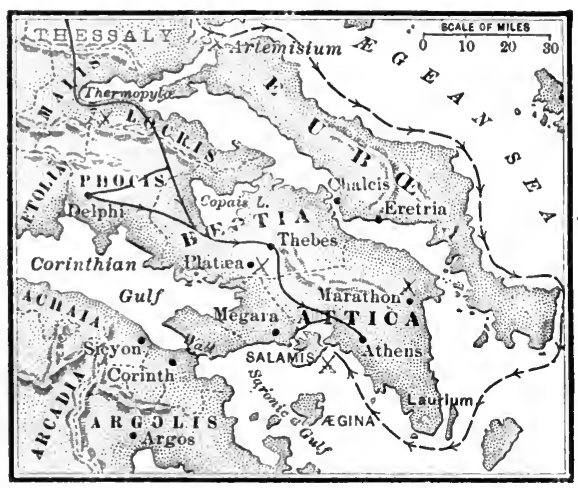

Seat of the Second Persian War lioute of I'ersian A $\mathrm{rmy} \longrightarrow \longrightarrow$ Course of Persian Fleet - -nearly three hundred vessels, more than half of which were furnished by Athens. By persuasion, and even by bribery, Themistocles induced the Spartan commander to hold his position. For three suceessive days the Greeks fought the Persian navy. Although these battles were indecisive, they prevented the Persians from approaching Thermopyla by the sea. But when the news came that Thermopyle was lost, it was useless to hold this position longer; and the fleet retired southward to the island of Sal'amis. All central Greece was now open to the invader.

Themistocles and the Battle of Salamis (480 B. C.).-The army of Xerxes pushed through central Greece into Attiea, burned Athens, and destroyed the temples on the Acropolis. 'The inhabitants fled to the neighboring towns. The Persian fleet moanwhile followed the Greeks to Salamis. It was here that Themistocles by his influence and adroitness brought on the decisive battle of the war. The Peloponnesian army had 
retreated behind the wall thrown across the Isthmus of ('orinth, and its leaders insisted that the fleet should retire to the same place. But 'Themistocles saw the great advantage of fighting in the narrow strait between Salamis and the Attic shore, where only a part of the Persian fleet could be brought into action. A council was called, and in the heat of debate Themistocles was charged with being a " man without a country," now that Athens was lost. But he replied that with a hundred and eighty war ships at his command he could found a eity anywhere. He threatened to withdraw his vessels and sail to Italy if the allies saw fit to abandon their Athenian comrades. By this threat the allies were persuaded to stand firm and fight in the strait. But to prevent any further indecision, Themistocles sent a messenger to Xerxes, giving the advice, as coming from a friend, that the Greeks must be attacked immediately to prevent their escape. Xerxes accordingly ordered up his fleet, and sent the Egyptian squadron to the strait opposite Megaris, to prevent any escape west of Salamis. At this juncture Aristides arrived from his retirement in Egina, and pleaded with his old rival that they should now be rivals only in the cause of Greece. He announced that the battle must take place at Salamis, as all means of escape were cut off. This showed Themistocles that his plans had been successful.

The Greek fleet now held the strait east of Salamis. The Persian squadrons gathered on its front. The Phœnicians moved in heavy columns on the right

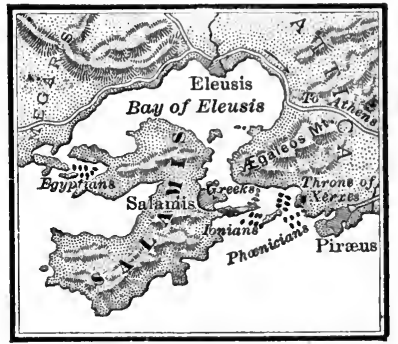

Battle of Salamis, 480 B. C. and the Ionians on the left. The great king sat upon a throne erected on the slope of Mt. AEga'leos to watch the conflict. The details of this battle are uncertain; but the victory of the Greeks was decisive. The 
Phœnician squalron, upon which the king chiefly relied, was shattered. Nearly half of the Persian fleet was destroyed; and a new glory crowned the loyal states of Greece.

Continuance of the War under Mardonius.-The victory at Salamis had broken the naval power of Persia; but the land forces were still intact. Xerxes, however, seemed to regard the cause of Persia as lost, and ordered a general retreat of the army. He directed the remnants of his flect to hasten to the Hellespont to guard the bridges by which he might recross into Asia, and which were now threatened by the Greeks. But there was one man who believed that a Persian army might still conquer Greee. This man was Mardonius. He it was who had failed in the first expedition under Darius, and who had encouraged Xerxes to undertake the present invasion. Intrusted with three hundred thousand men, Mardonius was permitted to remain in Greece to retrieve the disaster at Salamis. Before beginning his campaign the following year, Mardonius sought the alliance of $A$ thens against the rest of Greece. He promised to aid the $A$ thenians to rebuild their eity and to give them all the neighboring territory that they desired. But the Athenians sent back the word that "so long as the sun keeps its course, we will never join the cause of Xerxes" (Herodotus, VIII., 143). Attica was once more invaded, and the Athenians were again obliged to flee for safety. $\Lambda$ gain Greece was called upon to resist the invaders. Athens again called upon Sparta for aid, which was furnished after the usual delay. While the Grecian army was being collected, Mardonius retreated into Bootia, near Platxa, to await the final contest.

Battles of Platæa and Mycale (479 army of Mardonius the Greeks brought a force of about a hundred thousand men under the command of the Spartan Pausa'nias. The Athenian division was led by Aristides. The Spar$\tan$ commander was evidently convinced of the superiority of the Athenian division. for he insisted that it should hold the place of honor and danger against the strongest wing of the 
Persian army. After fighting and maneuvering in three different positions, the battle was finally decided near the walls of Platæa. 'The Persian army was nearly annihilated. Mardonius was killed. Another decisive victory was thus added to those of Salamis and Marathon. In commemoration of this victory the assembled allies made an offering of thanksgiving to Zeus Eleuthe'rios (the Deliverer), and instituted a public festival, called the Eleuthe'ria, to be cele-

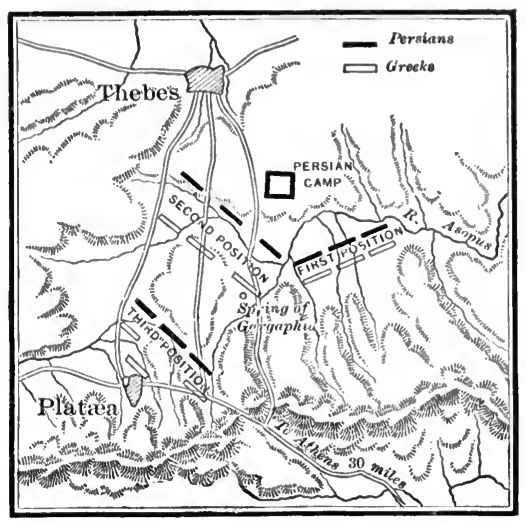

Battle of Platea, 479 B. C. brated once in every four years. The defensive alliance against Persia was also renewed; this is known as the "League of Platæa."

On the same day, it is said, on which the battle of Platra was fought, the Grecian fleet, having set out from Delos, gained a signal victory over the Persian navy on the Asiatic coast near the promontory of Myc'ale (map, page 152). This gave the Ionian Greeks fresh hope that the day of their deliverance was near.

The Carthaginian Attack; Battle of Himera.-While the Persians were trying in vain to conquer Greece, the Carthaginians, who were in alliance with Persia, were trying to conquer Sicily. Carthage, we remember, was a colony of Phœnicia; it had already an extensive empire in northern Africa and held certain cities in the western part of Sicily. Carthage, like Persia, represented the civilization of the Orient; and the struggle in Sicily, as well as that in Greece, was a conflict between Orientalism and the new culture of Europe. The largest part of the coast of Sicily had long before been settled by Greek 
colonies, and formed a part of what we have called "Western Greece" (which also included the Greek colonies on the southern coasts of Italy). ${ }^{1}$ The cities in Sicily had become the centers of Greek civilization, which was now exposed to the attack of Carthage. The leading eity in the defense of Western Greece was Syracuse, now under the rule of the tyrant Gelo (or Gelon). The decisive battle of this war took place at Himera (480 B. c.), on the northern coast of Sicily. Here the Carthaginians suffered a severe defeat at the hands of Gelo. According to tradition the battle of Himera was fought on the same day that the Greeks gained their decisive victory over the Persians at Salamis.

The Liberation of Greece.-The story of these struggles between the Greeks and their foreign enemies is of more than ordinary significance; for they belong to the most heroic period of Greek history. This war against Persia and Carthage has been aptly called "the war of liberation." It preserved Greece and Europe from Oriental domination. It revealed to the Greeks their own character and strength. The battles of Marathon and Thermopylæ and Salamis and Platæa taught them that courage and patriotism are virtues necessary to national independence. They gave to the Greek people the consciousness of unity and showed them the importance of their own institutions and culture. They also gave a new inspira-• tion to Greek life which was expressed in art and literature. This new spirit is shown in the lyric poetry of Simon'ides, who sang the praises of the dead heroes, and of Pindar, who glorified the national institutions of the Greeks. But more than all, this war gave to the Greeks a half century of comparative peace in which they might devote themselves to fulfilling their high mission in the world, unhindered by foreign interference.

1 The Greek cities in Sicily Included the Ionlan colonies of Cat'ana, Naxos, Yancle (Messa'na), and Him'era; and also the Dorian colonies of Syracuse, Gela, Agrigen'tum, and Selinus (see map, p. 110). 


\section{SYNOPSIS FOR REVIEW}

I. The First Persian Invasion, under Darius.-Greece and Persia.-The Asiatic Cities and the Ionian Revolt.-Plans of Darius against Greece.-Persian Invasion uncler batis and Artaphernes.-Miltiades and the Battle of Marathon.

II. Athens during the Ten Years' Respite.-Democratic Progress at Athens.-Aristides and Themistocles.-The Naval Programme of 'Themistocles.- $\Lambda$ thens Becomes a Maritime Power.-The Congress of Corinth.

III. The Second Persian Invasion, under Xerxes.-Preparations and Advance of Xerxes.-Battles at Thermopyles and Artemisium.-Themistocles and the Battle of Salamis.-Continuance of the War under Mardonius.-Battles of Platrea and Mycale.-The Carthaginian Attack; Battle of Himera.-The Liberation of Greece.

\section{REFERENCES FOR READING}

Smith, Wm., Ch. 16, "The Ionic Revolt"; Ch. 17, "The Battle of Marathon"; Ch. 18, "The Battles of Thermopyla and Artemisium"; Ch. 19, "The Battle of Marathon" (10). ${ }^{1}$

Cox, History, Part II., Ch. 5, "Invasion and Flight of Xerxes" $(10)$.

Greeks and Persians, Ch. 5, "The Ionian Revolt" (10).

Greek Statesmen, "Miltiades," "Aristides," "Themistocles" (26).

Oman, Chs. 19, 20, "The Invasion of Xerxes" (10).

Alleroft, Vol. II., Ch. 13, "Themistocles and the Naval Programme" (10).

Bury, Ch. 7, "The Perils of Greece" (10).

Abbott, Vol. II., Ch. 3, "The Great Invasions" (10).

Curtius, Vol. II., Bk. III., Ch. 1, "The War of Liberation" (10). Plutarch, "Aristides," "Themistocles" (26).

Herodotus, Bk. I., Chs. 1-38, 61-66 (reign of Cambyses); Bk. VII., Chs. 1-4 (last days of Darius); Bk. VIII., Chs. 74-95 (battle of Salamis) (17).

Aschylus, Drama of "The Persians" (account of the battle of Salamis) (17).

${ }^{1}$ The figure in parenthesis refers to the number of the topic in the Appendix, where a fuller title of the book will be found. 


\section{CHAPTER XII}

\section{THE ATHENIAN EMPIRE; AGE OF PERICIES}

\section{Athens and the Delian Confederacy}

The New Athens under Themistocles.- We have seen the important part taken by Athens in the Persian wars. Herodotus tells us that in this great crisis the Athenians were the saviors of Greece-that, next to the gods, they repulsed the invader. It is also true that they were the greatest sufferers in the cause of Greece. Their city had been twice occupied by the enemy and was now a heap of ruins. The inhabitants had been obliged to flee for safety to the neighboring islands of Salamis and Agina. The first need of the Athenians was now a home. Themistocles determined that on the ruins of the old city there should be built a new Athens, surrounded by strong and extensive walls sufficient to protect the people in any future war. In spite of the jealousy and opposition of the Peloponnesian states 'Themistocles, by his adroitness, was able to outwit his opponents and to aceomplish his purpose.

When the walls of $\Lambda$ thens were erected, Themistocles turned his attention to strengthening the harbor of Athens. This was located at the Piraus, on the Saronic Gulf, about four miles from the city. The fortifications begun after the first Persian invasion were now completed; and became an important factor in the commereial growth of $A$ thens. There soon grew up at the Pirreus a large commercial population-merchants, sailors, and resident foreigners who carried on trade. Thus 'Themistocles not only ereated the naval power of Athens and secured the triumph of Greece during the great Persian war; but he also rescued Athens from the disasters of that 
war, and raised her to a position in which she might command the commerce of the sea. To him more than to any other man, $A$ thens was indebted for her maritime and commereial supremacy; upon the foundations which he laid was built

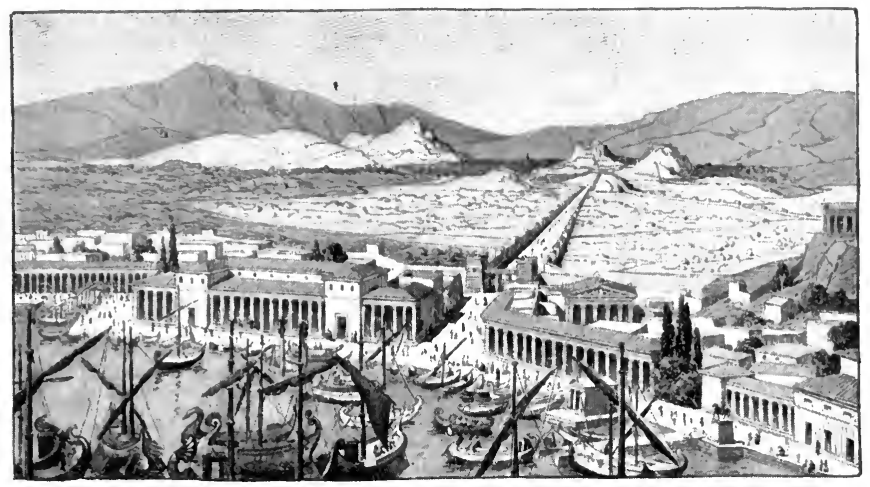

The Pireus, the Port of Athens (Restoration)

the Athenian empire. Although he had many faults, and was at last driven into exile, he was yet one of the greatest of the statesmen of Greece.

Athenian Supremacy in the Egean.-Athens took another step in the development of her power by getting command of the Grecian fleet in the Agean Sea. The fleet was now engaged in freeing the cities that had fallen under the Persian power during the late war. As Sparta had been, since the congress of Corinth (p. 150), the recognized leader of Greece. the chief command of the Agean fleet was in the hands of a Spartan admiral, who was no other than Pausanias, the victor of Platæa. The Athenian division of the fleet was under the command of Aristides, with whom was associated Cimon, the son of the great Miltiades. Pausanias began his work well, by freeing part of Cyprus in the eastern Mediterranean and Byzantium in Thrace. But with the spoils of Byzantium in his hands, Pausanias became arrogant toward the Greeks and 
friendly toward the Persians. He even offered to ally himself with the Persian king, and to betray to him the states of Greece. When the officers of the fleet compared the brutal and treacherous conduct of Pausanias with the upright character of Aristides, they with one aceord turned over the command from the Spartan to the Athenian admiral. By thus obtaining the chief eommand of the Grecian fleet, Athens acquired the supreme control of the Agean Sea. Sparta withdrew from the leadership which she had held sinee the congress of Corinth, and relapsed into her former position as simply the head of the Peloponnesian Ieague. ${ }^{1}$

\section{Formation of the Delian Confederacy under Aristides.-} The work of freeing the cities of the AEgean was continued by Aristides. It now seemed necessary to provide for their common defense against any future encroachments of Persia. This was done by the organization of a confederacy under the leadership of Athens. The chief duty of organizing the new league fell to Aristides, the commander of the fleet. $\mathrm{He}$ formed alliances with the cities, not only on the islands, but also on the Asiatic coasts, for the.purpose of forming a union to resist the Persian power. All members of the confederacy were to be equal; they were to send delegates to a common congress; and they were to of urnish ships or money for the eommon cause. The confederacy was to be a perpetual union; and no member could withdraw without the consent of the others. The island of Delos, the seat of the shrine of Apollo, was selected as the place where the common meetings were to be held, and where the common treasury was to be established. The assessments for the treasury were intrusted to Aristides, in whose justice all had confidence. The Confederacy of Delos was essentially an. Ionian league, under the leadership of

'The fate of Pausanlas was suited to his crime. He was recalled to Sparta. When the evidence of his crime became clear and he was about to be arrested, he fled for safety into the temple of Athena. But this did not protect him from the vengeance of the people. The door of the temple was closed by a wall, anc? the traitor was starved to death. 
Athens; and it was an offset to the Dorian league of the Peloponnesus under the leadership of Sparta. Henceforth the interests of Athens and of Sparta became more and more opposed to each other; and they came to be recognized as the two rival powers of Hellas.

Growth of Imperialism under Cimon.-The work which was begun by Aristides was completed by his colleague and successor, Cimon. Cimon inherited the conservative spirit and military ability of his renowned father Miltiades. His policy comprised peace with Sparta and war with Persia. His chief work was to enlarge and make strong the newly formed confederacy. He proceeded to Thrace and freed many cities on

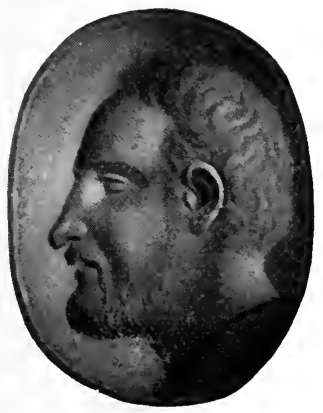

Cimon (So-called)

From a gem that coast. He reduced the rocky island of Scyros, where a nest of pirates threatened the commerce of Athens; and he planted upon it a colony of Athenian citizens. But his greatest military achievement was the defeat of the land and naval forces of Persia near the mouth of the river Eurym'edon in southern Asia Minor (466 B. c.; map, p. 111). This double victory insured the freedom of the cities of Caria and Lycia, on the Asiatic coast, and thus added to the strength of the confederacy.

While the chief purpose of Cimon was to destroy the Persian influence in the Agean, he was unfortunately compelled to use force to hold together the confederate cities. For example, the island of Naxos wished to withdraw from the league; but it was besieged and reduced to submission. Again, the island of Thasos, embittered by a quarrel with Athens, revolted; but it was compelled to submit by the allied fleet under Cimon. The tendency of this policy of coercion was to change the allied cities into subjects, and to make Athens not merely the leader of a confederacy, but the sovereign of an empire. 
Jealousy between Sparta and Athens.-The whole course of events at this time was to increase the jealousy existing between Sparta and Athens. Sparta had complained that the Athenians had shown deceit and an undue spirit of independence in fortifying their eity. She was also chagrined at losing the command of the fleet, and was envious of the growing power of Athens. On the other hand, Athens charged the Spartans with a treacherous attempt to assist the people of Thasos in their recent revolt. It was the policy of Cimon to appease, so far as possible, this enmity between the leading states of Greece, and to present a united front to Persia, their common enemy. Sparta was now suffering from the effects of a terrible earthquake and from a revolt of her subject population, the helots. She appealed to Athens for aid in putting down this revolt. Cimon was in favor of giving this aid. The new leaders of the democracy, Ephialtes and Per'icles, opposed it. But the influence of Cimon prevailed, and the Athenian assembly decided to send an army to assist the Spartans in their distress. When the army arrived and did not succeed immediately in putting down the revolt, the Spartans thought its failure was due to treachery, and dismissed it insolently. This piece of effrontery served to widen the breach between the two states. The party of Cimon, which had favored Sparta, lost its influence, and Cimon himself was ostracized (461 B. C.)

\section{Pericles and the Athenian Empire}

Pericles and his Policy.-In the same year in which Cimon was exiled, Ephialtes, the chief leader of the democratic party, was assassinated. By the removal of these two party chiefs, Pericles became the leading man in Athens.

In his character this great man united many of the best qualities of his predecessors, - the skillful statesmanship of Themistoeles, the patriotic spirit and democratic sympathies of Aristides, the military accomplishments and imperial ambition 
of Cimon. But he added to these the power of persuasive oloquence, which made him the foremost orator of his day, and

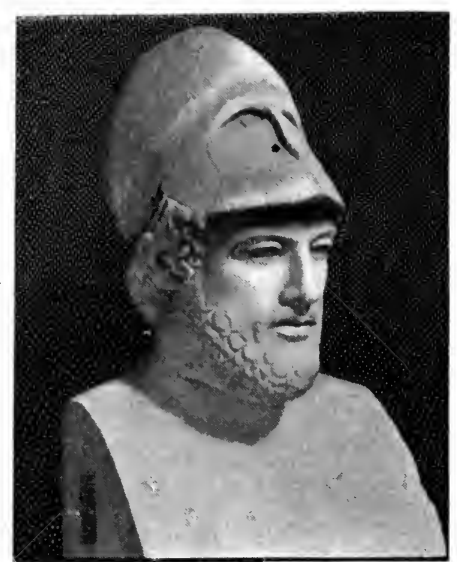

Pericles gave him almost absolute control of the Athenian asscembly. His political policy was to extend and secure the imperial power of Athens, and to make it the foremost city of the world. This policy included: (1) the extension of the fortifications of Athens; (*) the establishment of a land empire over the continental states of Greece; (3) the completion of the maritime empire over the cities of the Agean; and (4) the weakening of the power of Persia, not only by protecting the Greek cities in Asia Minor, but also by aiding the Persian subjects in their revolts, especially in Egypt and in Cyprus..

The Building of the Long Walls.-Pericles followed the policy of Themistocles in seeking first of all to make Athens an impregnable city. The fortifications erected by Themistocles about Athens and about the Piræus $h$ ad created two separate centers of

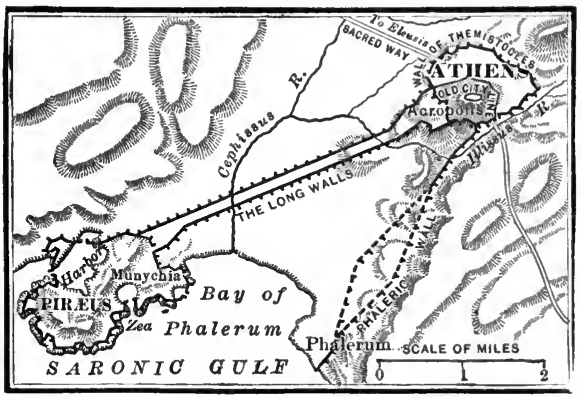

The Walts of Athens ${ }^{1}$ defense. Pericles desired to unite these two places by one sys-

"There is some question as to the exact location of the "Phaleric wall," and some writers even doubt that there was such a wall. 
tem of defensive works, and thus to prevent Athens from being cut off from her harbor and from the rest of the world. This defensive system may have been begun by Cimon; but it was completed by Pericles. One of the new walls, the southern, ran from the city to the Bay of Phalerum; and another, the northern, ran to the harbor of the Piræus. In a few years a third and middle wall was erected near and parallel to the northern one, the two together being known as the "Long Walls." These formed a wide and secure avenue from the city to the Piræus. Athens and the Piræus were thus united in a single fortified area, which formed a military and naval base of operations for the whole empire.

Athenian Attempts at a Land Empire.-Pericles desired to extend the influence of Athens upon the land as well as upon the sea, and thus to make Athens the head of a continental as well as a maritime league. The first step in this direction was taken as the result of an alliance which had already been formed by Athens with Argos and Megara. This alliance exeited the jealousy of the neighboring Dorian states, Corinth and Egina; a war followed, and Agina was reduced to the condition of a tributary state. The next step was the result of an attempt made by Sparta to interfere in the affairs of central Greece. This brought on a war between Athens, on the one side, and Sparta and Bootia, on the other. After battles at Tan'agra ( 457 в. c.) and (Enoph'yta (456 в. с.; map, p. 168), several disaffected states either became the willing allies of Athens, or were compelled to join the new continental league. By these two movements the Athenian power was extended over most of central Greece.

Completion of the Maritime Empire.-While Athens was gaining new allies on the land, she was also obtaining greater power over her allies upon the sea. The members of the Delian Confeleracy were at first expected simply to furnish ships and sufficient money to maintain the fleet. Soon they were inclined to make their contributions entirely in money, while 
retaining their independence. Afterward the contributions were regarded as tribute due to Athens, which $\Lambda$ thens had a right to collect. Again, it was at first expected that the affairs of the confederacy were to be mianaged by a congress of delegates, meeting at Delos; but the allies soon regarded these meetings as irksome, and the political eontrol of the confederacy gradually passed into the hands of Athens. Finally, the common treasury was transferred from Delos to Athens (about 454 B. с.). By these steps the political and financial administration of the league became completely centralized in Athens; and the Delian Confederacy became transformed into an Athenian empire. Of all the members of the original confederacy, only three-Chios, Lesbos, and Samos-were allowed to retair their position as equal and independent allies.

Restoration and Death of Cimon.-After the empire was finally established, Cimon, who had been recalled from his banishment, recovered for a brief time his influence over the Athenian assembly; and his policy of peace with Sparta and war with Persia again found favor with the people. A Five Years' Truce was accordingly formed between Athens and Sparta (450 B. c.), by which each party agreed to respect the rights and possessions of the other. Cimon then set out on a new expedition against Cyprus, in which island Persia was now attempting to reëstablish her authority. This expedition resulted in a decisive victory over the Persians, and also in the death of Cimon (449 B. c.). It is said that Cimon concluded a treaty of peace with Persia; but concerning this there is much doubt. With the death of Cimon, Pericles regained his previous position as the ruling spirit of Athens.

Failure of the Imperial Policy of Athens.-The wonderful energy which Athens displayed at this time is evident when we consider that, within a period of thirty years, she had recovered all the Agean cities lost during the Persian wars, and had established her authority over a large part of European Greece. But her ambitious policy to maintain an empire 


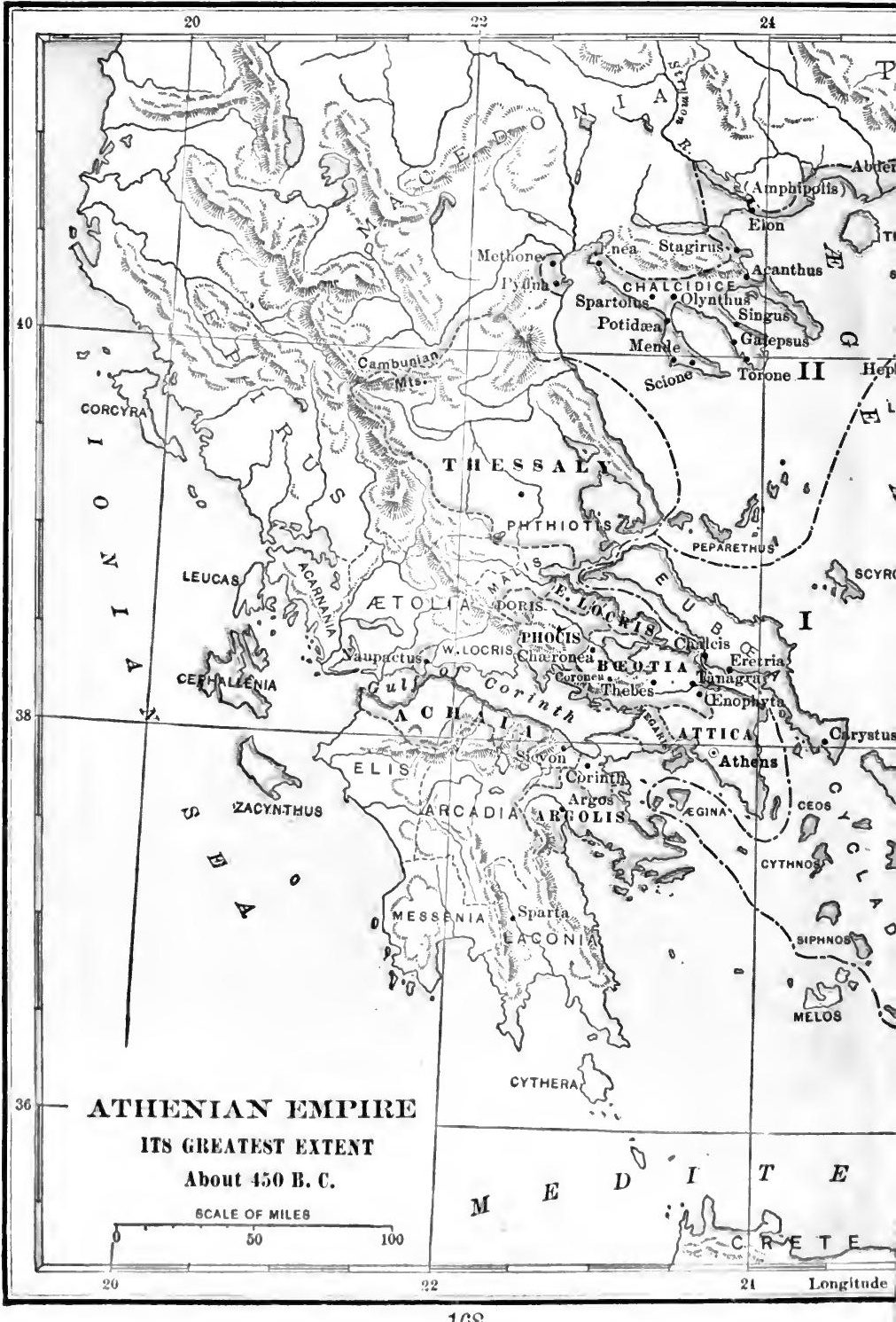




\section{MAP No.8.}

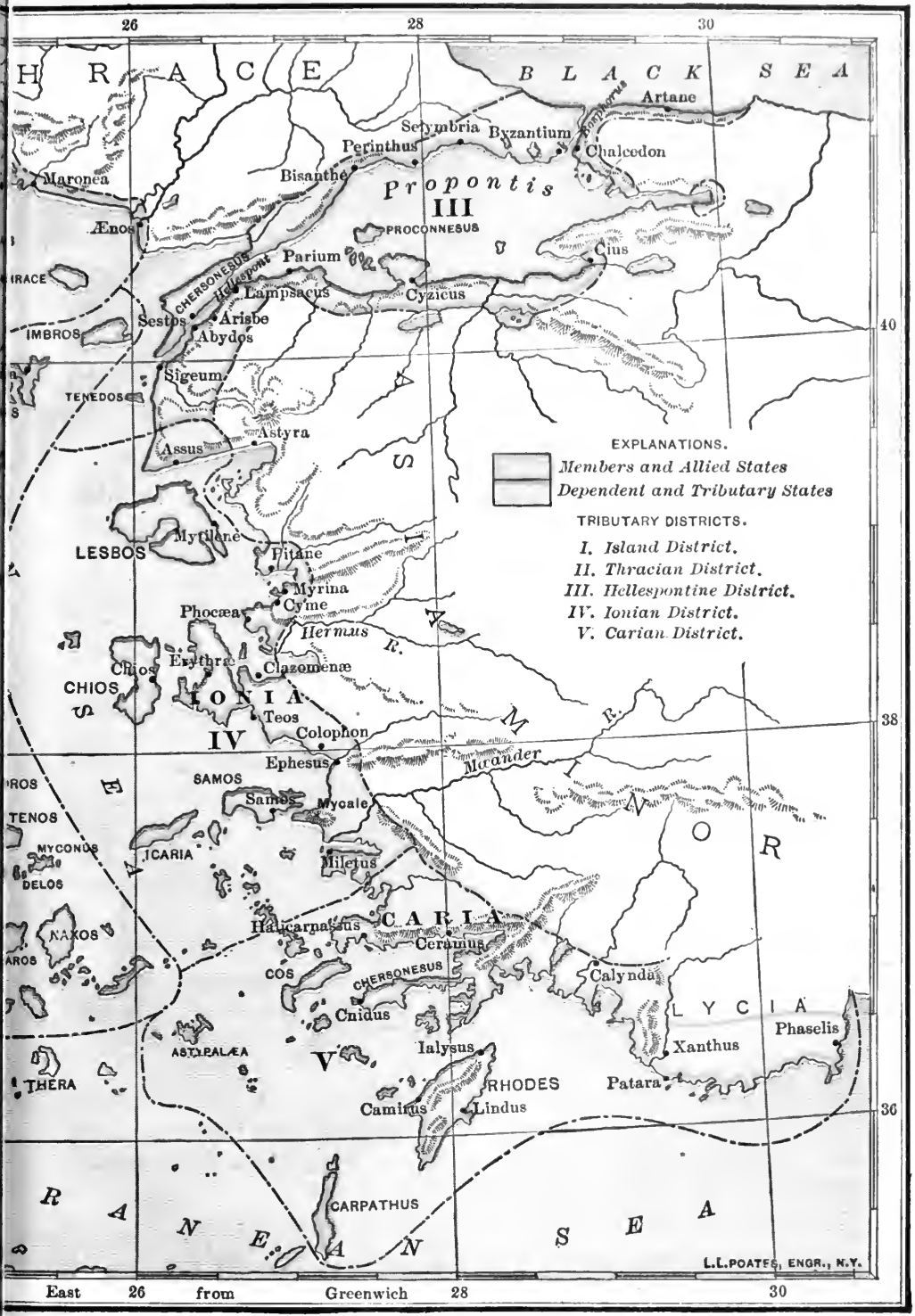




\section{TRIBUTARY STATES OF THE ATHENIAN EMPIRE}

The following table gives a list of the tributary states that paid annually more than one talent, arranged by tributary districts :-

I. Island District. - Egina, Ceos, Cythnos, Siphnos, Paros, Naxos, 'Tenos, Andros, Carystus and Chalcis in Eubœa, and Hephæstia in Lemnos.

II. Thracian District. - Peparethus, Methone, Enea, Potidæa, Mende, Scione, Spartolus, Olynthus, Galepsus, Torone, Singus, Acanthus, Abdera, Maronea, Anos, Thasos, Samothrace.

III. Hellespontine District. - Perinthus, Selymbria, Byzantium, Chalcedon, Cyzicus, Proconnesus, Lampsacus, $\Lambda$ risbe, $\Lambda$ bydos, Tenedos.

IV. Ionian District. - Myrina, Cyme, Phocæa, Clazomenæ, Erythræ, Teos, Colophon, Ephesus, Miletus.

v. Carian District. - Halicarnassus, Ceramus, Cnidus, Chersonesus in Caria, Calynda, Phaselis, Cos, Astypalæa ; also Camirus, Ialysus, and Lindus in the island of Rhodes.

The following is a list of the above tributary. states arranged according to the amount of their annual tribute : 30 talents, Fgina, Thasos ; $16 \frac{1}{5}$ talents, Paros; 15 talents, Abdera, Byzantium; 12 talents, Lampsacus ; ro talents, Enos, Chalcis, Perinthus ; 9 talents, Chalcedon, Cyme, Cyzicus ; 7 talents, Erythræ ; $6 \frac{2}{3}$ talents, Naxos ; 6 talents, Andros, Ephesus, Ialysus, Camirus, Lindus, Potidæa, Samothrace, Scione, Teos, Torone; 5 talents, Carystus, Cos, Mende, Miletus, Selymbria ; 4 talents, Abydos, Ceos; 3 talents, Anea, Acanthus, Chersonesus in Caria, Hephæstia, Cnidus, Cythnos, Methone, Peparethus, Phaselis, Proconnesus, Siphnc:Tenedos, Tenos ; 2 talents, Arisbe, Olynthus, Phocæa, Singus, Spartolus ; $\mathbf{I}_{\frac{2}{3}}$ talents, Halicarnassus ; $\mathbf{I}_{\frac{1}{2}}$ talents, Astypalæa, Galepsus, Calynda, Ceramus, Clazomenæ, Colophon, Maronea, Myrina. (Cf. Beloch, Griechische Geschichte, Ed. 1893, I., 402.)

The whole number of tributary states was as follows: Island District, 41; Thracian District, 68; Hellespontine District, 50 ; Ionian District, 42; Carian District, 62 ; undetermined, 4 ; total, 267. (Cf. Boeckh, Staatshaushaltung der Athener, Ed. 1886, II., 362-369.) 
upon the land proved a failure. She was soon beset with difficulties and afflicted with reverses which weakened her influence among her continental allies. News had already come that a fleet of two hundred vessels, sent some time before to free Egypt from Persia, had been annihilated (454 B. c.). Sparta still claimed the right to interfere in the affairs of central Greece. Bocotia opposed the effort to establish democratic governments within her borders, and defeated the Athenians in a battle at Corone'a ( 4.47 в. c.). The spirit of revolt extended to other cities; and one after another the $\Lambda$ thenian land allies renounced their allegiance. Under these depressing circumstances Pericles concluded a 'Thirty Years' Truce with Sparta (445 B. c.), by which each party was restricted to its present possessions. Athens thus lost her peninsular empire, but retained her empire upon the sea.

The "Years of Peace" (445-431 в. с.).-After the conclusion of the treaty with Sparta, there followed a period of peace, during which Pericles gained his highest distinction as a patron of Athenian culture. Pericles was himself a man of high intellectual accomplishments and of refined artistic taste. He represented in his own person and character the best qualities of the Greek people. While he exercised his influence to strengthen the Athenian democracy and also to maintain the authority of Athens over her maritime empire, his most important and enduring work was the encouragement that he gave to literature and art. It is on account of his patronage of culture more than anything else that the period of his administration has been called the "Age of Pericles." It was then that Athens became the intellectual and artistic capital of Hellas. The influence of Pericles did not cease, however, with the termination of the years of peace, but continued, for nearly a century, to give character to the culture of Greece. ${ }^{1}$

- The culture of Athens during the age of Pericles was so closely connected with that which followed his death, that we shall consider them together as forming successive phases of the "Attic period." See pp. $197-223$. 


\section{The Athenian Constitution under Pericles}

Character of the Athenian Democracy.-It was during the time of Pericles that the democratic constitution of Athens reached its highest development. We have already seen the general tendency in the direction of popular government-in the decline of the monarchy, in the growth of the archonship, in the extension of the franchise by Solon, and in the radical reforms of Clisthenes. And this popular tendency had continued since the time of Clisthenes. Ephialtes had restricted the ancient privileges of the Areopagus; and Pericles had induced the people to take an active part in the exercise of their political duties, by introducing a system of payment for public service.

By the term " democracy," the Athenians understood a state in which all the powers of government are exereised directly by the eitizens, and in which all eitizens are equal before the law. The Athenian idea of democracy differed from the modern idea chiefly in two ways: first, in that the Athenians had very little notion of the modern idea of representation; and second, in that the number of citizens formed a comparatively small part of the whole population.

Classes of the Population.-We may get an idea of the limited nature of the Athenian democracy by looking at the different classes of persons residing in Attica, which formed the territory of the Athenian city state: the slaves, the resident foreigners or "meties," and the citizens.

(1) The slaves of Attica have been estimated at about 100,000 . They included captives taken in war and persons imported from the slave markets on the Thracian and Scythian coasts. They were employed in domestic and agricultural labor, and were even allowed to work for themselves on consideration of paying their master a yearly sum. 'The state sometimes employed slaves as policemen and clerks. The slave, however, had no political or civil rights, although he might be 
protected from the cruelty of his master, and sometimes, in grave emergencies, might be called upon to serve in the army or the fleet.

(2) The resident foreigners, or " metics," numbered perhaps 10,000. These persons were engaged mostly in trade, and formed a valuable part of the population. But they had no share in the government. They could not hold land in Attica. They were obliged to pay a yearly tax and sometimes to serve in the army and navy; for example, as shield-bearers or rowers. Every resident foreigner was bound to choose a citizen to represent and protect his interests.

(3) The class of citizens formed the rest of the population of Attica. The early policy of admitting foreigners to citizenship was changed by Pericles, who restricted citizenship to those who were born of an Athenian father and an Athenian mother. The whole number of Athenian citizens, including men, women, and children, was at the time of Pericles in the neighborhood of 120,000 . Of this population the number of voters is generally estimated as about 30,000. This comparatively small body of persons, scattered through the local districtsthat is, the tribes and demes-of Attica, formed the Athenian democracy.

$X$ The Athenian Assembly, or Ecclesia.-The most important political body in the state was the ecclesia, or general assembly of the people. It consisted of the whole body of male citizens above eighteen years of age. It met forty times each year on the Pnyx - a sloping hill backed by a perpendicular rock, where was located the bema, the stone platform upon which the orators stood to address the people. The assembly was the ultimate source of political authority. Here any citizen could speak and vote upon questions properly submitted by the council. The assembly was often brought under the power of some influential man, whose character and oratorical ability enabled him to sway the multitude and to become the "leader of the people,", or, as Aristoph'anes puts it, " the master of the 


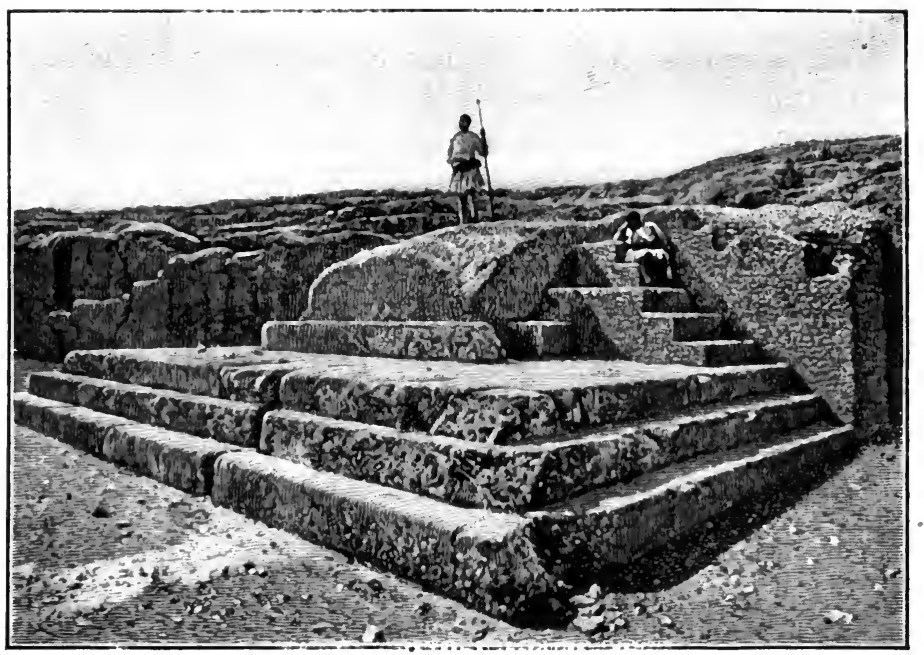

The Bema on the PNyx

stone in the Pnyx." Thucyd'ides describes Athens at the time of Pericles as "a democracy ruled by its ablest citizen."

The Athenian Council, or Boulé.-Since the decline of the Areopagus, the most important political body after the assembly was the council of five hundred. The council was composed of ten sections, being made up of fifty members, at least thirty years of age, chosen annually by lot from each of the ten local tribes. This body exercised the highest administrative and executive powers in the state. It prepared the measures to be submitted to the assembly. It could itself pass ordinances, provided they did not conflict with the existing laws. It had charge of the public buildings, festivals, and religious ceremonies. It had control of the public finances. It saw that the laws of the state were carried into execution, and in certain exceptional cases it exercised judicial functions.

The Athenian Magistrates; the Generals.-As the decline of the Areopagus was followed by the growing importance of 
the council, so the decline of the archonship was attended by the growth of the "generalship" as an executive office. 'The ten strategi, or generals, came to be the most important magistrates in the government. On account of the fact that they required a special kind of ability, they were elected, not by lot, but by the vote of the assembly. 'The first duty of the generals was to command the army, but to this were added other functions. They had charge of the means for defending the statethe maintenance of the fortifications, the army, and the navy. They also had charge of foreign affairs, the negotiation of treaties, and the receiving of ambassadors. They furthermore had the power to call extra sessions of the assembly, if in their judgment the public interests required it.

The Athenian Courts; the Dicasteries.-One of the most peculiar features of the Athenian constitution was the organization of the courts. The old council of the Areopagus retained a certain jurisdietion over some grave offenses, like murder. But the great majority of judicial cases were tried by jurors drawn from the body of citizens, and from these courts there was no appeal. The whole jury list (helicea) was made up of six thousand citizens, at least thirty years of age, who each year voluntarily presented themselves before the archon and took an oath to perform their duties faithfully. This whole judicial body was divided into ten sections, or "dicas'teries," of five hundred members each-leaving a thousand supernumeraries who could be drawn upon when necessary. The jurors serving on a single case were drawn from these sections, and might number two hundred or more. From the time of Pericles the jurors received a small pay for their services. The popular character of the Athenian courts shows the extreme democratic principles which controlled the state, since an opportunity was given to every citizen at some time to share in the administration of justice.

The Military System.-The army, like the government, was based upon democratic principles. Every man between the 
ages of twenty and sixty was liable to be called upon to serve the state as a soldier. 'The army consisted of three branches: (1) the heary-armed troops, armed with the defensive equipment, the shield, helmet, breastplate, and greaves, and the offensive weapons, the sword and spear; (2) the light-armed troops, who fought without the defensive armor with the sword and spear, and sometimes with the bow and arrow; and (3) the cavalry, which was not much used in Greece, on aecount of the mountainous character of the country. The military organization was based upon the "phalanx," a body of from two to four thousand men, made up of divisions and subdivisions, each under its own officers, and usually drawn up in eight ranks. The Greek phalanx was the most effective military organization before the time of the Roman legion.

The Financial System.-The administration of the public finances was in the hands of the council. The expenses of the state were due chiefly to (1) the maintenance of religion and the public games and festivals, (2) the payment for civil and military services, (3) the construction and repair of public buildings, and (4) public bounties paid to poor citizens, and pensions to the orphans of deceased soldiers. The revenues of the state. were derived principally from (1) the tribute laid upon the allied cities (p. 170), (\&) the rent of state property, like the silver mines at Laurium, (3) duties on goods exported and imported or sold in the market, and (4) the tax on resident foreigners. The state was also accustomed to receive voluntary contributions from patriotic citizens.

Political Parties at Athens.-The growth of the Athenian democracy, like that of every popular government, was marked by the development of parties and of factional strife. We have already seen, from very carly times, political divisions between different portions of the people,-for example, the Eupatrids and the common people; and the men of the Hill, the Plain, and the Shore. But from the time of Clisthenes, there had come to be two quite well-defined political parties, the demo- 
cratic and the oligarchical. 'The democratic party was in favor of the new constitution, with the popular changes brought about by Clisthenes, Ephialtes, and Pericles; it was eminently the patriotic party of Athens, opposed to foreign influences, whether Spartan or Persian. The oligarchical party, on the other hand, was opposed to the constitution, which had deprived its members of their old exclusive privileges; it was in sympathy with the aristocratic ideas of Sparta, and did not hesitate sometimes to take the part of Persia. Between these two extreme parties, there was what may be called a moderate party, less defined than the others, which did not oppose the democratic constitution so much as it did the policy of the democratic leaders. The strife between these parties was allayed for a time by the overpowering influence of Pericles, only to become more bitter, as we shall see, during and after the Peloponnesian war.

\section{SYNOPSIS FOR REVIEW}

I. Athens and the Delian Confederacy.-The New Athens under Themistocles.-Athenian Supremacy in the Agean.Formation of the Delian Confederacy under Aristides.-Growth of Imperialism under Cimon.-Jealousy between Sparta and Athens.

II. Pericles and the Athenian Empire.-Pericles and his Policy.-The Building of the Long Walls.-Athenian Attempts at a Land Empire.-Completion of the Maritime Empire.Restoration and Death of Cimon.-Failure of the Imperial Policy of Athens.-The "Years of Peace."

iII. The Athenian Constitution under Pericles.-Character of the Athenian Democracy.-Classes of the Population.-The Athenian Assembly, or Ecclesia.-The Athenian Council, or Boulé.-The Athenian Magistrates; the Generals.-The $\Lambda$ thenian Courts; the Dicasteries.-The Nilitary System.-The Financial System.-Political Parties at Athens.

\section{REFERENCES FOR READING}

Smith, Wm., Ch. 23, "Rise and Growth of the Athenian Empire" $(10){ }^{1}$

Cox, History, Bk. III., Ch. 1, "The Thirty Years Truce" (10).

${ }^{1}$ The figure in parenthesis refers to the number of the topic in the Appendix, where a fuller title of the book will be found. 
Allcroft, Athenian Empire, Ch. 1, "Confederacy of Delos and the Foundation of the Athenian Empire" (10).

Oman, Ch. 22, "Origin of the Confederacy of Delos"; Ch. 23, "Building of the Athenian Empire"; Ch. 24, Athens at the Height of Her Power; Ch. 25, "The Years of Peace" (10).

Alleroft, Vol. II., Ch. 10, "Athens under Pericles"; Ch. 11, "Constitutional Development in Athens"; pp. 145-147 (ethics of Athenian policy) (10).

Curtius, Vol. II., Bk. III., Ch. 2, "Growth and Power of Athens"; Ch. 3, "The Years of Pericles" (10).

Holm, Vol. II., Ch. 14, "Pericles to the Thirty Years Peace"; Ch. 16, "The Government of the City" (10).

Grote, Part II., Ch. 44 (treason and death of Pausanias); Ch. 46 (constitutional and judicial changes under Pericles) (10).

Abbott, Pericles, Ch. 1, "The Alcmæonidæ"; Ch. 6, "The Areopagus and Ephialtes"; Ch. 16, "The Athens of Pericles; the Government" (2i).

Greenidge, Ch. 6, "Democracy" (11).

Whibley, Political Parties, Ch. 1, "Athenian Constitution and Empire" (11).

Bury, pp. 336-342 (Athens's treatment of her subject states) (10).

Freeman, Essay, "The Athenian Democracy" (3).

Plutarch, "Cimon," "Pericles" (26).

Aristotle's Constitution, Chs. 23-27 (Ephialtes and Pericles) (17).

\section{CHAP'TER XIII}

\section{THE STRUGGLES FOR SUPREMACY IN GREECE}

\section{The Peloponnesian War (431-404 B. C.)}

Causes Leading to the War.-In tracing the political growth of Greece up to this time, we have seen not only certain elements of greatness, but also certain elements of weakness in the Greek character. We have seen that while the Greeks possessed a love of political liberty and of local independence, they seemed incapable of forming a single national state based upon their common interests. Only during the brief period of the Persian invasions had they been able to drop their local pride sufficiently to unite against their common enemy. As the danger from Persia passed away they relapsed into a condition of 
strife and mutual jealousy. During the next seventy years the Grecian states were continually at war with one another, trying to settle the question as to who should be, or should not be, supreme. 'The first struggle was an attempt to deprive Athens of the supremacy which she now held in the Hellenic world. The initial steps of this struggle had already been taken when Athens had attempted to establish a land empire in central Greece and had been balked by Sparta and other states (see pp. 166, 171). This struggle was now renewed in the so-called Peloponnesian war, and continued with little interruption for twenty-seven years. We may briefly indicate the remote causes of the war as follows: (1) the strong spirit of local independence, and lack of a common feeling of patriotism, which marked the whole Greek people; (2) the opposing interests of the Dorian and Ionian races-the one being agricultural, the other commercial; the one favoring aristocratic, the other democratic principles; the one strong in their armies, the other in their fleets; (3) the bitter jealousy which had long been growing between Sparta as the head of the Peloponnesian League and Athens as the ruler of the Delian Confederacy.

The direct cause of the war was the interference of Athens in the affairs of Corinth, one of the members of the Peloponnesian League. Of all the Peloponnesian states Corinth was the one which had sufficient maritime interests to be a commercial rival of Athens. In a quarrel which arose between Corinth and one of her colonies-Corcy'ra-Athens thought that her own interests were endangered, and took the part of Corcyra. This led Corinth to appeal to Sparta for aid, on the ground that Athens had broken the Thirty Years' Truce (see p. 1\%1). A meeting of the Peloponnesian states was called, and it was decided to uphold the cause of Corinth and to declare war" against Athens.

The War Policy of Pericles (431-429 B. c.).-If we compare the respective forces of the two leading states, we may see the reason of the war policy adopted by Pericles. The Athenian 
PROGRFASIVE MAP No. 9.

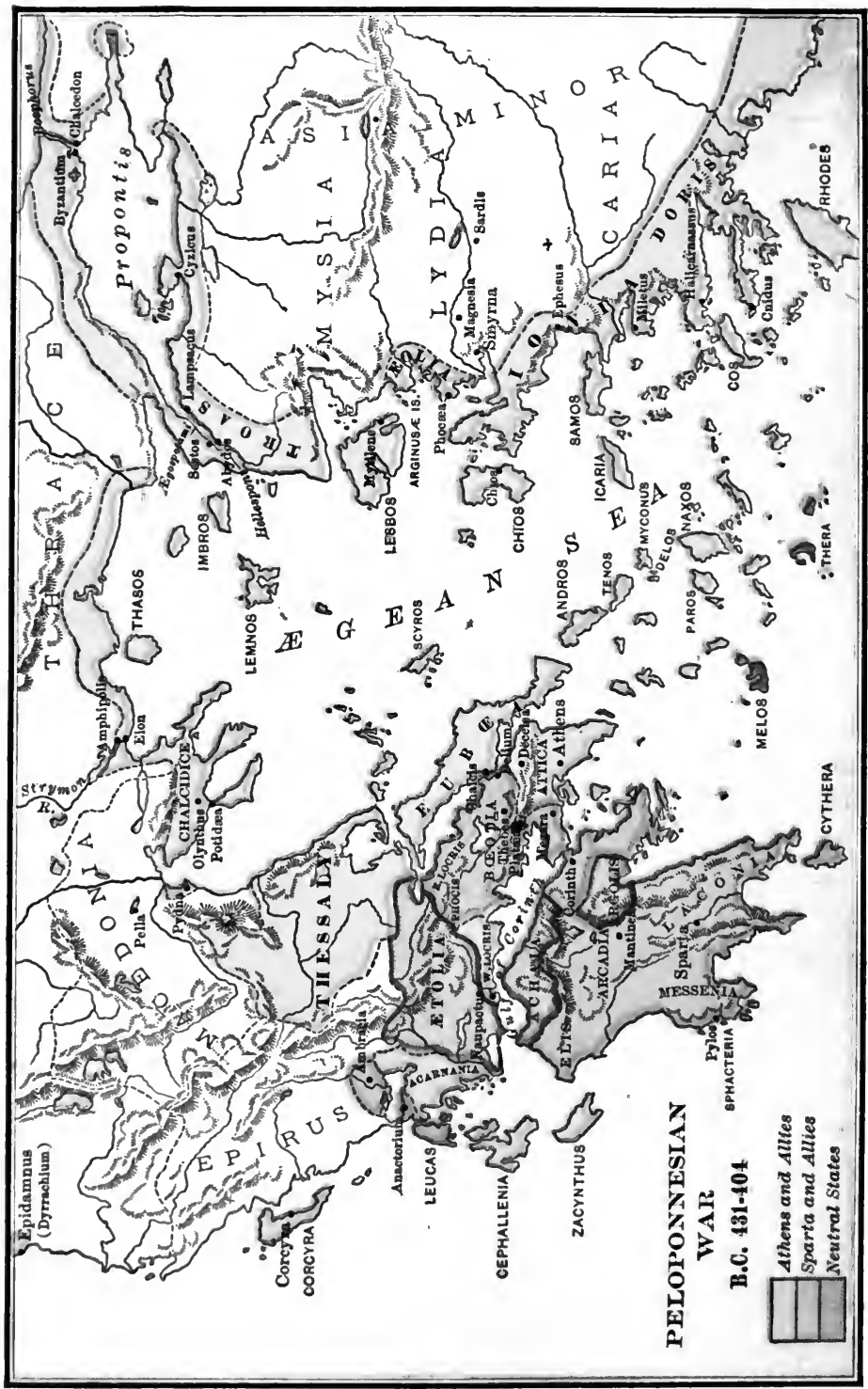


army could not hope to defeat the superior land forces which Sparta sent to invade Attica; and so the inhabitants of Attica were called upon by Pericles to find a safe refuge within the walls of the city, while the powerful Athenian navy was sent to harass and ravage the coasts of the Peloponnesus. In this way the war was conducted during the earlier years-that is, by periodical invasions of $\Lambda$ ttica by the Spartan army, and by successive attacks upon the Peloponnesian coasts by the Athenian navy. In the third year of the war Pericles died (429 B. C.), stricken down by a terrible plague which broke out in the overcrowded city. In the death of Pericles Athens lost her greatest statesman, at a time when she needed him most. No other man whom she had ever produced expressed more fully what was best in the Athenian character; and at this critical moment Athens possessed no man able to fill his place. After his death, new and less experienced leaders came forward to guide the affairs of state. The man who aspired to the position of Pericles was Cleon, a coarse leather-dealer, a bold demagogue, and a vociferous orator. Opposed to him was Nicias (nish'i-as), a well-bred man, a conservative leader, but overcautious and devoid of encrgy.

Conduct of the War under Cleon.-The direction of affairs now fell to Cleon, who became the leader of the war party. We need not attempt to follow all the many details of the war during this second stage. Its most important events were the following:

(1) The surrender of Platæa, a city on the borders of Bœotia and a steadfast ally of Athens. This city was invested by the Spartans, and after a prolonged siege of two years was forced to surrender, and its valiant defenders were mercilessly put to death (429 в. с.).

(2) The revolt of Mytilene on the island of Lesbos, an ally of Athens. This revolt was excited by the oligarchical party of Mytilene; it was finally put down by Athens after a severe struggle; the walls of the city were dismantled; a thousand 
of its inhabitants were put to death, and its lands were allotted to Athenian citizens ( 427 B. C.).

(3) 'The sedition at Coreyra. This was also instigated by an oligarchical party, and was aided by Sparta; it was marked

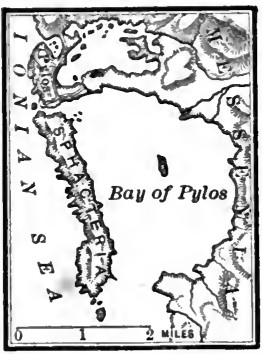

SPIACTERIA by the most bitter and deadly strife between the factions, but was finally suppressed by Athens, and the oligarchical party there was exterminated.

(4) The capture of Sphacte'ria and a beleaguered army of Spartans. Sphacteria was an island on the western coast of Messenia. The neighboring height of Pylos had been taken by the $A$ thenian general, Demos'thenes, in one of his naval expeditions along the coast. A Spartan army and fleet were sent to relieve the place; the fleet was destroyed in the bay, and the army was entrapped on the island. After some delay, the beleaguered Spartan soldiers-numbering about three hundredwere captured by Cleon, who had boasted in the assembly that he could perform this feat in twenty days-which he in fact accomplished, with the aid of Demosthenes.

(5) The campaign of Bras'idas in Chalcidice. Brasidas was the most able of the Spartan generals. As the war had thus far been favorable to $\Lambda$ thens, he eonceived the brilliant idea of weakening Athens by striking her allies in the north from whom she derived her supplies. This plan was carried pout in a successful campaign, and Athens lost most of her Chaleid'ian allies. While Brasidas was in the north, Athens tried to get possession of Bœotia, but was defeated in a battle at De'lium (424 B. c.). After a year's truce, Cleon determined to continue the war in Chalcid'ice, but suffered a severe defeat in a battle at Amphip'olis (422 в. c.), in which both generals, Brasidas and c'leon, were killed.

The Peace of Nicias, and its Failure.-With the death of Cleon, who was the war leader, Nicias became the lead- 
ing man at Athens. Always opposed to the war, he now negotiated with Sparta the treaty of peace which bears his name $(421$ в. с.). By the terms of this treaty each party agreed to restore the acquisitions made during the war-Sparta to give up Amphipolis and the other Chaleidian towns, and Athens to give up Pylos and the eaptives taken at Sphacteria. This peace was to last for fifty years; but it proved futile, and was followed by new combinations and intrigues among the different states. The failure of the Peace of Nicias was due chiefly to the refusal of the allies of Sparta to respect it, on the ground that they had not been consulted in making it.

Alcibiades and the Sicilian Expedition.-While the conservative and feeble Nicias was trying to maintain peace, there appeared a new and resolute war leader in the person of Aleibi'ades-one of the most brilliant and accomplished, yet selfish, cunning, and unscrupulous characters that Athens ever produced. Under his influence the Athenians were led to join the disaffected allies of Sparta and to invade the Peloponnesus, where they suffered a defeat at Mantine'a (418 в. C.). Failing in this undertaking, Alcibiades now induced the Athenians to conquer Melos, simply because this

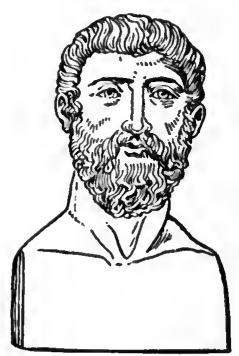

AlCIBIADES was the only important island of the Egean not included in the Athenian empire; the island was besieged and subdued, and the inhabitants were either slaughtered or enslaved.

But the most dazzling scheme of Alcibiades was the proposal to conquer Sicily. Trouble between two of the Sicilian towns afforded a pretext for this undertaking. Influenced by the alluring words of the new war chief, the Athenians fitted out an immense fleet, which sailed to Syracuse ( 415 B. c.), under the command of Alcibiades himself, together with Nicias and a third general, Lam'achus. No sooner had they reached the shores of Sicily than an order came from Athens command- 
ing Alcibiades to return to the city to answer a charge of sacrilege. But Alcibiades, fearing to face his accusers, now fled to Sparta and became the open enemy of Athens. Nicias, with his remaining colleague Lamachus, proceeded to invest the city of Syracuse. He landed on the north and rear of the city, stormed the heights of Epip'olæ, captured a strong position, encircled it with a fortification, and extended his siege lines to the south and west of the city. This was done in the

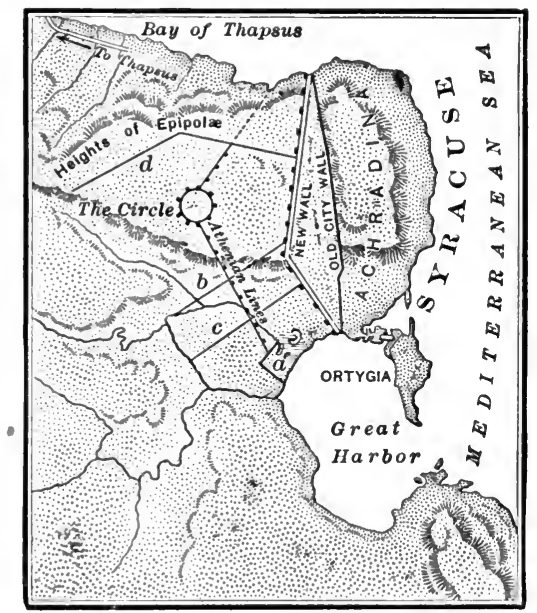

Syracuse and Vicinity

$a$, Athenian camp; $b$, $c$, first two cross wails, which the syracusans lost; $d$, third cross wall, which the Syracusans held face of the Syracusans, who had thrown up two cross walls to resist him. Although Lamachus was killed, this first stage of the war seemed successful to the Athenians.

Acting under the advice of Alcibiades, the Spartans now determined to send strong reënforcements to the aid of Syracuse, and also to invade Attica and, by seizing the town of Decele'a, to threaten Athens at her very walls. They sent to Syracuse their ablest general, Gylip'pus, who defeated Nicias; and prevented the further investment of Syracuse by erecting a third cross wall, which could not be taken. Although reënforeed by their greatest general, Demosthenes, the $A$ thenians were everywhere unsuccessful (413 в. c.). Their fleet was destroyed in a sea fight in the harbor of Syracuse. Their army was destroyed in a desperate attempt to retreat by land. With their fleet and army lost and their generals, Nicias and Demosthenes, condemned to death, this expedition 
proved the greatest disaster that had ever befallen the Athenian state.

The Reappearance of Persia.-One of the effects of the Sicilian disaster was to bring Persia once more upon the scene of war. It was for the interest of Persia, as well as of Sparta, to encourage the revolt of the $\Lambda$ thenian allies on the $\Lambda$ siatic coast. These two powers were thus induced to act together for the weakening of the Athenian empire, and the war was transferred to the coasts of Asia Minor. Alcibiades, who had favored the alliance between Sparta and Persia, now turned traitor to Sparta and took up his residence with the Persian satrap at Sardis. The great ambition of Alcibiades, from this time, was to secure his own restoration to power at Athens. While apparently favoring Persia, he was also trying to gain the good will of the Athenians by aiding their cause. He therefore induced the Persian governor no longer to aid Sparta, arguing that Persia would be the gainer if both Sparta and Athens were worn out by warring upon each other.

The "Four Hundred" at Athens.-The chief obstacle to the ambition of Alcibiades was the present government of Athens, which had condemned him to death. His return could evidently be accomplished only by a revolution at Athens. With the aid of the oligarchical faction this change was effected. All power was placed in the hands of a council of four hundred, which was constituted in an arbitrary way and which ruled in a despotic manner. The officers of the Athenian fleet in the Egean Sea protested against the revolution, and claimed themselves to represent the legal government at A'thens. They prepared to carry on the war and hoped with the aid of Alcibiades to win Persia to their side. They deposed those of their own number who favored the revolution; and the democracy at Athens overthrew the Four Hundred and restored the old constitution.

The Last Years of the War (411-404 B. c.).-Having placed Alcibiades in command of the fleet, the Athenians gained some 
notable victories. The Peloponnesian fleet, now operating in the Propontis, was destroyed near Cyz'icus, and Chalce'don and Byzantium on the Bosphorus were taken. But on an unfortunate day, during the temporary absence of Alcibiades, the Athenian fleet was defeated by the new Spartan admiral Lysan'der. For this failure, the Athenians deposed Alcibiades from his command, and he retired in disgrace to his own castle on the Hellespont. It required two more battles to finish the war. One of these was fought (406 B. c.) near the small islands of Arginu'sæ, between Lesbos and the mainland, where the Athenians gained a victory. But this victory proved a disgrace to Athens; for she condemned to death the generals who had won it, on the ground that they failed to rescue their shipwrecked comrades-a thing which, under the circumstances, was doubtless impossible. The last battle was fought (405 B. c.) in the Hellespont near the mouth of a little river called AEgospot'ami ("Goat's Streams"). A new Spartan fleet had been built with the aid of Persian gold furnished by the younger Cyrus, the new Persian governor in Asia Minor. With this new armament Lysander captured the entire Athenian fieet; and this event destroyed the maritime power of Athens. Lysander followed up his victory by reducing the cities on the Hellespont and Bosphorus. The allies fell away, and nothing was now left for Sparta but to reduce the city of Athens itself.

The Fall of Athens (404 B. c.).-In a short time Iyssander sailed into the Saronic Gulf and blockaded the Piræus; and the Spartan army came down from Decelea and encamped before the walls of the city. Without money, ships, allies. or food supply, Athens refused to surrender. It was only famine and starvation that brought the city to terms. Corinth and Thebes demanded that the city be totally destroyed. But Sparta refused to destroy a city that had done so much for Greece in the past. Athens was, however, required to destroy the Iong Walls and the fortifications of the Piræus, and to become a subject ally of Sparta. Accepting these conditions, 
Athens opened her gates to the enemy, and the $\Lambda$ thenian empire was no more.

Thus ended the Peloponnesian war, which had lasted for twenty-seven years, which had desolated nearly every part of the Greek world, and which, in spite of the courage displayed, had revealed some of the weakest and worst phases of the Greek character-political jealousy, local self-interest, deceit, and cruelty.

\section{The Supremacy of Sparta}

The Policy of Sparta in Greece.-Sparta now succeeded for a time to the empire which Athens was compelled to give up. The cities of Greece had been called upon to revolt against Athens in order to obtain their liberties. But they soon found that the tyranny of Athens was light compared with the despotism of Sparta. As Sparta was the patron of oligarchy, she compelled the cities to give up their democratic governments. A military governor, called a " harmost," was placed over most of them; and whatever civil authority there was to be exercised, was placed in a board of ten persons, called a "decarchy." Under such a government the property and lives of the people could not be safe. The imperial policy of Sparta was determined largely by the influence of Lysander, who, on account of his recent victories, was now the leading man in the Spartan state.

In Athens there was established a board of thirty oligarchs -who have received the name of the "Thirty Tyrants" (404403 в. с.). Under their leader, Crit'ias, their rule was harsh and oppressive and resulted in anarchy and a reign of terror. Citizens were put to death, and property was confiscated without mercy. It was only by a popular revolution led by the patriot Thrasybu'lus that the Thirty were deposed and a democratic form of government reëstablished. This was sufficient to show that the imperial rule of Sparta might arouse effective opposition in other cities also. 
Persia and the "March of the Ten Thousand" (401-400 B. C.).-While Sparta was trying to establish her authority over the cities in Greece and Asia Minor, her ally, Cyrus the Younger, the Persian governor of Asia Minor, aspired to place himself on the Persian throne in place of his brother, Artaxerx'es. He enlisted in his service about ten or twelve thousand Asiatic Greeks, besides a large number of native troops, and with these pushed his way through Asia Minor, Syria, and Mesopotamia toward the Persian capital at Susa. He met

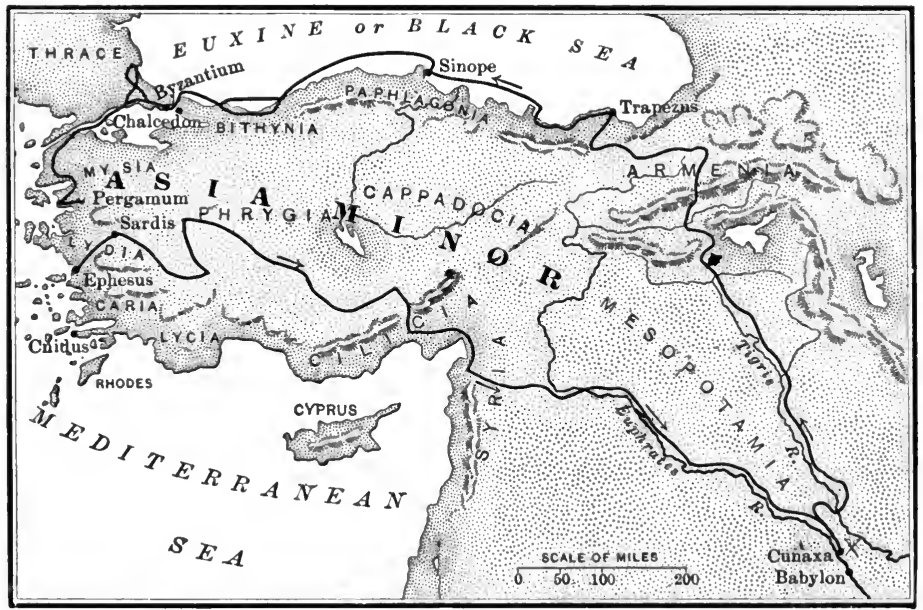

March of the Ten Tliousand

Artaxerxes in battle at Cunax'a, near Babylon. The Greek, forces defeated the great army of the king; but Cyrus was killed, and the other leaders were soon entrapped and put to death. 'The Greeks chose new leaders, chief among whom was Xen'ophon. They then retreated up the banks of the Tigris River, harassed by the Persian army, through the snows of Armenia, suffering from cold and hunger, and finally along the shores of the Euxine to the friendly eity of Chalcedon and so to the Agean Sea. This famous "March of the Ten 
Thousand," described by Xenophon in his "Anab'asis," revealed the weakness of the Persian empire and the superiority of the Greek soldiers, and led directly to a conflict between Persia and Sparta.

War between Persia and Sparta (399-394 в. c.).-The rebellious attempt of Cyrus, assisted as it was by Greeks, aroused the wrath of the Persian king. He therefore appointed his faithful general, 'Tissapher'nes, as governor of Asia Minor, with orders to reduce all the Grecian eities on the coast. Sparta now regarded herself as the protector of the Greeks, and answered their eall for help. The war against Persia which followed was carried on for six years, at first under inferior generals, but finally under the Spartan king Agesila'us. This able commander defeated 'Tissaphernes, recovered the Asiatic eities, carried the war into the enemy's country, and threatened to overthrow the empire itself. To relieve his empire from the presence of the Spartan army, the Persian monarch sent an emissary to Greece with bags of gold to stir up a revolt among the subjects of Sparta in Europe. The dangers at home compelled the Spartans to recall Agesilaus from Asia, and the conquest of Persia was delayed for more than half a century.

The Corinthian War; Peace of Antalcidas (395-387 в. с.).When Agesilaus reached Sparta, he found a large part of Greece united in an attempt to throw off the Spartan yoke. Thebes, Corinth, Athens, and Argos had formed a league for the liberation of the Hellenic states. The war which ensued is called the "Corinthian war," because it was waged to a great extent in the vicinity of the isthmus. Besides many engagements fought on land, a decisive naval battle was fought near Cnidus on the southwest coast of Asia Minor (394 B. c.). In this battle the Greek allies, under the Athenian general Conon, assisted by the Persians, practically destroyed the maritime power of Sparta. Conon freed the cities on the Asiatic coasts from the Spartan power, and then sailed to Athens. Under his 
direction, the fortifications of the Piræus and the Long Walls, which had been razed after the Peloponnesian war, were rebuilt. The stress of the war was so great that Sparta appealed to Persia to act as arbiter in the affairs of Greece; and this resulted in the so-called Peace of Antal'cidas (387 в. c.). By this peace the Greek cities in Asia were once more given up to the Persian king; the islands of Lemnos, Imbros, and Scyros were given to Athens; and all the cities of Greece proper were henceforth to be "free and independent."

Further Aggressions of Sparta (387-379 B. c.).-It is true that Sparta had by the late war lost her maritime power and her control of the Asiatic cities. But still, by the terms of the Peace of Antalcidas, the bonds which had united her enemies were broken; and she was now free to deal with them separately. She claimed the right to carry into execution the terms of the peace, and made her despotic influence felt everywhere. To offset the power of Thebes in Bœotia, Sparta caused the city of Platæa to be rebuilt. To weaken her enemies in the Peloponnesus, she razed the walls of Mantinea, the chief city of Arcadia. In order to prevent a rival power from growing up outside of Greece, she waged the so-called "Olyn'thiac war" (382-379 B. c.), which broke up the confederacy in Chalcidice newly formed by a union of the Greek and Macedonian cities under the headship of Olynthus. For fear that Thebes might rise against her while her armies were engaged in Chaleidice, Sparta seized the Theban citadel, the Cadmea, and placed within it a Spartan garrison. This most arrogant piece of aggression led to the uprising of Thebes with other states, and to the overthrow of the Spartan supremacy.

\section{The Attempted Supremacy of Thebes}

The Liberation of Thebes $(379$ B. c.).-The story of the revolution which resulted in freeing Thebes and the rest of Greece from Spartan domination, centers about the names 
of two great Theban patriots-Pelop'idas and Epaminon'das. Pelopidas was a Theban who had taken refuge in Athens. With a band of companions he entered his native city in disguise, killed the oligarchic leaders, and with the aid of the people foreed the Spartan garrison to withdraw from the citadel. Thebes was thus made free. Under the guidance of Epaminondas the other cities of Bœotia gained

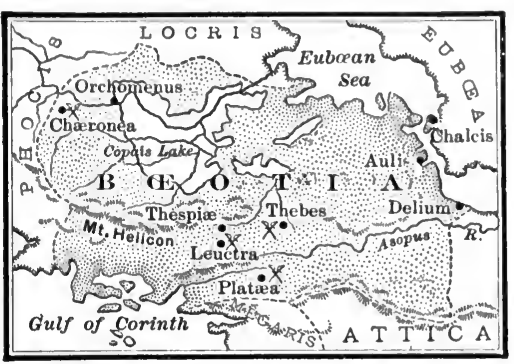

BeEotia their independence, and formed a new Bœotian confederacy to withstand the power of Sparta. We shall now see the attempt of Thebes to displace Sparta as leader of the Greek statesresulting in her temporary success and her final failure.

The New Confederacy of Athens (37\% B. C.).-Athens took courage from the success of Thebes, and gathered together many of her old allies in a new Ithenian confederacy. She built a new navy and regained something of her old maritime power. She at first aided Thebes in resisting Sparta; and then, envious of the growing power of Thebes, she formed a treaty with Sparta.. In the midst of these jealous intrigues and the attending conflicts, Athens proposed that a general conference be held at Sparta for the pacification of Greece. It was there proposed that the Peace of Antalcidas should be renewed - that all states should remain free and independent. Athens and Thebes wished this to mean that all cities should be free to form alliances if they chose, and thus to preserve their newly formed leagues. But Sparta refused to accept this meaning, although she wished still to retain her hold upon her own allies. The treaty was hence signed without Sparta. While Athens had been able to recover some of her influence, Thebes and Sparta were now the great rival powers of Greece. 


\section{Overthrow of the Spartan Power; Battle of Leuctra (3r1}

B. c.).-Sparta was now alarmed at the rising power of Thebes. She therefore sent an army into Bœotia to destroy the newly

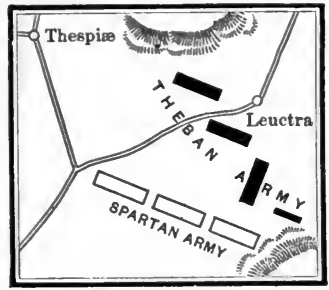

BATTLE OF LEUCTRA, 371 B. C.

formed confederacy, but was defeated in the memorable battle of Leuctra. The ruling spirit in Bœotia was Epaminondas, the great Theban patriot, whose name is one of the most distinguished among Grecian statesmen and generals. To him is due the new arrangement of the Grecian phalanx which won the battle of Leuctra. He seems to have discovered one of the great principles of successful warfare-that is, to be stronger than the enemy at the point of contact. The old Greek phalanx was arranged in lines eight men deep. The Spartan army was so formed at Leuctra. Epaminondas also arranged the main part of his line in the same way. But on his left wing, which he intended to be the point of contact, he arranged the phalanx in the form of an irresistible column fifty men deep, guarded on the extreme left by a body of cavalry. In this way he crushed the Spartan right wing; and the rest of his army was pushed forward to complete the victory. The battle of Leuctra had two important effects: first, it introduced a new feature into ancient warfare, which was afterward employed by the Macedonians; secondly, it overthrew the Spartan power and insured for the time being the ascendency of 'Thebes.

\section{Temporary Supremacy of Thebes (371-362 в. c.).-The} policy of Epaminondas was to make Thebes the supreme power in Greece. He completely alienated Athens by attempting to establish the Theban power over the Atbenian allies; and he even called upon Persia to aid him in his purpose. To extend Theban influence into the Peloponnesus, Epaminondas invaded this territory, and delivered the people from Spartan control. 
In Arcadia, he helped the city of Mantinea to rebuild its prostrate walls, and gathered the Arcadian towns into an independent union, with the new eity of Megalop'olis as their capital. In Messenia he rescued the population from their long serfdom, and built for them a new city, Messe'ne. Sparta, fearing for her safety, appealed to Athens for assistance. Athens accordingly sent an army into the Peloponnesus to prevent the further encroachments of Thebes.

While Thebes was thus extending her power to the south under Epaminondas, she was also extending her power to the north under Pelopidas. She brought Thessaly under her authority, and even established influential relations with Macedonia. It was not long before troubles arose again in the Peloponnesus. Epaminondas again invaded the country and met the Spartans and their allies at Mantinea (362 B. c.), where he gained a victory; but at this battle Fpaminondas was killed. As the Thebans, without their leader, were unable to follow up their victory, peace was established. With the decline of the Theban power, Athens was once more regarded as the leading city of Greece.

Failure of the Grecian State System.-The supremacy of Thebes had failed to create a national state for Greece. just as the supremacy of Sparta and that of Athens had failed before. The Greeks had, it is true, been able to develop a city state with local self-government, far in advance of the Oriental system of government. But they did not possess the capacity to organize their cities into a single state, based upon their common nationality. Their various leagues failed, because under the predominance of one city the rights of the others were disregarded. Athens had failed to respect the equal rights of her allies. Sparta had ruled with despotic authority over her subjects. With all their love of liberty springing from their own self-interest, the Greeks failed to recognize that other essential principle of good government, the respect for a higher law based upon the common welfare. 


\section{The Supremacy of Syracuse in Sicily}

Parallel History of Sicily and Greece.-In tracing the general course of Greek history, we have seen the growth of a number of city states, which were agitated by political revolution, and in which tyranny, oligarehy, and democracy were contending for mastery. We have also seen Greece, under the leadership of Athens, delivered from the invasion of Persia. We have, moreover, seen a tendency on the part of some one city to lift itself into a position of supremacy over the others. There is a general similarity between these movements in Greece proper and those in western Hellas. In Sicily there was a similar movement in the development of a large number of cities disturbed by political revolution; a similar conflict against a foreign enemy; and a similar tendency toward supremacy on the part of one city. But the predominant city in Sicily was not Athens or Sparta or Thebes, but Syracuse; and, as we have seen (p. 15\%), the foreign enemy of Sieily was not Persia, but Carthage.

Dionysius the Elder, and the Younger.-A few years after the destruction of the Athenian fleet at Syracuse, the Carthaginians made a new and more vigorous attempt to subdue the

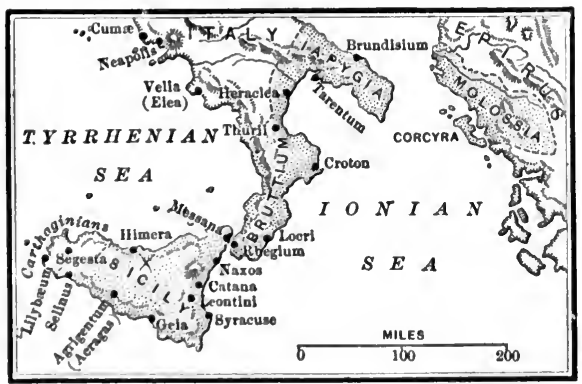

Domisioxs of Dioxysius, 379 B. C. island. They captured the cities of Selinus, Himera (409 B. C.), and Agrigentum (406 B. C.). In their extremity the Syraeusans chose Dionys'ius the Elder as their leader in war. and from this position he became a tyrant. He was a man of varied virtues and vices, of unusual clemency to a vanquished foe, and of unwonted cruelty to his 
own subjects. His great achievement was the driving back of the Carthaginians to the western extremity of the island, and the defense of Syracuse by an enlarged fortification, which took in the heights of Epipolæ (see map, p. 184). He also brought under his control many of the cities of Sicily, and then extended his Syracusan empire, as shown by the map (p. 194), to southern Italy, and even northwestern Greece. He adorned Syracuse with splendid buildings and works of art, and made it the home of noted men; so that it vied with Athens as the most cultivated city of the Greek world. He was succeeded by his son, Dionysius the Younger, who had none of the remarkable abilities of his father. Under his rule, the city rapidly fell into discord and anarchy, from which it was rescued by Timo'leon.

Timoleon the Liberator.-Suffering under the weak rule of the Younger Dionysius and threatened again by the Carthaginians, Syracuse appealed to the mother city of Corinth for help. Corinth fitted out a small expedition, and appointed Timoleon, one of her citizens, as its leader. This commander took possession of the citadel of Syracuse. Then advancing against the Carthaginians, he defeated them in a decisive battle. There were other cities of Sicily which were ruled by tyrants. These tyrants he expelled, and in these cities, as in Syracuse, he erected democratic governments. With the expulsion of the Syracusan tyrants, the cities of Magna Græcia also recovered their independence. Thus Timoleon became the true liberator of western Hellas. When he had accomplished his great mission, he laid down his power and retired to private life. Sicily remained a flourishing seat of Grecian culture, but in its political life the island soon relapsed into the disturbed condition which marked the rest of the Greek world.

\section{SYNOPSIS FOR REVIEW}

I. The Peloponnesian War.-Causes Leading to the War.The War Policy of Pericles.-Conduct of the War under Cleon.-The Peace of Nicias, and its Failure-Alcibiades and the 
Sicilian Expedition.-The Reappearance of Persia.-The "Four Hundred" at Athens. - The Last Years of the War.-The Fall of Athens.

II. The Supremacy of Sparta.-The Policy of Sparta in Greece.-Persia and the "March of the Ten Thousand".-War between Sparta and Persia.-The Corinthian War; Peace of Antalcidas.-Further Aggressions of Sparta.

III. THE ATtempted Supremacy of 'TheBes.-The Liberation of Thebes.-The New Confederacy of Athens.-Overthrow of the Spartan Power; Battle of Leuctra.-Temporary Supremacy of Thebes.-Failure of the Grecian State System.

IV. The Supremacy of Syracuse in Sicily.-Parallel History of Sicily and Greeee.-Dionysius the Elder, and the Younger.Timoleon the Liberator.

\section{REFERENCES FOR READING}

Smith, Wm., Ch. 25, "Causes of the Peloponnesian War"; Ch. 40, "The Supremacy of Thebes" (10). ${ }^{1}$

Oman, Ch. 26, "Outbreak of the Peloponnesian War and its Causes"; Ch. 32, "Expedition of the Athenians to Syracuse"; Ch. 37, "The Greeks of the West" (10).

Bury, Ch. 11, "Decline and Downfall of the Athenian Empire"; Ch. 15, "The Syracusan Empire and the Struggle with Carthage" (10).

Alleroft, Vol. III., Ch. 1, "Introductory" (comparison of Athens and Sparta); Ch. 6, "Brasidas and Cleon"; Vol. IV., Ch. 6, "Sicilian Affairs" (10).

Curtius, Vol. III., Ch. 5, "The Decelean War"; Vol. IV., Ch. 1, "Athens under the Thirty" (10).

Sankey, Ch. 3, "Athens under the Thirty"; Ch. 9, "Peace of Antalkidas" (10).

Holm, Vol. II., Ch. 21, "Corcyra, Potidæa and Platæa"; pp. 492497 (rule of the Four Hundred); pp. 526.534 (rule of the Thirty); Vol. III., pp. 8-10 (Epaminondas and Thebes); Ch. 5, "The Arrogance of Sparta" (10).

Gilbert, pp. 416-445 (first and second leagues of Athens).

Harper's Dictionary, "Exercitus" (military formations among the Greeks) (11).

Plutarch, "Alcibiades," "Lysander," "Nicias," “Agesilaus," "Pelopidas," "Timoleon," "Dion" (26).

Thucydides, Bk. II., Chs. 35-46 (funeral oration of Pericles); Bks. VI., VII. (account of the Sicilian expedition) (17).

${ }^{1}$ The figure in parenthesis refers to the number of the topic in the Appendix, where a fuller title of the book will be found. 


\section{CHAPTER XIV}

THE ATTIC PERIOD OF HELLENIC CULTURE

I. Athens as the Center of Hellenic Art

Greek Politics and Hellenic Culture.-We have been considering the political life of Greece since the time of the Persian invasions. We have seen the various Greek states, under the leadership of Sparta, uniting to repel a foreign enemy. We have seen the rise and fall of a maritime empire under the control of Athens. And finally we have seen the failure of the Greek cities to develop a true national state, on account of their mutual jealousies and their strong spirit of local independence. While the Greeks no doubt did a great deal toward the development of political liberty, of local self-government, and of democratic institutions, we must be convinced that their greatest importance in the world's history does not rest upon what they accomplished in their political life. The preëminent genius of the Greeks was shown not in the sphere of polities, but in the domain of culture-not in their state-building, but in their intellectual and artistic achievements. We should, therefore, overlook the most essential qualities of the Greek people, did we fail to recognize the contributions they have made to the world in literature, in philosophy, and in art.

The Attic Period, its Character and Phases.-The most remarkable progress in the intellectual life of Greece took place after the great Persian wars. It is true that before these wars the Greeks were beginning to show a genius distinctly their own-in the growth of their epic and lyric poetry, and in the early stages of a strictly Hellenic art (see pp. 129-142). But 
this early form of Greek culture sprang up outside of Greece proper, in Asia Minor and in western Hellas. The Persian wars tended to smother the intellectual life of the Asiatic Greeks, and to arouse the intellectual spirit of Athens. This period of intellectual activity which began with the Persian wars and extended to the Macedonian supremacy, and in which the culture of Greece was centered in Athens, we may call the "Attic period." The culture of this period was characterized by those qualities which distinguished the Greek mind from the Oriental mind, and which found their highest embodiment in the men of Athens. During this period we may distinguish certain phases in the progress of this Attic spirit. It was the most creative and vigorous in the time of the great Persian wars and the years just following these wars; it was the most refined and exalted in the age of Pericles; and it was the most reflective and critical in the subsequent period of internal strife. But through all these phases, it preserved its essentially "classic" qualities-simplicity and moderation, symmetry and proportion, severe conformity to rational ideals, contempt for all that is tawdry and meretricious. The Attic spirit might perhaps best be characterized by the single Greek word $\Sigma \omega \phi \rho о \sigma \dot{v} \nu$ (sophros'yne) - which might be freely translated, life under the control of reason.

The City of Athens.-Our chief interest in Greece must always be centered in Athens, because it was in this renowned city that the culture of Greece found its highest expression. Let us glance at a few of its most important topographical features. With the Acropolis as its center, the limits of the city had been gradually widening from the earliest times. At the time of the Persian wars, the "old line" of the city had been reached. With the building of the new wall of Themistocles, the circumference of the city was enlarged to five or six miles. During the times of Cimon and Pericles the eity was still further extended by the erection of the Long Walls so as to take in the Pirrus (p. 165). To make the circuit of the city walls 
at this time would require a journey of perhaps twenty miles. 'The chief entrance to the city was the Dip'ylon gate, to the northwest. The city contained a number of hills, the most important of which were the following: (1) the Acropolis, the central pinnacle of Athens, formed of limestone rock rising abruptly to the height of two hundred feet, with a length of about a thousand feet-upon or near which were the most im-

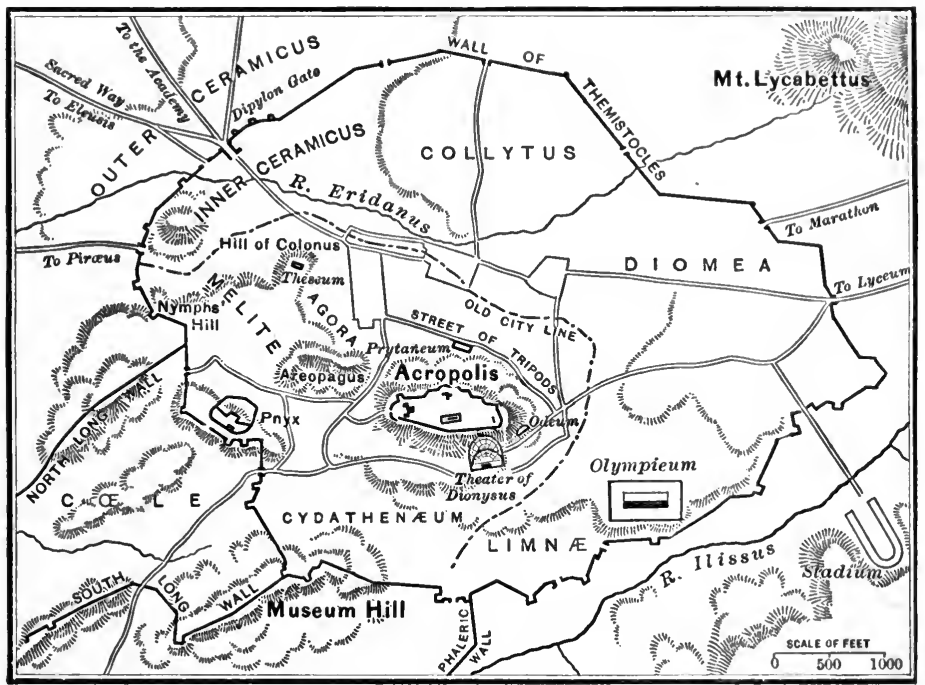

Plan of Athens, Time of Pericles

portant buildings of the city; (2) the Pnyx, to the west, upon which the assembly, or ecclesia, held its meetings; (3) the Areopagus, a little to the north, where the old council of the Areopagus held its sessions; (4) the Colo'nus, still further to the north, upon which is located the so-called These'um, said to be to-day the best preserved temple of Greeee. Between the hill of Colonus and the Areopagus was the $\mathrm{Ag}^{\prime}$ ora, the public square or market place, lined with beautiful trees and porticoes, and the center of the political and commercial life of Athens. 
The whole city was divided into certain districts, or wards, corresponding to the "demes" of Attica. Beyond the city walls to the east was the Lyce'um, and to the northwest the Academy-both of which were places of resort and amusement for the Athenians. The population of Athens at the time of Pericles is variously estimated at from 120,000 to 190,000 , including those who were slaves.

Athenian Architecture.-After the destruction of the city by the Persians, $A$ thens was entirely rebuilt and adorned with many structures of great architectural beauty. This work was begun by Themistocles and Cimon, and was carried on extensively by Pericles with the aid of the tribute collected from the Agean cities. The greatest work of Pericles was the adornment of the sacred height of the Acropolis, which became the center, not of defense, according to its original purpose, but of religious adoration. Upon the foundations laid by Cimon (or perhaps Themistocles) Pericles erected the magnificent temple of $\Lambda$ thena-the Par'thenon. 'This was the most beautiful specimen of classic architecture; and the surpass-

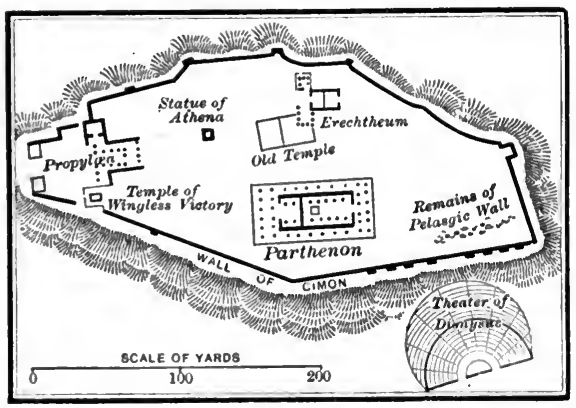

Plat of the Acropolis ing superiority of the Greek taste is evident when this temple is compared with the old temples of the East. The Parthenon was of moderate size, built of Pentelic marble, in the Doric style refined by Attic taste, and of the most exquisite proportions. The next important building on the Acropolis built by Pericles was the Propyle'a, the entrance to the sacred hill. In this building we see for the first time the combination of the Doric and Ionic styles, the outside of the building being supported by Doric columns and the inside passageway by Ionic 


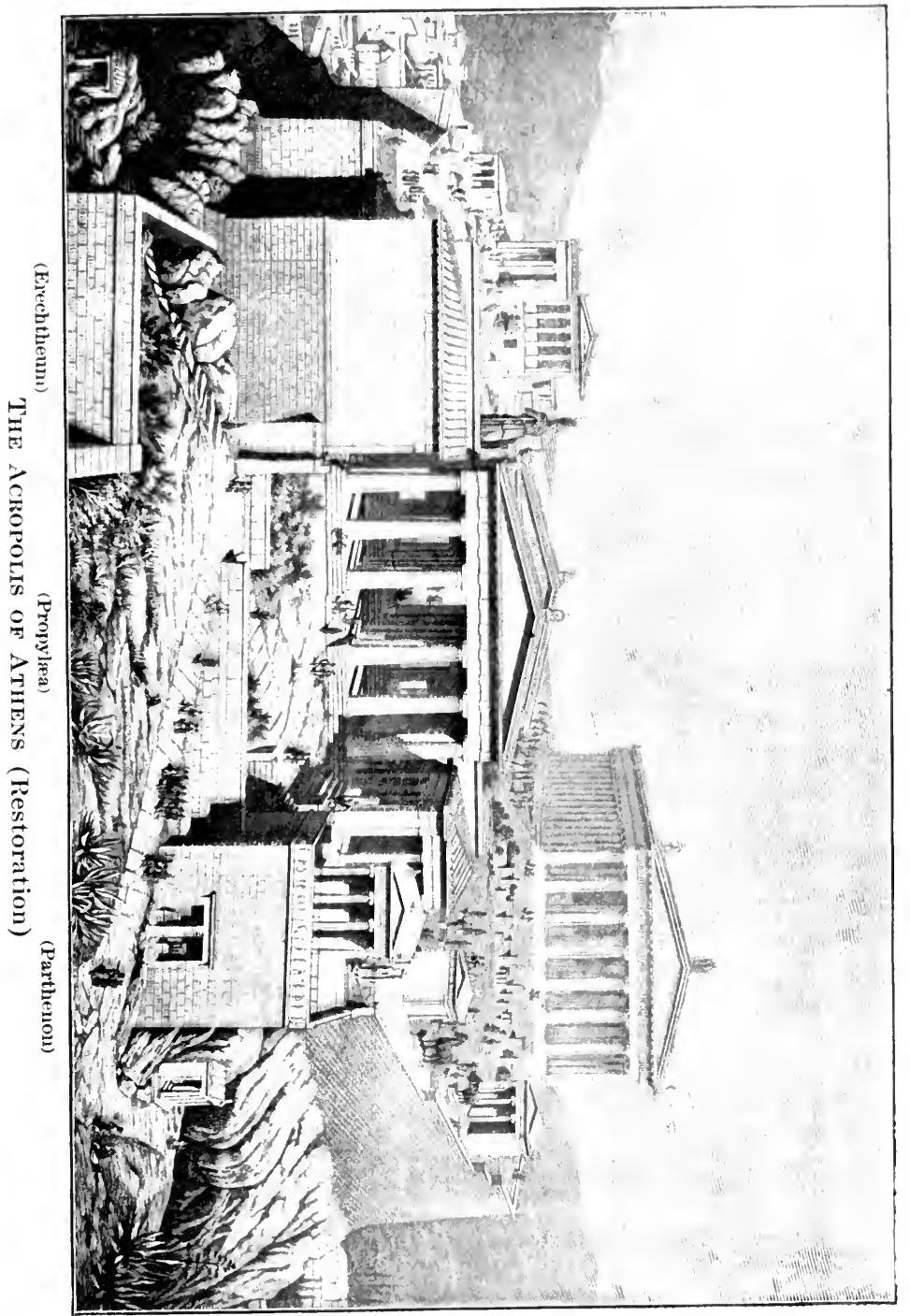


columns. The whole effect of this great portal was beautiful and imposing. It the time of Pericles the Propylæa was approached not by a flight of steps, but by inclined walks leading up from the foot of the hill. Another notable building of the Acropolis was the Erechthe'um, built near the site of an old temple destroyed by the Persians. Its name was derived from that of one of the ancient mythical kings of Athens, Erech'theus, whose worship became conneeted with that of Poseidon. As this temple was intended to cover different shrines-that of Athena and that of Erechtheus-Poseidon-its plan was the

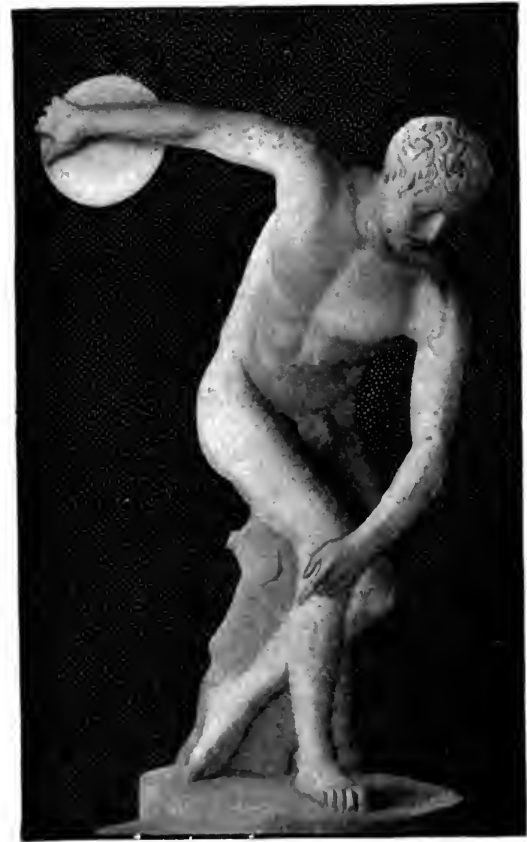

"Discobolits" of Myron most irregular of all the temples of Greece. It is supported by beautiful Ionic columns; but a small porch on the south of the temple has for its support six carved female figures (Caryat'ides) and hence is known as the "Porch of the Maidens." During this time the architectural styles employed by the Athenians were the Doric and the Ionic-the former being regarded as typical of masculine strength and dignity, and the latter of feminine refinement and grace.

\section{Athenian Sculpture.-}

It was not until after the Persian wars that the s(rulpture of the Creeks hegan to lose its early crudeness and to acquire more artistic qualities. 'The first great 
sculptor of the Attic period was Myron. Mis best-known statue is the "Discob'olus" (the disc-thrower), which illustrates not only the important place which gymnastics held in Greek life, but also the beneficial effect of the national games upon the sculptor's art by furnishing him living models for his work. The most renowned of all the Greek sculptors was Phid'ias, who assisted Pericles in the adornment of the Acropolis. The sculptures of Phidias were inspired by a high religious purpose, like that which led to the building of the Parthenon-namely, the worship of the goddess Athena. Her colossal statue in bronze was erected upon the summit of the Acropolis, and her statue in ivory and gold was placed within the Parthenon. In tlie eastern pediment $^{1}$ of this temple was placed a sculptured scene representing her

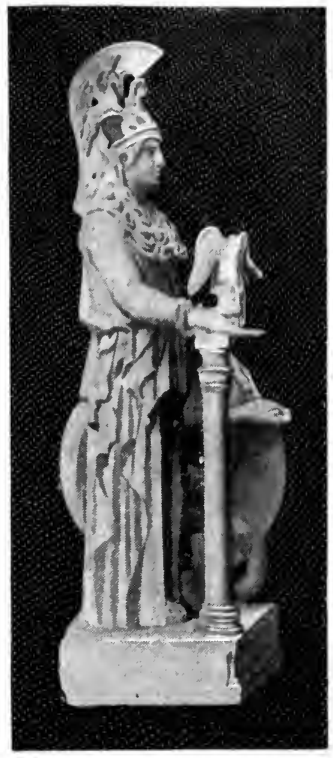

Athena Parthenos birth from the forehead of Zeus; and in the western pediment was another group representing her contest with Poseidon for the soil of Attica. On the walls of the temple was a remarkable series of reliefs carved in marble, representing the procession which on her birthday carried her robe through the streets of Athens to her shrine on the Acropolis. This Parthenon decoration contained a vast variety of figures-prancing horses held in check by the steady hands of their riders, chariots occupied by armed warriors, beautiful maidens and dignified magistrates, a group of Olympian deities, and many other subjects. The work of Phidias was not confined to Athens. His statue of Zeus in 1 The "pediment" is the triangular space forming the gable of the roof. 
the temple at Olympia was regarded by many as his masterpiece and as one of the wonders of the world.

After the time of Phidias art became less inspired with a purely religious spirit, and acquired more of a human character. To depict the grace and beauty of the human form seemed now the highest ideal of the artist. .'This is seen espe-

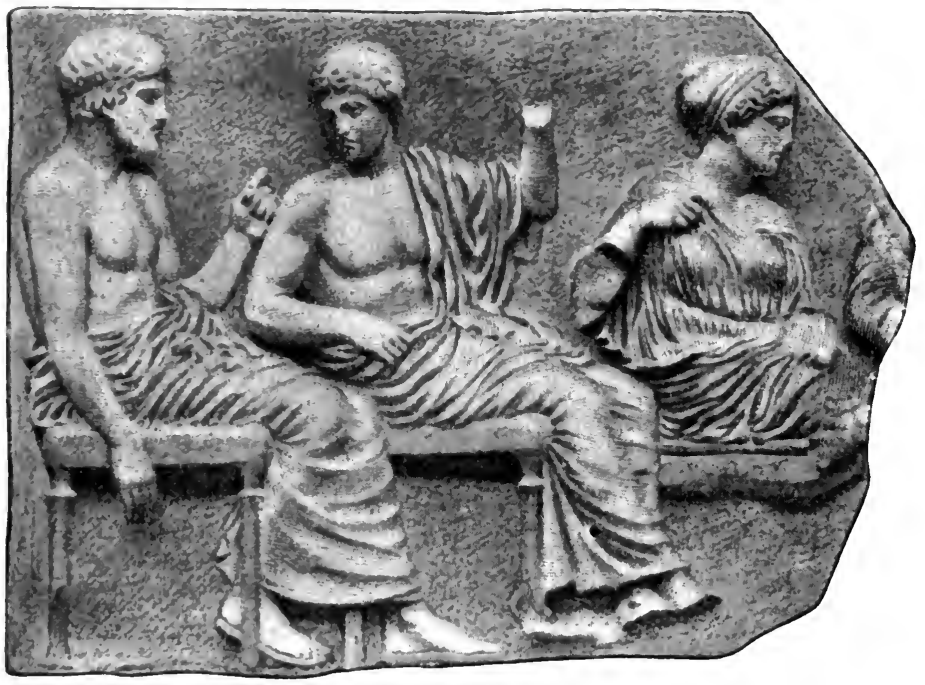

Part of the Parthenon Decoration

cially in the work of Praxit'eles of Athens, the most eminent of Greek sculptors after Phidias. One of the most famous statues of Praxiteles was the Aphrodite at Cnidus. which was visited from all parts of Greece by its admirers. But eritics have been disposed to give the place of honor to his Hermes with the infant IDionysus, which has come down to us in a mutilated form. The Greeks also aequired at this time great skill in the making of portrait statues. 'This is shown in the works of Lysip'pus of Sicyon. whose statue of the poet Soph'oeles (see p. 209) is regarderl as the finest ancient work of the kind. 
Athenian Painting.-It is difficult for us to form a very clear idea of the progress made in painting in the Periclean age, because this art is less durable than that of sculpture. The great painter of this period was l'olygno'tus. He was born in the island of Thasos, but came to $\Lambda$ thens and is said to have been made an Athenian citizen. His most famous works were placed upon the walls of temples, porticocs, and other public buildings, especially the Propylæa. His subjects were mostly mythological and historical scenes. After the time of Pericles there was a marked advance in the method of painting. Hitherto colors had been applied in flat tints with no gradations of light and shade; and hence the so-called paintings were more properly colored drawings. But colors were now

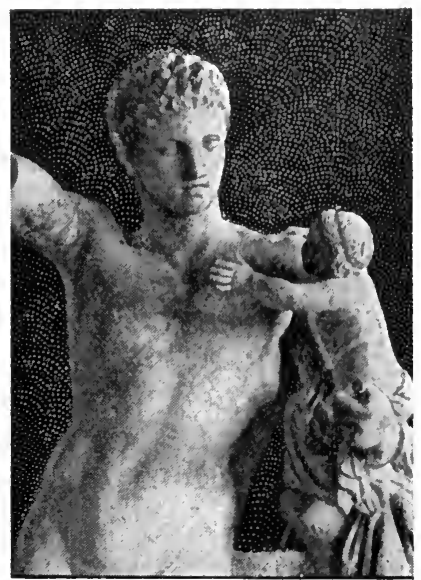

hermes of Praxiteles graded so as to produce the effect

of light and shade, which we call chiaroscuro. This method was introduced by Apollodo'rus of Athens, but was improved by the great painters Zeuxis and Parrha'sius. The realistic effect of the new style of painting is illustrated by the story often told of these rivals-how Zeuxis painted a bunch of grapes that deceived the birds, and Parrhasius a curtain that deceived the rival painter himself.

\section{- II. The Theater and Dramatic Literature}

The Theater of Dionysus.-One of the chief centers of the intellectual life of Athens was the theater. This was a place not simply for amusement, but for instruction and for moral 
and religious inspiration. Athens had but one place where dramatic performances were placed upon the stage-the theater of Dionysus. It was situated on the southeastern slope of the Acropolis, and was, it is said, capable of seating thirty thousand people, or the whole voting population of Attica. The performances took place in the open air during the festivals of Dionysus, the wine god, and consisted of tragedies,

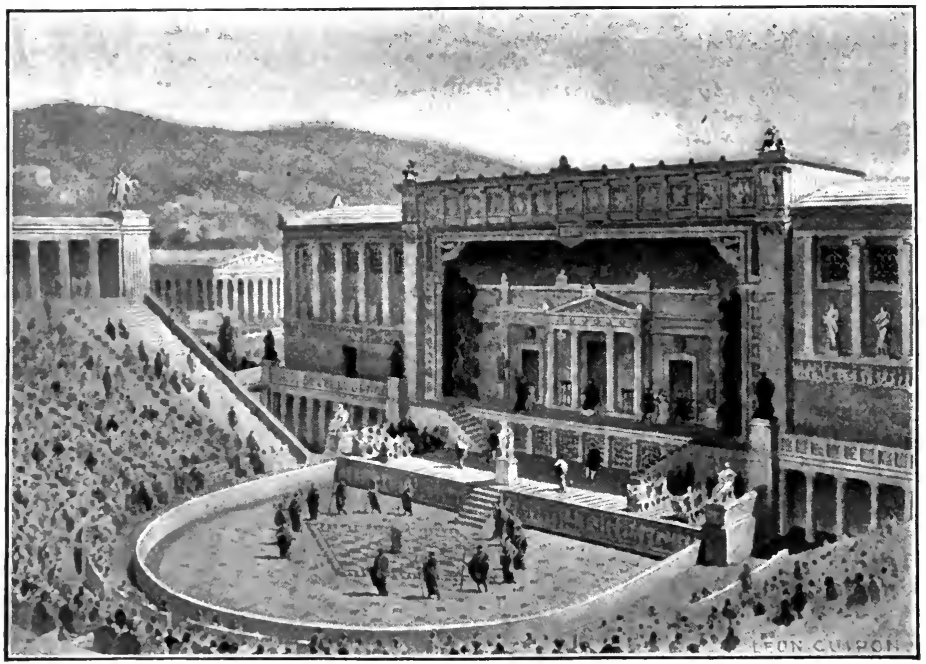

THE THeater of Droxysus (Restoration)

comedies, satyric dramas, and choral hymns, the most important of these being the works of the great tragedians. The theater of the Greeks consisted of three parts, the stage, the orchestra, and the auditorium. The stage was an elevated platform, upon which the players performed their parts, and in the rear of which was an architectural baekground used to represent or to sugrest the locality where the action was supposed to take place. 'The orchestre was a semicircular space in front of the stage, sot apart for the "chorus."- -this being an essential part of the performance, consisting of singing, daneing, 
and gesticulations which were intended to interpret the thought and emotions of the play. The auditorium was the rising tiers of seats which encircled the orchestra and were oceupied by the spectators. The central place of the orchestra and chorus in the Greek theater can hardly be understood except by referring to the origin of the drama itself.

Origin of the Greek Drama.-We have seen that, before the Persian wars, one of the forms of lyric poetry was the hymn, or chorus, sung by a number of voices at public festivals in honor of the gods (p.139). It was this choral hymn as used by Arion in the worship of Dionysus that became transformed into the drama. The words of the old chorus were accompanied by dancing and gesticulations, and expressed in a rude and wild way the emotions supposed to be appropriate to the worship of Dionysus, the wine god. But Thespis, a lyric poet of Attica, introduced an actor who assumed different characters and carried on a sort of dialogue with the leader of the chorus; and this served to explain the motive of the choral hymn. This first form of the drama, with the chorus and a single actor, was cultivated by Phryn'ichus, who took for his subjects events in the Persian wars. His tragedy on the "Capture of Miletus" melted his audience to tears; but as it seemed to reproach the Athenians for not aiding their kin beyond the sea, a fine was imposed upon him and the play was proscribed. In a later tragedy, however, he stirred the patriotic feeling of his audience by depicting the effect which the news of the battle of Salamis had upon the Persian court.

Eschylus, the Father of Tragedy.-The early form of the drama was improved by Es'chylus, who was born in Attica and lived during the period of the Persian wars. He introduced a second actor, so that the dialogue became the principal feature, while the chorus was used chiefly to echo the emotions produced by the play. The chorus still retained its central place in the theater, while the actors were elevated to a more conspicuous position on the stage. The chief purpose of 
the poet now was not simply to compose the lyric hymn to be sung by the chorus, but to construct a worthy dialogue that would depict great events and stir the feelings of the people. It was Aschylus who lifted the dialogue to the plane of genuine art; and on this account he may properly be called the father of Greek tragedy. He was a man inspired with patriotism and religious fervor. He had been present at the battles of Marathon, Artemisium, Salamis, and Platæa. In what was probably his earliest tragedy, "The Persians," he followed his predecessor Phrynichus in picturing the effect of the news of Salamis upon the Persian court. The subjects of his later

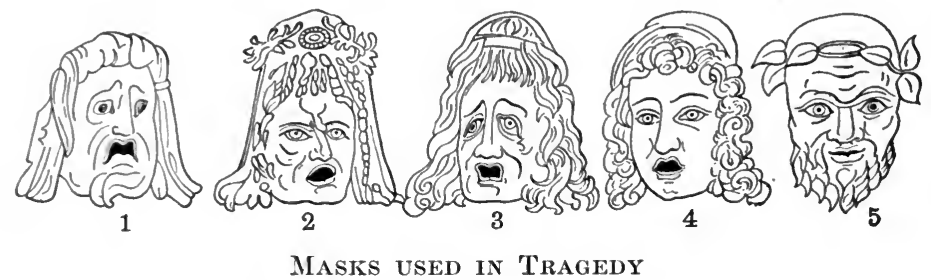

tragedies were taken from the heroic myths, but infused with deep human feeling and religious sentiment. His greatest work was perhaps the "Prome'theus Bound," in which a god, chained to a rock by command of Zeus, is made to suffer for good deeds done to men.

Sophocles, the Dramatic Artist.-If Aschylus represented the patriotic and heroic spirit horn of the Persian wars, his successor, Sophocles, represented the finer artistic spirit of the age of Pericles.

He introduced the third actor upon the stage, thus giving greater freedom to dramatic composition. He also gave less prominence to the chorus, which he used chiefly to accompany the dialogue and to give' a moral background to the play. Noreover. he introduced less of the heroic and superhuman element, and hrought his characters into closer relation to humian life. Sophocles is said to have composed more than a 
hundred dramas, of which only seven have come down to us. The most important of his plays are perhaps " Edipus the King," "CEdipus at Colonus," and the "Antig'one." 'These are all based upon stories related of the mythical king of Thebes and his family. But these stories are told with graphic power, and in such a way as to illustrate the poct's idea of the supremacy of fate and the moral law, the penalty awaiting those who disobey that law, and the suffering which must often be endured even by those who strive to obey it. The character of Antigone is one of the noblest in all literature. She presents the most beautiful example of filial devotion and of feminine courage, by clinging to her unfortunate father in his distress and by always doing what she believes to be her duty.

In estimating the significance of Sophocles we should look at him not simply as a tragedian but as an artist-as truly an - artist as was Phidias or

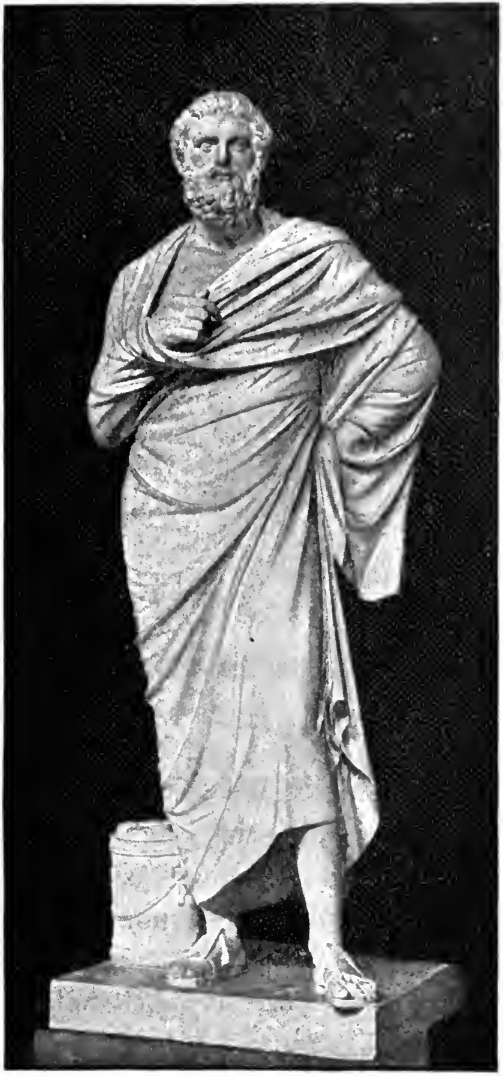

SOPHOCLES Praxiteles. His works, like theirs, are distinguished by proportion and symmetry, by extraordinary grace and beauty of form. In his dramas, as in the buildings and sculpture of the 
Acropolis, we see the distinctive features of the best Hellenic taste.

Euripides, the Dramatist of the People.-The last of the great tragedians was Eurip'ides, who began to write during the period of Pericles, but composed the most of his dramas during the Peloponnesian war. He thus represents to a certain degree the changing spirit of the age. While less of an artist

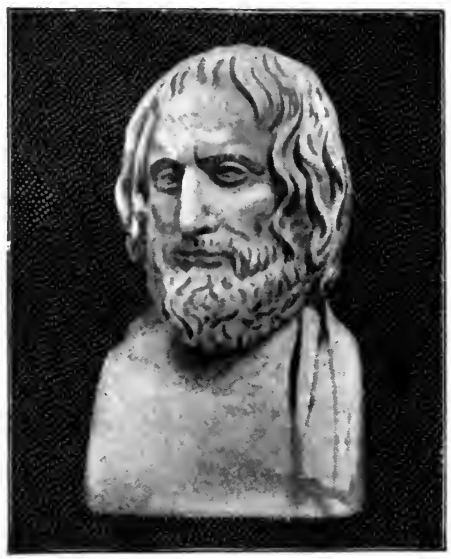

Euripines than Sophocles, he appealed more strongly to the sympathies of the people. Aristotle called him the "most tragic of poets." Eighteen of his plays are still extant; and from these we can judge of his style and method of treating his subjects. In his hands the chorus became less connected with the action of the play, and his characters were brought into closer relation to common life. The ancient legends, which Eschylus had clothed with a sublime pathos, and Sophocles had invested with a dignified charm, Euripides often reduced to the level of ordinary events. Although he showed a lack of reverence for the old mytho' ogy, he was a poet of the common people, and appreciated more than his predecessors the human element in the drama.

The Attic Comedy; Aristophanes.-In its origin the Greek comedy was closely related to tragedy; for they both sprang from the hymns which accompanied the worship of Dionysus. But while tragedy sprang from the graver choral songs which accompanied the winter festival, the other phase of the drama - that is, comedy-sprang from the more frolicsome songs which attended the rural festivals in the springtime. To each 
of them was added the dialogne; but each retained its own character-the one grave and the other gay. The comedy had already begun to be used at the time of Pericles; but it reached its highest development during the Peloponnesian war. The purpose of the comedy was to exeite laughter and ridicule, and hence it shows the capacity of the Greeks for wit and humor.

The greatest of all the comic writers of the Greeks was Aristoph'anes, who flourished duri-g the period of the Peloponnesian war. He mingled in the political life of Athens, and belonged to the party which was "against the government." His comedies might give us the best picture we have of $\Lambda$ thenian life, if they contained less of caricature and satire. From

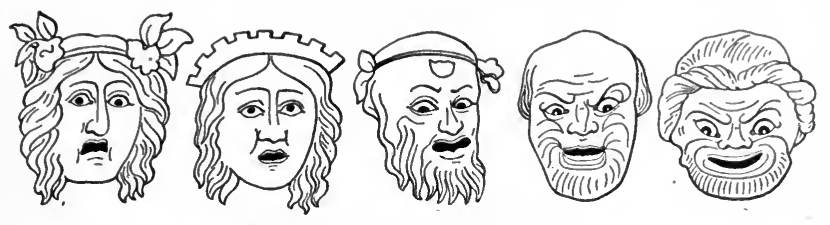

MASKS USED IN COMEDY

other sources we may learn that some of his pictures are fairly just, while others are marked by the grossest injustice. Among his most noted works are the "Clouds," the "Knights," the "Wasps," and the "Birds." The "Clouds" is chiefly noted for the unjust attack which it makes upon the philosopher Socrates. The "Knights" describes with brilliant satire that coarse demagogue Cleon, who, though not an admirable character, perhaps does not merit all the abuse he received. The "Wasps" is an amusing picture of the Athenian jury system, in which every man is represented as trying to get a day's pay without a day's work. The "Birds" is "a fantastic satire upon the Athenian habit of building castles in the air, and of indulging in extravagant dreams of conquest." With all his ribaldry, Aristophanes was a poet of real genius, of sparkling wit, and sometimes of exquisite beauty. 


\section{Prose Literature: History and Oratory}

Herodotus, the Father of History.-In Greece, as elsewhere, poetry preceded prose in the order of development. The epic, the elegy, the lyrie, the drama, had been eultivated before any noteworthy works in prose were written. 'The first really great work of prose literature in the Greek language was the history

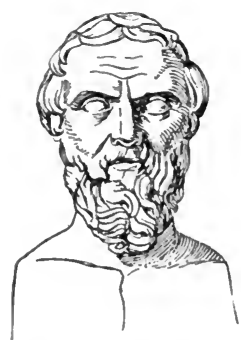

Herodotus written by Herodotus, a native of Halicarnassus. Herodotus was born during the period of the Persian wars. This great conflict between the Greeks and the Persians was to him the greatest of all events. It became the subject of his history, and furnishes to us our chief knowledge of that struggle. He traveled cxtensively, and became acquainted with the manners, institutions, and legends of many countries. He came to Athens when the culture of that city was at its height; and he became a close friend of Sophocles and an ardent admirer of Pericles. Under these influenees his history became imbued with an Athenian spirit, and aequired the character of an artistic literary composition. Into his work are skillfully woven the narrative of historical events and the description of foreign countries, facts which he himself observed as well as stories and myths told him by others. The critical accuracy of Herodotus has often been questioned; but the charming qualities

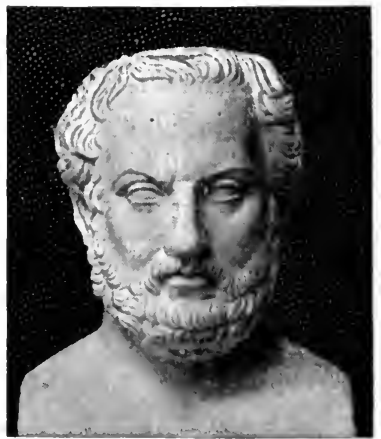

THuCYidides of his simple and graphic style have always been admired.

Thucydides, the Scientific Historian.-While we may regard Herodotus as the father of narrative history, we must 
regard Thucydides as the creator of scientific history. His subject was the Peloponnesian war-a war in which he had taken a subordinate part. His work is marked by calm judgment, a love of truth, honesty, and accuracy in the statement of facts, and a perception of the relation of cause and effect in historical events. His style, though sometimes obscure, is pure and forcible, and withal "classic,"-which means "the absence of all that is tawdry, the absence even of all that we call florid, a certain severity and reticence, which are as marked in the prose of Thucydides as in the marble of Phidias" (Mahaffy).

Xenophon, the Historical Essayist.-Following in the wake of Thucydides was the genial historical writer Xen'ophon. Although he can hardly be compared with Thucydides as an historian, he wrote in an easy and interesting manner upon a great variety of subjects. His "Anabasis" tells the story of the March of the Ten Thousand, in which he himself took part (see p. 188). His "Hellen'ica" continues that part of the Peloponnesian war left unfinished by Thucydides. His "Memorabil'ia" draws a lifelike portrait of his great master, Socrates. His "Cyropædi'a" professes to describe the education of Cyrus the Great, but is quite as much a description of what the author regards as a just prince. His " Econom'icus" gives us an insight into the home life of the Greeks. He wrote interesting works upon other subjects, the variety of which might justify us in calling him an essayist as well as an historian.

Athenian Oratory; Lysias, Isocrates, Demosthenes.-That branch of prose literature which is distinctively Greek in its origin, is oratory. Indeed, it may be said that oratory was the product of the democratic institutions of Athens. The greatest orator of the age of Pericles was no doubt Pericles himself; since by his eloquence he controlled for twenty years the $A$ thenian assembly. But his speeches have been preserved to us only in the reports contained in the history of Thucydides. 
Not only the Athenian assembly, but the Athenian courts afforded a field for the cultivation of eloquence, for here every

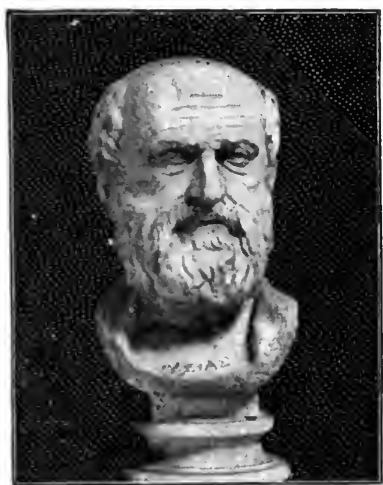

LYSIAS man was compelled to plead his own cause.

Of the many Athenian orators who attained distinction, we may select three as the most representative-Lys'ias. Isoc'rates, and Demosthenes (who is not to be confused with the general of the same name). Lysias was employed, like many others, to write speeches for those who were obliged to plead their own cause in the courts. As he wrote for plain men, he used a plain, direct, and simple style. By writing clearly and distinctly, he became a master of vivid and effective speech. Somewhat different from Lysias was Isocrates. He was primarily a teacher of rhetoric, and hence the orations which he wrote-but did not deliverhave more of a rhetorical finish, and are perhaps more attractive in language than effective in thought. But the greatest of all the orators of Greece was Demosthenes, who holds the same preëminent place in oratory that 'Thucydides loes in history. His life belongs to the later part of

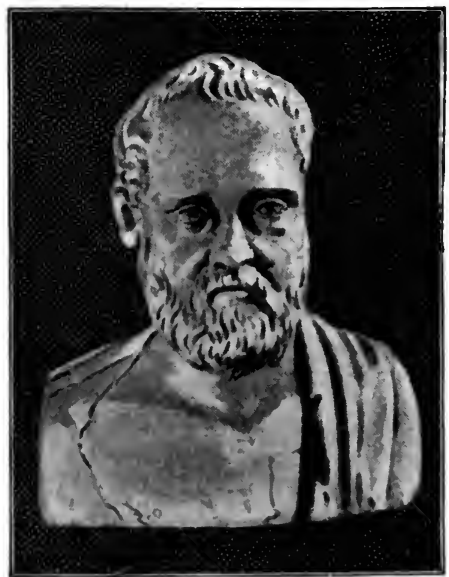

IsOCBATES the Attic period. and even reaches over into the Macedonian epoch. In the face of innumerable obstacles he attained the 
greatest skill and power in the art of expression. He combined the vivid effective speech of Lysias with the finished periods of Isocrates; but he possessed, more than either of these, an earnestness of purpose, a force of argument, a power of persuasion, and an energy of diction which have given him a place among the world's greatest orators. The most celebrated of his orations are his twelve "Philippics," in which he appealed to his countrymen to resist the encroachments of Philip of Mac'edon.

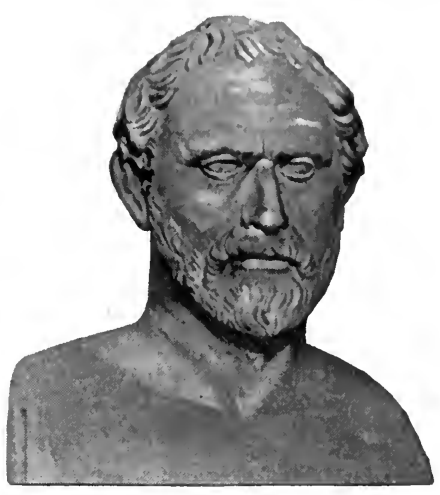

Demosthenes

\section{The Philosopity of Atiens}

Anaxagoras, the First Athenian Philosopher.-One of the greatest gifts of Athens to the world has been, no doubt, the contributions made by her philosophical thinkers. It was not until after the Persian wars that Athens became the philosophical center of Greece. The first thinker who belonged to what we might call the Athenian school was Anaxag'oras. Although born at Clazomenæ in Asia Minor, he early came to Athens, where he spent the most of his life, and numbered among his friends Pericles and Euripides. His name marks an epoch in the development of Greek thought, because he seems to have been the first to recognize the controlling influence of mind and reason in the universe. He seems to have believed that matter is subordinate to mind-that as the actions of the human body are controlled by the human intelligence, so the movements of the universe are controlled by a universal intelligence. This doctrine was opposed to the old mythology; and as the people were jealous of their ancient beliefs, MOREY'S ANCIENT HIST.- 13 
Anaxagoras was charged with atheism and banished from the city.

The Sophists and Greek Dialectics.-There grew up in A thens a certain class of men known as "sophists." They were not so much philosophers in the old sense as thinkers. That is, they did not seek to discover the laws of the universe so much as the laws of the human mind. They sought to find out the methods in which men reason and arrive at conclusions. This study of the methods and the art of reasoning was the essential feature of Greek "dialectics." We might therefore properly characterize the Greek sophists as "dialecticians." They gained their living by teaching the subjects of grammar, rhetoric, and logic, and preparing young men for the practical affairs of life. It was often charged against them that their learning was more of a pretense than a reality; and it was asserted that their art of reasoning degenerated into mere

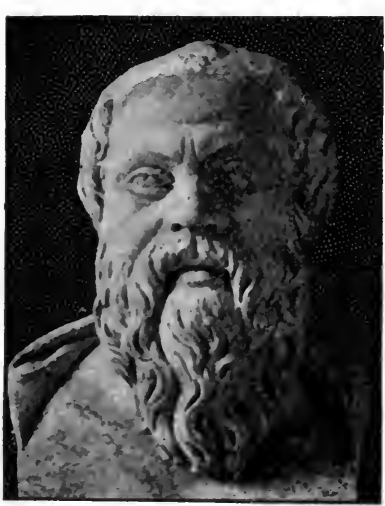

SOCIRATES quibbling, or the attempt "to make the worse appear the better reason." But with all the faults charged against them, they no doubt exercised some beneficial influence, both upon Greek education and upon Greek philosophy.

\section{The Practical Philosophy of} Socrates.-The name of Socrates was associated with that of the sophists. He adopted something of the same method of dialectics. But he believed that the art of reasoning should be employed not as mere exercise or discipline, but as a means of discovering those practical truths which are important in the conduct of human life. 'The son of a poor sculptor, with no personal attractions, he became one of the most conspicuous figures 
in Athens. He turned the thoughts of men into new channels. He showed them how foolish it was to follow the method of the old philosophers and to speculate about things which cannot be known. His first maxim was, "Know thyself." He taught men that true wisdom consists in knowing that which is good and doing that which is right. He taught them the difference between justice and injustice, between virtue and vice, between courage and cowardice. He taught them their duties to themselves, to their fellow-men, and to God. His long life extended beyond the period of the Peloponnesian war. He was finally tried and condemned to death by a small majority of his fellow-citizens, on the charge of introducing new gods into the state and of corrupting the youth. Socrates represented the higher intellectual and moral life of Greece. He left no writings; but his beneficial influence upon the world has never ceased.

\section{The Idealistic Philosophy} of Plato.-Socrates left behind him many disciples who founded new schools. But the most distinguished of these was Plato, the founder of the

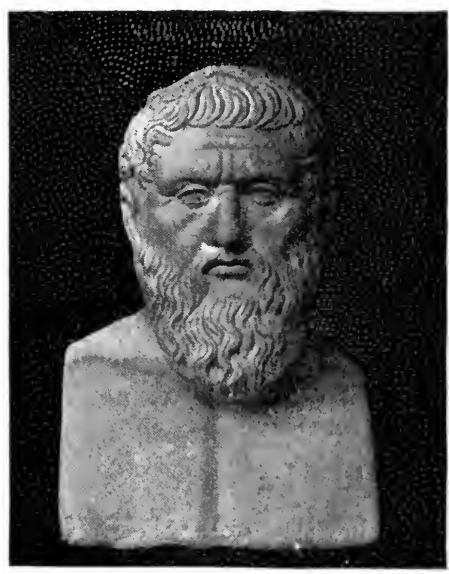

Plato so-called "Academic school."

He carried out still farther the method of Socrates. In order to discover truth, he studied the ideas in the human mind, which he believed are reflections of the ideas in the divine mind. He believed that our ideas are born with us, brought into the world from our preëxistent state. The divine ideas are embodied, not only in us, but in the world; and we should study the universe to discover these ideal principles in accord- 
ance with which all things are governed. So, in human life, we should conform to the ideal principles of justice and virtue; in other words, a perfect life is a life in harmony with the divine Idea. By such a method of thinking, Plato constructed a broad system of idealistic philosophy. 'The writings of Plato are in the form of dialogues, in which Socrates is often represented as the chief speaker. The dialogues are often named after some person; for example, the "Protag'oras," which discusses the nature of virtue; the "Phædo," which sets forth the arguments in favor of immortality. One of the most celebrated of Plato's Dialogues is "The Republic," which discusses the principles which should govern the perfect state. From the political conflicts of the time Plato stood aloof; and hence he shows to us the Greek mind in its purest and most tranquil frame.

\section{The Realistic Philosophy} of Aristotle.-The course of Greek philosophy was continued in Aristotle, who, though born in the city of Stagi'ra (or Stagirus) in Chalcidice, came to Athens and became a pupil of Plato. Although he regarded himself as a follower of Plato, his method differed considerably from that of his master. If we call Plato's philosophy idealistic,

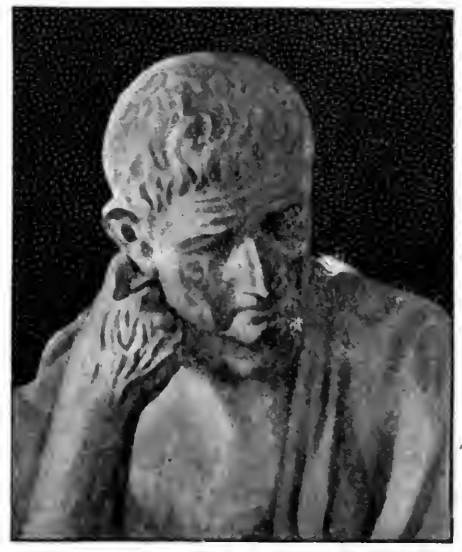

Aristothe (So-called)

we may call Aristotle's realistic. Instead of beginning with ideas, Aristotle began with facts; and he tried to discover the general laws which govern the facts of nature. He was therefore a man of wide observation and general learning. By gathering and classifying a vast number of facts, he became the founder of many sciences-of Logic, which treats of the laws 
of thought; of Psychology, or the science of the human mind; of Biology, or the science of living things; of Polities, or the science of the state. He is said to have studied the constitutions of many of the states of Greec; and the recently discovered work on the Athenian constitution, which is attributed to him, has added much to our knowledge of that government. Aristotle, like Demosthenes, belongs to the later part of the period we are now considering, and his life extended into the Macedonian period.

\section{Social Liffe and Manners}

Industrial 0ccupations. - As we regard $A$ thens as the intellectual center of Greece, so we may regard its social life as typical of that which prevailed in most of the Grecian cities. The democratic spirit of the Athenian people was opposed to any strict division into classes-except the distinction between freemen and slaves. All freemen were equal, having the same rights and privileges. We may, however, group the free inhabitants of Attica according to their industrial occupations, or the modes in which they obtained their living. We might, in the first place, regard "polities" as a business at Athens. It is true that the higher officers of the state received no pay; but pay was given to those who served in the army and fleet, in the council, and in the courts. The courts often swarmed with persons who desired to make their living by receiving the small pay given to jurors. Again, there was a class of professional men like physicians, artists, teachers, legal advisers, some of whom received not only fees for their services, but fixed salaries paid by the state. Besides these were the commercial classes, including the merchants, brokers, and traders, who formed the wealthier body of the citizens. Moreover, there was a large class of artisans, such as workers in wood, iron, clay, glass, silver and gold, who furnished many products that were exported to other parts of Hellas. Agricultural pursuits 
were always regarded as honorable by the Athenians, and it is said that no one but a free citizen could own land in Attica. The more menial kinds of labor were performed by the slaves, of whom there were a very large number in Attica, but whose condition cannot be regarded as very wretched, since they gen-

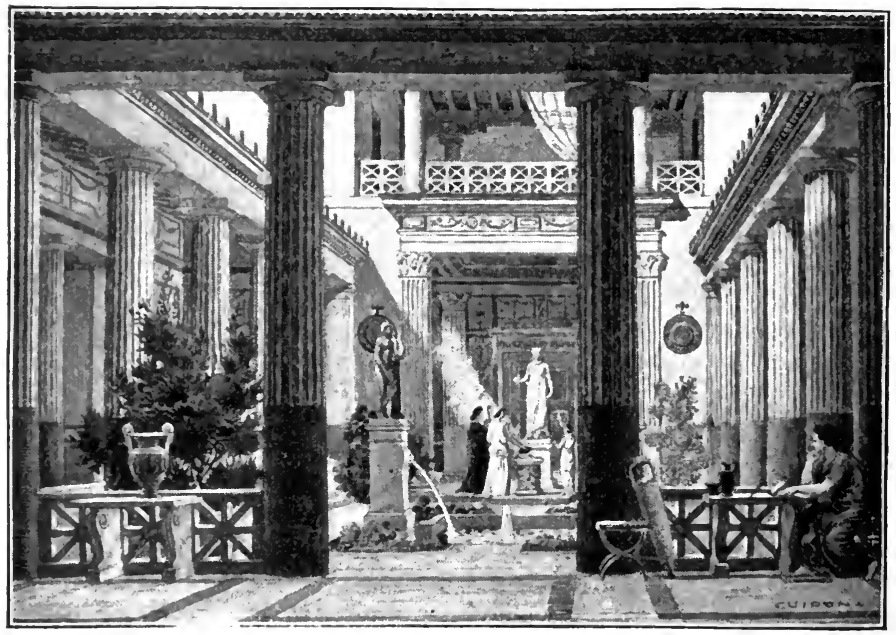

Interior of a Greek House (Restoration)

erally received humane treatment at the hands of their masters. 'The worst feature of Athenian slavery was to throw a reproach upon manual labor, and thus degrade the poorer class of freemen who were obliged to engage in such work.

The Athenian House, Furniture, Dress.-Although the public buildings of Athens were magnificent and expensive, the ordinary dwelling house was in its external appearance simple and umpretentious. It consisted of a series of rooms, surrounding a court which opened to the sky. 'The interior of the finer houses, however, presented a dignified and artistic appearance, with their peristyles of eolumns and rich lecorations and furniture. Chairs and couches of ornamental woodwork, artistic 
lamps of bronze or terra cotta, bronze or marble statuettes, and elegant vases of precious metal, all showed the refinement of the Greek taste.

The Greeks also showed their simple and refined taste in their dress, which presented astrong contrast to the elaborate and gaudy apparel of the Oriental peoples. It consisted usually of two garments : first a tunic called chiton (pron. ki'ton), held in place by clasps upon the shoulders; and second, a broad cloak, called hima'tion, thrown in loose folds about the person. The dress of the men and that of the women were quite similar, although the latter was more full and flowing. 'The graceful effect of the simple female

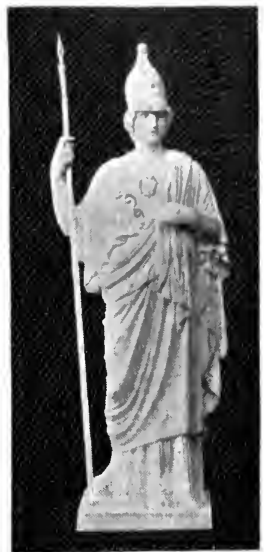

A Thena costume may be seen in the accompanying illustrations.

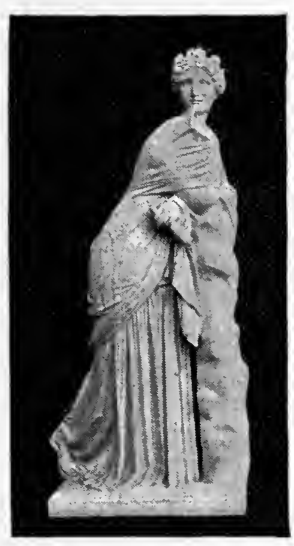

Polymina

Marriage and the Position of Women. -The father of the family provided for the marriage of his children, and the betrothal was really an engagement between the parents of the bride and groom. Although marriage was a legal contract, the wedding was a sacred as well as a festive ceremony, attended with a sacrifice to the gods, and a banquet in which the guests partook of the wedding cake and joined in the nuptial song.

The Athenians believed that the proper sphere of woman was the home, and hence she was deprived of the liberty which she enjoyed in Homeric times, and even at this time in Sparta. She was taught that politics and the turmoil of the street should be left to men. Her domestic employ- 
ments-spinning, weaving, and embroidering-were not of course conducive to high intellectual culture. She could not, therefore, exercise the elevating social influence that is possible in modern times. But in spite of her inferior position, the Athenians were not unappreciative of the nobler qualities of the female character, as is seen, for example, in the "Antigone" of Sophocles.

Athenian Education.-Education formed a very important part of Greek life. Its aim was to develop as far as possible a perfect physical, intellectual, and moral manhood, and to prepare young men for the duties which belong to free citizens. The Athenians were thoroughly impressed with the importance of training the body, the mind, and the character. Gymnasties, mental discipline, and moral inspiration were the chicf features of their educational methods. The boy was not only taught by his teacher at school, but was constantly under the supervision of his " pedagogue," a trusty servant who accompanied him to school and watched over him elsewhere. The elementary training consisted of reading, writing, and arith-

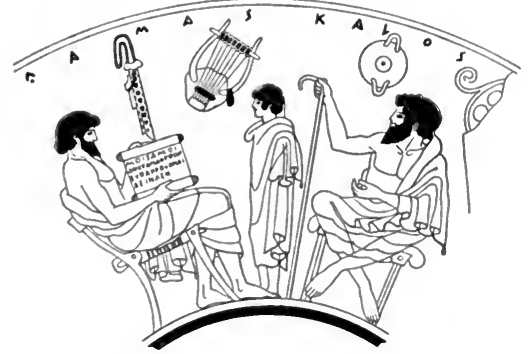

A Lesson in the Poets metic. The boy committed to memory the wise sayings of the old poets, and copied these proverbs upon a waxen tablet by means of the stylus; and his arithmetical computations were made with the aid of the abacus, or counting board. T'o this was added music, for the cultivation of the feelings; while his systematic exercise in the gymnasium was intended to give him a sound, symmetrical, and vigorous body. Besides this elementary discipline there was added the more advanced education olstained from the conversation and lectures of professional 
teachers, like the sophists. Such instruction was given in the porches of the Agora, and in other public places. It included all branches of practical and theoretical knowledge; and its aim was to give what we should call a liberal elueation-to make broad-minded men and enlightened citizens.

Athenian Sociability; the Banquet and Symposium.-The Athenians were essentially a sociable people. 'This is seen in their hospitality, their love of companionship., of conversation, and of social entertainments. The open air was in many respects the home of the Athenian gentleman; for in the streets he could always find his friends, with whom he was aceustomed to pass away many hours of the day. One of the chief centers of the social life of Athens-as it was of the political and commercial life-was the Agora. The Athenians also found other places of resort and social pleasure in the gymnasia, of which the most famous were the Lyceum and the Academy-the former situated just outside of the city to the east, and the latter about a mile to the north. There were also clubs, originally founded for the sake of companionship, and afterward acquiring a political character as well.

The chicf source of social entertainment in the evening was the banquet, with the accompanying "symposium." Reclining on couches, the guests partook of the repast furnished by the host, and then were regaled with dashes of oratory, sparks of wit, rehearsals from the poets, and the music of the flute or lyre, or perhaps amused by professional dancers, jugglers, and contortionists. The character of the symposium of course varied with the refinement of the guests; but it was a fair expression of Greek social and intellectual culture.

\section{SYNOPSIS FOR REVIEW}

I. Athens as the Center of Hellenic Art.-Greek Politics and Hellenic Culture.-The Attic Period, its Character and Phases.-The City of Athens.-Athenian Architecture.-Athenian Sculpture.-Athenian Painting. 
II. The Theater and Dramatic Literature.-The Theater of Dionysus.-Origin of the Greek Drama.-Aschylus, the Father of Tragedy.-Sophocles, the Dramatic Artist.-Euripides, the Dramatist of the People.-The Attic Comedy; Aristophanes.

III. Prose literature: History and Oratory.-Herodotus, the Father of History.-Thucydides, the Scientific Historian.Xenophon, the Historical Essayist.-Athenian Oratory; Lysias, Isocrates, Demosthenes.

IV. The Philosophy of Athens.-Anaxagoras, the First Athenian Philosopher.-The Sophists and Greek Dialectics.-The Practical Philosophy of Socrates.-The Idealistic Philosophy of Plato.-The Realistic Philosophy of Aristotle.

V. Social Life and Manners.-Industrial Occupations.-The Athenian House, Furniture, Dress.-Marriage and the Position of Women.-Athenian Education.-Athenian Sociability, the Banquet and Symposium.

\section{REFERENCES FOR READING}

Alleroft, Vol. II., Ch. 13, "The Imperial City"; Ch. 15, "Literature" (10).'

Abbott, Pericles, Ch. 17, "The Athens of Pericles" (27).

Ducoudray, Ch. 9, "Greek Literature and Art" (1).

Smith, Wm., Ch. 34, "Athens and Athenian and Grecian Art during the Period of her Empire"; Ch. 35, "History of Athenian Literature to the End of the Peloponnesian War" (10).

Mahaffy, Survey, Ch. 4, "Passage from Sporadic to Systematic Culture" (10).

Bury, Ch. 11, § 6, "The Restoration of the Temples"; $\S 11$, "Higher Education; the Sophists" (10).

Curtius, Vol. II., pp. 592-641, "Athens the Center of Intellectual Life" (10).

Holm, Vol. II., Ch. 20, "Athens under Pericles"; Ch. 26, "The New Culture, Rhetoric and Sophistry"; Ch. 29, "Art and Literature" (10).

Macaulay, Essay on History (Herodotus and Thucydides compared).

Zeller, Second Period, "Socrates, Plato, and Aristotle" (15).

Guhl and Koner, \$ 30, "The Theater" (11).

Symonds, Greek Poets, Ch. 9, "Ancient and Modern Tragedy" (15).

Tarbell, Chs. 8, 9, Great Age of Greek Sculpture (12).

Gulick, Ch. 14, "Social Life and Entertainments" (11).

Bliimner, Ch. 4, "Marriage and Women" (11).

Mahaffy, Old Greek Life, Ch. 4, "Public Life of the Greek Citizen" (11).

Felton, Vol. II., Second Course, "The Life of Greece" (10).

'The figure in parenthesis refers to the number of the topic in the Appendix, where a fuller title of the book will be found. 


\section{PERIOD IV. THE UNION OF GREEOE AND THE ORIENT (359-146 B. C.)}

\section{CHAP'TER XV}

MACEDONIA AND THE EMPIRE OF ALEXANDER

\section{The Rise of Macedonia under Philip}

The New Epoch in Greek History.-We have now reached a new and important epoch in the history of Greece-and, in fact, in the history of the ancient world. 'The failure of the Greek states to develop a national government-either in the form of a permanent confederacy, or by submitting to the leadership of one of their own number-led to the final overthrow of the very liberties which they were so anxious to preserve. In striving to maintain their independence from one another, they were compelled at last to submit to the control of a foreign power. The supremacy which they were unwilling to give to Athens, to Sparta, or to Thebes, they were at last obliged to yield to Macedonia. The rise of Macedonia, and the interference of this new power in the internal affairs of Greece, therefore, mark a crisis in the history of the Grecian states.

But we shall see that Macedonia established her supremacy not only over the states of Greece, but also over the countries of western Asia; so that Greece and the Orient became united in a common world-empire. The most important feature of this new period, however, is not so much the establishment of a common political authority over the countries of the ancient 
world, as the diffusion of the Greek genius among the peoples of the East. If in earlier times the tide of Orientalism once flowed toward the Aigean, now the tide of Hellenism is to flow back toward the Orient. If during the Attic period the Hellenic culture tended to become centralized in Athens, now the culture of Greece is to transcend the narrow limits of Hellas and to become a possession for every people. The essential feature of the coming epoch is, therefore, the union of Greece and the Orient in a wider civilization, which we may call "Græco-Oriental." But first let us see how this union was accomplished, under the supremacy of Macedonia and the leadership of Philip II. and Alexander the Great.

Macedonia and the Greeks.-Macedonia was a country lying to the north of 'Thessaly, beyond the Cambunian Mountains.

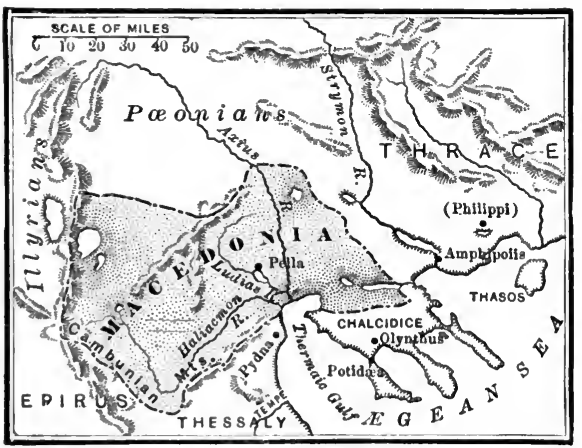

Macedonia at the Accession of PHILIP II. The people were remotely related to the Greeks. But they were still for the most part in a semi-barbarous condition, although they were capable of becoming a strong nation. They were a hardy race, and had in them the making of good soldiers. In the highlands they were separated into many tribes, each under its own chief. But in the lowlands, near the sea, they had come into contact with the Greek colonies, and had begun to be more civilized and to have something like a united govermment. It the time of the Theban supremacy, Macedonia became so strong and threatening that Pelopidas invaded the country, checked the ambition of its ruler, and brought back to 'Thebes the young prince Philip as a hostage. 'This young 
Philip, while in bondage, became versed in the civilized arts of Greece and especially in the military system of Epaminondas, and thus became fitted for his future work as the king of Macedonia.

Accession and Character of Philip II. (359 B. C.).-On his return to Macedonia Philip was appointed regent of the kingdom at the age of twenty-three; and in a short time he had himself proclaimed king. He proved to be a man of wonderful ability, versed in the best as well as the worst arts of statecraft. $\mathrm{He}$ possessed unusual powers of organization. He was able as a warrior,
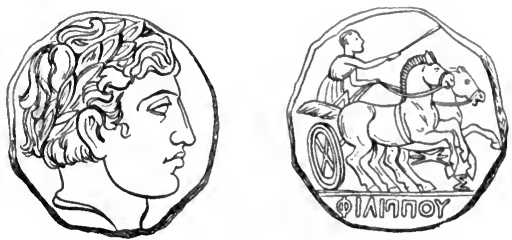

PiIllip II. (Coin)

and still more able as a wily diplomatist. IIe extended his power over the mountain tribes, and pushed back the barbarians who were threatening the frontiers of his kingdom on the north and west. But more than this, he gathered together his scattered subjects into a well-organized army. This gave to the people a common military discipline and a common national spirit. In organizing his army, Philip adopted the Greek phalanx; but he strengthened it by making the line sixteen instead of eight men deep. He armed the men with lanees twenty-one feet long, so that the front of the phalanx presented a projecting forest of bristling spears. He also organized a fine body of heavy-armed cavalry, made up of the best men of the kingdom and called "companions," which formed in action the right arm of his battle line. By his political and military skill he was able in a few years to convert a semi-barbarous country into a well-organized and growing kingdom.

The Aggressions of Philip upon Greece-The chief ambition of Philip was to make himself master of Greece. He first interfered in the affairs of the Athenian colonies in Chalcidice, which Athens was not able to prevent, as she was at 
the same time engaged in an unsuccessful war with some of her allies-the "Social war" (358-355 B. c.). Philip was aided in his aggressions upon Greece by the distracted condition of the Greek states themselves,--especially in the so-called "Sacred war" (357-346 в. с.). This war grew out of the attempt of Thebes and the Amphictyonic League to punish Phocis for seizing lands belonging to the temple of Apollo at Delphi. Nearly the whole of Greece was affected, either directly or indirectly, by this war. Philip now appeared as the ally of Thebes and the champion of Apollo. He invaded Thessaly and made himself master of that country. Pressing on to Thermopylæe, he found this pass held by an Athenian army. Instead of exposing his own army to slaughter, he deemed it wiser to withdraw and to wait for a more convenient season in which to extend his influence in Greece.

Demosthenes and Philip.-The one great man who now appeared as the defender of Greece against Philip was Demosthenes. He had already made a reputation as an orator; and he now assumed the rôle of a statesman. To arouse Greece to a sense of her danger, he delivered the first of a series of famous orations known as "Philippies." Philip was now busy in the north, trying to get possession of Olynthus, and to reduce to his power the whole Chalcidian confederacy. Olynthus appealed to Athens for aid; and Demosthenes delivered his "Olynthiac orations," to urge the people to make war upon Philip and to save the Chalcidian city. His earnest efforts induced the Athenians to declare war, but failed to save the beleaguered town. Olynthus fell (348 B. c.), and with it all the Chalcidian cities, whose inhabitants, according to the ancient custom, were either put to death or sold into slavery. The kingdom of Philip now extended nearly to the Hellespont on the east, and to the pass of Thermopylx on the south.

To allay the fears which had been inspired by Demosthenes, Philip consented to a peace with A thens-the Peace of Philoc'rates $(346$ B. C.) -in which each party professed friendship for 
the other and each agreed to respect the other's possessions. Having conciliated Athens, Philip marched to Delphi, dismantled the Phocian towns, scattered their inhabitants in small villages, and received himself the two rotes in the Amphictyonic couneil that hitherto had belonged to Phocis. 'To extend his influence in Greece, he then formed friendly alliances with a number of the states in the Peloponnesus.

Battle of Chæronea; the End of Greek Freedom (338 в. c.). -But Athens was still suspicious of the designs of the Macedonian king. She saw that Philip was threatening to make further aggressions in Thrace and also in central Greece. Through the influence of Demosthenes Athens and 'Thebes now joined in a final effort to crush the king. But at Chæronea, in Bœotia (map, p. 191), Philip defeated the combined forces of the Grecian allies, and destroyed the last opposition to his power. This battle is generally regarded as marking the loss of Grecian independence. But we ean see that the independence of Greece had been gradually declining since the first interference of Philip in Grecian affairs. Greece fell before Macedonia on account of her incapacity to form a united state, like that which Philip had created for his people.

The Congress of Corinth; Death of Philip.-Philip now proceeded to do for Greece what Greece had failed to do for herself. He called together at Corinth a congress of all the states. This congress is said to have been the most representative body that the Hellenic world had ever seen-Sparta only standing aloof. The king gave to the Greeks a constitution which formed a kind of federal state. Every city was to be free, and to manage its own affairs, and not to be subject to any tribute. The Amphictyonic council was to be the supreme arbiter in the settlement of disputes between the different states. The king was to be the president, having the power to declare war and peace. At this congress Philip also revealed his greatest project, which was nothing less than the conquest of Persia, in which Greeks and Macedonians would 
unite in avenging the wrongs done to Greece since the days of X́erxes. The proposals of the king were accepted, and he was appointed commander in ehief of the armies which were to invade the Persian empire. But while making plans for this expedition, Philip was assassinated (336 в. с.), and the completion of his work was left to his son, Alexander the Great.

\section{The Empire of Alexander}

Beginning of Alexander's. Career.-Alexander was well qualified to earry on the work begun by Philip. He was fitted both by nature and by education for a career which in many respects has no parallel in the world's history. From his

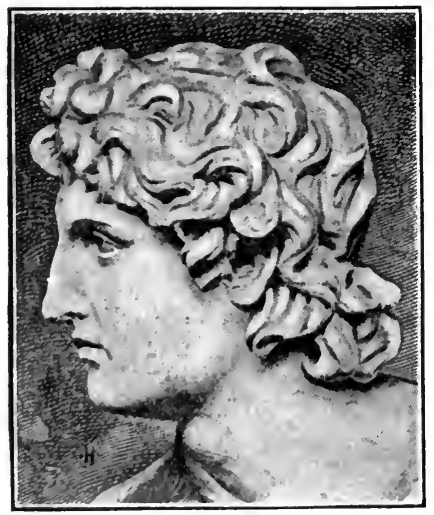

ALEXANDEl? father he inherited an imperial will, a keen insight into men and things, and a genius for military organization. From his mother-a half-barbarian princess-he inherited an impetuous nature, a fitful, fiery temper, and a tendency to superstition. By his great teacher, Aristotle, he was trained to virtue and the love of truth, to an exalted appreciation of knowledge, and to a sympathy with the Hellenie spirit. From his favorite author, Homer, he derived a heroic inspiration, a zeal for warlike action, and a passion to rival the deeds of Achilles. From the time that he was a boy of twelve-when, aceording to Plutarch. he had tamed the fiery steed Buceph'alus-to the battle of Chæronea, where he harl led the Macedonian eavalry, he had shown that he was born to rule. At the age of twenty he ascended his father's throne. His first work was to quell the spirit of re- 
volt which seemed everywhere to show itself with the news of his father's death. He put out of the way his possible rivals. He entered Greece and had himself proclaimed commander in chief, as his father had done. He punished the tribes of the north and west which threatened the frontiers of his kinglom. Angered by a Grecian revolt led by 'Thebes, he wiped that rity from the earth, sparing only the temples and the house of the poet Pindar. Having pacified his kingdom in Europe, he was ready to enter upon the conquest of $A$ sia.

Asia Minor; Battle of the Granicus (334 B. c.).- The first country to be brought under his control was Asia Minor. He crossed the Hellespont with a small but well-trained army, consisting of thirty thousand infantry and five thousand cavalry. $\mathrm{He}$ first visited the plains of Troy, already hallowed in his imagination by the tales of Homer; here he offered a sacrifice to Athena, and paid homage to the tomb of Achilles. His first battle was fought at the river Grani'cus, a

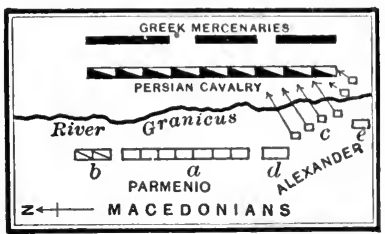

Battle of Granicus

$a$, Macedonian phalanx; $b$, allied cavalry ; $c$, companion cavalry; $d$, light infantry ; $e$, arehers and javelin throwers small stream flowing into the Propontis, where he practically destroyed the whole Persian army, with but a small loss on his own part. The victory at the Granicus was followed by the speedy submission of the cities in Asia Minor. Alexander then moved north to Gordium, the old capital of Phrygia, where he quartered his army for the winter, and according to the well-known story "cut the Gordian knot."

Syria; Battle of Issus and Siege of Tyre (333 B. c.).-The next country to be conquered was Syria. Alexander marched from Gordium southward through the passes of the Taurus Mountains to Tarsus; then through the city of Issus into the open plains of Syria, where he expected to meet the armies of the Persian king, Darius III. In the meantime, Darius had 


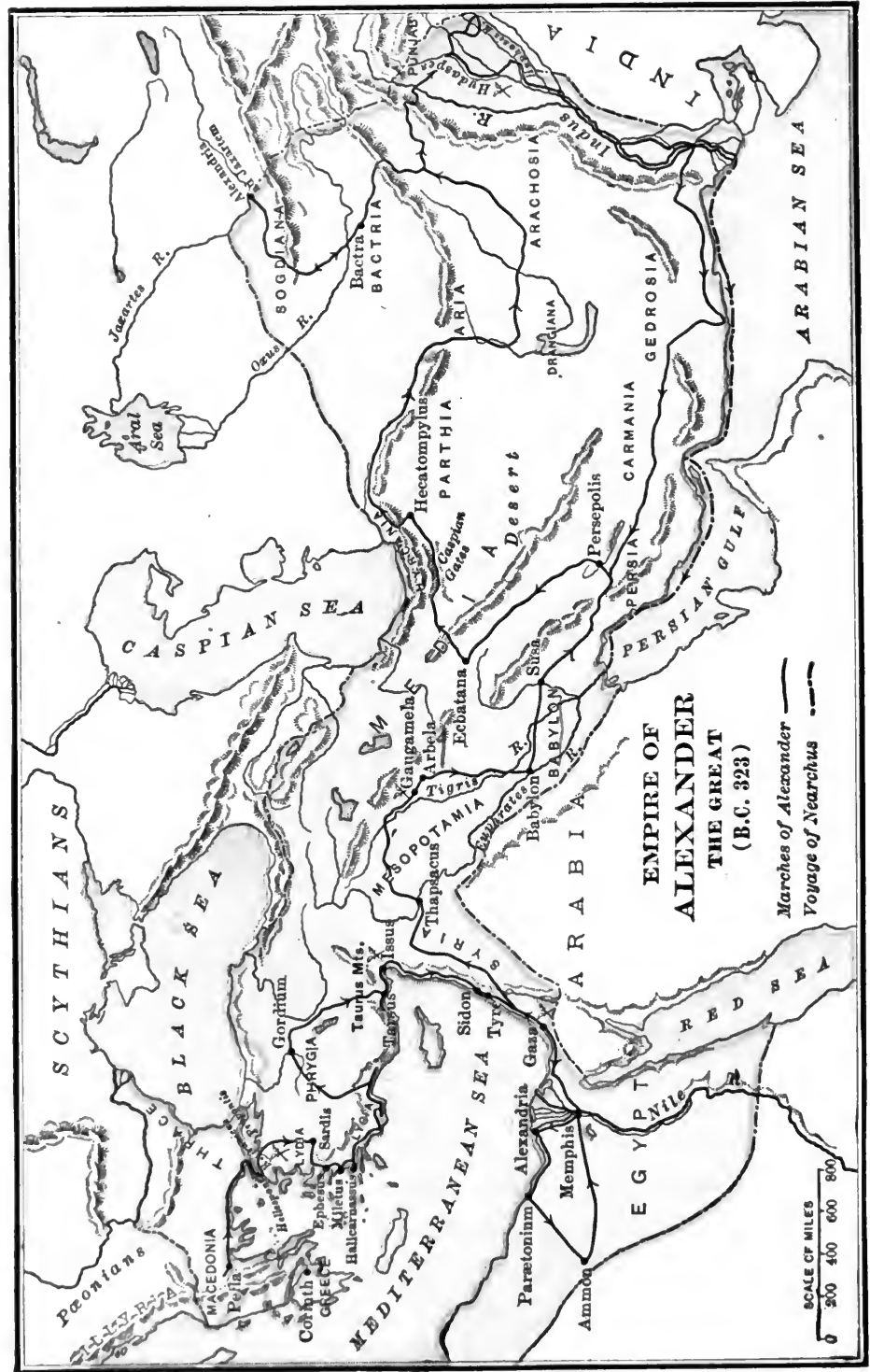


X

assembled a vast horde of six hundred thousand men and moved to the north and to the rear of Alexander's army, hoping to cut off its retreat. Nlexander marched back and attacked Darius in his chosen position, near Issus. After a severe contlict, a large part of the Persian army was destroyed and the rest put to flight. Alexander then continued his march southward through Sidon and reached Tyre. At this place he met the most serious resistance that he encoun-

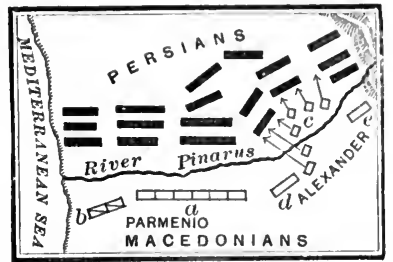

Battile of Issus

(For letters, see p. 231) tered in all his campaigns. The new city of Tyre was situated on an island about half a mile from the coast. Having no fleet at hand, Alexander could

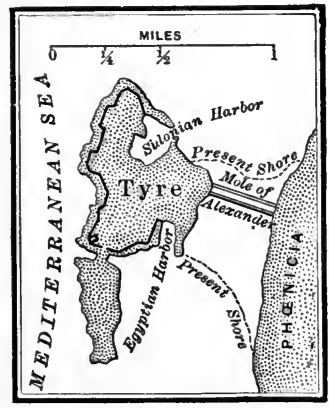

SiEgE OF TrRe reach the city only by building an immense mole, or causeway, through the sea to the walls. By this stupendous piece of work he was able to storm and capture the city. 'The overtures for peace which the Persian king now felt disposed to offer him were seornfully rejected.

\section{Egypt; Founding of Alexandria} (332 в. c.).- There remained only one more province on the Mediterranean to be secured, and that was Egypt. The march to the south, however, was blocked at Gaza, a strongly fortified town defended by its faithful governor, Batis. To assault these walls Alexander performed another great feat of enginsering skill. He built a mound of earth, two hundred and fifty feet high and twelve hundred feet broad at the base, around the entire city. Although repulsed three times, he finally took the town by storm. He put to death what remained of the garrison, and sold the women and children into 
slavery. The way was now open to Egypt, which welcomed Alexander as a deliverer. On the coast west of the Delta, he founded the new eity of Alexan'dria, the first and most famous of many towns which perpetuated his name. Thence he moved westward along the coast, and then southward through the Libyan desert to the noted temple and oracle of Zeus Ammon. Here, it is said, the oracle addressed him as the son of Zeus and the future conqueror of the world. This may have had some influence upon Alexander, in leading him to claim divine honors for himself.

Central Persia; Battle of Arbela (331 B. c.).-Having organized the government of Egypt, Alexander returned to Tyre and made his preparations to pierce the heart of the Persian

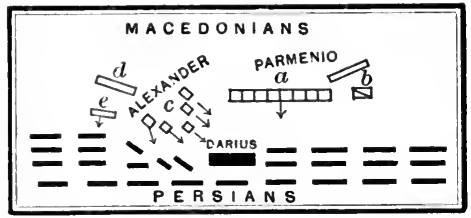

BATTLE OF "ARBELA"

(For letters, see p. 231) empire. He crossed the Euphrates River and passed through upper Mesopotamia beyond the Tigris. In a broad plain near the village of Gaugame'la, and thirty miles west of Arbe'la, he came face to face with the army of the great king. Here was to be fought the battle which was to decide the fate of Persia. Since his defeat at Issus, Darius had gathered an immense armament which rivaled that of Xerxes, - a million infantry, forty thousand cavalry, two hundred scythed chariots, and fifteen clephants. To meet this host Alexander had now an army of forty thousand infantry and seven thousand cavalry. His attack began with a cavalry charge toward the enemy's left; and this he suddenly changed and direeted in the form of a wedge against the center, where Darius himself was urging on his troops. 'The frightened king fled; his army became demoralized; while the rest of Alexander's troops pressed forward and gained a complete victory. 'The battle at Gaugamela-usually called the "battle of Arbela"-sealed 
the doom of the empire. Alexander then moved south to Babylon, which surrendered to him; next to Susa, which also opened its gates; and then to Persepolis, which was taken alter a feeble resistance. These three cities were the richest in the world; and by their capture Alexander came into possession of immense treasures. He proclaimed himself the monarch of Persia; but he disgraced his name by wantonly firing with his own hand the magnificent palace at Persepolis.

The Far East; Battle of the Hydaspes $(326$ в. с.).-Alexander had now traversed the western and central provinces of the Persian empire. There remained the far eastern provinces, which were speedily reduced to his authority. It was during this period that Alexander blackened his name by two of his most infamous crimes. The one was the assassination of his faithful general, Parme'nio, on the charge of conspiracy; the other was the murder, in a fit of drunken frenzy, of his dearest friend, Clitus, who had saved his life at the battle of the Granicus. Of these dastardly crimes, it can only be said to his credit that he bitterly repented of them.

Not satisfied with the conquest of Persia, Alexander crossed the Indus, and proceeded through the Punjab to the river Hydas'pes. Here, after a severe engagement, he gained a victory over the armies of India, led by Porus, the most able king of the Far East. Struck by the royal bearing of Porus, Alexander made him viceroy of his new Indian province. The Macedonian soldiers, now wearied with years of marching and fighting, refused to go farther into unknown lands; and Alexander was obliged to return. Down the Indus and then westward through the sands of the desert. his army marched back to Persepolis and Susa; while his fleet under Nearchus explored anew the ancient water route from the Indus to the Fuphrates. Alexander repaired to Babylon, now the capital of his newly conquered world.

Death and Character of Alexander.-On his return to Babylon Alexander did not rest. He hoped to push his conquests 
into Arabia, and to give a firmer organization to his GræcoOriental empire. But in a short time he was stricken down by a fever, and died (323 B. c.) at the age of thirty-two years and eight months. His last words were a request that the empire be given "to the most worthy." His body was carried to Egypt, and was buried at Alexandria with divine honors.

What shall be thought of Alexander? This is a question upon which there has been much difference of opinion. Some

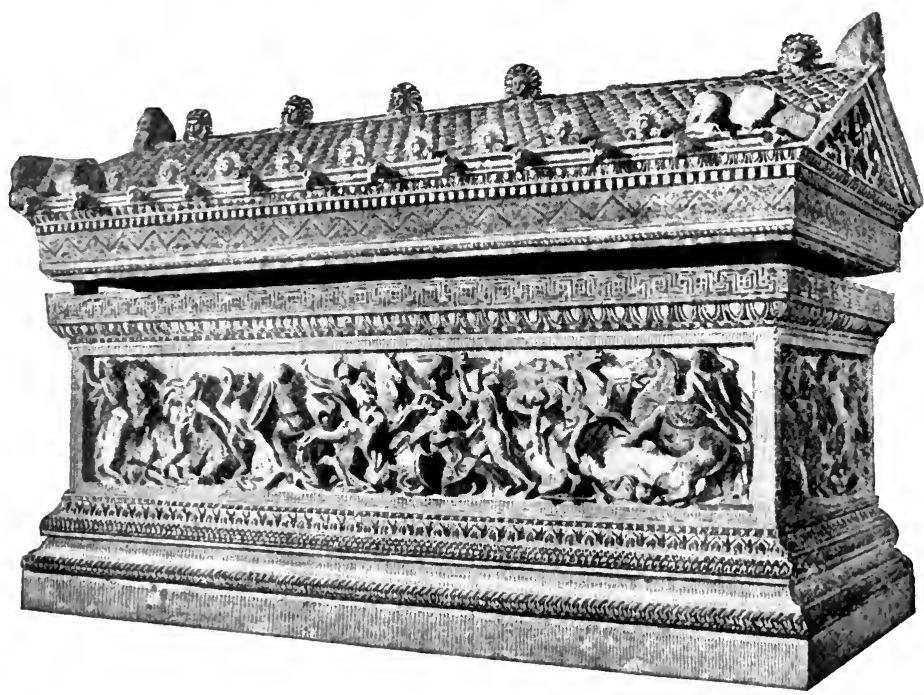

Sarcopilagus of Alexander (So-called)

have regarded him as scareely more than a brilliant military adventurer. Others have looked upon him as having done more for the world's civilization than any other human being. Without assuming too much confidence in our own opinion, let us look at his chief characteristics as a man. as a soldier, and as a statesman.

As a man Mlexander possessed remarkable natural endowments-a borly of great heanty, agility, and strength. capable of extraordinary feats of endurance; a mind of transcendent 
genius, of restless aetivity, of wonderful power's of insight, of broad and comprehensive views, prolific in resources, and unerring in the adjustment of means to ends; a will power such as is rarely given to men, irresistible and untiring; and an emotional nature made up of a strange mixture of generosity and cruclty, of self-control and self-indulgence, of calm repose and furious passion, capable of performing the worst of crimes, and immediately giving way to penitence and remolse.

As a soldier he has had scarcely a peer in the world's history - a born commander of men, a supreme master of strategy and tactics, equally great in marches, sieges, and battles.

As a statesman he possessed a cosmopolitan breadth of view. He believed that the state should not be narrowed to the limits of a city or small territory, like that of the Greeks, but should take in all civilized peoples. He showed his broad ideas by favoring the mixture of races, by encouraging a wider commercial intercourse, by patronizing the arts and the sciences, by building up new cities as centers for the diffusion of Greek civilization. He adopted, in some respects, higher methods of government than those which had hitherto prevailed in the East. But it remains true that the great world empire which he carved out with the sword fell to pieces almost immediately after his death.

\section{Dissolution of Alexander's Empire}

The Wars of the Diadochi.--The years which followed the death of Alexander were years of intrigue and war between his different generals, who are known in history as the "Diad'ochi," or the successors of Alexander. Various attempts were made to keep the empire together. At first one of the generals, Perdic'cas, tried to rule. and divided the provinces between himself and the other chieftains; but they refused to recognize his authority. Afterward another general, Antig'onus, aspired to the position of the great king; but he was opposed by the 
PROGRFASIVE MAP NO. 11.

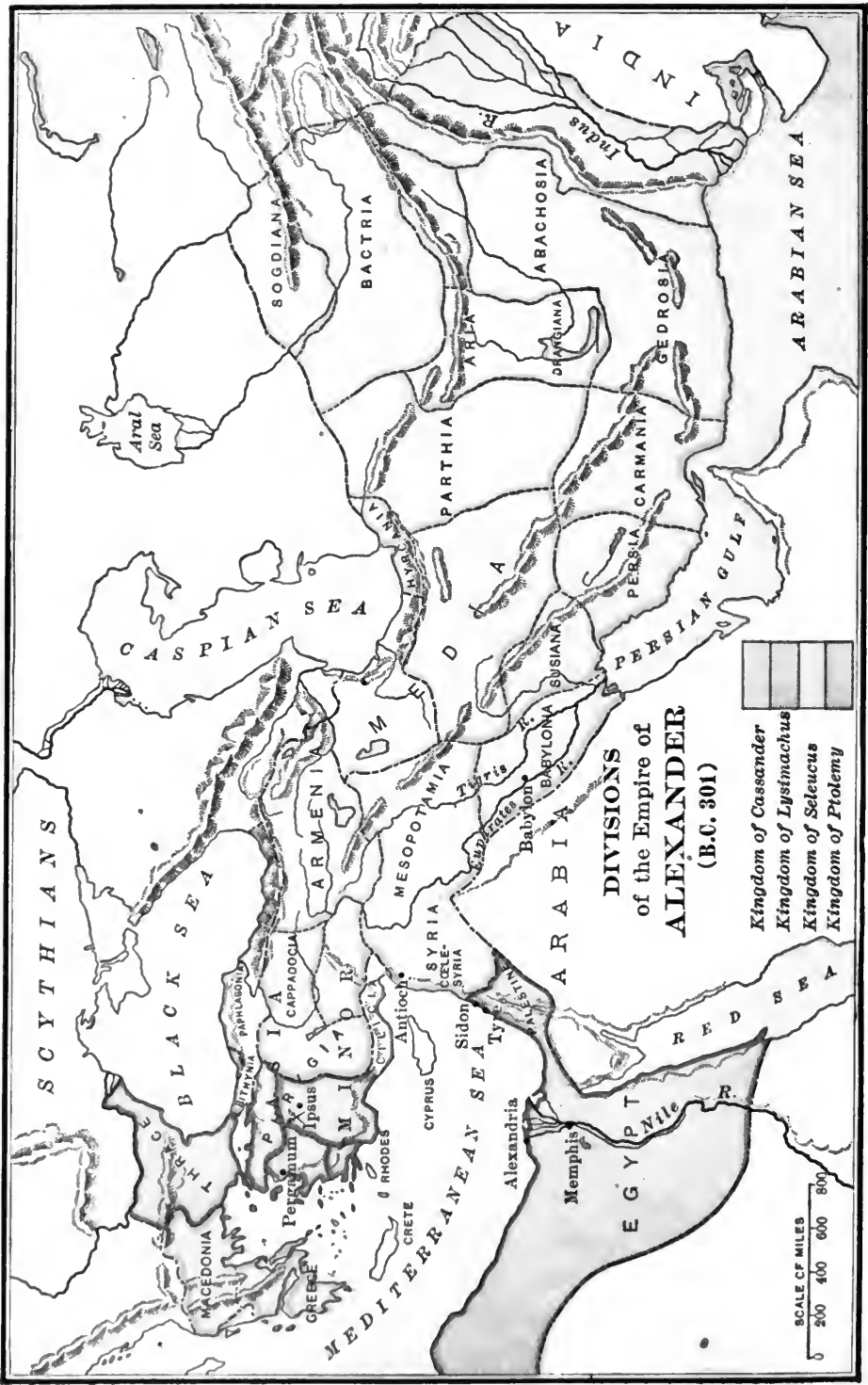


other generals, who were themselves getting control of various provinces. After years of bitter strife, Antigonus was defeated and slain at the battle of Ipsus in Phrygia (301 в. с.) ; and the vietorious generals divided among themselves the fragments of the empire that Alexander had established (map, p. 238).

Kingdom of the Seleucidæ; Syria.-Seleucus was the general who had already taken possession of Babylon, together with a large part of the eastern provinces. He now received in addition Mesopotamia, Syria, and the eastern part of Asia Minor. He removed his capital from Babylon to An'tioch in Syria; but in this way he also weakened his hold upon his eastern provinces. He divided his whole territory into seventytwo satrapies, ruled not by natives but by Greeks and Macedonians. The eastern provinces were intrusted to his son Anti'ochus, who afterward succeeded to his father's throne (280 B. c.). This extensive empire was known as Syria, or rather the "Kingdom of the Seleu'cidæ," and remained the greatest power in Asia until the Roman conquest ( $6+$ B. C.).

Kingdom of the Ptolemies; Egypt.-Ptolemy I. (Soter) was one of Alexander's generals who was put in possession of Egypt directly after the death of the conqueror, and had maintained himself there during the wars of succession. He afterward added to his kingdom Palestine, lower Syria, and Cyprus. Under his administration and that of his successors Egypt rose to prosperity and greatness. The first Ptolemy organized the kingdom into provinces based upon the ancient divisions of the country; but the civil and military authority was placed in the hands of Greeks and Macedonians. Alexandria became the great commercial emporium of the Mediterranean, and the center of the world's learning. Egypt remained the land of commerce and of culture until it was absorbed by the Roman empire (30 в. c.).

Kingdoms in Asia Minor.-No part of Alexander's empire was so completely broken up after his death as was Asia Minor. 
Here, after some years, we find the new kingdoms of Per'gamum, Bithyn'ia, and other smaller states, as well as the island republic of Rhodes, which included some of the cities on the adjacent coast. Of these several states the kingdom of Pergamum was the most important, and under'its kings Eu'menes I. and $\Lambda t^{\prime}$ talus $I$. rose to a position of considerable power and influence.

Macedonia and the Greek Federations.-After the death of Alexander the Greeks made a fresh attempt to throw off the power of Macedonia. This unsuccessful revolt, which is known as the "Lamian war" (323-321 B. c.), was inspired chiefly by Demosthenes, who after its disastrous close fled from Athens and took his own life by poison. After the battle of Ipsus, Macedonia fell into the hands of Cassander, who received it as his share of Alexander's empire.

While weak successors of Cassander were trying to maintain their authority in Greece, there grew up two confederations which were the most important factors in later Greek polities. In the course of time they came to include the most important states of Greece, except Athens and Sparta. One of these confederations was the Etolian League in central Greece. This was originally a union of warlike mountain tribes in Etolia, but it gradually extended its power so as to include a considerable number of states north of the Gulf of Corinth, and also Elis in the Peloponnesus.

A body quite similar to the Atolian League in its organization, but far superior in its character, was the Achæan League, which comprised most of the states in the Peloponnesus. The power and greatness of the Achean League were due to the famous leader Ara'tus, who for a time appeared as the deliverer of Greece from Macedonian rule. In a few years the whole Peloponnesus, except Laconia and Elis, was combined ( 229 в. с.) in a single federal state-the most advanced political organization that had ever existed in Greece. 
Constitution of the Achæan League.-The Achæan League is often referred to as the most striking example of a federal republic existing in the ancient world; and we should therefore notice its principal features. In the first place, each city retained its equality and independencehaving its own government, electing its own officers, and managing its own local affairs. In the next place, the general powers of the league were vested in a central or federal government. $\mathrm{Th}$ is consisted of (1) a general (or president), and a council or cabinet of ten persons who exercised

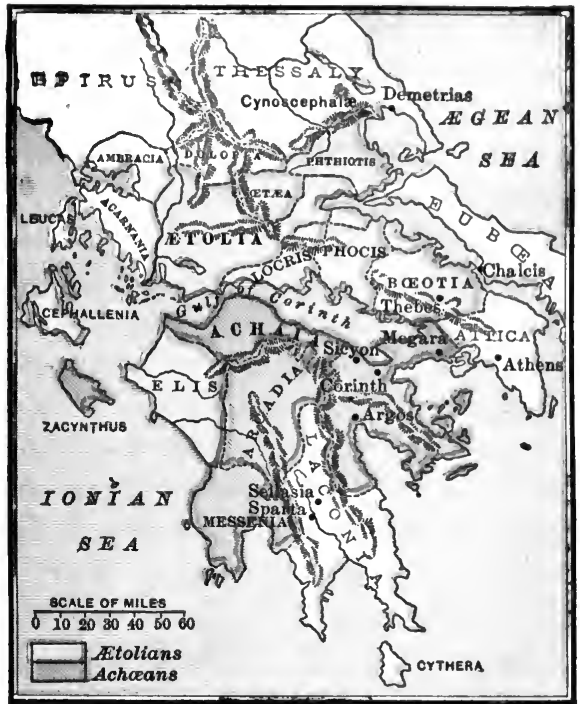

The Etolian and Achæan Leagues, ABOUT 229 B. C. administrative powers; (2) a boulé, or senate, of about one hundred and twenty persons, which prepared measures for the assembly and managed foreign affairs; and (3) an assembly of the whole people, in which the citizens of each city possessed one vote. The assembly passed all federal laws, and elected all federal officers. As the federal assembly was not a representative body, and as all the citizens would not be disposed to attend its meetings, there was a tendency for the league, although democratic in theory, to become aristocratic in fact, and also for the "general" to exercise a great influence in shaping its policy. 
Conflict between the Achæan League and Sparta.-The only state of the Peloponnesus which now remained outside of the Greek federations was Sparta. Once the head of the Peloponnesian League, Sparta was now envious of the growing influence of the Achæans. She was herself trying to recover some of her ancient prestige. She had reformed and strengthened her decaying institutions through the efforts of her two energetic kings, Agis III. and Cleomenes III. Cleomenes believed that the interests of Sparta required the breaking up of the Achran League. He appealed to the Atolians, and with their aid waged a successful war against the Achæans. The cause of the Achæans seemed about to be lost, when their general Aratus.felt obliged to appeal to Macedonia for aid. The Macedonian king, Antigonus, was quite willing to interfere in this conflict, since he saw an opportunity to strengthen his own authority in Greece. He invaded the Peloponnesus, defeated cleomenes in the battle of Sella'sia (221 B. c.), and forced Sparta into submission. But the most unwelcome result of this so-called "Cleomenic war" was its effect upon the Achæan League. The league was originally organized to repel the power of Macedonia; but now, by accepting an alliance with Macedonia, it was compelled to submit to her authority.

Macedonia and the Etolian League.-When Macedonia had defeated Sparta and had brought the Achæans into subjection,

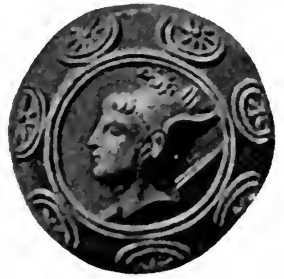

PHil.IP V. the Ftolians were left the chief independent power in Hellas. It was now their turn to make an attempt to establish their supremacy in Greece. The time seemed especially favorable on account of the recent death of the warlike king Antigonus, and the accession of the young prince Philip V. to the Macedonian throne. The Atolians accordingly invaded the Peloponnesus and made war upon the Achæans. They obtained the assistance of Sparta, still smart- 
ing under her recent defeat at Sellasia. In this war hetween the leagues-called the "Social war" (220-217 B. (.) - the young Macedonian king felt bound to protect his Acharan allies. He therefore entered upon a series of vigorous campaigns by land and sea against the Etolians. IIe was everywhere sucessful. Etolia and the whole of Greece seemed on the point of being redueed to the condition of a Macedonian province, when Philip received the news that the Romans had been defeated in a great battle hy Han'nibal. He determined to make peace with the Greeks, and to join Hannibal against the Romans. By the terms of this peace, called the Peace of Naupactus ( $21 \%$ B. c.), the two leagues were compelled to lay down their arms and to return to the condition in which they were at the beginning of the warthat is, the Acheans continued to recognize the authority of the Macedonian king; the Spartans withdrew into their own territory of Laconia; and the Etolians retained their independence.

The Intervention of Rome.-During this period in which the Grecian leagues were striving to resist the encroachments of Macedonia, events were taking place which finally led to the supremacy of a new foreign power in Greece. This new power was Rome, which was beginning to make its influence felt to the east of the Adriatic Sea. It was the interference of the Macedonian king, Philip V., in the war between Rome and Hannibal that led, as we shall hereafter see, to the interference of Rome in the affairs of Macedonia and Greece. From this time the history of Greece became a part of the history of Rome. But before we begin to study the rise and extension of the Roman power and the development of its new world empire-which absorbed not only Macedonia and Greece, but all the countries bordering on the Mediterranean Sea-we must first get some idea of that new culture which the ancient world received through Alexander's conquests and the work of his successors. 


\section{SYNOPSIS FOR REVIEW}

I. Tine Rise of Macedonia under Pinlip.-The New Epoch in Greek History.-Macedonia and the Greeks.-Accession and Character of Philip II.-The Aggressions of Philip upon Greece. -Demosthenes and Pinilip.-Battle of Chæronea; the End of (ireek Freedom.-The Congress of Corinth; Death of Philip.

II. THE EMpIRE oF Alexander.-Beginning of Alexander's Career.-Asia Minor; Battle of the Granicus.-Syria; Battle of Issus and Siege of Tyre.-Egypt; Founding of Alexandria.Central Persia; Battle of Arbela.-The Far East; Battle of the Hydaspes.-Death and Character of Alexander.

III. Dissolution of Alexander's EMPIRE.-The Wars of the Diadochi.-Kingdom of the Seleucidæ; Syria.-Kingdom of the Ptolemies; Egypt.-Kingdoms in Asia Minor.-Macedonia and the Greek Federations.-Constitution of the Achæan League.Conflict between the Achrean League and Sparta.-Macedonia and the Atolian League.-The Intervention of Rome.

\section{REFERENCES FOR READING}

Curteis, Ch. 3, "Macedonia and Hellasat Philip's $\Lambda$ ceession" (10). ${ }^{1}$ Oman, Ch. 42, "Plilip and Demosthenes"; Ch. 43, "The End of Grecian Freedom"; Ch. 44, "Alexander the Great" (10). Bury, Ch. 16, "The Rise of Macedonia"; Ch. 17, "The Conquest of Persia" (10).

Wheeler, Alexander, Ch. 12, "The Persian Empire"; Ch. 31, "Death of Alexander" (27).

Mahafiy, Survey, Ch. 8, "Alexander and His Successors" (10).

- Greek Life, Ch. 18 (Hellenism, society, literature, art) (10). Alexander's Empire, Ch. 8, "The Invasion of the Celts [Gauls] and its Consequences" (10).

Schuekburgh, Ch. 22, "Atolian and Achran Leagues" (10).

Curtius, Vol. V., Bk. VlI., Ch. 3, "Athens and Philip" (10).

Holn, Vol. III., Ch. 26, "Concluting Years of Alexander's Reign"; Index, "Atolian League," "Achan an league" (10).

Dodge, Alexander, Ch. 12 (military system of Philip and Alexander); Ch. 48, "The Man and the Soldier" (27).

Freeman, Essay, "Alexander the Great" (3).

Brédif, Demosthenes, Ch. 2, "Philip-the Athenians" (the Athens of Demosthenes) (27).

Plutarch, "Demosthenes," "Alexander," "Aratus," “Agis," "Cleomenes" (26).

Arrian, Bk. II., Chs. 18-24 (siege of Tyre); Bk. III., Ch. 1 (conquest of Egypt); Bk. IV.. Ch. 8 (murder of Clitus); Bk. VII., Ch. 1 (Alexander's plans); Chs. 8-11 (mutiny of Alexander's army) (17).

Demosthenes, Orations, "The First Olynthiace," “The First lhilippice" (17).

Thle fieme in latrentlessis refers to the number of the topic in the Appendlx, where a fuller title of the book will be found. 


\section{CHAP'TER XVI}

THE NEW GRACO-ORIENTAL, OR HELLENISTIC, CUL'TURE

\section{Hellenic and Hellenistic Cul'ture}

Hellenic Culture in Greece.-In taking a brief review of the general culture which had its beginning in the Macedonian period, we may first look at Greece itself, where the Hellenic spirit was least affected by Oriental influences. Athens was still the center of Grecian life and thought. Here flourished the men who represented better than elsewhere the continuance of the old Hellenic s p irit. Here Demosthenes and As'chines continued to deliver their orations in pure Attic Greek. Here Aristotle continued to write his works on philosophy and science. Here comedy continued to flourish in the writings of Menan'der; and painting sur-

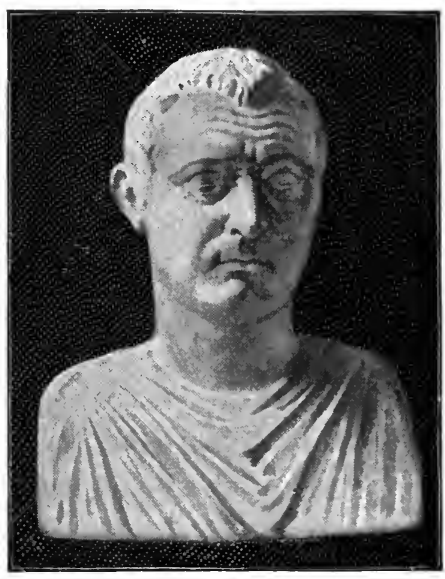

MENANDER vived in the famous portraits and other works produced by Apel'les. These men represented the old Hellenic culture-a culture which had been developing in Greece since the days of the Persian wars, but which was destined to lose its Attic purity by contact with the thought and spirit of the East. 
Post-Aristotelian Philosophy.-One of the evidences of the influence of the East upon the native culture of Greece is seen in the growth of certain new schools of philosophy which followed Aristotle. These schools were a protest, not only against the old religious ideas of the Greeks, but also against the foreign superstitions which were coming into Greece from the East. 'The foremost of these schools were the Epicure'an and the Stoic. The Epicurean school took its name from Epicu'rus, who was born at Samos and had taught in the cities of Asia Miner before he came to Athens. Epicurus tried to rescue men from the influence of superstition and the old mythological ideas concerning the gods. He taught that men should be influenced, not by the fear of the gods, but by the desire to obtain the highest happiness-not the passing pleasure of the hour, but the permanent happiness of a lifetime. The Stoic philosophy, which was a higher system than the Epicurean, was founded by Zeno. He taught at Athens in a portico on the Agora (Sto'a Precile, or Painted Porch), from which his school received its name. He also rejected the prevailing mythological notions, and believed that the world is governed by a Universal Reason which is revealed in the laws of nature. According to Zeno, men should live, not to appease the gods, but to conform to the highest "law of nature." He also sympathized with the broader ideas of the age, and believed that men's duties should not be limited to their own city or even to Greece, but should extend to all mankind.

In these new schools of philosophy we may see some of the influences of the new period-the influx of Oriental superstition which these schools tried to withstand, and also the desire to enter into the new world spirit which followed the breaking down of national barriers. The new philosophy taught that every one should be, not simply a member of his own city, but a "citizen of the world."

The Spread of Hellenism in the East.-But the most interesting feature of this age is not so much the influence of Orien- 
tal ideas upon the old culture of Greece, as the diffusion of the Hellenic eulture into other parts of the world-that is, the "Hellenizing" of the Orient. This was due, not only to the work of Alexander himself, but to the continuance of his policy by his successors. Jike him, they also planted new eities; placed over them Greek and Macedonian governor's; encouraged Greek colonization; introduced the customs of Greek life; favored the use of the Greek language; and patronized Greek learning and art. These new cities became new centers of Greek civilization, and in some respects they surpassed the older cities of Greece. The accumulated wealth of the East was used to construct splendid works of art, fashioned upon Greek models-temples, colonnades, sculptures, market places, gardens.' In such ways as these the Greeks became the citizens of the world, and the culture of Greece became the heritage of other people.

Meaning of Hellenistic Culture.-As we consider this great movement by which the Greek language and eivilization were gradually extended over the East, there is one important point which should be kept in mind. This is the fact that the culture which had been developed by the Greeks themselves was considerably modified by being taken up by the people of foreign countries. For example, the Greek language, when spoken by a Syrian, a Jew, or an Egyptian, would not longer remain the pure language of Sophocles or Plato, but would acquire features foreign to the Attic tongue. So the architecture and sculpture of Greece would have impressed upon them a certain Oriental character and spirit, which would distin-. guish them from the more refined art of Phidias and Praxiteles. To this Greek culture modified by Oriental influences we apply the term "Hellenistic," to distinguish it from the purer Greek culture of the Greeks themselves, which we call "Hellenic." The Hellenistic culture, then. means the language and civilization of the people of the East who adopted the speech and culture of the Greeks. It is, in short, the 
Orientalized form of Hellenism. 'The Greek influence extended into central Asia and as far east as the Indus; but the chief seats of the Hellenistic culture were the countries on the eastern shores of the Mediterranean-Asia Minor. Syria, and Egypt.

\section{Hellenistic Culture in Asia Minor}

Pergamum as a Center of Culture.-The chief seat of the new civilization in Asia Minor was the city of Pergamumthe capital of the kingdom of the same name. The kings of

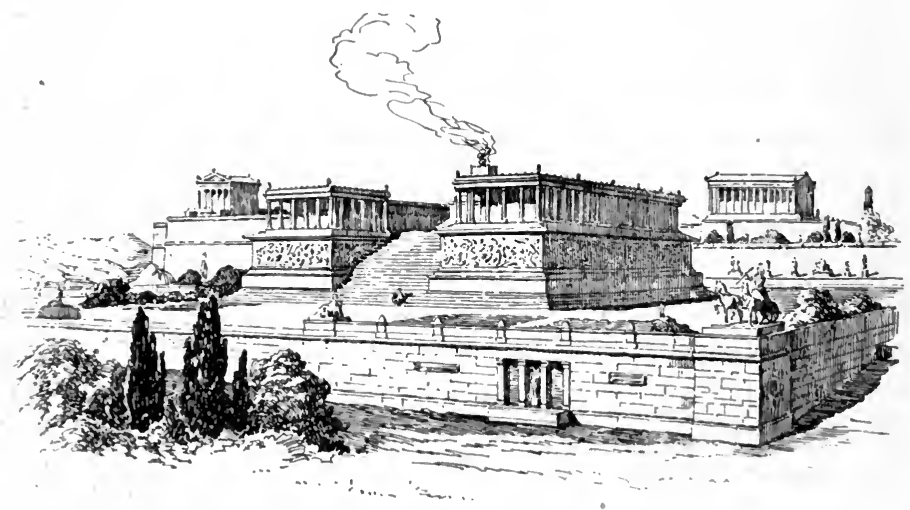

Tile Great Altar at Pergamum (Restoration)

this country came to be wealthy and somewhat powerful monarchs. They gained an enviable reputation by ending the depredations of the Gauls - a barbarian people who in the third century invaded Greece and Isia Minor, and were finally settled in the province of Calatia, in the interior of $A$ sia Minor. This victory over the Gauls was the heroic event in the history of Pergamum, and was commemorated in many works of art.

Architecture and Sculpture of Pergamum.-The kings of Pergamum adorned their capital with splendid buildings, 
which rivaled the architecture of $\Lambda$ thens. The central architectural feature of the city was a vast altar dedicated to 'ceus Soter (the Savior). This was built by Eumenes II. to commemorate the victory over the barbarian Gauls, and the divine assistance then given. 'The altar was situated on the summit of the acropolis, said to have been more than eight hundred feet above the level of the sea. It was adorned with elaborate sculptures and especially with a gigantic frieze, on which was

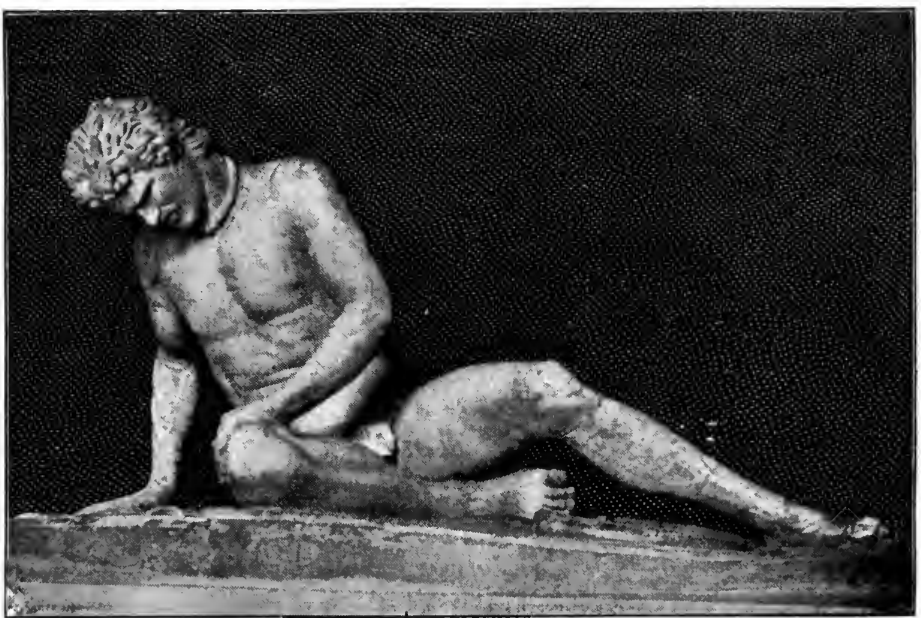

The Dying Gaul

represented the battle between the gods and the barbarian giants. This altar with its decorations was regarded as one of the marvels of the ancient world. We have preserved to us a valuable relic of the Pergamean art, and also of the Gallic invasion, in the well-known copy of the Dying Caul (usually called the "Dying Gladiator"). This is worth our careful study as a specimen of Hellenistic art. showing a departure from the purest Greek models in the realistic representation of a wounded barbarian warrior. 
Literature and Science of Pergamum.-This city was a center not only of art, but also of learning. Although it made no important contributions to literature, it was distinguished for a remarkable collection of literary works-a library of two hundred thousand volumes, which rivaled the more renowned collection at Alexandria. Books, or rather manuscripts, had previously been written upon Egyptian papyrus. But as the exportation of this material was prohibited by the Egyptians, the kings of Pergamum adopted in its place the skins of animals (called Pergamence chartce, from which comes our word "parchment"). The city of Pergamum also became the home of many scientific men,-_grammarians, mathematicians, natural philosophers, and physicians, - of whom many acquired great renown, as

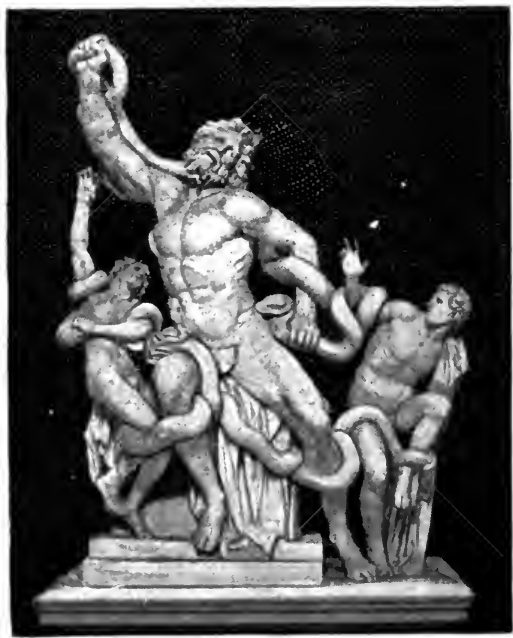

LAOCoÖN ANI HIS Sons Cra'tes in philology, and Galen in medicine.

\section{The School of Rhodes.}

-Another important center of Hellenistic culture in Asia Minor was Rhodes, famous for its school of rhetoric and its code of maritime law. The art of Rhodes reveals the same Oriental influences that appeared at Pergamum. This is seen in the taste for colossal figures and impressive groups of statuary. The f a mous Colossus of Rhodes, a statue one hundred and fifty feet high. was reckoned as one of the seven wonders of the world. 'The most important example of Rhodian sculpture that remains to us is the group of Laoc'oön, a priest 
of Apollo, and his sons, who were destroyed by serpents sent by Athena. 'The agony depicted upon the face of the prisst,

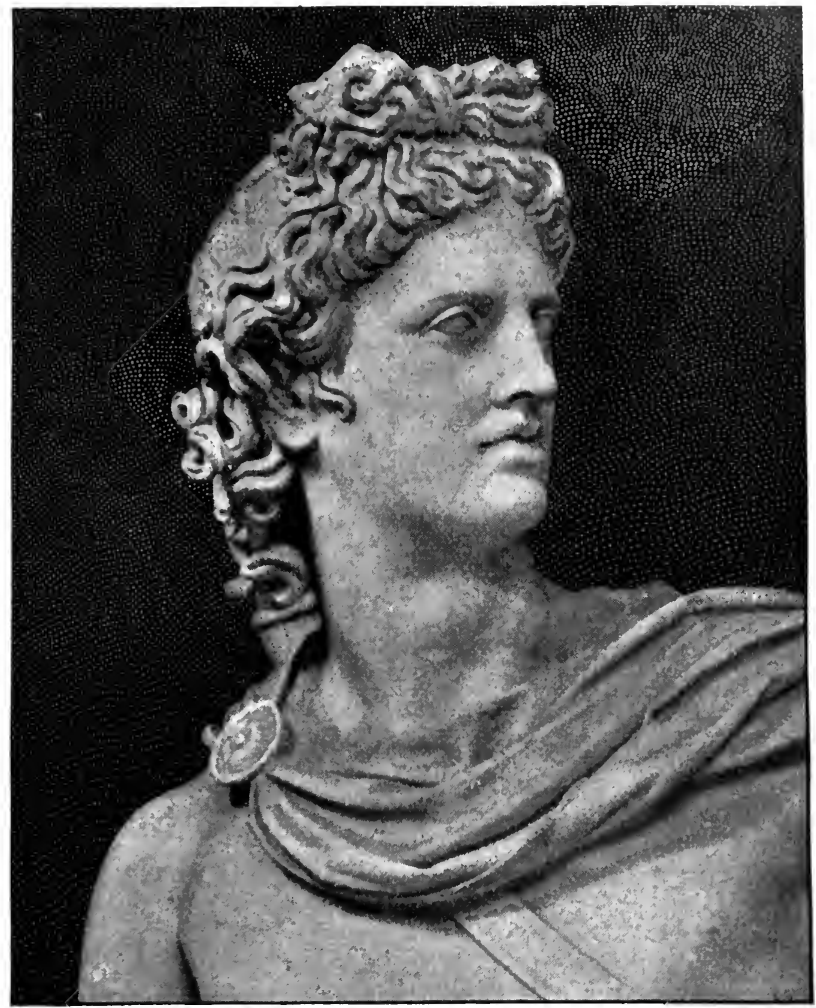

Head of the Apollo Belvedere

though wonderfully expressive, is far removed from the calm repose which marks the purer Hellenic art.

Examples of Pure Hellenic Art. - As we stuajy the art of what is called the "Hellenistic period," we should bear in mind the fact that not all the works produced at this time show in an equal degree the influence of Orientalism. Some works show 
this influence to a greater, and some to a less extent. Before we leave the shores of the Egean, we should therefore notice at least two examples of the art of this period which preserve in the greatest degree the pure Hellenic spirit, and to which is given a high rank among the statues of the world. One of these is the Apollo Belvedere, which is now generally assigned to this period, although the place where it was produced

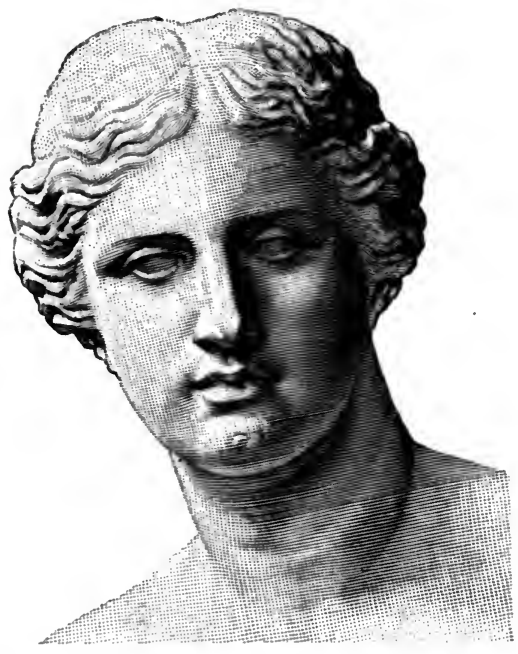

ilead of the A phrodite of Melos is not known. So nearly does it approach the perfect Greek style, that it has been said that in it "we see Lysippus in the form and Praxiteles in the face" (Perry). The other example of the pure Hellenic art of this period, and one which is perhaps still more remarkable, is the Aphrodite found on the island of Melos, and usually called the "Venus of Melos." The faces of these two marble statues express the Greek ideal of perfect masculine and feminine beauty. In them we see that grace of form and calmness of spirit which the Greeks regarded as essential to the purest art.

\section{Hellenistic Culture in Syria}

The Civilization of the Seleucidæ.-The Selencidx were the most zealous followers of Alexander in the founding of new cities. These new towns, which numbered more than seventy, hecame the active centers of Greek influence. They were 
colonized by Greeks. In them the Greek language was spoken; Greek methods of city government were adopted; the commercial spirit of the Greeks was present; and Greek buildings were erected. But these Greek towns, springing up by the side of the older Asiatic cities, felt the influence of Oriental customs and ideas. 'The Greeks absorbed the Oriental love of wealth and passion for luxury, and developed a form of life which was neither purely Greek nor purely Eastern, but a mingling of the two-a composite culture in which the Oriental features were improved and the Hellenic features debased.

Antioch as a Center of Culture.-The city which presented the most conspicuous type of this Græeco-Oriental or Hellenistic culture in Syria was Antioch, the capital of the kingdom. The original city was founded by Seleucus I. (Nica'tor), and named in honor of his father Antiochus. Here were gathered the people of many nations; but the prevailing form of culture was Greek, imbued with the Oriental taste for magnificence. The buildings glistened with precious stones and ornaments of gold. The broad, regular streets were lined with the most splendid porticoes, colonnades, and statues. Beyond the walls of the city was the cypress grove of Daphne, said to be one of the most attractive places in the world. It contained the tree of Daphne, into which this nymph, according to tradition, was changed when fleeing from Apollo. The grove was reached by a road passing through beautiful villas and gardens enlivened with fountains and medicinal springs. It was adorned. with stately temples, baths, and places of amusement. In the temple of Apollo was a colossal statue of that god, said to rival the Zeus of Phidias. All this fondness for luxury shows that the Greeks, while exercising a powerful influence upon the East, were themselves coming under the spell of Orientalism.

Attempt to Hellenize the Jews.-The only opposition to the Hellenizing movement in western Asia appeared in Judea. Here the people were attached to their ancient language and 
religion. It is said that Alexander offered strong inducements for the Jews to settle in Alexandria, where they could retain their religion unmolested. Many of them took advantage of this offer; but while preserving their own religion, they could not help imbibing much of the Hellenistic spirit. In Judea itself, however, the people succeeded in resisting these foreign influences. It is true that the Jews in Palestine sometimes affected the Greek culture, by learning to speak the Greek language and adopting Greek names; but the mass of the people clung to their Hebrew language and customs. When Palestine passed from the control of Egypt to that of Syria, a systematic attempt was made by the Syrian king, Antiochus IV. (Epiph'anes), to force upon the Jews the Greek language and customs, including the Greek religion. This was accompanied by a most unjust and bitter persecution. It aroused a national revolt, which ended only with the establishment of the independence of the Jewish nation.

\section{Hellenistic Culture in Egypt}

Alexandria as a Center of Culture.-In Egypt we find the most important intellectual center of the Hellenistic world. The Ptolemies did not, like the Seleucidæ, attempt to bring the whole kingdom under Greek influence by the erection of many new cities. They rather attempted to concentrate into a single focus the various elements of Greek culture. This focus was the city of Alexandria, founded by the great conqueror himself. It was first of all a commercial center, taking the place of 'Tyre as the important emporium of the Mediterranean. It came to be the most cosmopolitan city of the world, with a population of nearly a million inhabitants, made up of Egyptians, Greeks, Macedonians, Jews, and people from nearly every Asiatic country. The ideas of various people found here a common meeting place. The Ptolemies respected the religion of the Egyptians and that of the Jews, while cling- 
ing to their own Grecian gods. But these various religions were often mingled with one another. 'The god Sera'pis, for example, was a deity in whom were united the character of the Greek Zeus and that of the Egyptian Osiris. Though the country surrounding Alexandria was not attractive, the architerture of the city united Greek taste with Oriental splendor. There were many public buildings, such as theaters, amphitheaters, race courses, and sanctuaries; but the most imposing of these was the Serape'um, the temple of the common god Serapis.

Museum and Library of Alexandria.-Alexandria obtained its highest renown as the home of scholars. In this city we find blended the Greek and the Egyptian taste for philosophy and science. The most famous work of the Ptolemies was the establishment of the Museum and the Library. 'The Museum was a collection of buildings dedicated to the Muses, and might not inaptly be called a "University." Here were gathered the philosophers, scholars, and students of all countries-Greece, Asia Minor, Judea, Babylon, and even India. It is said that at one time as many as fourteen thousand students found a home in Alexandria. In connection with the Museum were botanical and zoölogical gardens, dissecting rooms, and astronomical observatories. But the most famous of these buildings was the great Alexandrian Library, containing over five hundred thousand manuscripts. It was the desire of the Ptolemies to possess an authentic copy of every existing work of Greek literature. This library was the most extensive collection of manuscripts in the ancient world.

The Literature and Scholarship of Alexandria.-The kind of literary work done at Alexandria was less creative than critical. The literature which was produced at this time was mostly elegiac and lyric poetry. One poet of this period holds the first rank among the pastoral poets of the world; this was Theoc'ritus. Although born at Syracuse, he lived at Alexandria. His "Idylls," describing the beauties of nature, have 
been admired by all people, and perhaps approach more nearly than any other literature of this period to the pure æsthetic spirit of the early Greeks. History also was cultivated by Nanetho, an Egyptian priest, who wrote the "Chronicles of Egypt"; while the Babylonian Berosus was doing a similar kind of work for Babylonian history. But the most thorough literary scholarship of Alexandria was devoted to the critical study of the ancient Greek texts. Aristar'chus may be called the father of textual criticism and the science of grammar. Translations of important works of literature also formed a part of the work of these Alexandrian scholars. The most noted of these translations was the Sep'tuagint, a Greek version of the Jewish Scriptures.

The Alexandrian Science and Philosophy.-Alexandria was also a meeting place for Greek and Oriental science; and a great impulse was given in the direction of a more strictly scientific method. There are many famous names of scientists connected with this seat of ancient learning. Euclid was the founder of our modern geometry: Modern astronomy has grown out of the works of Hippar'chus and Ptolemy (Claudius Ptolemæus). Eratos'thenes was the first to give a mathematical estimate of the size of the earth. Archime'des, a native of Syracuse, came here to study; he was a noted mathematician, and made brilliant discoveries in physical and mechanical science. In Alexandria, too, we see in later times a remarkable mingling of the philosophical ideas of the world-Greek idealism, Jewish monotheism, Oriental mysticism, and afterward even Christian theology. But the complex systems which grew up under such names as "Neo-Platonism" and "Gnosticism," we need not attempt to explain. For us they simply illustrate. like the other phases of Alexandrian culture, the various ideas and forms of thought resulting from the union of the Greek and the Oriental world which followed the conquests of Alexander.

Influence of Greek Civilization.-As we look back over the history of Greece and its influence upon other countries we 
may understand the important place which it oceupied in the growth of ancient civilization. We have seen Greece at first the heir of the Orient, developing an early culture under foreign influences, which soon passed away, leaving only the memories and monuments of the Mycenæan age. We have seen her afterward showing a spirit of freedom and independence, -in politiss, in literature, in art, in philosophy,-breaking away from the servile spirit and despotic authority of the East, and developing in the age of Pericles a culture far superior to that of any earlier people. We have also seen her in her political decline and fall, still maintaining her intellectual supremacy and scattering the fruits of her culture among the various peoples with whom she was brought into contact. We must, therefore, look upon the influence of Greece as one of the most powerful factors in the civilization of the ancient world, and we should also remember that this beneficial influence was not limited to the countries of the old world. but has continued down to our own day. Whatever flaws we may have discovered in the old Greek character, we should not fail to appreciate that peculiar type of intellectual and asthetic culture which was developed by the people of Hellas and which forms one of the great bequests of antiquity to modern times.

\section{SYNOPSIS FOR REVIEW}

I. Hellenic and Hellenistic Culture.-Hellenic Culture in Greece.-Post-Aristotelian Philosophy.-Spread of Hellenism in the East.-Meaning of Hellenistic Culture.

II. Hellenistic Culture in Asia Minor.-Pergamum as a Center of Culture.-Architecture and Sculpture of Pergamum.Literature and Science of Pergamum.-The School of Rhodes.Examples of Pure Hellenic Art.

III. Hellenistic Culture in Syria.-The Civilization of the Seleucidæ.-Antioch as a Center of Culture.-Attempt to Hellenize the Jews.

IV. Hellenistic Culture in Egypt-Alexandria as a Center of Culture.-Museum and Library of Alexandria.-The Literature and Scholarship of Alexandria.-Alexandrian Science and Philosophy.-Influence of Greek Civilization. 


\section{REFERENCES FOR READING}

Ducoudray, Ch. 10, "The Diffusion of the Greek Genius" (1). Felton, Vol. II., pp. 275-278, "Spread of Hellenism" (10).

Mahaffy, Survey, Ch. 9, "The Hellenistic World" (10).

— Greek Life, Ch. 9, "Alexandria and its Rivals" (10).

- Alexander's Empire, Ch. 10, "The Golden Age of Hellenism"; Cl. 20, "Commerce and Culture of Felgamum and Rhodes" (10).

Holm, Vol. IV., Ch. 14, "Culture of the Greek World, 300-220 B. C." (10).

Gardner, P., Ch. 15, "Successors of Alexander and Greek Livilization" (10).

Gardner, E. A., Handbook, Ch. 5, "The Hellenistic Age" (12).

Freeman, Essay, "The Macedonian Period" (3).

Tarbell, Ch. 10, "Hellenistic Period of Greek Sculpture" (12).

Butcher, pp. 1-40, "What We Owe to the Greeks" (10).

${ }^{1}$ The figure in parenthesis refers to the number of the topic in the Appendix, where a fuller title of the book will be found. 


\section{THE ROMAN WORLD}

\section{PERIOD I. BEGINNINGS OF THE ROMAN STATE (753-343 B. C.)}

\section{CHAP'TER XVII}

ITALY AND THE TRADITIONAL ORIGIN OF ROME

\section{The Geography of Italy}

Transition to Roman History.-In our study of the history of the ancient world we have considered the early stages of civilization among the peoples of the Orient, and also the great advancement made by the Greeks in the way of intellectual and æsthetic culture. We are now to consider the work performed by another people in promoting the progress of mankind. This people was the Romans. It was the Romans who supplied what was lacking in all the other great nations of antiquity-the genius for political organization. It is true that we have seen great empires established in the East; but these empires were founded only upon conquest, and did not incorporate their subjects as a part of the state. It is also true that the Greeks developed a great love of liberty; but their love of liberty was so great as to prevent them from forming a political union with a common national authority. The Romans, on the other hand, not only conquered the most important countries of the old world; they also made of these 
different countries one united people organized under a common government and a common system of law.

In our study of the history of Rome there are three things which we should constantly keep in mind. In the first place, we should notice the successive steps by which the Roman territory was enlarged-expanding from a small spot on the

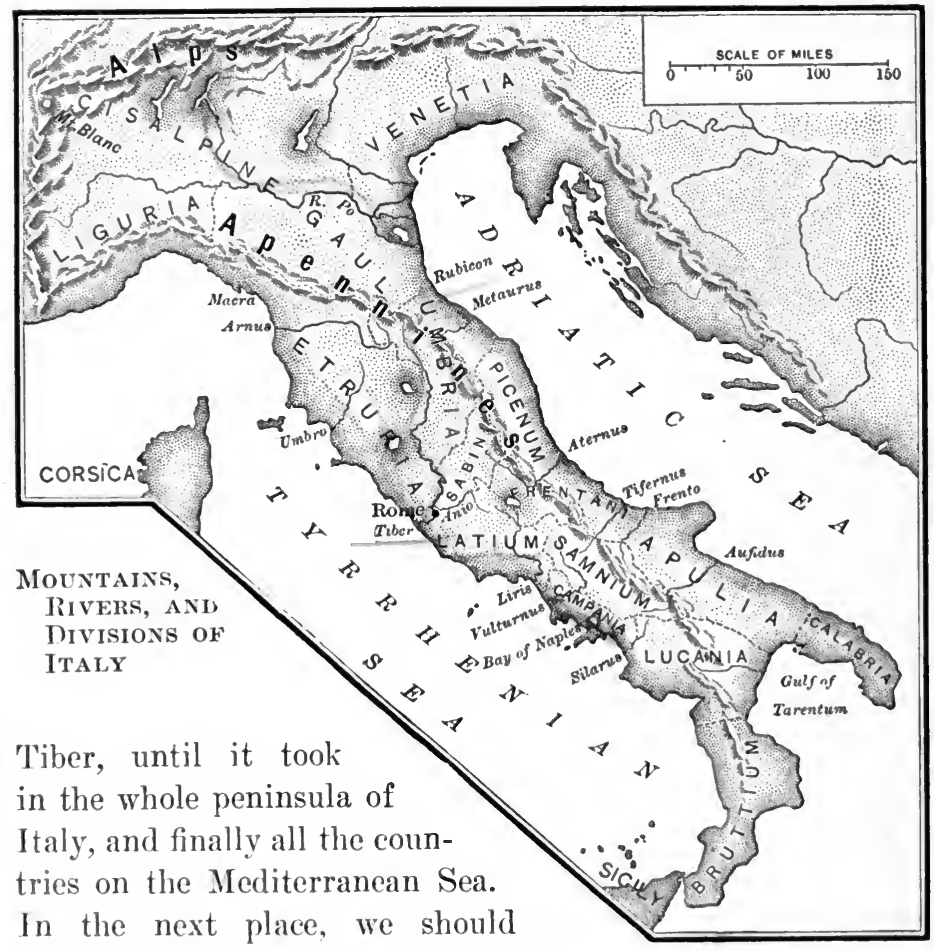
notice the methods by which the

various conquered peoples were gradually ineorporated into the state, and the way in which the government was modified and strengthened to meet the wants of the growing nation. Finally, we should notice how the ideas and customs of the 
conquered countries were taken up and welded together into a new and wider civilization.

The Italian Peninsula.-The study of Roman history properly begins with the geography of Italy ; because it was in I taly that the Roman people had their origin, and it was here that they began their great career. It was only when the Romans had conquered and organized Italy that they were able to conquer and govern the world. The position of the Italian peninsula was favorable to the growth of the Roman power. It was situated almost in the center of the Mediterranean Sea, on the shores of which had flourished the great nations of antiquityEgypt, Phœnicia, Carthage, Greece, and Macedonia. By conquering Italy, Rome thus obtained a commanding position among the nations of the ancient world. As the peninsula projects southward into the Mediterranean it bends toward the east, so that its southern coasts afforded an easy access to the civilized peoples of Greece. The eastern shores of the peninsula, washed by the Adriatic Sea, with few bays and harbors, were not favorable to the early progress of the people; while the western coasts, bordering upon the Tyrrhenian Sea, with their numerous indentations furnished greater opportunities for commerce and a civilized life.

The Mountains and Rivers of Italy.-There are two important mountain chains which belong to Italy, the Alps and the Ap'ennines. (1) The Alps form a semicircular boundary on the north and afford a formidable barrier against the neighboring countries of Europe. Starting from the sea at its western extremity, this chain stretches toward the north for about 150 miles, when it rises in the lofty peak of Mt. Blanc, 15,000 feet in height; and then continues its course in an easterly direction for about 330 miles, approaching the head of the Adriatic Sea, and disappearing along its coast. It is crossed by several passes, through which foreign peoples have sometimes found their way into the peninsula. (2) The Apennines, beginning at the western extremity of the Alps, 
extend through the whole length of the peninsula, forming the backbone of Italy. From this main line are thrown off numerous spurs and scattered peaks. Sometimes the Apennines have furnished to Rome a kind of barrier against invaders from the north.

The most important river of Italy is the Po, which, with its hundred tributaries, drains the fertile valley in the north, lying between the Alps and the Apennines. In the peninsula proper the eastern and western slopes are drained by many streams, the largest and most noted of which is the Tiber, flowing into the Tyrrhenian Sea.

Climate and Products.-The climate of Italy varies greatly, as we pass from the north to the south. In the valley of the Po the winters are often severe, and the air is chilled by the neighboring snows of the Alps. In central Italy the elimate is mild and agreeable, snow being rarely seen south of the Tiber, except on the ranges of the Apennines; while in southern Italy we approach a climate almost tropical, the land being often swept by the hot south wind, the sirocco, from the plains of Africa.

The soil of Italy is generally fertile, especially in the plains of the Po and the fields of Campania. The staple products in ancient times were wheat, the olive, and the vine. For a long time Italy took the lead of the world in the production of olive oil and wine. The production of wheat declined when Rome, by her conquests, came into commercial relation with more fertile countries, such as Egypt.

The Divisions of Italy.-For the purpose of convenience and to aid us in our future study, we may divide ancient Italy into three divisions: northern, central, and southern.

(1) Northern Italy comprised the whole continental portion from the Alps to a line drawn along the Apeninnes from the river Macra on the west to the Ru'bicon on the east. It contained three distinct countries: Liguria toward the west, Cisalpine Gaul in the center, and Venetia toward the east. 
(2) Central Italy comprised the northern part of the peninsula proper, that is, the territory between the line just drawn from the Macra to the Rubicon, and another line drawn from the Sil'arus on the west to the Frento on the east. 'This territory contained six countries, namely, three on the western coast,-Etruria, Latium (la'shi-um), and Campania; and three on the eastern coast and along the Apennines,-Umbria, Pice'num, and what we call the Sabellian country, which included many mountain tribes, chief among which were the Sa'bines and the Sam'nites.

(3) Southern Italy comprised the rest of the peninsula and contained four countries, namely, two on the western coast, Lucania and Bruttium, extending into the toe of Italy; and two on the eastern coast, Apulia and Calabria (or Iapygia), extending into the heel of Italy.

\section{The Peoples of Italy}

The Settlement of Italy.-Long before Rome was founded, every part of Italy was already peopled. Many of the peoples living there came from the north, around the head of the Adriatic, pushing their way toward the south into different parts of the peninsula. Others came from Greece by way of the sea, settling upon the southern coast. It is of course impossible for us to say precisely how Italy was settled. It is enough for us at present to know that most of the earlier settlers spoke an Indo-European, or Aryan, language, and that when they first appeared in Italy they were scarcely civilized, living upon their flocks and herds and just beginning to cultivate the soil.

The Italic Tribes.-The largest part of the peninsula was occupied by a number of tribes which made up the so-called Italic race. We may for convenience group these tribes into four divisions, the Latins, the Oscans, the Sabellians, and the Umbrians. 
(1) The Latins dwelt in central Italy, just south of the Tiber. They lived in villages seattered about Latium, tilling their fields and tending their Hocks. The village was a collection of straw-thatched huts; it generally grew up about a hill, which was fortified, and to which the villagers could retreat in times of danger. Many of these Latin villages or hill-towns grew into eities, which were united into a

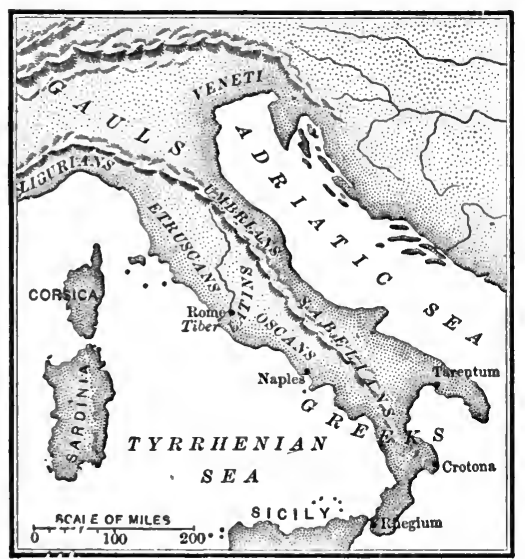

The Peoples of Italy league for mutual protection, and bound together by a common worship (of Jupiter Latiaris), and by an annual festival which they celebrated on the Alban Mount, near which was situated Alba Longa, their chief eity (see map, p. 284).

(2) The Oscans were the remnants of an early Italic people which inhabited the country stretching southward from Latium, along the western coast. In their customs they were like the Latins, although perhaps not so far adranced. Some authors include in this branch the Equians, the Her'nicans, and the Volscians, who carried on many wars with Rome in early times.

(3) The Sabellians embraced the most numerous and warlike peoples of the Italic stock. They lived to the east and south of the Latins and Oscans, extending along the ridges and slopes of the Apennines. They were devoted not so much to farming as to the tending of flocks and herds. They lived also by plundering their neighbors' harvests and carrying off their neighbors' cattle. They were broken up into a great number of tribes, the most noted of which were the Samnites, a hardy 
race which became the great rival of the Roman people for the possession of central Italy. Another Sabellian people were the Sabines, who were early united to Rome.

(4) The Umbriens lived to the north of the Sabellians. They are said to have been the oldest people of Italy. But when the Romans came into contact with them, they had become crowded into a comparatively small territory, and were not very important. They were broken up into small

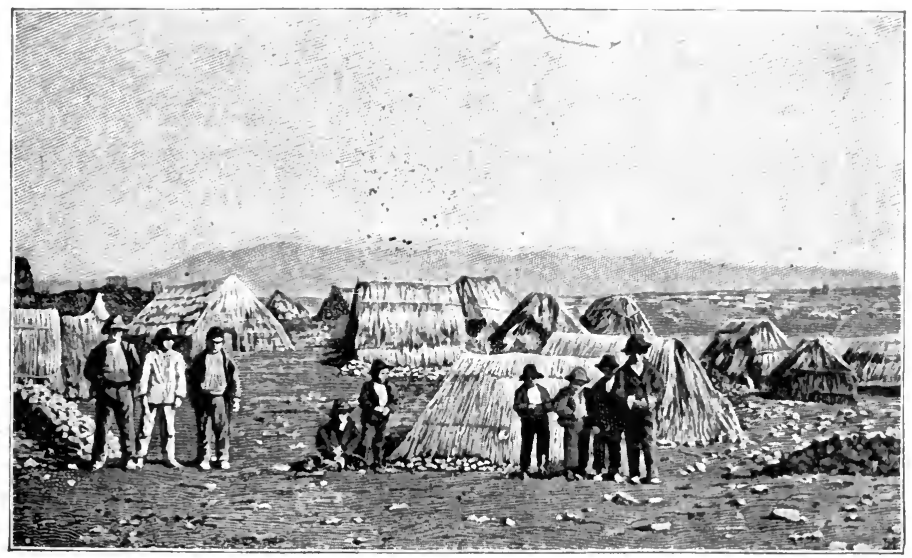

a Temporary Village of Straw Huts in Monern Italysupposed to be like an Axcient Latin Village

tribes, living in hill-towns and villages, and these were often united into loose confederacies.

The Etruscans.-Northwest of Latium dwelt the Etruseans, in some respects the most remarkable people of early Italy. Their origin is shrouded in mystery. In early times they were a powerful nation, stretching from the Po to the Tiber, and having possessions even in the plains of Campania. Their cities were fortified, often in the strongest manner, and also linked together in confederations. Their prosperity was founded not only upon agriculture, but also upon commerce. Their religion was a gloomy and weird superstition, in 
which they thought that they could discover the will of the gods by means of augury, that is, by watching the flight of birds and by examining the entrails of animals. The Etruscans were great builders; and their massive walls, durable roads, well-constructed sewers, and imposing sepulchers show the greatness of their civilization.

The Greeks in Italy.-But the most civilized and cultivated people in Italy were the Greeks, who had planted their colonies at Taren'tum, and on the western coast as far as Naples (Neapolis) in Campania. So completely did these coasts become dotted with Greek cities, enlivened with Greek commerce, and influenced by Greek culture, that this part of the peninsula received the name of Magna Græcia. The Greeks also, as we have already seen (p. 157), held the eastern and southern coasts of Sicily, while the Carthaginians were encroaching upon the western coast of the island.

The Gauls.-If the Greeks in the extreme south were the most civilized people of Italy, the Gauls or Celts, in the extreme north, were the most barbarous. Crossing the Alps from western Europe, they had pushed back the Etruscans and occupied the plains of the Po; hence this region received the name which it long held, Cisalpine Gaul. From this land the Gauls made frequent incursions toward the south, and were for a long time a terror to the other peoples of Italy.

\section{The Early Legends of Rome}

Legends regarding the Founding of the City.-The ancient Romans knew as little as we do regarding the way in which Italy was first peopled. But they fancied that they had in their legends the true story of the settlement of Latium and the founding of their own eity. These legendsas told by the historian Livy and sung by the poet Vergilrecount the wanderings of Ene'as with his heroic band of Trojan warriors after the fall of Troy; their landing upon 
the shores of Latium; their founding of the city of Lavinium and later of Alba Longa. These legends also tell of the miraculous birth of the twin children Rom'ulus and Remus, whose reputed father was Mars, the god of war; of their being thrown into the Tiber and of their being rescued by a wolf, near the foot of the Pal'atine hill (map, p. 272); of their desire afterward to found a new city on the spot of

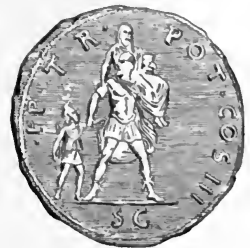

Aneas (Coin)

their deliverance; of their quarrel, which resulted in the death of Remus, leaving Romulus as the surviving founder of the city. The date of the founding of the city, according to Roman reckoning, was 753 в. C.

\section{Legends of the Early Kings.-According} to the old legends Rome was at first a kingdom, and the first king was Romulus. To people his new city he opened an asylum for refugees, and he captured wives from the neighboring Sabines. He divided the people into tribes, curies, and clans. He formed an alliance between the Romans and the Sabines, who agreed to live peacefully together as citizens of one town. After a reign of thirty-seven years he was translated to heaven and worshiped under the name of Quiri'nus.

The second king was Numa Pompil'ius, a Sabine, who was elected by the people, after an interregnum of a year. He was a peaceful ruler;

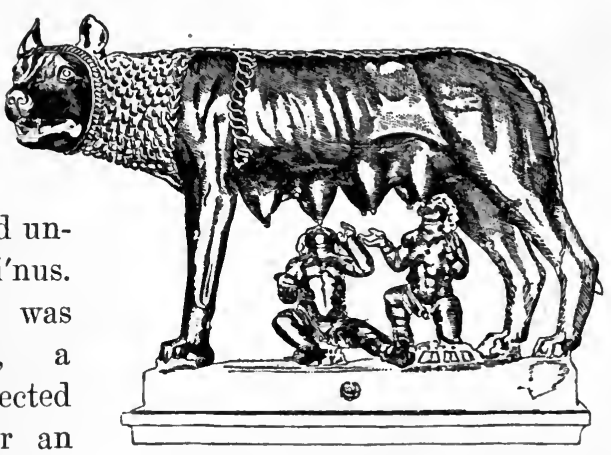

Romulus and Remus and THE WOLF.

was said to hold communication with the gods; and was regarded as the founder of the religions institutions of Rome, 
as Romulus was regarded as the founder of the political institutions.

During the reign of the third king, 'Tullus Hostil'ius, a war was carried on with Alba Longa. The issue of this war was decided, so the story goes, by a combat between the three Hora'tii, champions of the Romans, and the three Curia'tii, champions of Alba-resulting in the triumph of the Romans and the submission of Alba to the Roman power.

The fourth king, Ancus Marcius, was a Sabine, the grandson of Numa. He too was a man of peace, but was drawn into a war with several of the Latin cities. Having subdued them, he transferred their inhabitants to the Av'entine hill (map, p. 2\%2).

Legends of the Later Kings. - The three later kings of Rome are represented as having been Etruscans. 'The first of these was 'Tarquin'ius Priscus, who migrated to Rome from

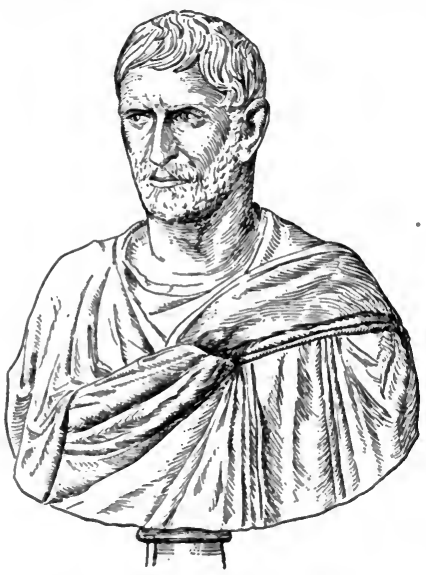

The hIDER Brutus the Etruscan city of Tarquinii. He strengthened his position as king by adopting the royal insignia of the Etruscans-a erown of gold, a scepter, an ivory chair, a purple toga, etc. He carried on war with the Latins and Sabines, drained the city, laid out the forum, and dedicated a temple to Jupiter on the Cap'itoline hill.

'The next of the later kings was Servius 'Tullius, the son of a slave woman of the king's household. He united Rome and the Latin cities in a league; reorganized the government, and erected a new wall inclosing the seven hills.

'The last king was 'Tarquinius Superbus, who ruled as a 
despot, and was at last driven from the throne by the elder Brutus and his friend Collati'nus (510 B. c.)

Legends of the Early Republic.-'The legends contain many stories relating not only to the overthrow of the kingdom but to the early years of the republic. It is said that after the last Tarquin was expelled, the people elected in his stead Brutus and Collatinus to rule them for a year; that Brutus condemned his own sons to death for conspiring to restore the Tarquins; that the Etruscans under a prince called Lars Porsen'na (or Por'sena) lent their aid to the Tarquins, and that their armies were prevented from entering Rome by the heroic defense of the wooden bridge by Horatius Cocles. It is related that the cause of the banished king was then espoused by the Latins and that their armies were defeated at

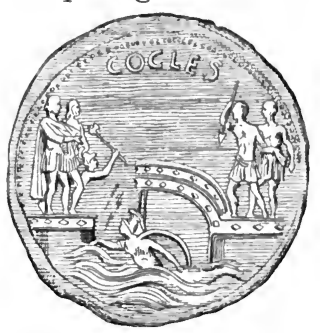

Horatius Cocles

(Medallion) the battle of Lake Regil'lus (near 'Tusculum) by the aid of the twin gods Castor and Pollux.

Significance of the Roman Legends.- Such were some of the stories which, embellished with many miraculous incidents, the Romans were proud to relate, as explaining the origin of their city and the beginning of their institutions. Like all other legends these stories have little value as evidence of what actually took place. 'They contain many improbable details, which were evidently based not upon fact, but upon fancy. They refer to particular persons as the creators of their institutions, although these must have been the result of a slow process of growth. Some of the stories were borrowed from the Greeks, and used by the Romans for their own purpose. So incredible are some of these legends that the whole body of this traditional history is sometimes set aside as unworthy of belief or even of serious consideration.

But while their credibility may be questioned, the signifiMOREY'S ANCIENT HIST.- 16 
cance of these traditions should not be overlooked. While they may not indicate what actually occurred, they show what the people really believed. 'They show that the Romans took pride in their political institutions, that they honored the virtues of courage and patriotism, and that they believed their destiny was in the hands of the gods. They continued to be an inspiration to the Roman people-in their wars, in their political life, in their literature and art. While we may not regard these legends as history, it is yet true that, without a knowledge of them, there is much in Roman history that we could not understand.

\section{SYNOPSIS FOR REVIEW}

I. The Geography of Italy.-Transition to Roman History.The Italian Peninsula.-The Mountains and Rivers of Italy.Climate and Products.-The Divisions of Italy.

II. The Peoples of Italy.-The Settlement of Italy.-The Italic Tribes.-The Etruscans.-The Greeks in Italy.-The Gauls.

III. The EARLY Legends of Rome.-Legends regarding the Founding of the City.-Legends of the Early Kings.-Legends of the Later Kings.-Legends of the Early Republic.-Significance of the Roman Legends.

\section{REFERENCES FOR READING}

Liddell, Bk. I., "Rome under the Kings" (18)."

Merivale, General History, Ch. 3, "The Earliest Legends" (18).

Pelham, Bk. I., Ch. 1, "The Traditions" (18).

How and Leigh, Ch. 2, "The Peoples of Italy"; Ch. 3 (legends of the kings) (18).

Thne, Early Rome, Ch. 5 (18).

Mommsen, Vol. I., Bk. I., Ch. 9, "The Etruscans"; Ch. 10, "The Hellenes in Italy" (18).

Livy, Bk. I. (legends of the kings) (25).

Vergil, Bk. I. (wanderings of Aneas) (25).

Munro, Source Book. Part I., "Italy-Rome" (25).

${ }^{1}$ The figure in parenthesis refers to the number of the topic in the Appendix, where a fuller title of the book will be found. 


\section{CHAPTER XVIII}

\section{THE EARLY CITY STATE-REGAL ROME}

\section{Origin of the Roman City}

The Site of Rome.-By studying the situation of Rome itself we may perhaps get a clearer idea of the probable origin of the city than we can obtain from the traditional stories. The city was located on the southeast bank of the river Tiber, about eighteen miles from the sea. To the south of this locality was Latium, or the country of the Latins; to the northeast was the country of the Sabines; and to the northwest, across the Tiber, was the land of the Etruscans. .The city thus grew up at the point of contact between three

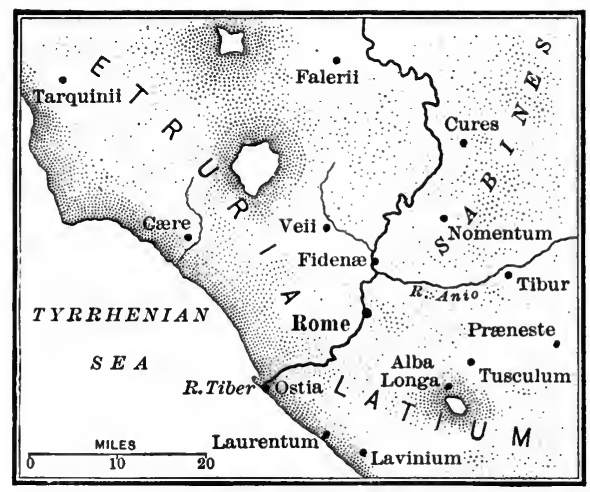

LANDS ABOUT THE TIBER different peoples, who exercised a great influence upon the carly development of the state.

If we look more closely at this locality, we shall see that it contained a group of seven hills which could be occupied and defended against the attack of enemies. Of these hills three lay to the northeast-the Quir'inal, the Vim'inal, and the Es'quiline; three lay to the south-the Palatine, the Cælian, and 
the Aventine; while between these two minor groups rose the small and rugged elevation of the Capitoline. The most important of these hills were the Quirinal in the first group,

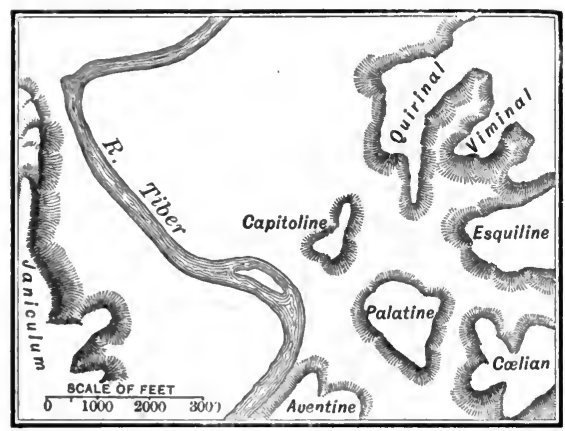

The Hills of Rome and the Palatine in the second. These hills were the best fitted for defense, and hence for occupation by settlers. If we compare these two hills, it is evident that the Palatine occupies the most central and com manding position, and its settlers, as we shall see, became the controlling people of the seven-hilled city.

The Latin Settlement on the Palatine.-So far as we know, the first people to get a foothold upon the site of Rome were the Latins, who formed a settlement upon and about the Palatine hill. This Latin settlement was at first a small village. It consisted of a few farmers and shepherds who were sent out from Latium (perhaps from Alba Longa) as a sort of outpost, both to protect the Latin frontier and to trade with the neighboring tribes. The people who formed this settlement were called Ramnes. They dwelt in their rude straw huts on the slopes of the Palatine, and on the lower lands in the direction of the Aventine and the Cxlian. The outlying lands furnished the fields which

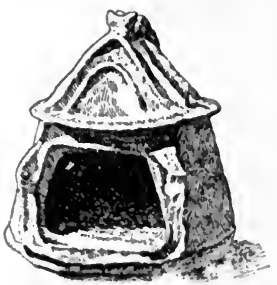

HuT-SHAPED URN they tilled and used for pasturage. For protection against attacks, the sides of the Palatine hill were strengthened by a wall built of rude but solid masonry. 'This fortified place was 
called Roma Quadra'ta, or "Square Rome." It formed the citadel of the colony, into which the settlers could drive their cattle and conduct their families when attacked by hostile neighbors. It is interesting to know that the primitive wall of the Palatine

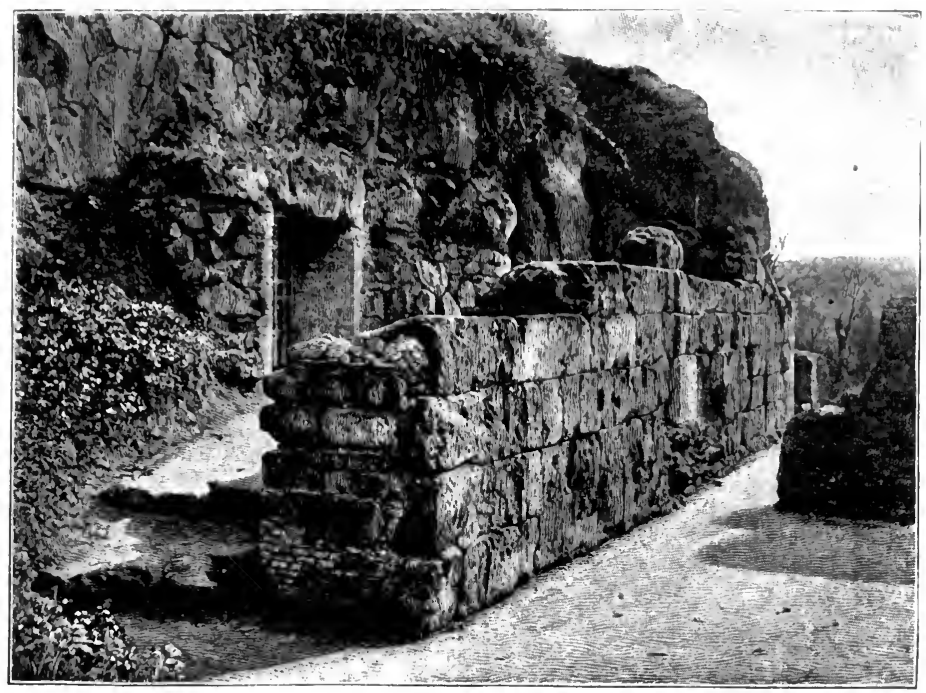

"Wall of Romulus"

city, known as the "Wall of Romulus," has in recent years been uncovered, so that we can see its general character.

The Sabine Settlement on the Quirinal.-Opposite the Palatine settlement there grew up a settlement on the Quirinal hill. This Quirinal settlement seems to have been an outpost or colony of the Sabine people, just as the Palatine settlement was a Iatin colony. The Sabines were pushing southward from beyond the A'nio. The settlers on the Quirinal were called Tit'i-es; their colony formed a second hill-town, similar in character and nearly equal in extent to the Palatine town.

Union of the Romans and the Sabines.-The two hill-towns which thus faced each other naturally became rivals for the 
possession of the lands near the Tiber; but being so nearly of equal strength, neither could conquer the other. They therefore formed an alliance, were united by a permanent league, and really became a single city —or perhaps we might better call it a double city. To celebrate this union, the intervening space was dedicated to the two-faced god, Janus, who watched the approaches of both towns, and whose temple was said to have been built by Numa. The Capitoline hill was chosen

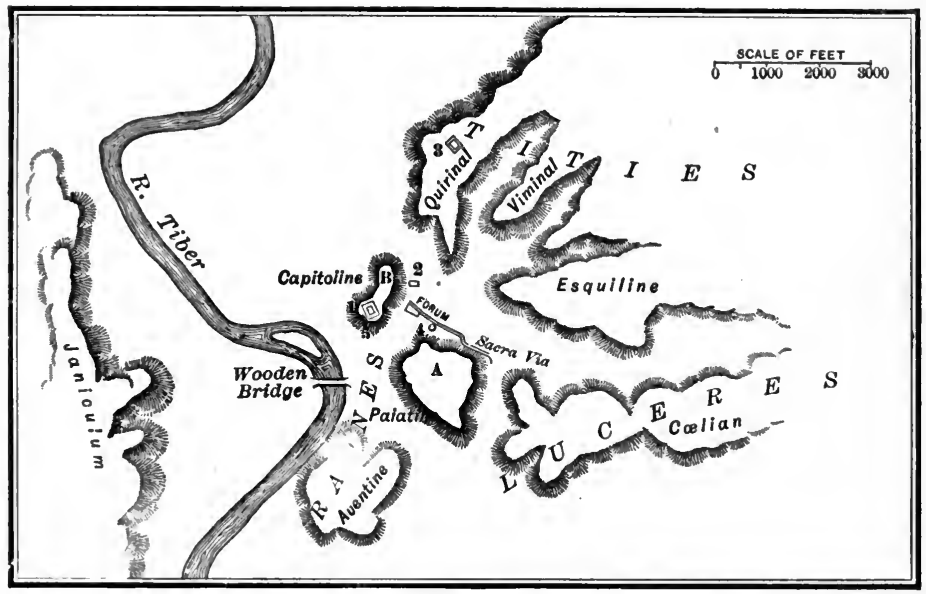

The City of the Early Kings-The Tirne .Tribes

A, Roma Quadrata. B, Arx, or Citadel

Temples, Altars, etc.: 1, Jupiter Capitolinus ; 2, Janus; 3, Quirinus; 4, Vesta; 5, Tarpeian Rock

as the common citadel. The space between the two towns was used as a common market place (forum), and also as a place for the common meeting of the people (comitium). This union of the Palatine and Quirinal towns into one community, with a common religion and government, was an event of great importance. It was, in fact, the first step in the process of "incorporation" which afterward made Rome the most powerful eity of Latium, of Italy, and finally of the world: 
The Third Settlement, on the Cælian.-The union of the. Romans (Ramnes) and the Sabines (Tities) was followed by the introduction of a third people, called the Lu'ceres. This people was probably a body of Latins who had been conquered and settled upon the Crelian hill, although they are sometimes regarded as having been Etruscans. Whatever may have been their origin, it is quite certain that they soon came to be incorporated as a part of the whole city community. The city of the early Roman kings thus came to be made up of three divisions, or "tribes" (tribus, a third part, from tres, three). The evidence of this threefold origin was preserved in many institutions of later times. The three settlements were gradually united into a single city state with common social, political, and religious institutions. By this union the new city became strong and able to compete successfully with its neighbors.

\section{The City State of tile Early Kings}

The Early Roman Society.-To understand more fully the beginnings of the Roman state, we must look at the way in which the people were organized, that is, how they were arranged in social groups. Each tribe was made up of a number of smaller groups, called curies (curio) ; and these in turn were composed of different clans (or gentes), which themselves consisted of several families. The early Roman society was therefore formed by the union of families, gentes, curiæ, and tribes.

(1) The family was the smallest unit of Roman society. At its head was the household father (pater familias). His power extended to "life and death" - which is simply another way of saying that his authority was supreme within the household. He performed the family worship about the domestic altar, upon which the sacred fire was kept burning. The family consisted of the mother, the sons and grandsons, the 
unmarried daughters and granddaughters, as well as the adopted children-all of whom remained under the father's power as long as he lived.

(2) The gens was a group of families which were related to one another, having the same name and supposed to be descended from a common ancestor. It was presided over. by a common chief, who performed the religious rites of the gens, and led the people in time of war.

(3) The curia was a collection of gentes which had united at first for their common defense, but had come to form an organized community, with a common chief, a council of elders, and an assembly composed of all men capable of bearing arms.

(4) The tribe was composed of a number of curiæ which had formed an alliance for their common protection. The tribe had come to have a political organization-a chief, who was priest, commander in war, and judge; a council of elders; and a general assembly. The communities on the Palatine and Quirinal hills were each such a tribe, before they united to form a common state.

The Early Roman Government.-With the union of the first two tribes, their governments were also united so as to form a single government. For example, their two kings were replaced by one king chosen alternately from each tribe. Their councils and assemblies were also united so as to form single bodies. And when the third tribe is added, we have a single king, a single couneil of three hundred members, and a single assembly of thirty curiæ (comi'tia curia'ta).

(1) The Roman king (rex) was the chief of the whole people. He was elected, or at least approved, by the people, and inaugurated under the sanction of the gods. He was in a sense the father of the whole nation-their chief priest, their commander in war, and their supreme judge. Like the father in the household, he had the power of life and death over all his subjects. 
(2) The Roman senate, or council of elder's, was composed of the chief men of the gentes, who were chosen by the king to assist him with their advice. Upon the death of the king they might choose a temporary king (interrex) to act as ruler until the regular successor was elected.

(3) 'The comitia curiata was the assembly of all the people capable of bearing arms, arranged by curiæ. Each euria hat a single vote, and the will of the assembly was determined by a majority of such votes. In a certain sense the assembly was the highest authority in the state. It elected the king and passed a law (lex curiata de imperio) conferring upon him his power. To it the king submitted important questions, like those regarding peace or war. The early city state may therefore be described as a democratic monarchy, in which the king derived his power from the people.

The Early Roman Religion.-The Roman people were strongly influenced by religious ideas. All power, from that of the household father to that of the king, was believed to be sanctioned by the gods. The general character of the early Roman religion may be seen in the nature of their deities, their religious officers, and the religious observances.

(1) To the ancestral gods, which were worshiped in the family and gens, were added the gods of nature, which the Romans saw everywhere. These early deities were those which naturally sprang from the imagination of a pastoral and agricultural people,-Tellus, the goddess of the earth; Saturn, the god of sowing; Ceres, the goddess of the harvest; Minerva, of olives; Flora, of flowers; Liber, the god of wine. When the people were united into one state, they chose as their national gods, Jupiter, the god of the sky; Mars, the god of war; and Quirinus, or the deified Romulus.

(2) The religious officers were appointed by the king to maintain the national worship. 'T'o each of the three national gods was assigned a special priest, called a flamen. The Satii watched over the shield of Mars, which was supposed 


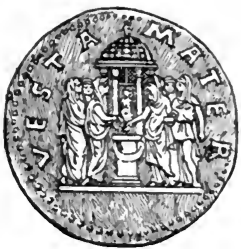

to have fallen from heaven. Six vestal virgins kept always burning the fires of Vesta, the goddess of the hearth and of domestic happiness. The fetia'les presided over the formalities of declaring war. Special pontiffs, under a pontifex maximus, The Six Vestals had charge of the religious festivals and (Medallion) ceremonies.

(3) The religious observances of the Romans consisted chiefly of prayers, offerings, and festivals. Their prayers were addressed to the gods to obtain divine favors, and were often accompanied by vows. Their offerings consisted either of the fruits of the earth, as flowers, wine, milk, and honey; or the sacrifice of animals, such as oxen, sheep, and swine. Their festivals, which were celebrated in honor of the gods, were very numerous

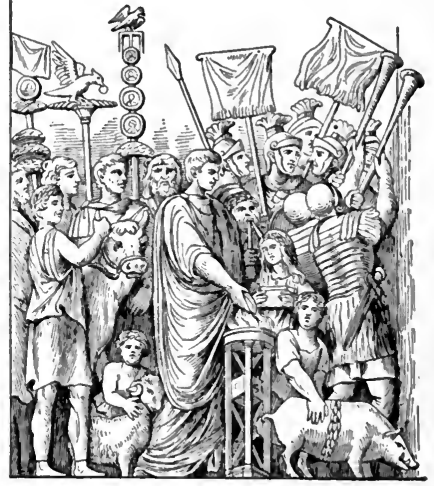

A Roman SACRIFICE and were scattered through the different months of the year.

\section{The City State of the Later Kings}

The Etruscan Influence.-The city state of the early kings was, as we have seen, extremely simple in its organizationwith its king. its senate, and its general assembly. This political organization was somewhat changed by the later kings, who are supposed to have come from Etruria. The kings of Etruria were powerful rulers, and for a time threatened to become the sovereigns of central Italy. It seems quite eertain that Rome, during the later period of the kingdom, 
came under their control. 'These kings brought with them their own insignia of royal power-the golden crown, the ivory scepter, the ivory throne or "curule chair," the twelve lictors, each carrying a bundle of rods (fasces) containing an ax, the symbol of absolute power. The Etruscans also brought with them the art of the harus'pices, or soothsayers, by which the will of the gods was supposed to be discerned in the heavens, as well as in the entrails of the animals slain for the sacrifice. Moreover, the Etruscans were great builders; they introduced the arch, which they used in sewers, and which the Romans afterward used in other public works.

The Clients and Plebeians.-To understand the political changes made by the Etruscan kings, we must consider the new population which was growing up at Rome. The early Roman society, we remember, consisted of the old families and gentes which had united to form the original state. But there grew up in time a new body of persons, made up of refugees and other immigrants, and perhaps of captives taken in war. As these persons had at first no rights in the state, they attached themselves to the old Roman families, and were called "clients." The rights of such persons could be protected by the Roman citizen whom they might choose as their "patron." The persons who did not thus attach themselves to a Roman citizen were in a certain sense the clients of the state, and were protected in their rights of person and property by the laws of the state. They had, however, no right to intermarry with Roman citizens, and no right to a share in the government." This new population came to be known as "plebe'ians," as opposed to the old body of Roman citizens, who were known as "patricians."

The view here given is questioned by some writers, who hold that the plebeians, including the clients, were citizens, having the right to vote in the assembly. Such an opinion, however, seems inconsistent with the later historical struggles between the patricians and the plebeians, unless the plebeians were disfranchised after the time of the kingdom-and there is no evidence of such disfranchisement. 
The New Local Tribes.-The Etruscan kings were less desirous to preserve the old distinctions than to make the state strong and able to defend itself from its enemies. They found that the old army-as well as the old tax-levy-was drawn from the three patrician tribes, each tribe furnishing 1000 foot soldiers and 100 horsemen. It was evident that the state would be strengthened if the plebeians, as well as the patricians, were called upon to serve in the army and to pay taxes. An entirely new division of the people was therefore made, based not upon their birth and descent, like the old patrician tribes, but upon their domicile, that is, the place where they lived. This change is ascribed to Servius Tullius. $\mathrm{He}$ is said to have divided the whole Roman territory, city and country, into local districts, like wards and townships. There were four of these in the city, and sixteen in the country, the former being called "city tribes" (tribus urbance),

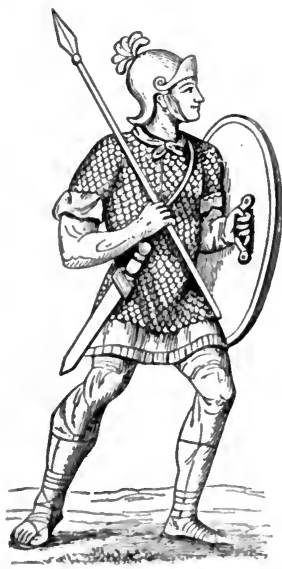

SOLDIFR witII FULL, ARMOR and the latter "rural tribes" (tribus rustic(e). All persons, whether patricians or plebeians, who had settled homes (assidui), were enrolled in these new "local tribes," and were made subject to military service and the tribal tax (tributum).

The New Military Organization.-The next step ascribed to Servius was the reorganization of the Roman army, so that it should include all persons who resided in the Roman territory and were enrolled in the new local tribes. First came the cavalry (eq'uites), made up of young wealthy citizens. and arranged in eighteen centuries, or companies of 100 men each. Next came the infantry (ped'ites), which comprised all the rest of the men capable of bearing arms. In ancient times every man was obliged to furnish his own 
weapons. Now as all the people could not afford to obtain the heavier armor, they were subdivided into "classes" according to their wealth, and according to the armor it was supposed they could afford to furnish. 'There were five of these classes, each containing a certain number of centuries-one half of which were made up of the younger men (iuniores) and held for active service, and the other half made up of the older men (seniores) and held as reserves. By this arrangement, in place of the old army of 3300 men, provision was now made for an army of nearly 20,000 men, which probably comprised the whole population of Rome capable of bearing arms. ${ }^{1}$

The New Assembly, Comitia Centuriata.-This arrangement of the people was first intended for a purely military purpose; but it soon came to have a political character also. There was every reason why the important questions relating to war, which had heretofore been left to the old body of armed citizens, should now be left to the new body of armed citizens. As a matter of fact, in the course of time the new fighting body hecame a new voting body; and there thus arose a new assembly called the assembly of the centuries (comitia centuria'ta). But this new assembly did not lose its original military character. For example, it was called together, not by the voice of the lictors, like the old assembly, but by the sound of the trumpet. Again, it did not meet in the Forum, where the old assembly met, but in the Field of Mars (Campus Martius), outside of the city. It also voted by centuries, that is, by military companies. After a time the comitia centuriata acquired

${ }^{1}$ We may perhaps get a clearer idea of this new military arrangement by the following table:

I. Cavalry (Equites)

II. Infantry (Pedites)

1st class (40 iuniores, 40 seniores) . . . . 80 centuries.

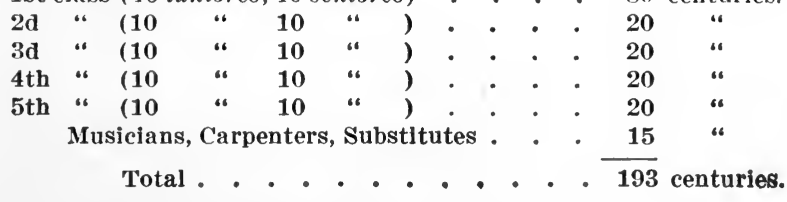


the character of a real political and legislative body, of greater importance than the old comitia curiata.

Growth of the City.-These changes in the state show the influence of the Etrusean kings, who evidently broke away

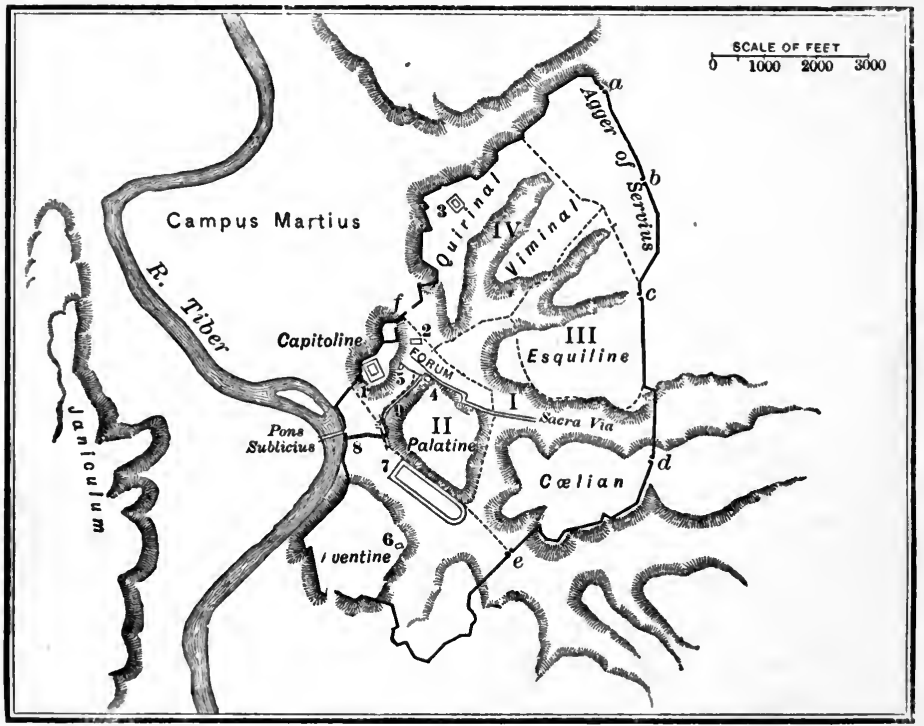

The City of the Later Kings-Walls of Servius

The four Scrvian regions: I., Suburana; II., Palatina; III., Esquilina; IV., Collina.

The chief gates of Rome: $a$, Colina; $b$, Viminalis; $c$, Esquilina; $d$, Querquetulana; $e$, Capena ; $f$, Ratumena.

The chief buildings. etc.: 1, Temple of Jupiter Capitolinus; 2, Janus : 3, Quirinus; 4, Vesta ; 5, Saturn ; 6, Diana ; 7, Circus Maximus ; 8, Cloaca Maxima ; 9, Vicus Tuscus.

from the narrow ideas of the old patrician aristocracy. 'Their influence is also seen in the more durable temples and other buildings which were constructed during the later kingdomthe temple to .Jupiter or the Capitoline hill, the one to Diana on the Aventine, and the one to Saturn at the foot of the Capitoline; the Circus Maximus laid out between the Pala- 
tine and the Aventine for the amusement of the people; the Cloa'ca Maxima, or the great drain which ran under the Forum and emptied into the 'Tiber; and the new Servian wall by which the seven hills were encircled by a single fortification. The memory of this Etruscan influence was preserved in the name of the "Tuscan Street" (vicus Tuscus) which was laid out near the Forum.

Conquests in Latium.-While Rome was thus becoming strong, and her people were becoming more united and better organized, she was also gaining power over the neighboring lands. The people with whom she first came into contact were the Latins. A number of Latin towns were conquered or otherwise brought under her power, and some of the conquered territory was added to the Roman domain (ager Roma'nus). She also pushed her conquests across the Anio into the Sabine country, and across the Tiber into Etruria. So that before the fall of the kingdom, Rome had begun to be a conquering power.

Review of the Roman Kingdom.-By the end of the period of the later kings, Rome had come to be a strong city, and was growing into something like a new nation, with a kind of national policy. If we should sum up this policy in two words, these words would be expansion and incorporation. By "expansion" we mean the extension of Roman power over the neighboring territory, whether by conquest or by alliance. By "incorporation" we mean the taking of subject people into the political body. For example, Rome had first incorporated the Sabine settlement on the Quirinal ; then the Latin settlement on the Celian; and finally the plebeian class, which had grown up by the side of the patrician class. By pursuing this kind of policy, Rome had come to be, at the end of the kingdom, a compact and quite well-organized city state with a considerable territory of her own (ager Romanus) about the lower part of the river Tiber, and having a control over the cities of Latium. 
PROGRASSIVF MAP No. 12.

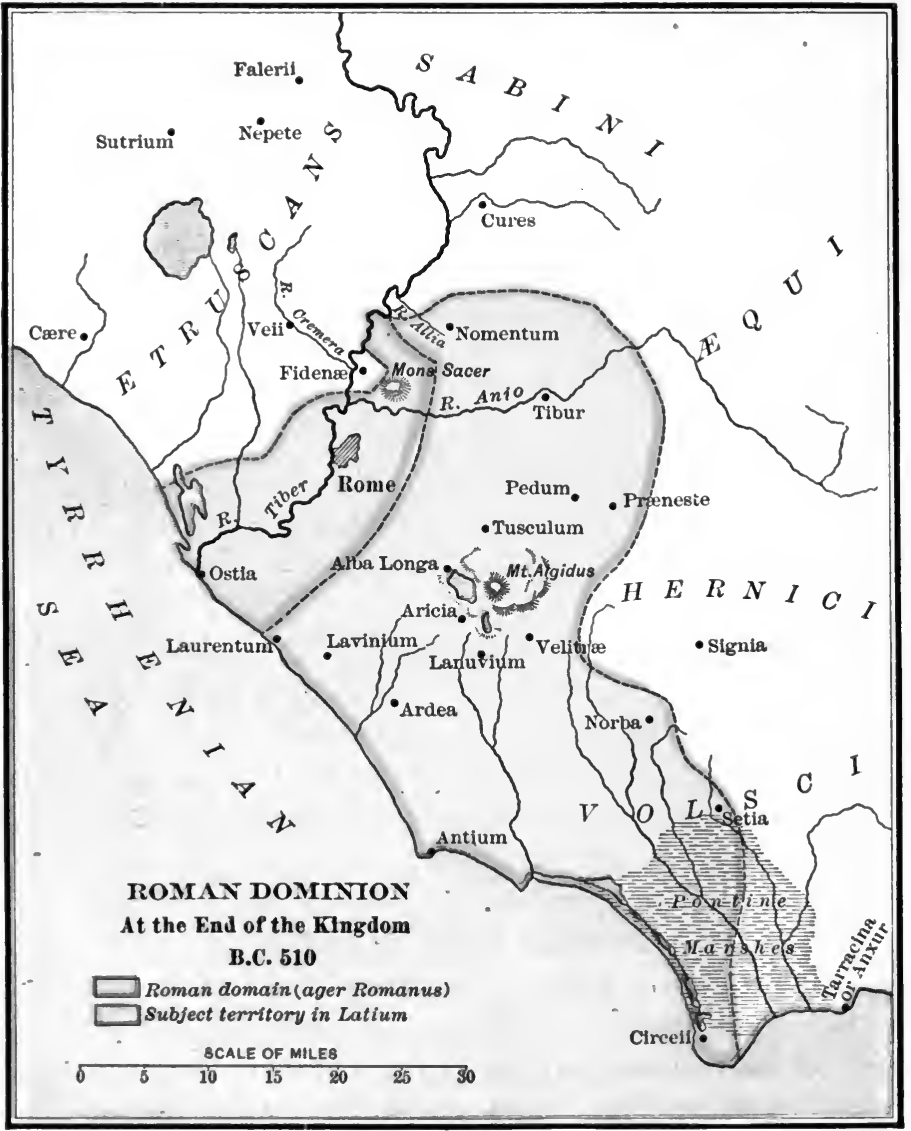




\section{SYNOPSIS FOR REVIEW}

I. Origin of the loman City.-The Site of Rome.-The Jatin Settlement of the Palatine.-The Sabine Settlement of the Quirinal.-Union of the Romans and the Sabines.-The Third Settlement, on the Calian.

II. 'The City State of the Early Kings.-The Early Roman Society.-The Early Roman Government.-The Early Roman Religion.

III. The City State of the Later Kings.-The Etruscan Influence.-The Clients and Plebeians.-The New Local Tribes.-The New Military Organization.-The New Assembly.-Growth of the City.-Conquests in Latium.-Review of the Roman Kingdom.

\section{REFERENCES FOR READING}

Schuckburgh, Ch. 5, "The Regal Period" (18). ${ }^{1}$

Pelham, Bk. I., Ch. 2, "Origin of the City and Commonwealth"; Ch. 3, "Rome under the Kings" (18).

How and Leigh, Ch. 4, "The Regal Period" (18).

Ihne, Early Rome, Ch. 9, "People of the Regal Period" (18).

Abbott, Ch. 1," "Rome under the Kings"; Ch. 2, "Monarchical Institutions" (22).

Granrud, First Period, Ch. 1, "Original Constitution of Rome"; Ch. 2, "Later Royal Constitution" (22).

Mommsen, Vol. 1., Bk. I., Ch. 4, "Beginnings of Rome"; Ch. 5, "Original Constitution of Rome"; Ch. 6, "The Non-Burgesses and the Reformed Constitution" (18).

Abridged, Ch. 3, "Rome's Original Constitution"; Ch. 4, "Reforms of Servius Tullius" (18).

Greenidge, Public Life, Ch. 1, "Earliest Constitution of Rome"; pp. 9-33 (the Roman family) (22).

Parker, Ch. 2, "Roma Quadrata"; Ch. 5, "The City of the Seven Hills" (20).

Munro, Source Book, Part II., "Religion" (25).

${ }^{1}$ The figure in parenthesis refers to the number of the topic in the Appendix, where a fuller title of the book will be found. 


\section{CHAPTER XIX}

THE DEVELOPMENT OF THE REPUBLICAN CONSTITUTION

\section{The Early Republican Government}

The Two Consuls.-When the kingdom came to an end, the power of the kings was put into the hands of two consuls (at first called pr(etors), elected by the people. The consular power, though derived from the old kingly power, was yet different from it in many respects. In the first place, the power of the king had been a lifelong power; but the power of the consuls was limited to one year. Again, the royal power had been held by one person; but the consular power was held by two persons, so that each was a restraint upon the other. Moreover, the power of the king had been absolute, that is, it had extended to life and death over all citizens at all times; the power of the consuls, on the other hand, was limited, since they could not exercise the power of life and death, except outside of the city and over the army in the field. The consuls retained the old insignia of the king; but when in the city, the ax was withdrawn from the fasces. In this way the chief authority which was placed in the hands of the consuls was shorn of its worst features. It must also be noted that the priestly power of the king was not given to the consuls, but to a special officer, called king of the sacrifices (rex sacrorum); and the management of the finances was put in charge of two quastors elected by the people.

The Dictatorship.-The Romans were wise enough to see that in times of great danger the power of the consuls might not be strong enough to protect the state. 'To meet such an emergency a dictator was appointed, who was a sort of tempo- 
rary king. He had entire control of the eity and the army. He was even given the power of life and death over eitizens; and his lictors (attendants) retained the ax in the fasces. But this extraordinary power could be held for only six months, after which time the dictator could be held responsible for his acts while in office. With the dictator there was generally appointed another officer, who was second in authority, called the master of horse; but over him, as over every one else, the dictator was supreme.

The New Senators.-When the consuls were elected, it is said that one of their first acts was to fill up the senate to the number of three hundred members. The last king had practically ruled without the senate, and he had

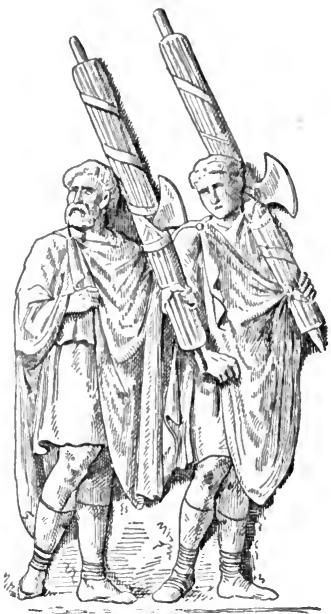

LICTORS no reason to fill the vacancies when they occurred. But the new consuls wished the help of the senate, and therefore desired to keep its numbers complete. The new senators who were enrolled were called conscripti; and the whole body of senators became known as patres conscripti.

The Popular Assemblies.-With the establishment of the republic, the two assemblies with which we are already acquainted, the comitia curiata and the comitia centuriata, both remained. But the former lost a great deal of its old power, which became transferred to the latter. The assembly of the centuries was thus the body in which the people generally expressed their will. Here they elected the officers, and passed the most important laws. It was this assembly which became the chief legislative body during the early republic.

The Laws of Valerius Poplicola.-It is said that after the death of Brutus, his colleague Valerius (who had succeeded 
Collatinus) did not call an assembly to elect another consul. This aroused the fear that Valerius wished to make himself king. But it was soon found that instead of aiming to be king, he was preparing a set of laws which would prevent any one from becoming king, and would also protect the people from the arbitrary power of their magistrates. One of these laws declared that any person who assumed the chief power without the people's consent should be condemned as a traitor. Another law granted to every citizen the right of an appeal to the people, in case he was condemned for a capital srime. These laws, known as the Valerian laws, may be called the "first charter of Roman liberty," because they protected the people from the exercise of arbitrary power. So highly honored was Valerius that he was surnamed Poplic'ola, or the People's Friend.

\section{The Struggle for Economic Rights}

Relation of the Patricians to the Plebeians.-The patricians and plebeians had united in their efforts to drive out the kings; but when the struggle against the kingship was ended, the chief fruits of the victory fell to the patricians. The plebeians could, it is true, still vote in the comitia centuriata; but they could not hold any of the new offices, nor could they sit in the senate. Rome became a republic, but it was an aristocratic, and not a democratic republic; that is, the chief power rested not in the whole people, but in a particular class. The plebeians might perhaps have submitted to the government of the patricians, if it had not been exercised in a selfish and oppressive manner. But the patrician rule proved to be as despotic as that of the kings; and a long and fierce struggrle ensued between the two orders.

Economic Distress of the Plebeians.-The sorest burden which now rested upon the plebeians was the harsh law of debt. Having lost their property by the misfortunes of war, 
they were obliged to borrow money of the rich patricians; and they were thus reduced to the condition of a debtor class. But a debtor in the early days of Rome was especially wretched. If he could not pay his debt, he was liable to be arrested. thrown into a dungeon, and made the slave of his creditor. His lot was chains, stripes, and slavery.

Another cause which kept the plebeians in a state of poverty was the unjust distribution of the public land (ager publicus) which had been acquired in war. This land properly belonged to all the people, and might have been used to relieve the distress of the poor. But the government was in the hands of the patricians, and they disposed of this land for their own benefit;

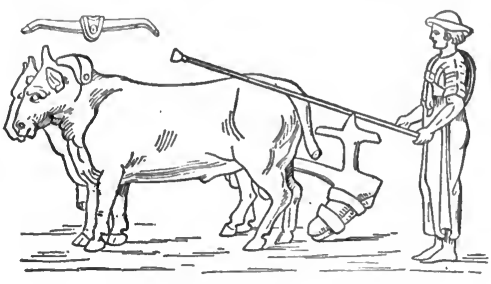

ROMAN FARMER they allowed it to be "occupied," at a nominal rent, by members of their own order. As long as the land remained public, it could not be sold by the occupants; but the longer the rich patricians retained the occupation of this land, the more they would look upon it as their own property, and ignore the fact that it belonged to the whole Roman people. Thus the common people were deprived of their just share of the land which they had helped to conquer.

First Secession of the Plebeians. - It was the hard law of debt which first drove the plebeians to revolt. As there was no legal way to redress their wrongs, they decided that they would no longer serve in the army, but leave the patricians to fight their own battles. They therefore deserted their general, marched in full array to a hill beyond the Anio, which they called the Sacred Mount (Mons Sacer), and proposed to form an independent city $(494$ B. c.). The patricians saw that the loss of the plebeian army would be the destruction of Rome. They were therefore compelled to agree that the debts 
of all insolvent persons should be canceled, and that those imprisoned on account of debt should be released.

The Tribunes of the People.-But the most important result of this first secession was the creation of a new office, that of tribune of the people. In order to protect the plebeians from any further oppressive acts on the part of the patrician magistrates, it was agreed to appoint two tribunes from among the plebeians themselves. These new officers were given the power to "veto" - that is, to forbid-the act of any magistrate which bore unjustly upon any citizen. In order that the tribunes might exercise their authority without hindrance, their persons were made "inviolable" - which means that they could not be arrested, and that any one who interfered with them in the exercise of their lawful duty could be put to death. There were also appointed two plebeian adiles, to take charge of the public buildings and to perform police duty.

The Plebeian Assembly; the Comitia Tributa.-The meetings which the plebeians had occasionally held before this time now assumed the character of a permanent assembly (concilium plebis). This assembly could be called together by the tribunes, and was permitted to elect its own officers, the tribunes and ædiles.

We find soon after this that the plebeian assembly was reorganized upon a "tribal" basis, and was made to comprise all the people living in the different "local tribes"- both patricians and plebeians. This newly organized assembly was generally called the comitia tribu'ta, and in it the plebeians, being more numerous, were able to exercise a great deal of influence. ${ }^{1}$

The Agrarian Proposal of Spurius Cassius.-The second

${ }^{2}$ The relation of the concilium plebis to the comitia tributa is a subject concerning which there has been much dispute, on account of the indefinite references malle to them by the ancient writers. The various views are (1) that they were identical; (2) that they were distinct, and so remained; and (3) that the concilium plebis was at first a purely plebeian assembly, which was later trinsformed into the comitia tributa, composed of all plebelans and paticians living in the tribal districts. 
great cause of complaint was, as we have seen, the unjust distribution of the public land. 'To remove this injustice was the effort of the consul Spurius Cassius. He it was who proposed the first "agrarian law," that is, a law intended to reform the division of the public land ( 486 B. c.). It was not his purpose to take away any private land which legally belonged to the patrician's; but to make a more just distribution of the land which properly belonged to the whole state. The passage of this law was prevented by the patricians; and its author was charged with treason and condemned to death.

\section{The Struggle for Equal Laws}

The Demand for a Written Code.-The plebeians were at a great disadvantage during all this time, because the law was administered solely by the patricians, who kept the knowledge of it to themselves, and who regarded it as a precious legacy from their ancestors, too sacred to be shared with the low-born plebeians. The laws had never been written down or published. The patricians could therefore administer them as they saw fit. Accordingly one of the tribunes, Gaius Terentilius Harsa, proposed that a commission be appointed to codify the law and to publish it to the whole people. This proposal, though both fair and just, was bitterly opposed by the patricians, and was followed by ten years of strife and dissension. It was finally agreed that a commission of ten men, called "decemvirs," should be appointed to draw up the law, and that this law should be published and be binding upon patricians and plebeians alike. It was also agreed that the commissioners should all be patricians; and that they should have entire control of the government while compiling the laws. Thus for a time the patricians were to give up their consuls and quæstors, and the plebeians were to give up their tribunes and ædiles. Both parties were to cease their quarreling and await the work of the decemvirs. 
The Decemvirs and the XII. Tables (450 в. c.).-The first body of commissioners, or the First Decem'virate, entered upon the work assigned to it, gathered together the law which had hitherto been kept secret, and inscribed it on ten tables of brass. 'These tables were erected in the Forum, where they could be seen by every one, and were declared binding on all the people. At the close of the year, a Second Decemvirate was appointed to complete the code, and two more tables were added. This whole body of law was called the Twelve Tables, and formed the basis of the most remarkable system of law that the world has ever seen. There was nothing strange, however, in the XII. Tables themselves. They contained nothing especially new. The old law of debt remained as it was, and the distinction between patricians and plebeians was not destroyed. The XII. Tables were important because they put the law before the eyes of the people; and plebeians, as well as patricians, could know what were their rights.

The Second Secession and Overthrow of the Decemvirate.While the decemvirs were engaged in codifying the laws, the old republican officers were temporarily suspended. It was expected that the decemvirs would lay aside their exceptional authority when their work was accomplished. But it seems that the second body of decemvirs refused to resign, and threatened to establish a permanent despotic government in place of the old consulate. It is said that the leader of this movement was Appins Claudius. ${ }^{1}$ However this may be, the people, fearing that their liberties were in danger, once more secedri from the city. The Roman state seemed again on the point of ruin, and the decemvirs were forced to resign. The old government was restored, with newly elected con-

1 With this movement is connected the traditional story of Virginla : that she was the benutiful daughter of a plebeian soldier and was killed by her father to prevent her from falling into the hands of Appius Claudius. Some anthorities. however, are inclined to believe that Appius Clandius was really the friencl of the people, and that this story was invented by the patricians to bring his name into dishonor. 
suls friendly to the plebeians. These were Lucius Valerius and Marcus Horatius.

The Valerio-Horatian Laws (448 B. с.).-The second secession of the plebeians resulted not only in the overthrow of the decemvirate and the restoration of the consulate; it resulted also in the passage of certain important laws, which received the name of the new consuls:

(1) The right of appeal in capital cases (p. 288) was reaffirmed, and this applied to plebeians as well as patricians.

(2) The power of the plebeian tribunes was sanctioned by the declaration that he who raised his hand against them should be accursed.

(3) The authority of the plebeian assembly was made clear by the provision that its acts should be binding upon the whole people-patricians as well as plebeians. This provision, with the changes made in its organization (p. 290), made the comitia tributa a real legislative body for the whole state.

These laws made definite and clear the constitutional rights of the people, and secured to them the privileges they had already obtained. They may be called "the second charter of Roman liberty" (for the first charter, see p. 288).

The Right of Intermarriage.-The XII. Tables had preserved the old customary law prohibiting intermarriage between patricians and plebeians. But soon after the overthrow of the decemvirate this was superseded by a new law (lex Canuleia, 445 B. c.) which granted the right of intermarriage between the two orders. This insured their social and civil equality, and paved the way for their political equality, and finally their union into a harmonious people.

\section{The Struggle for Political Equality}

Progress of the Plebeians.-In order that we may keep in mind a little more clearly just what progress the plebeians had made up to this time, and what they still demanded, let us 
look for a moment at the following table, which contains a list of the general rights possessed by a full Roman citizen :

\begin{tabular}{|c|c|c|}
\hline The rights of & $\begin{array}{l}\text { Public rights } \\
\quad \text { (iura pub- } \\
\text { lica). }\end{array}$ & $\begin{array}{l}\text { Right of holding office (hon- } \\
\text { ores). } \\
\text { Right of voting (suffragium). }\end{array}$ \\
\hline $\begin{array}{l}\text { citizenship } \\
\text { (civitas) }\end{array}$ & $\begin{array}{l}\text { Private rights } \\
\quad \text { (iura pri- } \\
\text { vata). }\end{array}$ & $\begin{array}{l}\text { Right of intermarriage (conu- } \\
\text { bium). } \\
\text { Right of property and con- } \\
\text { tract (commercium). }\end{array}$ \\
\hline
\end{tabular}

The plebeians already possessed the lowest right, the commercium; they could hold property and carry on trade just like any other Roman citizens. They had just now obtained the conubium, or the right of contracting a legal marriage with a patrician. They had also the suffiragium, or the right of voting in the assemblies of the centuries and of the tribes. As regards the honores, or the right of holding office, they could be elected to the lower offices, that is, could be chosen tribunes of the people and ædiles; but could not be elected to the higher offices, that is, could not be chosen consuls and quæstors. What the plebeians now wanted was a share in the higher offices, especially in the consulship.

The Consular Tribunes (444 B. C.).-Instead of allowing the plebeians a direct share in the consulship, the patricians agreed to the appointment of certain new officers, who should have the same power but not the same honor as the consuls, and who could be elected from either the patrician or the plebeian class. These new officers were called " military tribunes with consular power," sometimes known as consular tribunes. It was provided, however, that the senate might in any given year determine whether consuls or consular tribunes should be elected. As a matter of fact, the senate for many years after this time decided in favor of the election of consuls. But later, as the plebeians grew in political influence, the election of consular tribunes became the rule. 


\section{The Censorship and the New Quæstors.-As the patricians} saw that the plebeians were growing stronger, they resorted to a new plan to keep as much power as possible in their own hands. 'To do this, they created another new office, the censorship ( 443 B. C.), and transferred to the two censor's some of the most important powers hitherto exereised by the consuls. 'The censors were to draw up the census, that is, to make an estimate of every man's property, to assign each man to a proper class in the centuries, whether he belonged to the equites or the pedites, and to designate who was entitled to sit in the senate. The new censors were to be elected every five years, from the patrician class. But to offset this advantage, the patricians agreed that there should be two new quastors $(421$ в. c.), to be elected from the plebeians.

The Licinian Legislation (367 B. c.).-For many years after the creation of the offices just mentioned the Roman people were engaged in war with their foreign enemies-during which time occurred the siege and capture of the Etruscan city of Ve'ii (405-396 в. c.) and the destruction of Rome by the Gauls (390 B. c.). These wars resulted not only in distracting the attention of the people from constitutional questions, but also in reducing the lower classes again to a condition of poverty and distress. This brought economic questions again to the front. The new reformers were called upon not simply to continue the work in the direction of political equality, but to devise some methods to relieve their fellow-citizens impoverished by the recent wars. ${ }^{1}$ The cause of the people was at last taken up by two able leaders, the tribunes C. Licin'ius Stolo and L. Sextius. ${ }^{2}$ These men brought forward the following proposals :

${ }^{1}$ The first attempt to relieve the distress of the poor is said to have been made by Marcus Manlius, who had defended the Capitol at the time of the Gallic invasion. But like a previous reformer, Spurius Cassius (see p. 291), he was charged with treason and put to death.

'The abbreviations for the most common Latin proper names are the following: C. for Gaius; C'n. for Gineus : L. for Lucius : M. for Marcus : P. for Publius; Q. for Quintus ; Ap. for Spurius ; T. for Titus. 
(1) 'To relieve debtors, it was proposed to apply the interest already paid on a debt to the reduction of the principal and to allow three years in which to pay the rest of the debt.

(2) To improve the condition of the poorer citizens, it was provided that the oecupation of the public lands should be open to all; that no person should be allowed to hold more than five hundred ju'gera (about 300 acres); and that the number of slaves on any estate should be limited, so that free laborers should have an opportunity to work for wages.

(3) To settle the political strife between the classes it was proposed that the consular tribunes should be done away with, and that consuls only should henceforth be elected, one of whom must be a plebeian.

After some years of strife these proposals became laws; and one of their authors, I. Sextius, was elected the first plebeian consul. On account of the importance of this body of laws we may call it " the third charter of Roman liberty."

Final Equalization of the Orders.-When the Licinian laws were finally passed, their economic provisions were soon forgotten. but the political struggle for the offices still continued. With the loss of the consulate, the patricians succeeded in taking away its judicial power and conferring it upon a new officer called the pretor $(367$ B. c.), who had to be a patrician. It was also provided that there should be two patrician ædiles (called curule ædiles) to offset the plebeian adiles. But it was not many years before all the offices retained by the patricians were opened to the plebeians, and political equality was fully established between the two orders. ${ }^{1}$ The old Roman aristocracy based upon blood no longer possessed any political distinction. The union of patricians and plebe-

\footnotetext{
1The distinction between the plebclan and the eurule adileship gradually passed away. The dietatorship was opened to the plebelans in $356 \mathrm{B.}$.; the censorship in 351 B. $c .:$ and the pratorship in 337 B. c. The independent legislative power of the comitia tributa was confirmed by the Iortensian law in 286 B. C.
} 
ians into one compact body of citizens was a great step in the growth of that principle of incorporation which finally made the Romans the strongest people and gave them the best-organized government of the ancient world.

Summary of the Republican Constitution.-Following is a brief outline of the constitution of the Roman republic:

I. The Senate-three hundred members, chosen by the censor, having control of the religion and the finances, of the provinces and of foreign affairs, and generally the approval of laws submitted to the assemblies (auctoritas patrum).

II. The Popular Assemblies.

1. The Comitia Curiata-assembly of the curies, with, generally speaking, no power except formally to confer the imperium.

2. The Comitia Centuriata-assembly of the centuries, presided over by an officer having the imperium (consul, prator, or dictator); having the power to elect the consuls, censors, and prætors, to declare war, to act upon laws submitted to it, and to decide on appeals in capital cases.

3. The Comitia Tributa-assembly of the tribes, presided over by a tribune, or other high magistrate; having power to elect the curule ædiles and quæstors and to pass laws submitted to it.

4. The Concilium Plebis-originally an assembly of the plebeians only; having power to elect the tribunes and plebeian ædiles and to pass laws at first for the plebeians and afterward for the whole people. The relation of this assembly to the comitia tributa is not clear (p. 290, note).

\section{The Magistrates.}

1. The Curule Magistrates.

(1) The Consuls-two, presided alternately over the senate, proposed laws to the assemblies, and commanded the armies.

(2) The Dictator-one, having supreme administrative power for not more than six months; appointed by the consul when directed by the senate; assisted by the Master of Horse (Magister Equitum).

(3) The Prætor-at first one, protor urbanus, with judicial authority in cases between citizens; afterward a second, pretor peregriuns, to judge between foreigners or between citizens and foreigners.

(4) The Censors-two, with power to make the census, assess the property, classify the people, revise the senatorial list, and supervise the public morals.

(5) The Curule Fidiles-two, having charge of the public works and the public records. 
2. The Non-Curule Magistrates.

(1) The Plebeiun Ediles-two, having powers like the curule ædiles.

(2) The Plebeian 'Tribunes-two, afterward ten, with power of veto and intercession.

(3) The Quæstors-two, afterward eight, having charge of the treasury and public accounts.

All these magistrates were elected annually, except (1) the censors, who were elected every five years to hold office for a year and a half, and (2) the dictator, who was appointed only as occasion required.

\section{SYNOPSIS FOR REVIEW}

I. The Early Republican Government.-The Two Consuls.The Dictatorship.-The New Senators.-The Popular Assemblies.-The Laws of Valerius P'oplicola.

II. The Struggle for Ecoxomic Rights.-Relation of the Patricians to the Plebeians.-Economic Distress of the Plebeians. -First Secession of the Plebeians.-The Tribunes of the People.-The Plebeian Assembly; the Comitia Tributa.-Whe Agrarian Proposal of Spurius Cassius.

III. The Struggle for Equal Laws.-The Demand for a Written Code.-The Decemvirs and the XII. Tables.-The Second Secession and Overthrow of the Decemvirate.-The ValerioHoratian Laws.-The Right of Intermarriage.

IV. The Struggle for Political Equality.-Progress of the Plebeians.-The Consular Tribunes.-The Censorship and the New Quæstors.-The Licinian Legislation.-Final Equalization of the Orders.-Summary of the Republican Constitution.

\section{REFERENCES FOR READING}

Schuckburgh, Ch. 8, "Constitutional History from 509 to 390 B. C." $(18){ }^{1}$

Pelham, Bk. I., Ch. 1, "The Foundation of the Republic and the Struggle between the Orders" (18).

How and Ieigh, Ch. 5, "Institutions of the New Republic"; Ch. 12,

"The Licinian Laws and the Equalization of the Orders" (18).

Taylor, Chs. 3-5, "Struggle between the Orders" (22).

Ihne, Early Rome, Ch. 13, "Tribunes of the People" (18).

Granrud, Second Period, "The Equalization of the Orders" (22).

Greenidge, Public Life, Ch. 2, "Growth of the Republican Constitution" (22).

Mommsen, Vol. I., Bk. II., Ch. 1, "Changes of the Constitution"; Ch. 2, "The Tribunate of the Plebs"; Ch. 3, "Equalization of the Orders" (18).

Livy, Bk. II., Chs. 27-33 (first secession of the plebeians); Bk. III., Chs. 33-34 (the decemvirate) (25).

Plutarch, "Publicola" (26).

${ }^{1}$ The flgure in parenthesis refers to the number of the topic in the Appendix, where a fuller title of the book will be found. 


\section{PERIOD II. THE EXPANSION OF THE ROMAN REPUBLIC (343-133 B. C.)}

\section{CHAP'TER XX \\ THE CONSOLIDATION OF ITALY}

\section{Conguest of the Italian Peningula}

Character of the New Period.-We have traced the steps by which the early Roman state was gradually developed-by the union of the hill settlements on the 'Tiber, and by the incorporation of the plebeians into the body politic. We are now to trace the steps by which this early city state was gradually enlarged until it took in the whole of Italy and a large part of the Mediterranean coasts. The next period is, therefore, largely a period of wars and conquests. But it is also a period in which Rome learned new lessons of government and law, and in which she came into contact with more civilized peoples and became herself more civilized.

The Early Wars of Rome.-Previous to the beginning of this period of conquest, Rome had already been surrounded by enemies, who looked with envy upon her growing power and with whom she was obliged either to make treaties or to wage wars. Nearest to the, city were the Latins, who had asserted their independence at the time when the kingship was abolished. On the eastern and southern borders of Latium were the Aquians, the Hernicans, and the Volscians (map, p. 284). Through a treaty of alliance, which was formed by Sp. Cassius 
with the Latins and Hernicans, Rome was able to wage successful wars with the Equians and the Volscians. ${ }^{1}$ But the most important of these early wars were those in which the city of Veii was captured from the Etruscans, and in which the city of Rome was destroyed by the Gauls.

(1) Veii was situated northwest of the Tiber and was the strongest city of the Etruscans. In order to recover the territory north of the Tiber which they had held under the Etruscan kings and which they had lost with the overthrow of the kingdom, the Romans laid siege to this city. The siege lasted for nearly ten years (405-396 B. с.). Veii was finally captured by the dictator Camillus, and furnished to the Romans a strong foothold in Etruria.

(2) Shortly after the capture of Veii, Italy was invaded by the Gauls who had settled in the valley of the Po and from whom this territory was called Cisalpine Gaul. The Romans met these fierce invaders near the little river Allia, about eleven miles north of the city, and suffered a terrible defeat. The Gauls pressed on, and captured and burned the city (390 в. с.). Only the Capitol was saved, which was defended by Marcus Manlius. After the retreat of the Gauls, the Romans quickly rebuilt their city. The neighboring peoples again made war on Rome, but the city succeeded in recovering most of its former possessions. By the year 343 B. c., the Roman territory included not only the greater part of Latium, but also lands in the Volscian country and in southern Etruria.

The First Samnite War (343-341 B. c.).-In extending their territory to the south, the Romans now came into contact with

${ }^{1}$ The history of the Volscian wars is made interesting by the story of Coriola'nus, which tells us that this young patrician incurred the hatred of the common people, fled to the Volscians, and led an army against his native city; that his mother and his wife went to the Volscian camp and pleaded with him to cease his wars; and that Rome was thus saved. The memory of the . Equian wars is preserved in the story of the loman patriot Cincinna'tus, who was called from his country home to rescue the Roman army from a detile where it was surrounded by the Aquians and threatened with destruction: and who with great speed and skill conquered the Aquian army and returned the next evening to lome in triumph. 
the Samnites, the most warlike people of central Italy. Some of the Samnite tribes had already moved from their mountain home and settled in Campania, having taken possession of the old Etruscan city of Cap'ua and the Greek city of Cumæ (map, p. 302). The Samnites of Campania soon became refined by their contact with the higher culture of the Greeks and Etruscans, and lost all sympathy with their kinsmen of the mountains. This separation led to quarrels between the older Samnites and the Campanians, and the latter appealed to Rome for protection. In answer to this appeal Rome, with the support of her Latin allies, invaded Campania, and after two campaigns drove out the Samnites. As a result of this war Rome assumed the position of protector of the Campanian cities, which were thus brought under her power.

The Great Latin War (340-338 B. c.).--Rome was next compelled to face a danger which threatened her position in Latium. Her Latin allies, who had fought with her in the late war, demanded an equal share in the Roman government and in the spoils of conquest. This demand was refused; and the spirit of revolt spread not only throughout the cities of Latium, but among the newly conquered cities of Campania. The Roman people, being now well united and organized, carried on a vigorous and successful war against the insurgents. A decisive battle was fought near Mt. Vesuvius, where, according to tradition, the consul Decius Mus secured a victory at the cost of his own life. The Latin confederacy was finally broken up; all connection between the cities was destroyed; and each town was made subject directly to Rome. This policy of isolation prevented the cities from uniting with one another and secured the supremacy of the Roman authority.

The Second Samnite War (326-304 B. c.).-After a few years of peace the Romans and the Samnites became embroiled in another war, which led to a struggle for supremacy in central Italy. This war was brought on by the attempt of the Samnites to garrison one of the Campanian cities (Palæop'olis) 
in spite of the protest of Rome. At the beginning of the war Palrepolis was besieger and captured by the consul Publilius Philo, who was kept in command beyond the term of his office, and was hence the first to receive the title of "proconsul." 'The Romans formed alliances with the Apulians and Lucanians, and took possession of the strong city of Luce'ria in Apulia. But they soon suffered a most terrible defeat at the Caudine Forks (3:1 B. c.). Here their army was entrapped

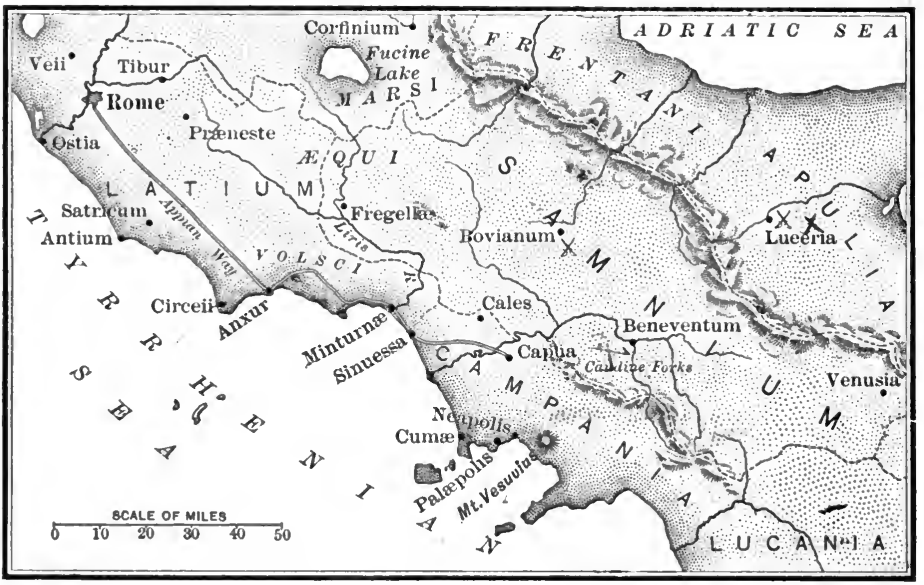

Central Italy-The Samnite Wars

in a mountain pass, and the commanding consuls were obliged to surrender and sign a treaty of peace. The Roman senate, however, refused to ratify this treaty, and the war continued. 'The Samnites were now joined by the Etruscans, who wished to recover the lost portions of their own territory. The series of disasters which now followed the Roman arms was at last repaired by the great hero of the war, Fabius Maximus Rullia'nus, who defeated the Etruscans at Iake Vadimo'nis. The Samnites were again driven out of Campania, and followed into their own territory, where their capital city. Bovia'num, was captured. As a result of this war the IRcmans reëstablished 
and strengthened their authority in Campania and Etruria, and restrieted the Samnites to their original boundaries in Samnium.

The Third Samnite War (298-290 B. c.).-The peace which followed the second Samnite war proved to be nothing more than a truce. The question of supremacy in central I taly was yet to be decided. The Sammites were determined to bring to their aid other nations of Italy - the Lueanians on the south, and the Etruscans, Umbrians, and Gauls on the north-and by such a coalition to overthrow the Roman power. The attempt of the Samnites to get control of Lucania led to a declaration of war by Rome. The Samnites placed three armies in the field-one to defend Samnium, one to invade Campania, and the third to march into Etruria. This last army was expected to join with the Etruscans, the Umbrians, and the Gauls and to attack Rome from the north. The Roman forces marehed into Etruria under $\mathrm{Fa}$ bius Maximus Rullianus, who had won the battle at Lake Vadimonis, and

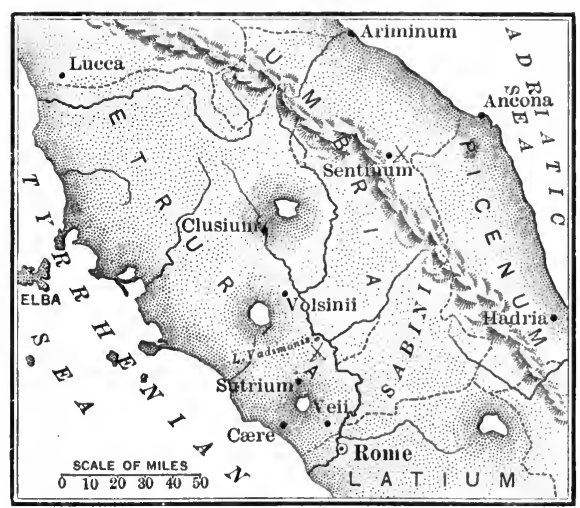

WAR IN ETRURIA

Decius Mus, the son of the hero who sacrificed himself in the battle of Mt. Vesuvius. The Etruseans and Umbrians were soon seattered; and the Samnites and Gauls retreated across the Apennines to Senti'num. Here was fought the decisive battle (295 в. с.). The Roman victory was due, according to tradition, to the heroic efforts of Decius, who, following the example of his father, sacrificed himself in order to maintain 
the Roman lines. This battle was followed by the dispersion of the Gauls, and, after a few years of hopeless resistance, by the submission of the Samnites. Rome thus became the ruling power of the peninsula from Cisalpine Gaul on the north to Magna Græcia on the south.

War with Tarentum and Pyrrhus (280-275 в. с.).-The most important of the Greek cities in southern Italy was Tarentum. This city was alarmed at the rapid progress made by the Romans along the southern coasts. The appearance of a

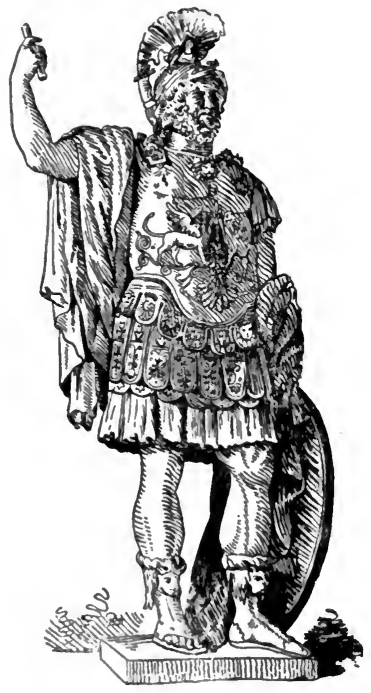

PYRRIUS Roman squadron in the bay of Tarentum-contrary to an existing treaty-angered the inhabitants of the city, who attacked the intruding vessels, killed the admiral, and destroyed a number of the ships. A Roman embassy sent to Tarentum to demand satisfaction was insulted. These acts led to a declaration of war by the Romans. Tarentum then turned to Greece for help, and called upon Pyrrhus, the king of Epirus. Pyrrhus was the most able general that had appeared since the death of Alexander the Great. He hoped to rival the work of Alexander by building up an empire in the West. He was, therefore, ready to respond to the call of Tarentum, and soon landed in Italy with an army of twenty-five thousand men and twenty elephants.

The first battle between the Roman and the Greek soldiers took place at Heracle'a, not far from Tarentum (280 B. c.); and it was here that the Roman army first came into contact with the Macedonian phalanx. The Romans were defeated. owing chiefly to the panic caused by the elephants which 
Pyrrhus had brought with him. The victory of Pyrrhus was attended with great loss to his own army; and he sent his ambassador, Cin'eas, to Rome, asking for terms of peace. But the Roman senate, under the influence of the blind old sensor Appius Claudius, refused to make peace with an enemy on

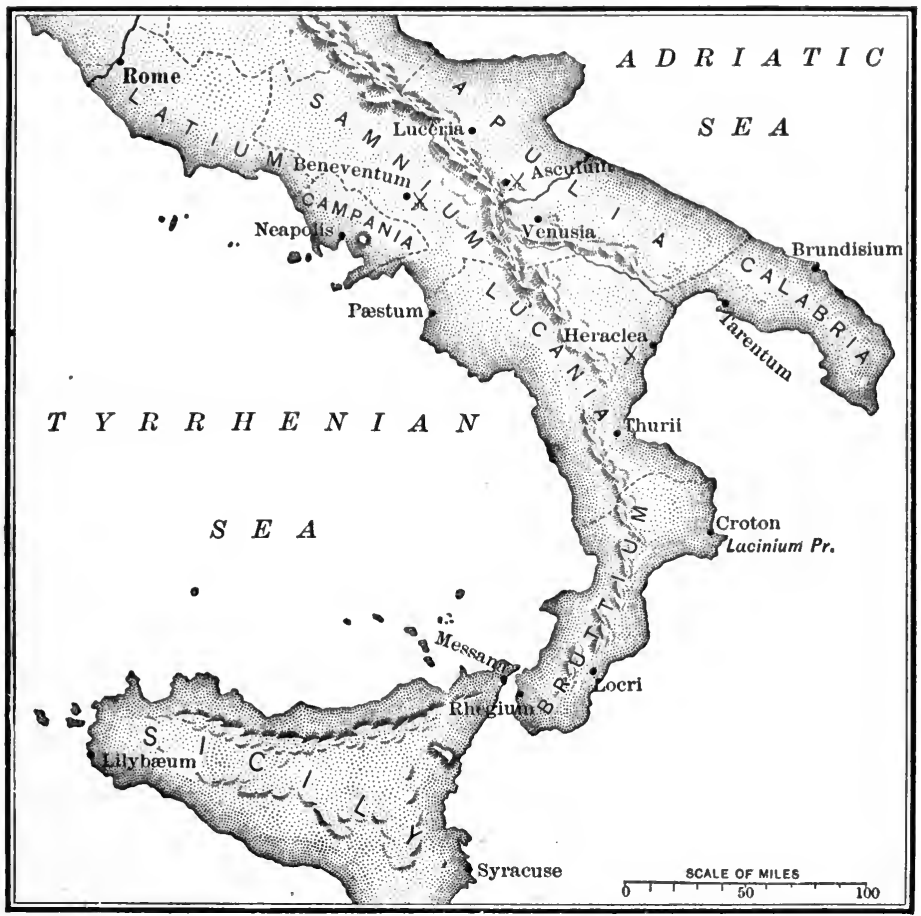

Magna Gracia-The War with Pyrrius

Italian soil. Pyrrhus then gathered to his support the peoples of southern Italy, including the Samnites; he marched into $\Lambda$ pulia, and at Asculum again defeated the Roman army (279 B. C.). Discouraged by the great losses incurred in these two "Pyrrhic victories," he crossed over into Sicily, hoping to gain greater renown by rescuing his Greek kinsmen from the 
Carthaginian power. Although at first successful, he failed to receive the expected support from the Greek cities. He returned to Italy. marched north into Samnium, and suffered a severe defeat at the hands of the Roman consul Curius Denta'tus $(275$ в. с.). He then withdrew from Italy, and in a short time 'Tarentum fell into the hands of the Romans ( $2 \%$ в. с.). Within the next few years the spirit of revolt which lingered in certain parts of Italy was suppressed; and the Roman authority was completely established from the Rubicon to the Sicilian strait.

\section{Political Organization of Italy}

The Roman Policy of Government.-To understand how Rome conquered the peoples of Italy is less important than to understand how she governed these peoples after they were conquered. From the time that she broke up the Latin league until she brought Italy under her control, she was gradually developing that remarkable capacity for political organization which finally made her the greatest governing power of the ancient world. We must not suppose that she had from the first a completely formed policy of government. On the contrary, this policy was growing with her growth, and becoming more clearly defined with her increasing dominion. So far as we are able to define her general method of governing we might say that it included three important features: (1) isolation, or the separation of the subject communities from one another so as to prevent the possibility of united resistance: (2) local government, or the granting to each community the right to manage its own local affairs so far as this was consistent with Roman supremacy; (3) gradual incorporation, or the conferring upon different communities, to a greater or less extent, of the rights of citizenship.

The Sovereign and Subject Communities.-If we would comprehend the political system which grew up in Italy, we must keep clearly in mind the distinetion between the peonle 
who made up the sovereign body of the state, and the people who made up the subject communities of Italy. Just as in early times we saw two distinct bodies, the patrician body, which ruled the state, and the plebeian body, which was subject to the state; so now we shall see, on the one hand, a ruling body of citizens, who lived in and outside the eity upon the Roman domain (ager Romanus), and on the other hand, a subject body of people, living in towns and cities throughout the rest of Italy. In other words, we shall see a part of the territory and people incorporated into the state, and another part still unincorporated - the one a sovereign community, and the other comprising a number of subject communities.

The Roman State; Ager Romanus.-The sovereign commu. nity, which made up the Roman state proper, comprised the people who lived upon the Roman domain (ager Romanus). In other words, the Roman domain, or ager Romanus, was that part of the territory in whieh the people were incorporated into the state, and received the rights as well as the burdens of citizenship. This domain land, or incorporated territory, had been gradually growing while the conquest of Italy was going on. It now included, speaking generally, the most of Latium, northern Campania, southern Etruria, the Sabine country, Picenum, and a part of Umbria. There were a few towns within this area, like Tibur and Prænes'te, which were not incorporated, and hence not a part of the domain land, but retained the position of subject allies. The ager Romanus included the local tribes, as well as the Roman colonies and the municip'ia.

The Thirty-three Tribes.-The local tribes (p. 280) had now increased in number to thirty-three. They included four urban tribes, that is, the wards of the city, and twenty-nine rural tribes, which were like townships in the country. All the persons who lived in these tribal districts and were enrolled, formed a part of the sovereign body of the Roman people; that is, they had not only the private rights, but the 
public rights of Roman citizens, having a share in the government, in the holding of office, in the election of magistrates, and in the making of the laws. ${ }^{1}$

The Roman Colonies.-The early colonies which Rome sent out were allowed to retain all their rights of citizenship, being permitted even to come to Rome at any time to vote and help make the laws. These colonies of Roman citizens thus formed a part of the sovereign state; and their territory, wherever it might be situated, was regarded as a part of the ager Romanus. Such Roman colonies were the maritime garrisons along the seacoast, the most important of which were situated on the shores of Latium and of adjoining lands.

The Roman Municipia.-Certain conquered towns were incorporated into the state, and yet were allowed to retain their rights of local government. They accepted the sovereignty of Rome and their inhabitants received the rights of Roman citizens. In some cases the inhabitants received the full rights of citizenship, including the pubiic rights, being permitted to be enrolled and to vote with the local tribes. In other cases, they received only the private rights (civitas sine suffragio), being permitted to trade and to intermarry with Roman citizens, and made subject to all the burdens of Roman citizens, but not allowed to take part in the government. Under certain circumstances a town, as a penalty, might be deprived of its local government and placed under a prefect-in which case it would be called a "prefecture." 2

The Subject Communities.-Over against this sovereign body of citizens, living upon the ager Romanus and made up of

${ }^{1}$ The number of the tribes was afterward increased to thirty-five, which was the maximum number.

${ }^{2}$ There were very few towns that were reduced to the condition of prefectures. The majority of towns, however, within the IRoman domain were regarded as municipia, elther of the first or of the second class. The loyalty of a munjcipal town would be stimulated, on the one hand, by the hope of attaining to the first class, or of remaining there: or, on the other hand, by the fear of being reduced to a prefecture. The Roman "municlpality" as a self-governing community incorporated into the state, was one of the most advanced features of the Roman system of government. 
the local tribes, the Roman colonies, and the municipia, were the subject communities scattered throughout the length and breadth of the peninsula. The inhabitanis of this territory had no share in the Roman government. Neither could they declare war, make peace, form alliances, or coin money, without the consent of Rome. Although they might have many privileges given to them, and might govern themselves in their own cities, they formed no part of the sovereign body of the Roman people. They comprised the Latin colonies and the Italian allies.

The Latin Colonies were the military garrisons which Ronie sent out to hold in subjection a conquered city or territory. They were generally made up of veteran soldiers, or sometimes of poor Roman citizens, who were placed upon the conquered land and who ruled the conquered people. But such garrisons did not retain the full rights of citizens. They lost the political rights, and generally the conubium, but retained the commercium. These colonies carried with them the Latin language and the Roman spirit, and were thus means of extending Roman institutions. ${ }^{1}$

The Italian Allies.-The largest part of the subject communities comprised the Italian cities which were conquered and left free to govern themselves, but which were bound to Rome by a special treaty. They were obliged to recognize the sovereign power of Rome. They were not subject to the land tax which fell upon Roman citizens, but were obliged to furnish troops for the Roman army in times of war. These cities of Italy, thus held in subjection to Rome by a special treaty, were known as federated cities (civitates foderatce), or simply as allies (socii); they formed the most important part of the Italian population not incorporated into the Roman state. ${ }^{2}$

1 Important Latin colonies were Luceria and Venusia in Apulia, Beneventum in Samnium, Pæstum in Lucania, Iadria in Picenum, and Arim'inum in Umbria (maps, pp. 302, 303,305 ).

2 This organization of Italy continued substantially until the Social war (90 в. c.). For the territorial divisions of Italy under this system see map, page 368. 


\section{III. 'The Military Sxstem}

The Roman Army.-The conquest of Italy was due, in great measure, to the efficieney of the Roman army. The strength of the Roman government, too, depended upon the army, which was the real support of the civil power. By their conquests the Romans became a nation of warriors. Every citizen between the ages of seventeen and forty-five was obliged to

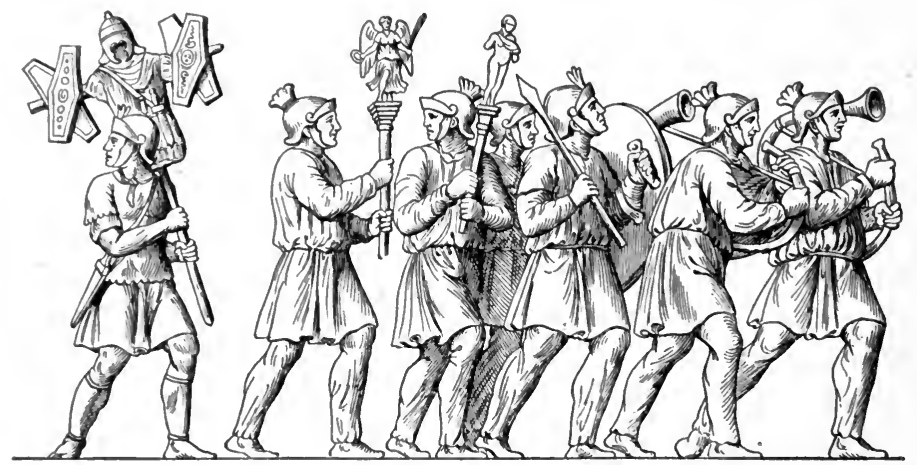

Soldiers AND TIIEIR BOo'TY

serve in the army when the public service required it. In early times the wars lasted only for a short period, and consisted in ravaging the fields of the enemy; and the soldier's reward was the booty which he was able to capture. But after the siege of Veii, the term of service became longer, and it became necessary to give to the soldiers regular pay. This pay, with the prospect of plunder and of a share in the allotment of conquered land, furnished a strong motive to render faithful service.

Divisions of the Army.-In case of war it was customary to raise four legions, two for each consul. Each legion contained thirty maniples, or companies, of heavy-armed troops, - twenty maniples consisting of one hundred and 
twenty men each, and ten maniples of sixty men each,-making in all three thousand heavy-armed troops. There were also twelve hundred light-armed troops, not organized in maniples. The whole number of men in a legion was therefore forty-two hundred. To each legion was usually joined a body of cavalry, numbering three hundred men. After the reduction of Isatium and Italy, the allied cities were also obliged to furnish a certain number of men, according to the terms of the treaty.

Order of Battle.-In ancient times the Romans fought in the manner of the Greek phalanx, in a solid square. This arrangement was well suited to withstand an attack on a level plain, but it was not adapted to aggressive warfare. About the time of Camillus, the Romans introduced the more open order of " maniples." When drawn up in order of battle, the legion was arranged in three lines: first, the hasta'ti, made up of young men; second, the prin'cipes, composed of the morc experienced soldiers; and, third, the tria'rii, which comprised the veterans, capable of supporting the other two lines. Each line was composed of ten maniples, those of the first two lines consisting of one hundred and twenty men each, and those of the third line consisting of sixty men each; the maniples, or companies, in each line were so arranged that they were opposite the spaces in the next line, as follows:

\section{Hastati}

2. Principes

3. Triarii

This arrangement enabled the companies in front to retreat into the spaces in the rear, or the companies in the rear to advance to the spaces in front. Behind the third line usually fought the light-armed and less experienced soldiers (rorarii and accensi). Each maniple carried its own ensign; and the legion carried a standard surmounted with a silver eagle.

Armor and Weapons.-The defensive armor of all the three lines was alike - a coat of mail for the breast, a brass helmet for the head, greaves for the legs, and a large oblong shield 
carried upon the left arm. For offensive weapons, each man carried a short sword, which could be used for cutting or thrusting. The soldiers in the first two lines each had also two javelins, to be hurled at the enemy before coming into close quarters; and those of the third line each had a long lance, which could be used for piercing. It was with such arms as these that the Roman soldiers conquered Italy.

Military Rewards and Honors.-The Romans encouraged the soldiers with rewards for their bravery. These were be-

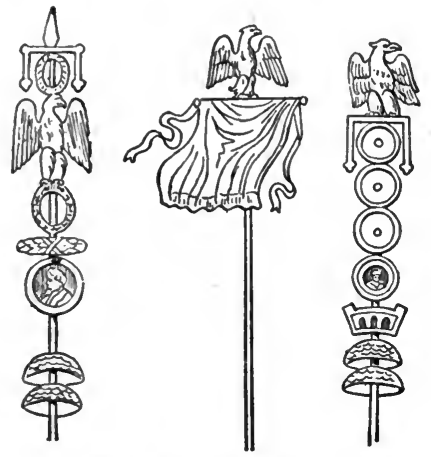

Roman Standardos stowed by the general in the presence of the whole army. The highest individual reward was the "civic crown," made of oak leaves, given to him who had saved the life of a fellow-citizen on the battlefield. Other suitable rewards, such as golden crowns, banners of different colors, and ornaments, were bestowed for singular bravery. The highest military honor which the Roman state could bestow was a "triumph"-a solemn procession, decreed by the senate, in which the victorious general, with his army, marched through the city to the Capitol, bearing in his train the trophies of war.

Military Roads.-An important part of the military system of Rome was the network of military roads by which her armies and munitions of war could be sent into every part of Italy. The first military road was the Appian Way (via Appia), built by $\Lambda$ ppius Claudius during the Samnite wars. It connected Rome with Capua, and was afterward extended to Beneventum and Venusia, and finally as far as Brundisium. This furnished a model for the roads which were subsequently laid out to other points in Italy. Although we read of roads in Persia 
(p. 6\%) and in other ancient countries, the Romans were probably the first people to reduce road-making to an art. 'They spared no labor and expense to make these highways straight, smooth, and durable. The roads were laid out upon the most direct and level course from city to city, without regard to natural obstacles, piercing mountains and spanning morasses

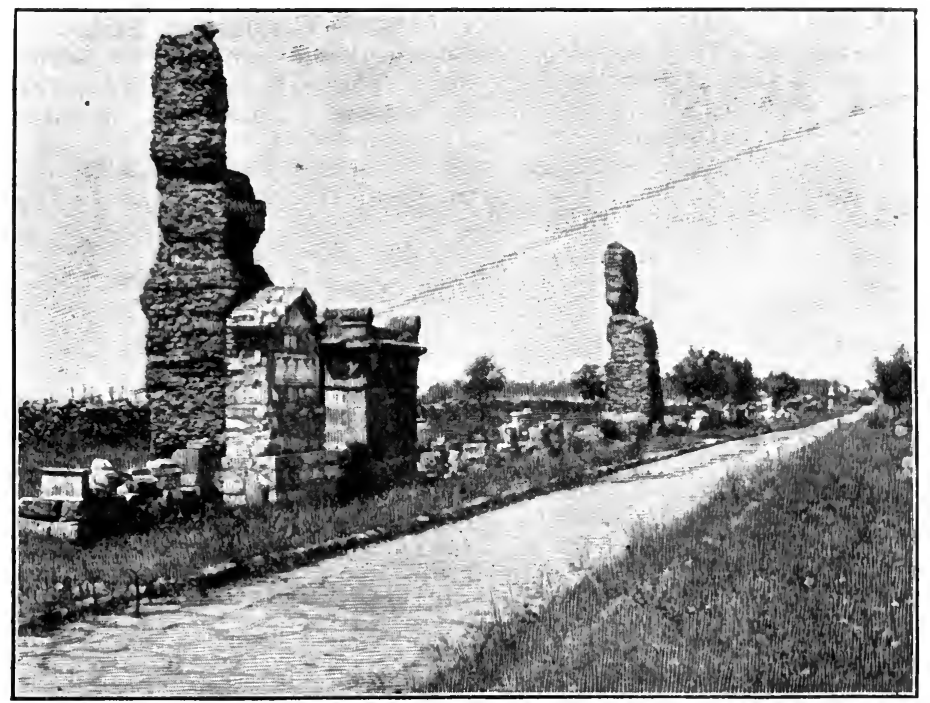

APPIAN WAY

and rivers. The surface of the road was a pavement constructed of polygonal slabs of hard rock, nicely fitted together; and this was supported by strata of stones and gravel laid in cement to the depth of two feet or more, and having a width of about fifteen feet. So durable were these highways that the remains of many of them exist to the present day. After a . time they came to be used by the Romans not merely for the movement of troops, but as pathways of trade and also as lines of communication, or post-roads. The Roman roads were thus a means of binding together the different parts of 
the Roman state, securing the dominion of Rome and extending her civilization.

\section{SYNOPSIS FOR REVIEW}

I. Conquest of the Italian Peninsula.-Character of the New Period.-The Early Wars of Rome.-The First Samnite War.The Great Latin War.-The Second Samnite War.-The Third Samnite War.-The War with Tarentum and Pyrrhus.

II. Political Organizatiox of Italy. - The Roman Policy of Government.-The Sovereign and Subject Communities.-The Roman State; Ager Romanus.-The Thirty-three Tribes.-The Roman Colonies.-The Roman Municipia.-The Subject Communities.-The Latin Colonies.-The Italian Allies.

III. The Military Srstem.-The Roman Army.-Divisions of the Army.-Order of Battle.-Armor and Weapons.-Military Rewards and Honors.-Military Roads.

\section{REFERENCES FOR READING}

Liddell, Ch. 27, "Final Reduction and Settlement of Italy" (18). ${ }^{1}$ Pelham, Bk. II., Ch. 2, "The Conquest of Italy" (18).

How and Leigh, Ch. 13, "Subjugation of Latium and Campania"; Ch. 16, "War with Tarentum and Pyrrhus" (18).

Merivale, General History, Ch. 16, "Summary of Roman Institutions" (18).

Ihne, History, Third Book, Ch. 17, "The Conquest of Italy" (18). Mommsen, Vol. I., Bk. JI., Ch. 7, "Struggle between Pyrrhus and Rome and Union of Italy" (18).

Taylor, Ch. 6, "Rome and Italy" (22).

Granrud, pp. 98-101, "Conquest and Organization of Central and Southern Italy" (22).

Seignobos, Ch. 7, "The Roman Army" (18).

Smith, Dictionary, "Colonia" (the Roman colonial system); "Viæ" (Roman road-making); "Exercitus" (the Roman army) (19).

Munro, Source Book, Part IV., "The Constitution of the Republic" (25).

Livy, Bk. IX., Chs. 1-6 (battle of Caudine Pass) (25).

\footnotetext{
${ }^{1}$ The figure in parenthesis refers to the number of the topic in the Appendix, where a fuller title of the book will be found.
} 


\section{CHAP'TER XXI}

THE STRUGGLES WITH CARTHAGE; THE PUNIC WARS

\section{The Finst Punic War (264-241 B. c.)}

Rome and Carthage.-The first foreign power with which Rome came in contact, outside of Italy, was Carthage. 'This city was originally a colony of Tyre, and had come to be the capital of a great commercial empire on the northern coast of Africa. Carthage brought into the western Mediterranean the ideas and civilization which the Phœnicians had developed in the East. Her power was based upon trade and commercial supremacy. She had brought under her control the trading colonies of northern Africa and many of the Greek cities of Sicily.

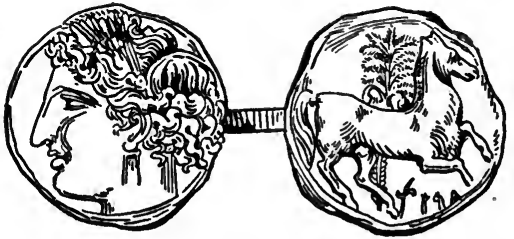

Carthaginian Coin

Rome and Carthage were thus each striving to get control of the cities of western Hellas; and they soon became rivals for the possession of the countries bordering upon the western Mediterranean Sea.

In comparing these two great rivals of the West, we might say that they were nearly equal in strength and resources. Carthage had greater wealth, but Rome had a better organization. Carthage had a more powerful navy, but Rome had a more efficient army. Carthage had more brilliant leaders, while Rome had a more steadfast body of citizens. The main strength of Carthage rested in her wealth and commercial re- 
PROGRF:SITF MAP NOO. 13.

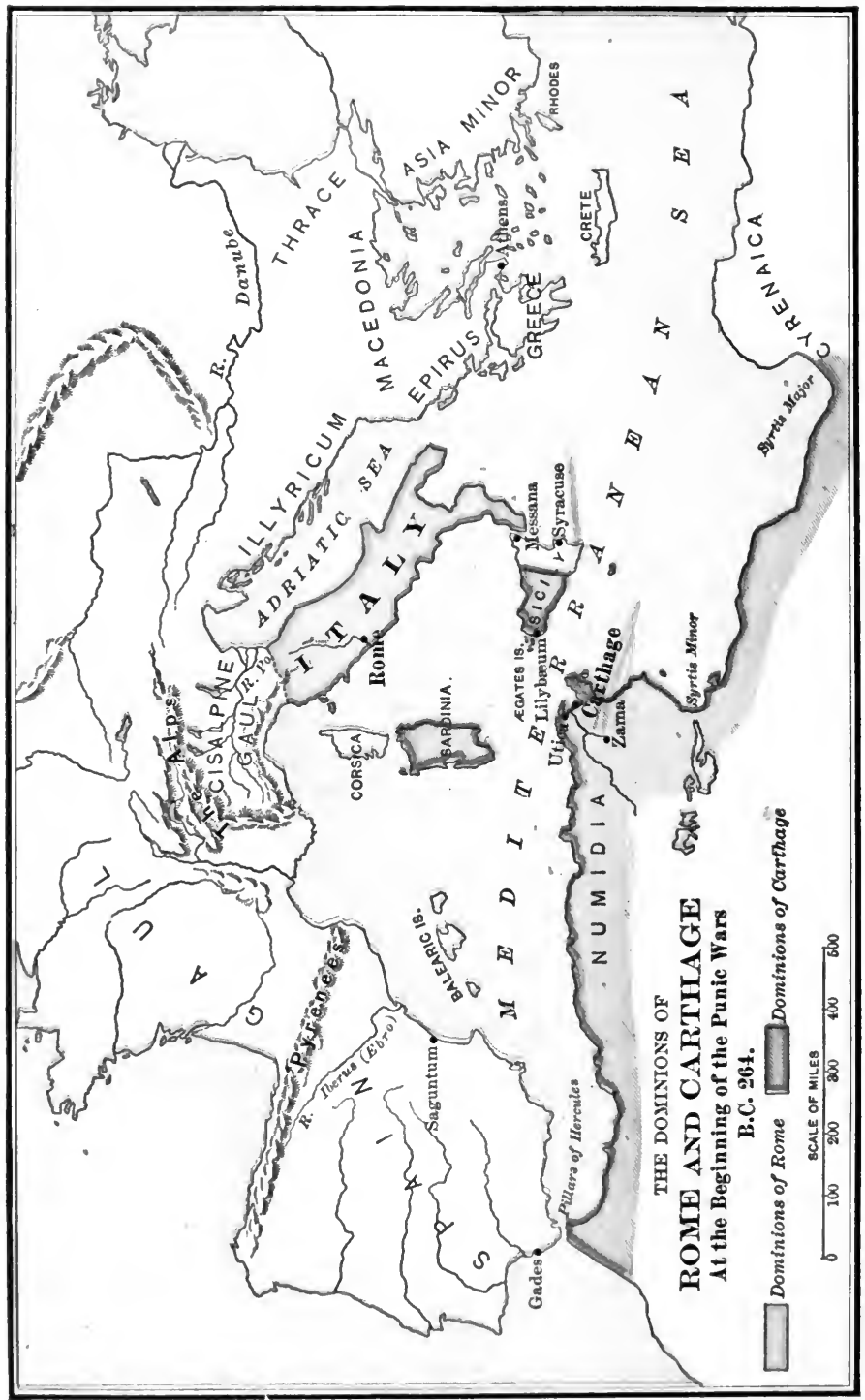


sources, while that of Rome depended upon the character of her people and her well-organized political system. 'The greatness of the Carthaginians was shown in their successes, while the greatness of the Romans was most fully revealed in the dark hours of trial and disaster.

Outbreak of the War in Sicily (264 B. c.).- The first conflict between Rome and Carthage, which is known as the first

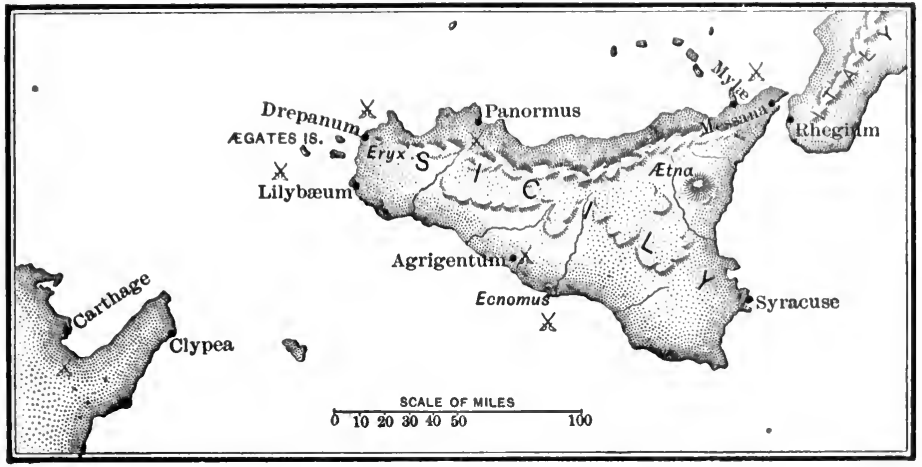

Sicily-The First Punic War

Punic $^{1}$ war, began in Sicily; and really came to be a contest for the possession of that island. Sicily was at this time divided between three powers. (1) Carthage held all the western part of the island, with the important cities of Agrigentum on the south, Panormus on the north, and Lilybæum at the extreme point. (2) The southeastern part of the island was under the control of the king of Syracuse, who ruled not only this city, but also some of the neighboring towns. (3) The northeastern corner of the island was in the possession of a body of Campanian soldiers who, after serving the king of Syracuse, had treacherously seized the city of Messana.

These Campanian mercenaries, who called themselves Mam'ertines, or Sons of Mars, murdered the inhabitants and ravaged the surrounding country. The king of Syracuse attacked them,

${ }^{1}$ So called because the Latin word for Carthaginian is Punicis. 
laid siege to their city, and reduced them to such an extremity that they called upon Rome for help. The Roman senate hesitated to help these robbers against Syracuse, which was a friendly power. But when the question was left to the assembly, the people decided to help the Mamertines, because they rightly feared that Carthage would be called upon if they refused. The Roman army that was sent to Messana found a Carthaginian force already on the ground; but it defeated both the Carthaginians and the Syracusans, and the war quickly developed into a struggle to drive the Carthaginians out of Sicily. Town after town fell before the Roman army; and in the second year of the war, the important city of Agri-

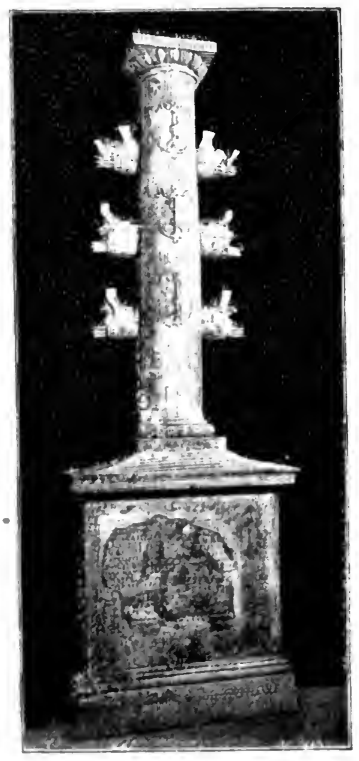

Columa of Duilius gentum was captured, after a siege of seven months (262 B. c.).

The New Roman Navy; the Vic. tory at Mylæ (260 B. c.).-When the enemy's fleet appeared off the coasts of Sicily, the Romans saw that Carthage, to be overcome, must be met upon the sea as well as upon the land. Taking as a model a Carthaginian vessel which had been wrecked on the Italian shore, they constructed, it is said, a hundred vessels like it in sixty days. In the meantime their soldiers were trained into sailors by practicing the art of rowing upon rude benches built upon the land and arranged like the banks of a real vessel. The Romans knew that their soldiers were better than the Carthaginians in a hand-to-hand encounter. To maintain this advantage, they provided their ships with drawbridges which could be used in boarding the enemy's ressels. Thus equipped 
with 'a fleet, Rome ventured upon the sea as a rival of the first naval power of the world. The new navy was placed under command of the consul Duil'ius, who gained a decisive victory off the northern coast of Sicily near Myla. The Romans thus had fought and won their first great battle upon the sea. Duilius was given a magnificent triumph, and to commemorate the victory a column was erected in the Forum, adorned with the beaks of the captured vessels (Colum'na Rostra'ta).

Invasion of Africa by Regulus ( 256 B. c.).-Elated by this success, the Romans felt prepared to carry the war into Africa. With a still larger fleet, they defeated the Carthaginian squadron which attempted to bar their way on the southern coast of Sicily, off the promontory of Ec'nomus. Two legions, under L. Manlius Vulso and Reg'ulus, landed on the coast of Africa east of Carthage, and laid waste the country. So easily was this accomplished that the Romans decided that one consul, with his army, would be enough to finish the work in Africa. Vulso was therefore recalled, and Regulus remained. The Carthaginians attempted in vain to make peace. They then placed their army in the hands of a Spartan soldier named Xanthip'pus. This general defeated the Roman legions with great slaughter, and

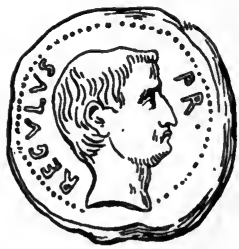

Regulus (Coin) made Regulus a prisoner. A fleet was then sent from Italy to rescue the survivors, but this fleet on its return was wrecked in a storm. Thus ingloriously closed the war in Africa.

Progress of the War in Sicily (255-241 B. c.).-For several years after this, the war languished in Sicily. The long series of Roman disasters was relieved by the capture of Panormus on the northern coast, which was soon followed by a second victory over the Carthaginians, at the same place. It is said that the Carthaginians, after this second defeat, desired an exchange of prisoners, and sent Regulus to the Roman sen- 
ate to advocate their cause, under the promise that he would return if unsuccessful. But Regulus, it is said, persuaded the senate not to accept the offer of the Carthaginians; and then, in spite of the tears and entreaties of his friends, went back to Carthage. Whether this story is true or not, it illustrates the honor and patriotism of the true Roman.

After the Roman victories at Panormus, the Carthaginians were pushed into the extreme western part of the island. The Romans then laid siege to Lilybaum, the stronghold of the Carthaginian power. Failing to capture this place, the Roman consul, P. Claudius, determined to destroy the enemy's fleet lying near Drep'anum; but he was defeated with the loss of over ninety ships. 'The superstitious Romans believed that this defeat was due to the fact that Clandius had impiously disregarded the auguries; when the sacred chickens had refused to eat, he had in a fit of passion thrown them into the sea. The consul was recalled by the senate, and a dictator was appointed in his place. After the loss of other fleets by storms, and after fruitless campaigns against the great Carthaginian soldier, Hamil'car Barca, the Roman cause seemed a failure.

Victory at the Ægates Islands (241 B. c.). - It is in the midst of such discouraging times as these that we are able to see the strong elements of the Roman eharacter-patriotism, fortitude, and steadfast perseverance. With a loss of one-sixth of their population and a vast amount of treasure, they still persisted in the attempt to conquer Sicily. Wealthy citizens advanced their money to build a new fleet. In this way two hundred ships were built and placed under the consul C. Iutatius Cat'ulus. A decisive victory was gained at the Aga'tes Islands, off the western extremity of Sicily. The Carthaginians wore unprepared for the terrible defeat which they suffered, and were obliged to sue for peace. They were obliged to give up Sicily: release all the Roman prisoners without ransom; and pay to the Romans 3,200 talents (about $\$ 4,000,000$ ), 
within ten years. 'Thus ended the first Punic war, which had lasted for twenty-three years. During this time Rome had shown her ability to fight upon the sea, and had fairly entered the lists as one of the great powers of the world. But this first contest with Carthage, severe as it was, was merely a preparation for the more terrible struggle which was yet to come.

II. Events between the First and Second Punic Wars (241-218 в. C.)

Sicily, the First Roman Province.--In the interval between the first and second Punic wars, both Rome and Carthage sought to strengthen and consolidate their power. They knew that the question of supremacy was not yet decided, and that sooner or later another contest was sure to come. Rome found herself in possession of a new territory outside of Italy, which had to be organized. She had already three kinds of territory: (1) the Roman domain (ager Romanus), where the people were, generally speaking, full citizens; (2) the Latin colonies, in which the people had a part of the rights of citizens; and (3) the Italian land, in which the people were not citizens, but were half independent, having their own governments, but being bound to Rome as allies in war. In Sicily a new system was introduced. The land was generally confiscated, and the inhabitants were obliged to pay a heavy tribute. The whole island-except Syracuse, which remained independent-was governed by a prætor sent from Rome. By this arrangement Sicily became a "province"-which is another name for a conquered territory outside of Italy, under the control of a Roman governor.

Aunexation of Sardinia and Corsica (239 B. c.).-Besides Sicily, there were in the Mediterranean two other islands which seemed by nature to belong to Italy. These were Sardinia and Corsica. While Carthage was engaged in Africa in suppressing a revolt of its own mercenaries, who did not receive their MOREY'S ANCIENT HIST.- 19 
pay after the late war, Rome saw a favorable opportunity to get possession of Sardinia. Carthage protested against such an act; and Rome replied by demanding the cession of the island, and also the payment of a fine of 1,200 talents (about $\$ 1,500$,000). Carthage was obliged to submit to this unjust demand; but she determined to avenge herself in the future. As Sardinia came to her so easily, Rome proceeded to take Corsica also, and the two islands were erected into a second Roman province. Rome thus obtained possession of the three great islands of the western Mediterranean.

Suppression of the Illyrian Pirates (229 B. c.).-The attention of Rome was soon directed to the eastern coast of the Adriatic Sea. An appeal came from the cities of Greece - the Etolian and Achæan leagues-for protection against the pirates of the Adriatic. These pirates were the people of Illyrieum, who made their living by plundering the ships and ravaging the coasts of their Greek neighbors. With a fleet of two hundred ships, Rome cleared the Adriatic Sea of the pirates. She then took the Greek cities on the coast under her protection; Rome thus obtained a foothold upon the eastern shores of the Adriatic, which brought her into friendly relations with Greece, and afterward into hostile relations with Macedonia.

Conquest of Cisalpine Gaul (225-222 B. c.).-As Rome began to be drawn into foreign wars, she became aware that her position at home could not be secure so long as the northern part of Italy remained unconquered. The Alps formed the natural boundary of Italy; and to this boundary she felt obliged to extend her power. She planted colonies upon the Gallic frontier, and in these towns made a large assignment of lands to her own citizens. The Gauls resented this as an encroachment upon their territory; they appealed to arms, invaded Etruria, and threatened Rome. The invaders were defeated and driven back, and the war was continued in the valley of the Po until the whole of Cisalpine Gaul was finally 
subdued. 'The conquered territory was secured by new colonies, and Rome was practically supreme to the Alps. Her people were made more devoted to her by the share which they received in the new land. IIer dominions were now so well organized, and her authority so secure, that she felt prepared for another contest with Carthage.

\section{The Second Punic War (218-201 в. c.)}

Extension of the Carthaginian Power in Spain.-'The second Punic war was to decide the fate of Rome, and perhaps of Europe. Its real cause was the growing rivalry between the two great powers that were now struggling for supremacy in the western Mediterranean. But it was directly brought about by the rapid growth of the Carthaginian dominion in Spain. While Rome was adding to her strength by the conquest of Cisalpine Gaul and the reduction of the islands in the sea, Carthage was building up a great empire in the Spanish pen-

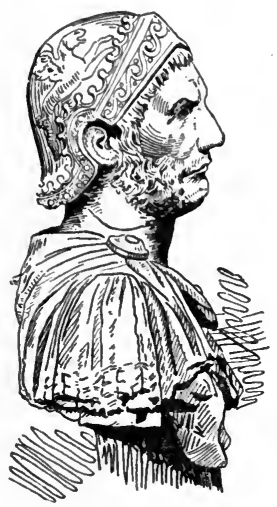

HANNIBAL insula. Here she expected to raise new armies, with which to invade Italy. This was the policy of Hamilcar Barca, her greatest citizen and soldier. The work was begun by Hamilcar himself, and then continued by his son-in-law, Has'drubal, who founded the city of New Carthage as the capital of the new province. Carthage continued the work of conquering the southern part of Spain, without infringing upon the rights of Rome, until Hasdrubal died. Then Hannibal, the young son of the great Hamilear, and the idol of the army, was chosen as commander. This young Carthaginian, who had in his boyhood sworn an eternal hostility to Rome, now felt that his mission was come. He marched from New 
Carthage and proceeded to attack Saguntum, the ally of Rome; and after a siege of eight months, captured it. 'This led to a declaration of war by Rome.

Hannibal's Invasion of Italy; his Early Victories.-Even at the beginning of the war Hannibal showed his great genius

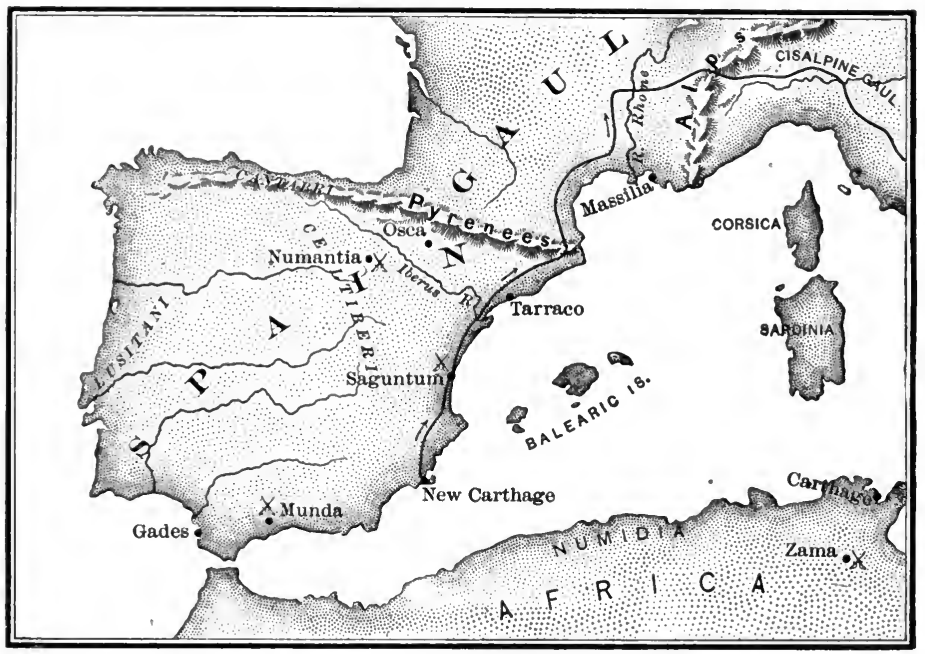

Spain-Hannibal's Route

as a soldier. The Romans formed an excellent plan to send two armies into the enemy's country-one into Africa under Sempronius, and the other into Spain under P. Cornelius Scipio (sip'io). But Hannibal, with the instinct of a true soldier, saw that Carthage would be safe if Italy were invaded and Rome threatened. Leaving his brother Hasdrubal to protect Spain, he crossed the Pyrenees with fifty thousand infantry, nine thousand eavalry, and a number of elephants. Without delay he pushed on to the river Rhone; outflanked the harbarians who were trying to oppose his passage; and crossed the river above, just as the Roman army (which had expected to meet him in Spain) had reached Massilia (Marseilles). 
When the Roman commander, P. Cornelius Scipio, found that he had been outgeneraled by Hannibal, he sent his brother Cn. Scipio on to Spain with the main army, and returned himself to Cisalpine Gaul, expecting to destroy the Cartha-

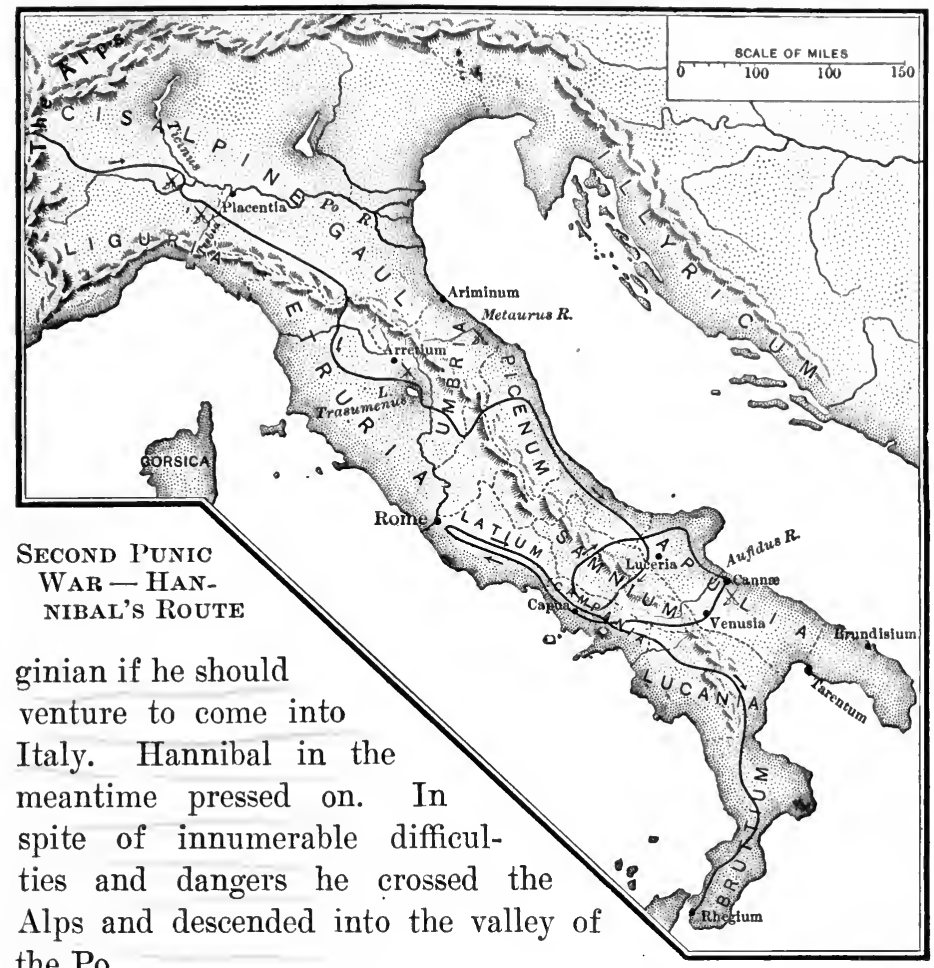
the Po.

He first defeated the Roman cavalry on the north of the Po, near the little stream Tici'nus. He then moved south of the Po, and on the banks of the Trebia gained a victory over the Roman army commanded by Scipio and Sempronius-the latter having been recalled from the intended expedition into Africa. Hannibal then pushed through the marshes of Etruria, and placed himself between a new Roman army and the 
Roman capital; and on the shores of Lake Trasume'nus he entrapped and practically annihilated the whole Roman army.

Battle of Cannæ (216 в. c.).-The.frightful disaster at Lake Trasumenus led to the appointment of a dictator, Q. Fabius Maximus, who on account of his cautious policy was called "Cuncta'tor," or the Delayer. New armies were raised and the city was put into a state of defense. The Romans soon grew tired of the cautious and indecisive movements of Fabius; and two new consuls were elected to take his place, who were expected to pursue a more vigorous policy. These were Terentius Varro and Aimilius Paullus. Hannibal's army was now in Apulia, near the little town of Cannæ on the A' ' fidus River. To this place the consuls led their new forces, consisting of eighty thousand infantry and six thousand cavalrythe largest army that the Romans had, up to that time, ever gathered on a single battlefield. Hannibal's army consisted of forty thousand infantry and ten thousand cavalry. As this was Hannibal's greatest battle, we may learn something of his wonderful skill by looking at its plan.

The Romans drew up their heavy infantry in solid columns, facing to the south, to attack the center of Hannibal's line. In front of the heavy-armed troops were the light-armed soldiers, to act as skirmishers. On the Roman right, near the river, were two thousand of the Roman cavalry, and on the left wing were four thousand cavalry of the allies. With their army thus arranged, the Romans hoped to defeat Hannibal. But Hannibal laid his plan not simply to defeat the Roman army, but to draw it into such a position that it could be entirely destroyed. He therefore placed his weakest troops, the Spanish and Gallic infantry, in the center opposite the heavy infantry of the Romans, and pushed them forward in the form of a crescent, with the expectation that they would be driven back and pursued by the Romans. On either flank he placed his heavy infantry of African troops, his best and most trusted soldiers, drawn back in long, solid columns, so that they could 
fall upon the Romans when the center had been driven in. On his left wing, next to the river, were placed four thousand Spanish and Gallic cavalry, and on the right wing his superb body of six thousand $\mathrm{Nu}-$ midian cavalry, which was to swing around and attack the Roman army in the rear, when it had become engaged with the African troops upon the right and left.

The description of this plan is almost a description of the battle itself. When the Romans had pressed back the weak center of Hannibal's line, they found themselves

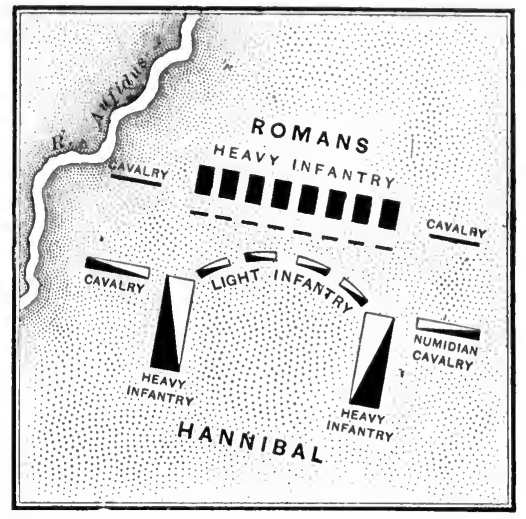

Battle of Canne ingulfed in the midst of the Carthaginian forces. Attacked on all sides, the Roman army became a confused mass of struggling mien, and the battle became a butchery. The army was annihilated; seventy thousand Roman soldiers are said to have been slain, among whom were eighty senators and the consul Amilius. The small remnant of survivors fled to the neighboring towns, and Varro, with seventy horsemen, took refuge in Venusia. This was the most terrible day that Rome had seen since the destruction of the city by the Gauls, nearly two centuries before. Every house in Rome was in mourning.

Dismay and Fortitude of the Romans.-During the period which followed the battle of Cannæ, the Roman character was put to its severest test. The people feared the worst. Everything seemed turning against them. The Apulians, the Lucanians, the Samnites, and the Bruttians revolted. Capua, the most important city in Italy, after Rome, opened her gates to Hannibal; and Tarentum, which held a Roman garrison, 
was betrayed into his hands. Syracuse transferred her allegiance from Rome to Carthage, and many other cities in Sicily threatened to revolt. Philip V., the king of Macedonia, also made an alliance with Hannibal (see p. 243), and threatened to invade Italy to assiat him. In the face of all these discouragements, the Roman people, supported by the faithful Latin towns and colonies, remained firm; and with fixed resolution determined to prosecute the war with greater vigor than ever before.

It was not long before the tide began to turn, and the energetic efforts of the Romans began to be rewarded. Syracuse was recaptured (212 B. C.) by the prætor Marcellus, at that time the governor of the province of Sicily. Capua also was retaken (211 в. с.), in spite of the efforts of Hannibal to draw away the Roman army from besieging that city, by marehing to the gates of Rome. Moreover, Tarentum was recaptured (209 B. C.) by Fabius Cunctator, his last service in the field. Besides, the Romans, by forming an alliance with the cities of Greece, were able to prevent the Macedonian king from invading Italy.

Battle of the Metaurus (207 B. c.).-While Hannibal had been engaged in Italy, Hasdrubal had been kept in Spain by the vigorous campaign which the Romans had conducted in that peninsula under the two Scipios. Upon the death of these generals, the young Publius Cornelius Scipio was sent to Spain and earned a great name by his victories. But Hasdrubal was determined to go to the rescue of his brother in Italy. He followed Hannibal's path over the Alps into the valley of the Po. Hannibal had moved into Apulia, where he was awaiting news from Hasdrubal. There were now two enemies in Italy, instead of one. One Roman army under Clandius Nero was therefore sent to oppose Hannibal in Apulia; and another army under Livius Salina'tor was sent to meet Hasdrubal, who had just crossed the river Metau'rus, in Umbria. 
It was necessary that Hasdrubal should be crushed before Hannibal was informed of his arrival in Italy. 'The consul Claudius Nero therefore left his main army in $A$ pulia, and with eight thousand picked soldiers hurried to the aid of his colleague in Unbria. The battle which took place at the Metaurus was decisive, and really determined the issue of the second Punic war. The army of Hasdrubal was entirely destroyed, and he himself was slain. The first news which Hannibal received of this disaster was from the lifeless lips of his own brother, whose head was thrown by the Romans into the Carthaginian camp. Hannibal saw that the death of his brother was the doom of Carthage; and he sadly exclaimed, "O Carthage, I see thy fate!" Hannibal retired into Brut-

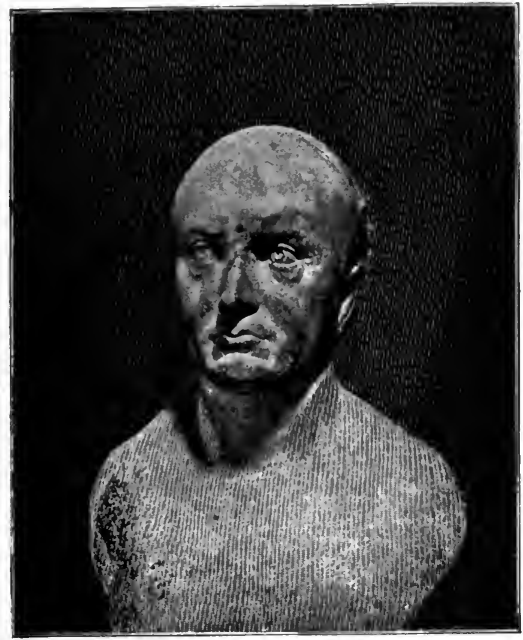

Publius Scipio Africanus tium; and the Roman consuls received the first triumph that had been given since the beginning of this disastrous war.

\section{Publius Scipio Afri-} canus._-Of all the men produced by Rome during the Punic wars, Publius Cornelius Scipio (afterward called Africa'nus) came the nearest to being a military genius. From boyhood he had, like Hannibal, served in the army. At the death of his father and uncle, he had been intrusted with the conduct of the war in Spain. With great ability he had defeated the armies which opposed him, and had regained the entire peninsula, after it had been almost lost. With his conquest of New Carthage and Gades (see map, 
PROGRFSSTVE MAP No. 14.

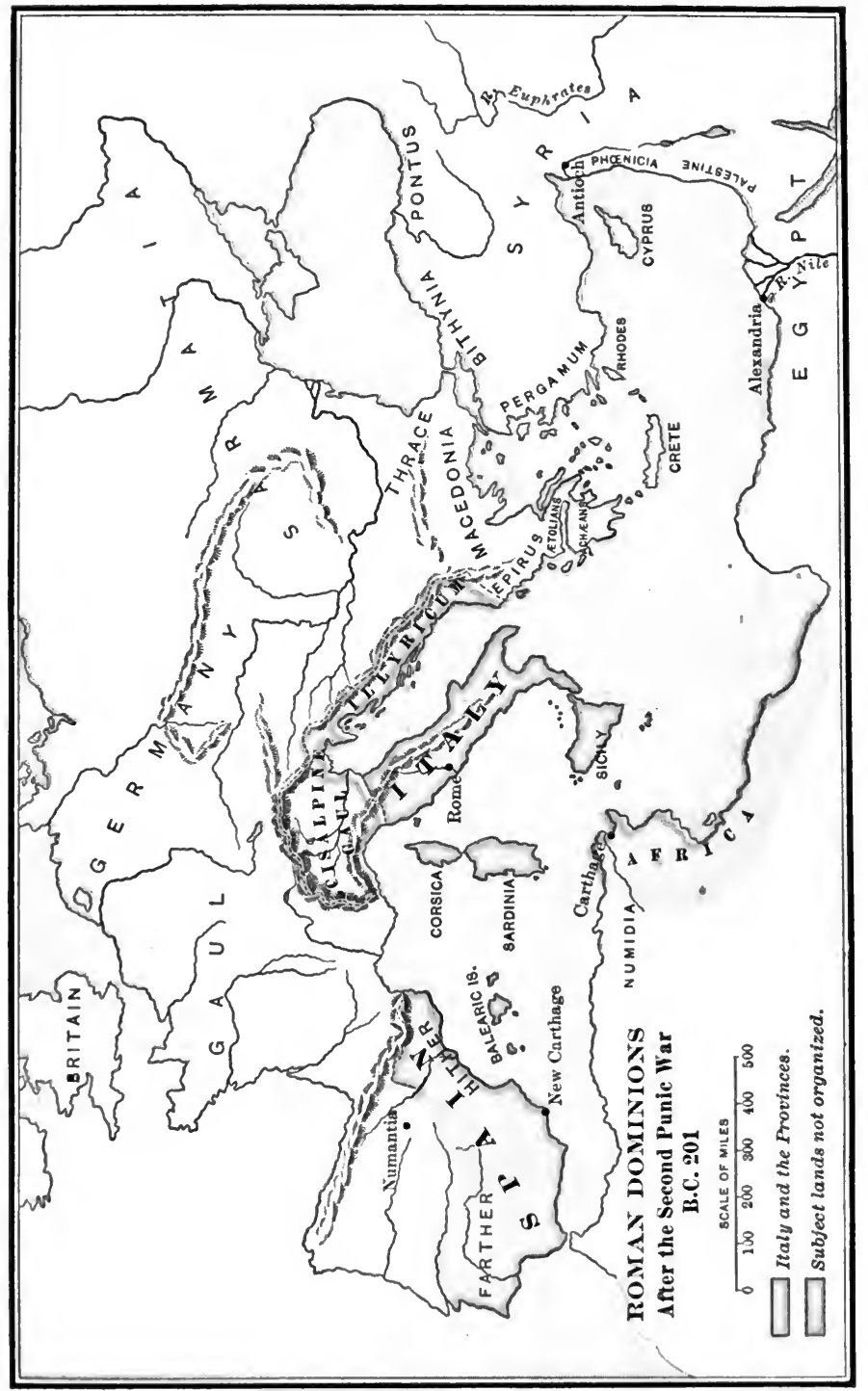


p. 324), Spain was brought under the Roman power. On his return to Rome, Scipio was unanimously elected to the consulship. He then proposed his scheme for closing the war. 'This plan was to keep Hannibal shut up in the Bruttian peninsula, and to carry the war into Africa. This plan received the support of the people; and Scipio proceeded to carry it into execution. When her armies in Africa were defeated, Carthage felt compelled to recall Hannibal from Italy.

Battle of Zama, and End of the War (201 в. c.).-The final battle of the war was fought (202 B. c.) near Zama (sce map, p. 324). In this battle Hannibal was defeated, and the Carthaginian army was annihilated. It is said that twenty thousand men were slain, and as many more taken prisoners. The great war was now ended, and Scipio imposed the terms of peace (201 в. с.). 'These terms were as follows: (1) Carthage was to give up the whole of Spain and all the islands between Africa and Italy; (2) Carthage was to pay an annual tribute of 200 talents (about $\$ 250,000$ ) for fifty years; (3) Carthage agreed not to wage any war without the consent of Rome.

Rome was thus recognized as the mistress of the western Mediterranean. Carthage, although not reduced to a province, became a dependent state. Syracuse was added to the province of Sicily, and the territory of Spain was divided into two provinces, Hither and Farther Spain, each under a Roman governor. Rome had, moreover, been brought into hostile relations with Macedonia, which paved the way for her conquests in the East.

\section{SYNOPSIS FOR REVIEW}

I. The Finst Punic WAr.-Rome and Carthage.-Outbreak of the War in Sicily.-The New Roman Navy; Victory at Mylæ.Invasion of Africa by Regulus.-Progress of the War in Sicily.Victory at the Egates Islands.

II. Events between othe First and Second Punic Wars.Sicily, the First Roman Province.-Annexation of Sardinia and Corsica.-Suppression of the Illyrian Pirates.-Conquest of Cis. alpine Gaul. 
III. The Second Punic War.-Extension of the Carthaginian Power in Spain.-Hannibal's Invasion of Italy; his Early Victories.-Battle of Cannæ.-Dismay and Fortitude of the Romans.-Battle of the Metaurus.-Publius Scipio Africanus.-Battle of Zama, and End of the War.

\section{REFERENCES FOR READING}

Pelham, Bk. III., Ch. 1, "Rome and Carthage" (18)..

Schuckburgh, Ch. 17, "Rome and Carthage" (18).

Liddell, Ch. 28, "Events Leading to the First Punic War" (18).

How and Leign, Ch. 20, "Hamilear and Hannibal"; Index, "Scipio,

P. Cornelius Africanus" (18).

Mommsen, Vol. II., Bk. III., Ch. 1, "Carthage" (18).

Munro, Source Book, Part IV., "The Punic Wars" (25).

Plutarch, "Narcellus," "Fabius" (26).

Polybius, Bk. I., Chs.-22, 23 (the victory of Duilius); Chs. 49-51

(defeat at Drepana); Ch. 59 (the fleet built by private subscription); Ch. 62 (treaty at end of the first Punic war); Ch. 88 (annexation of Sardinia); Bk. VI., Chs. 19-42 (the Roman army); Bk. VIII., Chs. 5-9, 37 (siege of Syracuse by Marcellus) (25).

Livy, Bk. XXI., Chs. 6-15 (siege of Saguntum); Chs. 32-38 (Hannibal's passage of the Alps); Bk. XXII., Chs. 4-7 (battle of Lake Trasumenus); Chs. 44-52 (battle of Cannæ); Bk. XXX., Ch. 43 (treaty at the end of the second Punic war) (25).

\section{CHAP'TER XXII}

THE CONQUEST OF THE MEDITERRANEAN LANDS

\section{The Wars with Macedonia and Syria}

Relation of Rome to the East.-For some years after the close of the second Punic war, the attention of Rome was directed almost entirely toward the East. We remember that after the death of Alexander the Great his empire had been split up into various kingdoms (p. 239). The most important of these kingdoms were Egypt in Africa, Syria in Asia, and Macedonia in Europe. Besides these three great kingdoms

${ }^{1}$ The flgure in parenthesis refers to the number of the topic in the Appendix, where a fuller title of the book will be found. 
there were also several smaller states, among them P'ergamum and Rhodes on the coasts of Asia Minor; and also the Atolian and Achaan leagues in Greece. 'The relations of Rome to these various states were quite different. With Egypt she had formed a friendly alliance and was receiving from that country her most important supplies of grain. With Syria Rome was not now ready to come into open conflict; although that state was on friendly terms with her greatest enemy, Hannibal, and was threatening the possessions of her most important ally, Egypt. But against Macedonia the Roman people cherished the most bitter hatred, on account of the aid which her king, Philip V., extended to Carthage during the second Punic war. Toward the smaller states above mentioned Rome entertained a friendly feeling, and assumed the position of their protector. With no evident desire at first to conquer these various countries, Rome was constantly called upon to interfere in their disputes; until she became the arbiter and finally the mistress of the East.

The First Macedonian War (215-206 B. c.).- It was the indiscreet alliance of Philip V. of Macedonia with Hannibal,during the second Punic war, which we have already noticed, that brought about the first conflict between Rome and Macedonia. But Rome was then so fully occupied with her struggle with Carthage that all she desired to do was simply to prevent Philip from making his threatened invasion of Italy. Rome therefore sent a small force across the Adriatic, made friends with the Atolians, and kept Philip occupied at home. The Macedonian king was thus prevented from sending any force into Italy. The Etolians, not satisfied with the support given to them by Rome, soon made peace with Philip; and the Romans themselves, who were about to invade Africa, were also willing to conclude a treaty of peace with him. Thus closed what is generally called the first Macedonian war, which was really nothing more than a diversion to prevent Philip from giving aid to Hannibal after the battle of Cannæ. 
The Second Macedonian War (200-197 B. c.).-When the second Punic war was fairly ended, Rome felt free to deal with Philip of Macedonia, and to take a firm hand in settling the affairs of the East. Philip had annoyed her, not only by making an alliance with Hannibal, but afterward by sending a force to assist him at the battle of Zama. And now the ambitious

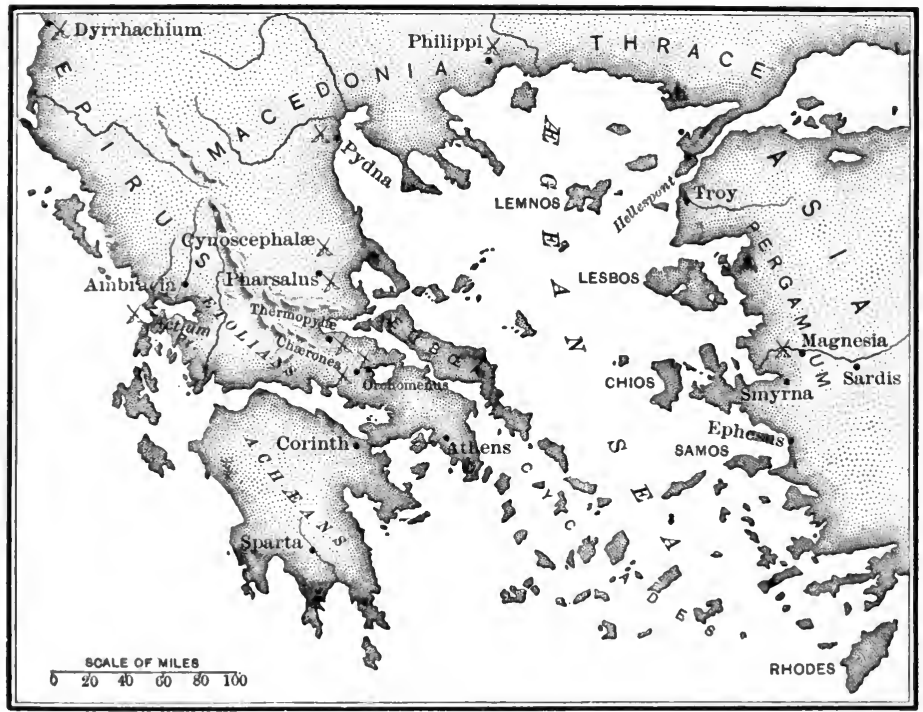

Seat of the Macedonian.and Syrian Wars

schemes of Philip were not at all to her liking. For instance, he made an agreement with Antiochus III. of Syria to cut up the possessions of Egypt, a country which was friendly to Rome. He was also overrunning the coasts of the Agean Sea, and was threatening Pergamum and Rhodes, as well as the cities of Greece. When appeal came to Rome for protection. she espoused the cause of the small states, and declared war against Macedonia. The great hero of this war was $T$. Quinctius Flamini'nus; and the decisive battle was fought 
(197 в. с.) near a hill in Thessaly called Cynosceph'alæe (1)og's Heads). Here Philip was completely defeated, and his army was destroyed. Macedonia was thus humbled, and there was now no power in Europe which could successfully dispute the supremacy of Rome.

The Liberation of Greece (196 в. c.).-To complete her work in eastern Europe, and to justify her position as defender of the Greek cities, Rome withdrew her garrisons and announced the independence of Greece. This was proclaimed by Flamininus at the Isthmian games, amid wild enthusiasm and unbounded expressions of gratitude. Rome was hailed as "the nation which, at its own expense, with its own labor, and at its own risk, waged war for the liberty of others, and which had crossed the sea that justice, right,

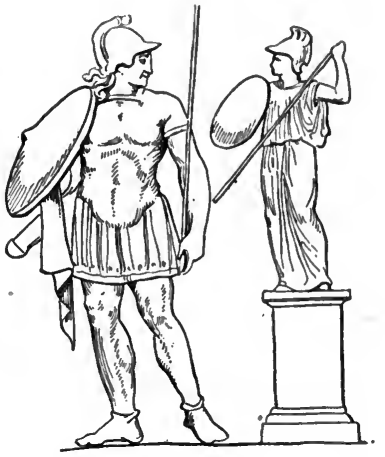

Roman Herald and law should everywhere have sovereign sway" (Livy, xxxiii, 33).

War with Antiochus of Syria (192-189 B. c.).-The cities of Greece generally seemed contented with their treatment at the hands of the Romans-except the members of the Etolian League. This restless people desired to be free from the protection of Rome, and appealed for aid to the king of Syria, Antiochus III. In response to this appeal the Syrian king landed in Greece with a small army of 10,000 . He was speedily defeated and driven into Asia Minor. The Roman armies followed him, and fought their first battle upon Asiatic soil at Magnesia (190 в. с.) - which proved a decisive victory. The Romans fought under the command of Lucius Scipio, who was accompanied and aided by his famous brother Africanus. Much of the territory conquered from Antiochus was turned 
over to Pergamum and Rhodes. The free states of Asia Minor were left independent under the protection of Rome. The

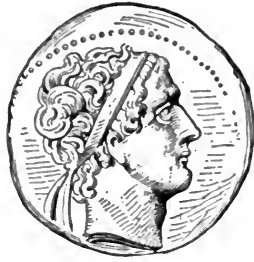

Axtiochus III. (Coin)

Romans then subdued the revolted Etolians and pacified the cities of Greece.

One of the conditions of the peace with Antiochus was the surrender of Hannibal, who had actively aided the king in the late war. But Hannibal fled from Syria; and being pursued by the Romans, this great soldier and enemy of Rome took his own life by poison.

The Third Macedonian War (171-168 в. C.).-Macedonia had been an ally of Rome during the late war with Antiochus; and at its close Philip was disappointed that he had not received some share of the conquered lands. But it was Rome's policy to strengthen the weak, and to weaken the strong. At the death of Philip V. his son Perseus came to the throne of Macedonia. This young king determined to throw off the dictation of Rome, to reëstablish the independence of his own kingdom. and to champion the rights of the Greek cities against the interference of Rome. The ambitious schemes of Perseus led to another war between Rome and Macedonia. After three unsuccessful campaigns, the Roman armies under Emilius Paullus (son of the consul slain at Cannæ) gained a decisive victory near Pydna (168 в. c.). Here the Macedonian phalanx fought its last great battle; and the Roman legions gave a new evidence of their superior strengif. Macedonia was now broken up into four separate districts, which were to be governed by their own officers, but which were forbidden to have any relations with one another.

All the chief men of Greece who had given any aid to the Macedonian king were transported to Italy, where they could not stir up a revolt in their native country. Among the Achæan captives was the historian Polyb'ius, who now gathered the materials of his great work on Roman history. 


\section{Reduction of the Roman Conquests}

Change of the Roman Policy.-We sometimes think that Rome started out upon her great career of conquest with a definite purpose to subdue the world, and with clear ideas as to how it should be governed. But nothing could be farther from the truth. She had been drawn on from one war to another, often against her own will. When she first crossed the narrow strait into Sicily at the beginning of the first Punic war, she little thought that in a hundred years her armies would be fighting in Asia; and when in earlier times she was compelled to find some way of keeping peace and order in Latium, she could not have known that she would, sooner or later, be compelled to devise a way to preserve the peace and order of the world. But Rome was ever growing and ever learning. She learned how to conquer before she learned how to govern. It was only after the third Macedonian war that Rome became convinced that her method of governing the conquered lands was not strong enough to preserve peace and maintain her own authority. She had heretofore left the conquered states to a certain extent free and independent. But now, either excited by jealousy or irritated by the intrigues and disturbances of the conquered peoples, she was determined to reduce them to a more complete state of submission.

Reduction of Macedonia and Illyricum.- She was especially convinced of the need of a new policy by the continued troubles in Macedonia: The experiment which she had tried, of cutting up the kingdom into four separate states, had not been entirely successful. To add to the disturbances, there appeared a man who called himself Philip. and who pretended to be the son of Perseus. He incited the people to revolt, and even defeated the Romans in a battle; but he was himself soon defeated and made a prisoner. The time had now come for Rome to adopt her new policy in respect to Macedonia. The previous divisions of the kingdom (p. 336) were abolished, 
and each city or community was made directly responsible to a governor sent from Rome. By this new arrangement, Macedonia became a Roman province $(146$ B. c.).

About this time-perhaps a little earlier-the king of Illyricum was accused of favoring the cause of Macedonia, and of

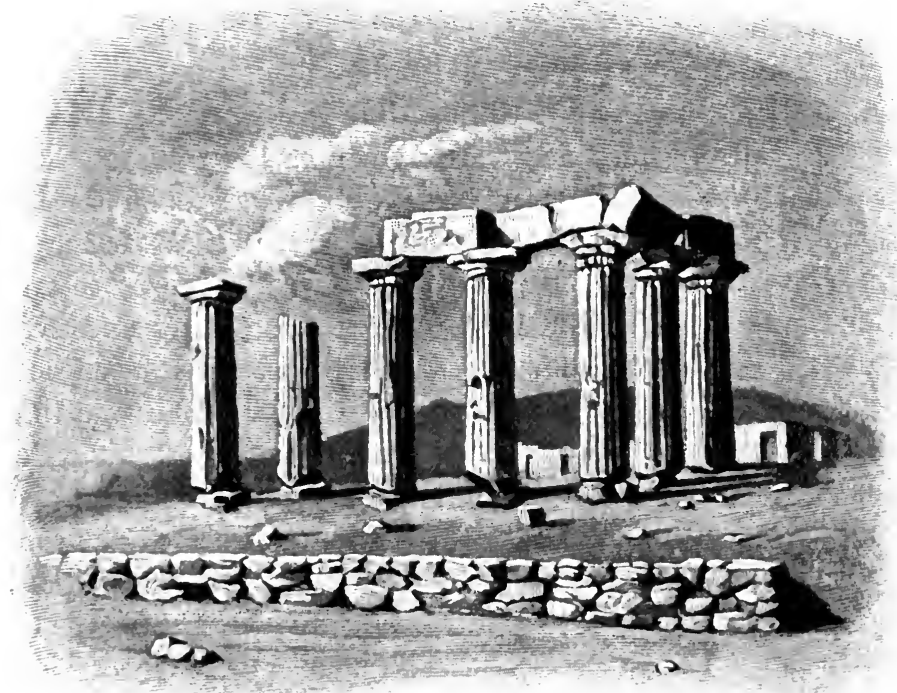

Ruins at Corinth

having formed a secret alliance with Perseus. The country was hence invaded by a Roman army; its king was deposed and a Roman governor appointed in his place. Thus Macedonia and Illyricum became the first two Roman provinces east of the Adriatic Sea.

Destruction of Corinth and Reduction of Greece.-The Achean Ieague, the capital city of which was Corinth, was now the only important independent state in the Hellenic. peninsula. This league was trying to exercise authority over 
all the cities of the Peloponnesus. But Sparta resisted, and appealed to Rome for protection. 'The commissioners sent by Rome to settle this difficulty were grossly insulted by the Achaan assembly sitting at Corinth. The Romans were now determined to break up the league. Corinth was ruthlessly destroyed (146 B. c.), and its art treasures were sent to Rome. 'The commander of the Roman army at this time was Mummius, a boorish man. The story is told that Mummius warned the sailors that if they destroyed or injured any of the Greek statues or pictures on their voyage "they must replace them with others of equal value." The destruction of Corinth was a barbarous act of war, such as no civilized nation has ever approved. Rome now applied to Greece her policy of isolation, and forbade all confederations among the cities. A few cities-Athens, Sparta, and Sicyon-were allowed to retain their freedom, while the rest of the cities were placed under the authority of the Roman governor of Macedonia. In later times Greece became a separate province, called Acha'ia.

The Third Punic War and Reduction of Africa.-Another example of the severe policy which Rome, was now adopting is seen in the destruction of Carthage. This city had been growing in prosperity since the second Punic war, and seemed to be exciting the envy, if not the fear, of Rome. The bitter jealousy of Rome was expressed by Cato the Censor, who ended every speech in the senate with the words_- "Carthage must be destroyed." Rome waited for a pretext to destroy the prosperity of her old and hated rival. This they soon found in the fact that Carthage had taken up arms against the neighboring kingdom of Numidia, which was an ally of Rome. Rome interfered and demanded that Carthage must, to insure peace, give up three hundred of her youths as hostages; then, that she must give up her arms and munitions of war; finally, that the city of Carthage itself must be abandoned. With this last unjust demand the Carthaginians refused to comply. Whereupon Rome invaded Africa with an army under Scipio 
Emilia'nus-the nephew of the great Africanus who had previously defeated the Carthaginians at /ama. History records no more heroic defense than that offered by the Carthaginians to the Roman armies. At last Carthage fell, and by command of the senate the city was consigned to the flames and its surviving inhabitants were carried away as captives. The destruction of Carthage took place in the same year $(146$ B. c.) in which Corinth was destroyed. The terrible punishment in-

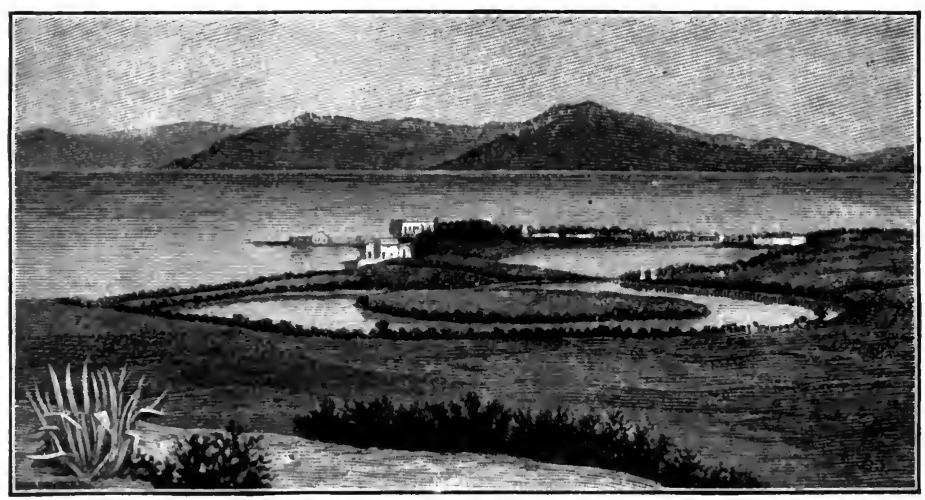

\section{Site of Carthage}

flicted upon these two cities in Greece and Africa was an evidence of Rome's grim policy to be absolutely supreme everywhere. Like Macedonia, the territory of Carthage, called "Africa," was reduced to the form of a province under a Roman governor, residing at Utica. It soon became a Romanized country. Its commerce passed into the hands of Roman merchants; the Roman manners and customs were introduced; and the Latin language became the language of the people.

Revolt and Subjugation of Spain.-While the Romans were engaged in creating the new provinces of Macedonia and Africa, they were called upon to maintain their authority in the old provinces of Spain and S.cily. We remember that, 
after the second Punie war, Spain was divided into two provinces, each under a Roman governor (see p. 331). But the Roman authority was not well established in Spain, except upon the eastern coast. The tribes in the interior and on the western coast were nearly always in a state of revolt. The most rebellious of these tribes were the Lusitanians in the west, in what is now Portugal; and the Celtiberians (see map, p. 324) in the interior, south of the Ibe'rus River. In their efforts to subdue these barbarous peoples, the Romans were themselves too often led to adopt the barbarous methods of deceit and treachery.

The war against the Lusitanians was disgraced by the treacherous conduct of the Roman general, Galba, and distinguished by the heroic deeds of the young Lusitanian leader, Viria'thus. But after nine years of resistance this tribe was obliged to submit to the Roman authority (138 в. с.).

The war against the Celtiberians centered about their chief stronghold, Numantia, a town south of the head waters of the Iberus. The defense of Numantia, like that of Carthage, was heroic and desperate. Its fate was also like that of Carthage. It was compelled to surrender $(133$ B. c.) to the same Scipio Amilianus. Its people were sold into slavery, and the town itself was blotted from the earth.

The Servile War in Sicily.-While Spain was being pacified, a more terrible war broke out in the province of Sicily. This was an insurrection of the slaves of the island. One of the worst results of the Roman conquests was the growth of the slave system. Immense numbers of the eaptives taken in war were thrown upon the market. One hundred and fifty thousand slaves had been sold by Emilius Paullus; fifty thousand captives had been sent home from Carthage. Italy and Sicily swarmed with a servile population. It was in Sicily that this system bore its first terrible fruit. Maltreated by their masters, the slaves rose in rebellion under a leader, called Eunus, who defied the Roman power for three years. Nearly two hun- 
PROGRTSSITF: MAT NO. 15.

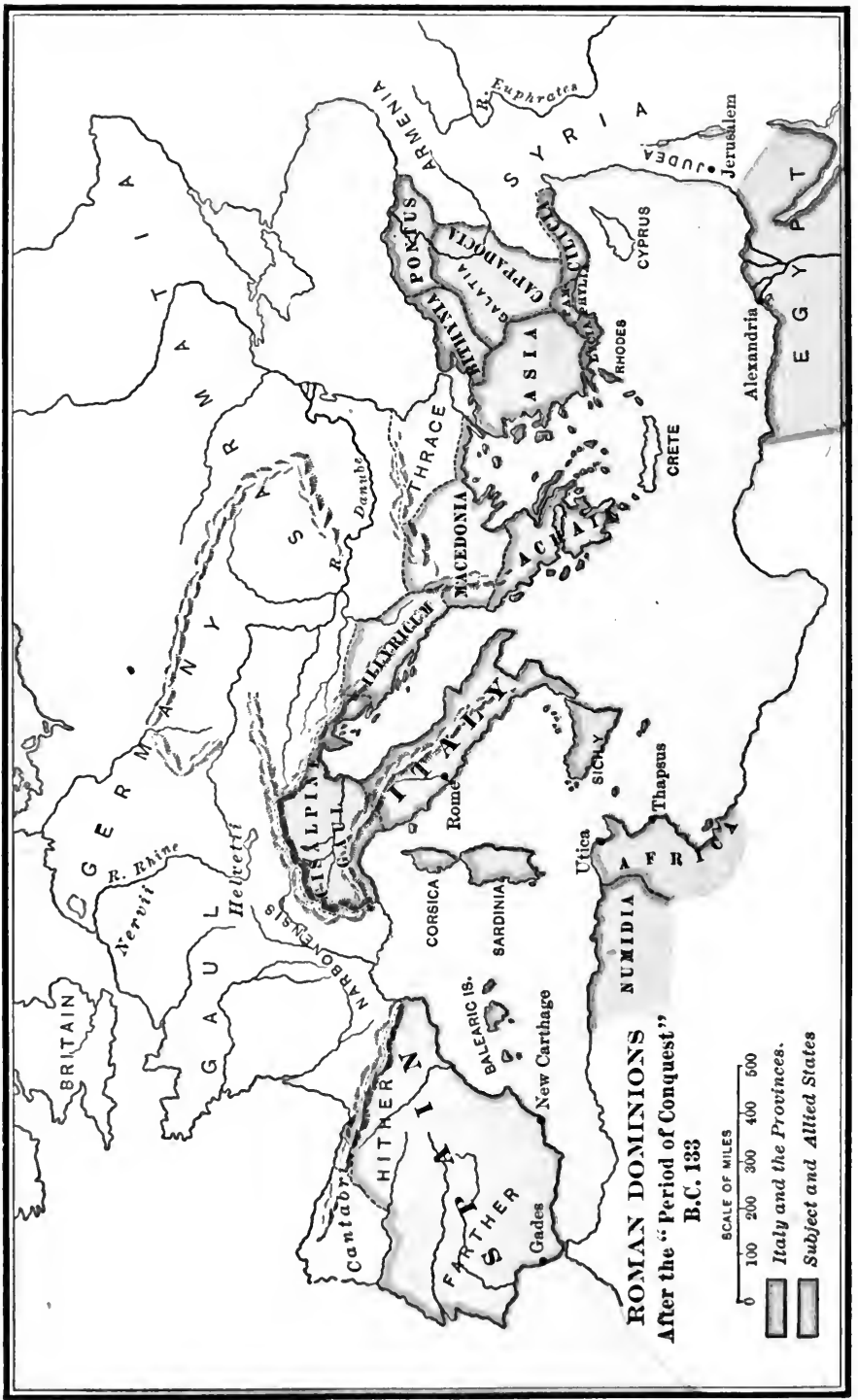


dred thousand insurgents gathered about his standard. Four Roman armies were defeated and Rome herself was thrown into consternation. After the most desperate resistanee, the rebellion was finally quelled and the island was pacified (132 D. C.).

Pergamum, the First Asiatic Province.-This long period of war and conquest, by which Rome finally obtained the proud position of mistress of the Mediterranean, was closed by the almost peaceful acquisition of a new province. The little kingdom of Pergamum, in Asia Minor, had maintained, for the most part, a friendly relation to Rome. When the last king, Attalus III., died (133 в. C.), having no legal heirs, he bequeathed his kingdom to the Roman people. This newly aequired territory was organized as a province under the name of "Asia." The smaller states of Asia Minor, and Egypt, still retained their peaceful and sub-

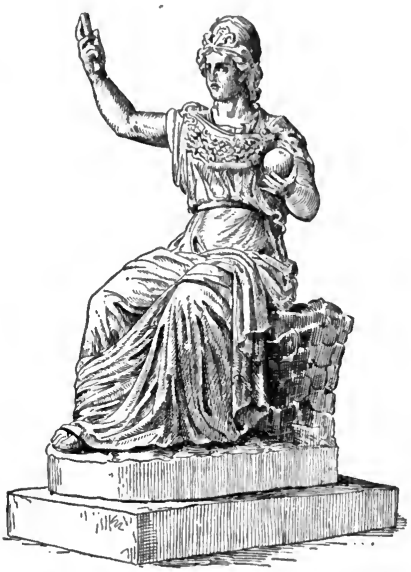

RoMe Mistress OF THE WORLD ordinate relation as dependencies. The supreme authority of Rome, at home and abroad, was now firmly established.

\section{SYNOPSIS FOR REVIEW}

I. The Wars with Macedonia and Syria.-Relation of Rome to the. East.-The First Macedonian War.--The Second Macedonian War.-The Liberation of Greece.-War with Antiochus of Syria.-The Third Macedonian War.

II. Renuction of the Roman Conquests.-Change of the Roman Policy.-Reduction of Macedonia and Illyricum.-Destruction of Corinth and Reduction of Greece.-The Third Punic War and Reduction of $\Lambda$ frica.-Revolt and Subjugation of Spain.-The Servile War in Sicily.-Pergamum, the First Asiatic Province. 


\section{REFERENCES FOR READING}

Pelham, Bk. III., Ch. 2, "Rome and the East" (18)."

How and Leigh, Chs. 23-27, "Fifty Years of Conquest"; pp. 25:3. 261 (the eastern states and their rulers) (18).

Liddell, Bk. V., "kome and the Conquest of the World" (18).

"Schuckburgh, Ch. 33, "Wars in Spain" (18).

Mommsen, Vol. II., Bk. III., Ch. 8, "The Eastern States and the Second Macedonian War" (18).

Ihne, History, Vol. III., Bk. V., Ch. 4, "Fall of Macedonia and Greece" (18).

Plutarch, "Flamininus" (26).

Livy, Bk. XXXIII., Chs. 32, 33 (the liberation of Greece) (25).

\section{CHAPTER XXIII}

\section{ROME AS A WORLD POWER}

\section{The Conquests and the Government}

Effects of the Conquests.-By her conquest of the Mediterranean lands Rome had become a great world power. We may well wonder what would be the effect of these conquests upon the character of the Roman people, upon their government, and upon their civilization. Many of these effects were no doubt very bad. By their conquests the Romans came to be ambitious, to love power for its own sake, and to be oppressive to their conquered subjects. By plundering foreign countries, they also came to be avaricious, to love wealth more than honor, to indulge in luxury, and to despise the simplicity of their fathers. But still it was the conquests that made Rome the great power that she was. By bringing foreign nations under her sway, she was obliged to control them, and to create a system of law by which they could be governed. In spite of all its fanlts, her government was the most successful that had

'The figure in parenthesis refers to the number of the topic in the. Appendix, where a fuller title of the book will be found. 
ever existed up to this time. It was the way in which Rome secured her conquests that showed the real eharacter of the Roman people. 'The chief effect of the conquests was to transform Rome from the greatest conquering people of the world, to the greatest governing people of the world.

The New Nobility.-During the whole period that we are now studying, the Roman government was a republic. But it would hardly be correct to think of Rome at any time as a democratic republic. When the old kingdom was overthrown, the new republican government passed into the hands of the patrician class. And when the political distinction between patricians and plebeians was broken down, there was soon developed a new aristocracy, made up of the richest and most influential men of both orders, which got control of the government. This new nobility was not based upon birth, like the old patriciate, but upon office-holding; and it was only the superior or so-called curule offices-those of consul, dictator, prætor, and curule ædile-that conferred distinction. All those who could boast of an ancestor that had held such an office were regarded as nobles (nobiles); and their superior distinction consisted in the right to set up in their home the aneestral image (jus imaginis). It is true that any full Roman citizen had the legal right to be elected to a curule office; but, as a matter of fact, the noble families were able by their wealth to influence the elections so as practically to retain these offices in their own hands.

The Nobility and the Senate.-But it was not simply the holding of the curule offices that gave to the new nobility their great political power. It was the fact that the eurule offices opened the way to the senate. The members of the senate were chosen by the censor, who was obliged to place upon his list, first of all, those who had held a curule office. On this account, the nobles had the first claim to a seat in the senate; and, consequently, they eame to form the great body of its members. When a person was once chosen senator 
he remained a senator for life, unless disgraced for gross misconduct. In this way the nobles gained possession of the senate, which became, in fact, the most permanent and powerful branch of the Roman government. It managed the finances of the state; controlled the erection of public works; directed the foreign policy; administered the provinces; determined largely the character of legislation; and was, in fact, the real sovereign of the Roman state.

The Decline of the Assemblies.-As the power of the senate increased, that of the popular assemblies declined. The old patrician assembly of the curies (comitia curiata) had long since been reduced to a mere shadow. But the other two assemblies - that of the centuries and that of the tribes-still held an important place as legislative bodies. But there were two reasons why they declined in influence. The first reason was their unwieldy character. As they grew in size and could only say $Y e s$ or No to the questions submitted to them, they were made subject to the influence of demagogues, and lost their independent position. The second reason for their decline was the growing custom of first submitting to the senate the proposals which were to be passed upon by them. So that, as long as the senate was so influential in the state, the popular assem-blies were weak and inefficient.

\section{Rome AND the Provinces}

Organization of the Provinces.-The most important feature of the new Roman government was the organization of the provinces. There were now eight of these provinces: Sicily, acquired as the result of the first Punic war; (2) Sardinia and Corsica, obtained during the interval between the first and second Punic wars; (3) Hither Spain and (4) Farther Spain, acquired in the second Punic war: (5) Illyricum, reduced after the third Macedonian war: (6) Macedonia (towhich Achaia was attached), reduced with the destruction of Corinth; 
(7) Africa, organized after the third Punic war; and (8) Asia, bequeathed by Attalus III., the last king of Pergamum.

The method of organizing these provinces was in some respects similar to that which had been adopted for governing the cities in Italy. Rome saw clearly that to control these newly conquered cities and communities, they must, like the cities of Italy, be isolated, that is, separated entirely from one another, so that they could not combine in any effort to resist her authority. Every city was made directly responsible to Rome. The great difference between the Italian and the provincial town was the fact that the chief burden of the Italian town was to furnish military aid-soldiers and ships; while that of the provincial town

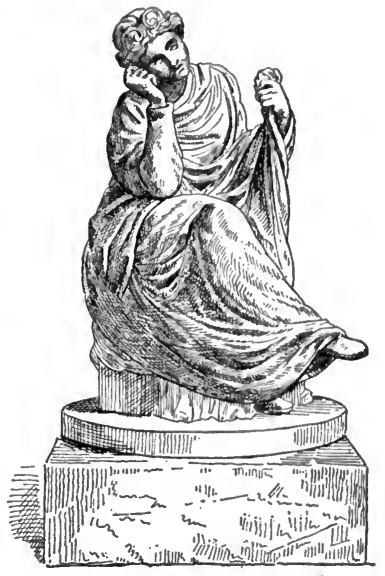

The Captive Province was to furnish tribute-money and grain. Another difference was that Italian land was generally free from taxes, while provincial land was subject to tribute.

The Provincial Governor. $-A$ province might be defined as a group of conquered cities, outside of Italy, under the control of a governor sent from Rome. At first these governors were prætors, who were elected by the people. Afterward they were proprætors or proconsuls-that is, persons who had already served as prætors or consuls at Rome. The governor held his office for one year; and during this time was the supreme mili- . tary and civil ruler of the province. He was commander in chief of the army, and was expected to preserve his territory from internal disorders and from foreign invasion. He controlled the collection of the taxes, with the aid of the quæstor, who kept the accounts. He also administered justice between the provin- 
cials of different cities. Although the governor was responsible to the senate, the welfare or misery of the provincials depended largely upon his own disposition and will.

The Towns of the Province.-All the towns of the province were subject to Rome: but it was Rome's policy not to treat them all in exactly the same way. Like the cities of Italy, they were graded according to their merit. Some were favored, like Gades and Athens, and were treated as allied towns (civitates fæderatce); others, like Utica, were free from tribute (immunes); but the great majority of them were considered as tributary (stipendiarica). But all these towns alike possessed local self-government, so far as this was consistent with the supremacy of Rome; that is, they retained their own laws, assemblies, and magistrates.

The Administration of Justice.-In civil matters, the citizens of every town were judged by their own magistrates. But when a dispute arose between citizens of different towns, it was the duty of the governor to judge between them. At the beginning of his term of office, he generally issued an edict, setting forth the rules upon which he would decide such differences. Each succeeding governor reissued the rules of his predecessor, with the additions which he saw fit to make. In this way there grew up a body of common law which applied to the whole province and was intended to afford justice in cases not reached by the existing town laws. The people of the province were thus united under a common judicial system, and their rights were protected in their dealings with one another.

The Collection of Taxes.-The Roman revenue was mainly derived from the new provinces. But instead of raising these taxes directly through her own officers, Rome let out the business of collecting the revenue to a set of money dealers, called publica'ni. These persons agreed to pay into the treasury a certain sum for the right of collecting taxes in a certain province. Whatever they collected above this sum, they appropri- 
ated to themselves. 'This rude mode of collecting taxes, called "farming" the revenues, was unworthy of a great state like Rome, and was the chief cause of the oppression of the provincials. The governors, it is true, had the power of protecting the people from being plundered. But as they themselves received no pay for their services, except what they could get out of the provinces, they were too busy in making their own fortunes to watch closely the methods of the tax-gatherers.

\section{The New Civilization}

Foreign Influences; Hellenism.-When we think of the conquests of Rome, we usually think of the battles which she fought, of the armies which she defeated, and the lands which she subdued. But these were not the only conquests which she made. She appropriated not only foreign lands, but also foreign ideas. While she was plundering foreign temples, she was obtaining new ideas of religion and art. The educated and civilized people whom she captured in war and of whom she made slaves, often became the teachers of her children and the writers of her books. In such ways as these Rome came under the influence of foreign ideas. The most powerful of these foreign influences was that of Greece. The conquest of Greece led to the introduction of Hellenism into Rome. We might say that when Greece was conquered by Rome, Rome was civilized by Greece. These foreign influences were seen in her new ideas of religion and philosophy, in her literature, her art, and her manners.

The Roman Religion.-As Rome came into contact with other people, we can see how her religion was affected by foreign influences. The worship of the family remained much the same; but the religion of the state became considerably changed. It is said that the entire Greek Olympus was introduced into Italy. The Romans adopted the Greek ideas and stories regarding the gods; and their worship became more 
showy and elaborate. Even some of the superstitious and fantastic rites of $A$ sia found their way into Rome. These changes did not improve the religion. On the contrary, they made it more corrupt. 'The Roman religion, by absorbing the various ideas of other people, became a world-wide and composite form

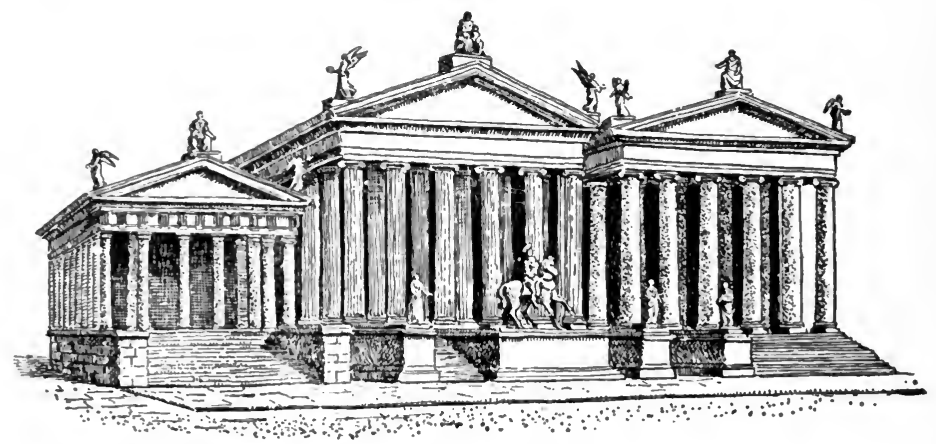

Temples of Loyalty, Juno, and Hope

of paganism. One of the redeeming features of the Roman religion was the worship of exalted qualities, like Honor and Virtue; for example, alongside of the temple to Juno, temples were also erected to Loyalty and Hope.

Roman Philosophy.-The more educated Romans lost their interest in religion, and betook themselves to the study of Greek philosophy. They studied the nature of the gods and the moral duties of men. In this way the Greek ideas of philosophy found their way into Rome. Some of these ideas, like those of the Stoies, were elevating, and tended to preserve the simplicity and strength of the old Roman character. But other ideas, like those of the Epicureans, seemed to justify a life of pleasure and luxury.

Roman Literature.-Before the Romans came into contact with the Greeks, they did not have anything which can properly be called a literature. They had. it is true, certain crude verses and ballads; but it was the Greeks who first 
taught them how to write. It was not until the close of the first Punic war, when the Greek influenee became strong, that we begin to find the names of any Latin authors. The first author, Androni'cus, who is said to have been a Greek slave, wrote a Latin poem in imitation of Homer. Then eame Nævius, who combined a Greek taste with a Roman spirit, and who wrote a poem on the first Punic war; and after him, Ennius, who taught Greek to the Romans, and wrote a great poem on the history of Rome, called the "Annals." The Greek influence is also seen in Plautus and Terence, the greatest writers of Roman comedy; and in Fabius Pictor, who wrote a history of Rome, in the Greek language.

Roman Art.-As the Romans were a practical people, their earliest art was shown in their buildings. From the Etruscans they had learned to use the areh and to build strong and massive structures. But the more refined features of art they obtained from the Greeks. While the Romans could never hope to acquire the pure æsthetic spirit of the Greeks, they were inspired with a passion for collecting Greek works of art, and for adorning their buildings with Greek ornaments. They imitated the Greek models and professed to admire the Greek taste; they came to be, in fact, the preservers of Greek art.

Roman Manners and Morals.-It is difficult for us to think of a nation of warriors as a nation of refined people. The brutalities of war seem inconsistent with the finer arts of living. But as the Romans obtained wealth from their wars, they affected the refinement of their more cultivated neighbors. Some men, like Scipio Africanus, looked with favor upon the introduction of Greek ideas and manners; but others, like Cato the Censor, were bitterly opposed to it. When the Romans lost the simplicity of the earlier times, they came to indulge in luxuries and to be lovers of pomp and show. They loaded their tables with rich services of plate; they ransacked the land and the sea for delicacies with which to please their palates. Roman culture was often more artificial than real. The survival of the 
barbarous spirit of the Romans in the midst of their professec refinement is seen in their amusements, especially the gladiatorial shows, in which men were forced to fight with wild beasts and with one another to entertain the people.

In conclusion, we may say that by their conquests the Romans became a great and, in a certain sense, a civilized people,

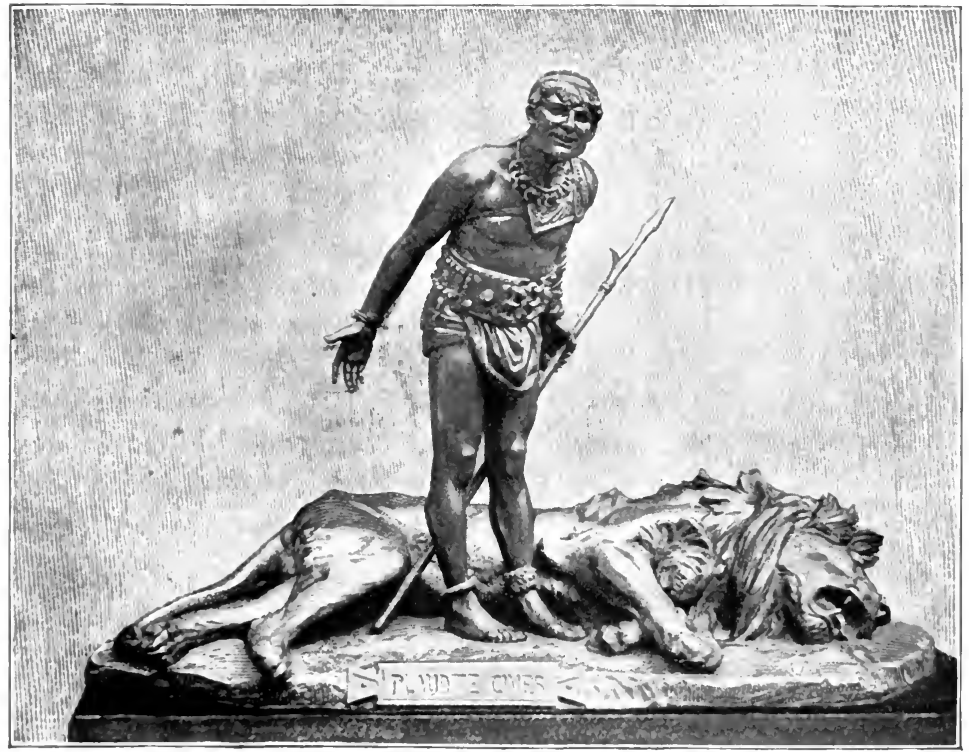

The Glaidator

who appropriated and preserved many of the best elements of the ancient world. They began to show a genius for political organization far superior to that hitherto shown by any other nation, and to develop a progressive system of law based upon broader ideas of justice. But still they came to be selfish, ambitious, and avaricious, and failed to acquire the genuine taste and generous spirit which belong to the highest type of human culture. 


\section{SYNOPSIS FOR REVIEW}

I. The Conquests and the Government.-Effects of the Conquests.-The New Nobility.-The Nobility and the Senate.-The Deeline of the Assemblies.

II. Rome and tile Provinces.-Organization of the Provinces. -The Provineial Governor.-The Towns of the Provinee.-The Administration of Justice.-The Collection of Taxes.

III. ThiE New Crvilization.-Foreign Influences; Hellenism.The Roman Religion.-Roman Philosophy.-Roman Literature.Roman Art.-Roman Manners and Morals.

\section{REFERENCES FOR READING}

Pelham, Bk. III., Ch. 3, "The Roman State and People" (18)." How and Leigh, Chs. 28-30, "Internal History" (266-146 B. c.) (18). Merivale, General History, Chs. 26, 27, "Rome after the Conquests" (18).

Liddell, Chs. 49, 50, "Rome at the Close of the Conquests" (18). Nommsen, Vol. II., Bk. III., Ch. 11, "The Government and the Governed"; pp. 470-491 (the new Hellenism and introduction of foreign luxuries); pp. 500-518 (the Roman drama) (18). Abbott, Ch. 5, "The Supremacy of the Nobilitas" (22).

Harper's Classical Dictionary, "Provineia," "Stipendium," "Publicani," "Veetigalia" (19).

Granrud, Third Period, "The Supremacy of the Senate" (22).

Taylor, pp. 212-234 (the supremacy of the senate) (22).

Arnold, Ch. 1, "What a Province Was"; Ch. 2, "Period of the Republic"; Ch. 6, "Towns in the Provinces" (22).

Friedländer, pp. 21-30 (the classes in the towns); pp. 30-43 (the finances in the towns) (19).

Seignobos, Ch. 11, "The Results of Conquest"; Ch. 12, "Social and Politieal Transformation" (18).

Munro, Source Book, Part VII., "Results of Foreign Wars" (25). Plutarch, "Cato the Censor" (26).

${ }^{1}$ The figure in parenthesis refers to the number of the topic in the Appendix, where a fuller title of the book will be found. 


\section{PERIOD III. TRANSITION FROM THE REPUBLIO TO THE EMPIRE (133-31 B. O.)}

\section{CHAP'TER XXIV}

\section{THE REVOLUTION UNDER THE GRACCHI}

\section{Causes of Civil Discontent}

General Decay of Patriotism.-We have seen some of the more direct results of the wars and conquests of Rome-in the extension of her authority over foreign lands and in making her a world power, in the changes brought about in the government, and in the introduction of new elements of civilization. But if we look a little decper into Roman society we shall see that her conquests also brought with them many evils, which resulted in civil strife, and finally in the overthrow of the republic. One great evil which now began to show itself was the decay of patriotism among the Roman people. While the wars may have been looked upon by some as a means to glorify the Roman state, they were regarded by many as affording an opportunity to appropriate the spoils of conquest. The men who conducted these wars and who ruled the conquered land, were often more anxious to benefit and enrich themselves than to promote the public good. Those who were intrusted with official duties became more devoted to their own interests than to the common interests of the whole people.

Class Distinctions. - We may find some special causes of civil discontent in the wide separation between the different classes 
of Roman society, each having its own distinct interests. These different classes may be arranged as follows:

(1) First and above all others were the aristocratic classes. These consisted of (a) the senatorial order-men who kept control of the higher offices, who furnished the members of the senate, and who really ruled the state; and (b) the equestrian order-men who were called equites, or knights, on account of their great wealth, who formed the moneyed class, the capitalists of Rome, and whe made their fortunes by all sorts of speculation, especially by gathering the taxes in the provinces.

(2) Next below the aristocratic classes came the body of poorer Roman citizens. These comprised (a) the great mass of the city population-the poor artisans and paupers, who formed a rabble and the materials of a mob, and who lived upon public charity and the bribes of office-seekers, and were amused by public shows given by the state or by rich citizens; and (b) the poor country farmers living upon the Roman domain-the peasants, many of whom had been deprived of their lands by rich creditors or by the avaricious policy of the government.

(3) Outside of the Roman domain were the non-citizen classes. These included (a) the Latin colonists, who were settled upon conquered lands in Italy, who had practically no political rights, and who were in very much the same social condition as the Roman peasant's; (b) the Italian allies, who had been subdued by Rome in early times, and had been given none of the rights of citizenship; and (c) the provincials, outside of Italy, some of them favored by being left free from taxation, but the mass of them subject to the Roman tribute, and all of them excluded from the rights and privileges of citizens.

(4) Finally, if we go to the very bottom of the Roman population, we find the slaves, having none of the rights of citizens or of men. The house slaves were treated with some consideration; but the field slaves were treated wretchedly, chained in gangs by day and confined in dungeons by night.

Economic Conditions.-Never was the economic condition of 
the Roman people more deplorable than it was after the period of the great conquests. Not only had the population of Italy been depleted by the wars, but there were several causes which tended to keep the people in a state of poverty and distress. Among these were:

(1) The unequal distribution of wealth.-Rome had acquired great riches as the result of her wars; but this wealth was appropriated by the moneyed class-the speculators and contractors. The desire to make money and to accumulate wealth became a passion among this class. But the poorer classes received no benefit from this increase of wealth; so that the rich were actually becoming richer, and the poor poorer.

(2) The growth of large estates.-The public lands of Italy passed into the hands of a comparatively few landlords. The Licinian laws, enacted more than two centuries before (p. 296), had become a dead letter; and the small farms had practically disappeared. The growth of large estates thus benefited one class of the people at the expense of the rest. The evils of such a system were afterward pointed out by Pliny, who said that it was the large estates which ruined Italy.

(3) The decay of agriculture and of the peasant class.-The lands of Italy ceased for the most part to be tilled, since the large estates were turned into cattle ranches and sheep pastures. The raising of grain ceased to be profitable, as agrieultural products could be obtained more cheaply from Egypt and the provinces. The absorption of the small farms and the decline of agriculture led to the decay of the peasant class. The small farmers were driven into the army; and if they returned from the field, they flocked to Rome to reënforce the city rabble.

(4) The evils of slave labor.-The great inerease in the num. ber of slaves brought into Italy from the conquered lands not only tended to degrade the condition of the slaves themselves. but also to render it unprofitable to employ the free laborers. In addition to the loss of their lands and the inability to obtain capital, the common people were thus deprived of the 
value of their labor; and hence they lost the last means of obtaining an honest living.

Political Evils.-There were also political reasons for the discontent which prevailed among the Roman people and which was destined to break forth in riot and revolution. For example, we may mention:

(1) The selfish rule of the senate.-The absorption of political power by the senate made this body responsible for the evils of the state, so far as these evils could be remedied by legislation. But the senate was a body of oligarchs, ruling the people for its own benefit. Its policy seemed to be to benefit the aristocratic classes only, having little concern for the welfare of the great body of Roman citizens and subjects.

(2) The practical disfranchisement of the people.-With the growing power of the senate, the popular assemblies, as we have seen (p. 346), were less and less important as organs of legislation. This means that the political rights which the people legally possessed had little real significance. Their elections were controlled by demagogues and influenced by bribery; and they could pass upon no laws which were not submitted to them. By thus being deprived of an effective voice in the government, it is hardly too much to say that the people were practically disfranchised.

(3) The abandonment of the policy of incorporation.-We know how the early state had become strong by the incorporation of its subjects. But this policy had been abandoned after the introduction of the plebeians. With the conquest of Italy and the provinces millions of new subjects had been brought under the Roman authority, but not admitted to the Roman state. The new subjects in Italy-that is, the Latin colonists and the Italian allies-were now desirous of being admitted to political rights; although it is difficult for us to see how their condition would have been improved without some radical reforms in the government.

(4) The oppression of the provinces.-The inhabitants of the MOREY'S ANCIENT HIST. - 21 
provinces were especially the vietims of Roman misrule. On account of the wretched system of taxation the provincials held their property at the disposal of the tax-gatherer. 'The property that was left by the tax-gatherel was often seized by the governor of the province to add to his spoils of office. It is very seldom that we hear of the governor being called to account for his acts of oppression.

From the enumeration of the evils in the Roman state we need not wonder at the prevailing discontent and the disposition to revolt against the existing government. The people, after a time, became divided into two principal parties: the aristocratic party (optima'tes), or those who supported the policy of the senate; and the popular party (popula'res), or those who sought to bring about reform. The conflicts between these factions resulted in revolution, in civil wars, and finally in the overthrow of the republic.

\section{The Reforms of Tiberius Gracchus}

Character of Tiberius Gracchus.-The first serious attempt to remedy the existing evils was made by 'Tibe'rius Sempronius Gracehus. He was the elder of two brothers who sacrificed their lives in efforts to benefit their fellow-citizens. Their mother was the noble-minded Cornelia, the daughter of the great Scipio Africanus. Tiberius when a young man had served in the Spanish army under Scipio Emilianus, the distinguished Roman who conquered Carthage and Numantia. It is said that when Tiberius Gracchus passed through Etruria, on his way to and from Spain, he was shocked to see the fertile fields cultivated by gangs of slaves, while thousands of free citizens were living in idleness and poverty. He was a man of refined nature and a deep sense of justice, and he determined to do what he could to remedy these evils.

His Agrarian Laws.- Tiberius Gracehus was elected tribune and began his work of reform in $133 \mathrm{~B}$. c. He believed that 
the wretched condition of the Roman people was due chicfly to the unequal division of the public land, and especially to the failure to enforee the Lieinian laws. He therefore proposed to revive these laws; to limit the holding of public land to five hundred iugera (about three hundred acres) for each person; to pay the present holders for any improvements they had marle; and then to rent the land thus taken up to the poorer

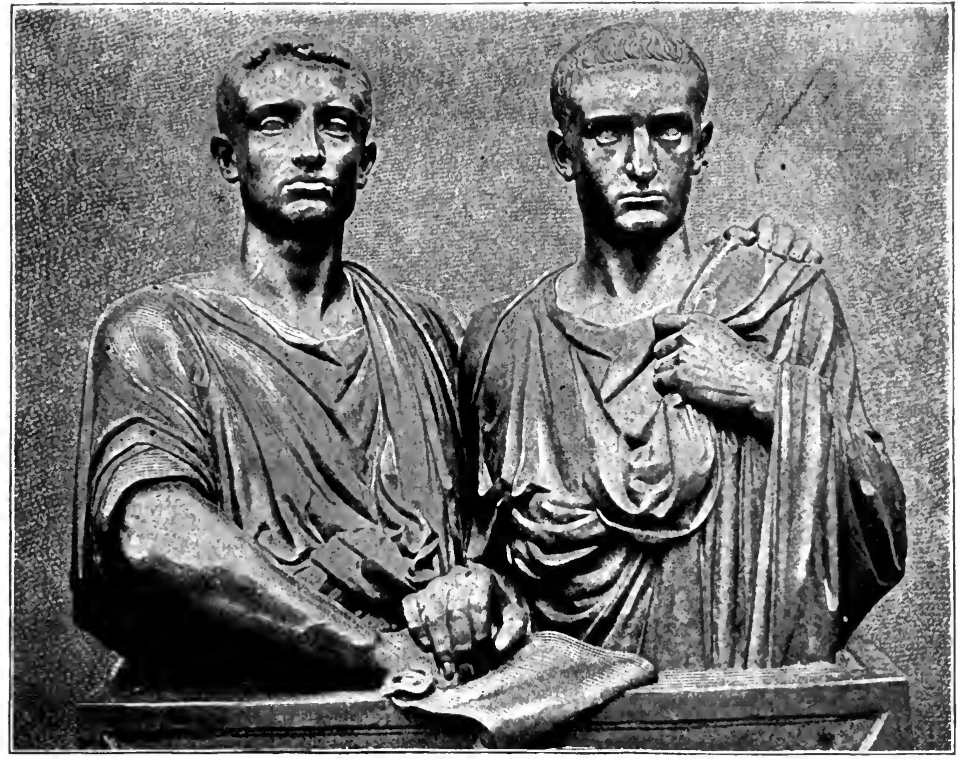

The Gracchi

class of citizens. This seemed fair enough; for the state was the real owner of the public land, and could do what it wished with its own. But the rich landlords, who had held possession of this land for so many years, looked upon the measure as the same thing as taking away their own property; and there immediately arose a fierce conflict between the old senatorial party and the followers of Tiberius. 
His Illegal Action.-Tiberius determined to pass his law in the assembly, without the approval of the senate. The senate, on the other hand, was equally determined that the law should not be passed. Accordingly, the senators induced one of the tribunes, whose name was M. Octa'vius, to put his "veto" upon the passage of the law. 'This act of Octavius was entirely legal, for he did what the law gave him the right to do. Tiberius, on the other hand, in order to qutdo his opponent, had recourse to a high-handed measure. Instead of waiting a year for the election of new tribunes who might be devoted to the people's cause, he called upon the people to deprive Octavius of his office. This was an illegal act, because there was no law which authorized such a proceeding. But the people did as Tiberius desired, and Octavius was deposed. The law of Tiberius was then passed in the assembly of the tribes, and three commissioners were chosen to carry it into effect.

Fall of Tiberius Gracchus.-The law of Tiberius and the method which he had used to pass it increased the bitterness between the aristocratic party and the popular party. Contrary to law Tiberius announced himself as a candidate for reëlection. The day appointed for the election came. Two tribes had already voted for the reëlection of Tiberius, when a band of senators appeared in the Forum, headed by Scipio Nasi'ca, armed with sticks and clubs; and in the riot which ensued Tiberius Gracchus and three hundred of his followers were slain. 'This was the first blood shed in the civil wars of Rome. The killing of a tribune by the senators was as much an illegal act as was the deposition of Octavius. Both parties had disregarded the law, and the revolution was begun.

\section{The Reforms of Gatus Gracchos}

The Rise of Gaius Gracchus.- $-\Lambda$ fter the death of Tiberius his law was for a time carried into execution. Thi commissioners proceeded with their work of redividing the land. 
But the people were for a time without a real leader. The cause of reform was then taken up by Gaius Gracchus, the brother of Tiberius, and the conflict was renewed. Gaius was in many respects an abler man than 'liberius. No more sincere and patriotic, he was yet a broader statesman and took a wider view of the situation. He did not confine his attention simply to relieving the poor eitizens. He believed that to rescue Rome from her troubles, it was necessary to weaken the power of the senate, whose selfish and avaricious policy had brought on these troubles. He also believed that the Latins and the Italians should be protected, as well as the poor Roman citizens.

His Efforts to Benefit the People.-When Gaius Gracchus obtained the position of tribune (123 B. c.) his influence for a time was all-powerful. He was eloquent and persuasive, and practically had the control of the government. From his various laws we may select those which were the most important, and which best show his general policy. First of all, he tried to help the people by a law which was really the most mischievous of all his measures. This was his famous "corn law." It was intended to benefit the poor population in the city, which was at that time troublesome and not easy to control. The law provided that any Roman citizen could receive grain from the public storehouses for a certain price less than its cost. Gaius may not have known what evil effect this law was destined to produce. But it insured his popularity with the lower classes. He then renewed the agrarian laws of his brother; and also provided for sending out colonies of poor citizens into different parts of Italy, and even into the provinces.

His Effort to Weaken the Senate.-But Gaius believed that such measures as these would afford only temporary relief, as long as the senate retained its great power. It was, of course, impossible to overthrow the senate. But it was possible to take from it some of the powers which it possessed. 
From the senators had hitherto been selected the jurors (iu'dices) before whom were tried cases of extortion and other crimes. By a law Gaius took away from the senate this right to furnish jurors in criminal cases, and gave it to the equites, that is, the wealthy class outside of the senate. This gave to the equites a more important political position, and drew them over to the support of Gains, and thus tended to split the aristocratic classes in two. The senate was thus deprived not only of its right to furnish jurors, but also of the support of the wealthy men who had previously been friendly to it. This was a great triumph for the popular party; and Gaius looked forward to another victory.

His Effort to Enfranchise the Italians.-When he was reelected to the tribunate Gaius Gracchus came forward with his grand scheme of extending the Roman franchise to the people of Italy. This was the wisest of all his measures, but the one which cost him his popularity and influence. It aroused the jealousy of the poorer eitizens, who did not wish to share their rights with foreigners. The senators took advantage of the unpopularity of Gaius, and now posed as the friends of the people. They induced one of the tribunes, by the name of Drusus, to play the part of a demagogue. Drusus proposed to found twelve new colonies at once, each with three thousand Roman eitizens, and thus to put all the reforms of Gaius Gracchus into the shade. The people were deceived by this stratagem, and the attempt of Gaius to enfranchise the Italians was defeated.

His Failure and Death.-Gaius did not succeed, as he desired, in being elected tribune for the third time. A great part of the people soon abandoned him, and the ascendency of the senate was again restored. It was not long before a new law was passed which prevented any further distribution of the public land (lex Thoria). Gaius failed to bring about the reforms which he attempted; but he may be regarded as having accomplished three things which remained after his death: 
(1) the elevation of the equestrian order; (2) the establishment of the Roman poor law, or the system of grain largesses; and (3) the extension of the colonial system to the provinces. He lost his life in a tumult in which three thousand citizens were slain (121 B. C.).

'Thus' in a similar way perished the two Gracchi, who had attempted to rescue the Roman people from the evils of a corrupt government. Their efforts at agrarian reform did not produce any lasting effect; but they pointed out the dangers of the state, and drew the issues upon which their successors continued the conflict. Their career forms the first phase in the great civil conflict at Rome.

\section{SYNOPSIS FOR REVIEW}

I. Causes of Civil Discontentr-General Decay of Patriotism.-Class Distinctions.-Economic Conditions.-Political Evils.

II. The Reforms of Tiberius Gracchus.-Character of Tiberius Gracchus.-His Agrarian Laws.-His Illegal Action.-Fall of Tiberius Gracchus.

III. The Reforms of Gaius graccuus.-The Rise of Gains Gracchus.-His Efforts to Benefit the People.-His Effort to Weaken the Senate.-His Effort to Enfranchise the Italians.His Failure and Death.

\section{REFERENCES FOR READING}

Pelham, Bk. IV., Ch. 1, "From the Gracchi to Sulla" (18)." Beesly, Ch. 1, "Antecedents of the Revolution" (18).

Ihne, History, Vol. IV., Bk. VII., Ch. 1, "Political and Economical Conditions"; Ch. 3, "Scipio Amilianus" (18).

How and Leigh, Ch. 33, "Internal Affairs and Tiberius Gracchus"; Ch. 34, "Gaius Gracchus" (18).

Taylor, Ch. 9, "The Reformers" (22).

Mommsen, Vol. II., Bk. III., Ch. 12, "Management of Land” (18). — Abridged, Ch. 20, "Reforms of the Gracchi" (18).

Harper's Classical Dictionary, "Agrariæe Leges," "Equites" (19). Smith, Dictionary, "Servus, 22" (the position of slaves) (19). Plutarch, "Tiberius Gracchus," "Gaius Gracchus" (26).

${ }^{1}$ The figure in parenthesis refers to the number of the topic in the Appendix, where a fuller titie of the book will be found. 


\section{CHAPTER XXV}

\section{THE LEADERSHIP OF MARIUS AND SULLA}

\section{The Rise of Marius}

The Rule of the Restoration.-The Gracchi had failed. The senate and the aristocracy were too strongly intrenched to be overthrown by the tribunes, even though supported by the popular assembly. Hence with the death of these reformers the senate was restored to its previous position as the chief ruling body of the state. The government became more corrupt than ever before. The senators ruled to enrich themselves, while the real interests of the people were forgotten. On the other hand, the people had no capable leaders, and their cause for a time seemed lost. It is true that the people had learned something from the revolutionary attempts of the Gracchi. They had learned that they could pass laws, even without the approval of the senate; and that they could obstruct, if they could not overthrow, the policy of the nobles. The next issues between the people and the aristocracy were upon questions not of domestic, but of foreign policy. But unfortunately, when questions of war became mixed up with questions of politics, it eame to pass that both parties were led to seek the support of the army.

The War with Jugurtha (111-105 в. c.).-It was a border war in Africa that gave the people their first opportunity to interfere with the foreign policy of the senate. The kingdom of Numidia was an ally of Rome. It was now disturbed by the attempt of a usurper. named Jugur'tha, to get control of the kingdom. The senators undertook to settle this question; but 
they were evidently more influenced by Jugurtha's gold than by any sense of justice. Jugurtha bought the Roman commissioners sent to Africa to investigate the condition of affairs. He then bought the consul sent by the senate to conduct the war against him; and when he was summoned to Rome to testify against the guilty parties, he bribed a tribune to veto the proceeding. The indignation of the people became so great that the senate was forced to send an able commander, the consul Cæcil'ius Metel'lus, to conduct the war in Africa. But as the people became conscious of their power, they determined to join issue with the senate upon the appointment of a new commander. Metellus was an aristocrat; and when his term of office had expired the people elected as con-

- sul his lieutenant, Gaius Ma'rius, a man of humble origin, but an able soldier. Marius was assigned to the command; he soon defeated Jugurtha, brought $\mathrm{him}$ in chains to Rome, and became the people's hero.

\section{War with the Cimbri} and Teutones (113-101 B. C.). - Italy was now threatened by a barbarian invasion, which called to

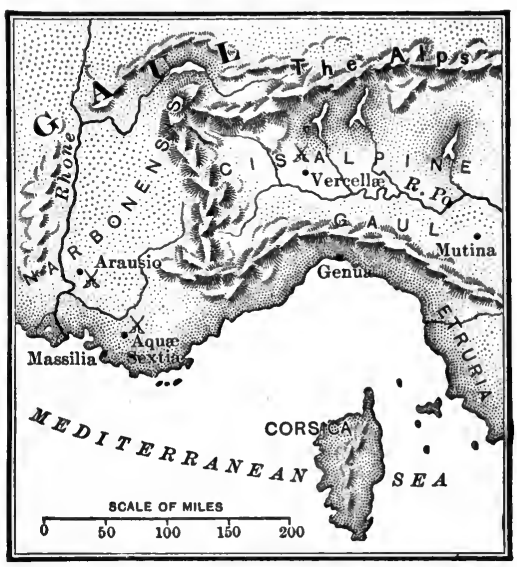

Seat of the Cimbric War mind the terrible days when the Gauls had invaded Italy and destroyed Rome. The present invaders were the Cimbri and Teutones, from the borders of Germany. These fierce people had pushed down into southern Gaul and had overrun the new province of Narbonensis (established 120 B. C.). Already the Roman armies had been defeated; and in one battle, at Arausio (107 B. c.), sixty thousand Romans are said to have perished. 
The people were inclined to believe that these misfortunes were due to aristocratic mismanagement; and hence they called upon Marius to save Rome from the impending danger. Marius was repeatedly elected to the consulship, and was kept in command of the army until he had destroyed the barbarians. He gained one great victory over the Teutones at Aquæ Sextiæ in southern Gaul (102 B. C.); and another over. the Cimbri at Vercellæ in northern Italy (101 в. с.). Marius was now saluted as the "savior of Rome," and received a magnificent triumph.

Marius and the Popular Party.-On account of his humble origin Marius was by nature in sympathy with the cause of the

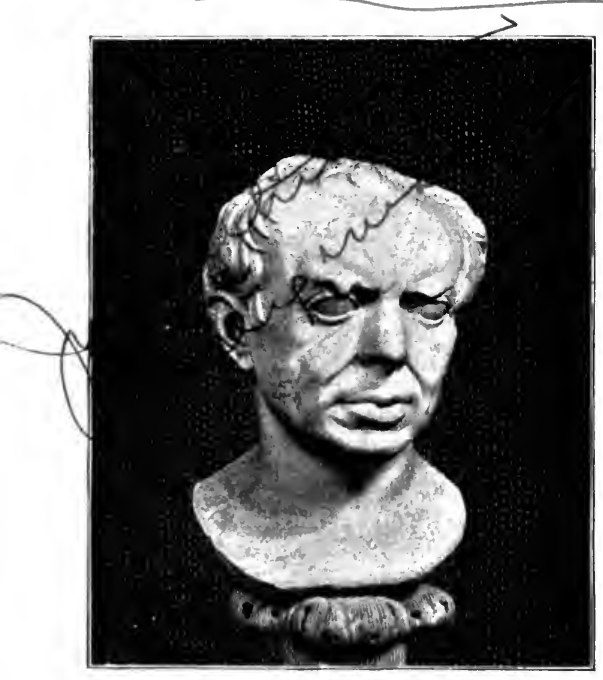

Marius (So-called) people. During his military career, he had already broken down the class distinctions in the army, and had placed the rich and the poor, the Romans and the Italians, side by side in the ranks. The popular leaders now sought the support of his great name and his military prestige in their war against the senate. The chief leaders of the popular party, since the death of the Gracehi, were Saturni'nus and Glaucia-men of no great political ability. Marius now joined these leaders, and was again elected to the consulship_the sixth time he had held that office. Saturninus was elected tribune and proposed a new set of laws: (1) to reduce the price of grain; (2) to distribute the land in Transalpine Caul among the poor citizens and the Italians; and (3) to open colonies in the provinces for the veter- 
ans of Marius. These laws were passed in spite of the violent opposition of the senate; and the cause of the people for the moment seemed victorious. Saturninus then proposed his own reëlection as tribune, and attempted to overawe the assembly by an armed force. A riot followed; and the senate called upon Marius, as consul, to put down the insurrection and save the republic. He reluctantly obeyed, and in the ensuing conflict his colleagues Saturninus and Glaucia were killed. Marius himself showed no capacity as a party leader. He fell into disrepute and retired from Rome. The senate again assumed the reins of government; and this first attempt to support the people's cause by the aid of a military commander proved a failure.

\section{The Rivalry of Marius and Sulla}

\section{The Social War, and the Incorporation of Italy (90-88} B. c.).-For a brief time after the retirement of Marius, the polities of the capital were overshadowed by a new danger which threatened the very existence of the Roman state. This was the revolt of the Italian allies. The Italians had long been clamoring for the rights of citizenship. Their cause was first espoused by a well-meaning but impracticable man, the tribune M. Livius Drusus (the son of the Drusus who had opposed Gaius Gracchus). But the failure of Drusus to accomplish anything in their favor drove them into open war. This war of the allies (socii) is known as the "Social war." Its purpose was to found a new Italian state, "Italica," with its capital at Corfin'ium. The parties at Rome ceased from their quarreling and united to preserve the republic. Even Marius returned to serve as a legate in the Roman army. A hundred thousand men took the field against an equal number raised by the allies. In the first year the war was unfavorable to Rome. In the second year (89 в. c.) new preparations were made and new commanders were appointed. Marius, on account of his age, 
was not continued in his command; while L. Cornelius Sulla, who was once a subordinate of Marius, was made chief commander in Campania. The great credit of bringing this war to a close was due to Sulla and another commander named Pompe'ius Strabo. The first Italian capital, Corfinium, was taken by Pompeius; and the second capital, Bovianum, was

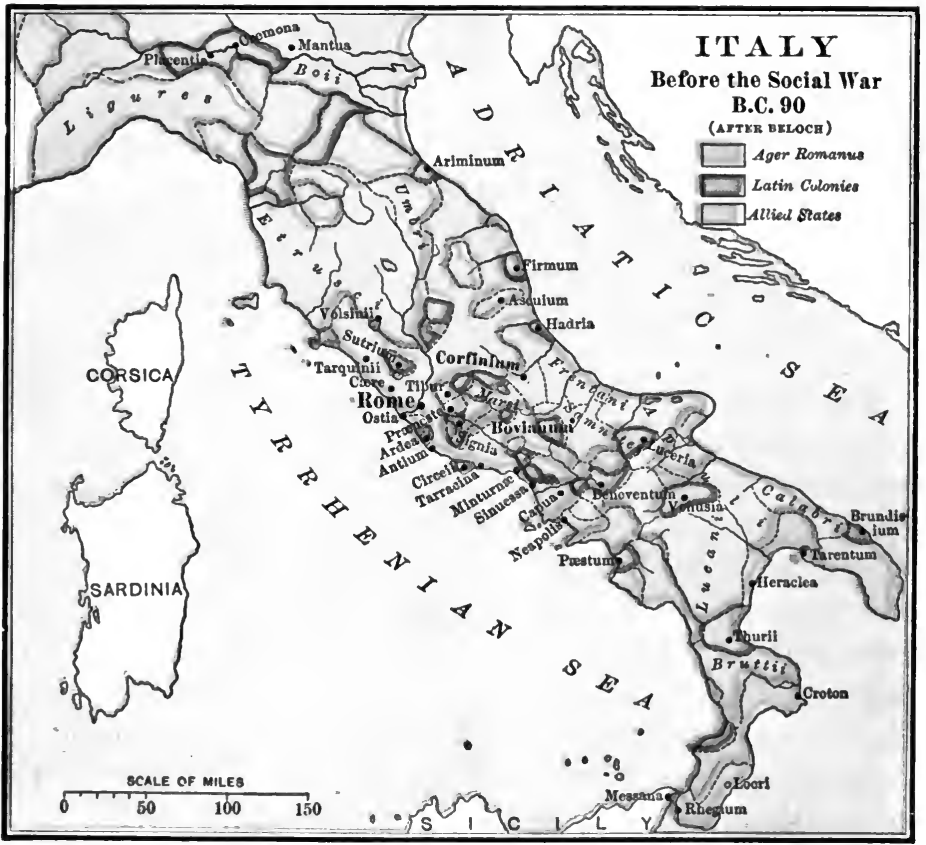

captured by Sulla (88 B. c.). 'The Social war was thus ended; but it had been a great afiliction to Italy. It is roughly estimated that three hundred thousand men, Romans and Italians, lost their lives in this struggle.

Although Rome was victorious in the field, the Italians obtained what they had demanded before the war began, that is, the rights of Roman citizenship. 'The Romans granted the 
franchise (1) to all Latins and Italians who had remained loyal during the war (le.x Iulia, 90 B. c.); and (2) to every Italian who should be enrolled by the pretor within sixty days of the passage of the law (lex Plautia Papiria, 89 B. c.). Every person to whom these provisions applied was now a Roman citizen. 'The policy of incorporation, which had been discontinued for so long a time, was thus revived. 'The greater part of I taly was joined to the ager Romanus; and Italy and Rome became practically one nation.

The Elevation of Sulla.-One important result of the Social war was to bring Sulla into prominence, and thus to give to the aristocratic party a military leader-a leader perhaps quite equal to Marius as a soldier, and far superior to him as a politician, War was not a new occupation for Sulla. In the campaign against Jugurtha he had served as a lieutenant of Marius. In the Cimbric war he had displayed great courage and ability. And now he had become the most conspicuous commander in the Italian war. As a result of his brilliant exploits, he was elected to the consulship. The senate also recognized him as the ablest general of the time, when it now appointed him to conduct a war in the East against the great enemy of Rome, Mithrida'tes, king of

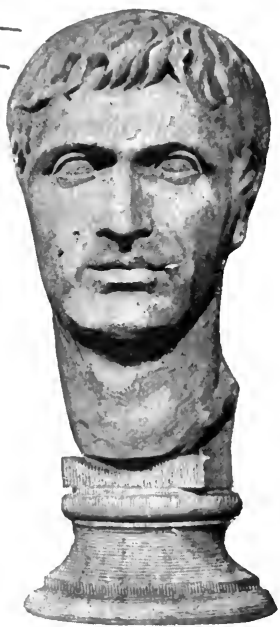

Sulla (So-called) Pontus, who was now encroaching upon the Roman territory in Asia Minor and Greece.

Attempt of Marius to displace Sulla; the Sulpician Laws.Marius had watched with envy the growing fame of Sulla during and after the Social war. His whole nature was now inflamed with revenge and the desire to displace and destroy his hated rival. To regain his influence with the people, he 
reëntered pofitigs and joingd himself to the popular leader, the tribune P. Sulpicius Rufus. Sulla had scarcely left Rome, when Marius and Sulpicius embodied their scheme in the socalled "Sulpician laws." Besides some measures intended to humor the people and to weaken the senate, these laws contained a provision giving to Marius instead of Sulla the command of the Mithridatic war. This last law reversed the decree of the senate which had already given the command to Sulla. The Sulpician laws thus made a diret issue between the people and the senate; and this political issue-became also a personal issue between Marius and Sulla. The laws were passed with the usual riotous proceedings; and two messengers were sent to Sulla with the order that he turn over his command to Marius.

\section{Sulla's Occupation of Rome and Departure for the East.-} Sulla had not yet left Italy. His legions were still encamped in Campania. He appealed to them to support the honor and authority of their commander. They responded to his appeal, and Sulla at the head of his troops marched to Rome. ' For the first time the Roman legions fought in the streets of the capital, and a question of politics was settled by the army. Marius and Sulpicius were driven from the eity, and Sulla for the time was supreme. He called together the senate, and caused the leaders of the popular party to be declared outlaws. He then annulled the laws passed by Sulpicins, and gave the senate the power hereafter to approve or reject all laws before they should be submitted to the people. With the army at his back Sulla could do what he pleased. When he had placed the government securely in the hands of the senate, as he thought, he left Rome for the purpose of conducting the war against Mithridates in the East.

The Marian Massacres; Cinna's Despotic Rule.-During the absence of Sulla Romo passed through a reign of terror. The popular party, now under the leadership of I. Cornelius Cinna, sought to regain control of the government. But in an 
armed conflict, in which ten thousand citizens are said to have lost their lives, Cinna was defeated and driven from the city. Cinna then, following the example of his enemy Sulla, appealed to the army for support. At the same time Marius, who had fled to Africa, returned with a body of Numidian eavalry. Uniting their forces, Marius and Cinna marehed to Rome and took possession of the city. 'Then began that scene of carnage which is known as the "Marian massacres," in which the enemies of Marius were everywhere cut down without mercy. 'The man who had once been saluted as the "savior of Rome" forever blackened his name by the most revolting deeds of a despot. This spasm of slaughter lasted for five days. Marius and Cinna then declared themselves to be consuls. But Marius held this, his seventh consulship, only a brief time, when he died-the "horror of Rome." Cinna continued to rule with absolute power. He declared himself consul each year, and named his own colleague. His incapacity is shown by the fact that during the three years of his supremacy he did nothing to strengthen the people's cause, of which he professed to be the leader. At last hearing that Sulla was about to return from the East, he led an army to prevent his landing in Italy; but he was killed in a mutiny of his own soldiers.

\section{The Triumph and Dictatorsfirp of Sulla}

- Sulla and the First Mithridatic War (88-84 B. c.).-While Rome was thus suffering from the massacres of Marius and the despotic rule of Cinna, Sulla was gathering fresh glories in the East. When he landed in Greece he found the eastern provinces in a wretched state. Mithridates, the king of Pontus (see map, p. 342), had extended his power over a large part of Asia Minor. He had overrun the Roman province of Asia. He had induced the Greek cities on the coast, which had been brought under the Roman power, to revolt and join his cause. He had massacred over eighty thousand Italians living on the 
Asiatic coast. He had also sent his armies into Macedonia and Greece, and many of the cities there, including Athens, had declared in his favor. The Roman power in the East seemed well-nigh broken. It was at this time that Sulla showed his greatest abiiity as a soldier. He drove back the armies of Mithridates, besieged Athens, and reduced it. He destroyed an army at Chæronea (86 B. c.; see map, p. $33 \pm$ ), and another at Orchomenus ( 85 B. C.). Within four years he reëstablished the Roman power, and compelled Mithridates to sign a treaty of

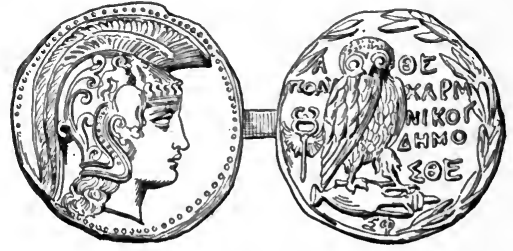

Coin of Athens peace. He then returned to Italy to find his own party overthrown and himself an outlaw.

Sulla's War with the Marian Party.-Sulla landed in Italy (83 B. c.) with a victorions army of forty mensand men. He had restored the power of Rome against her enemies abroad; he now set to work to restore her authority against her enemies at home. He looked upon the poptlar party as a revolutionary faction, ruling with no sanction of law or justice. Its leaders since the death of Cinna were Cn. Papirius Carbo, the younger Marius, and Q. Sertorius. The landing of Sulla in Italy without disbanding his army was the signal for civil war. Southern Italy declared in his favor, and many prominent men looked to him as the deliverer of Rome. 'The choicest of his new allies was the son of Pompeius Strabo, then a young man of twenty-three, but whose future fame, as Pompey the Great, was destined to equal that of Sulla himself. Sulla marched to Campania and routed the forces of one consul, while troops of the other consul deserted to him in a body. He then attacked the young Marius in Latium, defeated him, and shut him up in the town of Preneste (see map. p. 302). Northern Italy was at the same time held in check by Pompey. A desperate bat- 
tle was fought at Clusium, in Etruria (sce map, p. 303), in which Sulla and Pompey defeated the army of Carbo. At last an army of Samnites which had joined the Marian cause was cut to pieces at the Colline gate (see map, p. 282) under the very walls of Rome. Sulla showed what might be expected of him when he ordered six thousand Samnite prisoners to be massacred in cold blood.

The Sullan Proscriptions.-With Italy at his feet and a victorious army at his back, Sulla, the champion of the senate, was now the supreme ruler of Rome. Before entering upon the work of reconstructing the government, he determined first of all to complete the work of destroying his enemies. It is sometimes said that Sulla was not a man of vindictive nature. Let us see what he did. He first outlawed all civil and military officers who had taken part in the revolution against him, and offered a reward of two talents (about $\$ 2,500$ ) to the murderer of any of these men. He then posted a list (proscriptio) containing the names of those citizens whom he wished to have killed. He placed eighty names on the first list, two hundred and twenty more on the second, as many more on the third, and so on until nearly five thousand citizens had been put to death in Rome. If the proscriptions of Sulla were not inspired by the mad fury of revenge which led to the Marian massacres, they were yet prompted by the cool and merciless policy of a tyrant.

The Sullan Constitution.-When Sulla had destroyed his enemies, not only in Rome but throughout Italy, he turned to the work of reconstructing the government in the interests of the senate and aristocracy. Not relying upon the tribune's power which had been used by the Gracchi, nor upon the consular power which Marius had repeatedly held, he had himself appointed "perpetual dictator." This made him the absolute ruler of the state. As a support to his power he planted his veterans in military colonies in different parts of Italy, where they could be called upon in case of emergency. He then 
proceeded to frame his new constitution, the most important provisions of which were the following:

(1) He restored the senate to its previous position as the chief ruling body of the state, granting to it the right to initiate all legislation; and he united the senatorial and equestrian orders by appointing many equites to the senate.

(2) He weakened the power of the people by taking away from the comitia tributa the power of making laws, transferring this power to the comitia cenluriata, which was controlled by wealth, but which could not pass any law without the previous approval of the senate.

(3) He reduced the power of the tribune to the mere right of "intercession," or the protection of a citizen from official injustice, forbidding the tribune from proposing laws, and providing that no tribune could afterward be elected to any curule office.

(4) He reënacted the old law of succession to office, whereby no person could hold the same office a second time within a period of ten years.

(5) He restricted the power of the consul to matters of civil administration, so that no consul could command the army until the expiration of his term.

(6) He organized a system of permanent criminal courts (quastiones perpetuce), and restored the jury list to the senate, as it had been before the days of the Gracchi.

The general tendency of Sulla's legislation was to annul all the principal changes which had grown out of the revolutionary attempts of the popular party and its leaders, and thus to reëstabksh the government upon its old aristocratic basis.

After a reign of three years Sulla resigned his office as dictator. He retired to his country home on the bay of Naples, and died in a few months, before he could know of the fate of his constitution. Upon his monument were inscribed the words: "No friend ever did him a kindness, and no enemy a wrong, without being fully repaid." 


\section{SYNOPSIS FOR REVIEW}

I. The Rise of Marius.-The Rule of the Restoration.-The War with Jugurtha.-War with the Cimbri and 'Teutones.Marius and the Popular Party.

II. The Rivalky of Marius and Sulla.-The Social War, and the Incorporation of Italy.-The Elevation of Sulla.Attempt of Marius to Displace Sulla; the Sulpician Laws.Sulla's Oeeupation of Rome and Departure for the East.-The Marian Massacres; Cinna:s Despotic Rule.

III. The Thumpi and Dictatorsmp of Sulda.-Sulla and. the First Mithridatic War.-Sulla's War with the Marian Iarty.The Sullan Proseriptions.-The Sullan Constitution.

\section{REFERENCES FOR READING}

Pelham, Bk. IV., Ch. 2, "From the Graechi to Sulla" (18)."

How and Leigh, Ch. 39, "The Social War"; Ch. 44, "The Sullan Constitution" (18).

Merivale, Gen. Hist., Ch. 32, "Rivalry of Marius and Sulla" (18).

Taylor, Ch. 11, "Cinna and Sulla" (22).

Beesly, Ch. 4, "War with Jugurtha"; Ch. 15, "Sulla's Reactionary Measures" (18).

Schuekburgh, Ch. 38, "Mithridates in Asia and Greece" (18).

Mommsen, Vol. III., Bk. IV., Ch. 10, "The Sullan Constitution"; pp. 458-470 (character of Sulla) (18).

(Abridged), Ch. 22, "Marius as a Revolutionist" (18).

Ihne, History, Vol. V., Bk. VII., Ch. 8, "The Jugurthine War"; Ch. 14. "The Social War" (18).

Freeman, Essay on "Sulla" (3).

Plutarch, "Marius," "Sulla" (26).

\section{CHAP'TER XXVI}

THE GROWTH OF IMPERIALISM-POMPEY AND CASAR

\section{The Rise of Pompey and Crassus}

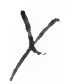

The Drift of Roman Politics.--From what we have seen of the political conflicts going on at Rome since the first appearance of the Gracchi, we might infer that no important results had been accomplished. 'The constitution of Sulla was

${ }^{1}$ The figure in parenthesis refers to the number of the topic in the Appendix, where a fuller title of the book will be found. 
evidently intended to put the government back where it was before the revolution began. The efforts of the people to overthrow the power of the senate and the aristocracy seem to have come to nothing. 'The chiefs of the popular party had shown no great capacity for leadership, and had often degenerated into mere demagogues. But in spite of all these discouragements, there were two facts which seemed to show the drift of Roman politics. In the first place, there had been a growing tendency in the direction of the one-man power. This is shown in the tribunate of the Gracchi, in the successive consulships of Marius, in the absolute rule of Cinna, and in the dictatorship of Sulla. In other words, the Roman state was drifting toward monarchy. In the seeond place, the determined spirit of the people showed that the one-man power could not be permanently established upon an aristocratic basis like that of Sulla. The Roman people would evidently be satisfied only with a form of monarchy or imperialism which reeognized the welfare of the whole Roman state. We are now to trace how such a form of imperialism came to be established.

The Three Revolts: Lepidus, Sertorius, Spartacus.-Sulla had hardly passed away when signs of discontent everywhere appeared. The evidence of this discontent is seen in three important revolts which took place at this time-the revolt of Lep'idus, the rebellion of Sertorius, and the insurrection led by Spar'tacus.

(1) The first attempt to oppose the new constitution was made by the consul Lepidus, a vain and petulant man who aspired to be ehief of the popular party, but who proved to be an incompetent leader, like many of his predecessors. He proposed to restore the tribunate, and to overthrow the whole Sullan régime. Failing in this, he raised an armed force, as Sulla and Cinna had done before hin, to carry ont his views. The senate placed in command of the army Pompey, one of Sulla's lieutenants. Pompey defeated Lepidus; and this feeble attempt at revolution failed (7\% B. с.). 
(2) A more serious attempt at revolution was made by Sertorius, a popular leader who had escaped to Spain during the Sullan proscriptions. Here he espoused the cause of the provincials, and attempted to establish in Spain an independent republic. This rebellion had been begun before the death of Sulla; it continued for some years afterward, and presented a serious problem for the senate. Sertorius was himself a man of noble character, and also a very able soldier. After he had defeated three Roman generals, Pompey was appointed proconsul, and was sent with a large army to put dowh this rebellion. The war under Pompey was successfully carried on; but it was only after Sertorius had been treacherously slain by one of his own followers that the province was finally pacified ( 12 в. с.).

(3) Before the war in Spain was ended, the senate was called upon to meet a still more formidable danger in Italy. This was the revolt of the gladiators, under their renowned leader Spartacus. The gladiators were captives trained to fight one another in the arena for the amusement of the Roman populace. Seventy of these desperate men escaped from the training school at Capua, and gathered about them a motley

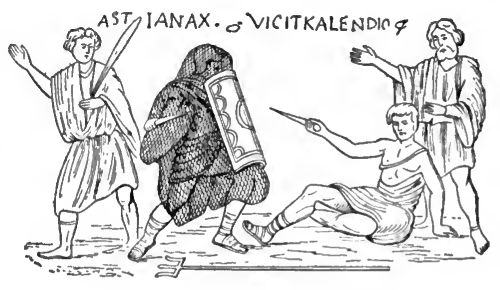

ROMAN GLADIATORS horde of a hundred thousand slaves and outlaws. They defeated four Roman armies, and threatened to devastate the whole of Italy. In the absence of Pompey the senate selected Crassusa wealthy aristocrat who had served as a soldier under Sullato put down this fearful insurrection. Spartacus was finally defeated ( 71 в. c.). A small remnant of his band fled to the north and fell in with Pompey on his return from Spain, and was destroyed. By this stroke of luck Pompey had the assurance to claim that, in addition to closing the war with Spain, he had also finished the war with the gladiators. 
The Consulship of Pompey and Crassus (70 B. c.).-The senate had thus succeeded in maintaining its authority and putting down three attempts at revolution, with the aid

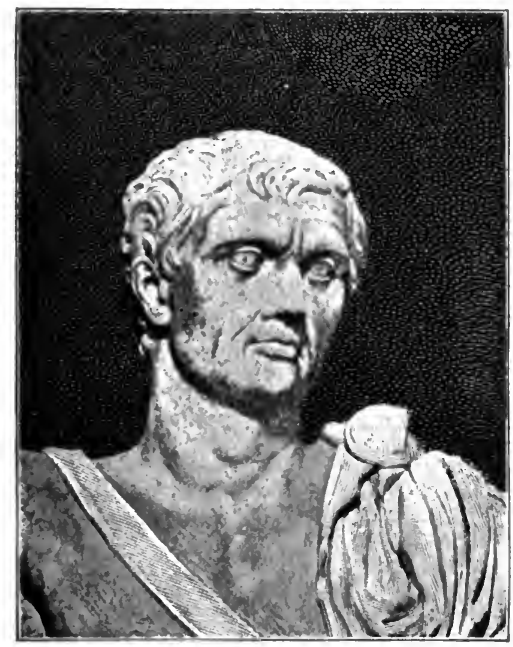

Head of the Statue of Pompey (So-called) of Pompey and Crassus. These generals now claimed the consulship as a reward for their service. But according to the Sullan laws they were not yet eligible to this office; and the senate was committed to the Sullan régime. Finding no hope of support from the senate, the two generals turned to the popular party. In return for the consulship they agreed to carry out the schemes of this party and annul the laws of Sulla. As a result of this bargain Pompey and Crassus joined hands, broke with the senate, became supporters of the democratic cause, and were elected to the consulship.

Overthrow of the Sullan Constitution.-True to their agreement, Pompey and Crassus proceeded, with the support of the people, to overthrow the constitution which Sulla expected would be lasting. The old power was given back to the tribunes. The legislative power was restored to the assembly, which now could pass laws without the approval of the senate. The exclusive right to furnish jurors in criminal eases was taken away from the senate. Also the power of the censors to revise the list of the senators, which sulla had abolished, was restored; and as a result of this, sixty-four senators were ex- 
pelled from the senate. By these measures the Sullan régime was practically destroyed, and the supremacy of the senate taken away. This was, in fact, the most decisive victory won by the popular party since the beginning of the revolution. It was also achieved without an armed conflict, simply by winning to the democratic cause the support of the two successful generals.

The Military Supremacy of Pompey.-Since the death of Sulla, the senators had taken comparatively little interest in the eastern provinces except as a source of wealth to themselves and to their supporters. As a result of this weak policy, the Last was falling into a condition nearly as wretched as its condition before the campaigns of Sulla. The seas were infested with pirates, who cut off the grain supplies from Egypt; and the king of Pontus was still a menace to the Roman provinces. The people now determined to take into their own hands the management of eastern affairs. By two laws they raised their new leader, Pompey, to a position never before held by a Roman eitizen-except perhaps by Sulla.

(1) The Gabinian law (67 в. c.).-To rid the sea of the pirates (who made their home in Cilicia and Crete) a law was proposed by the tribune Gabinius, giving to Pompey for three years supreme control over the Mediterranean Sea and its coasts for fifty miles inland. This law was passed, and Pompey was placed in command of a large fleet and army. Within ninety days he had swept the seas and cleared the coasts, and the Mediterranean was once more open to Roman commerce.

(2) The Manilian law (66 в. c.).--In the next year a law was proposed by the tribune Manilius and supported by Rome's greatest orator, Cicero, giving to Pompey the entire control of the East until the tedious and desultory war now in progress against Mithridates should be brought to an end. The war had recently been conducted by Lucullus, a wealthy aristocratic general, who was charged with prolonging the war to enrich himself. Pompey now received the command. He de- 
feated Mithridates and drove him out of his kingdom. He then invaded Syria and took possession of that country. He entered Judea, and after a severe struggle succeeded in capturing Jerusalem ( 63 B. c.). All the eastern coasts of the Mediterranean were brought under his control. He organized the conquered territory into new Roman provinces, and planted, it is said, thirty-nine new cities. Pompey was now looked upon as the most successful of Roman generals, and worthy of the title " the Great," once conferred upon him by Sulla.

\section{The Coalition of Pompey, Cesar, and Crassus}

The Rise of Julius Cæsar.-During the absence of Pompey in the East the politics of the capital were in a confused and

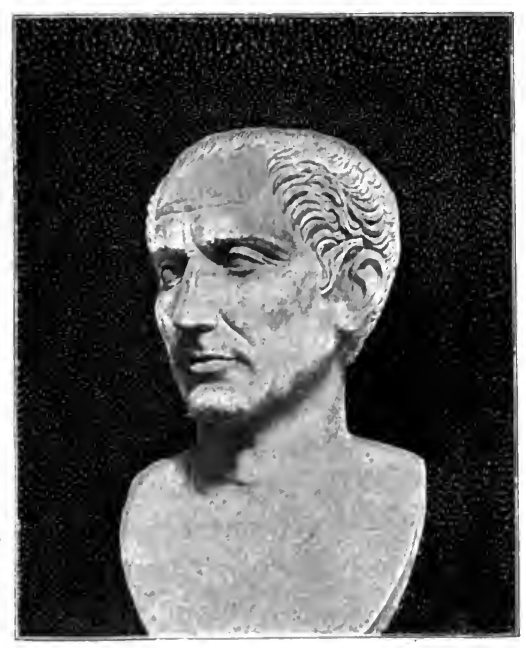

Cassar (Naples) uncertain state. The senate was striving to maintain its old dignity, even though it could not exercise its old authority. The popular party was under the professed leadership of Crassus, who had no ability as a politician, and who was influential chiefly on account of his wealth. The party had, in fact, won what laurels it had gained, through the military prestige of Pompey. But even in the case of Pompey it was uncertain how much confidence could be placed in a man who had already broken with the senate. In the meantime, a new leader was coming to the front-a leader who was destined to become the 
greatest statesman of Rome, and to perform a work which no one else was able to accomplish. This man was Julius Cæsar. He was a nephew of Marius and the son-in-law of Cinna. He was, therefore, from the first well disposed toward the popular cause. He had favored the restoration of the tribunate, and had supported the Manilian law. He had also tried to procure the franchise for the Latin colonies beyond the Po; and he had, while curule sdile, won the plaudits of the populace by the splendor of his games. Cresar saw that the people's eause was in the ascendeney; and he aspired to become its leader, and to place himself at the head of the Roman state. This was a noble ambition on the part of Cæsar-to identify his own suecess with that of his fellow-citizens. But his ambition was checked for a brief time by the suspicion that he was implicated in the conspiracy of Cat'iline-a movement which aroused in the minds of all good citizens the most intense indignation.

Cicero and the Catilinian Conspiracy.-Catiline was a man of the stripe of Cinna. He professed to represent the cause of the people. He was like Cinna in not caring so much for the real interests of the people as for his own aggrandizement, and also in being perfectly unscrupulous as to the methods by which he attained his ends. That he was at first looked upon as a legitimate party leader is evident from the fact that he was supported for the consulship by Cæsar and Crassus. But he proved to be a demagogue and a desperado. He came to be feared by all the best citizens of Rome. He was hence defeated at the elections by the senatorial party, under the lead of Cicero. After a second failure to obtain the consulship, Catiline's true character was revealed. He adopted the desperate methods which had proved temporarily successful in the days of Marius and Cinna. He determined to raise an army from all the lawless and discontented classes of Italy, to march upon Rome, seize the city, and destroy his enemies. This nefarious plan was discovered by Cicero, who had been elected 
consul. Catiline's army was defeated in Etruria. Catiline himself was killed in battle, and five of his fellow-conspirators were condemned to death by the senate; and Cicero put the

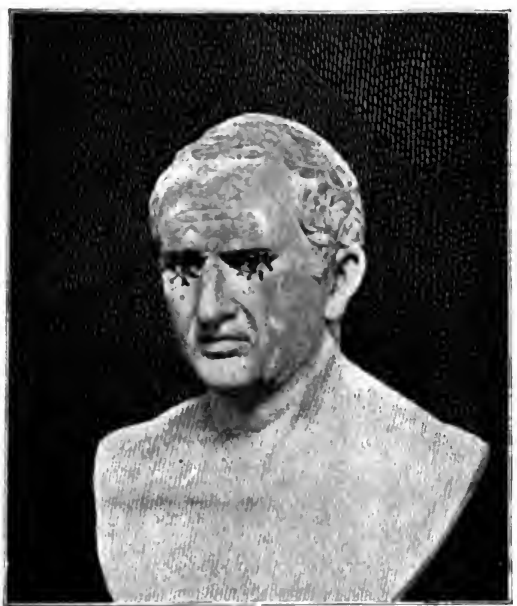

Cicero (Naples) judgment into execution (62 B. c.). Cicero had already done good service to the republic by h is impeachment of Verres, the corrupt governor of Sicily; and now he was hailed as the "Father of his Country." The senate regarded the suppression of the conspiracy as an aristocratic victory; and the popular leaders, although denying all connection with the conspiracy, fell into disrepute.

Formation of the "First Triumvirate" (60 B. c.).-The senate now supposed that the time had come to assert its own authority. The only leaders of the people who seemed strong enough to oppose the senatorial policy were Pompey and Cresar. The senate, therefore, determined first to humiliate Pompey, and next to embarrass Cæsar. In the first place, when Pompey returned from his victories, he expected that his arrangements in the East would be confirmed by the senate, and that his veterans would be rewarded with grants of land. The senate refused to do either. In the next place, when Casar returned from Spain-to which province he had been sent as propretor and where he had won a military reputation-he wished to receive a triumph and to be elected to the consulship. The senate decided that he could not receive a triumph while in the city, and could not be elected to the consulship while ontsido 
the city. Cæsar accordingly waived the triumph and entered the city. Here he found Pompey chafing against the senate; and the two generals agreed to unite in opposing the senatorial party. By its blundering policy, the senate had thus driven the two chieftains into a coalition, to which the wealthy Crassus was admitted. This coalition is usually called the "First 'Triumvirate." It was composed of the most successful soldier, the most able statesman, and the richest capitalist of Rome. These men united to advance their own interests in opposition to the senate. They were also, to all appearances at least, in sympathy with the popular party; and their success would no doubt advance the cause of the people.

$\checkmark$ The Consulship of Cæsar (59 terms of the agreement Cæsar was elected to the consulship. On his election Cæsar went faithfully to work to fulfill his obligations to Pompey, and to pass laws to strengthen the cause of the triumvirs. (1) He secured a law confirming all the acts of Pompey in the East. (2) He had passed an agrarian law which not only provided for the veterans of Pompey, but which also gave estates in Campania to the needy citizens of Rome. (3) He then obtained a law remitting one third of the price which the capitalists had agreed to pay for collecting the taxes in Asia. (4) Finally, a bill was passed by which he himself was assigned to the provinces of Cisalpine Gaul and Illyricum, to which Transalpine Gaul was added. By these laws Pompey was satisfied; the people were pleased; the capitalists were reconciled; and Cæsar himself was secured in a military command.

But before leaving for his provinces, Cæsar desired still further to cripple the power of the senate, by depriving it of its chief leaders. These were Cicero and Cato the YoungerCicero, who had restored the prestige of the senate by crushing the Catilinian conspiracy; and Cato, who was the grandson of Cato the Censor, and who was now the most conservative of the senatorial party. Cæsar's tool in this work was the 
tribune Clodius, a radical and unscrupulous politician, but a devoted friend of Cæsar. Through his influence, Cicero was banished on the charge of having put to death the Catilinian conspirators without giving them a regular trial. Cato was sent on a mission to Cyprus, where he would be removed from the politics of the capital. With such an arrangement of the affairs at Rome, Cæsar departed with his legions to Gaul.

\section{Renewal of the Triumvirate at Lucca (56 в. с.).-If Cæsar} made a mistake, it was in putting such a man as Clodius in charge of his interests at Rome. Clodius was by nature an adventurer and a demagogue; and by his rash acts he eame near breaking up the triumvirate. He allied himself with the rabble of Rome; he paraded the streets with bands of armed ruffians, and the capital was threatened with mob rule. Pompey as well as the senate beeame disgusted with the régime of Clodius. They united their influence and obtained the recall of Cicero from his exile. At the same time Cato returned from his absence in Cyprus. With the return of the old senatorial leaders, and the disaffection of Pompey, it looked as though the senate would once more regain its power, and the triumvirate would go to pieces.

But the watchful eye of Cæsar detected these symptoms of discontent, and a conference of the leaders took place at Lucea, a town in northern Italy ( see map, p. 303), where a new arrangement was brought about. Cæsar was now to be given an additional term of five years in Gaul, and to be elected consul at the end of that time; Pompey and Crassus were now to receive the consulship; and at the close of their term of office Pompey was to have the provinces of Spain and Africa, and the money-loving Crassus was to receive the rich province of Syria. In this way they would divide the world among them. 'The terms of the agreement were apparently satisfactory to the parties concerned. Cæasar now felt that matters at Rome were safe, at least until he could complete his work in 
Gaul and fortify his own power with a devoted and invincible army.

Cæsar and the Conquest of Gaul (58-51 B. c.).-Within eight years Cæsar brought under his power all the territory bounded by the Pyrenees, the Alps, the Rhine, and the Atlantic

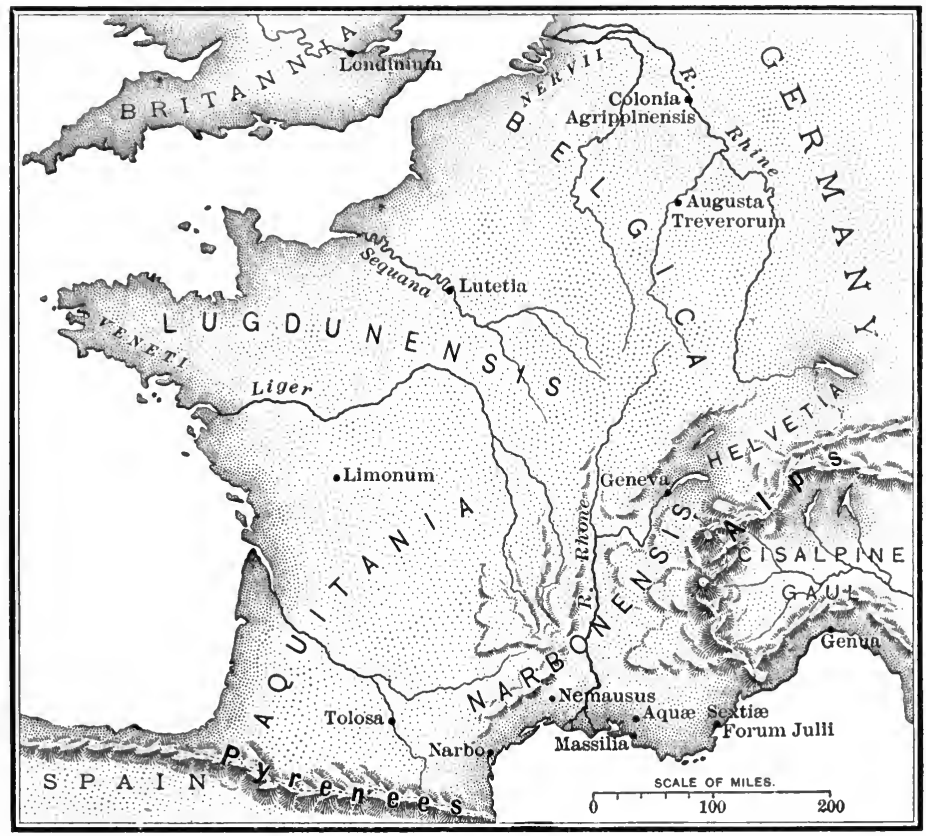

The Province of Gaul

Ocean, or about what corresponds to the modern countries of France, Belgium, and Holland. He at first conquered the Helve'tii, a tribe lying on the outskirts of his own province of Narbonensis. He then met and drove back a great invasion of Germans, who, under a prince called Ariovis'tus, had crossed the Rhine, and threatened to overrun the whole of Gaul. He then pushed into the northern parts of Gaul, and conquered the Nervii and the neighboring tribes. He overcame the 
Ven'eti on the Atlantie coast, and conquered Aquitania. He also made two invasions into Britain $(55,54$ B. c.), crossed the Rhine into Germany, and revealed to the Roman soldiers countries they had never seen before. After once subduing the various tribes of Gaul, he was finally called upon to suppress a general insurrection, led by a powerful leader called Vercinget'orix. The conquest of Gaul was then completed.

A large part of the population had been either slain in war or reduced to slavery. 'The new territory was pacified by bestowing honors upon the Gallic chiefs, and self-government upon the surviving tribes. The Roman legions were distributed through the territory; but Cæsar established no military colonies like those of Sulla. The Roman arts and manners were encouraged; and Gaul was brought within the pale of civilization.

\section{The Supremacy of Cesar}

Dissolution of the Triumvirate.-While Cæsar was absent in Gaul, the ties which bound the three leaders together were becoming weaker and weaker. The position of Crassus tended somewhat, as long as he was alive, to allay the growing suspicion between the two great rivals. But after Crassus departed for the East to take control of his province in Syria, he invaded Parthia, was badly defeated, lost the Roman standards, and was himself killed (53 в. с.). The death of Crassus practically dissolved the triumvirate; or we might rather say, it reduced the triumvirate to a duumvirate. But the relation between the two leaders was now no longer one of friendly support, but one of mutual distrust.

+ Alliance of Pompey with the Senate.-Pompey was not only drawing away from Casar; he was also coming into eloser relations with the senate, which felt the need of some strong military support. The eity was distracted by continual street fignts between the armed bands of Clodius, the dofmagogue, 
and those of T. Annius Milo, who professed to be defending the cause of the senate. In one of these broils Clodius was killed. His excited followers made his death the occasion of riotous proceedings. His body was burned in the Forum by the wild mob, and the senate house was destroyed by fire. In the anarchy which followed, the senate felt obliged to confer some extraordinary power upon Pompey. On the proposal of Cato, he was appointed "consul without a colleague." Under this unusual title Pompey restored order to the state, and was looked upon as "the savior of society."

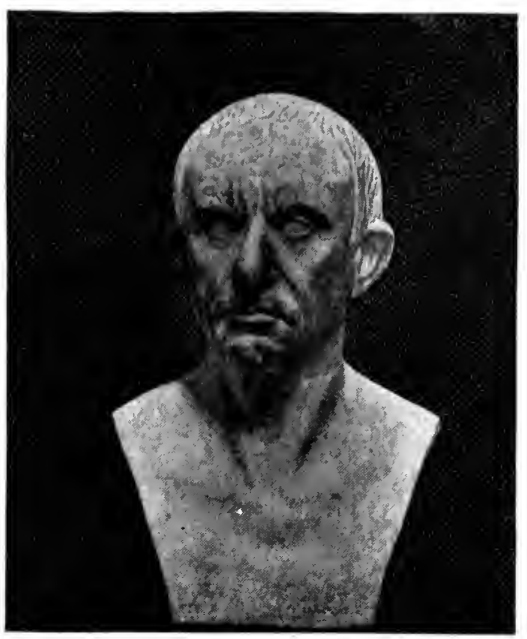

Cato ThE Younger $\mathrm{He}$ became more and more closely bound to the cause of the senate; and the senate recognized its obligations to him by prolonging his command in Spain for five years.

Rupture between the Senate and Cæsar.-It was a part of the agreement made at the conference of Lucca, we remember (p. 384), that Cæsar was to receive the consulship at the close of his command in Gaul. He naturally wished to retain the control of his army until he had been elected to his new office. The senate was determined that he should not, but should present himself at Rome as a private citizen before his election. Cæsar well knew that he would be helpless as a private eitizen in the presence of the enemies who were seeking to destroy him. Cato had already declared that he would prosecute him as soon as he ceased to be proconsul in Gaul. Cæsar promised, 
however, to give up his province and his army, if Pompey would do the same; but Pompey refused. The senate then called upon Cæsar to give up two of his legions, on the plea that they were needed in the Parthian war. The legions were given up; but instead of being sent to the East they were stationed in Campania. Upon further demands, Cæsar agreed to give up eight legions of his army if he were allowed to retain two legions in Cisalpine Gaul until the time of his election. This the senate refused; and demanded that he must give up his province and his whole army by a certain day, or be declared a public enemy. The senate had offered him humiliation or war. He chose war, and crossed the Rubicon (49 в. с.), the stream which separated his province of Cisalpine Gaul from Italy.

Civil War between Pompey and Cæsar.-The contest was now reduced to a struggle between Pompey, the champion of the senate, and Cæsar, the champion of the people. Cæsar knew the value of time; at the instant when he decided upon war, he invaded Italy with a single legion. Pompey, unprepared for such a sudden move and not relying upon the two legions which the senate had taken from Cæsar, was obliged to withdraw to Brundisium (see map, p. 305). Besieged in this place by Cæsar, he skillfully withdrew his forces to Greece, and left Cæsar master of Italy.

The campaigns of Cæsar against Pompey and his supporters may be summed up as follows: (1) He dispatched his Gallic legions across the Pyrenees into Spain (49 в. c.) and destroyed the armies of Pompey's lieutenants. (2) He crossed the Adriatic Sea into Greece; was defeated at Dyrra'chium (map, p. 334), and then in the decisive battle at Pharsa'lus (48 в. с.) defeated Pompey, who fled to Egypt and was treacherously slain by an Egyptian soldier. (3) He entered Egypt to quell a civil war between the young Egyptian prince, Ptolemy, and his sister, Cleopattra: defeated the army of Ptolemy, and placed Cleopatra on the Egyptian throne. (4) On his re- 
turn to Italy by way of Asia Minor, he defeated (at Zela, $4 \%$ B. c. ; map, p. 394) Phar'naces, the king of Pontus and son of the great Mithridates, who was trying to stir up a revolt in the eastern provinces,- -sending to the senate the famous dispatch, "Veni, vidi, vici." (5) He passed over into Africa, and at the battle of Thapsus ( 46 в. с.) defeated the senatorial forces led by Cato, who committed suicide after the battle. (6) $\Lambda$ t the battle of Munda in Spain ( 45 в. C.) he crushed the last attempt at resistance, led by the sons of Pompey.

Cæsar's Triumphs and Titles.-When Cæsar returned to Rome, he came not as the servant of the senate, but as niaster of the world. He crowned his victories by four splendid triumphs, one for Gaul, one for Egypt, one for Pontus, and one for Africa. He made no reference to the civil war; and no citizens were led among his captives. His victory was attended by no massacres, no proscriptions. no confiscations. He was as generous in peace as he had been relentless in war. Cæsar was great enough to forgive his enemies. A general amnesty was proclaimed; and friend and foe were treated alike. During the period of his rule (49-44 B. c.) he exercised his power under various titles. He was consul, dictator, controller of public morals ( $p r e-$ fectus morum), tribune, pontifex maximus, and chief of the senate (princeps senatus). He thus gathered up in his own person the

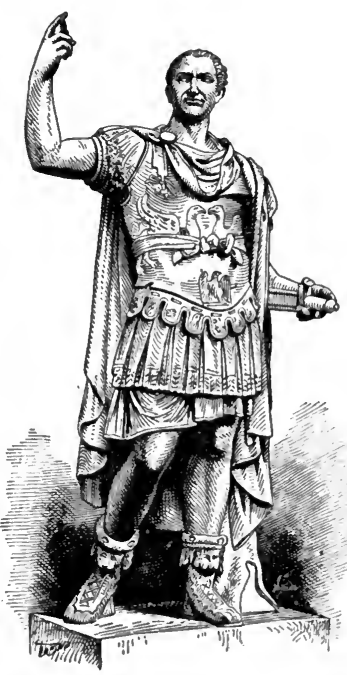

Julius Ceesar (Capitol) powers which had been scattered among the various republican officers. The name of "impera'tor," with which the soldiers had been accustomed to salute a victorious general, was now 
made an official title, and prefixed to his name. In Cæsar was thus embodied the one-man power which had been growing up during the civil wars.

Cæsar's Legislation.-The only man of the Roman republic who can well be compared with Casar is Sulla. They both obtained an imperial position in the Roman state. They were also both able politicians and constructive statesmen. But a wide gulf separates the constitution of Sulla from the legislation of Cæsar. The one was based upon the narrow interests of a selfish aristocratic class; the other rested upon the common interests of the Roman people. In the light of this whole period which we are now studying, we may say that the constitution of Sulla was an obstacle to the general drift of popular reform; while the legislation of Cæsar brought to a successful issue the beneficent movement begun by the Gracchi. Let us make a brief summary of what Cæsar did during his brief career as political ruler:

(1) He took away the aristocratic character of the senate by raising the number of its members to nine hundred, including representative men from all classes in Italy and the provinces.

(2) He extended the right of citizenship to the people beyond the Po and to many communities in Gaul and Spain.

(3) He opened colonies in the provinces, by which 80,000 landless citizens in Italy were provided with homes.

(4) He revived the municipal life of Italy, and reorganized the municipal system so as to make it apply equally to Italy and the provinces.

(5) He changed the oppressive system of taxation in the provinces by dispensing with the avaricious tax-gatherer and permitting each town to collect its own fixed share of the tax.

(6) He reënacted the old Licinian law which provided for a certain number of free laborers on every estate.

(7) He passed a bankruptey law which relieved debtors from their obligations by relinquishing their entire estates to their creditors-thus doing away with imprisonment for debt. 
(8) He reduced the number of poor receiving state aid from 320,000 to 150,000 , and afforded means of employment by encouraging public works.

(9) He also reformed the calendar, which has remained substantially as he fixed it, to the present day; and he provided for a regular census which should apply not only to Rome but to every Roman community.

Besides these acts it was his purpose also to codify the Roman law; to provide for the founding of public libraries; to improve the architecture of the city; to drain the Pontine Marshes for the improvement of the public health; to 'cut a channel through the Isthmus of Corinth; and to extend the empire to its natural limits, the Euphrates, the Danube, and the Rhine. These acts and projects illustrate the comprehensive mind of Cæsar. They show that the one-man power which he established had for its object the highest welfare of the whole Roman state.

The Assassination of Cæsar.-If Cæsar failed in anything, it was in not adjusting himself sufficiently to the conservative spirit of the time. There were still living at Rome men who were blindly attached to the old republican forms. To them the reforms of Cæsar looked like a work of destruction, rather than a work of creation. They saw in his projects a scheme for reviving the kingship. It was said that when Cæsar was offered a crown he looked at it wistfully; and that he had selected his nephew Octavius as his royal heir.

The men who hated Cæsar, and who conspired to kill him, were men who had themselves received special favors from him. The leading conspirators, M. Brutus and C. Cassius, had both served in Pompey's army, and had been pardoned by Cæsar and promoted to offices under his government. Joined by some fifty other conspirators, these men formed a plot to kill Cæsar in the senate house. The story of his assassination has been told by Plutarch and made immortal by Shakespeare: When the appointed day came, the Ides of March (March 15, 44 MOREY'S ANCIENT HIST. - 23 
B. C.), Cæsar was struck down by the daggers of his treacherous friends, and he fell at the foot of Pompey's statue. It has been said that the murder of Cosar was the most senseless act that the Romans ever committed. His death deprived Rome of the greatest man she ever produced. But the work of the conspirators did not destroy the work of Cæsar.

\section{SYNOPSIS FOR REVIEW}

I. The Rise of Pompey and Crassus.-The Drift of Roman Polities.-The Three Revolts: Lepidus, Sertorius, Spartacus.The Consulship of Pompey and Crassus.-Overthrow of the Sullan Constitution.-The Military Supremacy of Pompey.

II. The Coalition of Pompey, Casar, and Crassus.-The Rise of Julius Cæsar.-Cicero and the Catilinian Conspiracy.Formation of the "First Triumvirate."-The Consulship of Cæsar.-Renewal of the Triumvirate at Lucca.-Cæsar and the Conquest of Gaul.

III. The Supremacy of Cesar.-Dissolution of the Triumvirate. -Alliance of Pompey with the Senate.-Rupture between the Senate and Cæsar.-Civil War between Pompey and Cæsar.Cæsar's Triumphs and Titles.-Cæsar's Legislation.-The Assassination of Cæsar.

\section{REFERENCES FOR READING}

Liddell, Ch. 72, "Revolutionary Attempts of Lepidus, Sertorius, Spartacus" (18). ${ }^{1}$

Schuckburgh, Ch. 42, "Pompey in the East" (18).

How and Leigh, Ch. 47, "Cicero and Catiline"; Ch. 49, "The Conquest of Gaul" (18).

Merivale, General History, Ch. 40, "The First Triumvirate" (18). Pelham, Bk. V., Ch. 1, "The Dictatorship of Julius" (18).

Mommsen, Vol. IV., Bk. V., Ch. 11, "The Old Republic and the New Monarchy" (18).

(A bridged), Ch. 35, "Joint Rule of Pompey and Cæasar" (18). Taylor, Ch. 15, "Cæsar" (22).

Abbott, Ch. 6, "Struggle between the Democracy and the Nobilitas" (22).

Granrud, Fourth Period, Ch. 7, "The Rule of Cæsar" (22).

Shakespeare, "Julius Cæsar."

Forsyth, Cicero, pp. 319-330 (character of Cicero) (27).

Oman, Seven Great Statesmen, Ch. 5, "Sulla"; Ch. 8, "Pompey";

Ch. 9, "Cessar" (26).

Froude, Cæesar, Ch. 11. "Conspiracy of Catiline"; Ch. 28, "Character of Casar" (27).

'The figure in parenthesis refers to the number of the topic in the Appendix, where a fuller title of the book will be found. 
Fowler, Cæesar, Ch. 7, “Cæesar's First Consulship"; Ch. 18, "Cæasar's Use of Absolute Power" (27).

Dodge, Ciesar, Ch. 24, "Ciesar's Army" (27).

Munro, Source Book, Part VIIl., "Last Century of the Republic" (25).

Plutarch, "Sertorius," "Lucullus," "Pompey," "Crassus," "Cato the Younger," "Cresar," "Cicero" (26).

\section{CHAPTER XXVII}

THE LAST STRUGGLE FOR THE EMPIRE-ANTONY AND OCTAVIÚS

\section{The Rise of Antony and Octavius}

The Confusion after Cæsar's Death.-We need not be surprised that the death of Cæsar was followed by confusion and dismay. His murderers considered themselves as "liberators" of the republic. But their rash act gave to Rome another period of strife and civil war. They had killed Cæsar; but they had provided for no one to take his place. If they thought that the senate would be restored to its old position they were grievously mistaken. The only leading man of the senate who had survived the last civil war was Cicero; but Cicero with all his learning and eloquence could not take the place of Cæsar. Soon there appeared new actors upon the scene, men struggling for the supreme power in the state-M. Anto'nius (An'tony), the friend of Cæsar and his fellow-consul; C. Octavius, his adopted son and heir; M. Emilius Lepidus, his master of horse; Sextus Pompeius, his previous enemy and the son of his greatest rival; ·while Cicero still raised his voice in defense of what he regarded as his country's freedom.

The Elevation of Antony.-The man who had stood nearest to Cæsar was Antony, his fellow-consul. He claimed that it was his duty to carry out the purpose of his murdered chief. He got possession of Cæsar's will and treasures, and influenced 
PROGTRASTVF MAP No. 16.

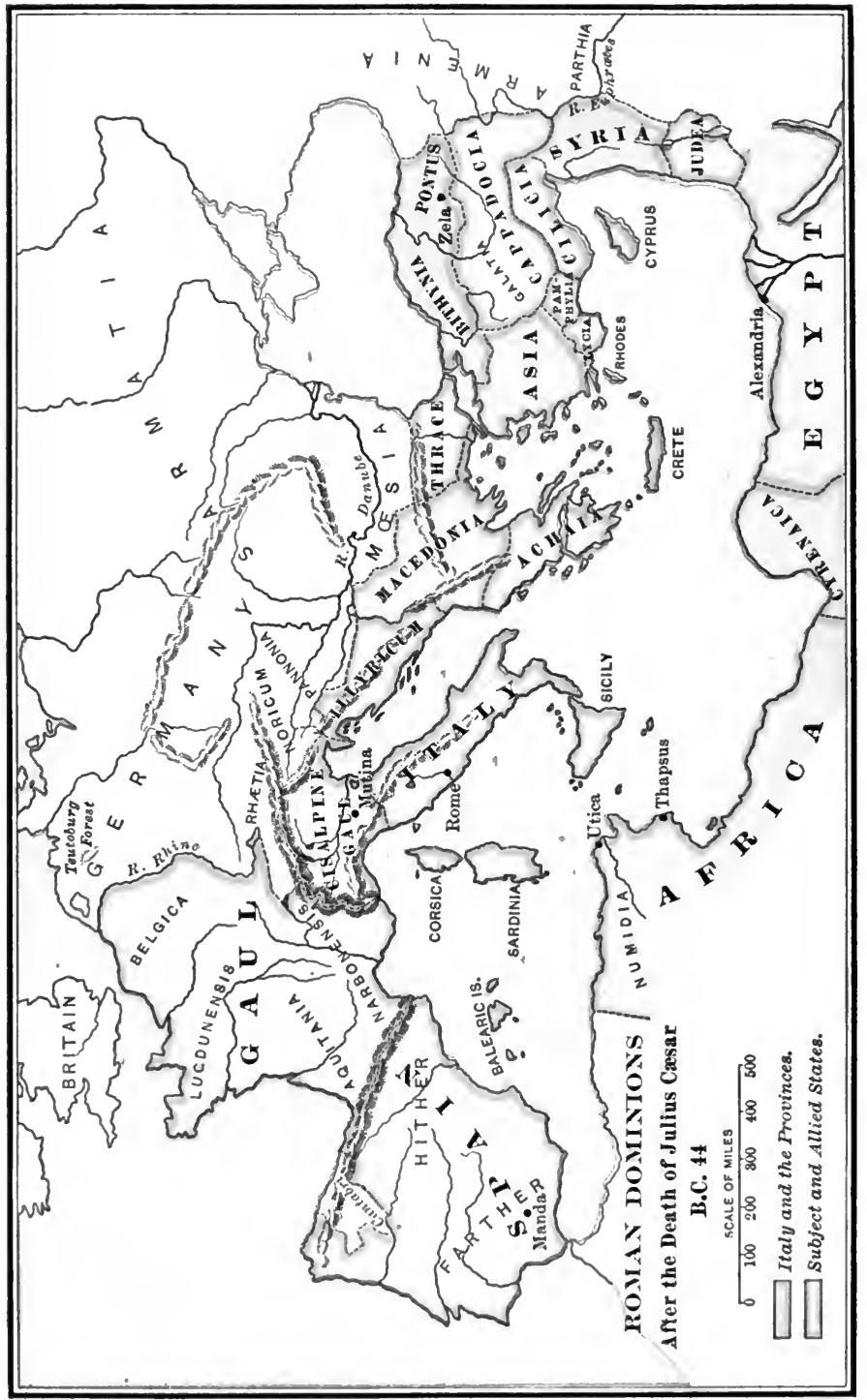


the senate to confirm all of Cresar's acts. He called upon the people to rise up and avenge the death of their greatest friend. The liberators were obliged to flee from the city. They hastened to the provinces to which they had previously been assigned by Censar-Cassius to Syria, Marcus Brutus to Macedonia, and Decimus Brutus to Cisalpine Gaul.

\section{The Appearance of} Octavius.-The only person who could well dispute the claims of Antony was Octavius - a young man of nineteen, who was Cæsar's grandnephew and adopted heir. This young man assumed his adopted name Gaius Julius Cæsar Octavia'nus

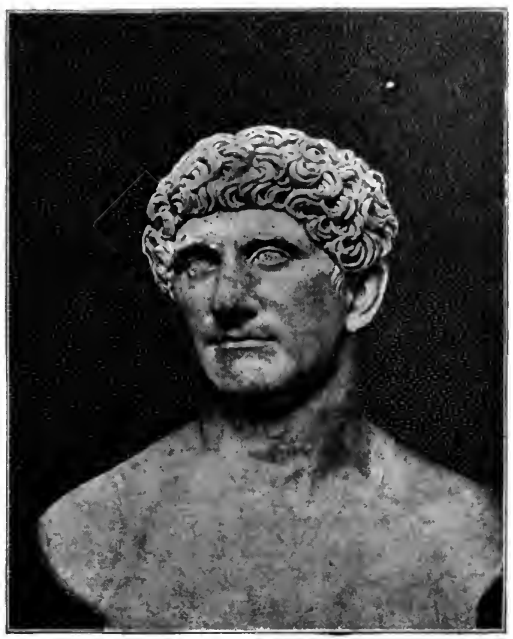

Antony

and disputed with Antony the right to act as Cæsar's representative. By his great generosity he won the favor of the people, who called him by the magic name of Cæsar. He now began to show that adroit skill for which he was afterward noted. His first purpose was to weaken Antony, who had deprived him of his inheritance. He therefore saw fit to unite his cause with that of the senate, which was already opposed to the ambitious schemes of Antony. By this piece of diplomacy Octavius gained the influence of Cicero, the leader of the senatorial party.

Cicero's Attack upon Antony.-The hostility between Cicero and Antony grew to be bitter and relentless; and they were pitted against each other on the floor of the senate. But in a war of words Antony was no match for Cicero. By a 
series of famous speeches known as the "Philippics," the popularity of Antony was crushed; and he retired from Rome to seek for victory upon other fields. He claimed Cisalpine Gaul as his province. But this province was still held by Decimus Brutus, one of the liberators, to whom the senate looked for military support.

When Antony attempted to gain possession of this territory, Cicero thought he saw an opportunity to use Octavius in the

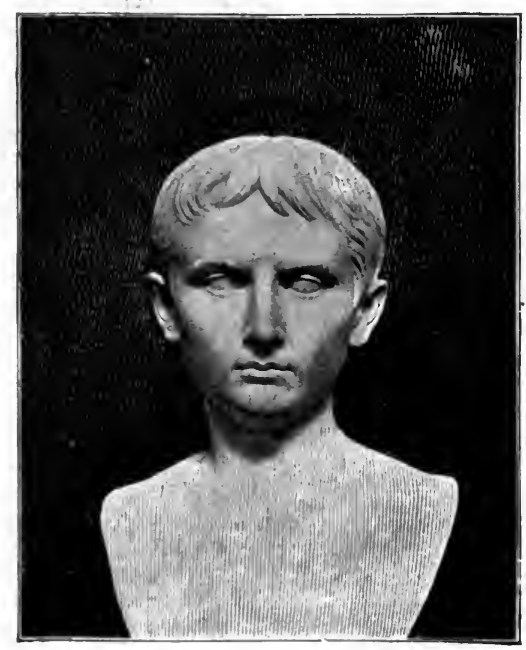

The Young Octavius interests of the senate. Accordingly Antony was declared a public enemy; Octavius was made a senator with the rank of consul, and was authorized to conduct the war against Antony. In this war-the so-called war of Mu'tina (44-43 B. C.)-Octavius was successful. As a reward fon his victory he demanded of the senate that he receive a triumph and the consulship. Cicero and the senate had intended Decimus Brutus for this office, and the request of Octavius was refused. But the young heir, then twenty years of age, following the example of Casar, enforcer his claim with the sword; he took possession of the city, and obtained his election to the consulship. Octavius thus became the ruling man in Rome.

Formation of the Second Triumvirate (43 в. c.).-The senate had lost the support of Octavius by opposing his election to the consulship. The young leader now sought to secure his position by reconciling his previous enemy, Antony. An- 
tony was supported by Lepidus, who had an army in 'Transalpine Gaul. A coalition was formed between these three leader's -Antony, Octavius, and Lepidus-usually called the "Second Triumvirate." Unlike the First 'Triumvirate, this was sanctioned by a law of the tribal assembly. The leaders agreed to oppose the senate, to divide among themselves the western provinces, and then to make war upon the chief liberators, Brutus and Cassius, who held possession of the eastern provinces. They assumed a dictatorial power for five years, with the right of appointing all magistrates. Their decrees were to have the force of law without the approval of either the senate or the people.

It is to the eternal disgrace of these men who professed to espouse the cause of Cæsar, that they abandoned the humane policy of their great exemplar, and returned to the infamous policy of Marius and Sulla. Antony especially desired a proscription, as he was surrounded by thousands of personal enemies, chief among whom was Cicero, the author of the "Philippics." It is said that three hundred senators and two thousand equites were outlawed and their property was confiscated; besides, a large number of persons were slain. The most distinguished victim of this horrible work was Cicero. When the old man was warned of his danger and urged to flee, he replied, "Let me die in my fatherland, which I have so often saved."

War against the Liberators; Battle of Philippi (42 B. C.).Having murdered their enemies at home, the triumvirs were now prepared to crush their enemies abroad. There were three of these enemies whom they were obliged to meet-Brutus and Cassius, who had united their forces in the East; and Sextus Pompeius, who had got possession of the island of Sicily, and had under his command a powerful fleet. While Lepidus remained at Rome, Antony and Octavius invaded Greece to meet the two liberators, Brutus and Cassius. The hostile forces met near Philip'pi (42 B. c.), a town in Macedonia on the north- 
ern coast of the Aggean Sea (see map, p. 334). Octavius was opposed to Brutus, and Antony to Cassius. Octavius was

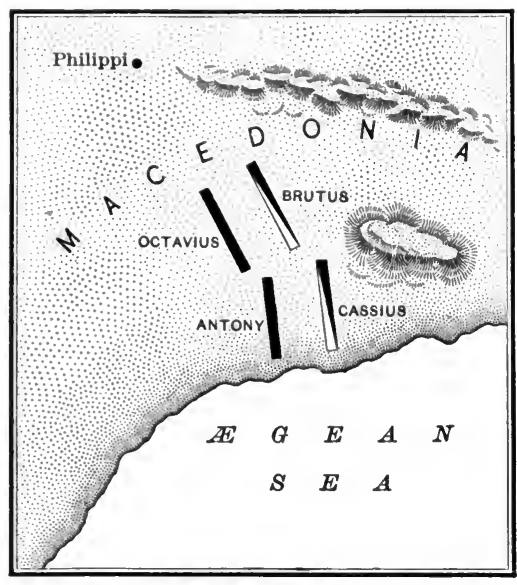

Battle of Philippi driven back by Brutus, while Antony, more fortunate, drove back the wing commanded by Cassius. As Cassius saw his flying legions, he thought that all was lost, and stabbed himself with the same dagger, it is said, with which he struck Cæsar. This left Brutus in sole command of the opposing army; but he also was defeated in a second battle, and, following the example of Cassius, committed suicide. By the battle at Philippi the last opposition to the triumvirs was destroyed.

\section{Civil War between Antony and Octavius}

New Division of the Provinces.-The Roman world was now under the power of Antony, Octavius, and Lepidus, who proceeded to a redivision of the provinces. But Lepidus was too weak to receive much consideration. Antony was to take control of the eastern provinces, and to push the Roman conquests if possible into Parthia. Octavius was to preserve the peace of Italy and the western provinces, and to destroy the fleet of Sextus Pompeius, which was interfering with Roman commerce and threatening to cut off the grain supplies of Italy. Lepidus had to be satisfied with the small province of Africa.

Octavius in the West.-Octavius proceeded to secure his position in the West by means of force and craft. He first 
put down an insurrection incited by the partisans of Antony. The young conqueror won the affections of the people, and tried to show them that peace and prosperity could come only through his influence. Next, with the help of his friend and able general, Agrip'pa, and with the aid of a hundred ships lent him by Antony, Octavius destroyed the forces of Sextus Pompeius. The defeated general fled to the East, and was killed by the soldiers of Antony.

Octavius was then called upon to deal with a treacherous friend. This was the weak and ambitious Lepidus, who with twenty legions fancied that he could defeat Octavius and become the chief man of Rome. But Octavius did not think the emergency grave enough to declare war. He defeated Lepidus without a battle. Unarmed and almost unattended he entered his rival's camp, and made an eloquent appeal to the soldiers. The whole army of Lepidus deserted to Octavius. Lepidus was deposed from his position as triumvir, but was generously allowed to retain the office of pontifex maximus. By the use of force and diplomacy Octavius thus baffled all his foes in the West, and he and Antony were now the undisputed rulers of the Roman world.

Antony in the East.-While everything in the West was turning in favor of Octavius, all things in the East were also contributing to his success. But this was due not only to his own skill but to the weakness and folly of Antony. Octavius had tried to cement the league of the triumvirs by giving his sister Octavia to Antony

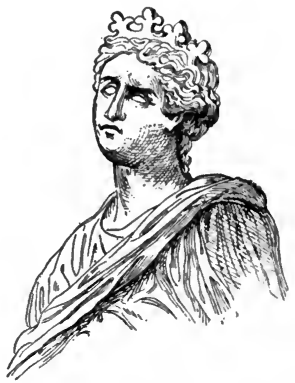

Cleopatra in marriage. But Antony soon grew tired of Octavia, and became fascinated by Cleopatra, the "Serpent of the Nile." He aspired to the position of an Oriental monarch. He divided the Roman provinces with Cleopatra, who was called "the queen of kings." The Roman people 
were shocked when he desired his disgraceful acts to be confirmed by the senate. They could not help contrasting this weak and infatuated slave of Cleopatra with their own Octavius, the strong and prudent governor of the West. While Octavius was growing in popularity, Antony was thus becoming more and more an object of detestation.

Rupture between Antony and Octavius.-The strong feeling at Rome against Antony, Octavius was able to use to his own advantage. The people suspected Antony of treasonable designs, as they saw his military preparations, which might be used to enthrone himself as king of the East, or to install Cleopatra as queen of Rome. All doubt as to Antony's real character and purpose was settled when his will was found and published. In it he had made the sons of Cleopatra his heirs, and ordered his own body to be buried at Alexandria beside that of the Egyptian queen. This was looked upon as an insult to the majesty of Rome. The citizens were aroused. They demanded that war be declared against the hated triumvir. Octavius suggested that it would be more wise to declare war against Cleopatra than against Antony and the deluded citizens who had espoused his cause. Thus what was really a civil war between Octavius and Antony assumed the appearance of a foreign war between Rome and Egypt. But Antony well understood against whom the war was directed; and he replied by publicly divorcing Octavia, and accepting his real position as the public enemy of Rome.

Battle of Actium (31 в. c.).-When war was declared, Antony and Cleopatra united their forces against Rome. Antony gathered together an immense army and occupied the western coasts of Greece. where he could either threaten Italy or resist the approach of Octavius. His main army was posted at Actium (see map, p. 334), south of the strait leading into the Gulf of Ambracia. His fleet was for the most part moored within the gulf. Octavius, with the aid of his trusted general $\Lambda$ grippa, succeeded in transporting an army to the coast of 
Epirus, and took up a position north of the strait and opposite the land forces of Antony. His fleet was stationed outside of the strait to await the approach of the enemy's vessels. Antorıy, on the advice of his ablest officers, desired that the battle should be waged with the land forces. But Cleopatra, proud of her navy, insisted that it should be fought on the sea. 'The contest was therefore decided by a naval battle. As the fleet of Antony emerged from the strait, it was immediately attacked by Octavius and Agrippa. But scarcely had the battle begun when Cleopatra with her squadron withdrew from the line, and was quickly

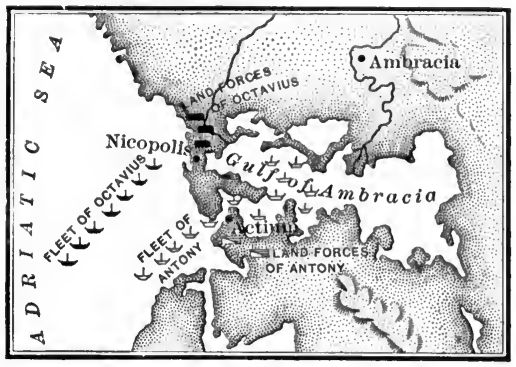

Battle of ACTium followed by Antony. Their sailors fought on until their fleet was destroyed. The battle of Actium closed the political career of Antony, and left Octavius the sole master of the Roman world.

Before returning to Rome Octavius restored order to the eastern provinces, and followed the fugitives to Egypt. Antony, defeated and ruined, committed suicide; and Cleopatra followed his example rather than be led a captive in a Roman triumph. Together this wretched pair were laid in the mausoleum of the Ptolemies. Egypt was annexed as a province of the new empire (30 в. с.). Octavius returned to Rome (29 B. c.), where he was given a triple triumph-for Dalmatia (part of Illyricum, where he had won some previous victories), for Actium, and for Egypt. The temple of Janus-the doors of which were always left open in time of war-was now.closed for the first time since the second Punic war; and the Romans, tired of civil strife and bloodshed, looked upon the triumph of Octavius as the dawn of a new era of peace and prosperity. 


\section{Review of the Period of the Civil Wars}

Political Progress at Rome.-There is no period of Roman history more eventful or instructive than that which we have just considered-extending from the time of the Gracchi to the triumph of Octavius. If we look merely at the surface of events, it may perhaps seem to be hardly more than a period of strife, of turmoil, of revolution, and of civil war. But if we compare the wretched condition of things which Tiberius Gracchus first sought to remedy, with the new system which Julius Cæsar established and Octavius sought to make permanent, we must conclude that it was during this time that the Roman people were working out the greatest political problems of their history. In the midst of the greatest discouragements, and often under incompetent leaders, they continued to fight for justice, until they at last found a chieftain capable of defending their interests. The people learned that they could not secure their rights by means of unwieldy assemblies, which were often ruled by ambitious demagogues-and they had not discovered the modern principle of representation. If they could not obtain a government by the people, they could at least obtain a government for the people, under the control of an efficient magistrate devoted to their interests. With our advanced political ideas and experience, we may not believe that Roman imperialism is the best form of government; it was yet the highest and most successful form of government developed in the ancient world. By such a government, the Roman people secured political equality, and perhaps as much political freedom as was possible without representative institutions.

Improvement of the Roman Law.-It was also during this time that the Romans were developing that remarkable system of law which surpassed that of any other ancient people. The basis of this law was the XII. Tables. In earlier times, the patricians only possessed legal rights; but these rights came to be extended to the plebeians, and with every enlarge- 
ment of the Roman state there had been an extension of civil rights. As to his civil rights, every free person was a Roman citizen, a Latin, or a foreigner. A Roman eitizen had both the conubium and the commercium-that is, he had, first, the rights growing out of the family organization, such as the paternal power and inheritance, and, second, the rights growing out of commercial transactions, such as property and contract. A Latin had only the commercium; ${ }^{1}$ while the foreigners (including the Italian allies) had at first no rights under the lioman law. During this time, however, the rights of citizens and of Latins were continually being extended. But more than this, the rights of all foreigners in Italy came to be protected by a special prætor (prcetor peregrinus). Under this new prætor there was gradually developed a new body of law, called the jus gentium, a law common to the nations of Italy which applied to those whose rights were not protected by the old XII. Tables. After the "Social war" all the inhabitants of Italy were admitted to the full rights of citizenship; and the jus gentium came to be extended so as to apply to all provincials whose rights could not otherwise be secured. In this way, the Romans developed a system of law by which every free person in the Roman world could have his civil rights protected, in some way or other, in a court of justice.

Advancement in Literature.-Another evidence of the progress of the Romans during the period of the civil wars is seen in their literature. It was at this time that the influence of Hellenism became very marked, and that under this influence Rome began to produce writers whose names belong to the literature of the world. Cæsar wrote his "Commentaries on the Gallic War," which is a fine specimen of clear historical narrative. Sallust wrote a history of the Jugurthine war and an account of the conspiracy of Catiline, which give us graphic and vigorous descriptions of these events. Lucre'tius wrote a

${ }^{1}$ This applies to the later Latinitas, after this franchise was extended beyond the limits of Latium to the Latin colonies throughout Italy. 
great poem "On the Nature of Things," which expounds the Epicurean theory of the universe and reveals powers of description and imagination rarely equaled by any other poet, ancient or modern. Catul'lus wrote lyrie poems of exquisite grace and beauty. Cicero was the most learned and prolific writer of the age; his orations, letters, rhetorical and philosophical essays furnish the best models of classic style, and have given him a place among the great prose writers of the world.

Progress in Architecture.-That the Romans were also improving in their culture and taste is shown by the new and splendid buildings which were ereeted during this period.

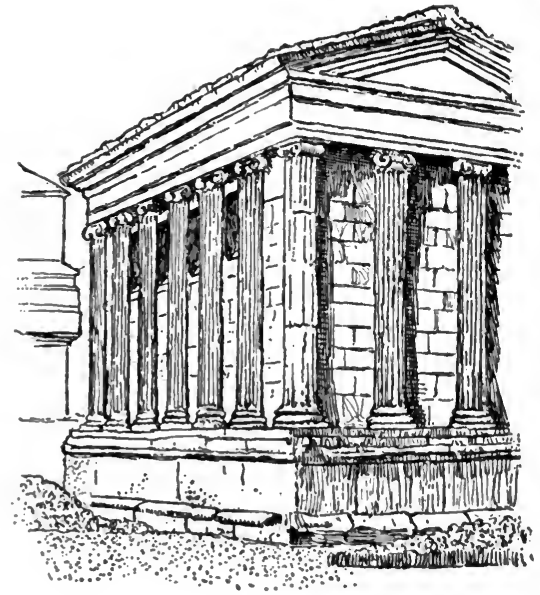

Temple of Fortune

While some public buildings were destroyed by the riots in the city, they were replaced by finer and more durable structures. Many new temples were built-temples to Hereules, to Minerva, to Fortune, to Coneord, to Honor and Virtue. There were new basilicas, or halls of justice, the most notable being the Basilica Julia, which was commenced by Julius Cæsar. A new forum, the Forum Julii, was also laid out by Cæsar, and a new theater was construeted by Pompey. The great national temple of Jupiter Capitolinus, which was burned during the civil war of Marius and Sulla, was restored with great magnificence by Sulla, who adorned it with the columns of the temple of the Olympian Zeus brought from $\Lambda$ thens. It was during this period that the triumphal arches were first erceted, and beeame a distinctive feature of Roman 
architecture. With the exception of the use of the arch, the general features of Roman architecture show the strong influence of Greck ideas-especially in the construction of temples, and in the use of columns, which the Romans generally surmounted with the Corinthian capitals (p. 136).

Roman Education.-The influence of Hellenism is also seen in the increasing attention which the Romans paid to education. Roman education, like that of the Greeks, was intended to develop all the mental powers, and to train the young man for public life. Childrenboth boys and girls-began to attend school at six or seven years of age. The elementary studies were reading, writing, and arithmetic. The children were taught to write from a copy set, upon their tablets, and to cipher by means of the counting board (abacus) and counters (calculi). The higher education comprised what were called the liberal arts (artes liberales), including the Latin and Greek languages, composition and oratory, and mental and

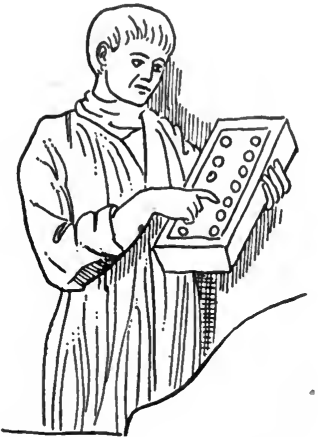

Boy with Calculating BOARD moral philosophy. An important part of education consisted in public recitals and declamations which were intended to train young men for the forum, and were often held in the temples.

Decay of Religion and Morals.-While the Romans, during this period, showed many evidences of progress in their laws, their literature, and their art, they were evidently declining in their religions and moral sense. Their religion was diluted more and more with Oriental superstitions and degrading ceremonies. In their moral life they were suffering from the effects of their conquests, which had brought wealth and the passion for luxury and display. Ambition and avarice tended 
to corrupt the life of the Roman people. The only remedy for this condition of religious and moral decay was found in the philosophy of the Greeks, which, however, appealed only to the more educated classes.

\section{SYNOPSIS FOR REVIEW}

I. Tie Rise of Antony and Octavius.-The Confusion after Cresar's Death.-The Elevation of Antony.-The Appearance of Octavius.-Cicero's Attack upon Antony.-Formation of the Second Triumvirate.-War against the Liberators; Battle of Philippi.

II. Civil War between Antony and Octavius.-New Division of the Provinces.-Octavius in the West.-Antony in the East.Rupture between Antony and Octavius.-Battle of Actium.

III. Review of the Period of the Civil Wars.-Political Progress at Rome.-Improvement of the Roman Law.-Advancement in Literature.-Progress in Architecture.-Roman Education.-Decay of Religion and Morals.

\section{REFERENCES FOR READING}

Merivale, General History, Ch. 48, "Octavius and Antony" (18). ${ }^{1}$ Empire, Vol. III., Ch. 25, "Cicero and the Philippies"; pp. 274, 275 (character of Antony) (18).

Pelham, Bk. V., Ch. 2, "Provisional Government of the Triumvirate" (18).

Taylor, Ch. 16, "The Struggle for the Crown" (22).

Abbott, Ch. 7, "The Period of Transition" (22).

Smith, Wm., Smaller History, Chs. 36, 37, "From the Death of Casar . . . to the Battle of Actium" (18).

Seeley, Essay, "The Great Roman Revolution" (18).

Morey, Roman Law, pp. 72-78, "Improvement of the Roman Law" (22).

Shakespeare, "Antony and Cleopatra."

Collins, Cicero, Ch. 9, "Cicero's Correspondence" (27).

Plutarch, "Antony," "Brutus" (26).

${ }^{1}$ The figure in parenthesis refers to the number of the topic in the Appendix, where a fuller title of the book will be found. 


\section{PERIOD IV. THE ROMAN WORLD UNDER THE EMPIRE (31 B. C.-395 A. D.)}

\section{CHAPTER XXVIII}

THE EMPIRE UNDER AUGUSTUS (31 B. C. -14 A. D.)

\section{The New Imperial Government}

The Policy of Augustus.-There was no other man so well fitted to put the new monarchy into an attractive form as Octavius, whom we may now call by his official title of Augustus. We have been accustomed to think of this man as merely a shrewd politician. But when we contrast the distracted condition of Rome during the last hundred years with the peace and prosperity which he brought with him, we shall be inclined to look upon him as a wise and successful statesman. His whole policy was a policy of conciliation. He wished to wipe out the hatreds of the civil war. He regarded himself as the chief of no party, but as the head of the whole state. He tried to reconcile the conservative and the progressive men of his time. All the cherished forms of the republic he therefore preserved; and he exercised his powers under titles which were not hateful to the senate or the people.

Titles and Powers of Augustus.-Soon after returning to Rome, Augustus resigned the powers which he had hitherto exercised, giving "back the commonwealth into the hands of the senate and the people" ( 27 B. c.). The first official title which he then received was the surname Augustus, bestowed 
by the senate in recognition of his dignity and his services to the state. He then received the proconsular power (imperium proconsulare) over all the frontier provinces, or those which required the presence of an army. He had also conferred upon himself the tribunician

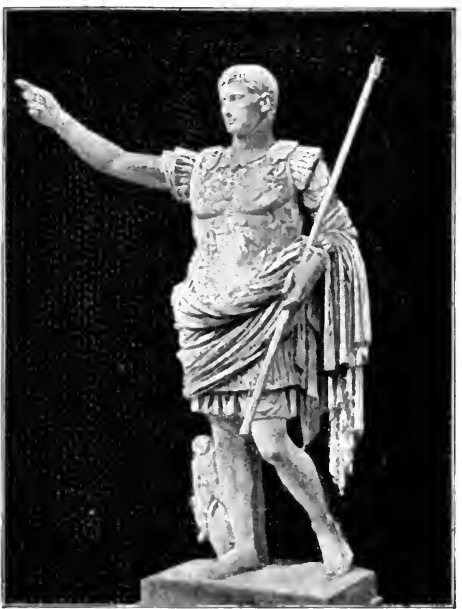

The EMperor Augustus power (tribunicia potestas), by which he became the protector of the people. He moreover was made pontifex maximus, and received the title of Pater Patrix. Although Augustus did not receive the permanent titles of consul and censor, he occasionally assumed, or had temporarily assigned to himself, the duties of these offices. He still retained the title of Imperator, which gave him the command of the army. But the title which Augustus chose to indicate his real position was that of Princeps Civitatis, or "the first citizen of the state." The new "prince" thus desired to be looked upon as a magistrate rather than a monarch-a citizen who had received a trust rather than a ruler governing in his own name.

Augustus and the Senate.-Augustus showed his conciliatory policy in fixing the position which the senate was to assume in the new government. He did not adopt fully the plan either of Sulla or of Julius Cæșar; but reconciled as far as possible their different ideas. He restored to the senate the dignity which it had in the time of Sulla. He did this by excluding the provincials and freedmen whom Cæsar had introduced into it, and by reducing its number from nine hundred to six hundred members. But still he did not confer upon it the 
great legislative power which sulla intender it shonld have; he rather made it a kind of advisory body, according to Gessar's idea. In theory the senate was to assist the emperor in matters of legislation, and hence the new government is sometimes called a "dyarchy"; but in fact the senate was simply to approve the proposals which the emperor submitted to it.

The Assemblies of the People.-Augustus did not formally take away from the popular assemblies their legislative power, but occasionally submitted to them laws for their approval. This was, however, hardly more than a discreet concession to custom. The people in their present unwieldy assemblies, the emperor did not regard as able to decide upon important matters of state. Their duties were therefore practically restricted to the election of the magistrates, whose names he usually presented to them.

The Republican Magistrates.-In accordance with his general policy Augustus did not interfere with the old republican offices, but allowed them to remain as undisturbed as possible. The consuls, prætors, quæstors, and other officers continued to be elected just as they had been before. But the emperor did not generally use these magistrates to carry out the details of his administration. This was performed by other officers appointed by himself. 'The position of the old republican magistrates was rather one of honor than one of executive responsibility.

The Imperial Army.-While the emperor knew that his power must have some military support, he was careful not to make the army a burden to the people. He therefore reduced the number of legions from fifty to twenty-five. As each legion contained not more than six thousand men, the whole army did not exceed one hundred and fifty thousand soldiers. These legions were distributed through the frontier provinces; the inner provinces and Italy were thus not burdened by the quartering of troops. To support the imperial authority at home, and to maintain public order, Augustus organized a 
body of nine thousand men called the "prætorian guard," which force was stationed at different points outside of Rome.

\section{The Imperial Administration}

The Administration of Rome.-The whole empire may be regarded as made up of three parts-Rome, Italy, and the

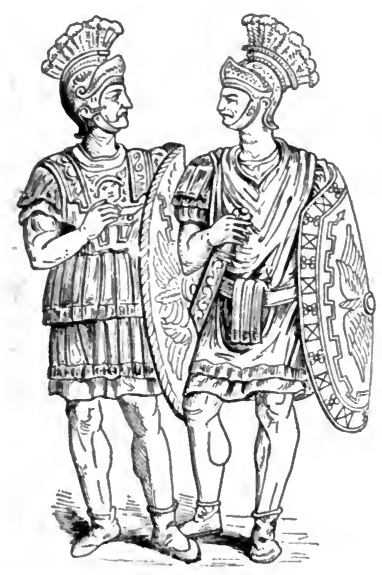

Pretorian Guards provinces. We are now to look at the improvements which Augustus made in these three spheres of administration. We have read enough of the distracted condition of the Roman eity during the last hundred years to see the need of some improvement. Augustus met this need by creating certain new officers to keep the city under better control. He established a city police under the charge of a chief (prcefectus urbi), to preserve order and prevent the scenes of violence which had been of such frequent occurrence. He created a fire and detective department under the charge of another chief ( $p r o$ fectus vigilum), to have jurisdiction over all incendiaries, burglars, and other night-prowlers. He placed the grain supply under a regular officer (prefectus annone) who was to superintend the transportation of grain from Egypt, and was held responsible for its proper distribution. Moreover, he broke up the "secret clubs" which had been hotbeds of disorder, and substituted in their place more orderly societies under the supervision of the government. For administrative purposes the city was divided into fourteen districts, or wards. By these arrangements, life and property became more secure, and the populace became more orderly and law-abiding. 
The Administration of Italy.-Italy was now extended to the Alps, the province of Cisalpine Gaul having lately been joined to the peninsula. 'The whole of Italy was divided by

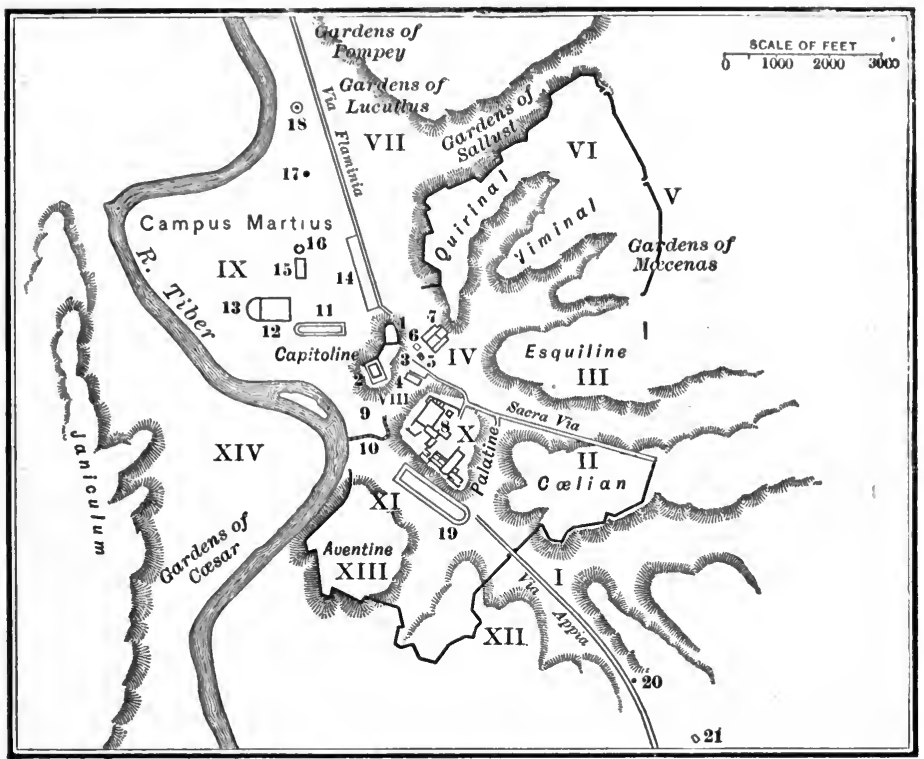

Rome under Augustus

The "Regions" of Augustus: I., Porta Capena ; II., Cælimontium ; III., Isis et Serapis ; IV., Templum Pacis; V., Esquilæ; VI., Alta Semita ; VII., Via Lata; VIİ., Forum Romanum; IX., Circus Flaminius; X., Palatium; XI., Circus Maximus; XII., Piscina Publica ; XIII., Aventinus ; XIV., Trans Tiberim.

Chief Buildings: 1, Arx; 2, Capitollum; 3, Forum Romanum ; 4, Basilica Julia ; 5 , Curia (senate house) ; 6 , Forum of Julius; 7 , Forum of Augustus; 8 , Paiace of the Cæasars: 9 , Forum Boarium; 10 , Cloaca Maxima ; 11, Circus Flaminius: 12. Portico of P'ompey: 13, Theater of Pompey : 14. Sæpta Julia (voting booths) ; 15, Baths of Agrippa ; 16, Pantheon ; 17, Solarium (obelisk) ; 18, Mausoleum of Augustus ; 19, Circus Maximus; 20, Tomb of Scipio; 21, Temple of Mars.

Augustus into eleven " regions," or administrative districts. In order to maintain the splendid system of roads which had been constructed during the republiean period, the emperor appointed a superintendent of highways (curator viarum) to keep them in repair. He also established a post system by 
which the different parts of the peninsula could be kept in communication with one another. He suppressed brigandage by establishing military patrols in the dangerous districts. It was his policy to encourage everywhere the growth of a healthy and vigorous municipal life. To relieve the poverty of Italy he continued the plan of Julius Cresar in sending out colonies into the provinces, where there were better opportunities to make a living.

The Administration of the Provinces.-During the reign of Augustus the number of provinces was increased by taking in the outlying territory south of the Rhine and the Danube. The new frontier provinces were Rhætia, Nor'icum, Pannonia, and Mœsia. The provinces were not only increased in number, but were thoroughly reorganized. They were first divided into two groups, - the senatorial, or those which remained under the control of the senate; and the imperial, or those which passed under the control of the emperor. The latter were generally on the frontiers, and required the presence of an army and a military governor. The governors of the imperial provinces were lieutenants (lega'ti) of the emperor. Appointed by him, and strictly responsible to him, they were no longer permitted to prey upon their subjects, but were obliged to rule in the name of the emperor, and for the welfare of the people. The senatorial provinces, on the other hand, were still under the control of proconsuls and propretors appointed by the senate. But the condition of these provinces was also greatly improved. The establishment of the new government thus proved to be $\varepsilon$ great benefit to the provincials. Their property became more secure, their commerce revived, their cities became prosperous, and their lives were made more tolerable.

The Finances of the Empire.- With the division of the provinces, the administration of the finances was also divided between the senate and the emperor. The revenues of the senatorial provinces went into the treasury of the senate, or the ararium; while those of the imperial provinces passed into 
the treasury of the emperor, or the fiscus. The old wretched system of farming the revenues, which had disgraced the republic and impoverished the provineials, was reformed. 'The collection of the taxes in the senatorial as well as the imperial provinees was placed in the charge of imperial officers. It was not long before the cities themselves were allowed to raise by their own officers the taxes due to the Roman government. Sugustus also laid the foundation of a sound financial system by making careful estimates of the revenues and expenditures of the state; and by raising and expending the public money in the most economical and least burdensome manner.

The Frontiers of the Empire.-By the wars of Augustus, the boundaries of the empire were extended, generally speaking, to the Phine and the Danube on the north, to the Atlantic Ocean on the west, to the desert of Africa on the south, and nearly to the Euphrates on the east. The only two great frontier nations which threatened to disturb the peace of Rome were the Parthians on the east and the Germans on the north. The Parthians still retained the standards lost by Crassus; but Augustus by his skillful diplomacy was able to recover them without a battle. He abandoned, however, all design of conquering that Eastern people. But his eyes looked longingly to the country of the Germans. He invaded their territory; and after a temporary success his general, Varus, was slain and three Roman legions were utterly destroyed by the great German chieftain, Arminius, in the Teutoburg forest $(9$ A. D.). The attempt to conquer Germany thus proved a failure. The frontiers remained for many years where they were fixed by Augustus; and he advised his successors to govern well the territory which he left to them rather than to inerease its limits.

\section{The Age of Augustus}

The Advisers of Augustus.-The remarkable prosperity that attended the reign of Augustus has caused this age to be 
called by his name. The glory of this period is largely due to the wise policy of Augustus himself; but in his work he was greatly assisted by two men whose names are closely linked to his own. These men were Agrippa and Mæce'nas.

Agrippa had been from boyhood one of the most intimate friends of Augustus, and during the trying times of the later republic had constantly aided him by his counsel and his sword. The victories of Augustus before and after he came to power

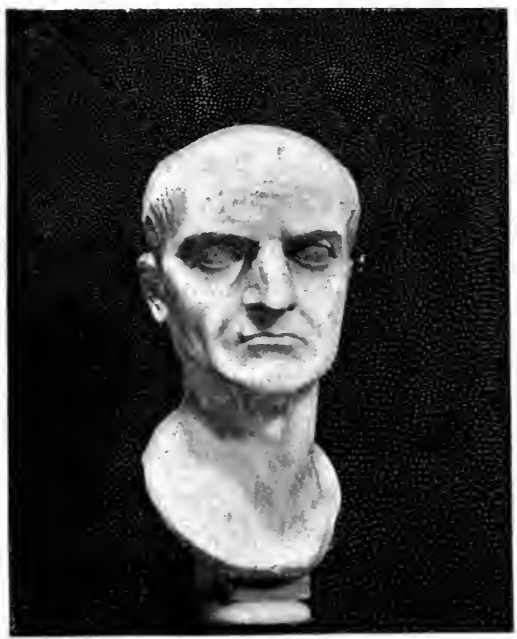

MFCENAS were largely due to this able general. By his artistic ability Agrippa also contributed much to the architectural splendor of Rome.

The man who shared with Agrippa the favor and confidence of Augustus was Mæcenas, a wise statesman and patron of literature. It was by the advice of Mrecenas that many of the important reforms of Augustus were adopted and carried out. But the greatest honor is due to Mæcenas for encouraging those men whose writings made this period one of the "golden ages" of the world's literature. It was chiefly the encouragement given to architecture and literature which made the reign of Augustus an epoch in civilization.

Encouragement to Architecture.-It is said that Augustus boasted that he "found Rome of brick and left it of marble." He restored many of the temples and other buildings which had either fallen into decay or been destroyed during the riots of the civil war. On the Palatine hill he began the construc- 
tion of the great imperial palace, which became the magnificent home of the Carsars. He built a new temple of Vesta, where the sacred fire of the eity was kept burning. He crected a new temple to Apollo, to which was attached a library of Greek and Latin authors; also temples to Jupiter 'T'onans and to the divine Julius. One of the noblest and most useful

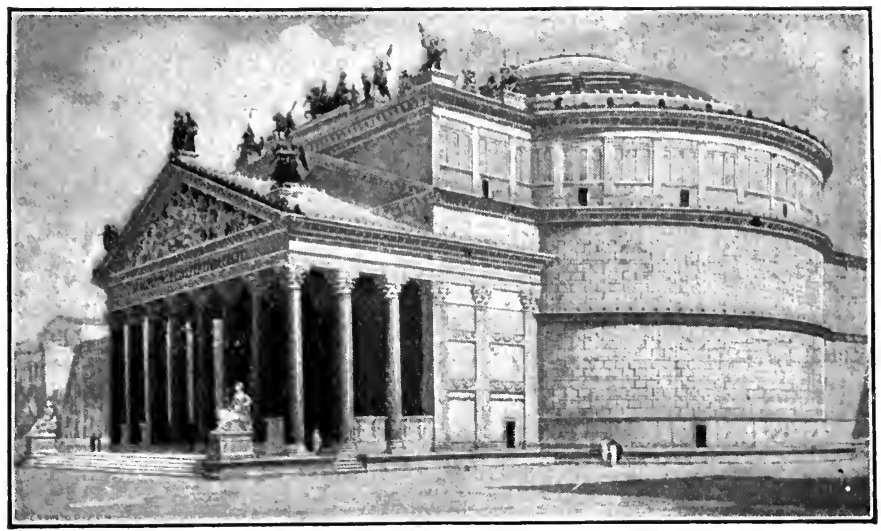

The Pantheon (Restoration)

of the public works of the emperor was the new Forum of Augustus, near the old Roman Forum and the Forum of Julius. In this new forum was erected the temple of Mars the Avenger (Mars Ultor), which Augustus built to commemorate the war by which he had avenged the death of Cesar. We must not forget to notice the massive Pantheon, the temple of all the gods, which is to-day the best preserved monument of the Augustan period. This was built by Agrippa, in the early part of Augustus's reign (27 B. c.), but was altered to the form shown above by the emperor Ha'drian (second century A. D.).

Patronage of Literature.-But more splendid and enduring than these temples of marble were the works of literature which this age produced. At this time was written Vergil's " Aneid," 
which is one of the greatest epic poems of the world. It was then that the "Odes" of Horace were composed, the grace and rhythm of which are unsurpassed. Then, too, were written the elegies of 'Tibul'lus, Proper'tius, and Ov'id. Greatest among the prose writers of this time was Livy, whose "pictured pages" tell of the miraculous origin of Rome, and her great achievements in war and in peace. During this time also flourished certain Greek writers whose works are famous. Dionysius of Halicarnassus wrote a book on the antiquities of Rome, and tried to reconcile his countrymen to the Roman sway. Strabo, the geographer, described the subject lands of Rome in the Augustan age. The whole literature of this period was inspired with a growing spirit of patriotism and an appreciation of Rome as the great ruler of the world.

Religious and Social Reforms.-With his encouragement of art and literature Augustus also tried to improve the religious and moral condition of the people. The old religion was falling into decay. With the restoration of the old temples, he hoped to bring the people

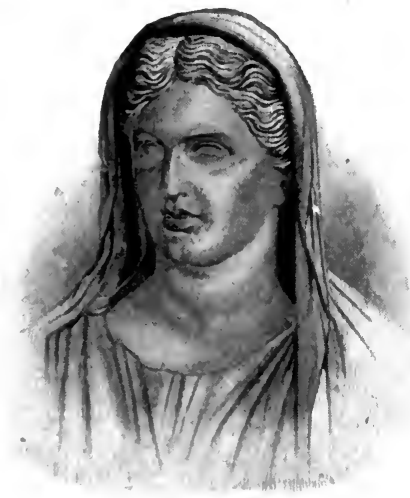
Livi^, Wife of Augustus back to the worship of the ancient gods. The worship of Juno, which had been neglected, was restored, and assigned to the care of his wife, Livia, as the representative of the matrons of Rome. Augustus tried to purify the Roman religion by discouraging the introduction of the foreign deities whose worship was corrupt. He believed that even a great Roman had better be worshiped than the degenerate gods and goddesses of Syria and Egypt; and so the divine Julius was added to the number 
of the Roman gods. He did not favor the Jewish religion; and Christianity had not yet been preached at liome.

With the attempt to restore the old Roman religion, he also wished to revive the old morality and simple life of the past. He himself disdained luxurious living and foreign fashions. He tried to improve the lax customs which prevailed in respeet to marriage and divorce, and to restrain the vices which were destroying the population of Rome. But it is difficult to say whether these laudable attempts of Augustus produced any real results upon either the religious or the moral life of the Roman people.

Death and Character of Augustus.-Augustus lived to the age of seventy-five; and his reign covered a period of forty-five years. During this time he had been performing " the difficult part of ruling without appearing to rule, of being at once the autocrat of the civilized world and the first citizen of a free commonwealth." His last words are said to have been, "Have I not played my part well?" But it is not necessary for us to suppose that Augustus was a mere actor. The part which he had to perform in restoring peace to the world was a great and difficult task. In the midst of conflicting views which had distracted the republic for a century, he was called upon to perform a work of reconciliation. And it is doubtful whether any political leader ever performed such a work with greater success. When he became the supreme ruler of Rome he was fully equal to the place, and brought order out of confusion. He was content with the substance of power and indifferent to its form. Not so great as Julius Cæsar, he was yet more successful. He was one of the greatest examples of what we may call the "conservative reformer," a man who accomplishes the work of regeneration without destroying existing institutions.

\section{SYNOPSIS FOR REVIEW}

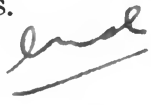

I. The New Imperial Government.-The Policy of Augustus.Titles and Powers of Augustus.-Augustus and the Senate.- 
PROGRESSIVE MAP No. 17.

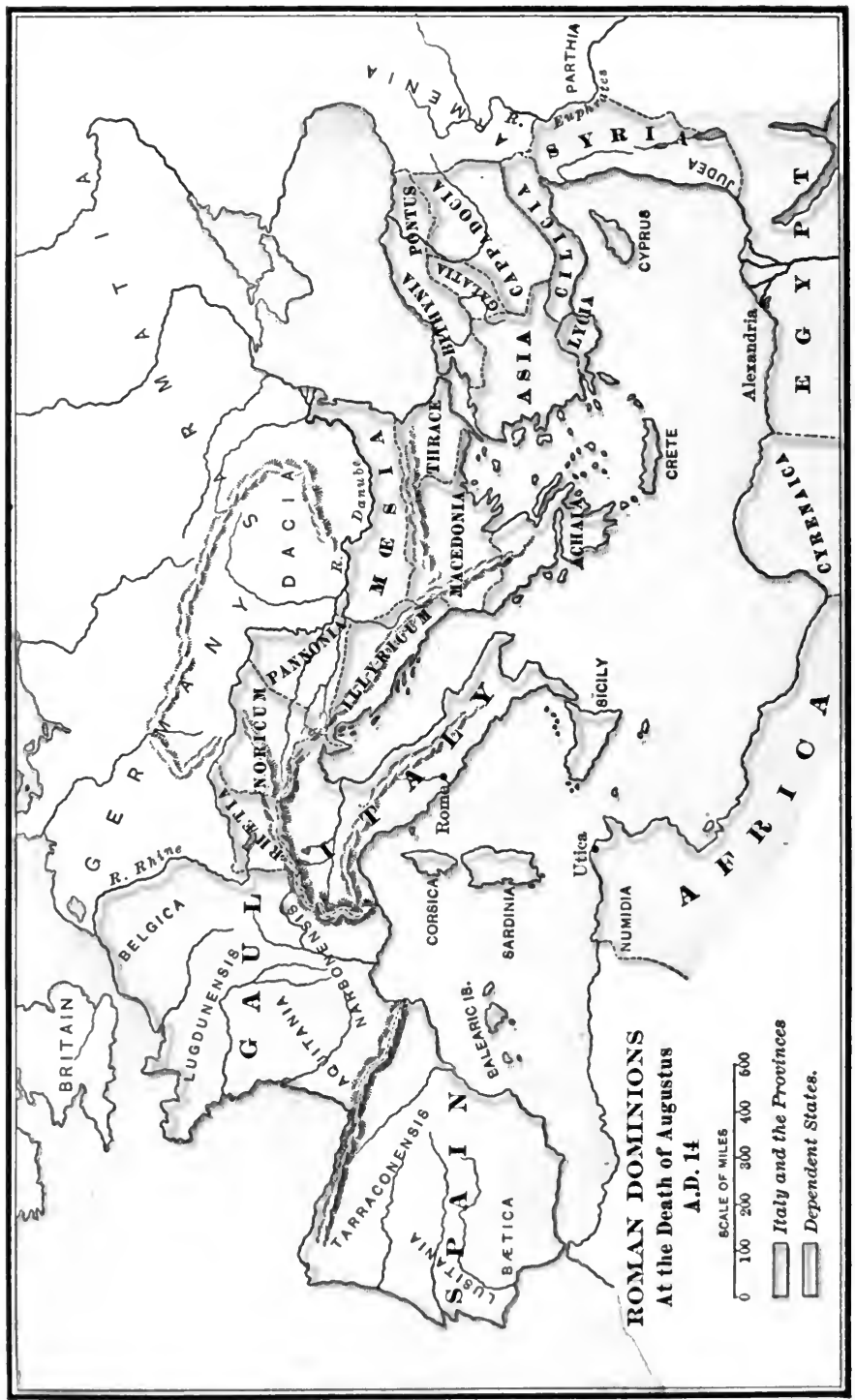


The Assemblies of the People.-The Republican Magistrates.The Imperial Army.

II. 'The Imperiat Anministration.-The Administration of Rome.-The Administration of Italy.-The Administration of the Provinces.-The Finances of the Empire.-The frontier's of the Empire.

1II. The $\Lambda$ ge of Augustus.-The Advisers of Augustus.-Encouragement to Architecture.-Patronage of Literature-Licligious and Social Reforms.-Death and Character of Nugustus.

\section{REFERENCES FOR READING}

Capes, Early Empire, Ch. 1, "Augustus" (18). ${ }^{1}$

Pelham, Bk. V., Ch. 2, "Foundation of the Principate" (18).

Bury, Roman Empire, Ch. 2, "The P'rincipate"; Chs. 6, 7, "Provincial Administration"; Ch. 10, "Rome under Augustus; His Buildings"; Ch. 11, "Literature of the Augustan Age" (18). Taylor, Ch. 18, "The Princeps and the Government" (22). Abbott, Ch. 12, "The Establishmert of the Empire" (22). Merivale, General History, Ch. 51, "The Government as Organized by Augustus” (18).

Empire, Vol. III., Ch. 31, "The Imperial Authority"; Ch. 32, "The Imperial Administration"; Vol. IV., Ch. 34, "Organization of the Provinces by Augustus" (18).

Lanciani, Ruins, pp. 138-144, 302-307 (Augustus as a builder) (20). Greenidge, Public Life, Ch. 10, "The Principate"; Ch. 11, "Italy and the Provinces under the Empire"; pp. 440-444 (the worship of the emperor) (22).

Schuckburgh, Augustus, pp. 265-293 (character of Augustus) $(2 \gamma)$.

Translations and Reprints, Vol. IV., No. 1, "Monumentum Ancyranum" (Deeds of Augustus) (25).

\section{CHAPTER XXIX}

THE DEVELOPMENT OF THE EARLY EMPIRE

\section{The Julian Emperors (14-69 A. D.)}

Tiberius and Caligula.-We shall now see that the imperial system established by Augustus was put to a severe test by the character of the men who immediately followed him. These

${ }^{1}$ The figure in parenthesis refers to the number of the topic in the Appendix, where a fuller title of the book will be found. 
rulers were related to the family of Julius and Augustus; but they had neither the great ability of Julius nor the adroit skill of Augustus. Of the first two of these emperors-Tiberius and Calig'nla-the one is usually characterized as a tyrant, and the other as a maniac.

Tiberius (14-3\% A. D.) was the adopted stepson of Augustus. He was an able general, and had had considerable experience as an administrator. But in his personal character he pre-

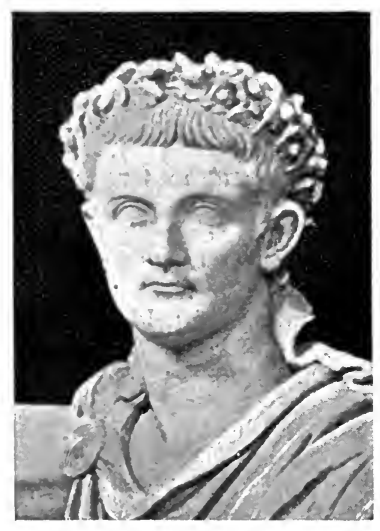

Tiberius sented a striking contrast to his predecessor. Instead of being generous and conciliatory like Augustus, he was sour and suspicious, and often severe and cruel in his treatment of others. He was, on this account, a very unpopular ruler. Even at his accession, the Roman legions on the Rhine and Danube were not disposed to accept his authority. But under the loyal generals - especially German'icus, the nephew of Tiberius - they became reconciled and made successful campaigns against the frontier nations. It is true that Tiberius tried to follow in general the policy of Augustus; but surrounded, as he was, by those whom he could not trust, he sought to strengthen his position by severe and tyrannical methods. His administration was at first vigorous, and the people prospered. He maintained the frontier, and managed the finances with skill and economy; and he also protected the provinces from the rapacity of the governors. But his life at Rome was embittered by court jealousies and intrigues. He retired at last to the island of Capri in the bay of Naples, leaving the control of affairs to his favorite adviser Seja'nus, the commander of the prætorian guards. Sejanus proved to be a more cruel 
and unscrupulous despot than Tiberius; and the last part of this reign was to a large extent filled with his wickedness and erimes.

Tiberius made no provision for a successor. 'The senate, therefore, chose as emperor a young favorite of the army, Gaius Casar, the son of the famous general Germanicus, who was a descendant of Augustus. Gaius $(37-41$ A. D.) is usually known as Caligula ("Little Boots"), a nickname given to him, when a boy, by the soldiers. After a brief period, in which he showed his respect for the senate and the people, his mind, already diseased, gave way; and he indulged in all the wild freaks of an insane person. Many strange stories are told of this delirious young man, which should perhaps excite our pity quite as much as our condemnation. His

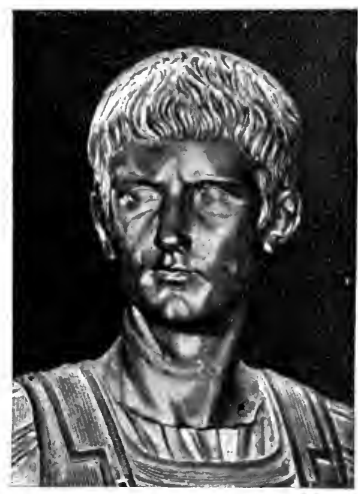

Caligula brief reign of four years has little political significance, except as showing that the empire could endure even with a mad prince on the throne.

Claudius and Nero.-Of the two remaining princes of the Julian line-Claudius and Nero-one is generally known as a moral weakling, and the other as a moral monster. Claudius (41-54 A. D.) was the brother of Germanicus, and was proclaimed by the soldiers. Although the senate did not consider him as a fit person to rule, still the choice of the soldiers was ratified. The Roman nobles were disgusted with the new emperor, because he received the advice of freedmen and provincials. But as a matter of fact these freedmen were often educated Greeks, and proved to be wise counselors and skilled administrators. Although Claudius was personally a weak and timid man, he held before him the example of Augustus. 
He maintained the purity of the senate. He extended the franchise to outlying communities. He abandoned the tyran-

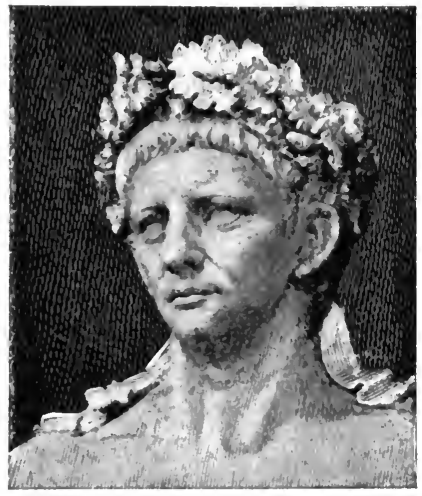

Claudius nical methods of Tiberius. IIe constructed many public works which benefited the people; and he looked after the interests of the provinees. We may look upon Claudius personally as a weakling; but his reign was marked by prudence and a wise regard for the interests of his subjects.

Claudius was followed by a ruler whose eareer proved to be as disgraceful as that of Caligula, and far more criminal. This ruler was Nero (5t-68), a grandson of Germanieus. He was proclaimed by the soldiers and aecepted by the senate. The early part of the reign was full of hope and promise. During this time he was under the influence of the wise philosopher Sen'eca, and the able commander of the pretorian guards, Burrhus. After five year's of beneficent rule (the quinquennium Neronis) the young prince threw aside his counselors, and abandoned himself not to a diseased mind, like Caligula, but to his own depraved nature. Then followed a career of wickedness, debauchery, extortion, and atrocions cruelty which it is not necessary to describe, but

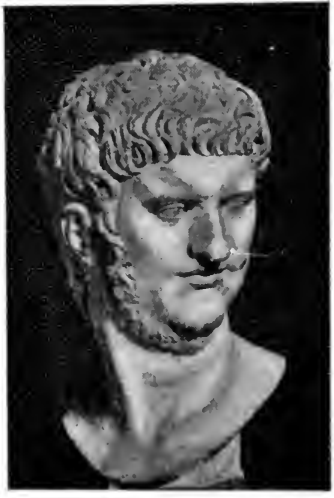

Nero which has rendered the name of this prince a synonym of all that is vicious in human nature and despicable in a ruler. 
The Emperor and the Empire.-If we would get a correct idea of the Roman world under the Julian line, we must distinguish between the character of the emperors and the condition of the empire. When we consider the severe and tyrannical methods of Tiberius, the wild vagaries of Caligula, the weakness and timidity of Claudius, and the eruelty and wickedness of Nero, we can find little to admire in the personal character of these princes. But when we turn from the princes themselves to the world over which they professed to rule, we find that the empire itself was little affected by their peculiarities. While the palace and the capital may have presented scenes of intrigue and bloodshed, the world in general was peaceful and prosperous. This condition of things was no doubt due to the thoroughness of the work done by the great founders of the empire, Julius and Augustus. The imperial system, which had for its purpose the welfare of the people, was not overthrown. The empire prospered in spite of the emperors. But it should be said that when the emperors or their advisers seriously considered the needs of the empire at all, they generally followed the policy of Augustus; and when they were oblivious of these needs, the world moved peacefully on without their aid.

Monarchical Tendencies.-So far as there were any actual changes made in the government, they tended to strengthen the monarchical power. Such changes were made chiefly by Tiberius. In the first place, this emperor took away from the assemblies the power of electing the magistrates, and transferred this power to the senate; so that the people could now neither make their own laws nor choose their own officers. In the next place, Tiberius changed the existing law of treason (lex maiestatis), so that it applied not only to offenses against the state, but to offenses against the emperor himself; and to carry out this law he instituted a class of informers or detectives (delatores) to spy out the enemies of the prince. Moreover, to give a stronger military support to his authority, Ti- 
berius gathered together into a single camp near Rome the prætorian guard, which had hitherto been scattered over Italy. Finally, there was growing up during the Julian period an imperial council, made up of persons selected by the emperor, whom he could consult in preference to the senate. These changes-were intended to strengthen the power of the prince, and to weaken the powers of the senate and the people. It should be noticed, however, in this connection, that the law of high treason and the practice of " delation," established by 'Tiberius, were discouraged especially by Claudius, and also by the other emperors during the sane periods of their administration.

Condition of the Provinces.-Although we must see a great deal in the early imperial system of which we in our day do not approve, still the establishment of the empire was a great benefit to the Roman provinces. 'The provincials, speaking generally, suffered no longer from the oppression and extortion which existed under the old republic. They were no longer plundered to support an avaricious class of nobles at Rome. Even Tiberius, who was tyrannical in many respects, was especially anxious concerning the welfare of the provinces. Claudius, also, was generous in extending the rights of eitizenship. It is true that the public or political right involved in the civitas had now no special importance; but it is also true that the private or civil rights were still a valuable possession for Roman subjects. During this time, also, the provinces were extended (by the emperor Claudius) so as to include Thrace, Lycia in Asia Minor, Mauretania in Africa, and the southern part of Britain.

Public Works. - The encouragement given to public works by Augustus was continued by his successors, especially by Claudius. This emperor constructed the Claudian aqueduet, which hrought water to the city of Rome from a distance of forty-five miles. He also built a new harbor-the Portus Romanus - at the mouth of the Tiber near Ostia. 'To improve 
the agriculture of certain districts in central Italy he constructed a great tunnel to drain the Fucine lake-a work which required the labor of thirty thousand men for eleven years. During the reign of Nero, a great fire occurred at Rome, which consumed a large part of the eity. 'This resulted

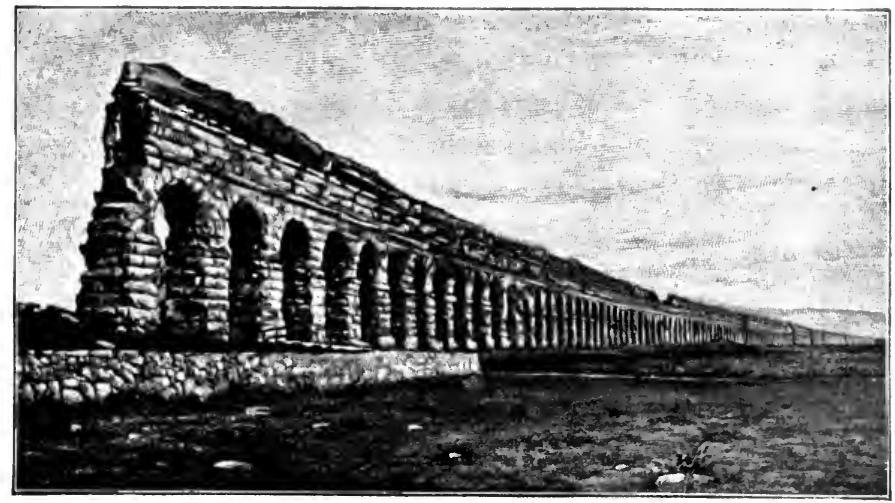

Ruins of the Claudian Aqueduct

in the rebuilding of the city on a more magnificent scale, with wider streets and more splendid edifices.

The Christians at Rome.-The burning of Rome was charged by Nero upon the Christians, in order, as Tacitus says, to remove the burden of suspicion from himself. This is the first time that the Christians are noticed by the Roman historians. The new religion had appeared in Judea about half a century before this time, and had made rapid progress in the eastern provinces. As the Romans were generally tolerant of all religions, there was at first no opposition to the spread of Christianity. There was now a large community of Christians at Rome, made up of converted Jews and other persons from the lower classes. They were despised by the upper classes; and the fire at Rome furnished the occasion of the first persecution. The innocent disciples of the new re- 
ligion were subjected by Nero to the most revolting tortureswhich alone should make the name of this emperor execrated by the human race.

\section{Time Flavian Emperons (69-96 a. D.)}

The Disputed Succession.-With the death of Nero the Julian line, which traced its descent from Julius and Augustus, became extinet. We may now discover one great defect of the imperial system-that is, the lack of any definite law of succession. In theory, the selection of a new emperor rested

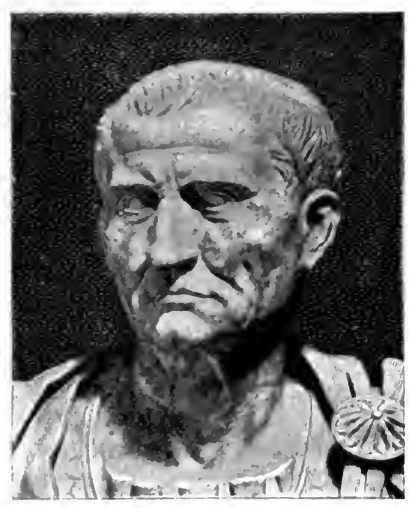

Galba with the senate, with which he was supposed to share his power. But, in fact, it depended upon the army, upon which his power rested for support. Since the time of Tiberius, the choice of the prince had been assumed by the prætorian guards. But now the provincial armies also claimed the right to name the emperor's successor; so that it seemed evident, as Tacitus says, "that a prince could be made elsewhere than at Rome." But it was not so clear which of the armies had the greatest right to make this choice. Hence we find different claimants for the throne-Galba supported by the Spanish soldiers, and soon afterwards Otho, supported by the pretorian guards, Vitellius by the troops on the Rhine, and Vespa'sian by the army in Syria. These disputed claims led to a war of succession, which lasted about a year-the first civil war which had occurred within a century, or since the battle of Actium. After the other claimants had ruled in succession for brief 
terms, Vespasian was finally victorious and made his position secure.

Vespasian and Titus.-With Vespasian (Flavius Vespasianus; 69-79 A. D.) began a new line of emperors, known as the Flavian line; this consisted of Vespasian himself and his two sons, 'Titus and Domitian (do-mish'i-an). 'The rule of Vespasian and that of his older son 'Titus were so nearly alike and were so closely related to each other as to form almost one continuous reign. Tespasian did not belong to any of the old Roman families, but was born in one of the outlying towns of Italy, and might be called a man of the people. He proved to be an able, upright, and efficient prince, and his judicious rule brought in a new era of prosperity for the empire. He restored Rome from the disorder resulting from the recent civil war. By his economy he rescued the treasury from the bankrupt condition into which it had been plunged by his predecessors. He constructed new buildings for the capital, the most important of which was the great Colosse'um,

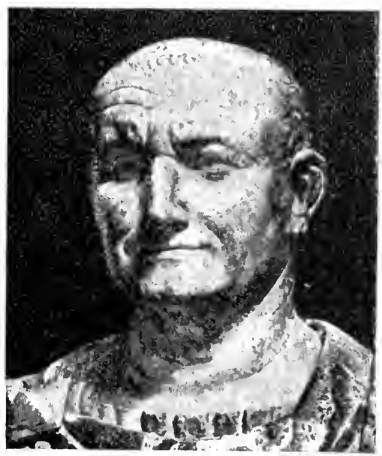

Vespasian or Flavian Amphitheater. He appointed good governors for the provinces, and extended the Latin right to the people of Spain. The only important disturbances during his rule were the revolt of Civi'lis, the governor of Gaul, which was speedily put down, and an unfortunate rebellion of the Jews, which resulted in the destruction of Jerusalem.

Titus (79-81 A. D.) had already been associated with Vespasian in the government, so that the change to the new reign was scarcely noticeable. The new prince ruled but a short time. But during this brief period he followed the benevolent policy of his father, and won from the people the title of "the 
Delight of Mankind." The story is told of him that one evening he recalled the fact that he had granted no favor to any

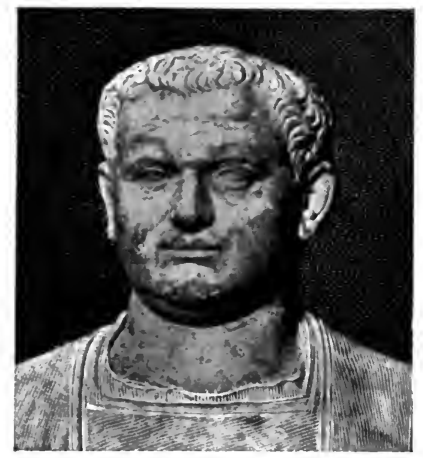

TITUS one since the morning, and in regret exclaimed to his friends, "I have lost a day." But the short reign of Titus, delightful as it was, was marked by two great calamities. One was a very destructive fire which swept over the city; and the other was a terrible eruption of Mt. Vesuvius, which destroyed the cities of Pompe'ii and Hercula'neum.

The Tyranny of Domitian.The happy period begun by Vespasian and Titus was interrupted by the exceptional tyranny of Domitian (87-96 A. D.). The reign of this prince stands out by itself as a dark blot upon an era of general happiness and prosperity. Instead of following in the footsteps of his father and elder brother, he seems to have taken for his models Tiberius and Nero. Morose and severe by nature, he became cruel and tyrannical. He revived the almost obsolete law of Tiberius regarding treason, restored the wretched practice of delation, and resorted to extortions and confiscations. He persecuted the Jews and the Chris-

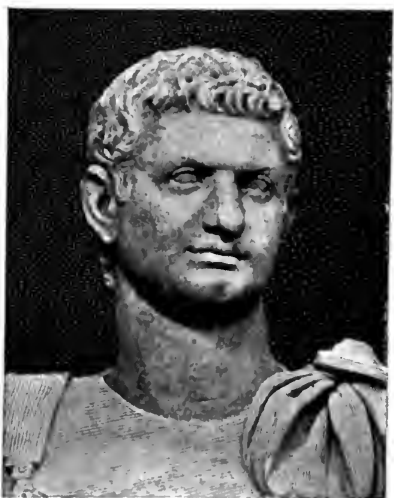

Domitan tians. Tike Tiberius. he was suspicious of those about him and lived in perpetual fear of assassination. His fears were finally 
realized, and he was murdered by a freedman of the palace. 'The most important event of his reign was the extension of the Roman power in Britain under the able governor and general Agric'ola - which event paved the way for the advance of civilization in that province.

Classes of Roman Society.-If we now look at the condition of society under the Flavian emperors, we shall notice that certain changes had taken place since the time of the republic. The general tendency of the imperial system was to create a greater degree of equality among the various classes. The wide distinctions which existed under the republic were breaking down, and the social grades were merging together. This will appear by considering the different classes of the Roman people :

(1) At the top of the social scale were the emperor and the imperial household. Although the position of the emperor was becoming more and more exalted, it was also becoming recognized that the position could be held by a man of humble origin, as in the case of Vespasian. Nearest the emperor were the so-called "friends of Cæsar," who made up his household and the coterie of his selected guests. These persons were chosen from all classes and were often freedmen and provincials, whose honored position depended solely upon the favor of the prince.

(2) Next were the aristocratic classes, who still formed a sort of nobility - the senators and equites. But the senatorial order was not now restricted, as formerly, to certain favored Roman families. On the contrary, the senators were selected by the emperor on account of their wealth, ability, or influence, and were chosen from persons from every part of the empire-Rome, Italy, and the provinces. The equestrian order, also, was becoming less and less an exclusive body, and admission to it was a gift of the prince. It had no important political privileges, although it came to be customary for the emperor to select his officials from its members. 
(3) The great body of the common people consisted of the professional classes, the lawyers, teachers, writers, physicians; the commercial classes, the merchants, bankers, traders; the artisan classes, the smiths, weavers, fullers, bakers, etc.; and the agricultural classes, the farmers and free laborers. So far as their strictly civil rights were concerned-that is, the rights of person, of property, of inheritance, of contract, and of suing in a court of justice-all these people were on a plane of practical equality with the upper classes.

(4) The slaves were, of course, at the bottom of the social scale, and were deprived of civil rights. But their condition was better than in the time of the republic. They were treated with more respect; their lives were protected; and there were increased facilities for manumission.

Domestic Life; Houses, Food, Dress.-To obtain a general idea of the life of the Roman people under the empire, we may first look at the Roman citizen in his own home, where he ruled as the head of his household. The Romans were now beginning to look upon the family more as a legal than as a religious institution. The formal ceremonies which in ancient times had usually accompanied marriage were often dispensed with; and the relation between husband and wife was looked upon as a mere civil contract, which might be entered into and broken by mutual consent. Divorces became common. and the general morals of society were corrupted. The home, especially in the city, did not present the simple domestic life of the ancients, but was affected by the general passion for luxiry and fondness for display. This is seen in the structure of the houses, the preparation of the food, and even in the character of the dress.

(1) The Roman houses were no longer the simple structures of the early republic, but were modeled after the most elaborate houses of the later Greeks, which had begun to show the effect of an Oriental taste. The excavations among the ruins of Pompeii have given us much knowledge of this domestic 
architecture. 'The principal room was the large reception room (atrium), entered from the strect by a vestibule; it was supported by marble columns, and paved with mosaic; it was lavishly decorated with ivory, grold, and precions stones, and adorned with statues of bronze and marble. On either side of the atrium were the library and the picture gallery, besides rooms for conversation. Leading to the rear was the peristyle,

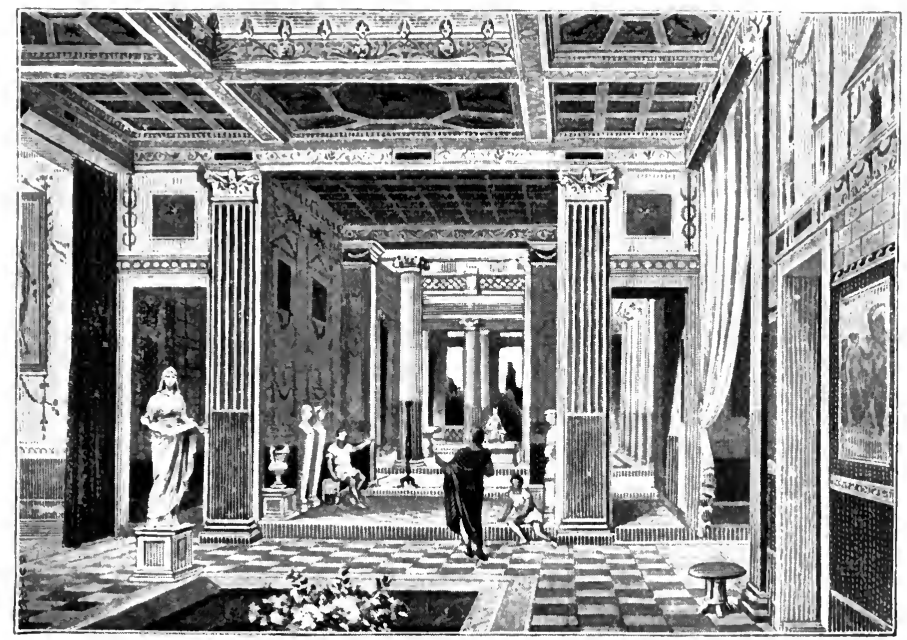

Roman House, showing the Atruum in the foreground

or open court, containing a garden and fountain, and surrounded by rows of columns. Beyond the peristyle were the dining room, the dormitories, the bathrooms, the kitchen, and the larder. The furniture was elaborate and expensivecarved tables and chairs of valuable woods, besides cabinets in which silver vessels were displayed.

(2) In the elaborate preparation of their food and in their costly banquets the Romans showed great fondness for display. Not satisfied with the simple meals of their ancestors, they vied with one another in obtaining the rarest delicacies from 
Italy and other parts of the world. Fortunes were spent upon single feasts; and gluttony was reduced to what was supposed to be a fine art.

(3) In very ancient times the Romans wore but a single garment, the tunic, made of wool. Afterward, the men adopted the toga, a loose garment thrown in ample folds about the person; and the women began to wear the stola, patterned after the Greek robe, together with the palla, or shawl, large enough to cover the whole figure. During the later republic and under the empire, the dress of the Romans became more expensive, being made of the richer materials of linen and silk imported from the East, and more elaborately trimmed; and a growing taste for expensive jewelry and other personal ornaments was developed among the Roman women.

Social Life and Amusements.-The social enjoyment of the Romans was in some respects like that of the Greeks, being found chiefly outside of the home. The Forum was to Rome what the Agora was to Athens, a center of public and social life. But the ordinary Roman had not the Greek taste for intellectual companionship; he rather sought his chief recreation in the baths and in the crowds of the circus, the theater, and the amphitheater.

(1) In their baths the Romans of the empire showed their growing appreciation of the luxuries of life. The private baths of the dwelling house no longer satisfied their needs. Public baths (therme) on an enormous scale were built by the emperors. These contained a large number of rooms, supported by columns of granite or marble, paved with mosaic, and adorned with works of art. They included not only bathing rooms, but gymnasia for exercising, gardens for lounging. galleries of statues and paintings, libraries for reading, and halls for conversation. 'The baths became centers of social life, where the rich and the poor, the emperor and the slave, met together-showing the democratic spirit of the life under the empire. 
(2) The circus afforded a greater attraction for the people in general. The most important circus of Rome was the Circus Maximus. It was an inclosure about two thousand feet long and six hundred feet wide. Within it were arranged seats for different classes of citizens, a separate box being reserved for the imperial family. The games consisted chicfly

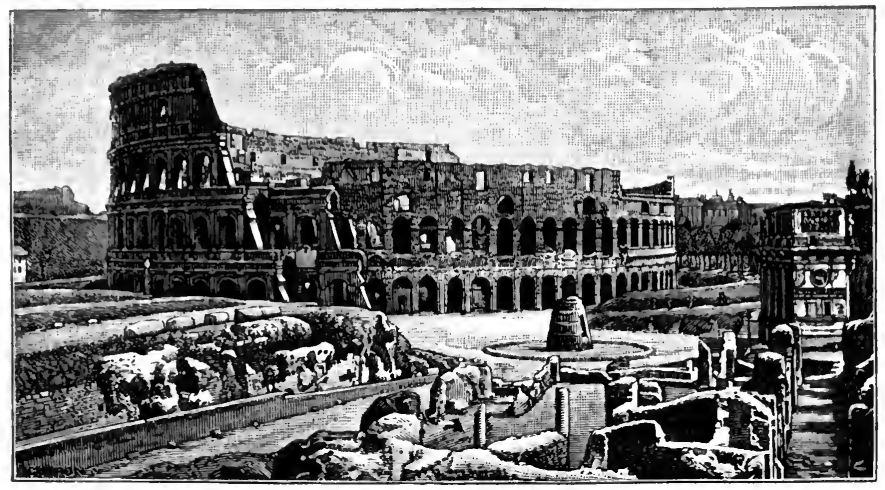

Ruins of the Flavian Ampiittheater

of chariot races. The excitement was due to the reckless driving of the charioteers, each striving to win by upsetting his competitors. There were also athletic sports; running, leaping, boxing, wrestling, throwing the quoit, and hurling the javelin. Sometimes sham battles and sea fights took place.

(3) The Romans were not very much addicted to the theater, there being only three principal structures of this kind at Rome, those of Pompey, Marcellus, and Balbus (pp. 468, 469). The theater was derived from the Greeks and was built in the form of a semicircle, the seats being apportioned, as in the case of the circus, to different classes of persons. The shows consisted largely of dramatic exhibitions, of mimes, pantomimes, and dancing.

(4) The most popular and characteristic amusements of the Romans were the sports of the amphitheater. This build- 
ing was in the form of a double theater, forming an entire circle or ellipse. Such structures were built in different cities of the empire, but none equaled the colossal building of Vespasian. known as the Colosseum. The sports of the amphitheater were chiefly gladiatorial shows and the combats of wild beasts. The amusements of the Romans were largely sensational, and appealed to the tastes of the populace. Their influence was almost always bad, and tended to degrade the morals of the people.

Life in the Towns; Pompeii and the Graffiti.- When we attempt to get an idea of the life in the various towns scattered over the empire, we find it difficult on account of the few references made to this life by the ancient writers. We may say in general, however, that the cities of the eastern provinces remained to a great extent under the Græco-Oriental influence which followed the conque t of Alexander; while the eities of the western provinces became more thoroughly Romanized. These western towns may, therefore, be regarded as reflections in miniature of the capital city on the 'Tiber.

The uncovered ruins of P'ompeii enable us to judge somewhat of the life in a Roman town. Here we find the remains of a city of small dimensions, of narrow streets, of houses of moderate size, but containing many features which we see in Rome itself-forums, theater, temples, as well as a basilica and an amphitheater. These monuments indicate a life quite similar to that of the metropolis. In some of the houseslike the "House of Pansa"-we see the same taste for luxury, as is evident in the mosaic work, paintings, and other works of art. We also find some remarkable evidences of the ordinary life of the townsmen in the graffiti, or writings left upon the walls of buildings, some of which hardly rise above the dignity of rude scribblings. These are most numerous upon the buildings in those places most frequented by the crowd. There are alvertisements of public shows, memoranda of sales, cookery receipts, personal lampoons, sentimental love effu- 
sions, and hundreds of similar records of the ordinary life and thoughts of this ancient people.

Provincial Life, Travel, and Correspondence.-The general features that we see in Pompeii were no doubt repeated in the various towns throughout the provinces, especially in the West. There was evidently the same tendency in the cities of Gaul, Spain, and Africa to imitate the culture of the central city, to adopt the Roman language, art, and manners. But there were certain special features of provincial life which are worthy of notice.

With the overthrow of the old system of official despotism that prevailed under the republic, there was a growing interest in public affairs on the part of the people. Each town vied with other towns in the improvement of the public works. The growing public spirit is shown in the buildings erected not only by the town itself, but by the generous contributions of wealthy private citizens.

The relations between the people of the provinees were also becoming closer by the improvement in the means of communication. The empire became covered with a network of roads, which were now used not merely for the transportation of armies, but for purposes of travel and correspondence. The Appian Way, originally built by Appius Claudius (p. $312)$, was reconstructed during this period, and was the model for the other highways of the empire. The Romans traveled for business and for pleasure; and by some persons traveling by land or by sea was regarded as a part of one's education. It was a mark of culture to have spent some time in Greece, Asia Minor, or Egypt. Many of the Roman highways were used as post-roads, over which letters might be sent by means of private runners or by government couriers. Foot-runners were accustomed to make a distance of twenty-five miles a day; while a mounted courier, with his relay of horses, might cover a hundred miles in the same time. The postal system of Rome, although hardly to be compared with that of 
modern times, afforded a useful means for the transmission of official dispatches and for the correspondence between private persons.

Industry and Commerce.-The industrial life of Rome still suffered from the introduction of slave labor which followed the great wars of conquest during the republican period. Practically all the agricultural and manufacturing labor was performed by slaves. This led to the degradation of these forms of industry. Hence Italy ceased to produce the commodities that she needed; and this in turn led to the necessity of importing from the provinces a large part of the grains and manufactured products necessary for consumption. Commerce, therefore, continued to be the most important industry during the imperial period. The mercantile pursuits-those of the merchant, the importer, the banker, the capitalistwere the most honored occupations. Rome carried on an extensive commerce with all parts of the world. From Spain she imported lumber, wool, linen, and silver ore; from Africa and Egypt, grains and fruit; from Greece, wines. From the seaboard of the eastern Mediterranean she received the luxuries of the Orient-the perfumes of Arabia, the spices, ivory, and precious stones of India, and the silks of China. There were three great commercial routes from the Far East-the first by way of the Indian Ocean and the Red Sea to Alexandria; the second by way of the Persian Gulf, the Euphrates River, and the Syrian desert to Antioeh; and the third by way of the Caspian Sea, the Volga, and the Don to Olbia on the Black Sea (map, p. 439).

\section{The Five Good Emperors (96-180 A. D.)}

Nerva, Trajan, and Hadrian.-With the death of Domitian the empire came back into the hands of wise and beneficent rulers. 'The period of prosperity which began with Vespasian, was now continued for nearly a century. These rulers are 
known as "the five good emperors"; and when we consider their uprightness of character, their political ability, and their uniform regard for the welfare of their suljects, we probably cannot find in the history of the world a like series of sovereigns, ruling with equal success for the same length of time. The first of these rulers was Nerva (96-98 1. 1). $)$, whose mildness and tolerance contrasted strongly with the severe qualities of Domitian. Nerva was chosen neither by the pretorians nor by the legions, but by the senatewhich fact indicates that the empire was returning to the normal political system established by Augustus. Within his brief reign, he could do little except to remedy the wrongs of his predecessor. He forbade the prosecutions for high treason and the practice of delation; he recalled the exiles of Domitian, and relieved the people of some oppressive taxes. In the words of Tacitus, " $\mathrm{He}$ blended things once irreconcil-

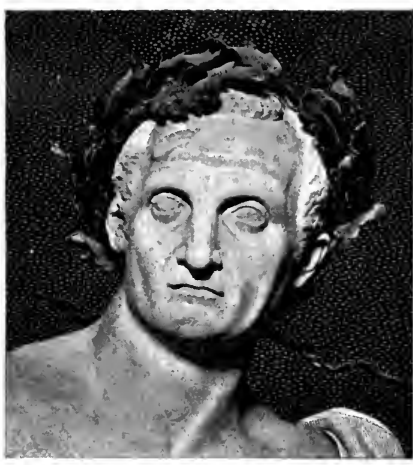

NERVA able, princely power and liberty" (principatum ac libertatem). To prevent any disturbance at his death, he associated Trajan with himself in the government.

Trajan (98-117 A. D.) has the great distinction of being the first emperor who was not a native either of Rome or of Italy. He was a Spaniard by birth; and this fact shows that the dividing line between Roman and provincial was becoming effaced. Trajan was one of the greatest of the Roman sovereigns. He was a brave soldier, a wise statesman, and an able administrator. He had something of the conciliatory spirit of Augustus, and preserved the forms of the republic, while maintaining the authority of the emperor. He restored to the 


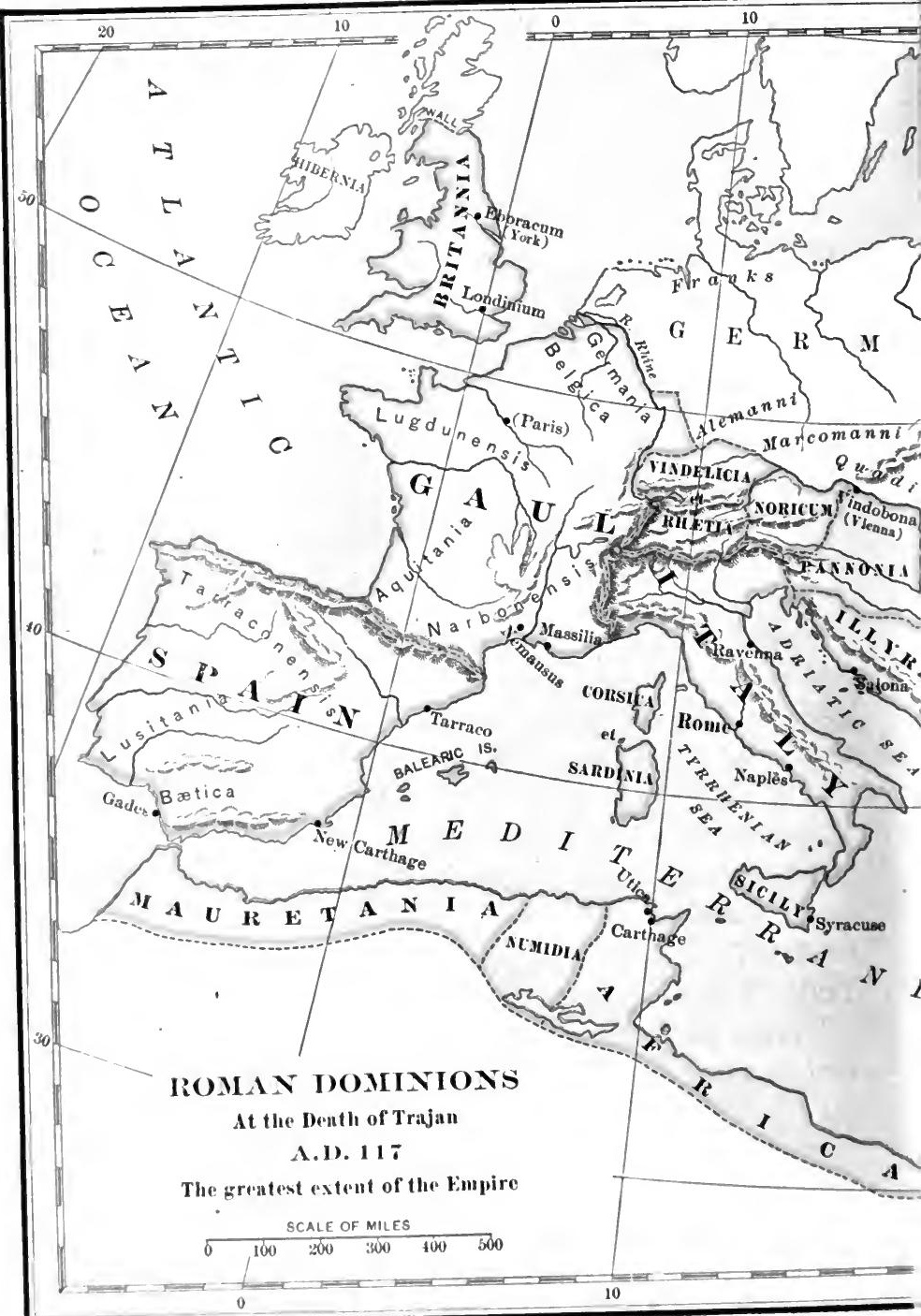




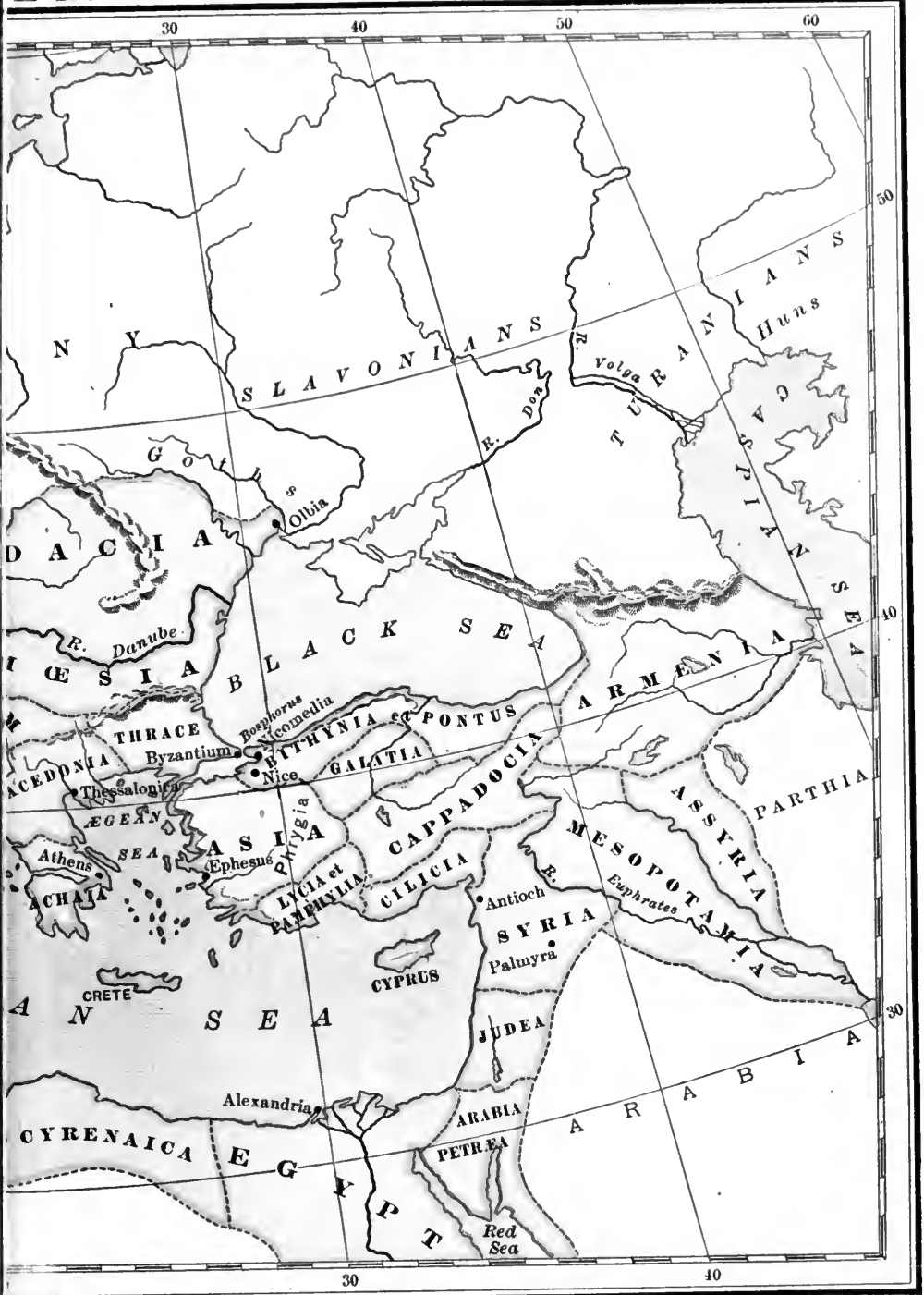




\section{A List of the Chief Roman Provinces}

WITH THE DATES OF THEIR ACQUISITION OR ORGANIZATION

\section{Erropean l'rovinces}

1. Western.

Spain (в.c. 205-19).

Gaul (B.c. 120-17).

Britain (A.D. 43-84).

2. Central.

Rhætia et Vindelicia (в.c. 15).

Noricum (B.c. 15).

l'annonia (A.D. 10).

8. Eastern.

Illyricum (в.c. 167-59).

Macedonia (B.c. 146).

Achaia (13.c. 146).

Mosia (13.c. 29).

Thrace (A.D. 46).

Dacia (A.D. 107).

\section{African Provinces}

Africa proper (B.c. 146).

Cyrenaica and Crete (B.c. 74, $63)$.

Numidia (в.c. 46).

Egypt (B.c. 30).

Mauretania (A.D. 42).

\section{Asiatic Provinces}

1. In Asia Minor.

Asia proper (B.c. 133).

Bithynia et Pontus (B.c. $74,65)$.

Cilicia (B.c. 67).

Galatia (в.c. 25).

Pamphylia et Lycia (B.c. 25, A.D. 43).

Cappadocia (A.v. 17).

¿. In Southwestern Asia.

Syria (в.c. 64).

Judea (B.c. 63-A.D. 70).

Arabia Petræa (A.D. 105).

Armenia (A.D. 114).

Mesopotamià (A.D. 115).

Assyria (A.D. 115).

IV. Island Provinces

Sicily (B.c. 241).

Sardinia et Corsica (B.c. 238).

Cyprus (B.c. 58).

'Total, 32.

NoTE. - Many of these chief provinces were subdivided into smaller provinces, each under a separate governor - making the total number of provincial governors more than one hundred. For a complete list of the Roman provinces in A.D. 117, see Leighton, p. xxix. 
people the right of electing the magistrates, which had been taken away by 'Tiberius. He respected the rights of the senate, and gave to it liberty of speech. He was also a liberal patron of literature and art. While Trajan followed, in the main the policy of Augustus, he departed from this policy in one particular. He did not restrict the frontiers within the limits that Augustus had intended. Under him the Romans became once more a conquering people. This warlike emperor pushed his conquests across the Danube and acquired the new province of Dacia. He also extended his arms into Asia, and

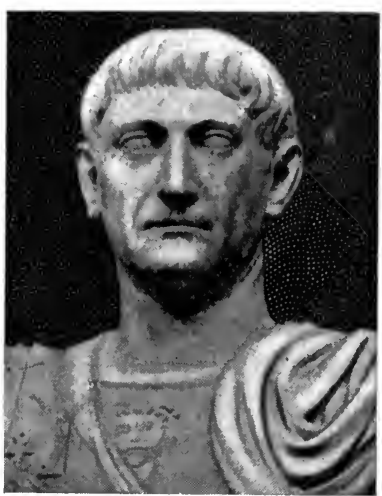

TraJan as a result of a war with the Parthians brought into subjection Armenia, Mesopotamia, and Assyria. It was during the reign of Trajan that the Roman empire

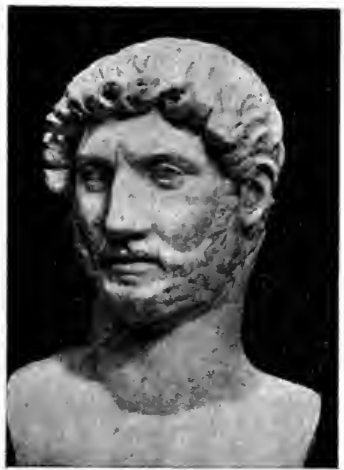

HADRIAN reached its greatest extent.

The next emperor, Hadrian (11\%138 A. D.), was proclaimed by the prætorians. But Hadrian did not regard this as a constitutional act, and requested to be formally elected by the senate. In some respects he was similar to Trajan, with the same statesmanlike ability, and the same desire for the welfare of his subjects. But he differed from Trajan in thinking that the greatness of Rome did not depend upon military glory. He therefore voluntarily gave up the extensive conquests which Trajan had made in the East, and once more made the Eu- 
phrates the frontier of the empire. In this regard he returned to the policy of Augustus, which was to improve the empire rather than to enlarge it. Hadrian showed, if possible, a stronger sympathy with the provinces than any of his predecessors. 'To become acquainted with their condition and to advance their interests, he spent a large part of his time in visiting them; and he is hence sometimes called "the Traveler." Of his long reign of twenty-one years he spent nearly two thirds outside of Italy. He made his temporary residence in the chief cities of the empire-in York, Athens, Antioch, and Alexandria-where he was continually looking after the welfare of his people. Hadrian also looked well to the defenses of the empire, especially against the German tribes on the north. He not only established military garrisons along the line of frontier rivers, the Danube and the Rhine, but also is said to have erected a fortification connecting the head waters of these rivers. The most durable evidence of his de-

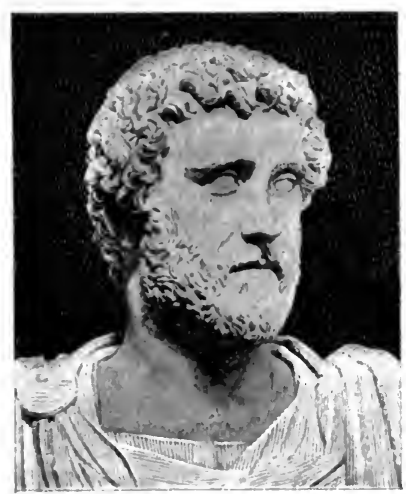

Antoninus Pius fensive policy is seen in the extensive wall built on the northern frontier of the province of Britain, the remains of which exist at the present day.

\section{Antoninus Pius and Marcus} Aurelius.-The two emperors that followed Hadrian belonged to the family of the An'tonines, and were among the purest and most upright characters that we find in Roman history. Antoni'nus Pius (138-161 A. D.) was a senator from the province of Gaul, whom Hadrian had recommended to the senate for election to the principate. As a man and a sovereign his life was inspired with the highest moral principles. As a private citizen he was simple and temperate in his habits; and as an 
emperor he was the same. His exalted character was reflected in his beneficent reign. Although not so great a statesman as Hadrian, he was yet more honored and beloved by his subjects. His reign of twenty-three years is usually known as the "uneventful reign," because there were no wars and calamities to mar the peaceful course of events. But while devoid of startling incidents, the reign of Antoninus was of great importance, because of the purifying influence which the emperor exereised upon law and legislation, and because it marked the beginning of the golden age of Roman jurisprudence.

Marcus Aurelius (161-180 A. D.), who came to the throne at the death of Antoninus, was in his personal character one of the most remarkable men of antiquity. He was a philosopher as well as an emperor; and his "Meditations"-a book on the conduct of life-has been highly esteemed as a moral text-book by all subsequent generations. But with all his personal worth, his reign was a period of misfortunes. It was now that Rome was afflicted with a deadly plague and famine, the most terrible in her history. In addition to this, the barbarians from the north-the Quadi and Marcomanni-were

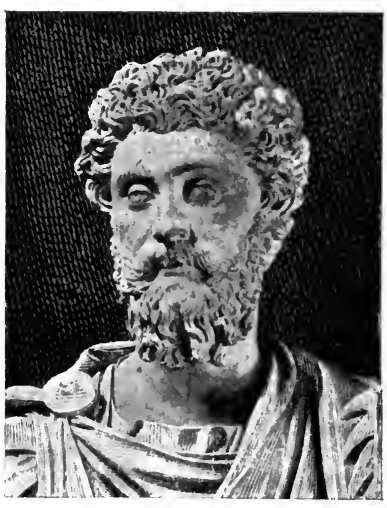

Marcus Aurelius trying to break through the frontiers on the upper Rhine, and threatening to overrun the provinces. But the emperor met these dangers with courage and patience; and he died at his post of duty while resisting the enemies of Rome. The only blot upon the memory of this noble prince is the fact that he was led to persecute the Christians, whom he regarded as a turbulent sect and whom the people superstitiously believed 
were the cause of their calamities. This act was thus a great mistake made by a conscientious man.

The Culmination of the Empire.-The death of Marcus Aurelius closed the most prosperous period of Roman history and the culmination of the empire. When one looks at the general condition of the Roman world it will not be difficult to see that the fall of the Roman republic and the establishment of the empire were not an evil, but a great benefit to the Roman people. In place of a century of civil wars and discord which closed the republic, we see more than two centuries of internal peace and tranquillity. Instead of an oppressive and avaricious treatment of the provincials, we see a treatment which is with few exceptions mild and generous. Instead of a government controlled by a proud and selfish oligarchy, we see a government controlled, generally speaking, by a wise and patriotic prince. From the accession of Augustus to the death of Marcus Aurelius (31 B. c. to 180 A. D.), a period of two hundred and eleven years, only three emperors who held power for any length of time-Tiberius, Nero, and Domitian -are known as tyrants; and their cruelty was confined almost entirely to the city, and to their own personal enemies. The establishment of the empire, we must therefore believe, marked a stage of progress and not of decline in the history of the Roman people. The Roman world reached its highest stage of development in the age of the Antonines, and the period has been called by Gibbon the happiest in the history of mankind.

The Imperial Government and Administration.-It was during this period that the imperial government of Rome furnished the highest example that the world has ever seen of what we may call a "paternal autocracy"-that is, a government in the hands of a single ruler, but exercised solely for the benefit of the people. In this respect the ideals of Julius and Augustus seem to have been completely realized. There was still a certain deference paid to the constitutional forms of the republic; but this deference to the past did not interfere 
with the emperor's present authority. 'The senate was treated with respect; but its members, being chosen by the emperor, were of course submissive to his will, and there was no oceasion to protest against an authority which received the unqualified support of the people. ${ }^{1}$

An effort was now made by the emperors to give to the administrative system a more complete organization. For example, the body of advisers which had been occasionally consulted by the previous emperors was organized by Hadrian into a permanent council (consilium principis); and he included among its members some of the most eminent jurists. This emperor also gave a more complete organization to the civil service-that is, the body of administrative officers who executed the imperial will. Hitherto, the emperor had relied upon his own private dependents-freedmen and even slavesto conduct his official business. But Hadrian organized a dignified body of officers drawn from the equites to preside over the departments of administration.

The Provincial and Municipal Systems.-The general organization of the provinces remained very much as it had been established by Augustus. There were still the two classesthe senatorial provinces governed by proconsuls and proprætors appointed by the senate; and the imperial provinces, governed by the legati, or emperor's lieutenants. But this distinction was now more formal than real, since the emperor exercised nearly the same supervision over the former as over the latter. We have a good example of the scrupulous care which the emperor exercised over the provinces in the correspondence between Trajan and Pliny the Younger, governor of Bithynia. The questions submitted by the governor and

1 It is hardly proper to call the Roman empire at this time a " constitutional monarchy," as we understand that phrase; since the emperor's power, properly speaking, was not restricted by any legal limitations. His sovereignty was not shared or restrained by any other body in the state. The "dyarchy," which to a great extent was a fiction under Augustus, was still more a fiction under his successors. 
the answers given by the emperor deal with many matters relating to the welfare of the province.

'The province was, in fact, a collection of towns or cities; and the political freedom of the provincials depended upon the status of the towns in which they lived. 'These towns were not all alike. While they generally had their own government and chose their own officers, their relations to Rome were quite various. The different kinds of towns and their relative numbers in the provinces we may judge from Pliny's enumeration of the towns of Bæt'ica, a province in Spain. Here were nine colonies, eight municipia, twenty-nine Latin towns, six free towns, three federate towns, and one hundred and twenty tributary towns. The colonies were generally settlements of soldiers or poor citizens sent out from Italy and retaining full Roman rights. The municipia were native towns which had received the same rights. The Latin towns were those which received the partial rights of citizenship (commercium). 'The free towns were the native cities which were exempted from all burdens. The federate towns were related to Rome by a special treaty. The tributary towns, which comprised the great mass of provincial cities, were subject to the Roman tribute or tax, which might be paid in money or in produce. The town had generally for its own government a municipal council (curia or ordo decurionum). composed of the landed aristocracy (curiales) and presided over by two magistrates (duumviri). The tendency of all towns in the West was to conform to this model.

Literature of the Early Empire.-The influence of the early emperors upon the intellectual life of Rome may be seer in the literature. The literary period which followed the brilliant age of Augustus has sometimes been called the "Silver Age." The despotic rule of the Julian emperors was not favorable to letters. Two names of that period, however, stand out with some prominence, those of Seneca and Lucan. Seneca was a distinguished Stoic philosopher and wrote in- 
structive essays upon moral subjects; Lucan wrote a lengthy epic poem describing the civil war between Pompey and Cxsar. Under the patronage of the Flavian emperors occurred a literary revival, which was marked by at least two distinguished writers, Pliny the Elder and Quintilian. Pliny, the most learned man of the day, wrote an extensive work on Natural History; while Quintilian, a native of Spain, was the author of an exhaustive treatise on Oratory. The revival which began under the Flavians culminated in the more vigorous literature of the time of the good emperors. During this time appeared two of the most distinguished of Roman writers-Tacitus, perhaps the greatest of Roman historians, and Ju'venal, the greatest of Roman satirists. Besides these may be mentioned Pliny the Younger, the writer of epistles, and Suetonius, the biographer of the "Twelve Cæsars." .

Roman Architecture.-It was during the period of the five good emperors, especially under Trajan and Hadrian, that the architecture of Rome reached its highest development. Roman architecture was still modeled after that of the Greeks, but the Romans continued to use their skill for more practical purposes, and expressed in a remarkable manner the ideas of massive strength and imposing dignity. By their splendid works they have taken rank among the world's greatest builders. We have already noticed the progress made in the age of Augustus. This progress was continued by his successors, and by the time of Hadrian Rome had become a city of magnificent public buildings. The architectural center of the city was the Roman Forum, with the additional Forums of Julius, Augustus, Vespasian, Nerva, and Trajan (see map, p. 468). Here were the buildings in which the gods were worshiped, the laws were enacted, and justice was administered. The most conspicuous buildings which would attract the eyes of one standing in the Forum were the splendid temples of Jupiter and Juno upon the Capitoline hill. Although it is true that the Romans obtained their chief ideas of architectural 
beauty from the Greeks, it is a question whether Athens, even in the time of Pericles. could have presented such a scene of imposing grandeur as did Rome in the time of Trajan and Hadrian, with its forums, temples, aqueducts, basilicas, pal-

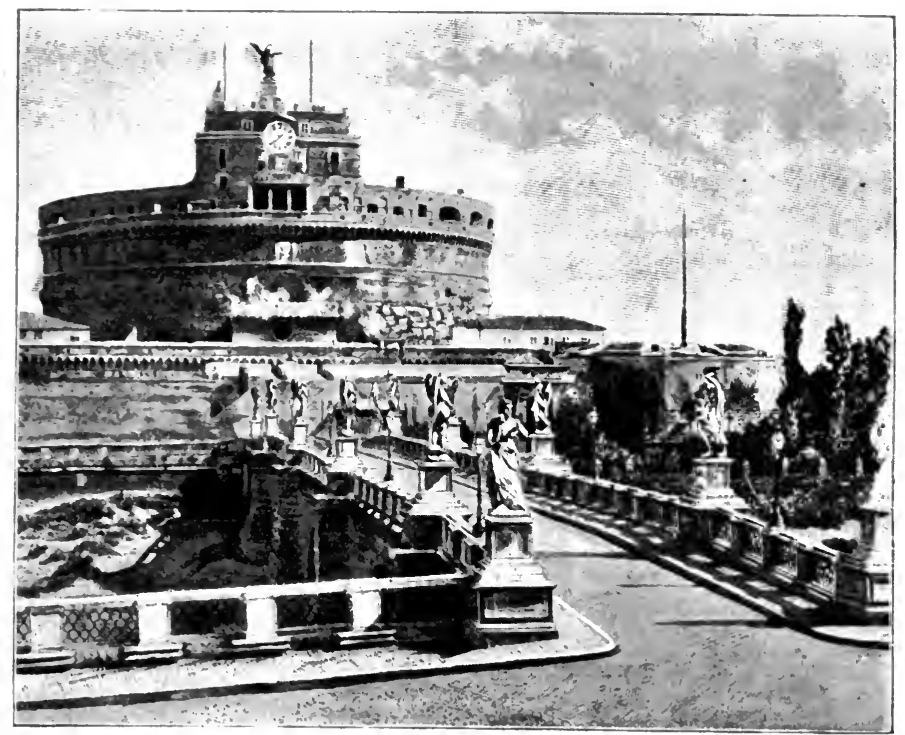

Mausoleum of Hadrian (Castle of St. Angelo)

aces, porticoes, amphitheaters, theaters, circuses, baths, columns, triumphal arches, and tombs.

Roman Philosophy. - As the Romans were essentially a practical people, they had little taste for pure philosophy. They adopted. however, some of the philosophical systems of the Greeks, and paid special attention to the practical or moral side of these systems. Their philosophy was largely the philosophy of life. The two systems which were most popular with them were Epicureanism and Stoieism. The Epieureans believer that happiness was the great end of life. But the high idea of happiness advocated by the Greek philosophers 
became degraded into the selfish idea of pleasire, which could easily excuse almost any form of indulgence. In Rome we see this idea of life exercising its influence especially upon the wealthy and indolent classes. The Stoies, on the other hand, believed that the end of life is to live according to the highest law of our nature. 'This doctrine tended to make strong and upright characters. It could not well have a degrading influence; so we find some of the noblest men of Rome adhering to its tenets--such men as Cato, Cicero, Seneea, and Marcus Aurelius. But the study of philosophy was restricted mainly to the educated classes, and had little influence upon the common people. The lower classes still retained their old religious notions, or else were gradually accepting the new teachings of Christianity.

Roman Jurisprudence.-The most distinctive product of Roman civilization was the Roman law; and this too reached its highest development under the empire. The Romans had come to believe that law was based upon principles of equality and justice. The rights of all free persons-citizens, Latins, and provincials-were now fully recognized and protected by the Roman courts. This law had been growing and broadening with the growth and extension of the Roman power. It was now scattered in a vast number of decisions and edicts made by the Roman prætors and the provincial governors, as well as by the emperor himself. Hadrian directed one of his jurists-Salvius Julia'nus-to make a collection of these laws, so that there could be a single code for the whole empire. This collection was called the Perpetual Edict (Edictum Perpetuum). But more than this, the Roman jurists were beginning to feel the influence of the Stoic philosophy and to recognize the truth of the high moral precepts laid down by such emperors as Antoninus Pius. They were led to believe that law is a science founded upon the principles of justice, and that the law of the state must be so interpreted as to conform to these principles. 


\section{V. Decline of the Early Empire $(180-284$ a. D.)}

The Period of Military Despotism.-The great defect of the imperial govermment was the fact that its power rested upon a military basis. It is true that most of the emperors were popular and loved by their subjects. But back of their power was the army, which now more than ever before asserted its claims to the government, and by its usurpation brought the empire to the verge of ruin. This period, extending from the death of Mareus Aurelius to the accession of Diocle'tian (180-284 A. D.), has therefore been called "the period of military despotism." It was a time when the emperors were set up by the soldiers, and generally cut down by their swords. During this period of one hundred and four years, the imperial title was held by twenty-nine different rulers, ${ }^{1}$ some few of whom were able and high-minded men. but a large number of whom were weak and despicable. Some of them held their places for only a few months. The history of this time contains for the most part only the records of a deelining government. There are few events of importance, except those which illustrate the tyranny of the army and the general tendency toward decay and disintegration.

Septimius Severus (193-211 A. D.).--The reign of Septimius Severus is noted for the re-forming of the prætorian guards, which Augustus had organized and Tiberius had eneamped near the city. In place of the old body of nine thousand soldiers Septimius organized a Roman garrison of forty thousand troops selected from the best soldiers of the legions. This was

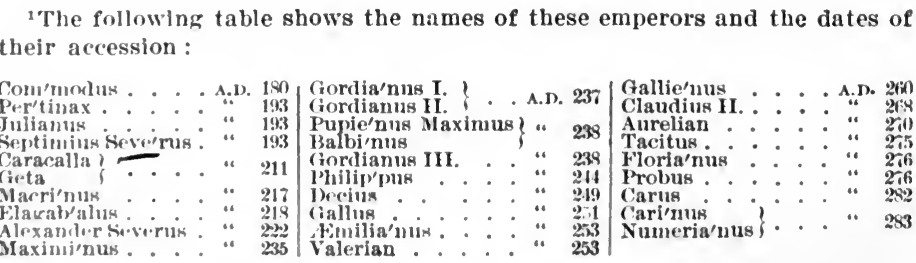


intended to give a stronger military support to the government; but in fact it gave to the army a more powerful influence in the appointment of the emperors.

Edict of Caracalla (211 A. D.).-The Roman franchise, which had been gradually extended by the previous emperors. was now conferred upon all the free inhabitants of the Roman world. This important act was done by Caracalla, whose motive. however, was not above reproach. The edict was issued to increase the revenue by extending the inheritance tax, which had heretofore rested only upon citizens. Notwithstanding the avaricious motive of the emperor, this was in the line of earlier reforms and effaced the last distinction be-

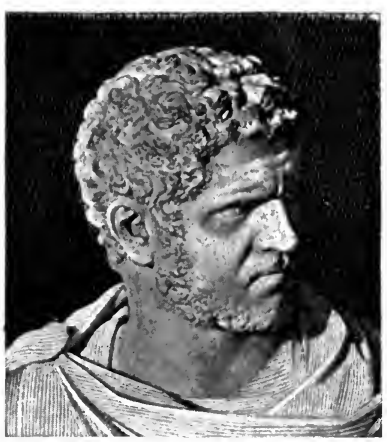

Caracalla tween Romans and provincials. The name of Caracalla is infamous, not only for his cruel proscriptions, but especially for his murder of Papinian, one of the greatest of the Roman jurists, who refused to defend his crimes.

Elagabalus and Alexander Severus.-We need not dwell upon the different reigns of the dreary period extending from Caracalla to Claudius II.; and we shall notice only two princes, who represented the most extreme types of the Roman character. The one was Elagabalus (218-222 A. D.), the most repulsive of the emperors, who took his name from the sungod worshiped in the East, and who became a devotee of the grossest superstitions and a monster of wickedness. The other was Alexander Severus (222-235 A. D.), a prince of the purest and most blameless life. He loved the true and the good of all times. It is said that he set up in his private chapel the jmages of those whom he regarded as the greatest teachers of mankind, including Abraham and Jesus Christ. He selected 
as his advisers the famous jurists, Ulpian and Paullus. The most important event of his reign was the successful resistance made to the Persians, who had just established a new monarchy (that of the Sassan'idæ) on the ruins of the Parthian empire.

Foreign Dangers of the Empire.-Ever since the time of Augustus it had been the policy of the emperors to maintain

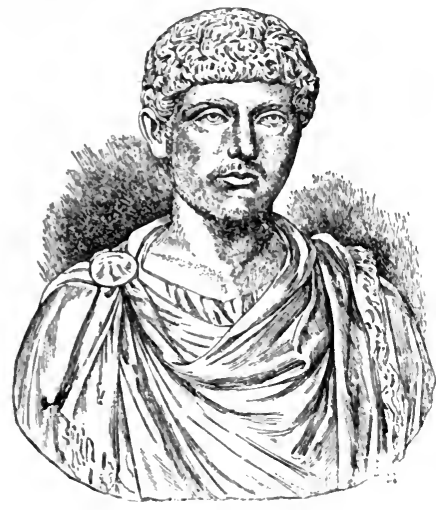

Alexanifir Severus the frontiers on the Rhine, the Danube, and the Euphrates. This policy had been generally carried out with success until the middle of the third century, when the outside nations began to break over these boundaries. There were several of these foreign peoples that were now encroaching upon the Roman territory. On the lower Rhine near the North Sea were a number of barbarous German tribes, united under the general name of Franks. On the upper Rhine in the vicinity of the Alps were various tribes gathered together under the name of Alemanni (all men). Across the Danube and on the northern shores of the Black Sea was the great nation of the Goths, which came to be the terror of Rome. On the east beyond the Euphrates was the new Persian monarchy (that of the Sassanide), which was now laying claim to all the Roman provinces in Asia. Under a succession of emperors whose names we need not remember, the Romans were engaged in wars with these various peoples-not now wars for the sake of concuest and glory as in the time of the republic, but wars of defense and for the sake of existence.

The Silent Invasions; the Coloni.-'The continual presst of the outside peoples-especially the Germans on the north 
led the emperors to adopt a conciliatory policy, and to grant to these barbarians peaceful settlements within the provinces. Sometimes whole tribes were allowed to settle upon linds assigned to them. Not only the Roman territory but the army and offices of the state were opened to Germans who were willing to become Roman subjects. The most able of the barbarian chiefs were even made Roman generals. This gradual infiltration of the barbarian population is sometimes called the "silent invasions." A part of the new population was treated in a manner new to them. Instead of being sold as slaves, like captives in war, they were given over to large landed proprietors, and attached to the estates as permanent tenants. This class of persons were called colo'ni, and were really serfs attached to the soil. The great body of coloni was made up not only of barbarian immigrants, but of manumitted slaves, and even of Roman freemen who could not support themselves. They formed a large part of the later population in the provinces.

Partial Recovery of the Empire (268-284 A. D.).-Under the leadership of five able rulers, the so-called Illyrian emperors-Claudius II., Aurelian, Tacitus, Probus, and Carusthe empire recovered somewhat from the disasters of the preceding years. Claudius II. defeated the Goths who had crossed the Danube. Aurelian (270-275 A. D.) built a new and more extensive wall about the city of Rome, restored the Roman authority in the East, and destroyẹd the city of Palmy'ra, which had been made the seat of an independent kingdom, ruled by the famous Queen Zenobia. The successful efforts of these emperors showed that the empire could still be preserved, if properly organized and administered. The events of the third century made it quite clear that if the empire was to continue, and the provinces were to be held together, there must be some radical change in the imperial government. The decline of the early empire thus paved the way for a new form of imperialism. 


\section{SYNOPSIS FOR REVIEW}

I. The Julian Emperors.-Tiberius and Caligula.-Claudius and Nero.-The Emperor and the Empire.-Nonarchical Tendencies.-Condition of the I'rovinces.-Public Works.-The Christians at Rome.

11. 'The Flaviax Emperors.-The Disputed Suecession.-Vespasian and Titus.-The Tyranny of Domitian.-Classes of Roman Society.-Domestic Life: Houses, Food, Dress.-Soeial Life and Amusements.-Life in the Towns; Pompeii and the Graffiti.Provincial Life, Travel, and Correspondence.-Industry and Trade.

III. The Five Good Emperons.-Nerva, 'Trajan, and Hadrian.Antoninus Pius and Marens Aurelius.-The Culmination of the Empire.-The Imperial Government and Administration.-The Provincial and Municipal Systems.-Literature of the Early Empire.-Roman Architecture.-Roman Philosophy.-Roman Jurisprudence.

IV. Decline of the Early Empire.-The Period of Military Despotism.-Septimius Severus.-Edict of Caracalla.-Elagabalus and Alexander Severus.-Foreign Dangers of the Empire.-The Silent Invasions; the Coloni.-Partial Recovery of the Empire.

\section{REFERENCES FOR READING}

Pelham, Bk. V., Ch. 4, "The Julian Line"; Bk. VI., Ch. 1, "The Flavians and the Antonines"; Ch. 2, "The Empire in the Third Century" (18). ${ }^{2}$

Gibbon, Chis. 1-3 (the Roman empire from Augustus to Marcus Aurelius); Ch. 8 (the new Persian empire); Ch. 11 (the wall of Aurelian; the conquest of Palmyra) (18).

Abbott, Ch. 13, "From Tiberius to Nero"; Ch. 14, "The Flavian Emperors"' (22).

Bury, Roman Empire, Ch. 30, "The Roman World under the Empire"; Ch. 31, "Roman Life and Manners"; pp. 366-373 (the destruction of Jerusalem); pp. 438-448 (eorrespondence between Trajan and Pliny the Younger) (18).

Capes, Early Empire, Ch. 14, "Life in the Provinces"; Ch. 15. "State of Trade" (18).

Antonines, Ch. 6, "Attitude of the Imperial Government toward Christians"; Ch. 9, "Administrative Forms of the Imperial (iovernment" (18).

Thomas, Ch. 1, "At Pompeii"; pp. 28-41 (the !raffiti); Ch. 4, "The Baths and the Games"; (h. 5 (gifts, peeuliar customs of the Romans); Ch. 8, "Country Life"; pp. 190-200 (country houses): Ch. 9. "Schools and Books" (edueation): Ch. 14, "A Typical Roman of the Empire, Pliny the Younger" (19).

Mau, Ch. 32, "The I'ompeian House"; Ch. 56, "The Graffiti" (20).

${ }^{1}$ The figure in parenthesis refers to the number of the topic in the Aplenclix, where a fuller title of the book will be found. 
Preston and Dodge, II., "The House and Every Day Life"; IV., "Food and Clothing" (19).

Inge, Ch. 6, "Grades of Society"; Ch. 9, "Amusements"; Ch. 10, "Luxury" (19).

Dill, Roman Society from Nero, Bk. I., Ch. 2, "Municipal Life"; Bk. IV., Ch. 1, "The Religion of Mithra" (19).

Merivale, Empire, Vol. IV., Ch. 39, "Unity of the Empire"; Ch. 41, "Life in Rome"; Vol. VII., pp. 58-62 (the eruption of Vesuvins) (18).

Boissier, Rome and Pompeii, Ch. 1, "The Forums"; Ch. 3, "The Catacombs"; Ch. 4, "Hadrian's Villa" (at Tivoli) (20).

Lanciani, Ruins and Exeavations, pp. 310-319 (the Forum of Trajan).

Midleton, Vol. I., pp. 343-345 (the arch of Septimius Severus); Vol. II., Ch. 12, "Walls of Aurelianus" (20).

Farrar, Seekers after God, "Mareus Aurelius."

Munro, Source Book, Part XI., "Roman Life and Society" (25).

Tacitus, Annals, Bk. XV., Chs. 38-43 (the burning of Rome); Ch. 44 (persecution of the Christians under Nero) (25).

Suetonius, The Twelve Cæsars (26).

\section{CIIAP'TER XXX}

THE LATER EMPIRE OF DIOCLETIAN AND CONSTANTINE

\section{The Government of Diocletian (284-305 A. D.)}

The New Imperialism.-It has been said that the early empire of. Augustus and his successors was an absolute monarchy disguised by republican forms. This is in general quite true. But the old republican forms had for a long time been losing their hold, and at the time of Diocletian they were ready to be thrown away entirely. By the reforms of Diocletian and Constantine there was established a new form of imperialisman absolute monarchy divested of republican forms. Some of their ideas of reform no doubt came from the new Persian monarchy, which was now the greatest rival of Rome. In this powerful monarchy the Romans saw certain elements of strength which they could use in giving new vigor to their own 
government. By adopting these Oriental ideas, the Roman empire may be said to have become Orientalized.

Diocletian and his Policy.-The first step in the direction of the new imperialism was made by Diocletian. Born of an obscure family in Dal-

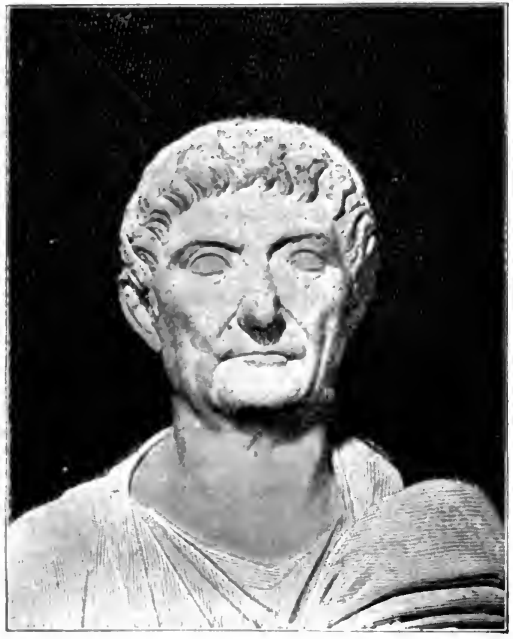

DIOCLETIAN matia (part of Illyricum), he had risen by his own efforts to the high position of commander of the Roman army in the East. It was here that he was proclaimed emperor by his soldiers. $\mathrm{He}$ overcame all opposition, assumed the imperial power, and made his residence not at Rome, but in Nicomedia, a town in Asia Minor. His whole policy was to give dignity and strength to the imperial authority. He made of himself an Oriental monarch. He assumed the diadem of the East. He wore gorgeous robes of silk and gold such as were worn by Eastern rulers. He compelled his subjects to salute him with low prostrations, and to treat him not as a citizen, but as a superior being. In this way he hoped to make the imperial office respected by the people and the army. The emperor was to be the sole source of power, and as such was to be venerated and obeyed.

The "Augusti" and "Cæsars."-Diocletian saw that it was difficult for one man alone to manage all the affairs of a great empire. It was sufficient for one man to rule over the East, and to repel the Persians. It needed another to take care of the West and to drive back the German invaders. He therefore 
associated with him his trusted friend and companion in arms, Maximian. But he was soon convinced that even this division of power was not sufficient. 'To each of the chief rulers, who received the title of Augustus, he assigned an assistant, who received the title of Casar. 'The two C'esar's were Gale'rius and Constan'tius; and they were to be regarded as the sons and successors of the chief rulers, the Augusti. Each Cxas was to recognize the authority of his chief; and all were to be subject to the supreme authority of Diocletian himself. 'The Roman world was divided among the four rulers as follows:

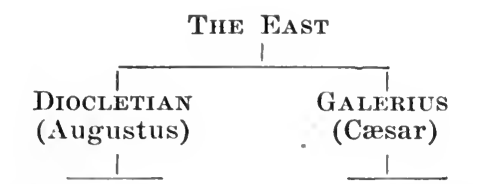

Thrace, Macedonia, Noricum, l'annonia, Asia, and Egypt.

and Mœsia.

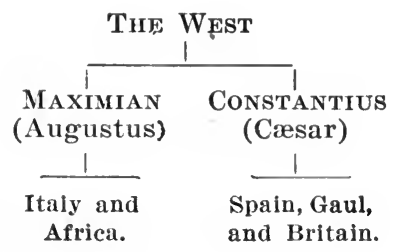

The Last Persecution of the Christians.-In the latter part of his reign Diocletian was induced to issue an edict of persecution against the Christians. It is said that he was led to perform this infamous act by his assistant Galerius, who had always been hostile to the new religion, and who filled the emperor's mind with stories of seditions and conspiracies. An order was issued that all churches should be demolished, that the sacred Scriptures should be burned, that all Christians should be dismissed from public office, and that those who secretìy met for public worship should be punished with death. The persecution raged most fiercely in the provinces subject to Galerius; and it has been suggested that the persecution should be known by his name rather than by the name of Diocletian.

Effects of Diocletian's Policy.-The general result of the new policy of Diocletian was to give to the empire a strong and efficient government. The dangers which threatened the state were met with firmness and vigor. A revolt in Egypt was 
quelled, and the frontiers were successfully defended against the Persians and the barbarians. Public works were constructed, among which were the great Baths of Diocletian at Rome. After a successful reign of twenty-one years Diocletian voluntarily gave up his power, either on account of ill health, or else to see how his new system would work without his supervision. He retired to his native province of Dalmatia, and spent the rest of his days in his new palace at Salo'na on the shores of the Adriatic.

\section{The Reign of Constantine (313-33\% A. D.)}

Accession and Policy of Constantine.-Even before the death of Diocletian, rivalries sprang up which led to civil war. By a succession of victories Con'stantine established his supe-

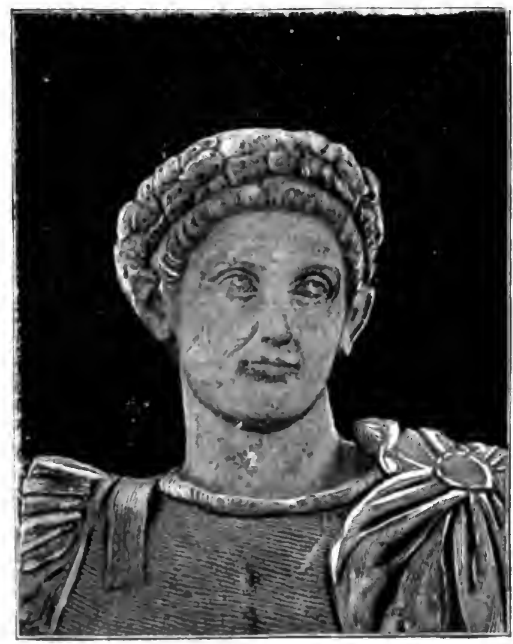

Constantine riority and became the sole and undisputed ruler of the empire. He was a man of wider views than Diocletian, and had even a greater genius for organization. The work which Diocletian began, Constantine completed. $\mathrm{He}$ in fact gave to Roman imperialism the final form which it preserved as long as the empire existed, and the form in which it exercised its great influence upon the modern governments. We should remember that it was not so much the early imperialism of Augustus as the later imperialism of Constantine which reappeared in the em- 
pires of modern Europe. This fact will enable us to understand the greatness of Constantine as a statesman and a political reformer. His poliey was to centralize all power in the hands of the chief ruler; to surround his person with an elaborate court system and an imposing ceremonial; and to make all officers, eivil and military, responsible to the head of the empire.

Conversion of Constantine.-Constantine is generally known as the "first Christian emperor." The story of his miraculous conversion is told by his biographer, Euse'bius. It is said that while marching against his rival Maxentius, he beheld in the heavens the luminous sign of the cross, inscribed with the words, "By this sign conquer." As a result of this vision, he accepted the Christian religion; he adopted the cross as his battle standard; and from this time he ascribed his victories to God, and not to himself. The truth of this story has been doubted by some historians; but that Constantine looked upon Christianity in an entirely different light from his predecessors, and that he was an arowed friend of the Christian ehurch, cannot be denied. His mother, Hel'ena, was a Christian, and his father, Constantius, had opposed the persecutions of Diocletian and Galerius. He had himself, while he was ruler in only the West, issued an edict of toleration (313 A. D.) to the Christians in his own provinees.

Adoption of Christianity.-Constantine was therefore prepared, when he became the sole emperor, to reverse the policy of Diocletian and to recognize Christianity as the state religion. How far Constantine himself was a sincere Christian it is not for us to say; but no one can doubt that the adoption of Christianity was an act inspired by political wisdom. A large part of the empire was already Christian, and the recognition of the new religion gave stability to the new government. Constantine, however, in accepting Christianity as the state religion, did not go to the extreme of trying to uproot paganism. The pagan worship was still tolerated, and it was not until many years after this time that it was proseribed by the Chris- 
PIROCHRAEAITF: MIAP NO. 19.

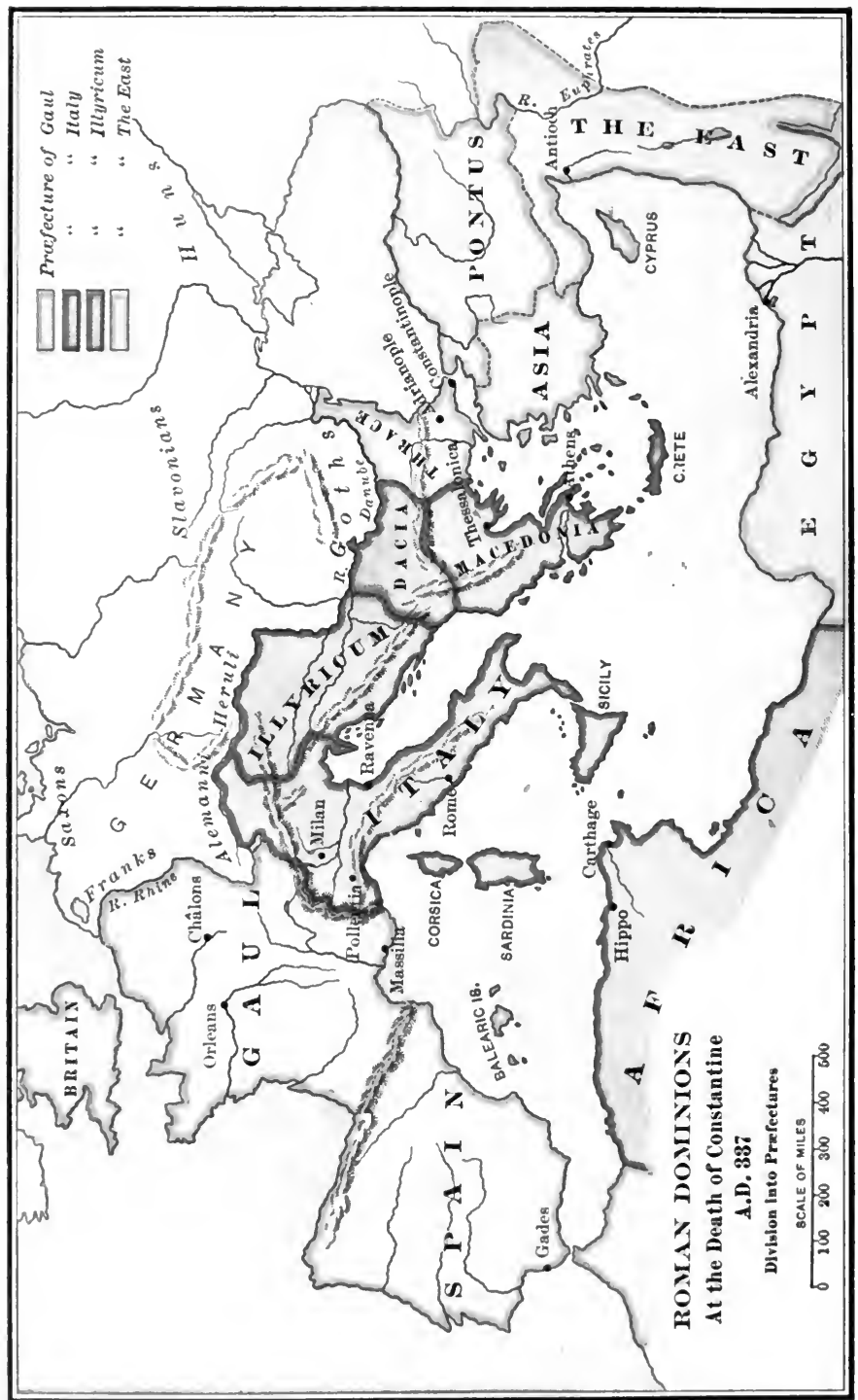


tian emperors. For the purpose of settling the disputes between the different Christian sects, Constantine called (325 A. D.) a large council of the clergy at Nice (Nicca, in Asia Minor), which decided what should thereafter be regarded as the orthodox belief. ${ }^{1}$

The New Provincial System.-Another important reform of Constantine was the reorganization of the Roman territory in a most systematic manner. This was based upon Diocletian's division, but was much more complete and thorough. The whole empire was first divided into four great parts, called "prefectures," each under a prætorian prefect subject to the emperor. Each prefecture was then subdivided into dioceses, each under a diocesan governor, called a vicar, subject to the pretorjan prefect. Each diocese was further subdivided into provinces, each under a provincial governor called a consular, president, duke, or count. Each province was made up of cities and towns, under their own municipal governments. The new divisions of the empire may be indicated as follows:

(1) The Prefecture of the East-containing the five dioceses of the East, Egypt, Asia, Pontus, and Thrace.

(2) The Prefecture of Illyricum-containing the two dioceses of Dacia and Macedonia.

(3) The Prefecture of Italy-containing the three dioceses of Italy, Illyricum, and Africa.

(4) The Prefecture of Gaul-containing the three dioceses of Spain, Gaul, and Britain.

The New Military Organization.-Scarcely less important than the new provincial system was the new military organization. One of the chief defects of the early empire was the improper position which the army occupied in the state. This defect is seen in two ways. In the first place, the army was not subordinate to the civil authority. We have seen how the

1 This was the doctrine regarding the nature of the Son held by Athanasius, as opposed to the doctrine which was heid by Arius and condemned as a heresy, receiving the name of "Arianism." 
prætorian guards really became supreme, and brought about that wretched condition of things, a military despotism. In the next place, the military power was not separated from the civil power. In the carly empire, every governor of a province had not only ciril authority, but he also had command of an army, so that he could resist the central government if he were so disposed. But Constantine changed all this. He abolished

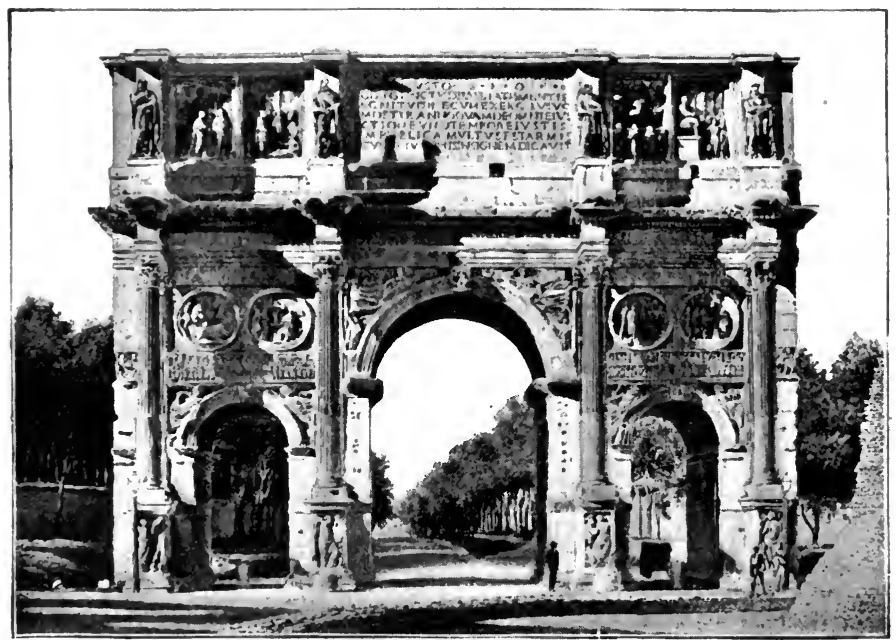

Arch of Constantine

the Roman garrison or prætorian guard. He gave to the territorial governors only a civil authority; and the whole army was organized under distinct officers, and made completely subject to the central power of the empire. This ehange tended to prevent, on the one hand, a military despotism; and, on the other hand, the revolt of local governors.

'The military ability of Constantine cannot be questioned. In commemoration of his early victories, the senate erected in the city of Rome a splendid triumphal arch, which stands tolay as one of the finest specimens of this kind of architecture. 
The New Capital, Constantinople.-One very important act of Constantine was to break away from the traditions of the old empire by establishing a new capital. 'The old city of Rome was filled with the memories of paganism and the relics of the republic. It was the desire of Constantine to give the empire a new center of power, which should be favorably situated for working out his new plans, and also for defending the Roman territory. He selected for this purpose the site of the old Greek colony, Byzantium, on the confines of Europe and Asia. This site was favorable alike for defense, for commerce, and for the maintenance of an Oriental system of government. Constantine laid out the city on an extensive scale, and adorned it with new buildings and works of art. The new capital was called the city of Constantine, or Constantinople.

The New Court Organization.-Constantine believed with Diocletian that one of the defects of the old empire was the fact that the person of the emperor was not sufficiently respected. He therefore not only adopted the diadem and the elaborate robes of the Asiatic monarchs, as Diocletian had done, but reorganized the court on a thoroughly Eastern model. An Oriental court consisted of a large retinue of officials, who surrounded the monarch, who paid obeisance to him and served him, and who were raised to the rank of nobles by this service. All the powers of the monarch were exercised through these court officials.

These Oriental features were now adopted by the Roman emperor. The chief officers of the court comprised the grand chamberlain, who had charge of the imperial palace; the chancellor, who had the supervision of the court officials and received foreign ambassadors; the quæstor, who drew up and issued the imperial edicts; the treasurer-general, who had control of the public revenues; the master of the privy purse, who managed the emperor's private estate; and the two commanders of the bodyguard. The imperial court of Constantine furnished the model of the royal courts of modern times. 
Effect of Constantine's Reforms.-If we should take no account of the eflects of Constantine's reforms upon the liberties of the Roman people, we might say that his government was an improvement upon that of Augustus. It gave new strength to the empire, and enabled it to resist foreign invasions. The empire was preserved for several generations longer in the West, and for more than a thousand years longer in the East. But the expenses neeessary to maintain such a system, with its elaborate court and its vast number of officials, was great. The taxes were oppressive. The members of every city council (curiales) were held responsible for the raising of the revenues. The people were burdened and lost their interest in the state. Constantine also, like Augustus, failed to make a proper provision for his successor. At his death (337 A. D.) his three sons divided the empire between them, and this division gave rise to another period of quarrels and civil strife.

\section{The Successors of Constantine (337-395)}

Attempt to Restore Paganism.-The first event of grave importance after the reign of Constantine was the attempt of the Emperor Julian (360-363 A. D.) to restore the old pagan religion, for which attempt he has been called " the Apostate." Julian was in many respects a man of ability and energy. He repelled the Alemanni who had crossed the Rhine, and made a vigorous campaign against the Persians. But he was by conviction a pagan, and in the struggle between Christianity and paganism he took the part of the ancient faith. He tried to undo the work of Constantine by bringing back paganism to its old position. He did not realize that Christianity was the religion of the future, and was presumptuous in his belief that he could aceomplish that in which Marcus Aurelius and Diocletian had failed. He may not have expected to uproot the new religion entirely; but he hoped to deprive it of the important privileges which it had already acquired. The religious 
changes which he was able to effect in his brief reign were reversed by his successor Jovian (363-364 A. D).), and ('hristianity afterward remained undisturbed as the religion of the empire.

Revolt of the Goths.-After the death of Jovian the empire was divided between Valentinian and his younger brother Valens, the former ruling in the West, and the latter in the East. Valentinian died $(375$ A. D. $)$, leaving his sons in control of the West, while Valens continued to rule in the East (till $3 \% 8$ ). It was during this latter period that a great event occurred which forewarned the empire of its final doom. This event was the irruption of the Huns into Europe. This savage race, emerging from the steppes of Asia, pressed upon the Goths and drove them from their homes into the Roman territory.

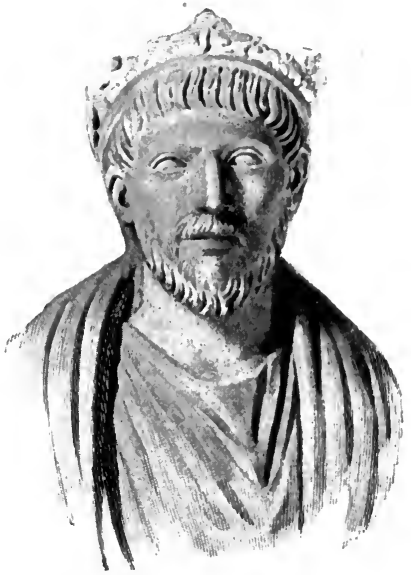

JULIAN

It was now necessary for the Romans either to resist the whole Gothic nation, which numbered a million people, or else to receive them as friends and give them settlements within the empire. The latter course seemed the wiser, and they were admitted as allies, and given new homes south of the Danube, in Mœsia and Thrace. But they were soon provoked by the illtreatment of the Roman officials, and rose in revolt, defeating the Roman army in a battle at Adriano'ple (3\%8 A. D.), in which Valens himself was slain.

Theodosius and the Final Division of the Empire (379395).- - Theodo'sius I. succeeded Valens as emperor of the East. He was a man of great vigor and military ability, although his reign was stained with acts of violence and injustice. He continued the policy of admitting the barbarians into the empire, 
but converted them into useful and loyal subjects. From their number he reënforced the ranks of the imperial armies, and jealously guarded them from injustice. When a garrison of Gothic soldiers was once mobbed in 'Thessaloni'ca, he resorted to a punishment as revengeful as that of Marius and as cruel as that of Sulla. He gathered the people of this city into the circus to the number of seven thousand, and caused them to be massacred by a body of Gothic soldiers $(390$ A. D.). For this inhuman act he was compelled to do penance by St. Ambrose,

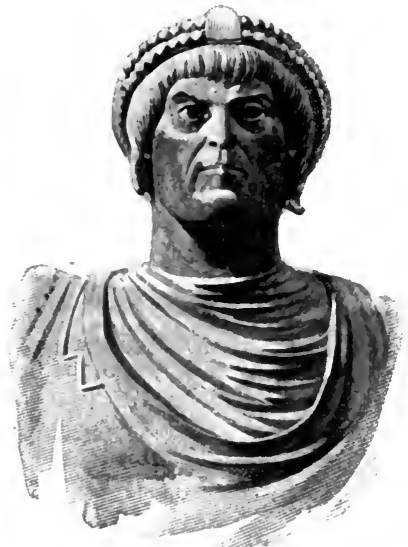

THEonosius

Statue at Barletta, Italy the bishop of Milan-which fact shows how powerful the Church had become at this time, to compel an emperor to obey its mandates. Theodosius was himself an ardent and orthodox Christian, and went so far as to be intolerant of the pagan religion, and even of the Christian heretics. In spite of his shortcomings he was an able monarch, and has received the name of "Theodosius the Great." He conquered his rivals and reunited for a brief time the whole Roman world under a single ruler. But at his death (395 A. D.), he divided the empire between his two sons, Arca'dius and Hono'rius, the former receiving the East, and the latter the West.

The death of Theodosius in 395 marks an important epoch, not only in the history of the Roman empire but in the history of European civilization. From this time the two parts of the empire - the East and the West-became more and more separated from each other, until they became at last two distinet worlds, having different destinies. The eastern part maintained itself for about a thousand years with its capital at Con- 
stantinople, until it was finally conquered by the Turks (1453 А. D.). 'The western part was soon overrun and conquered by the German invaders, who brought with them new blood and new ideas, and furnished the elements of a new eivilization.

\section{SYNOPSIS FOR REVIEW}

I. The Government of Diocletian.-The New Imperialism.Diocletian and his Policy.-The "Augusti" and "Cresars."-The Last Persecution of the Christians. - Effects of Diocletian's Policy.

II. The Reign of Constantine.-Accession and Policy of Constantine.-Conversion of Constantine.-Adoption of Christianity. -The New Provincial System.-The New Military Organization.The New Capital, Constantinople.--The New Court Organization.Effect of Constantine's Reforms.

III. The Successons of Constantine.-Attempt to Restore Paganism.- Revolt of the Goths.-Theodosius and the Final Division of the Empire.

\section{REFERENCES FOR READING}

Pelham, Bk. VII., Ch. 1, "From the Accession of Diocletian to the Death of "Theodosius" (18). ${ }^{1}$

Merivale, General History, Ch. 70, "The Epoch of Diocletian"; Ch. 73, "Reign of Julian" (18).

Gibbon, Ch. 17, "Foundation of Constantinople"; Ch. 23, "The Religion of Julian" (18).

Stanley, Lect. 6, "The Emperor Constantine"; Lect. 2, "The Council of Nicæa" (21).

Milman, History of Christianity, Ch. 3, "Foundation of Constantinople" (21).

Seeley, Essay, "The Later Empire" (18).

Seignobos, Ch. 24, "Christianity" (18).

Munro, Sourc Book, Part X., "Christianity-and Stoicism" (25).

${ }^{1}$ The figure in parenthesis refers to the number of the topic in the Appendix, where a fuller title of the book will be found. 


\section{ROM E}

\section{Under the Later Emperors}

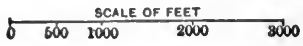

\section{PRINCIPAL BUILDINGS}

\section{FORTyS \\ 1. Roman \\ 8. Jullus \\ 3. Augustus \\ 4. Nerva \\ 5. Vespaslan \\ 6. Trajan}

\section{TEMPLES}

7. Juplter Capitolinus

8. Quirinus

9. Minerva

10. Pantbeon

1). Trajau

12. Hope

13. Fortune

14. Ceres

15. Dlana

36. Hopor and Virtue

17. Divine Clandius

18. Venus and Roms

\section{BATIIS}
19. Agrippa
20. Alexandrina.
21. Titus
22. Trajan
23. Constantine
24. Dlocletian
25. Caracalla

\section{TIEATERS}
26. Pornpey
27. Halbas
28. Marceilns

V. A Y PUITIFATERS

99. Flavian (Colonseum) 80. Mullary

\section{CIRCUSES \\ 31. Maximus \\ 32. Flaminius \\ 33. Nero \\ VII. PORTICOES \\ 34. Pompey \\ 35. Octaviug \\ 36. Livia}

VIII. BASILICAS

37. Julla

38. Constantine

39. Ulplan

40. Finilla

\section{Places OF ASSEM- BLY}

41. Site of the Comitium

42. Curia, or Senate House

43. Septa Julia (Voting)

X. ARCHES

44. Titus

45. Constantine

46. SeptImius Severus

XI. COLUMNS

47. Trajan

48. Antoninus

49. Marcus Aurelius

xil. TомBs

50. Augustus

51. Hadrian

52. Sciplo

\section{CAMPS}

63. Pratorlan

54. Agrippa

XIV. MISCELLANKOUS

B5. Arx

56. Palace of the Cresara b7. Emporium

Pokta Flaminia

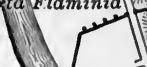

sellit

48

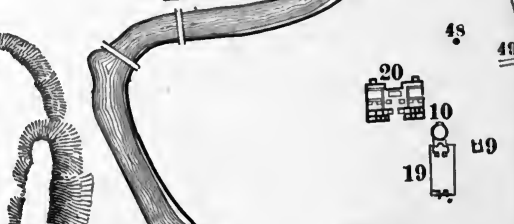

10
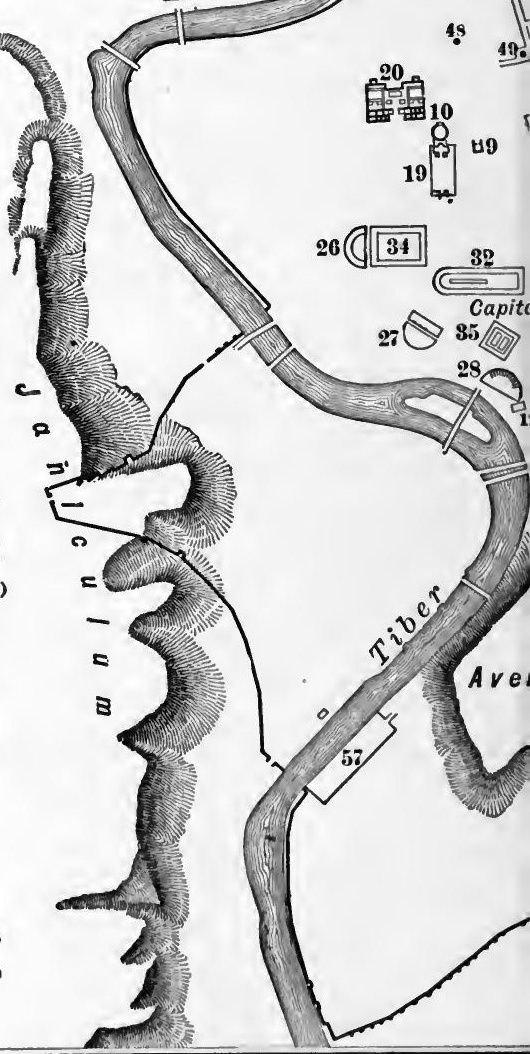


\section{CHAP'TER XXXI}

DISTINCTIVE FEATURES OF THE ROMAN EMPIRE

\section{The Political System of Rome}

Unity of the Ancient World.-Before we consider the fate of the Roman empire, and the changes that resulted from the barbarian invasions, let us take a brief review of the most distinguishing features of the Roman empire. The first thing that we notice is the fact that Rome brought under her anthority a great part of the civilized world. The great nations which had flourished on the shores of the Mediterranean Sea-Carthage, Macedonia, Greece, the nations of Asia Minor, Phœnicia, Judea, and Egypt-all beeame parts of one universal empire. The ideas and customs, the art and institutions of these countries were taken up, and notwithstanding their many differences were welded together into what was practically one civilization. The more barbarous peoples, also, which she conquered-like those of Spain, Gaul, and Britain-were transformed by her civilizing influence. Rome thus accomplished a result never before attained, to the same extent, by any other ancient people-the establishment of a world-unity in government, law, and religion.

The Roman Municipal System.-No nation before the Romans had shown such a genius for political organization, or had developed a system of government so well suited to maintain an authority over a wide territory. In looking at this political system we find that its fundamental element was the city. The Roman empire was, in fact, a collection of cities. The government which was established was a government over 
cities. Rome succeeded in giving to her cities not only local self-government, but also, in great measure, a uniform organization, patterned after that of the central eity. Each city had its senate, or council (curia), something like that of Rome itself; its body of magistrates (duumviri, and other officers), like the magistrates of the old republic; and in later times, its defender of the people (defensor populi), like the old plebeian tribune. The cities throughout the empire may thus be regarded as reflections of the central city of Rome; and they were bound to it by bonds of sympathy as well as by political ties.

The Roman Provincial System.-The next feature of the political organization was the provincial system, by which the cities were bound together under a common authority. This system was developed by the Romans, and passed through successive stages. In the first place, under thy renblic we see a number of cities in a certain toritas touped toger and placed under the quthorityo haquernar (proprcetor or proconsul) having civit and mitary power, and also a quæstor, having charge of the finances-both officers being under the supervision of the senate. In the next place, under the early empire this senatorial supervision-which was still retained in what were called the "senatorial provinces"-was supplemented by the direct supervision of the emperor over other provinces, called "imperial provinces." In the latter ease the province was governed by a military commander (legatus) appointed by the emperor, and accompanied by a financial officer (procurator). Finally, under the later empire, the military authority was taken away from the governor; the whole territory of the empire was arranged in divisions and subdivisions (præfectures, dioceses, and provinces) each under a civil governor (præfect, vicar, or præses) - each governor being subject to his immediate superior, and all being finally responsible to the emperor himself. The army was placed under a distinct set of imperial officers. By this arrangement the central authority was maintained throughout the whole Roman domain. For purposes 
of administration over a large territory, it was perhaps the most effective system ever devised.

The Roman Imperial Idea.-The Roman empire found its highest unity in the person of the emperor. 'The cities and the various territorial governments were all bound together under his supreme authority. We must keep in mind the fact that the Roman idea of imperialism was different from the old Oriental idea of monarchy. The Oriental idea was that the monarch was the representative of divine authority on earth. It was essentially theocratic. The Roman idea, on the other hand, was that the emperor was the representative of the state, the supreme magistrate of the people. It was, in a certain sense, democratic. We are able to see this by tracing the growth of the imperial idea. The imperium of the early kings was a delegated power, derived from the people and sanctioned by a special law (lex de imperio). When the ancient king exercised his power in a despotic way, he was driven out of the city; and the imperium was conferred upon several magistrates. Again, when the republican magistrates exercised this power selfishly in the interests of the aristocracy, the people revolted and placed the imperium once more in the hands of a single magistrate. And they did not rest until they found a ruler who could be regarded as the representative of the whole people. Such representatives they found in Julius Cæesar and Augustus.

The emperor was looked upon as the first man of the state (princeps civitatis, not merely princeps senatus). His authority was based upon the imperium and the tribunician power; that is, he was regarded as both the supreme magistrate and the defender of the people. The imperial idea found its highest expression in the rule of the Antonines. This idea was, it is true, somewhat modified by the Oriental influence under Diocletian and Constantine. But still the distinctive idea of Roman imperialism was this, that the emperor personified the authority of the state; and upon this idea was based the maxim, " the will of the prince has the force of law." 


\section{The Legal System of Rome}

Universality of the Roman Law.-The greatest addition which the Romans made to the civilization of the ancient world was no doubt their system of law. This does not mean, of course, that the Romans were the first people who ever had laws. Every ancient people possessed a certain body of laws. Even among the early Babylonians we have seen the evidence of legal customs relating to property and contracts, as well as the remains of written documents by which legal transactions were performed. The Egyptians, the Jews, and the Greeks possessed their own national laiws. But the Romans were the first to develop a universal system of law, applicable not only to all the people of the empire, but to all times and places. With every enlargement of the Roman state, there was an expansion of their system of law. The expansion of the law was at first, no doubt, due merely to political and commercial expediency; but it afterward recognized the rights of man as man and the principles of natural justice, and this gave it the character of a universal system.

Extension of the Franchise.-One of the methods by which the Roman law was broadened was by the extension of the franchise, or the rights of citizenship. We have seen that the civil rights of citizenship comprised: (1) the commercium, or the rights growing out of trade (as the rights of property and contract); (2) the conubium, or the right growing out of domestic relations (as the paternal power and the right of inheritance). These rights were at first restricted to the original Roman citizens. The extension of the franchise began by granting the commercium to outsiders-first to the plebeians, then to the Latins, and then under the name of the "Latin right" to the people of Italy and the provinces. The granting of the conubium followed, as the exclusive spirit of the Romans passed away, until finally the full rights of citizenship were given to all the free inhabitants of the Roman world. This gradual 
extension of the franchise shows that the fundamental policy of Rome was not conquest, but incorporation. 'The conquered people became not mere Roman subjects, but Roman citizens, sharing in all the privileges granted by the Roman law.

The Jus Gentium.-Another and more important way in which the Roman law was broadened, was by the development of a new body of legal principles, which grew up by the side of the old law. The old law was called the jus civile, and was based upon the XII. Tables. Being an old law it was narrow, and soon became antiquated; it did not meet the needs of a growing eommunity. Besides, this old law applied only to Roman citizens, and did not protect any persons before they had received the franchise. Now in early times before the extension of the franchise, there were many persons in Italy who were not yet citizens, but were subject-foreigners (peregrini). The Romans were obliged to trade with these foreigners; and hence disputes would arise between the Romans and such foreigners, or between the foreigners living in different citieswhich disputes could not be settled by the old Roman law. 'To settle such disputes the Romans appointed a new prætor (prator peregrinus); and this prætor was allowed to decide such cases in the way that seemed most fair and just, without reference to the old law. In the provinces, also, the governors were allowed to settle similar disputes. From the various decisions of the "foreign prætors" and provincial governors, there grew up an extensive body of legal prineiples, broader and more equitable than the old law. This new body of law was called the jus gentium; and it formed a great part of Roman jurisprudence, far more important in fact than the old jus civile.

Scientific Nature of the Roman Law.-By the extension of the old law and especially by the development of the new law. every free inhabitant of the Roman world could secure his rivil rights in a court of justice. These influences made the Roman law tho l, roadest system of jurisprudence that the world had yot seen. But there was another influence at work which 
gave to the law a truly scientifie character. This was the influence of the Roman jurists. These men wrote treatises upon the law, and explained its real meaning. They gathered together the vast mass of legal rules, and reduced them to a system. Being schooled in the principles of the Stoic philosophy, they believed that law was founded upon natural justice and the universal rights of man. By reducing the law to a system and by discovering general principles that should govern it, they gave to it the character of a science. These men-like Gaius, Ulpian, Paullus, Modesti'nus, and Papinian-represent the highest genius of the Roman people. By their writings they built up a noble system of jurisprudence, suited not only to the wants of the Roman empire, but to the needs of those nations which grew up after the Roman empire passed away.

\section{Christianity and the Imperial Church}

The Spread of Christianity.-The Roman empire came to be one, not only in government and law, but also in religion; and this religion was Christianity. But it was a long time after its first appearance in the remote province of Judea that Christianity was accepted as the religion of the Roman world. The ancient Romans had already a religion of their own. This had grown out of an early ancestor worship and a polytheistic nature worship. With the extension of their power over other peoples, the Romans became tolerant of foreign religions; and had even accepted many of the features of these foreign systems. They accepted the Greek notions regarding the nature of the gods; and adopted some of the elements of the Syrian and Egyptian religions. The only spot in the empire where a pure monotheism existed, was in Judea; but even here the spiritual idea of religion had come to be obscured by an excessive attention to external forms and ceremonies.

Christianity arose from Judaism: but it emphasized the fact that true religion consists in a spiritual life, based upon love 
to God and love to man. The new religion spread from Judea to Syria, to the eities of Asia Minor, Macedonia, and Greece, and finally to all the provinces of the empire. The early pregress of Christianity was in the face of opposition and persecutions. These persecutions were excused on the ground of political necessity. But in spite of all apologies, the eruel and revolting barbarities which accompanied them must always remain a dark blot upon the history of the empire. The new religion could not be destroyed; it continued to spread, and to exercise its humanizing influence upon all the phases of Roman life. After Christianity became practically the religion of the Roman people, it was, as we have already noticed, accepted as the religion of the state (p. 459).

Growth of the Church Organization.-With the spread of Christianity throughout the provinces there grew up an ecelesiastical organization, patterned somewhat upon the organization of the empire. For example, in the town we find the parish church presided over by the parish priest. A number of parish churches were grouped together into a diocese and governed by a bishop. A number of dioceses were united into a province under a higher church officer, called a metropolitan or archbishop. In the East a few of the metropolitans-like those of Constantinople, Antioch, and Alexandria-rose above the other bishops in dignity and authority, and became recognized as "patriarchs." In the West the bishop of Rome exercised even greater authority, and was recognized as the chief bishop. In this way there grew up in the chureh territorial divisions and subdivisions, and gradations of authority, similar to those that existed in the empire. And so it came about that while the Roman empire was becoming Christianized, Rome eame to be recognized as the head and center of Christianity.

Development of an Ecclesiastical Culture.-As the church acquired a listinct organization of its own. modeled after that of the empire, so it aequired a distinct culture of its own, de- 
rived to a certain extent from that of the empire. In the first place, its architecture was borrowed from Rome. 'The early churches were modeled after the lioman basilica-the hall of justice or court house. But when the basilica was consecrated as a Christian church, it acquired a sacred character that distinguished it from the secular building. In the next place, the

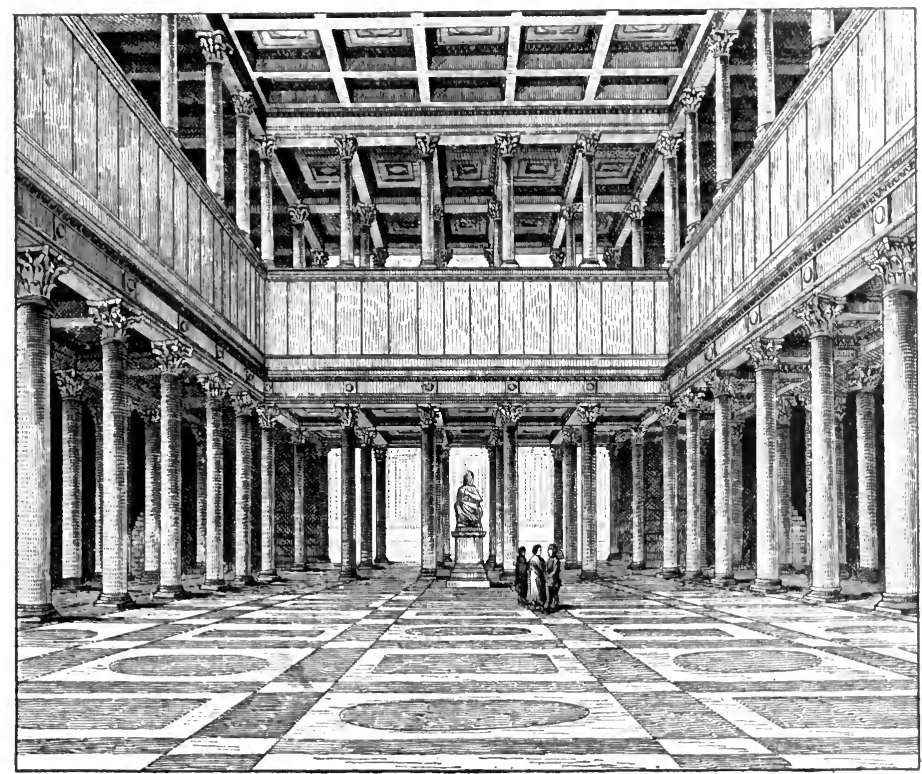

Interior of the Basilica of TraJan (Restoration)

language of the church was the language of the empire. This language was in the eastern provinces principally Greek, and in the western provinces Latin; so that the eastern churches used the Greek language in their literature and ritual, while the western churches used the Latin language. Moreover, the thought of the church was greatly influenced by the modeg of thinking which prevailed in different parts of the empire. 'The Greek mind was essentially speculative and philosophical; and 
so the eastern or Greek churches busied themselves in discussing difficult questions regarding the nature of the Father and the Son and their relations to each other. On the other hand, the Roman mind was more practical and legal, and so the western or Latin churches were more concerned with questions relating to the divine government and the relations of man to that government.

By such means the church acquired an art, a literature, and a philosophy which, though derived in a certain sense from the empire, came to be distinctly ecclesiastical. The highest culture of the church is seen in the writings of " the Fathers." Among the Greek Fathers were Athanasius, patriarch of Alexandria, who formulated the orthodox creed; and Chrysostom, patriarch of Constantinople, the most eloquent preacher of his age. Chief among the Latin Fathers were Jerome, who first translated the Scriptures into Latin (the Vulgate); and Augustine, bishop of Hippo in Africa, who wrote the "City of God."

\section{Weakness of the Empire}

Defects of the Imperial System.-With all the strength which the empire acquired by its centralized government, its universal law, and its organized church, it yet contained certain elements of weakness which led to its final dissolution. One of these elements of weakness may be found in the defects of the imperial system itself. The purpose of the empire was to create a government which would insure the welfare of the people. 'This purpose had, to a great extent, been realized in the policy of the best of the emperors. Still the imperial government, even in its highest form, was scarcely more than a beneficent paternalism in which everything was done for the people, and the people could do nothing for themselves. 'The people had no share in making the laws or in electing the officers of the state, and they lost all interest in public affairs. The government of the empire, then, was defective because 
it had no democratic basis. It might be a government for the people; but it could not be a government by the people. In fact, democratic institutions were practically impossible because (1) all the people of such an extensive territory couldi not assemble in one place; and (2) the Romans had not discovered the modern principle of " representation."

Burdens of Taxation.-Another element of weakness may be found in the grinding system of taxation which existed in the later empire. The old abuses which prevailed in the republic had been corrected by the reforms of Augustus and his successors. But the later empire, with its Orientalized form of government and its elaborate system of bureaus and officials, required a vast amount of money to support it. This money had to be raised from the people. The duty of collecting the taxes rested upon the curiales, that is, the governing elass in the cities, which consisted of those holding a certain amount of land. If the curiales could not collect the money from the lower classes, they were obliged to furnish it from their own fortunes. They could not evade this responsibility. They could not abandon their position for that of the law or the clergy or the army; nor could they quit the eity without the permission of the provincial governor. They became practically an hereditary class, upon which rested largely the financial weight of the empire. The heavy exactions laid upon the people for the support of the government tended to the impoverishment of the empire.

Degradation of the Peasantry.- Still another cause of the weakness of the later empire was the degradation of the free agricultural classes, or the small landowners and the free laborers. The condition of the slaves, it is true, was considerably improved during the later period. They were better protected by the law, and they obtained their freedom more easily than before. But even when freed they were obliged to obtain their living by settling upon the estates of the great landlords, who granted them a little plot of ground on condition of man- 
ual labor or a certain amount of produce. Here they lived from one generation to another; and by being attached to the soil they became serfs, or coloni. This movement was no doubt beneficial to the slave population. But the burdens resting upon the small landowner and the free laborer compelled them also to oceupy this servile condition. The lifting up of the slaves was thus aceompanied by the lowering of the free peasant classes. In this way a large part of the Roman people was reduced practically to the condition of serfdom. And this class of serfs, or coloni, was augmented by the settlement of barbarians within the limits of the empire.

Decay of the Population.-Still further, the native population of the empire was continually decreasing in numbers. The vitality of the Roman people was becoming exhausted. The upper classes were worn out by a life of luxury and indolence. The lower classes were exhausted by a constant struggle for existence unler unfavorable conditions. Famines, plagues, and wars had decimated the population. The armies, notwithstanding their excellent organization, could not be replenished by rigorous native soldiers. Domestic life, too, had lost much of. its sanctity; and, as a consequence, the empire lost one of the conditions of national growth and prosperity. Human life itself was often held in light esteem. All these causes led to the depopulation and exhaustion of the later empire. It has been aptly said that Rome "perished for want of men."

Pressure of the Barbarians.-With such elements of internal weakness we cannot wonder that the Roman world fell a prey to the barbarians from the north. The pressure of these larlarians was met sometimes by a policy of active resistance, and sometimes by a policy of passive submission. We have already seen how they were admitted within the boundaries of the empire, receiving permanent settlements, sometimes absorbed into the armies and even into the government (p. 453). This "infiltration" of a foreign population into the empire tronded not only to dilute the life of the Roman people, but 
also to efface the boundaries between the Roman and the barbarian world. As a result of all this, the subsequent history of the empire is elosely related to the history of the barbarians who found their way into the Roman provinces.

\section{SYNOPSIS FOR REVIEW}

I. The Political System of Rome.-Unity of the Ancient World.-The Roman Municipal System.-The Roman Provincial System.-The Roman Imperial Idea.

II. The Legal Srstem of Rome.-Universality of the Roman Law.-Extension of the Franchise.-The Jus Gentium.-The Scientific Nature of the Roman Law.

III. Christianity and the Imperial Cinurch.-The Spread of Christianity.-Growth of the Church Organization.-Development of an Ecclesiastical Culture.

IV. Weakness of THE EMPIRE.-Defects of the Imperial System:-Burdens of Taxation.-Degradation of the Peasantry.Decay of the Population.-Pressure of the Barbarians.

\section{REFERENCES FOR READING}

Curteis, Ch. 1, "Administrative and Legal Unity"; Ch. 2, "The Christian Church in the First Four Centuries" (24). ${ }^{1}$

Merivale, General History, Ch. 80, "Reflections upon the History of Rome" (18).

Empire, Vol. VII., pp. 479-496, "Symptoms of Decline in the Empire" (18).

Bury, Students' Empire, Ch. 3, "The Roman World under the Empire."

Later Empire, Vol. I., Ch. 1, "Christianity and Paganism"; Ch. 2, "Influence of Christianity on Society" (the early church); Ch. 3, "Disintegration of the Empire" (24).

Milman, History of Christianity. Bk. IV., Ch. 1, "The Roman Empire under Christianity" (21).

Shahan, Beginnings of Christianity (21).

Healy, Valerian Persecutions (21).

Hodgkin, Vol. II., Ch. 9, "Causes of the Fall of the Western Empire" (24).

Seeley, Essay, "Proximate Causes of the Fall of the Roman Empire" (18).

Dill, Roman Society in the Last Century of the Western Empire, Bk. II., Ch. 2, "Decay of the Middle Class" (society in the fourth century) (19).

'Translations and Reprints, Vol. IV., No. 1, "The Early Christian Persecutions" (25),

'The figure in parenthesis refers to the number of the topic in the Appendix, where a fuller title of the book will be found. 


\section{PERIOD V. THE DISSOLUTION OF THE ROMAN EMPIRE $(395-800$ A. D.)}

\section{CHAP'TER XXXII}

THE GERMAN OCCUPATION OF THE WEST

I. The Germans and their Institutions

The Barbarian World.-We are now prepared to see how the Roman empire, which had played such an important part in the history of the ancient world, was broken up, and how it became the foundation of a new society and of new states. We shall see the western provinces conquered by the German tribes, and transformed into new kingdoms. We shall see the imperial power still preserved in the East, but passing into a state of decline. We shall also see the imperial title revived in one of the German kingdoms, resulting in the establishment of what was practically a new Roman empire in the West.

This breaking up of the old empire and the transformation of Europe were due largely to the encroachments of the barharian world upon the Roman world. For our purpose we may group the peoples of this outside barbarian world into three great branches: (1) the Germanie or Teutonic peoples, on the north of the Rhine and the Danube; (2) the Slavic or Slavonian peoples, in the central part of what is now European Russia; and (3) the peoples in the central and western parts of Asia, whom we call, for want of a better name, Scythians or 'Turanians. 'The most barbarous of these peoples were the Tura- 
nians, of which the Huns were the most warlike and aggressive. 'The Slavs were more peaceful and at this time did not make any important incursions into the empire. 'The Germans were nearest to the Roman border's, and also approached most nearly to the civilized stage. 'They comprised many tribes-the Goths, the Vandals, the Alemanni, the Burgundians, the Lombards, the Franks, the Saxons, and others of less importance. It was these Germans who now made the first inroads into the empire, and whose characteristics are the most important for us to consider.

German Characteristics.-Our knowledge of the early Germans is derived mostly from Casar and Tacitus. They are described by these writers as a vigorous and warlike race, of gigantic stature, with fierce blue eyes and long yellow hair, simple in their social and political life, and inspired with the spirit of liberty and independence. They differed from the more civilized Romans in their manners and customs, in their political organization, their laws, and their religion. They were, in fact, in that primitive stage of progress in which the Romans, as well as the Greeks, were at the beginning of the historical period. Their most striking characteristics were their love of liberty and their spirit of personal loyalty. Tacitus tells us that their chiefs ruled by persuasion rather than by authority. The chief was wont to surround himself with a following (comitatus) of young men, who voluntarily attached themselves to him, and shared in his dangers and glory.

The German Political System. - The unit of the German political society was not the city, as in the case of the Romans, but the village community (mark, or pagus). The Germans, who had been a nomadic people living by war and the chase, yere now beginning to settle down to an agricultural life. The most primitive form of agricultural life is the village community-which is simply a collection of families, settled upon a piece of land, and organized into a little body politic. The land upon which the people settled was, for the most part, held 
in common-upon it every one could pasture his flocks and herds. The arable land was divided into strips, and allotted each year to the householders for cultivation. The land upon which the house and garden were situated, was assigned permanently to each family. Thus we have three kinds of landthe common or waste land, the arable land, and the house land.

The village community was governed by an assembly composed of all freemen capable of bearing arms; and hence the village was a pure democracy. It was presided over by a headman, or village chief (gerefa, or reeve), who was chosen by the people and who led them to war. A group of villages formed a "hundred," which also had its democratic assembly and its chief. A collection of hundreds made the tribe; and the tribe was also governed by an assembly and a war chief. The political system of the Germans was thus democratic in character, and presented a striking contrast to the imperial system of Rome.

The German Judicial System.-Among primitive barbarians it is customary for injuries to be atoned for either (1) by private redress, in which each one takes the law into his own hands, or (2) by blood revenge, in which a family obtains redress for an injury done to its members. But the Germans had advanced beyond this primitive stage, and the person charged with a crime was allowed a trial before the chief and the whole assembly, or before a number of persons selected to try the case. The guilt or innocence of the culprit was usually determined in one of three ways: (1) by "compurgation," which required that a certain number of persons, called "compurgators," be found who would swear that they believed the accused, when he asserter his innocence; (2) by ordeal, which required that the accused should undergo some dangerous test, like handling red-hot iron, from which, if he escaped uninjured, he was judged to be innocent; or (3) by combat, or a fight between the contesting parties, or their champions. The penalty inflicted upon the guilty party was usually a money compensation, called 
weregild, which varied according to the rank of the injured person. 'The crimes which prevailed among the Germans were chiefly of the character of personal injuries; since the rights relating to property and contracts were scarcely yet recognized. The simple laws of the Germans thus showed a marked difference from the highly developed jurisprudence of the Romans.

Conversion of the Germans.-The early German religion was similar to the primitive worship of the early Greeks and Romans-a polytheistic nature worship. They worshiped 'Tuisco, Wodin (Odin), Thor, and Freya-names still preserved in the English names of the days of the week, Tuesday, Wednesday, Thursday, and Friday. Their idea of immortality was based upon what they regarded as most enjoyable in human life. Their heaven was the "Valhalla," the hall of the slain, where valiant heroes shared in the banquets of the gods. But it is especially important for us to notice that many of the German tribes were converted to Christianity before they made their final settlements in the Roman territory. When the followers of Arius were banished from the Roman empire as heretics, after the Council of Nice (p. 461), many of them became missionaries to the barbarians. The most distinguished of these missionaries was Ul'filas, "the apostle to the Goths." By his efforts the Gothic nation was converted to the Arian form of Christianity; and his translation of the Bible into their language was the first German version of the Scriptures. From the Goths Christianity spread among the neighboring tribes, the Burgundians and the Vandals. The acceptance by the Germans of a religion which was fundamentally the same as that of the Romans was one of the causes which finally led to the fusion of the Romans and the Germans into one society.

\section{The Great Invasions}

Nature of the Invasions.-If we recall what we have already learned, we may realize that the pressure of the northern 
barbarians upon the south was not a new thing in the history of the ancient world. In fact, it represents a long continued and almost constant struggle. We have seen, in early times, the Scythians pressing down upon the Medes and Persians (p. 62). We have seen the Gauls invading Macedonia and Greece (p. 248 ), and also, about the same time, invading Italy and destroying Rome (p. 300). We have seen the Cimbri and Teutones threatening the Roman republic in the days of Marius (p. 365); and the Quadi and Marcomanni harassing the empire during the reign of Marcus Aurelius (p. 443). We have seen the frontiers broken in during the decline of the early empire (p. 452), and the Goths obtaining a foothold in the provinces during the reign of Valens (p. 465). These events show that from the earliest times the barbarian north had been a constant menace to the eivilized south. The invasions were, in their nature, a struggle for the possession of the earth-or at least for the lands most favorable for human existence. As long as the Roman empire preserved its original strength, it was able to maintain itself in this struggle for existence. But when its resources were exhausted, its frontiers gave way to the barbarian pressure. These invasions were not of the nature of mere military expeditions; they were rather the migration of nations in the seareh of new settlements. The most important of the great invasions which now took place were those of the Visigoths under Al'aric, the Huns under At'tila, and the Vandals under Gen'seric.

Invasion of the Visigoths under Alaric.-The Gothie nation was divided into two parts, the Visigoths or West Goths, and the Ostrogoths or East Goths. 'The Visigoths were now settled in the Roman territory south of the Danube, and were subject to the Eastern emperor. Under their great leader, Alaric, they revolted (395 A. D.) against the Roman authority; they invader Macedonia and Greece, and threatened to devastate the whole peninsula. The Eastern emperor, Areadius, in order to relieve his own territory, pacified the Gothie leader 
by granting to him Illyricum and making him master general of the provinee. Not entirely satisfied with this territory, Alaric soon invaded Italy, and ravaged the plains of the Po. But he was defeated at Pollentia (403 A. D.) by the great Vandal soldier, Stil'icho, who was now enlisted in the service of the Western emperor, Honorius. The generalship of Stilicho was also shown in checking an invasion made by a host of Vandals, Burgundians, and Sue'vi, under the lead of Radagai'sus (406 A. D.). Italy seemed safe as long as Stilicho lived; but he was unfortunately put to death to satisfy the jealousy of his ungrateful master, Honorius (408 A. D.).

With Stilicho dead, Italy was practically defenseless. Alaric at the head of the Visigoths immediately invaded the peninsula, and marched to Rome. He was induced to spare the city only by the payment of an enormous ransom. But the barbarian chief was not satisfied with the payment of money. He was in search of lands upon which to settle his people. Honorius refused to grant his demand, and after fruitless negotiations with the emperor, Alaric determined to enforce it by the sword. He took the city of Rome and sacked it $(410$ A. D.). For three days the city was given up to plunder. He then overran southern Italy and made himself master of the peninsula. He soon died, and his successor, Adolphus (Ataulf), was induced to find in southern Gaul and Spain the lands which Alaric had sought in Italy.

Invasion of the Huns under Attila.-The next great invasion of the Western Empire was made by the Huns under Attila. This savage people from Asia had already gained a foothold in eastern Europe north of the Danube. Under their great chieftain, Attila, who has been called "the Scourge of God," they invaded Gaul and devastated the provinces; they laid siege to the city of Orléans, but were finally defeated by the Roman general Aëtius, with the aid of the Visigoths. The battle was fought near Châlons (451 A. D.), and has been called one of the great decisive battles of the world, because it re- 
lieved Europe from the danger of Scythian domination. Attila later invaded Italy, but retired without attacking Rome.

Notwithstanding the brilliant service which Aëtius had rendered, he was made the victim of court intrigue, and was murdered by his jealous prince, Valentinian III. The fate of Aëtius, like that of Stilicho before him, shows the wretched condition into which the imperial government had fallen.

Invasion of the Vandals under Genseric.-The Vandals who had fought under Radagaisus had, upon the death of that leader, retreated into Spain, and had finally crossed over into Africa, where they had erected a kingdom under their chief Genseric (Gaiseric). They captured the Roman city of Carthage and made it their capital; and they soon obtained control of the western Mediterranean. On the pretext of settling a quarrel at liome, Genseric landed his army at the port of Ostia, took possession of the city of Rome, and for fourteen days made it the sulject of pillage $(455$ A. D.). By this act of Genserie, the eity lost its treasures and many of its works of art, and the word "vandalism" came to be a term of odious meaning.

Fall of the Empire in the West (476 A. D.).-By these and other barbarian conquests, the authority of the Western emperor was now limited to Italy, together with a small part of northwestern Gaul, which still remained under the Roman governor Sya'grius. The emperors themselves were weak and incapable of ruling. The real power was exercised by others. The imperial administration at Rome was, for a time. in the hands of Placid'ia, sister of Honorius and daughter of Theodosius the Great. With the death of Stilicho and Aëtius, the command of the Roman armies fell to Ric'imer, who is known as the "king-maker." since he set up and deposed emperors at his will. Then followed Orestes, who was once the secretary of the barbarian chief $A$ ttila, and who now commanded the barbarian auxiliaries in Italy. He received the title of Roman "patrician" and attempted to rule after the manner of Rici- 
mer. He placed upon the throne his son, Romulus Augustulus, a boy six years of age, whose reign has no significance, except that he was the last of the Western emperors. Ilis brief reign was brought to an end by a revolt on the part of the barbarian mercenaries, who demanded one third of the lands of Italy. The young prince, Augustulus, was deposed by Odoa'cer, chice of the Her'uli ( 4 r 6 A. D.). Word was sent to the Eastern ruler that there was no longer any need of a separate emperor in the West. Odoacer accordingly received the title of patrician and ruled over Italy as the vicar of the Eastern emperor. The West was thus deprived of the imperial title; and this event is sometimes called the "fall of the Western Roman empire."

\section{The New Germanic Kingdoms}

In Italy, the Heruli and 0strogoths.-The West was now theoretically united to the Last; but as the result of the invasions it became, in fact, the seat of new Germanic kingdoms, which were practically independent of the Eastern emperor.

In order to realize the great changes which were now taking place in western Europe, let us locate on the map (p. 490) the new kingdoms established by the German invaders. Odoacer, the king of the Heruli, continued to rule over Italy for seventeen years (476-493 A. D.). Although a barbarian he respected the forms of the Roman government. Although an Arian he did not disturb the orthodox church. The brief dominion of the Heruli was cut short by the conquest of Italy by the Ostrogoths under Theod'oric.

The Ostrogoths, following their old kinsmen the Visigoths, had settled south of the Danube, and had become allies of the Eastern emperor. Their chief was Theodoric, who had been brought up as a hostage at Constantinople, and had become familiar with the customs and institutions of the Romans. To satisfy the demands of his people for better lands, Theodoric obtained from the emperor the authority to take possession of 


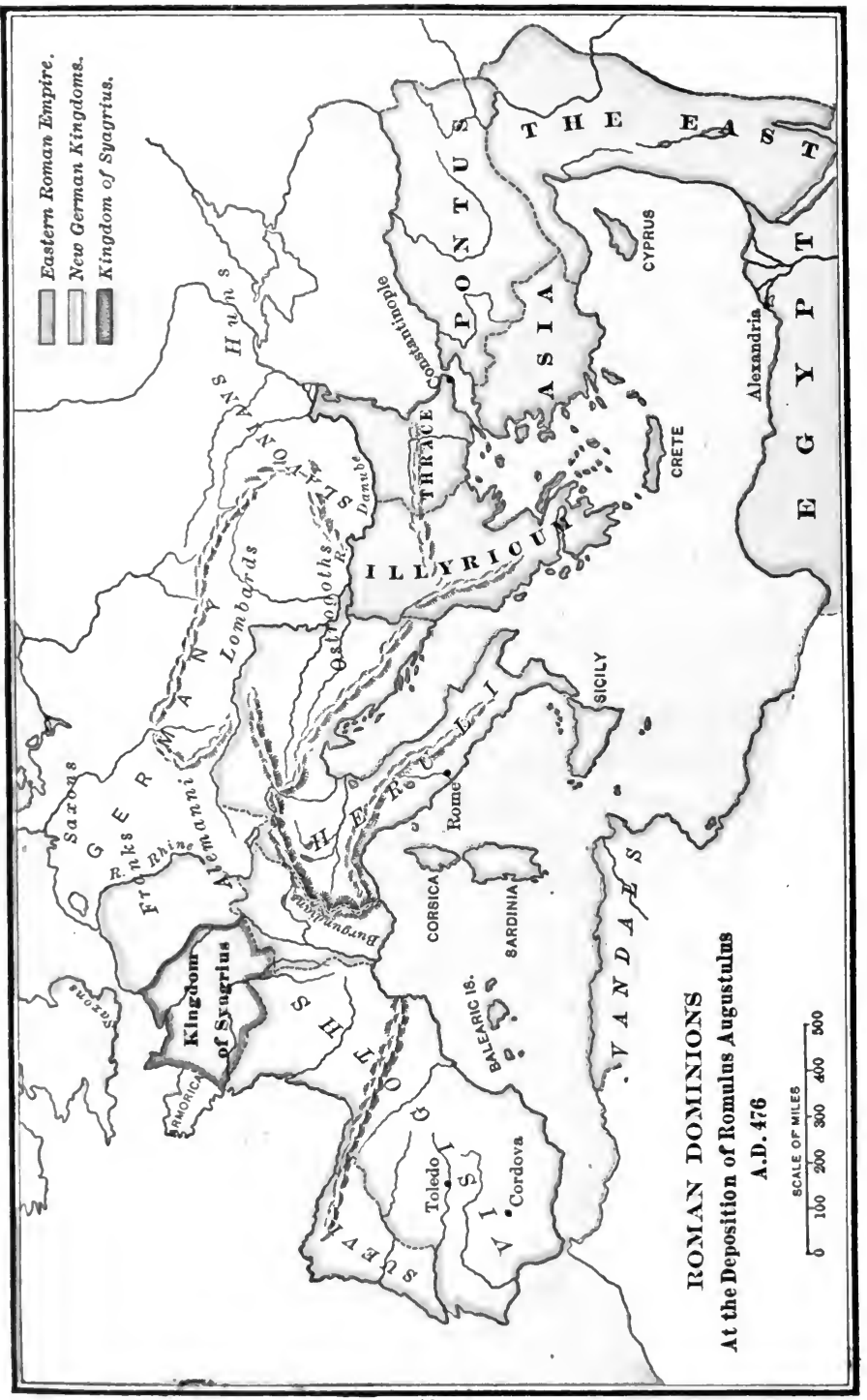


Italy. After a brief war he became master of the peninsula, and founded the new kingdom of the Ostrogoths (493-55\% А. D.). Ile acknowledged a nominal allegiance to the emperor at Constantinople; but, in fact, he ruled as an independent sovereign. He proved to be a great statesman and eivilizer, and may well be regarded as the greatest of the barbarian kings. He restored Italy to a prosperous condition, such as it had not seen

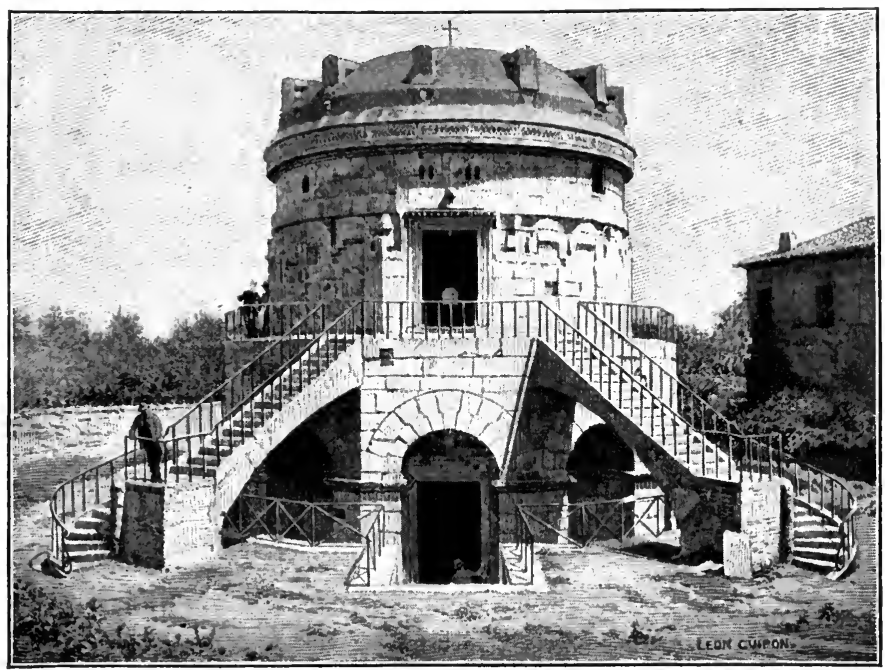

Tomb of Theodoric at Ravenna

since the days of the Antonines. He drained the marshes, repaired the highways, restored the old monuments, and built splendid edifices. His ambition was to infuse a new Teutonic vigor into the old civilization of Rome-to preserve the old institutions, while he gave to them a new spirit. He compiled the Roman law (the Edictum Theodorici) for the benefit of his Roman subjects; and, although an Arian, he respected the rights of the orthodox church. He also patronized learning. The chief ornaments of his reign were Boë'thius, who wrote the 
"Consolations of Philosophy"; and his private secretary, Cassiodo'rus, who wrote a "Ilistory of the Goths" (now preserved only in an abridged form). The last years of Theodoric were disturbed by intrigues and by acts unworthy of a great prince. At his death (527 A. D.), his enemies succeeded in having his ashes scattered; but his tomb at Ravenna remains as a monument of his greatness.

In Spain, the Suevi and Visigoths.-The peninsula of Spain became the seat of two Germanic kingdoms-that of the Suevi and that of the Visigoths. The Suevi had taken part in the great invasion under Radagaisus (p. 487). After the defeat of that barbarian leader by Stilicho, they had found a refuge in Spain, where they founded a kingdom in the northwestern part of the peninsula (409-585 A. D.). They had little influence upon the history of Spain, as they were absorbed into the greater kingdom of the Visigoths.

The Visigoths were led into Spain from Italy by Adolphus, the successor of Alaric (p. 48\%). Their kingdom lasted for many years (419-711 A. D.), and at one time extended over the entire Spanish peninsula and into southern Gaul as far as the river Loire. Iike many other barbarian chiefs, the Visigothic kings had great respect for the Roman institutions which they found among the conquered people. How much their first king. Adolphus, was under the influence of Rome we may judge from his own statement, in which he says that while he wished at first to destroy the Roman name, he was convinced that to maintain the Gothic state it was necessary to preserve the Roman institutions. 'The Visigothic kings respected the righis of their Roman subjects. While one king (Euric) drew up the barbarian laws for the Gothic people, another king (Alaric II.) Hrew up the Roman laws for the Roman people. The tendency in Spain was to preserve the equality of the Romans and thr Goths under the common authority of the king, who ruled more like a Roman emperor than like a barbarian (hioftain. 
In Gaul, the Burgundians and Franks. - In passing to the province of Gaul, we find the southeastern part, along the valley of the Rhone, oceupied by the kingdom of the Burgundians ( $410-534$ A. D.). Here, as in Italy and Spain, there was a disposition on the part of the lings to place the Roman and the German people on a plane of equality. For example, one Burgundian king (Gundibald) codified the barbarian laws of his own people; and another king (Sigismund) drew up a collection of the Roman law for his Roman subjects. The Burgundians were regarded as a brave people; and their heroic exploits are sung in the Niebelungen-lied, the great epic poem of the German race. Their kingdom was continued until it was absorbed by that of the Franks.

The most important of all the new German kingdoms was the Frankish monarchy, the first dynasty of which was called the Merovingian $(486-752 \mathrm{~A} . \mathrm{D}$.). The founder of this dynasty was Cloris (Clodwig, Clodovech), the chief of the Salian Franks-or that part of the Frankish nation that moved across the Rhine. This great chieftain, after defeating Syagrius (see p. 488) at the battle of Soissons (486 A. D. ; map, p. 516), soon overcame the neighboring tribes in Gaul,- the Alemanni in the northeast, the Burgundians in the southeast, and the Visigoths in the southwest,--and thus brought the whole of Gaul under his authority. He recognized a sort of allegiance to the Eastern emperor by accepting the title of "consul." During his reign and that of his successors the Roman people were respected, their cities were preserved, their language and laws remained untouched; and many of the Romans were even selected to assist the Frankish king in his government.

One of the most noteworthy facts in the reign of Clovis was his conversion to the orthodox form of Christianity,- which followed his victory over the Alemanni. The king became the protector of the church, and the church became a support of the king. The death of Clovis was followed by many divisions and reunions of the kingdom; but the policy which he 
adopted led to the blending of Roman ideas of law with the German ideas of liberty, and to an alliance between the church and the state which afterward made the Frankish monarchy the strongest political power in western Europe, as we shall hereafter see.

In Britain, the Anglo-Saxons.-The German conquest of Britain resulted from a series of migrations, beginning at the middle of the fifth century (449 A. D.) and extending over a

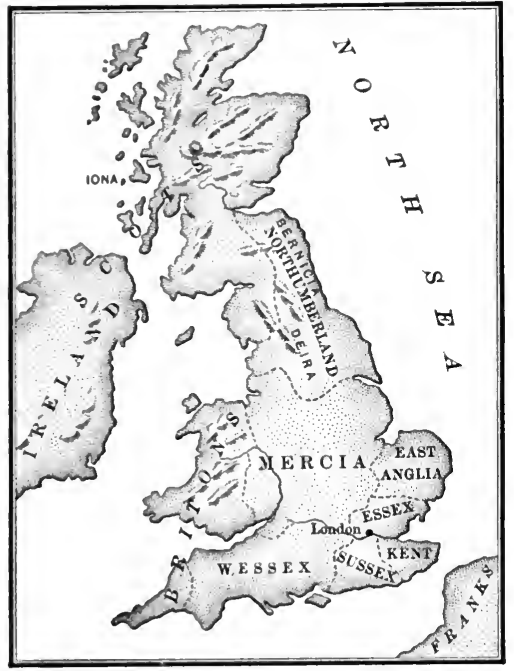

ANGLO-SAXON HEPTARCII period of a hundred and fifty years. The people whom we generally call the "Anglo-Saxons" included the Jutes, who settled in Kent; the Saxons, who settled in Sussex, Wessex, and Essex; and the Angles, who settled in East Anglia, Mercia, and Northum'berland. These settlements, which grew into as many kingdoms, are often spoken of as the "AngloSaxon Heptarehy." Although the province of Britain had previously been made a seat of Roman civilization, many of the remains of which exist at the present day, the Teutonic institutions beeame thoroughly transplanted to English soil; and the German ideas of personal liberty and of loeal self-government became more firmly fixed there than in any other country of Europe.

Rut still it would be a mistake to suppose that the Roman influence was entirely destroyed. The Roman cities still remained and preserved some of the municipal institutions of the empire. When the Roman missionary, Augustine, was sent 
to Britain, and the Anglo-Saxons were converted to Christianity, the church became organized on a Roman basis, and attained a sort of national unity, even before the Saxon kingdoms themselves were united. 'The Christian clergy, who were imbued with Roman ideas, became the advisers of the Saxon kings, and gave them lessons in the art of government and political administration.

When we speak of the conversion of the Anglo-Saxons by Augustine, we must not forget that Christianity had already been established in Britain during the Roman period. When the island was invaded by the pagan Germans, the Celtic Christians took refuge in Scotland and Ireland. The early British, or Celtic, church was thus preserved in these places, and had a strong seat in the island of Io'na. The rivalry between the Christian Celts and the missionaries from Rome was finally settled by an agreement to unite under an archbishop appointed by the Pope. The man selected was Theodore of Tarsus, who organized the Anglo-Saxon church upon a Roman model.

\section{The Romano-Germanic Society}

Fusion of the Romans and Germans.-The society which grew up in the new barbarian kingdoms was partly Roman and partly German. The two peoples lived side by side in the same territory - the one in the old municipalities, and the other, generally speaking, in the rural districts-in villages or upon great estates. Being thus brought together under the samo authority, they were necessarily influenced by each other. Their institutions, although diverse in origin and different in character, were modified by their mutual contact, resulting in a political system which possessed both Roman and German elements. One of the chief results of the invasions, therefore, was the fusion of the two peoples, the mingling to a great extent of their political and social institutions, their languages, and to a certain degree their systems of law. 
The German Kingship.-The chiefs of the new kingdoms became kings with something of an imperial dignity and authority. They assumed the imperial insignia-the crown, the imperial scepter, and the purple robe. They surrounded themselves with household officers, like an imperial court. They governed their territory in a manner similar to that of an imperial province. Thus the royal power, by appropriating the old imperial idea of Rome, gradually became more absolute than among the primitive German people.

The New German Nobility.-A new nobility also sprang up, which included both a German and a Roman element. It depended primarily upon the German principle of the comitatus (p. 483), or the personal relation between the chief and his followers. Those who were closely related to the king were his companions, and shared something of his dignity. Besides this personal nobility, there was what might be called an official nobility, made up of the military chiefs, or dukes (duces), and the territorial governors, or counts (comites). Persons were admitted to this privileged class, whether they were Germans or Romans; and this fact tended to break down the distinction be"tween the two peoples.

The Common Freemen.-The growth of the new kingship and the new nobility tended to degrade the condition of the common freemen. The pure democratic institutions of the primitive Germans beeame somewhat modified. In the old German society, before the invasions, all the freemen had been aceustomed to meet together in their assemblies, and had had a real share in the government. It is true that after the invasions the kings sometimes called the people together; but the national assemblies were more often made up of the nobles than of the common freemen. Moreover, the freemen who were excluded from the nobility, were obliged to live upon the soil; and many of them gradually descended to the condition of the old Roman coloni, or serfs.

The Christian Church.-During the period of the invasions 
the church was growing in authority and influence. By its eflicient organization, it was able to maintain its power, while the rest of society was breaking up and becoming reorganized. 'The elergy formed the most intelligent and influential class in the community. 'They not only exereised a great influence over the people, but became the adviser's of the kings, and, to a large extent, shaped their laws and administration. Moreover, the church, by bringing within its communion and under its authority both the German and the Roman population, became a powerful agency in fusing the two peoples together and breaking down their race prejudices. Finally, the division of the church between the Arians and the orthodox gradually passed away by the triumph of the orthodox faith. On this account the church eame to be united, and formed the greatest single power in western Europe.

\section{SYNOPSIS FOR REVIEW}

T. The Germans and their Institutions.-The Barbarian World.-German Characteristics.-The German Political System. -The German Judicial System.-Conversion of the Germans.

II. The Great Irvasions.-Nature of the Invasions.-Invasion of the Visigoths under Alaric.-Invasion of the Huns under Attila.-Invasion of the Vandals under Genseric.-Fall of the Empire in the West.

III. 'The New Germanic Kingdoms.-In Italy, the Heruli and Ostrogoths.-In Spain, the Suevi and Visigoths.-In Gaul, the Burgundians and Franks.-In Britain, the Anglo-Saxons.

IV. The Romano-Germanic Society.-Fusion of the Romans and Germans.-The German Kingship.-The New German Nobility.-The Common Freemen.-The Christian Church.

\section{REFERENCES FOR READING}

Emerton, Ch. 2, "The Two Races"; Ch. 3, "Breaking of the Frontiers"; Ch. 8, "Germanic Ideas of Law" (the Salic law) (24). ${ }^{1}$

Curteis, Ch. 6, "Alaric and the Visigoths"; Ch. 7, "Genseric and the Vandals"; Ch. 8, "Attila and the Huns"; Ch. 9, "The -Change of covernment" (24).

Thatcher and Schwill. Ch. 4, "The Migration of Nations" (24).

${ }^{1}$ The figure in parenthesis refers to the number of the topic in the Appendix, where a fuller title of the book will be found. 
Adams, Ch. 3, "Additions of Christianity"; Ch. 4, "The German Conquest and Fall of Rome" (24).

Milman, Latin Christianity, Vol. II., Bk. III., Ch. 2, "Conversion of the Teutonic Races" (Saint Columban; Saint Boniface); Ch. 3, "Theodoric the Ostrogoth" (21).

Hunt, History of the English Church (21).

Robinson, Ch. 3, "The German Invasions and Break-up of the Roman Empire" (24).

Oman, Dark Ages, Ch. 2, "Theodoric, King of the Ostrogoths"; Ch. 8, "The Visigoths in Spain" (24).

Bémont and Monod, Ch. 7, "Institutions in Gaul after the Invasions" (24).

Translations and Reprints, Vol. VI., No. 3, "The Early Germans" (25).

Robinson, Readings, Vol. I., pp. 52-55 (conversion of Clovis as told by (iregory of Tours) (25).

\section{CHAP'TER XXXIII}

\section{THE ROMAN EMPIRE IN THE EAST}

\section{Recovery of the EMpire by Justinian}

The Eastern Empire before Justinian.-While the Roman and the Teuton were uniting to build up a new society in the West, the old Roman Empire still continued in the East. The emperor at Constantinople still claimed to be the rightful ruler of the whole Roman world, and had succeded in gaining the nominal allegiance of most of the German kings; but his real authority was confined to the provinces east of the Adriatic. It is true that the East was relieved of such invasions as had destroyed the Western provinces. Still the government at Constantinople was very weak, often in the hands of incapable men and under the influence of intriguing women. 'The capital and the other cities of the empire were distracted by political dissensions and religions discord. Not till we come to the reign of Justinian do we see anything like a revival of the old Roman spirit. 
The Reign of Justinian ( $5 \cdot 2 \%-565$ A. D.). -Justinian was the most fanous puler of the Lastern Empire; and his deeds are recorded by Proco'pius, the most eminent historian of that period. A barbarian by birth. . Instinian came to Constantinople while yet a young man, and there received an excellent edu-

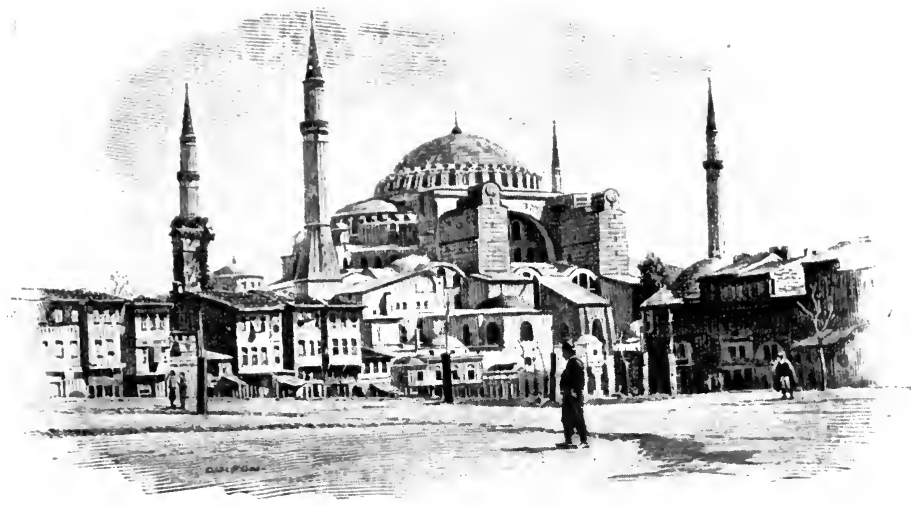

Church of St. Sophia at Constantinople

cation. He married the famous dancer Theodo'ra. who afterward became an orthodox Christian, and who at times aided the emperor by her keen intellect and her vigorous spirit. In spite of many stories which detract from the personal character of Justinian, his reign was, after that of Constantine, the most brilliant in the history of the East. He constructed many public buildings, chief among which was the Church of St. Sophia, dedicated to Wisdom. During his reign the culture of the silkworm was introduced into Europe, the eggs being stealthily brought from China, it is said, by being concealed in a hollow staff. But the greatest renown of Justinian rests upon his partial recovery of the western provinces, and his codification of the Roman law.

Recovery of Africa from the Vandals (534 A. D.).- - The great desire of Justinian was to restore the grandeur of the 
PROGRF:SSIVF MAP No.21.

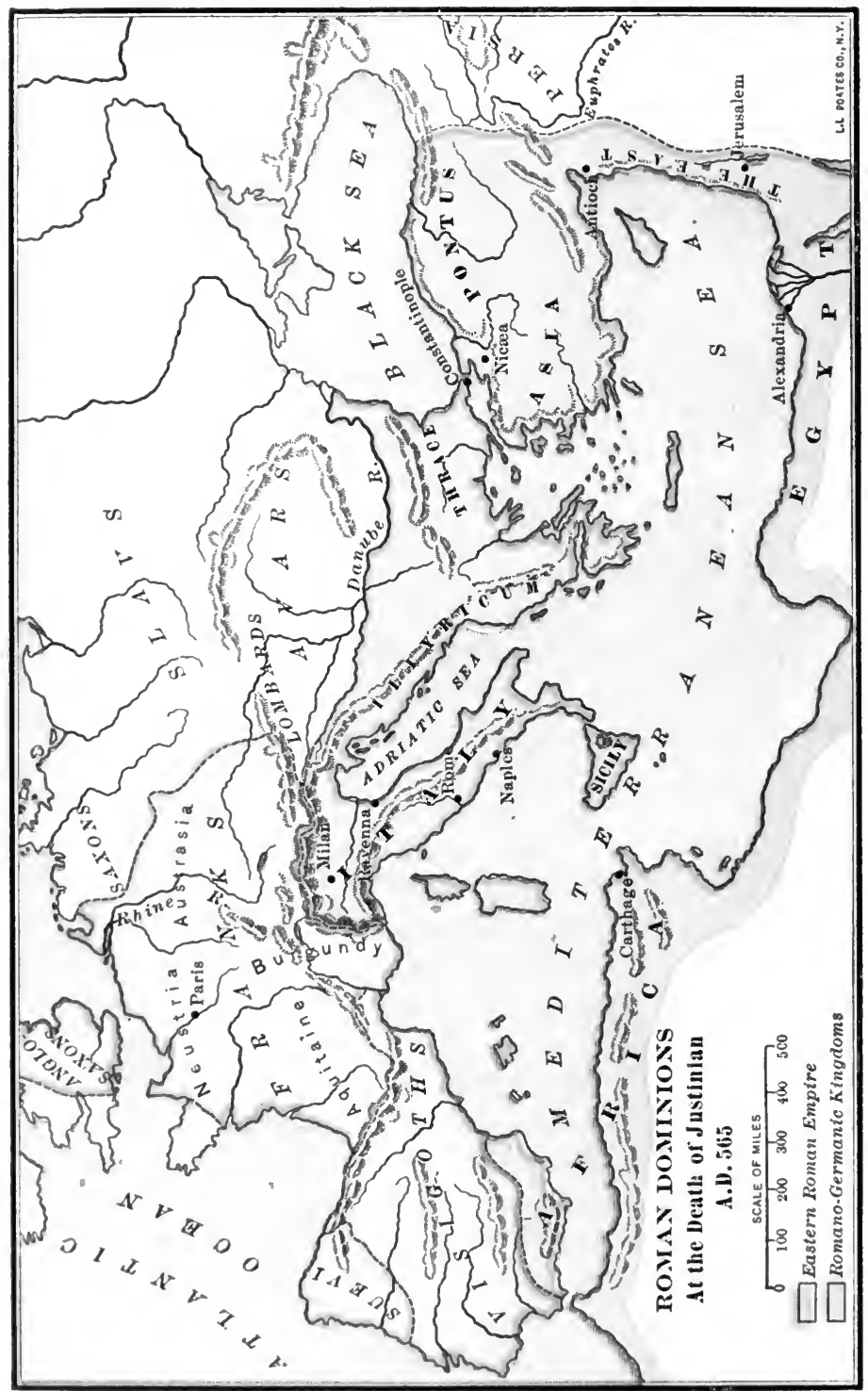


old Roman empire. To accomplish this, it was necessary not only to maintain the frontiers against the hostile Persians in the East, but also to recover the provinces in the West from the hands of the barbarian kings. The most hated and aggressive of the barbarians were the Vandals in Africa. They had swept the Mediterranean with their fleets, and had even threatened Constantinople. Unlike other tribes that had accepted Arian Christianity, the Vandals were intolerant in religion, and persecuted the members of the orthodox church. To rescue this province Justinian placed his greatest general, Belisa'rius, in command of a naval expedition to Africa. After a campaign of three months, the Vandals were conquered. Africa was restored to the empire, and placed under an "exarch," or governor, appointed by the emperor.

Recovery of Italy from the Ostrogoths (535-552 A. D.).Justinian soon found a pretext for invading Italy. But the conquest of the Ostrogoths proved a more serious undertaking than that of the Vandals. Belisarius was dispatehed with an expedition to Sicily ( 535 A. D.). After the conquest of that island, Naples and, Rome were taken. But Belisarius was himself shut up in the Roman capital and besieged for a year by the Gothic armies. When the siege was finally raised, he pursued the Goths to Ravenna, and compelled the surrender of that city. In the midst of his victories, he was recalled to Constantinople and sent against the Persians. In the meantime the Ostrogoths recovered Rome and a large part of the Italian peninsula. Belisarius was a second time sent into Italy. $\mathrm{He}$ succeeded in recapturing Rome; but he was feebly supported by the emperor and again recalled to Constantinople. 'The final conquest of Italy was left to another general, Narses. With the fall of the Ostrogothic kingdom, Narses was appointed exarch, with his capital at Ravenna. By these conquests in Africa and Italy-to which the southern part of Spain was added - the authority of the empire was reëstablished over a large part of the western provinces. 
The Codification of the Roman Law.-To the transient fame which resulted from the wars of Justinian was added the more permanent glory which came from his compilation of the Roman law. The emperor appointed the famous lawyer 'Tribo'nian, with the aid of a commission of jurists, to collect the laws of the empire. 'These consisted of the imperial " constitutions"- that is, the laws issued by the emperors-and the writings of the jurists. The newly codified body of the civil law was called the Corpus Juris Civilis, and consisted of four parts. (1) The Code was a collection of the imperial constitutions, issued since the time of Theodosius-who had already made a collection of the previous constitutions. (2) The $D i$ gest, or Pandects, comprised extracts from the writings of thirty-nine of the greatest Roman jurists-including Gaius, Ulpian, Paullus, Modestinus, and Papinian. It was the boast of the commission that three million lines had been reduced to one hundred and fifty thousand. (3) The Institutes was a textbook, containing the general principles of the law and intended for the use of students. (4) The Novels contained the later laws of Justinian issued after the publication of the Code. This compilation was perhaps the greatest legacy of Rome to the modern world. "It was in this form," as Savigny says, "that the Roman law became the common law of Europe."

\section{Barbarian Encroachments upon the Empire}

Conquest of Italy by the Lombards (568 A. D.).-The empire, which had recovered so much of its former greatness during the reign of Justinian, was after his death again exposed to barbarian incursions. The first great disaster was the loss of Italy, which had just been recovered by Belisarius and Narses. It is said that Narses-now the exarch at Ravenna-was illtreated by the authorities at Constantinople; and that he, in revenge, invited the Lombards to come to Italy. 'The Lombards had already settled in Pannonia. Under their leader, $\mathrm{Al}^{\prime}$ boin, 
they deseended into the valley of the Po, and afterward overran. nearly the whole of Italy. 'The principal seat of their power was in the north, their eapital being at Pavia. In the south they established a number of duchies-like that of Spole'tum and that of Beneventum. The Eastern Empire was able, however, to hold the territory about Ravenna and about Rome; and this territory remained under the authority of the exarch

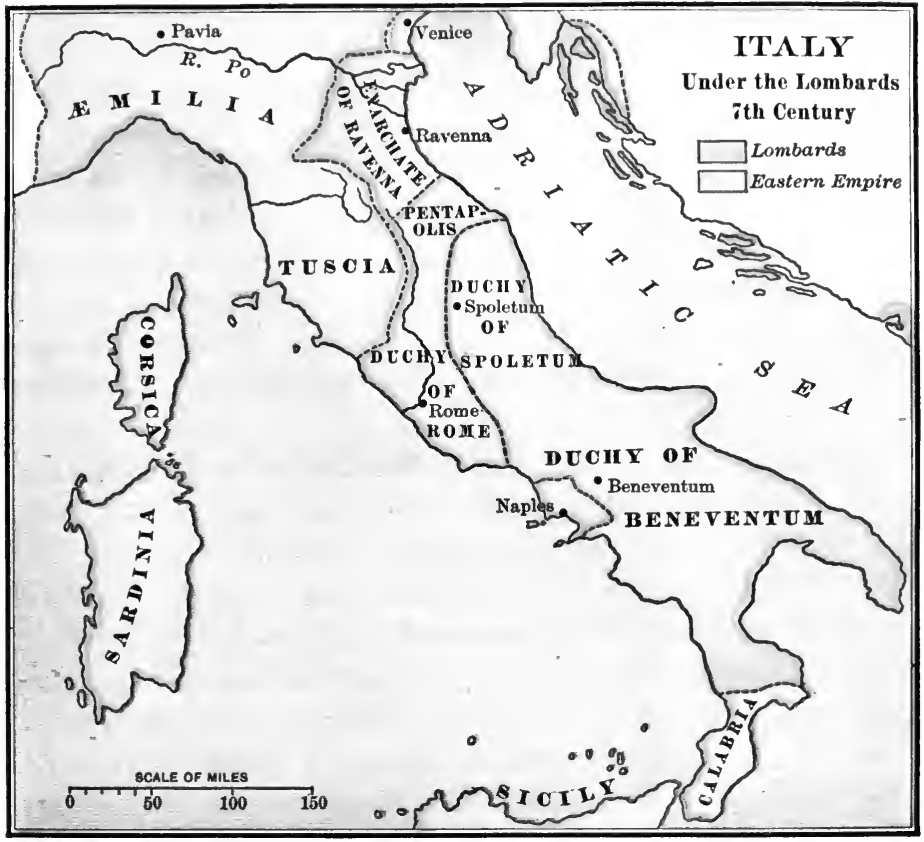

of Ravenna and of the Eastern Empire. The Lombards were oppressive and cruel. Unlike the Ostrogoths, they had little respect for the Roman people or for Roman institutions. They had adopted the Arian form of Christianity; but they were intolerant and were open enemies of the orthodox church. The Lombard rule marks the lowest point that Italy reached during the barbarian invasions. 
Slavic Settlements in the Eastern Provinces.-The invasion of the Lombards was the beginning of a new period of encroachments upon the Eastern Empire. We saw some time ago that the early Germans had been pushed forward upon the frontiers by the pressure of the Huns from Asia (p. 465). So now the Slavic peoples were being pressed forward by other Asiatic tribes, the Avar's and Bulgarians. The Slavs were thus brought into somewhat the same relation to the East as the Germans had been to the West. 'They did not, however, succeed in overthrowing the empire in the East, as the Germans had practically done in the West. But still there came to be established at least four new barbarian states south of the Danube. These were Servia, Croatia, Carinthia, and Bulgaria. The first three of these were founded by the Slavs; the last was founded by the Bulgarians, originally a "Turanian" people, who, however, having mixed with the Slavs, adopted the language and customs of the latter, and became themselves practically a Slavic people.

Heraclius and the Declining Empire.-The loss of these territories in Italy and on the Danube was a painful evidence of the weakness of the government at Constantinople. The Persians also renewed their wars and overran the provinces in the East. They took possession of Egypt and Syria, invaded Asia Minor, and their armies eneamped within sight of Constantinople. From this dangerous condition the empire was temporarily rescued by the heroic efforts of Heracli'us (610-641 A. D.), an emperor whose warlike deeds remind us of Justinian. He boldly attacked the enemy, rescued Asia Minor and Egypt and earried the war into the Persian territory. But the vigorous reign of Heraclius was hardly more than a parenthesis in the general movement toward decay and degeneracy. The Eastern Empire continued to exist for more than eight hundred years and to render some service to civilization. It protectod Europe from the encroachments of Asiatic peoples, and preserved the fruits of ancient learning to modern times. 


\section{III. 'T'He Mohammedan A'T'TaCK}

Mohammed and his Religion.-While the empire was struggling to defend itself against P'ersia, there appeared in $\Lambda$ sia a new power which was to prove a more formidable enemy than Persia, and a new religion which was destined to be a rival of Christianity itself. This new religious power sprang up in Arabia, of which little had been previously known. Its founder and leader was Mohammed. It is not necessary for us to recount the many stories which are told regarding his life-his early vocation as a merchant, his miraculous visions, his call to preach, his flight from his native city Mecea (from which date, 622 A. D., begins the Mohammedan era), his failure as a simple prophet, and his use of the sword as a tool of religious conquest. It is enough for us to keep in mind the fact that he welded together a disunited people, proclaimed a new religion to his fellow-men, and founded a new empire in the East.

The religion of Mohammed, it has been said, was compounded of an eternal truth and a novel fiction. It may be summed up in the words, "There is only one God, and Mohammed is his prophet." It was a protest against the polytheistic and idolatrous tendencies of the East. It was also the assertion of the prophetic character of a man who extended religion by means of the sword, and sought to exalt himself by imposing upon the world the choice between the Koran, ${ }^{1}$ tribute, or death.

\section{Mohammedan Conquests in the East and West.-The con-} quests begun by Mohammed were carried on by his successors, the "caliphs," as they were called. Of these the greatest warrior, and the real founder of the Arabian supremacy in the East, was Omar. This caliph united all the people of Arabia under his banner, and entered upon a remarkable career of conquest. He defeated Heraclius, as that emperor was returning from a

1 The Koran is the Bible of the Mohammedans; they believe it to nave been divinely revealed to the prophet, and accept it as the final authority in civil as well as religious law. 
victorious campaign against Persia; he wrested Syria and Palestine from the empire, and erected an Arabian mosque at Jerusalem on the site of Solomon's Temple. He then defeated the Persians and overthrew the dynasty of the Sassanidæ. He

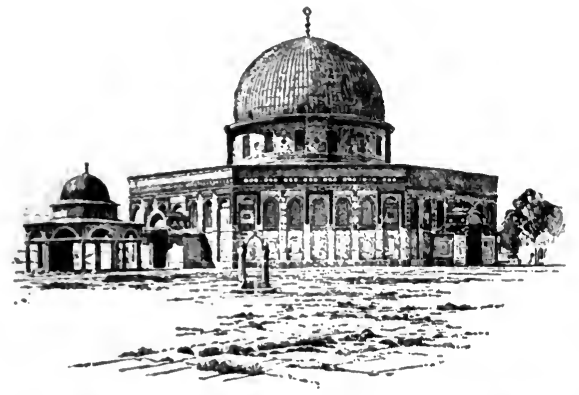

Mosque of OMar, Jerusalem invaded Egypt, and; after besieging Alexandria for fourteen months, became master of that country. With this beginning under Omar, the Arabians continued to push their conquests, under other caliphs, in northern Africa to the Atlantic. They then crossed into Spain and destroyed the kingdom of the Visigoths (711 A. D.), leaving only a small Christian kingdom (Astu'ria) in the extreme north. They invaded Gaul and threatened to overrun all the countries of western Europe, and even to destroy Christianity itself. From this disastrous fate Christian Europe was rescued by the Franks under Charles Martel' at the famous battle near 'Tours, which may well be called one of the decisive battles of the world. In a single century, from the death of Mohammed (632 A. D.) to the battle of Tours ( 732 A. D.), the Arabians, or Saracens, had established an empire extending from the Indus River to the Atlantic Ocean.

Dismemberment of the Caliphate.-By the middle of the eighth century the Mohammedan power had reached its greatest extent under the dynasty called the Ommi'ads, who made their capital at Damascus. From this time the caliphate gradually fell to pieces. The Ommiads were overthrown by a new dynasty, called the Abbas'sids, who removed their capital farther east, to the shores of the Tigris at Bagdad. One of the Ominiads, named Abd-er-Rah'man, escaped and fled to Spain, 
where he established an independent caliphate, with its capital at Cor'dova. It was not long before another independent caliphate arose in Africa, with its capital at Cairo, under the rule of the Fat'imites, who traced their descent from Fa'tima, the daughter of Mohammed. In spite of these and subsequent divisions, the Mohammedan religion continued to prevail over these countries.

Mohammedan Civilization.-By their conquests the Mohammedans came into contact with the higher eivilizations of Persia and the Eastern Empire. While western Europe was under the shadow of the German invasions, and the Eastern Empire was going into decline, Bagdad and Cordova, and other Mohammedan cities, became the centers of learning and culture. The Arabians studied philosophy, cultivated mathematics, and excelled in medicine. 'They obtained their chief ideas of architecture from the cities of the Eastern Empire; but they developed a new and beautiful style of ornamentation, called "arabesque," which is made up of lines and curves, and dispenses with the forms of living beings. The Arabians were not very original; but they took up much of the culture of the East and afterward transmitted it to the peoples of western Europe.

\section{SYNOPSIS FOR REVIEW}

I. Recovery of the Empire by Justinian.-The Eastern Empire before Justinian.-The Reign of Justinian.--Recovery of Africa from the Vandals.-Recovery of Italy from the Ostrogoths.-Codification of the Roman Law.

II. Barbarian ENCRoachments UPON the Empire.-Conquest of Italy by the Lombards. - Slavic Settlements in the Eastern Provinces.-Heraclins and the Declining Empire.

III. The Mohammedan ATtack.-Mohammed and his Religion.-Mohammedan Conquests in the East and West.-Dismemberment of the Caliphate.-Nohammedan Civilization.

\section{REFERENCES FOR READING}

Seignobos, Ch. 30, "The Eastern Roman Empire"; Ch. 31, "Mohammed and Mohammedanism" (18). ${ }^{1}$

1The figure in parenthesis refers to the number of the topic in the Appendix, where a fuller title of the book will be found. 
Bémont and Monod, Ch. 8, "The Roman Empire in the East"; Ch. 11, "The Arabian Empire" (24).

Duruy, Ch. 4, "The Greek Empire"; Bk. II., "The Arab Invasion" (24).

Curteis, Ch. 10, "The Emperor Justinian"; Ch. 11, "The Empire in Relation to the Barbarians of the East" (24).

Gibbon, Ch. 40, "The Reign of Justinian"; Ch. 41 (career of Belisarius); Chs. 50-52 (extension of the Mohammedan power); Ch. 51 (Saracen conquest of Spain); Ch. 52 (siege of Constantinople) (18).

Stanley, Lect. 8, "Mahometanism in its Relation to the Eastern Church" (21).

Milman, Latin Christianity, Bk. III., Ch. 4, "Justinian" (21).

Morey, Roman Law, pp. 158-163, "The Final Codification by Justinian" (22).

Smith, R. B., Lect. 3, "Mohammedanism" (teachings of the Koran) (24).

\section{CHAPTER XXXIV}

\section{THE GROWTH OF THE CAROLINGIAN EMPIRE}

\section{The Papacy and the Latin Church}

The Growth of the Papacy.-We have thus seen the breaking up and deeline of the old Roman empire-resulting (1) from the German oceupation of the West, and (2) the encroachments made upon the East by the Slavs, by the Persians, and finally by the Mohammedans. We are now prepared to look at the events which led to the progress and consolidation of western Europe. We shall see an alliance formed between the two strongest powers of the West-the papacy and the Franks. We shall then see the founding of a new Frankish dynasty, called the Carolingian; and the revival of the Roman empire under the Carolingian rulers. Our attention must first be directed to that power which was most influential in bringing about these results-namely, the papacy, the chief authority in the Latin church. 
The bishop of Rome-or the "Pope" (papa, father) as he was now called-had been acquiring new power and dignity during the whole period of the invasions. This was due to a number of causes, which we may briefly enumerate as follows: (1) the belief that the Roman bishop was the lineal successor of Saint Peter; $(2)$ the prestige of Rome as the previous capital of the world; (3) the reeognition of the Roman church as the "mother church" in the West; (4) the custom of appealing to the Roman bishop upon moral and ecclesiastical questions; and (5) the personal influence of three great bishops-Innocent I., Leo I., and

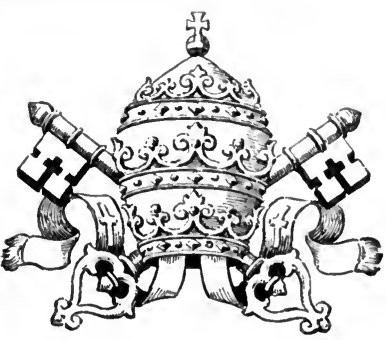

Papal Emilems Gregory I.-whose ability as statesmen and whose vigorous policy gave to the bishop of Rome a commanding position throughout the Christian world.

The Schism of the East and the West: the Iconoclastic Controversy.-Although the bishop of Rome had come to be recognized as superior to other bishops, the Eastern emperor assumed to exercise an authority over him, as he did over the ecclesiastical officers in the East. The distinction, however, between the Western or Latin churches, on the one hand, and the Eastern or Greek churches on the other, was so deeply rooted as to lead to their final separation. The most conspicuous cause of this schism between the East and the West was the famous "iconoclastic controversy." The emperor Leo III. (the Isaurian) had issued an edict (726 A. D.) forbidding the use of images, pictures, or other representations of Christ and the saints in the churches, and commanding the destruction of such symbols. As the emperor claimed that his authority was superior to that of any ecclesiastic-bishop, patriarch, or Pope-he intended this edict to apply to the Western as well as to the Eastern churches. The Pope, Gregory II., however, 
refused to recognize the authority of this edict, and proclaimed that all persons would be excommunicated who ventured to obey it. By this act the Pope proved his independence of the Lastern emperor. The controversy regarding "iconoclasm" (image-breaking) raged fiercely throughout the church. As a result of this-and of other causes-the Latin church was able to preserve its freedom from imperial dictation, and to maintain its independent organization, under the supremacy of the bishop of Rome; while the Greek church was content to fall under the headship of the emperor at Constantinople.

Western Monasticism.- The influence of the Latin church, as well as the authority of the Pope, was promoted by the establishment of monasticism in the West. This form of secluded religious life had long prevailed in the East, where its devotees had led a solitary and contemplative existence. When transplanted to the West, monasticism assumed a more practical and philanthropic character. Under the rule of Saint Benedict, who established a monastery at Monte Cassino in Italy (529 A. D.), it became a prominent feature of the Western church. The "rule of Saint Benedict" required the taking of three vows-poverty, chastity, and obedience. It also required the performance of three daily duties-prayer, study, and manual labor. The monastic system spread throughout the countries of Europe, and exercised an important influence, not only in strengthening the church, but also in improving the condition of society. By encouraging manual labor, the monks restored the waste lands in different countries, and gave a new dignity to agricultural pursuits. By their copying of manuseripts, they preserved from destruction many works of ancient literature, and encouraged learning and scholarship. By their hospitality, they furnished a refuge for the weak, the sick, and the distressed, and presented to the world examples of Christian charity.

The Papal Missions.-The influence of the Latin church was also extended by the encouragement given by the Popes to 
missionary work. We have already seen how Augustine was sent (by Pope Gregory I.) to Britain to rescue that island from paganism and to bring it under the authority of the church (p. 49t). The Irish monk and missionary, Saint Columban, was sent to the countries about the upper Rhine, where his work was continued by his disciple, saint Gall, the founder of one of the great monasteries in central Europe. But the greatest of the papal missionaries was Saint Boniface, who was sent by the Pope as the "apostle to the Germans." His work resulted not only in the conversion of many German tribes, but also in the reform of the Frankish church and in bringing it more completely under the papal authority. In this work he received the aid of Charles Martel, who had now come to be looked upon as the champion of Christendom and the faithful supporter of the Pope.

The Popes and the Lombards.-The people of western Europe who seemed to have the least respect for the dignity and authority of the Pope were his nearest neighbors, the Lombards. The Lombard kings desired to unite the whole of Italy under their own power. This would require, in the first place, the conquest of the Exarchate of Ravenna, which was still subject to the Eastern emperor. It would require, in the next place, the occupation of the city of Rome, the seat of the papal power. If this were accomplished, the Pope would be obliged to submit to the authority of the Lombard king-a master more oppressive than the emperor whose authority the Pope had denied. In the face of such a warlike people as the Lombards, the Pope was practically helpless, unless he could find some military support. He could not well appeal to the Eastern emperor from whom he wished to be free. The only people of Europe who could give him the necessary aid were the Franks-the people who had already saved Christendom by their victory over the Mohammedans (p. 506). The Pope, Gregory III., therefore, first turned for help to Charles Martel, the hero of the battle of Tours; but this great general 
died before the desired aid could be given. This appeal of the Pope for military assistance against the Lombards was an important step, which finally led to the alliance of the Franks and the papacy —an event of great significance in the history of Europe.

\section{The Alliance of the Franks and the Papacy}

The Frankish Monarchy; Mayors of the Palace.-We may ask why the Pope called for help upon Charles Martel and not upon the Frankish king. The fact is that the Frankish kings had ceased to possess any real authority: the governing power had passed into the hands of an officer of the king's household, called the "mayor of the palace." It is true that the early kings-like Clovis, the founder of the Merovingian dynasty, and Dagobert, who eonsolidated the Frankish power -were able rulers; but from the time of Dagobert, the crown was worn by feeble men, who reigned but did not rule. It was said by an old writer, "There was nothing left for the king to do but to be content with his flowing hair and long beard, and to sit on the throne and play the ruler" (Eginhard). The later Merovingian kings are hence known as fainéant (donothing) kings. But in spite of the weakness of these socalled kings, the Frankish monarehy found able rulers in the mayors of the palace. These officers had succeeded in making the Franks the strongest nation of Europe. Charles Martel was mayor of the palace when he defeated the Mohammedans at Tours; and it was to him as the real representative of the Frankish people, as well as the defender of Christendom, that the Pope now appealed for help against the Lombards.

Pepin the Short and the New Dynasty.-At his death Charles Martel was succeeded by his two sons, one of whom soon retired to a monastery. This left the other son, Pepin (or Pippin) surnamed the Short (1e Bref), as the sole mayor of the palace. Pepin was not disposed to exercise the real 
power of king without also having the title of king. He needed only some moral support to depose his feeble sovereign (Childeric III.), and to reign in his stead. He therefore appealed to the Pope as the supreme arbiter of moral questions. The Pope ('Macharias) replied, "It seems better that he who has the power in the state should be king, and should be called king rather than he who is falsely so called." With this sanction Pepin deposed the last Merovingian, assumed the royal title, and was raised on a shield, according to the German custom. He was also anointed with the holy oil, according to the Jewish custom, by Saint Boniface, now archbishop of Mainz. This ceremony was intended to give a religious sanction to the royal power, and to indicate that the king reigns "by the grace of God." In this way was established a new line of Frankish kings, called the Carolingian (or Carlovingian) dynasty (752 A. D.). The effect of this revolution was to cement more closely the alliance of the Franks with the papacy, and to give to the Popes the military support which they desired.

Pepin's Defeat of the Lombards. - The Pope could now urge upon Pepin his duty to protect the church from the encroachments of the Lombards. Under their king, Aistulf, the Lombards had already conquered the Exarchate of Ravenna, overrun the central part of Italy, and were laying siege to the city of Rome. The Pope (now Stephen II.) fled to Gaul and besought the new Frankish king to come to his aid, at the same time anointing and crowning the king in person, thus emphasizing the papal sanction of the king's title. Pepin was quick to respond. He crossed the Alps with his army, marched to Rome, relieved the city, and thinking that his work was accomplished. returned to Gaul. On his departure from Italy, the Lombards again besieged Rome with a larger force than before. A second time the Pope appealed to the Frankish king; and a second time Pepin led his army into Italy. The king was now determined to make a more thorough settlement 
of the Italian trouble. He not only raised the siege of Rome, but drove the Lombards from all the territory they had recently captured, and extorted from their king a promise to respect thereafter the rights of the church.

The "Donation of Pepin" and the Temporal Power of the Popes.-The question now arose as to what should be done with the territory rescued from the hands of the Lombards. This territory was claimed by the Eastern emperor as his rightful possession. But Pepin replied to this demand that his expedition into Italy was not made in the interests of the emperor, but in the interests of the church; that he himself had no desire for these lands, and that they should be given to the Pope. The whole territory-comprising the Exarchate of Ravenna, the Pentap'olis, and the Duchy of Rome (map, p. 503) - was therefore turned over to the church as the "patrimony of St. Peter" (756 A. D.). This gift is called the "Donation of Pepin," and it laid the foundation of the temporal power of the Popes. From this time the Pope became a temporal sovereign in Italy, exercising a political as well as an ecclesiastical authority. But quite as important was the fact that it established more firmly the alliance between the Franks and the papacy, by which each was bound to assist the other in their respective spheres of authority.

\section{The Empire of Charlemagne}

The Consolidation of Central Europe-The movements which we have already considered-namely, the growth of the papacy as the chief power in the Latin church, and the alliance of the Popes with the Frankish monarchy-resulted finally in the establishment of a Romano-Germanic empire under the Carolingian rulers. The founder of this empire was ('harles the 'Great, who was the son of Pepin, and who is generally known as Charlemagne. Charlemagne was not only the greatest man of his age, but one of the great men of his- 
tory. After the death of l'epin ( 668 A. D.) he ruled for a short time with his brother (arloman; but at the death of Carloman he became the sole ruler of the Frankish nation. He proved himself to be a born king and statesman. He was a man of gigantic stature, of imposing presence, and of broad ideas. His ambition was to consolidate the peoples of central Europe into one great Christian state, and to lift them to a higher plane of civilization.

A considerable part of his reign was occupied with wars with outlying peoples, and with efforts to organize them under his authority and to bring them under the influence of the church. We can only briefly refer to these wars: (1) He invaded the kingdom of the Lombards, to settle another quarrel between this people and the Popes; he conquered their territory, and was himself crowned with the "iron erown of

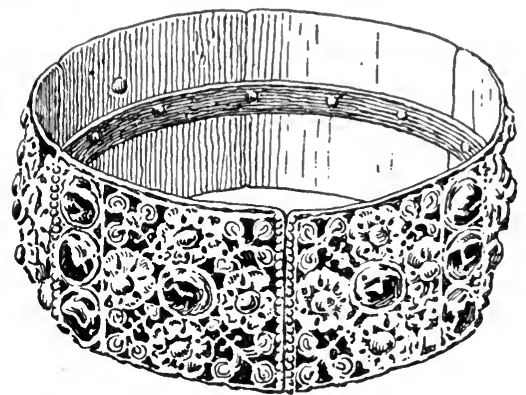

Tile Iron Crown of TIIE Lombards the Lombards," "thus annexing this kingdom to his own. He invaded northern Spain to free the Christians from the yoke of the Saracens (Mohammedans). On his retreat the rear guard of his army was attacked in the pass of Roneesvalles, where the heroic warrior Roland was killed; but this disaster did not prevent Charlemagne from annexing the northern part of Spain, which he did under the name of the "Spanish March." (3) He made war upon the barbarous ${ }^{1}$ This famous crown takes its name from a small fillet of iron within the broad band of gold and jewels which protects it. The piece of iron is said to have been wronght from a nail taken from the true cross, and to have been owned by constantine and Pope Gregoly the fireat before it p:issed into the hands of the Iombard kings. The crown was afterward used by Charlemagne and Napoleon. It is now in the church of Monza, a town in northern Italy. 
PROGRFSSIVF MAT No. 22.

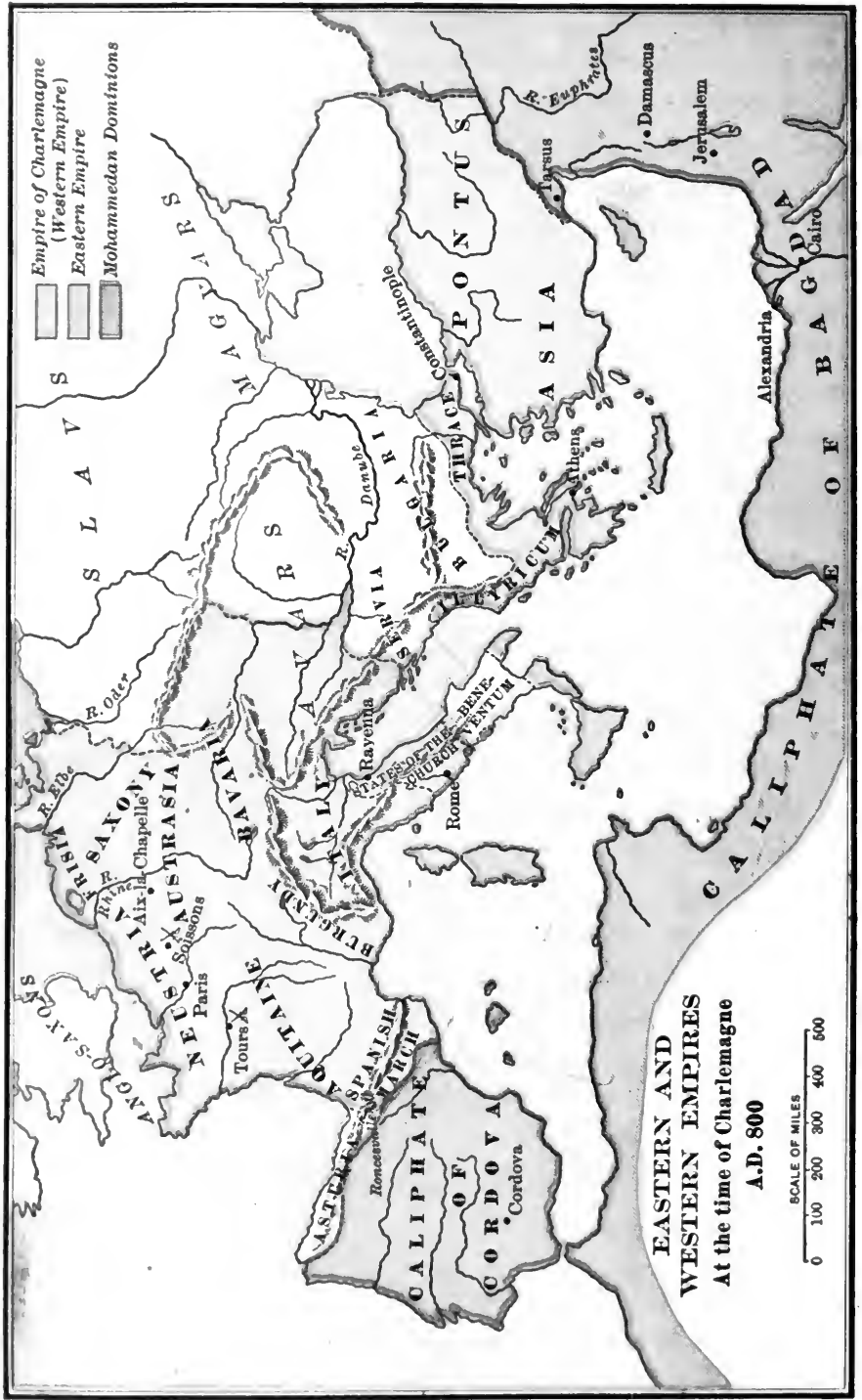


nations on the eastern frontier-the Avars and Bavarians; he drove back the Avars, and added to his territory Bavaria, the seat of the Bavarians, who lad hitherto remained independent. (4) He made many expeditions against the saxons on the north of the Rhine, who long resisted his power, but who were finally reduced to his authority and brought under the influence of Christianity. By these conquests the dominions of Charlemagne were extended over a large part of central Europe, and included the following chief provinces : Saxony and Frisia, Austrasia and Neustria, B u r gund y and Aquitaine, Lsom-

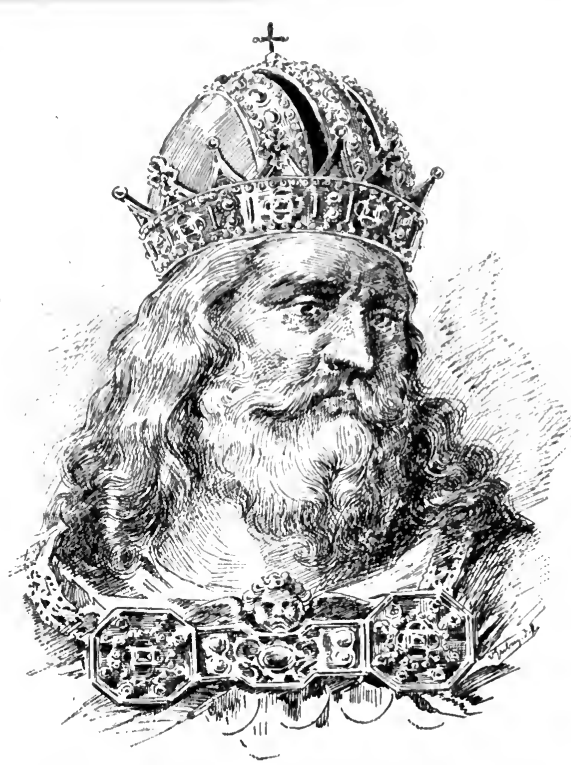

Charlemagne ('Traditional Portrait) bardy (northern Italy) and Bavaria, together with the Spanish March on the south, and the Avaric March on the east. This extensive dominion seemed to need only the sanction of the Pope to make it in name, as well as in fact, an empire.

Coronation of Charlemagne as Roman Emperor (800 A. D.). -At this time the imperial title at Constantinople was held by a woman-the empress Irene-whose authority was not recognized in the West. It needed only a suitable occasion to confer the title upon Charlemagne, who was now the most conspicuous ruler in Europe and the ablest defender of Christianity. The occasion soon presented itself. When the Popr. 
Leo III., was driven from Rome by an insurrection, Charlemagne, with his army, entered the eity and reinstated him. As a reward for this service, the Pope on Christmas Day, in the Church of St. Peter, placed upon Charlemagne's head a golden crown, and saluted him as "Charles Augustus, crowned of God, great and pacific emperor of the Romans." The Roman people who witnessed this impressive ceremony in the church shouted their approval, and the Frankish soldiers outside the building joined in the acclamation. In describing this memorable event, Mr. Bryce says: "In that shout, echoed by the Franks without, was pronounced the union, so long in preparation, so mighty in its consequences, of the Roman and the 'Teuton, of the memories and the civilization of the South and the fresh energy of the North, and from that moment modern history begins."

The coronation of Charlemagne has been variously interpreted. It has been regarded as the revival of the Western Roman empire which had been extinguished by the deposition of Romulus Augustulus (p. 489); but as a matter of fact there had never been recognized a Western Empire as legally distinct from the Eastern. Again, it has been considered as the transference of the imperial title from the East to the West; but the empire in the East continued to exist for centuries as a rival to that of the West. It has also been regarded as the simple recognition of the imperial position which Charlemagne himself had achieved and to which he was entitled by his own conquests. It has finally been considered as the bestowal of the title by the Pope as a reward for Charlemagne's services to the church, and to indicate that his authority was derived from the Pope. These various opinions are, to a great extent, merely theories to justify the later claims set up by the partisans of the emperor or of the Pope. Charlemagne himself professed to be surprised by the act of coronation; but he nevertheless gracefully accepted the title which was thereby conferred. 


\section{Charlemagne and his Imperial Government.-Charlemagne} was now both Frankish king and Roman emperor. But it is difficult for us to separate these two functions; since his government, like that of his predecessors, was made up of both German and Roman features. In looking at the political organization of Charlemagne's empire we may distinguish between the central government and the local government.

(1) 'The central government consisted of the emperor himself, the officers of the palace, and the national assemblies. The emperor was of course the supreme head of the empire, somewhat like the old Roman prince. His authority extended over all the affairs of the state. He was assisted by the officers of the palace, called the "palatines," each one of whom had charge of some particular branch of administration, like the issuing of the royal decrees, the administration of justice, the care of the imperial household, and similar matters. One of the peculiar features of Charlemagne's government was the preservation of the old German assemblies, in which the people had some share of political authority. There were two of these assemblies held each year. The larger one, which met in the spring and was called the "Field of May," was made up not only of the nobles, but of a large part of the common freemen. This assembly generally met in the open air, and approved the laws submitted to it by the emperor. The smaller assembly, which met in the autumn, was a gathering of the various officers of the empire for the purpose of giving an account of their administration, and of laying out the work for the coming year in accordance with the wish of the emperor.

(2) The local government consisted of a large number of officers who exercised authority within the different provinces or districts. There were several kinds of such local officers. There were two kings, the sons of Charlemagne, who ruled over Aquitaine and Italy. Then there were several dukes, the chiefs of barbarian tribes, who were permitted to govern their own people, subject to the imperial will; such were the dukes 
of Brittany in Gaul, and of Spoletum and Beneventum in Italy (p. 503). But the largest number of these local officers were counts, or "grafs,"-there were about three hundred of these,-who were appointed directly by the emperor to carry out his will in their separate districts or counties. The districts on the borders of the empire were called "marks," and were placed under officers called "margraves." (Bishops were also appointed over the various dioceses to supervise the affairs of the church. But all these officers, whatever their rank, were subject to the supreme authority of the emperor. To keep a strict control over all these local governors, and to protect the interests of the people, Charlemagne appointed two special officers, called missi dominici-the one a count and the other a bishop-to travel together through the various provinces for the purpose of inspecting the affairs' of each locality, of correcting abuses, and of administering justice. These last-named officers formed a sort of connecting link between the central and local governments. In the political system which he organized, Charlemagne showed his great ability as a statesman and an efficient administrator.

The Capitularies of Charlemagne.-The comprehensive mind of Charlemagne is seen in the vast number of laws passed by him for the government of his people. These laws were called "capitularies," and related to all matters which concerned the interests of his subjects. More than eleven hundred of such laws have been collected and preserved to us; so that we can learn much from them not only regarding the high ideals of Charlemagne, but regarding the condition of European society during this time. These laws emanated from the emperor himself or from his immediate counselors, and were prepared so as to meet the approval of the assemblies, to which they were generally submitted. They related to the duties of officers, the administration of justice, the punishment of crime, the rexgulation of industry, the suppression of beggary, the encouratgement of religion, and a multitude of other 
matters, all of which indicate the great eoncern which the emperor had for the welfare of his people.

Charlemagne and European Civilization.-Charlemagne's greatest distinction lies in the fact that he was a promoter of civilization. He brought about a union of the German and the Roman people, and laid the basis of a new European society. He encouraged habits of industry among his people, and published rules for the cultivation of the soil. He encouraged the revival of learning and of art. The long period which had elapsed since the beginning of the invasions had been a period of intellectual decline. But Charlemagne was a man who appreciated culture. He gathered about him the most learned men from all parts of Europe, and encouraged them in their scholarly pursuits. He also looked after the education of his subjects. He established schools in connection with the cathedrals and monasteries, as well as a "school of the palace" under the supervision of the famous scholar, Alcuin, archbishop of York. He promoted a taste for architecture, and built many churches, one of which was the cathedral at his capital, Aachen (Aix-la-Chapelle), where he was at last buried (814 A. D.). Charlemagne was the most efficient agent in uniting the German and the western Roman world, and in laying the basis of a new Romano-Germanic society, and thus in furnishing a broader foundation for the states which were to be formed from the ruins of the old Roman empire. Although his empire fell to pieces after his death, the beneficial results of his policy and work have remained as a heritage to modern Europe.

General Summary.-The name of Charlemagne closes the long period of ancient history which has been the subject of our study. As we look back we are able to see the successive stages of progress in the development of the old world.

(1) In the first place, we have seen the beginnings of civilization in the East-the early struggle of man for existence, and the growth of agriculture, manufactures, and com- 
merce; the formation of cities, and the rise and fall of great empires, and the initial stages in the development of art, science, and religion. In our study of the Oriental world we found that man first emerged from barbarism in those centers which were best fitted by nature for human existence-the fertile valleys of the Euphrates and the Nile. We found that the different forms of culture which were developed in these localities by the Babylonians and the Egyptians were brought together and commingled in Syria. Here we saw the rise of two important nations which earried to the highest point of development two phases of ancient civilization-the commercial under the Phœnicians, and the religious under the Hebrews. Then followed the consolidation of the Orient under the dominion of the Assyrians, the first great world power, which brought into a eloser union the various civilizations of the East. The dissolution of the Assyrian empire was followed by a still wider organization of the Oriental peoples under the second world power, Persia, which represented the highest unity attained by the Oriental world.

(2) In the next place, we have seen how civilization passed from the East to the West, and found a new center in Greecethe heir of the Orient, the home of liberty, and the seat of a higher intellectual and æsthetic culture. In our study of the Greek world we saw the rise of small city states scattered over the different parts of Hellas, each being the center of an independent political life. We saw the united struggle of these cities against the encroachments of the East, resulting in their triumph and the establishment of a period of peace and prosperity, during which time they developed an art, a literature, and a philosophy unequaled by any other nation. We then saw how their great love of independence brought about jealousies and conflicts, leading to the interference of a foreign power, and the growth of the third great world empire under Alexander-an empire which joined the Greek and Oriental worlds in one common civilization. 
(3) Finally, we have seen the shifting of the center of the aneient world from Greece to Italy and the growth of the imperial dominion of Rome. In our special study of the Roman world, we saw not only the progress of the Roman arms and the expansion of the Roman territory, but the development of the idea of incorporation as a political principle - the bringing of conquered peoples within the state and the extension of the privileges of citizenship. We noticed that the struggles between different parties, however bitter they were, resulted in the more complete equalization of rights and the establishment of a universal peace. We saw that the Roman genius for organization was not exhausted until the most important civilized nations of the old world were brought under one system of government, law, and religion. And we saw at last that when the Empire was broken up, and the Romans and the Germans were brought together, the influence of Rome still remained as a beneficial element in the reconstruction of European society.

From the study of these successive movements, we must be convinced of the "continuity of history," of the fact that the achievements of one age or people have been transmitted to those succeeding, and also of the fact that, in spite of wars and revolutions, of the rise and fall of nations, the progress of the race as a whole has been onward and upward.

\section{SYNOPSIS FOR REVIEW}

I. The Papacy and the Latin Church.-The Growth of the Papacy.-The Schism of the East and the West: the "Iconoclastic Controversy."-Western Monasticism.-The Papal Missions.The l'opes and the Lombards.

II. The Alliance of the Franks and the Papacy.-The Frankish Monarchy; Mayors of the Palace.-Pepin the Short and the New Dynasty.--Pepin's Defeat of the Lombards.-The "Donation of Pepin," and the Temporal Power of the Popes.

III. The EMpire of Charlemagne.-The Consolidation of Central Europe.-Coronation of Charlemagne as Roman Emperor. - Charlemagne and his Imperial Government.-The Capitularies of Charlemagne.-Charlemagne and European Civilization.-General Summary. 


\section{REFERENCES FOR READING}

Duruy, Bk. III., "The Carolingian Empire" (24)."

Emerton, Ch. 9, "Rise of the Christian Church"; Ch. 12, "The Franks from Charles Martel to Charlemagne"; Ch. 14, "Foundation of the Mediæval Empire" (24).

Thatcher and Schwill, Ch. 5, "The Franks" (24).

Curteis, Ch. 13, "The l'opes and the Franks in Italy"; Ch. 14, "The Franks and the Papacy" (24).

Robinson, Ch. 4, "The Rise of the Papacy"; Ch. 7, "Charlemagne" (24).

Seignobos, Ch. 32, "Charles the Great and the New Empire" (18). Bémont and Monod, Ch. 12, "The Fainéant Kings"; Ch. 13, "Empire of the Franks" (24).

Adams, Ch. 6, "The Formation of the Papacy"; Ch. 7, "The Franks and Charlemagne" (24).

Oman, Ch. 16, "The Lombards and the Papacy"; Ch. 22, "Charles the Great and the Fmpire" (24).

Bryee, Ch. 4, "Restoration of the Empire in the West"; Ch. 5, "Empire and Policy of Charles"; Ch. 7, "Theory of the Mediaval Empire" (24).

Milman, Latin Christianity, Vol. II., Bk. III., Ch. 6, "Western Monasticism"; Ch. 7, "Gregory the Great"; Bk. IV., Ch. 7, "Iconoclasm"; Ch. 9, "Severance of Latin and Greek Christianity" (21).

Guggenberger, History of the Christian Era (21).

Freeman, Essay, "The Unity of History" (3).

Henderson, Documents, pp. 274-314, "The Rule of St. Benedict" (25).

Eginhard, Life of Charlemagne (27).

Translations and Reprints, Vol. VI., No. 5, "Laws of Charles the Great" (25).

'The figure in parenthesis refers to the number of the topic in the Appendix, where a fuller title of the book will be found. 


\section{APPENDIX}

\section{A CLASSIFIED LIST OF IMPORTANT BOOKS UPON ANCIENT HISTOR ${ }^{1}$}

\section{GENERAL AND MISCELLANEOUS WORKS}

(1) Ancient History, General.

Ducoudray, G. History of Ancient Civilization. N. Y. 1889.

Fisher, G. P. Outlines of Universal History. Part I. Ancient History. N. Y. 1885.

Ploetz, C. Epitome of Ancient, Mediæval, and Modern History. Part I. Ancient History. Bost. 1884.

Rawlinson, G. Manual of Ancient History. N. Y. 1880.

Smith, P. History of the World. Ancient History. 3 vols. Seignobos, C. History of Civilization. Tr. by A. H. Wilde. Vol. I. Ancient Civilization. N. Y. 1906.

Souttar, R. Short History of Ancient Peoples. Lond. 1904.

(2) Anthropology and Ethnology.

Brinton, D. G. Races and Peoples. N. Y. 1890.

Clodd, E. Story of Primeval Man. N. Y. 1895.

Deniker, J. Races of Man. N. Y. 1891.

Hoernes, M. Primitive Man. Lond. 1901. (Primer.)

Joly, N. Man before Metals. N. Y. 1883.

Keary, C. F. Dawn of History. N. Y.

Morris, C. The Aryan Race. Chicago, 1892.

Taylor, I. Origin of the Aryans. Lond. 1890.

Tylor, E. B. Primitive Culture. 2 vols. N. Y. 1874.

- Early History of Mankind. Bost. 1878.

- Anthropology. N. Y. 1881.

Sayce, A. H. Races of the Old Testament. Lond. 1891.

Starr, F. Some First Steps in Human Progress. Meadville. 1895 .

(3) Miscellaneous Works.

Bourne, H. E. Teaching of History and Civies in the Elementary and Secondary School. N. Y. 1902.

Clarke, J. F. Ten Great Religions: an Essay in Comparative Theology. Bost. 1871.

1 The books contained in this list have been selected with special reference to their educational value in conrection with the work of secondary schools. More complete lists may be found in the author's "Outlines of Greek History" and "Outlines of Roman History." 
Committee of Seven. American Historical Association. Study of History in Schools. N. Y. 1903.

Diesterweg, G., and others. Methods of Teaching History. Bost. 1883.

Freeman, E. A. Historical Essays. Second Series. Lond. 1873.

Comparative Politics: with Lecture on the Unity of History. N. Y. 1874.

New England History Teachers' Association. Historical Sources in Schools. N. Y. 1902.

— Historical Syllabus for Secondary Schools. Bost. 1904.

\section{THE ORIENTAL WORLD}

(4) Oriental History, General.

Boughton, W. History of Ancient Peoples. N. Y. 1897.

Duncker, M. History of Antiquity (Oriental Nations).

Tr. by E. Abbott. 6 vols. Lond. 1877-82.

Hommel, F. Civilization of the East. N. Y. 1900. (Primer.) Lenormant, F., and Chevallier, E. Ancient History of the East. 2 vols. Phil. 1871.

Maspero, G. C. C. Life in Ancient Egypt and Assyria. N. Y. 1892 .

- Dawn of Civilization. Egypt and Assyria. Lond. 1894.

- Struggle of the Nations. N. Y. 1897.

- Passing of the Empires. N. Y. 1899.

MeCurdy, J. F. History, Prophecy, and the Monuments. 3 vols. N. Y. 1895-1901.

Sayce, A. H. Ancient Empires of the East. N. Y. 1889.

Rawlinson, G. Five Great Monarchies. 3 vols. N. Y. 1871.

Smith, P. Ancient History of the East. N. Y. 1871. (Students' Series.)

(5) Babylonia and Assyria.

Budge, C. A. W. Babylonian Life and History. Lond. 1891.

Goodspeed, G. S. History of the Babylonians and Assyrians. N. Y. 1904.

Jastrow, M. Religion of Babylonia and Assyria. Bost. 1898.

Murison, R. G. Babylonia and Assyria. Edin. (Primer.)

Perrot, G., and Chipiez, C. History of Art in Chaldrea and Assyria. 2 vols. Lond. 1884.

Ragozin, Z. A. Story of Chaldæa. N. Y. 1891.

Story of Assyria. N. Y. 1891.

Rogers, R. W. Babylonia and Assyria. 2 vols. N. Y. 1889.

Sayce, A. H. Social Life of the Assyrians and Babylonians. Lond. 1893. 
Schmidt, N. Outlines of a History of Babylonia and Assyria. Ithaca.

Smith, G. Assyria from the Earliest Times to the Fall of Nineveh. Lond.

(6) Egypt.

Breasted, J. H. History of Egypt from the Earliest Times to the Persian Conquest. N. Y. 1905.

Brugsch-Bey, H. History of Egypt under the Pharaohs. Revised by M. Broderick. N. Y. 1891.

Edwards, A. B. Pharaohs, Fellahs, and Explorers. N. Y. 1892.

Erman, A. Life in Ancient Egypt. Lond. 1894.

Mariette, A. Outlines of Ancient Egyptian History. N. Y. 1862.

Maspero, G. C. C. Egyptian Archæology. N. Y. 1891.

Murison, R. G. History of Egypt. Edin. (Primer.)

Newbury, P. E., and Garstang, J. Short History of Egypt. Lond. 1904.

Petrie, W. M. F. History of Egypt. 2 vols. N. Y. 1896. Perrot, G., and Chipiez, C. History of Art in Ancient Egypt. 2 vols. Lond. 1883.

Rawlinson, G. History of Egypt. 2 vols. Lond. 1881. Story of Egypt. N. Y. 1892.

Wendel, F. C. H. History of Egypt. N. Y. 1890. (Primer.)

(7) Phœnicia and Judea.

Day, E. Social Life of the Hebrews. N. Y. 1901.

Edersheim, E. W. Laws and Polity of the Jews. Lond.

Hosmer, J. K. Story of the Jews. N. Y. 1891.

Kendrick, J. Phœnicia. Lond. 1855.

Kent, C. F. History of the Jewish People. N. Y. 1899.

- History of the Hebrew People. 2 vols. N. Y. 18991901.

Milman, H. H. History of the Jews. Lond. and N. Y. 1878.

Ottley, R. L. Short History of the Hebrews. N. Y. 1901.

Perrot, G., and Chipiez, C. History of Art in Phœnicia. 2 vols. Lond. 1885 .

Rawlinson, G. History of Phœnicia. Lond. 1889.

- Story of Phœnicia. N. Y. 1896.

Renan, E. History of the People of Israel. 5 vols. Bost. 1888-95.

Sayce, A. H. Early History of the Hebrews. N. Y. 1897.

(8) Media and Persia.

Benjamin, S. G. W. Story of Persia. N. Y. 1891.

Ragozin, Z. A. Story of Media, Babylon, and Persia. N. Y. 1891.

Vaux, IV. S. W. Persia from the Earliest Times to the Arab Conquest. Lond. 
(9) Sources of Oriental History.

Hammurabi, Code of. Tr. by C. H. W. Johns. Edin. 1903. Same tr. by R. F. Harper, Chicago, 1904.

Josephus, F. Works, Tr. by W. Whiston. Lond. 1870. old Testament. Revised Version.

Sayce, A. H. Records of the Past. 6 vols. Lond. 1888-92.

\section{THE GREEK WORLD}

(10) Greek History, General.

Abbott, E. History of Greece. 2 vols. N. Y. 1888-92.

Allcroft, A. H., and Masom, W. F. History of Greece. 6 vols. Lond.

Bury, J. B. History of Greece (one vol. edition). N. Y. 1900.

Butcher, S. H. Some Aspects of the Greek Genius. Lond. and N. Y. 1893.

Cox, G. W. General History of Greece. N. Y. 1894. (Students' Series.)

The Greeks and the Persians. N. Y. (Epochs.)

- The Athenian Empire. N. Y. (Epochs.)

Curteis, A. M. Rise of the Macedonian Empire. N. Y. 1887. (Epochs.)

Curtius, E. History of Greece. 5 vols. N. Y. 1875.

Duruy, V. History of Greece. 8 vols. Bost. 1892.

Felton, C. C. Greece, Ancient and Modern. 2 vols. in one. Bost. 1893.

Freeman, E. A. History of Federal Government in Greece and Italy. 2d Edition. Lond. 1893.

Gardner, P. New Chapters in Greek History. Lond. and N. Y. 1892.

Grote, G. History of Greece. 12 vols. N. Y. 1857. Same 10 vols. Lond. 1888.

Holm, A. History of Greece. 4 vols. Lond. and N. Y. 1894-98.

Mahaffy, J. P. Survey of Greek Civilization. Meadville. 1896.

— Story of Alexander's Empire. N. Y. 1897.

Greek Life and Thought from the Age of Alexander

to the Roman Conquest. Lond. and N. Y. 1887.

Greek World under Roman Sway. Lond. and N. Y. 1890.

Oman, C. W. C. History of Greece. Lond. and N. Y. 1901.

Sankey, C. Spartan and Theban Supremacy. N. Y. 1887. (Epochs.)

Shuckburgh, E. S. Short History of the Greeks. Camb. 1901.

Smith, Wm. History of Greece, with supplementary chapters on the History of Literature and Art. N. Y. (Students' Series.) 
(11) Greek Antiquities. Public and Private Life.

Becker, W. A. Charicles. Lond. 1866.

Blümner, H. 'Home Life of the Ancient Greeks. Lond. 1893.

Davidson, T. Education of the Greek People. N. Y. 1894. Fowler, W. W. City State of the Greeks and Romans. N. Y. 1893.

Gardner, P., and Jevons, F. B. Manual of Greek Antiquities. N. Y. 1895.

Gilbert, G. Constitutional Antiquities of. Athens and Sparta. Lond. and N. Y. 1895.

Greenidge, A. H. J. Handbook of Greek Constitutional History. Lond. and N. Y. 1896.

Guhl, E. K., and Koner, W. D. Life of the Greeks and Romans. Lond. 1889.

Gulick, C. B. Life of the Ancient Greeks. N. Y. 1902.

Harper's Dictionary of Classical Literature and Antiquities. N. Y. 1897.

Mahaffy, J. P. Old Greek Life. N. Y. 1876.

- Social Life in Greece. Lond. and N..Y. 1890.

Seyffert, O. Dictionary of Classical Antiquities. Lond. 1891.

Smith, Wm. Dictionary of Greek and Roman Antiquities. 3d Edition. 2 vols. Lond. 1890.

Whibley, L. Political Parties in Athens. Camb. 1889.

— Greek Oligarchies. N. Y. 1896.

(12) Greek Archæology and Art.

Butler, H. C. Story of Athens. N. Y. 1902.

Collignon, M. Manual of Greek Archæology. Lond. 1886.

Gardner, E. A. Handbook of Greek Sculpture. Lond. and N. Y. 1897.

N Ancient Athens. N. Y. 1902.

Harrison, J. E. Introductory Studies of Greek Art. Lond. 1904.

- and Verrall, M. de G. Mythology and Monuments of Ancient Athens. Lond. 1890.

Mitchell, L. M. History of Greek Sculpture. 2 vols. N. Y. 1883.

Murray, A. S. History of Greek Sculpture. 2 vols. Lond. 1890.

- Handbook of Greek Archæology. N. Y. 1892.

Tarbell, F. B. History of Greek Art. Lond. 1896.

(13) Mycenæan Age.

Hall, H. R. The Oldest Civilization of Greece. Lond. 1901. Perrot, G., and Chipiez, C. History of Art in Primitive Greece; Mycenian Art. 2 vols. Lond. 1894.

Ridgeway, W. Early Age of Greece. 2 vols. Camb. 1901-02. Schliemann, H. Mycenæ. Lond. and N. Y. 1878.

— Tiryns. Lond. and N. Y. 1886. 
Schliemann, H. Troja. Lond. and N. Y. 1901.

Schuchhardt, C. Schliemann's Excavations. Lond. 1891. Tsountas, C., and Manatt, J. I. The Mycenæan Age. Bost. 1897.

(14) Homer and the Homeric Age.

Jebb, R. C. Introduction to Homer. Bost. 1869.

Keller, A. G. Homeric Society. N. Y. 1902.

Lang, A. Homer and the Iliad. N. Y. 1892.

Leaf, W. Companion to the Iliad. N. Y. 1892.

Warr, G. C. W. The Greek Epic. Lond. and N. Y. 1895.

(15) Greek Literature and Philosophy.

Benn, A. W. Philosophy of Greece in Relation to the History and Character of the People. Lond. 1898.

Burt, B. C. Brief History of Greek Philosophy. Bost. 1889. Fowler, H. N. History of Greek Literature. N. Y. 1902. Jebb, R. C. Greek Literature. N. Y. 1878. (Primer.) Jevons, F. B. History of Greek Literature. Lond. 1889. Lawton, W. C. Introduction to Classical Greek Literature. N. Y. 1903.

Marshall, J. Short Sketch of Greek Philosophy. N. Y. 1891.

Mayor, J. B. Sketch of Ancient Philosophy. Camb. 1881. Moulton, R. G. Ancient Classical Drama. Lond. and N. Y. 1890.

Murray, G. G. A. History of Ancient Greek Literature. N. Y.

Symonds, J. A. Studies of the Greek Poets. 2 vols. Lond. 1873.

Zeller, E. Outlines of the History of Greek Philosophy. N. Y. 1886.

(16) Greek Religion and Mythology.

Bulfinch, T. Age of Fable. (New Edition.) Phil. 1898. Collignon, M. Manual of Greek Mythology in relation to Greek Art. Lond. 1890.

Gayley, C. M. Classical Myths. Bost. 1893.

Guerber, H. A. Myths of Greece and Rome. N. Y. 1893. Murray, A. S. Manual of Mythology. Phil. 1895.

(17) Sources of Greek History.

Aschylus. Tragedies. Tr. by E. H. Plumptre. N.Y.1868. Aristotle. Athenian Constitution. Tr. by F. G. Kenyon. Lond. 1891.

Arrian. Anabasis of Alexander. Tr. by E. J. Chinnock. Lond. 1893.

Demosthenes. Orations. 5 vols. (Bohn.) . . 2 vols. (Harpers.) 
Herodotus. Tr. by G. Rawlinson. 4 vols. N. Y. . . . Tr. by H. Cary. (Bohn.) . . Analysis and Summary by J. T. Wheeler. (Bohn.)

Homer. Iliad. Tr. by W. C. Bryant. Bost. 1870. . . . Tr. by Lang, Leaf, and Myers. Lond. 1893.

Odyssey. Tr. by W. C. Bryant. Bost. 1872. • . Tr. by Butcher and Lang. Lond. 1893.

Thucydides. Tr. by B. Jowett. 2 vols. N. Y. . . Analysis and Summary by J. T. Wheeler. (Bohn.)

Xenophon. Cyropæedia and Hellenics. Tr. by J. S. Watson and H. Dale. (Bohn.)

\section{THE ROMAN WORLD}

(18) Roman History, General.

Nlleroft, A. H., and Masom, W. F. History of Rome. 5 vols. Lond.

Beesly, A. H. The Gracchi, Marius, and Sulla. N. Y. (Epochs.)

Bury, J. B. History of the Roman Empire from its Foundation to the Death of Marcus Aurelius. N. Y. 1893.

Capes, W. W. 'The Early Empire. N. Y. (Epochs.)

The Age of the Antonines. N. Y. (Epochs.)

Duruy, V. History of Rome and the Roman People. Ed. by J. P. Mahaffy. 8 vols. Bost. 1888.

Gibbon, E. History of the Decline and Fall of the Roman Empire. Ed. by Milman. 6 vols. Phil. . . . Ed. by Bury. 7 vols. Lond. Same abridged in one vol. N. Y. (Students' Series.)

How, W. W., and Leigh, H. D. History of Rome to the Death of Cresar. N. Y. 1896.

Ihne, W. History of Rome. 5 vols. Lond. 1871-82.

- Early Rome. N. Y. (Epochs.)

Leighton, R. F. History of Rome. N. Y. 1890.

I.iddell, H. G. History of Rome. N. Y. 1890. (Students' Series.)

Matheson, P. E. Skeleton Outline of Roman History. (Chronologically Arranged.) Lond. 1890.

Merivale, C. History of the Romans under the Empire. 7 vols. N. Y. 1866.

C General History of Rome. N. Y. 1880. (Students' Series.)

- The Roman Triumvirates. N. Y. (Epochs.)

Mommsen, T. History of Rome. Tr. by W. P. Dickson. 4 vols. N. Y. 1871. Same abridged by Bryans and Hendy. N. Y. 1889.

Pelham, H. F. Outlines of Roman History. N. Y. 1893.

Shuckburgh, E. S. History of Rome to the Battle of Actium. N. Y. 1894.

Seeley, J. R. Roman Imperialism and other Lectures and Essays. Bost. 1871. 
Seignobos, C. History of the Roman People. N. Y. 1902. Smith, R. B. Rome and Carthage. N. Y. (Epochs.)

Smith, Wm. Smaller History of Rome. N. Y. 1899.

(19) Roman Antiquities. Life and Manners.

Becker, W. A. Gallus. Lond. 1866.

Church, A. J. Roman Life in the Days of Cicero. N. Y. 1890.

Dill, S. Roman Society from Nero to Marcus Aurelius. Lond. 1905.

- Roman Society in the Last Century of the Western Empire. Lond. 1898.

Friedländer, L. Town Life in Ancient Italy. Bost. 1902.

Guhl, E., and Koner, W. The Life of the Greeks and Romans. Lond.

Harper's Dictionary of Classical Literature and Antiquities. N. Y. 1897.

Inge, W. R. Society of Rome under the Cæasars. N. Y. 1888.

Pellison, M. Roman Life of Pliny's Times. Meadville. 1887.

Preston, H. W., and Dodge, L. Private Life of the Romans. Bost. 1894.

Ramsay, W., and Lanciani, R. Manual of Roman Antiquities. Lond. 1894.

Thomas, E. Roman Life under the Cæsars. N. Y. 1897.

Seyffert, O. Dictionary of Classical Antiquities. Lond. 1891.

Smith, Wm. Dictionary of Greek and Roman Antiquities. 3d Edition. 2 vols. Lond. 1890.

(20) Roman Archæology and Art.

Boissier, G. Rome and Pompeii: Archæological Rambles. Lond. 1896.

- Roman Africa. N. Y. 1899.

Burn, R. Ancient Rome and its Neighborhood. Lond. 1895.

Lanciani, R. Ancient Rome in the Light of Recent Discoveries. Bost. 1891.

- Ruins and Excavations of Ancient Rome. Bost. 1897. Middleton, J. H. Remains of Ancient Rome. 2 vols. Lond. 1892.

Mau, A. Pompeii: its Life and Art. Tr. by F. W. Kelsey. N. Y. 1899.

Parker, J. H. Architectural History of Rome. Lond. 1881.

(21) Christianity and Rome.

Fisher, G. I'. Beginnings of Christianity. N. Y. 1878.

- History of the Christian Church. N. Y. 1887.

Hatch, E. Organization of the Early Christian Churches. Lond. 1881. 
Carr, A. The Church and the Roman Empire. Lond. and N. Y. 1887.

Guggenberger, A. The History of the Christian Era. 3 vols. St. Louis 1900-01.

Hardy, E. G. Christianity and the Roman Government. Lond. 1894.

Healy, P. J. 'The Valerian Persecution. Bost. 1905.

Hunt, Wm. History of the English Church from its Foundation to the Norman Conquest. N. Y. 1901.

Milman, H. H. History of Christianity. N. Y. 1872. History of Latin Christianity. 8 vols. in $4 . \mathrm{N}$. Y. 1881.

Ramsay, W. M. The Church and the Roman Empire. N. Y. 1893.

Renan, E. Influence of Rome upon Christianity. N. Y. 1884.

Shahan, T. J. The Beginnings of Christianity. N. Y. 1903.

Stanley, A. P. History of the Eastern Church. N. Y. 1884.

Uhlhorn, G. Conflict of Christianity and Heathenism. N. Y. 1879.

(22) Roman Constitution and Law.

Abbott, F. F. History and Description of Roman Political Institutions. Bost. 1902.

Arnold, W. T. Roman System of Provincial Administration. Lond. 1879.

Granrud, J. E. Roman Constitutional History. Bost. 1902. Greenidge, A. H. J. Roman Public Life. Lond. 1901.

Hadley, J. Introduction to Roman Law. N. Y.

Maine, H. S. Ancient Law. N. Y. 1884.

Morey, W. C. Outlines of Roman Law. N. Y.

Muirhead, J. Historical Introduction to the Private Law of Rome. Lond. 1899.

Ortolan, E. History of Roman Legislation. Lond. 1871.

Taylor, T. M. Constitutional and Political History of Rome. Lond. 1899.

Tighe, A. Development of the Roman Constitution. N. Y. 1886.

(23) Roman Literature.

Cruttwell, C. T. History of Roman Literature. N. Y. 1887. Lawton, W. C. Introduction to Classical Latin Literature. N. Y. 1904.

Mackail, J. W. Latin Literature. Lond. 1896.

Middleton, G., and Mills, T. R. Student's Companion to Latin Authors. Lond. and N. Y. 1896.

Simcox, G. A. History of Latin Literature. 2 vols. Lond. 1883.

Teuffel, W. S. History of Roman Literature. Ed. by G. C. Warr. 2 vols. N. Y. 1891-92.

Tyrrell, R. Y. Latin Poetry. Bost. 1895. 
(24) Mediæval Period.

Adams, G. B. Civilization during the Middle Ages. N. Y. 1894.

Bémont, C., and Monod, G. Mediæval Europe from 395 to 1270 A. D. N. Y. 1902.

Bryce, J. Holy Roman Empire. 6th Edition. Lond. 1899. Bury, J. B. History of the Later Roman Empire from Arcadius to Irene $(395-800$ A. D. $) .2$ vols. Lond. and N. Y. 1889 .

Church, R. W. Beginnings of the Middle Ages. N. Y. 1877.

Curteis, A. M. History of the Roman Empire, 395-800 A. D. Lond. 1875.

Duruy, V. History of the Middle Ages. N. Y. 1891.

Emerton, E. Introduction to the Study of the Middle Ages. Bost. 1888.

Hodgkin, T. Italy and her Invaders. 8 vols. Oxf. 1880-95. Harrison, F. Byzantine History in the Middle Ages. Lond. 1900.

Kingsley, C. The Roman and the Teuton.

Mohammed. The Qur'ân (Koran). Tr. by E. H. Palmer. Oxford.

Oman, C. W. C. The Dark Ages, 476-918 A. D. N. Y.

Mullinger, J. B. Schools of Charles the Great. Lond. 1877. Robinson, J. H. Introduction to the History of Western Europe. Part I. ('The Middle Ages). Bost. 1902.

Sheppard, J. G. Fall of Rome and Rise of Modern Nationalities. Lond. 1861.

Smith, R. B. Mohammed and Mohammedanism. N. Y. 1875.

Thatcher, O. J., and Schwill, F. Europe in the Middle Ages. N. Y. 1896.

(25) Sources of Roman History.

Greenidge, A. H. J. Sources for Roman History. Oxford. Henderson, E. F. Select Documents of the Middle $\Lambda$ ges. Lond. 1892.

Munro, D. C. Source Book of Roman History. Bost. 1904. Robinson, J. H. Readings in European History. Vol. I. Bost. 1904.

Translations and Reprints from Original Sources. University of Pennsylvania. 7 vols. 1892-1900.

Ammianus Marcellinus. Roman History. (Bohn.)

Appian. Roman History. Tr. by H. White. 2 vols. N. Y. 1899.

Casar. Commentaries. (Harpers.)

Livy. History of Rome. 2 vols. (Harpers). . . 4 vols. (Bohn.)

Polybius. Histories. Tr. by E. S. Shuckburgh. 2 vols. Lond. 1889.

Tracitus. Works. Oxford translation. (Bohn.) 
Sallust. Works. (Harpers. Bohn.)

Vergil. Eneid. 'Tr. by C. P'. Cranch. Bost. 1897.

\section{BIOGRAPHY}

(26) Biography, Collected.

Collins, W. L. (Ed.). Ancient Classies for English Readers. 28 vols. Ellin. and Phil. 1879-88.

Cox, G. W. Lives of Greek Statesmen. 2 vols. N. Y. 1885.

Oman, C. Seven Roman Statesmen of the Later Republic. Lond. 1903.

Plutarch. Lives. Tr. by J. Dryden. 3 vols. N. Y. . . . Ed. by A. H. Clough. Bost. 1881. . . Tr. by A. Stewart and G. Long. N. Y. 1889.

Smith. Wm. Dictionary of Greek and Roman Biography and Mythology. 3 vols. Lond. 1880.

Suetonius. The Twelve Cæsars. (Bohn.)

(27) Biography, Individuals.

Alexander: By T. A. Dodge. Bost. 1890.

- By R. Steele. Lond. 1894.

- By B. I. Wheeler. N. Y. 1900.

Augustus Cesar. By J. B. Firth. N. Y. 1903.

— By E. S. Shuckburgh. Lond. 1903.

Charlemagne. By Eginhard (Einhard). N. Y.

— By J. I. Mombert. N. Y. 1888.

— By T. Hodgkin. Lond. 1897.

- By H. W. C. Davis. N. Y. 1900.

Constantine. By E. L. Cutts. Lond. 1881.

Cicero. By W. L. Collins. Phil. 1871. (Anc. Classics.)

- By W. Forsyth. 2 vols. in one. N. Y. 1871.

- By A. Trollope. N. Y. 1881.

— By J. L. Strachan-Davidson. N. Y. 1894.

- By G. Boissier. Lond. 1897.

Demosthenes. By Brédif. Chicago, 1881.

- By E. H. Butcher. N. Y. 1882.

Hannibal. By J. Abbott. N. Y. 1849.

— By 'T. Arnold. Bost. 1860.

— By T. A. Dodge. Bost. 1860.

- By W. O. Morris. N. Y. 1897.

Julian. By J. A. W. Neander. N. Y. 1850.

- By A. Gardner. N. Y. 1895.

Julius Cassar. By J. Abbott. N. Y. 1849.

— By J. Williams. Lond. 1854.

— By J. A. Froude. N. Y. 1880.

— By T. A. Dodge. Bost. 1892.

- By W. W. Fowler. N. Y. 1892.

Marcus Aurelius. By P. B. Watson. N. Y. 1884.

Mohammed. By W. Irving. 2 vols. N. Y. 1868. 
Mohammed. By Sir W. Muir. Lond. 1888.

Nero. By W. Henderson. Lond. 1903.

Pericles. By W. W. Lloyd. 2 vols. Lond. 1875.

- By E. Abbott. N. Y. 1891.

Tiberius. By J. Tarver. Westminster. 1902.

Theodoric. By T. Hodgkin. N. Y. 1896.

Zoroaster. By A. V. N. Jackson. N. Y. 1899.

\section{HISTORICAL FICTION}

(28) Oriental.

Arnold, E. L. L. Phra the Phœnician.

Ebers, G. Daughter of an Egyptian King. (6th century B. C.) The Sisters. (2d century B. c.)

- Uarda. (Time of Rameses II.)

(29) Greek.

Church, A. J. Heroes and Kings. (Mythical age.)

- Stories from Homer. (Mythical age.)

- Stories from Herodotus. (5th century B. C.)

- Callias. (5th century B. C.)

- Young Macedonian in the Army of Alexander. (4th century B. c.)

Haggard, H. R., and Lang, A. The World's Desire. (Trojan war.)

Hawthorne, N. Tanglewood Tales. (Mythical age.)

Wonder Book. (Mythical age.)

Kingsley, C. The Heroes. (Mythical age.)

Landon, R. Fountain of Arethusa. (5th century B. c.)

Landon, W. S. Pericles and Aspasia. (5th century B. C.)

Lamb, C. Adventures of Ulysses. (Trojan war.)

Leatham, E. A. Charmione. (5th century B. c.)

(30) Roman.

Bulwer-Lytton. Last Days of Pompeii. (1st century A. D.)

Church, A. J. The Hammer. (2d century B. c.)

- The Burning of Rome. (1st century A. D.)

- To the Lions. (2d century A. D.)

The Count of the Saxon Shore. (5th century A. D.)

Eckstein, E. Prusias. (1st century B. c.)

- Nero. (1st century A. D.)

Quintus Claudius. (1st century A. D.)

Farrar, F. W. Darkness and Dawn. (1st century A. D.)

Kingsley, (. Hypatia. (4th century A. D.)

Lee, E. B. Parthenia. (4th century A. D.)

Pater, W. Marius the Epicurean. (2d century A. D.)

Sienkiewic\%, H. “Quo Vadis?" (1st century A. D.)

Wallace, L. Ben Hur. (1st century A. D.) 


\section{INDEX}

Diacritic marks: $€$, $\epsilon h$ as in cart, chasm; $s$, the French nasal; single Italic letters ure sllent. The long and short marks used with vowels have their usual meaning. In all the names in this index, $c$ and $g$ fol. lowed by $e, 1$, or $y$ have respectively the somnds of $s$ and $j$; followed by a, $o$, or $u$, however, $c$ has the sound of $k$, and $g$ is sounded as in the word go.

Aachen (ah'klien), or Aix-la-Chapelle, Charlemagne's capital, 521.

Abbas'sids, Mohammedan dynasty, 506.

Al)der-Rah'man. caliph, 506.

A'bram (A'braham), IIebrew patriarch, 45.

Academy at Athens, 200.

Acarna'nia, district of Greece, 78.

Ac'cad, city of Babylonia, 22.

Acca'dians, early people of Babylonia, 21.

Achæ'an League, 240-242.

Afha'ia (Acliaea), district of Greece, 79: Roman province, 339.

Achil'lēs, Grecian hero, 96.

Acrop'olis of Athens. 79, 199 ; adorned by Pericles, 200.

Actium (ak'shĭ-um), battle of, 400 .

Adol'phus (Ataulf), Visigothic king. 487.

Adriano'ple, battle of, 465 .

A'dīles, plebeian, 290 ; curule, 296.

Aiga'tès Islands, battle at, 320 .

Aige'an Sea, 75; Athenian supremacy in, 161.

Egi'na, island of Greece, 79 ; conquered by Athens, 166.

E'gospot'ami, battle of, 186.

Ene'as, Trojan hero, 266.

Ao'lia, district of Greece, 78 .

Ao'lians, Hellenic tribe, 82; their migration to Asia Minor, 95; their lyric poetry, 139.

. E'quians, Italic tribe, 263, 299.

Fs'chylus, Greek tragic poet, 207.

Aëtius (a-ē'shī-us), Roman general, 487.

Nto'lian League, 242, 333, 336.

Africa, seat of the Carthaginian power, 315 ; Roman province, 340 ; conquered by Vandals, 488; by Justinian, 499 ; by the Saracens, 505.

Agamem'non, king of Mycenæ, 84, 96.

$A^{\prime}$ ger pub'licus, public land at Rome, 289 .

Ager Roma'nus, Roman domain, 307, 369.
Agesila'us, king of Sparta, 189.

A'gis III., king of Sparta, 242.

Ag'ora, Athenian market place, 199.

Agrarian laws, of Sp. Cassius, 290;

in the Llcinian legislation, 296;

of 'Tiberius (iracchus, 358 .

Agric'ola, Roman general, 429.

Agrigen'tum, town in Sicily, 318.

Anrip'pa, adviser of Augustus, 414.

Ah'riman, I'ersian deity, 69.

Aix-la-Chapelle', Charlemagne's capital. 521.

Al'aric, king of the Visigoths; 486 ;

Al'aric II., 492.

Al'ba Lon'ga, city of Latium, 266.

Al'boin, Lombard chief, 502.

Alcæ'us, Greek lyric poet, 139.

Alcibi'adēs, Athenian statesman and traitor, 183-185.

Alcmæon'idx, the, 121, note.

Alc'man, Greek lyrist, 139.

Al'cuin, archbishop of York, 519.

Aleman'ni, German tribe, 452, 493.

Alexan'der the Great, his accession, 230 ; his conquests, 231-235; his character, 235-237.

Alexin'dria, founded, 234 ; center of Hellenistic culture. 254 .

Al'lia River, battle at, 300 .

Alphabet, Phœenician, 43.

Am'brose, St., bishop of Milan, 466.

Amphic'tyonies, Greek leagues, 105.

Amphip'olis, battle of, 182.

Amphitheater, sports of the, 434 .

Amusements of the Romans, 322 , 432.

Anac'reon, Greek lyric poet, 139.

Anaxag'oras. Greek philosopher, 215.

Anaximan'der, Greek philosopher, 140.

Anaxim'inēs. Greek philosopher, 140.

An'cus Mar'cius (shǐ-us), king of Rome. 268.

Andronī'cus, Roman poet, 351.

Anglo-Sax'ons in Britain, 494.

Antal'cldas, Peace of, 189, 191.

Antig'onus, general of Alexander, 239 .

An'tioeh, capital of Syria, 239; center of Hellenistic culture, 253 . 
Anti'oehus I., king of Syria, 239.

Antlochus III. (the (Great), 335 .

Antiochus IV. (Epiphanes), 254.

Antoni'nus I'l'us, emperor, 442 .

Anto'nius, Marcus (Mark An'tony). friend of Cosar, 393: opposed by Octavius, 395; attacked by Cicero, 395; in second triumvirate, 396 ; war with Octavius, 397-401.

A pel'la. Spartan assembly. 116, 117. Apel'lès, Greek painter, 245 .

Aphrodi'tē (Venus), 100 ; statue of Melos, 252.

Apol'lo, 100; his oracle at Delphi, 130 ; Belvedēre', 252.

Apollodo'rus, Greek painter, 205.

Ap'pian Way, 312, 435.

Ap'plus Clau'dius, the decemvir, 292 ; the censor, $305,312$.

Apu'lians, people of Italy, join Hannibal, 327.

A'quæ Sex'tia, battle of, 366 .

Aqueduct. Claudian, 424, 425.

Arabs, 505-507.

Ara'tus, general of the Achæan League, $240,242$.

Arau'slo (-shi-o), battle of, 365 .

Arbe'la, battle of, 234 .

Arca'dia, district of Greece, 79 .

Arca'dius, emperor, 466, 486.

Arehil'ochus, Greek elegiac poet, 138.

Arehlmē'dēs, Greek mathematician, 256.

Arehitecture, Egyptian, 35 ; Assyrian, 56 ; early Greek, 135 ; of the Attic perlod, 200-202; at Pergamum, 248: at Alexandria. 255; Etruscan, 266 : Roman, under the kingdom, 282; under the republic, 404; under Augustus, 414; under the Antonines, 447: eariy Christian, 477.

Ar'chons at Athens, 121, 123.

Areop'agus, Council of the, 121, 172.

A'res (Mars), 100, 277.

Arginu'sæ, battle of, 186.

Ar'golis, district of Greece, 79, 114.

Argonau'tic expedition, 86 .

Ar'gos, city of Argolis, 82, 114, 118.

A'rianism, condemned as a heresy, 461, note.

Ari'on. Greek lyric poet, 139.

Ariovis'tus, German chlef, 385 .

Aristar'chus, Alexandrian critic, 256 .

Aristi'dēs, Gireek statesman, his pollcy, 149; ostraclzed, 150; at Salamis, 155: at Platæa, 156: forms the Delian confederacy, 162 .

Aristocracy, early Greek, 106; at Sparta, 115; at Athens, 121. See also Nobillty.

Aristogi'ton, Athenian tyrannicide, 125.

Aristoph'anēs, (ireek comic writer, 210.

Хr'istōtle, Greek philosopher, 218.
Armin'ius, German chlef, 413.

Army, Egyptian, 32 ; Persian, 68 ;

Spartan, 118; Athenlan, 175;

Theban, 192; Macedonian, 227; Roman, under the kingdom, 281 ; under the republic, 310 ; under Augustus, 410; under Constantine, 461. See also Prætorian Guard.

Art, Babylonian, 23 ; Egyptian, 35, 36 ; Assyrian, 56, 57 ; Mycenaran. 88-91 ; early Hellenic, 134-137: the Attic period, 197-205; Hellenistic period, 248 et seq.; Roman, 351. See also Architecture, Painting. Sculpture.

Artapher'nès, Persian general, 146. Ar'temis (Diana), 100

Artemis'ium (-mish'-) battle of, 154.

Ar'yan people, 16 ; in India, 61 ; in Media and Persia, 62; in Greece, 81: in Italy, 263.

As'culum, battle of, 305 .

Asia, Roman province, 343.

Asia Minor, early Greek settlements in, 81 ; migrations to, 93 ; seat of early culture, 95 ; cities conquered by Lydia and Persia, 144: freed by Athens, 165; conquered by Alexander, 231 ; new kingdoms in, 239: conquered by Pompey, 379. See also Pergamum, Rhodes. Assembly, Greek, in Homeric age, 98 ; in early city state, $104 ;$ at Sparta (apella), 116; at Athens (ecclesia), under Solon, 123; under Clisthenes, 126; under Pericles, 173.

Assembly, Roman. See Comitia.

As'sur, city of Mesopotamia, 21.

As'sur-ba'ni-pal. Assyrian king, 54. As'sur-na'zir-pal, Assyrian king, 52. Assyr'ia, 21; its civilization, 51-58; conquered by the Medes and Babylonians, 58 ; conquered by Trajan, 441.

Athe'na (Minerva), 100.

Ath'ens, city of Attica, its mythical founder, Cecrops, 84; its early history, 121-127; in the Ionian revolt, 145; in the first Persian Invasion, 145-148; democratic progress at, 148 ; becomes a maritime power, 150; destroyed by Xerxes, 154: rebuilt by Themistocles, 160 ; becomes supreme in the Agean, 161; head of the Dellan confederacy, 162: of the Athenian empire. 164-171: constitution under l'ericles, 172-177; in the Peloponnesian war, 178: 187; new confederacy of, 191; center of Hellenic art, 197 et seq. A'thos, Mt., 145, 152.

"A'treus. Treasury of," 90.

At'talus I.. king of Pergamum, 240. Attalus III., 343. 
At'tica, district of Greece, 79 : early divisions of the people, 1:0 : local tribes of Clisthenes, 1: 6 ; population under l'ericles. $17:$.

At'tila, king of the Huns, 487.

Au'gustine, missionary to Britain, 494.

Augustine, St., bishop of Ilippo, 478.

Augus'tus Casar, emperor, 407-417. Sce also Octavius.

Aurélian, emperor, 453.

Aure'lius, Marcus, emperor, 443.

Bab'ylon, city of Babylonia, 21 ; becomes the capital, 23; destroved by Assyria, 54; restored by Nebuchadnezzar, 58 ; captured by Alexander, 235 .

Babylo'nia, early empire, 19-27 ; later empire. 58-30.

Bagdad. Abbassid capital, 507.

Basil'ica, Roman coirt-house, used as model for Christian churches, 477.

Baths, Roman, 432.

Belisā'rius, general of Justinian, 501.

Beller'ophon, Greek hero, 85.

$B^{\prime}$ ma, platform on the Pnyx, 174.

Ben'edict, St., rule of, 510 .

Bithyn'ia, kingdom in Asia Minor, 240.

Bœo'tia (bë-ō'shì-a), district of Greece, 78; confederacy of, 191.

Boë'thius, Latin writer, 491.

Bon'iface, St., missionary, 511, 512.

Book of the Dead, Egyptian, 38 .

Bou'lé, Greek council or senate, in Homeric age, 98; in early city state, 104; in time of Pericles. 174. See also Council, Athenian.

Bovia'num, town in Samnium, 302.

Brah'manism, Hindu religion, 61 .

Bras'idas, Spartan general, 182.

Brit'ain, invaded by Julius Cæsar, 386 ; Roman province, 424, 429; settled by the Anglo-Saxons, 494.

Bru'tus, Dec'imus, one of the "liberators," 395, 396.

Brutus, Ju'nius (the Elder), 268, 269.

Brutus, Marcus, conspirator, 391 : assigned to Macedonia, 395; at the battle of Philippi, 397.

Buddhism, Hindu religion, 62.

Burgun'dians, kingdom of, 493.

Bur'rhus, adviser of Nero. 422.

By̆zan'tỉum (-shĭ-um), capital of the Eastern Roman empire, 463.

C., abbreviation of Gaius, 295 .

Cadme'a, citadel of Thebes, 190.

Cad'mus, the mythical founder of Thebes, 84.

Cæ'sar, Gaius Julius, Roman general and statesman, his appearance in politics, 380,381 ; in first trium. virate, 382 ; his consulship, 383 ; conquest of (iaul, 385 ; breaks with the senate, 387 : war with lompey, 385: his trlumplis and titles, 389; his legislation, 390 , his assassination, 391 ; his "Commentarles," 403.

"Carsars," office of, 456.

Calig'ula (Galus Cosar), emperor, 421.

Ca'liphs, successors of Mohammed, 505.

Calli'nus, Greek eleglac poet, 138.

Camby'sês, l'ersian king, 65.

Camil'lus, dictator, 300 .

Campä'nia. in Samnite wars, 301.

Cam'pus Mar'tius (-shľ-us), 281.

Can'næ, battle of, 326 .

Canu-le'ian law, 293.

Cap'itoline hill, 272, 274.

Capitularies of Charlemagne, 520 .

Cappado'cia, kingdom in Asia Minor, 240.

Cap'ua, city of Campania, receives Hannibal, 327 ; retaken by Rome, 328.

Căracăl'la, emperor, edict of, 451 .

Car'bo, Cn. Papir'ius, consul, 372.

Carolin'gians (or Carlovingians), Frankish dynasty, 314.

Car'thage, Phœenician colony, 43 ; in the Persian wars, 157; conflict with Syracuse, 194 ; in first I'unic war, 315-321; in second Iunic war, 323-331; reduced to a. Roman province, 339.

Cä'rus, Roman emperor, 453.

Caryat'idēs in the Erechtheum, 202.

Cassan'der of Macedonia, 239.

Cassiodo'rus, secretary of Theodoric, 492.

Cassius (kăsh'i-us), Gaius, conspirator, 391 ; assigned to Syria, 395 ; at the battle of Philippi, 397.

Cassius, Sp., his agrarian proposais, 290.

Cat'iline, conspiracy of, 381 .

Ca'to (the Elder), censor, 339, 350.

Cato (the Younger), leader of the senatorial party, 383 ; mission to Cyprus and return, 384; at the battle of Thapsus, 389 .

Catul'lus, Roman poet, 404.

Cat'ulus, C. Lutī'tius (-shǐ-us), consul, 320.

Cau'dine Forks, battle of, 392.

Ce'crops, mythical founder of Athens, 84.

Celtibe'rians. Spanish tribe, reduced by Rome, 341 .

Celtic church in Britain, 495 .

Censors, Roman, 295.

Census classes at Athens, 123.

Centuries, in Roman army, 280 ; in assembly, 281 .

Ehæronë'a, battle of (338 B. c.), 229. 
Ehalce'don. Greek city in Asia Minor, 186, 188 .

Ehalcid'icē, seat of Greck colonies, invaded by Brasidas. 183: confederacy of, 190 ; reduced by Philip, 228.

Ehal'cis, city of Eubœa, 79; as a colonizing center, 109.

Chalda'an empire, 22 note.

Chatons (shah-los'), battle of, 487 .

Champol'tion (sham-), Fre n c h scholar, 37.

Charlemagne (shar'le-mān), Charles the (ireat, 514-523.

Charles Martel, at the battle of Tours, 506; mayor of the palace, appealed to by the rope. 512 .

Che'ops. 30.

Ehi'os, island of the Egean. occupied by the Dorians, 95 ; ally of Athens, 167.

Elī'ton, Greek dress, 221.

Christianity, adopted by Constantine, 459 ; opposed by Julian, 464 ; restored by Jovian, 465 ; Its spread throughout the empire, 475.476 .

Christians persecuted by Nero, 425 : by Domitian, 428 ; by Marcus Aurelius, 443 ; last persecution under Diocletian, 457 .

Chrys'ostom, church father, 478.

Church, growth of its organization, 476; its culture, 476-478; influence during the migrations, 496; schism between the East and West, 500 .

Cic'ero, M. Tullius, Roman orator and statesman, supports the Manilian law, 379: suppresses the Catllinian conspiracy, 381 ; banished from lome and recalled, 384 ; attacks Antony in the "Philippies," 395 ; his death, 397 ; his writings, 404 .

Cim'bric war, 365.

Ci'mon, Greek statesman, associated with Aristides, 161: his imperial policy, 16:; his ostracism, 164; restoration and death, 167 .

Cincinnã'tus, legend of, 300 , note.

Cin'na, L. Cornelius, consul, his despotic rule, 370. 371.

Cir'cus Max'imus, $282,433$.

Cisal'pine (iaul, 266; conquered by Rome, 322.

Citizenship, at Athens, 173 ; rights at lome, 284; extended to the Italians, 367, 368; extension by Carsar, 390 ; by claudius, 424 ; by Caracalla, 451; summary, 473 .

City state, Babyonian, 22 ; early (ireek. 102-105; early Roman, 271-283.

Civilis, governor of raul, 427.

Civilization, first centers of, 19 ; beginnings of Aryan, 61 ; review of Uriental, 72 ; Mycenwan, 91 ; general character of Hellenic, 129; Greek in the Attic period, 197, 198: nature of Hellenistic. 247 ; influence of Greek upon Roman, 349; progress during civil wars, 402 ; In Augustan age, 413 et seq.; cuimination under the Antonines. 444 et seq.; IIohammedan, 507: influence of Charlemagne upon, 519. See also Art. Education. Government, industry, Laws, Literature, Philosophy, Religion.

Classes of society, in Egypt, 31 ; in Sparta, 115, 116; In Attica, 120; in Athens under Pericles, 172; in Rome under the kingdom, 279; under the republic, 354, 355; under the empire, 429,430 .

Clau'dius, emperor, 421.

Claudius II., emperor, 453.

Claudius, Ap'pius, the decemvir, 292 ; the censor, 305,312 .

Claudius, Publius, consul. 320.

Claudius Nero, consul, 329.

Cleom'enēs III., king of Sparta, 242.

Cleom'enic war, 242.

Cle'on, Athenian demagogue, 181, 182.

Cleopàttra, queen of Egypt, supported by Cæsar, 388; relations with Antony, 399 ; at the battle of Actium, 400.

Cle'ruchies, Athenian colonies, 109 note.

Clients at Rome, 279.

Clis'thenès, Athenian statesman, 126.

Cli'tus, his murder by Alexander, 235.

Clo-ä́ca Max'ima, 283.

Clo'dius, P., IRoman tribune and agent of Crsar, 384; his death, 387.

Clo'vis (Clodwig, Clodorech), king of the Franks, 493.

Clubs at Athens, 223.

Cni'dus, battle near, 189.

Col'ehis on the Euxine, 86.

Colise'um (Colosseum), 427, 434.

Collati'nus, colleague of the elder Brutus, 268.

Colo'ni, Roman, 452, 480.

Colonies, Phœenician, 43 ; Greek, 107112: Latin, 309; Roman, 308.

Colosse'um (Collseum), Flavian amphitheater, $427,434$.

Colum'ban, St., missionary, 511.

Comedy, 210, 211 .

Comititus, German custom, 483, 496.

Comitia (ko-mish'i-a) Centuria'ta, its origin, 277 ; its importance in the early republic, 287 .

Comitia Curia'ta, under, the Roman kings, 277 ; its decline in the repubilic, 287, 364 .

Comitia. Tribi'ta, rise of, 290. 
Commerce, Phœnician, 42 ; Greek, 108 ; Roman, 435.

Commer'cium, 294, 408, 473.

Concílium ple'bis, rise of, 290 and note.

Congress of Corinth, first, 150 ; second, 229.

Co'non, Athenian admiral, 189.

Consi'lium prin'cipis. 445.

Con'stantine, emperor, 458-464.

Constantino'ple, founded, 462.

Constan'tius (-shĩ-us), colleague of Constantine, $45 \pi$.

Consular tribunes (military tribunes with consular power), 294 .

Consuls, first appointed, 286 .

Conu'bium, 294, 408, 473 .

Corcy'rra, isiand of the Ionian Sea, embrolled with Corinth, 176; sedition at, 182.

Cor'dova, caliphate of, 507 .

Corfin'ium, capital of "Italica," 367.

Cor'inth, conquered by the Dorians, 114 ; commercial rival of Athens. 179 ; Congress of, under Themistocles, $150 ;$ under Philip, 229 ; destroyed by Rome, 338 .

Corin'thian style of architecture, 135.

Corinthian war, 189.

Coriolin'nus, legend of, 300, note.

Corn law of Gaius Gracchus, 361 .

Corone'a, battle of, 171.

Cor'pus Ju'ris civi'lis, 502.

Cor'sica, reduced by Rome, 321.

Council, Athenian, of the Areopagus. 121, 126 note. 172 : of four hundred and one, 122: of four hundred, 124 ; of five hundred, 126, 174.

Court organization under Constantine, 463.

Cras'sus, Mi., consul, in gladiatorial war, 377 ; in first triumvirate, 382; his governorship of Syria and death, 386 .

Crête, island of the Mediterranean, 80 ; prehistoric remains in, 91 .

Crit'ias, Athenian oligarch, 187.

Crœ'sus, king of Ludia, 64, 144.

Culture. Sce Civilization.

Cunax'a, battle at, 188.

Cune'iform writing, 25.

Cu'ria, collection of Roman gentes, 276 ; municipal council, 446, 471 .

Curia'lês, municipal aristocracy responsible for taxes, 479 .

Cu'rule offices, $297,345$.

Cyax'arēs, Median king, 62.

Cy'lon, conspiracy of, 121 , note.

Cynosceph'alæ, battle of, 335 .

Cy'rus the Great, Persian king, 64, $68,188$.

Cyrus the Younger, Persian governor of Asia Minor, 188.

Dā'cia (-shì-a), Roman province, 441.

Dag'obert, Frankish king, 512.
Dun'a-us, mythical founder of Argos, 84.

lari'us, Persian king, his conquests, 65; political organization of his empire, 67; invasion of Greece, $145-148$.

Da'tis, l'ersian general, 146.

Ia'vid, Hebrew king, 46.

lebt, early law at liome, 288. 289.

Dec'arehies, established by Sparta, 187.

Decele' $a$, town in Attica, hela by the spartans, $184,186$.

Decem'virs, at Rome, 291-293.

Décius (-shî-us) Mus, consul (father), 301; (son), 303.

Delato'rés, Roman informers, instituted by Tiberius, 423 ; abolished by Nerva, 437.

De'ium, battle of, 182.

De'los, island of the Ngean, and seat of the shrine of $A$ pollo, 79 ; confederacy of, 162 .

Del'phi, city of Phocis, seat of the oracle of Apollo, 78,130 ; in the second "Sacred war," 228.

Deme, Attic township, 126.

Deméter (Ceres), 100.

Democracy at Athens, 127, 172.

Demos'thenēs, Athenian general, 182, $184,185$.

Demosthenes, Athenian orator and statesman, 214; opposes Philip, 228 ; his death, 240.

Diad'oehi, successors of Alexander, 237.

Dicas'teries, in $\Delta$ thenian courts, 175.

Dictatorship, at Rome, established, 286 ; of Sulla, $371-374$.

Diocle'tian (-shan), emperor, 456458.

Dionys'ia, Greek festival, 133.

Dionys'ius (-nish'-) the Elder, of Syracuse, 194.

Dionysius, the Younger, 195.

Diony'sus (Bacchus), worship of, 140 : theater at Athens, 205,206 .

Domitian (do-mìsh'î-an), emperor, 428.

"Donation of Pepin," 514.

Do'rians, 82; their migration into the Peloponnesus, 93; their migrations to Asia Minor, 95 ; their Iyric poetry, 139.

Dor'ic style of architecture, 135.

Dörp'feld, German archæologist, 89.

Dra'co, Athenian lawgiver, 121.

Drama, Greek, 207-211.

Drep'anum (Drepana), battle near, 320.

Dress, Grecian, 221 ; Roman, 432.

Dru'sus, M. Liv'ius, Roman tribune (father). opposes C. Gracchus, 362 ; (son) espouses the Italian cause, 367 .

Duil'ius, consul, at the battle of Mylæ, 319. 
Duum'viri, municipal officers, 446. Dyrra'ehium, battle of, 388 .

Eccle'sia, Athenian assembly, under Solon, 1:3; under clisthenes, 126 ; under l'ericles, 173.

Fe'nomus, battle of, 319 .

Edic'tum Perpétuum of Salvius Julianus, 449 .

Education, Spartan, 117 ; Athenian, 222 ; Roman, 405.

E'gypt, early center of civilization, 19 ; periods of its history, 29-31: its civilization, 31-3s: nnder the Ptolemies, 239; Hellenistic culture in, 254; relation to Rome, 333 ; made a province, 401.

Elagab'alus, emperor, 451 .

E'lamites, thelr conquest of Babylonia, 22 ; expelled by Iammurabi, 23.

Elē'glac poetry, Greek, 138.

Eleusin'ia, Greek festival, 133.

Eleuthe'ria, Greek festival, $15 \overline{7}$.

Elis, district of Greece, 79 : member of the Atolian league, 240.

En'nius, Roman poet, 351 .

Epaminon'das, Theban patriot, 191; at battle of Leuctra, 192; invades the I'eloponnesus, 193 ; $\mathrm{h}$ is death, 193.

Eph'esus, city of Ionia, 95.

Ephial'tès, Athenian statesman, 164.

Ephialtes, the "Judas of Greece," 153.

Eph'ors, Spartan magistrates, 117.

Eplc poetry, Greek, 138.

Eplcurē'anism at Rome, 350, 448.

Epicu'rus, (rieek philosopher, 246.

Eplp'olx, heights of, 184.

E' $q^{\prime} u i-t \bar{e} s$, Roman, under Servius Tullius, 280: an aristocratlc order, 355 ; privileges granted by Gaius Gracchus. 361 ; status under the empire, 429.

Erastos'thenës, Greek astronomer, 256.

Ereehthe'um, temple on the Acropolis, 202.

Ereeh'theús, mythical king of Athens, 202.

Ere'tria, city of Eubca, 79 ; a colonizing center, 109; aids in the Ionfan revolt, 145; destroyed by the Persians, 146 .

Esarhad'lon, Assvrian king, 54.

Etrus'cans, people of Italy, 265; early influence at Rome, 278 ; in the second siamnite war, 302 ; in the third Samnite war, 303.

Eubre'a, island of freece, 79 ; its strategle inmortance, 153.

Eu'clid, Greek geometer, 256.

Eu'menès I., king of I'ergamum, 240.

rumenes III., 249.

Eupatrids, Athenian nobles, 120, 121.
Euphra'tēs, river of Mesopotamia, 19.

Eurip'idēs, Greek tragedian, 210.

Lurym'edon, battle at the river, 163.

Euse'bius, ecclesiastical historian and biographer of Constantine, 459.

Exar'chate of Ravenna, 503, 504, 514.

Fã'bius Max'imus Cunctā'tor, dictator, 326,328 .

Fabius Maximus Rulliā'nus, consul, 302.

Fabius Pictor, Roman historian, 351.

Family, Greek, 98, 103 ; Roman, 275.

Fas'ces, symbol of authority, 279 , 286.

Festivals, Greek, 133.

Fetia'les, Roman priests, 278.

Finances, Athenian, 176; Roman, under Augustus, 412.

Five Year's' Truce of Cimon, 167.

Flamini'nus, T. Quinc'tius, consul, $334,335$.

Fo'rum, Roman, 274, 415, 447.

Four Hundred, Athenian oligarchy, 185.

Franchise. Sce citizenship.

Franks, German tribe, 452 ; kingdom of, 493 .

Gabin'ian law, 379.

Già'ius, Roman jurist, 475.

Gala'tia in Asia Minor, settled by the Gauls, 248.

Gal'ba, emperor, 426.

Gale'rius, associate of Diocletian, 457.

Gall, St., missionary, 511.

Games, Greek, 131; Roman, 433, 434.

Gaugame'la, battle of, 234 .

Gaul, conquest by Caesar, 385 ; barbarian kingdoms in, 491-493.

Gauls, in Italy, 266 ; their invasion of Greece and Asia Minor, 247; their destruction of Rome, 300 .

Ga'za, captureal by Alexander, 233.

Ge'lo, tyrant of Sy'racuse, 158 .

Gens (or clan), Greek, 163; Roman, 276.

Gen'seric (Gai'seric), king of the Vandals, 485 .

German'icus, Roman general, 420.

Germans, their characteristics, 482 ; conversion of, 485; new kingdoms within the Roman empire, 489495; Romano-Germanic society, $495-497$.

Germany, inraded by Augustus, 413.

Gerou'sia, Spartan senate, 116.

Glad'iators, their shows, 352; their insurrection under Spartacus, 377.

Glau'cia (-shì-a), popular leader with Marius, $366,367$. 
Gor'dium, city of Phrygia, occupled by Alexander, 231 .

Goths, German tribe, tirst encroachment upon Rome, 452: revolt under emperor Valens, 465. Sce also Ostrogoths, Visigoths.

Government, llabylonian, 24; Egyptlan, 31: Hebrew, 47; Assyrian. 55; I'ersian, 68; Homeric, 98: of the ireek city state, 104: at Sparta, 116: at Athens to Cllsthenes, 120-127; under P'elicles, 172-176; Roman, under the kings, 276 ; in the early republic, 286;288 ; after the conquest of Italy, 306-309: after the Mediterranein conquests, $344-346$; under sulla, 373, 374; under Julius Casar, 390-391; under Augustus. 407. 413; under the Julian emperor's, 423, 424; under the Antonines, 444,445 ; under Dlocletian, 455457; under Constantine, 461-464: revlew of the Roman system, 470472 ; elements of its weakness. 478-480; German, 483-485; Romano-Germanic, 496: under Charlemagne, 519, 520. Sce also Assembly, Boulé, Citizenship, Comitia, Council, Kingship, Senate, Taxes.

Grac'ehus, Gaius, 360-362.

Gracchus, Tiberius, 358-360.

Graffiti (grabf-fee'te), at Pompeii, 434.

Grani'cus, battle of the, 231 .

Greece, its geography, $\mathbf{7 5 - 8 0}$; its people, 80-83: its early legends, 83-86 : its early civilization, 91, 92 ; its early political development, 105-107; its expansion by colonization, 107-113; its wars with I'ersia, 143-158. See also Athens, Sparta, Thebes.

Greek influence at Rome, 349 .

Greg'ory I. (the Great), Pope, $509,511$.

Gregoly II., Pope, 509.

Gregory III., Pope, 511.

Gylip'pus, Spartan general, at Syracuse, 184.

Gymnastics as a part of Athenian education, 222 .

Iİi'drian, emperor, 441.

II ā'lys, river in Asia Minor, 63, 64.

Hami 'car Bar'ca, Carthaginian soldier, $320,323$.

Ilamit'ic people, 15: in Egypt. 29.

Hammura'bi, king of Babylonia, 2:23.

Han'nibal, Carthaginian soldier, in second Punic war, 323-3:31; his alliance with Philip V., 243, 333 ; his aid to Antiochus III., and death, 336.

Harmo'dius, Athenian tyrannicide, 125.
Har'mosts of Sparta, 187.

Harus'pices, soothsayers, introduced into Rome from Etruria, 279.

IIas'drubal, brother of Hannibal, in span, 324: at battle of the Metaurus, 328.

Hebrew's, 44-49.

IIel'ena, mother of Constantine, 45!). Helice'a, popular court at Athens, 123.

IIel'las, the land of the Greeks, 75so.

Helle'nēs, the people of Greece, 8083.

Hel'lenism, its influence at Rome, 349.

llellenis'tic culture, its meaning, 247.

IIel'lespont, crossed by Xerxes, 152.

Ile'lots, at Sparta, 116 ; revolt of, 164.

IIelve'tii (-shǐ-î), conquered by Cæsar, 385.

Hephis'tus (Vulcan), 100.

IIe'ra (Juno), 100.

Heracle'a, battle of, 304 .

Her'acles (Ilercules), 85.

IIeracli'da, return of the, 93 .

Heracli'tus, Greek philosopher, 140.

IIeracli'us, Lastern emperor, 504.

Hercula'neum, destroyed, 428.

IIer'mes (Mel'cury), 100.

Herŏd'otus, Greek historlan, 15, 21, 212.

Hĕr'uli, kingdom of the, 489 .

IIe'siod, Greek poet, 138 .

Hes'tia (Vestia), 100.

Hieroglyph'ics, Egrptian, 37.

Hills, of Athens, 199; of Rome, 271.

Hima'tion, Greek dress, 221.

Him'era, battle of, 158 .

Hin'dus in India, 61.

Hippar'ehus, Athenian tyrant, 125.

IIipparchus, Greek astronomer, 256.

Hip'pias, tyrant banished from Athens, 125, 146.

Hissar'lik, site of 'Troy, 88 .

Hit'tites, their kingdom in Asia Minor, 73.

Homer'ic poems, 86, 96-100.

Hono'rius, emperor, 466.

Hor'ace, Roman poet, 416.

IIorä'tius (-shî-us) Cō'clēs, legend of, 269 .

IIouse, Athenian, 220 ; Roman, 430.

IIuns, barbarian tribe, encroachment upon Europe, 465 ; invasion under Attila, 487.

IIvdas'pès, battle of the, 235.

IIYy'sōs, shepherd kings of Egypt, 30. 31

IIymet'tus, mountain in Attica, 79.

Iconoclas'tie controversy, 509.

Il'iad, the. 96.

Illy̆r'ian pirates, reduced by Rome, 322.

Iily̆r'icum, Roman province, 338. 
Impera'tor, title of, 389, 408.

Impérium, its growth, 472 .

Incorporation as a principle of Roman policy, 274, 233, 306, 357.

India, 13 ; early seat of Aryan civilization, 61 ; invaded by Alexanaer. 235.

Indo-European. See Aryan.

Industry and industrial arts, Babylonian, 23; Egyptian. 32; Phœnician, 42; at Athens, 219; at Rome, 435.

Io'na, seat of the Celtic church, 495 .

Io'nia, district of Asia Minor, 80.

Io'nians, 82; their migration to Asia Minor, 95; their philosophy, 140 ; their revolt against Persia, 144 .

Ion'ic style of architecture, 135.

Ip'sus, battle of, 209 .

Iran (e-rahn'), plateau of. 62.

Irē'nē, Eastern empress, $\overline{5} 17$.

Iron crown of the Lombards, 515 .

Ish'tar, Babylonian goddess, 26.

Isoc'ratēs, Greek orator, 214.

Isolation as a feature of Roman policy, 301,306 .

Is'sus, battle of, 231.

Isth'mian games, 133 .

Italian allies, 309,355 ; attempt of Gaius Gracchus to enfrancisise them, 362 ; incorporation by the "Social war," 369.

Italy, geography, 259-263 ; early inhabitants, $233-266$; consolidation under Rome, 299-309 ; administration under Augustus, 411; a prefecture under Constantine, 461; conquered by the Heruli, and by the Ostrogoths, 489 ; recovered by Justinian, 50?: conquered by the Lombards, 502 ; by Charlemagne, 515.

I $u^{\prime}$ licès under Gaius Gracchus, 362.

Jänus, Roman deity, 274.

Ja'son, leader of the Argonauts, 86. Jeru'salem, destroyed by the Romans, 427.

Jew's, 44-49, 253.

Jo'vian, emperor, 465.

Jude'a and its civilization, 44-49.

Jugur'thine war, $364, \mathbf{3 6 5}$.

Ju'lian, emperor', 464.

Jurists, Roman, 449, 475.

Jurors. See I Icasteries, Iudices.

Jus gen'tium, 403, 474.

Justin'ian. Iastern emperor, 499.

Ju'venal, Roman satirist, 447.

Kar'nak, city of Eyypt, 35.

Kas'site's, conquer Babylonia; 23.

Khu'fu (Cheops), Egyptian king, 30.

Kineshlp, in Babyionla. 24: in Firypt, 22 : in Judea, 45, 46; in Assyrla, $5 \pi:$ in l'elsia, fi7; in IIomeric age, 98; at Sparta, 116; at Athens, 120, 121 ; in early Roman state, $267-269,276$.

Ko'ran, Mohammedan Bible, 505.

Laco'nia, district of Greece, 79 ; occupied by the Dorians, 114.

La'dê, battle off, 145 .

Lam'aehus, Athenian general, 183, 184.

La'mian war, 240.

Land at Rome. See Ager publicus, Agrarian laws.

Ianguage and races, 15.

Lat'ins, people of Latium, 263 ; settlement at Rome, 272 ; war with Rome, 301.

Là'tium (-shì-um), 263 ; Roman conquests in, 283 ; part of the Roman domain, 307.

Lau'rium, mines at, 150.

Laws, Babylonian, 24; of Draco, 121 ; of Solon, 122; of Clisthenes, 126. See also Roman law.

Lega'ti, governors of imperial provinces, 412.

Legends as a source of history, 8 ; Greek, 83-86; Roman, 266-269.

Legion, Roman, 310, 311.

Leo III. - (the Isaurian), Eastern emperor, 509.

Leon'idas, Spartan king, 153.

Lep'idus, M. Amilius, consul, revolt of, 376.

Lepidus, M. Emilius, triumvir, 393, 397; defeated by Octavius without a battle, 389 .

Les'bos, island of the Agean, occupied by the Dorians, 95 ; member of the Delian confederacy, 167 ; revolt against Athens, 181.

Leuc'tra, battle at, 192.

Lex curiata de imperio, 277 ; Canuleia, 293; Julia, 396: Plautia Papiria, 396; maiestatis, 423.

Library, of Assurbanipal, 54; at Pergamum, 250; at Alexandria, 255.

Licin'ian legislation, 295.

Lictors, official attendants, 287.

Life, at Sparta, 117, 118; at Athens, 219-223; at Rome, after the conquests, 251 ; under the empire, 432-436.

Literature, Babylonian, 25 ; Egyptian, 37; Hebrew, 48; Persian, 68; early Greek, 137-140; Attic period, 205-215; at Pergamum, 250 ; at Alexandria, 255; at Rome, after the conquests, 350 ; in the later republic, 402 ; under Augustus, 415; during the early empire, 446.

Liv'ia, wife of Augustus, 416.

Ifiv'y, Roman historian. 416.

Lombards, kingdom of, 502; encroachment upon the papacy, 511: defeated by Penin. 513 ; conquered by Charlemagne, 515. 
Long Walls, of Athens, built by Pericles. 165; destroyed by $\mathrm{L}$ y. sander, 156; rebuilt by Conon, 190.

Lu'can, Roman poet, 446.

Luc'ca, conference at. 384 .

Lu'cerés, settlement at Rome, 275.

Lucre'tius (-shĭ-us), Roman poet, 403.

Lucul'lus, Roman general, :379.

Lusita'nians, revolt of the 341 .

Luxury at Rome. 351, 430-432.

Lyce'um at Athens. 200 .

lyycia (lǐsh'î-a), Roman province, 424.

Lycur'gus, Spartan legislator, 115.

Lyd'ia, kingdont of Asia Minor, 63: conquered by I'ersia, 64.

Lyric poetry, Greek, 138.

Lysan'der, spartan admiral and statesman, 168, 187.

Lys'ias, Greek orator, 214.

Lysim'achus, general of Alexander. 239.

Marcedo'nia, rise of. 225: relation to the Greeks, 226: under Philip. 227-230; under Alexander, 230235 ; relation to the Greek federations, 240-243; first war with Rome, 333; second will, 334; third war. 336 ; reduced to a province, 337.

Mace'nas, friend of Augustus. 414.

Magna Grie'cia (-shî-a), 80, 266.

Magne'sia (-shǐ-a), battle of, 39...

Mahomet, or Mohammed. 505-507.

Mam'ertines at Messana. 317 .

Man'etho, Egyptian historian, 255.

Manil'ian law, 379.

Man'iple, military formation, 371.

Man'lius, M., his defense of the Capitol at Rome. 300.

Mantinē'a, walls razed by sparta. 190; rebuilt by Epaminondas 193.

Măr'athon, battle of, 146-148.

Marcel'lus, governor of Sicily, 328.

Marcoman'ni, German tribe, 443.

Mar'cus Aure'lius, emperor, 443.

Mardo'nius, Persian general, 145. 146.

Mā'rius, Gaius, in Jugurthine war, 365 ; in Cimbric war, 366 ; joins the popular party, 366 ; in Social war, 367 : driven from Rome, 371 ; joins Cinna in the "Marian massacres," 371 .

Marius, Gaius (adopted son), 372.

Mars. 267. $27 \pi$.

Massil'ia (Mar'seilles), 344.

Maureta'nia, Roman plovince, 424 .

Maxen'tius (-shĩ-us), rival of Constantine, 459 .

Maxim'ian, associate of Diocletian. 456.

Mayors of the palace, 512.

Mẽdes, 58; their empire, 61-63.
Medn'sa. slain by Perseus, 85.

Meralop'olis, city in Arcadia, 193.

Mer'ara, conquered by the Dorians. 114.

Mem'phis, city of Erypt, 29.

Menan'der, Greek comic writer, 245.

Menela'us, (ireek chleftain, 84, 86 .

Me'nes, king of Waypt, 2!).

Merovin'gians, Frankish dynasty, 512.

Měsopotā'mia, or 'Tigris-luphrates Valley. 21.

Messa'na, town in Sicily. 317.

Messē'ne, city of Messenia, 193.

Messe'nia, district of (ireece, $\mathbf{7 9}$; occupied by the Dorians, 11t; subdued by Sparta, 118.

Metau'rus, battle of the, 328 .

Metel'lus, Cacil'ius, consul, 3it.

Met'ies, resident foreigner's at Athens, 173.

Milétus, eity of Ionia, 95 ; is a center of colonization. 109 ; in the Ionian revolt, 144; destroyed, 145.

Mi'lo, T. Annius, opponent of Clodius, $386,387$.

Milti'adēs, Greek general, 146, 148 .

Mi'nos, mythical king of crete, 85 .

Min'otam, Cretan monster, 85.

Missions, papal, 510.

Mithridātes, ling of Pontus, 371, 372.

Mœ'lis, lake in Egypt, 33.

Mohammed and Iohammedanism, 505-507.

Monarchy. See Kingship.

Monasticism in the West. 510.

Mo'ses, Hebrew lawriver, 45.

Mum'mius, Roman general, 339.

Mun'da, battle of, 387 .

Municipal system of Rome, 308, $390,470$.

Muse'um at Alexandria, 255.

IIutina, war of, 396.

Myc'ale, battle of. 157.

İy cē'nxe, eity of Argolis, 82 ; ruins at, 89.

Mycenæ'an (or Myce'nian), culture, 91.

My'læ, battle of, $\mathbf{3 1 9}$.

Iy'lon, Greek sculptor, 203.

Mýytilē'ne, city of Lesbos, 95 ; revolt of, 181.

Næ'vius, Roman poet, 351.

Names, Roman, abbreviations of, 295.

Narbonen'sis, Roman province, 365.

Nar'sēs, general of Justinian, 501.

Naupac'tus. Peace of: 243.

Navy, Persian. 68: Athenian, 119, 120 ; Roman, 216.

Nax'os, island reduced by Cimon, 163.

Nebuchadnez'zar '(Nebuchadrézzar), Babylonian king, 58 .

Ne'mea, games at, 133 . 
Ne'ro, emperor, 422.

Ner'va, emperor, 437.

New Carthage, city in Spain, 323.

Nicæ'a, council of, 461 .

Nicias (nǐsh'i-as), Athenian statesman, 181: Peace of. 182; in Sicilian expedition, 183.

Nicome'dia, residence of Diocletian, 456.

Nile, river of Egypt, 19 ; the valley, 27.

Nín'e-veh, capital of Assyria, 21, 51 ; its destruction, 63.

Nip'pur, city of Babylonia, 22.

Nobility, at Athens, 120, 121; at Rome, under the republic, 345 ; under the empire, 496: RomanoGermanic, 496. See also Patricians, Optimates.

Nu'ma, king of Rome, 267.

Numan'tia (-shř-a), town in Spain, 341.

Numid'ia, kingdom in Africa, 339.

Octā'vius (Octavī̄inus), nephew and adopted son of Cæsar, appears at Rome, 395; joins the senate. 395 ; in second triumvirate, 396 ; at battle of Philippi, 397 ; war with Antony, 400, 401; emperor Augustus, 407-417.

Odo-a'tcer, king of the Heruli, 489.

Od'yssey, the, 96.

Cd'ipus, mythical king of Thebes, $86,209$.

Enoph'yta, battle at, 166.

Olym'pian games, 131 .

Olym'pus, Mt., 77; abode of the Homeric gods, 99.

Olyn'thiac war, 190.

O'mar, caliph, 505.

Ommi'ads, Mohammedan dynasty, 506.

Optima'tēs aristocratic party at Rome, 358.

Or'acle, at Dodona, 77,81 ; at Delphi, $78,130$.

Orehom'enus, city of Bceotia, 78: seat of Iycenæan culture, 98; battle at, 372 .

Ores'tēs, Roman "patrician," 488, 489.

Or'muzd, Persian deity, 69.

Os'cans, people of Italy, 264.

Os't1acism at Athens, 127.

Os'trogoths, kingdom of, 489.

()'tho, emperor, 426.

Ov'ld, Roman poet, 416.

l'ainting, Egyptian, 36 ; Assyrian, 58: Athenian, 205.

I'alsop'olis, city in Campania, 301, 302.

I'al'atine hill, settled by the Latins, 272.

I'al'la, Roman dress, 432.

l'almy'ra, flestruetion of, 453.

I'anathenge'a, Greek festival, 133.
Pan'theon at Rome, 415.

Papacy, its growth, 508-511; alliance with the Franks, 512-514.

Paphlago'nia, kingdom in Asia Minor, 240.

Papin'ian, Roman jurist, 451.

l'armen'idès, Greek philosopher, 141.

l'arme'nio, general of Alexander, .335.

I'arnas'sus, Mt., in Phocis, 78.

Parrhä'sius (-shĭ-us), Greek painter, 205.

Par'thenon at Athens, 200.

Par'thia, kingdom of Asia, invaded by Crassus, 386 .

Parties, at Athens, 176; at Rome. See Patricians, Plebeians, optimates, Populares.

Patricians, Roman, 279 ; relation to the plebeians, 288 et seq.; to the new nobility, 345 .

Paul'lus, Roman jurist, 452, 475.

Paullus, Amilius, consul (father), at the battle of Cannæ, 326 .

Paullus, Aimilius (son), at the battie of Iydna, 336.

Pausín'nias, Spartan general, at the battle of Platæa, 156: frees Agean cities, 161; his treachery and death, 162 and note.

Pelas'gians, early people of Greece, 80.

Pelop'idas, Theban patriot, 191, 193.

Peloponne'sian League, 118.

Peloponnesian war, 178-187.

Peloponne'sus, 79; occupied by the Dorians, 93.

Pentap'olis in Italy, part of the papal territory, 514.

Pèp'in (Pippin), king of the Franks, 512.

Perdic'cas, general of Alexander, 237.

Per'gamum, kingdom of, 240; a center of Hellenistic culture, 248 ; bequeathed to Rome, 343 .

Pěr'iclès, Greek statesman, his political policy, 164-171; his war policy, 179; his death, 181; his oratory, 213.

Perice'ci at Sparta, 116.

I'ersecutions. See Christians.

'ersep'olis, city of Persia, 68, 69 ; captured by Alexander, 235.

Per'seūs, king of Macedonia, 336.

Perseus, slayer of Medusa, 85 .

I'er'sia (-shî-a), ancient empire, 6371 ; wars with (irece, 143 et seq.; conquered by Alexander, 234, 235; new monarchy of the Sassanidre, 452, 485: conquered by the Saracens, 506 .

Phälanx, Greek, 176; Macedonian, 227 : early Roman, 311.

Phar'nacès, king of Pontus, defeated by Ciesar, 388.

Pharsā'lus, battle of, 388 . 
Phid'ias, Greek sculptor and architeet, 203.

Phi'don, ruler of Argos, 114.

Phil'ip 11., king of Macedonia, 227. 230.

Philip $V$., his alliance with Hannibal, 243,328 ; at war with Rome, 333-336.

Philip'pi, battie of, 397 .

Philip'pies, of Demosthenes, 228; of Cicero, 396.

Philoc'rates, leace of, 228, 229.

Philosophy, early Greek, 140, 141 ; in Attic period, 215-218; postAristotelian, 246; at Rome, 350 , 448.

Pho'cis, district of Greece, $7 \mathrm{~S}$; in second sacred war, 228.

Phoenī'cia (-shǐ-a), and its civilization, 41-44.

Phra'try, Greek brotherhood, 103.

Phryn'iehus, (ireek tragedian, 207.

I'in'dar, Greek lyrist, 1.s.

Pira'us, harbor of Athens, 150, 160, 165.

Pirates, Illyrian, 322 ; Cilician, 379.

Pisis'tratus, tyrant at Atlens, 124.

Placid'ía, ruler at Rome, 488 .

Platæ'a, city of Bootia, battle at, 156 ; in Peloponnesian war, 1s1, 190.

PIā'to, Greek philosopher, 217.

Plau'tus, Roman dramatist, 351.

Plebe'ians at Rome, early status, 279: struggle for economic rights, 285-291; struggle for equal law, 291-293; admitted to the consulship, 296.

Plin'y the Elder, Roman writer, 447.

Pliny the Younger, 447.

Pnyx, hill of Athens, 199.

Pollen'tia (-sh-a), battle of, 487 .

Polyb'ius, Greek historian, 336.

Polygno'tus, Treek painter, 205.

Pompe'ii $(-y \bar{i})$, destroyed, 428 ; excavations at, 430 ; life at, 434 .

Pompe'ius, Gnxus (Pompey the Great), joins Sulla, 372: defeats Lepidus, 376 ; defeats Sertorius, 377; becomes consul, 378; victories in the East, 379,380 ; member of the first triumvirate, 382 ; becomes sole consul, 386 ; war with Cæesar, 388.

Pompeius, Sextus, 393 ; his fleet destroyed by Octavius. 399.

Pon'tifex Max'imus, 278.

l'on'tus, kingdom in Asia Minor, 369.

Popula'rés, democratic party at Rome, 358.

Porsen'na (Por'sena), Etruscan prince, 269.

Poseí'don (Neptune), 100 ; wọrship on the Acropolis at Athens, 202.

Præfects, magistrates under Augustus, 410 .
Pre'tor peregri'nus, 403.

l'rato'rian guard, established by Augustus, 409, 410; stationed at liome by liberius, 424; reorganized by Septimius Severus, 450 ; abolished by constantine, 462 .

Praxit'eles, Greek sculptor, 204.

Pre'fecture, a subject city, 308; a territorial division of the later empite, 461.

Proco'pins, loman historian, 499.

P'ropertius (-shî-us), Roman poet, 416.

I'ropyla'a, entrance to the Acropolis, 200.

Proseriptions, of Sulla, 373 ; of the second triumvirate, 397.

Provinces, Roman, in l'unic wars, 321 , 322: after the conquests, 346-348; under Augustus, 412; under the Jullan line, 424; under the Antonines, 445; under Constantine, 461; review of the provincial system, 471.

Psammet'iehus, Esyptian king, 31.

Ptolemies, kingdom of the, 239 .

ptolemy, Greek astronomer, 256.

P'ublic lind at Rome, 289. Sce also Agrarian laws.

Publil'ius Phi'lo, first proconsul, 302.

Pu'nic wars. Sce Carthage,

lyana, battle of, 336 .

Pyramids, Egyptian, 30, 35.

Pyr'rhus, Greek general, in war with Rome, 304-306.

Pythag'oras, Greek philosopher, 141.

Quā'di, German tribe, 443.

Quxs'tors, first elected, 286.

Quintilian, Roman writer, 447 .

Quir'inal hill, settled by the Sabines, 273.

Quiri'nus, the deified Romulus, 277.

Race characteristics, 14.

Radagĩ $i$ 'sus, barbarian chief, 487.

Rame'ses (Ram'ses) II., Egyptian king, 31.

Ram'nes, Latin settlers at Rome, 272.

Raven'na, exarchate of, 501; conquered by the Lombards, 513 ; conquered by Pepin and granted to the l'ope. 514.

Reg'ulus, Roman general, 319 .

Religion, Babylonian, 25; Egyptian, 33: I'honician, 41; llebrew, 47; Persian, 69; Homeric, 99; an element of Greek culture, 130134; early Roman, 277 ; after the conquests, 349 ; decay during the later republic, 40\%: attempts at reform by Augustus, 416. See also Christianity, Church.

Re'mus, brother of Romulus, 267.

Rhōdes, republic of, 240 ; its eulture, 250. 
Ric'imer, the "king-maker," 488. Roads, lersian, 67: Roman, 312. Roman law, coditication of the XII. Tibles, 292; administration in the provinces, 345 ; improvement under the republic, 402, 403; under the empire. 449; codified by Justinian, 502; review of its character, 473 .

Romano-Germanic society, 495 .

Rome, the city, its traditional foundation, 266 ; its probable origin, $271-275$; its growth under the later kings, 282 ; destroyed by the Gauls, 300 ; occupied by Sulla, 370 ; administration "under Augustus, 410 ; salked by the Visigoths, 487; pillaged by the Vandals, 488 ; seat of the papacy, 508 .

Rom'ulus, legendary founder of Rome, $26 \pi$.

Romulus Augus'tulus, emperor, 489 .

Roncesval'les, battle near, 515 .

Roset'ta Stone, the key to the Exyptian hieroglyphics, 37.

Ru'bicon, crossed by C'xsar, 388 .

Sabel'lians, people of Italy. 264 .

Siibines, branch of the Sabellians, 264; union with the Romans, 273.

Sacred war, first, 131 ; second, 228.

Sagun'tum, city of Spain, captured by Hennibal, 324.

Saint Ephi'a, church of, 499.

Sa'is, city of Equpt, 31.

Salka'rah, village of Egypt, 30 .

Sal'amis, Island of Greece, 79 ; battle of, 154.

Sal'lust, Roman historian, 403.

Salo'na, seat of Diocletian's palace, 458.

Sal'vius Juliā'nus, Roman jurist, 449 .

Sam'nite wais, 301-304.

Sa'mos, island of the Trean, settled by the Ionians, 95 ; ally of Athens, 16 if.

Silppho (săf'o), Greek poetess, 139.

saracens, or Arabians, 505-507.

sardin'ia, reduced to a plovince. 321.

Sar'lis, capital of Lydia, captured hy Cruss, 65; burned by the Ionians, 145 .

Sar'gon I., liabylontan king, 22.

Siargon II., Assyilan king, 33, 47.

sassan'ldir, I'pl'slan dynasty, 452.

Sa'tra!)s, of Assyrla, 55; of Persia, 67.

Saturningus, tribune assoclated with Milius, : $; f ;$.

saul, IIplorew king, 45.

Saxons, conquered ly Charlemagne, 517.

sublirmann, Gierman archrologist, $4.8 !$.

srience, Babylonian, 27; Egyptian,
35: at Pergamum, 250; at Alexandria, 256 .

Scin'io, Lucius, defeats Antiochus at Magnesia, 335.

Scipio, P. Cornelius (father), his (ampaigns in Cisalpine Gaul and Spain, 324, 325.

Sclpio, P. Cornelius $\Delta$ fricanus (son), the hero of the second Punic war, 329,331 ; at the battle of Magnesia. 335.

Scipio Fmilia'nus, the conqueror of Carthage and Numantia, $340,341$.

Scipio Nasi'ca, senatorial leader against Tiberius Gracchus, 360.

Sculpture, Egyptian, 36 ; Assyrian, 57 ; early Greek, 136 ; Attic period, 202; at I'ergamum, 249 ; at Rhodes, 250 .

Scyth'ians, barbarian tribe, $63,65$. Secession of the plebeians, nrst, 289 ; second, 292 .

Sejā'nus, adviser of Tiberius, 420 . Seleu'cida, kingdom of the, 239 ; its civilization, 252 .

Sella'sia (-shǐ-a), battle of, 242.

Semit'ic peoples, 15,$16 ;$ in the Tigris-Euphrates valley, 21; in Syria, 41.

Sempro'nius, Tiberius, consul, in second l'unic war, $324,325$.

Senate, Roman, under the kings, $27 \tau$; in early republic, 287 ; growing power after the conquests. 345 ; weakened by Gaius Gracchus, 361 ; restored after his death, 364 ; under Sulla, 374; under Cresar, 390; under Augustus, 408. Sen'eca, Roman philosopher, 422 , 446.

Sennaeh'erib, Assyrian king, 53.

Sentīnum, battle of, 303 .

Sep'tuagint, Greek 'version of the Jewish scriptures, 256.

Serto'rius, Q., colleague of Carbo. 372 ; his revolution in Spain, 377.

Servile war in Sicily, 341 .

Ser'vius Tul'lius, king of Rome, 268.

$S^{\prime}$ ti I., Egyptian king, 31 .

Sevē'rus, Alexander, emperor, 451.

Severus, Septimius, 450.

Shalmanē'ser I., Assyrian king, 51.

Shalmaneser II., 52.

Sicily, island, a part of Hellas, so ; sent of Greek colonies, 113 ; Carthaginian attack upon, 157: Atlenian expedition to, 183, 184; supremacy of Srracuse in, 194, 195: campaign of Pyrrhus in, 305 ; seat of the tirst Punic war, 317 ; the tirst Roman province, 321 .

Slcyon (sish'í-on), city of the Peloponnesus, 107.

Sl'don, city of iphonicia, 42.

Simon'ides, Greek lyric poet, 158.

Sip'par, clty of Baliylonia, 22.

Slavery, Jewish, 47; Assyrian, 56 ; 
Greek, 172-220 ; Roman, 341, 355, 430.

Sociai customs, see Life.

Social war, Athenian, 228 ; Roman, 367.

Soc'ratēs, Greek philosopher, 216.

Soissons (swahs-sōx'), battle of, 493.

Sol'omon, Hebrew klng, 46.

So'lon, Athenian lawgiver, 122.

Sophists at Athens. 216 .

Soph'oclēs, Greek tragedian, 208.

Spain. Carthaginian power in. 323 ; the two Roman provinces, 331 ; revolt of the Celtiberians and Lusitanians, 340 ; settled by the Suevi and Visigoths, 492: conquered by the Saracens, 506 ; invaded by Charlemagne, 515 .

Spar'ta, city of Laconia, founded by the Dorlans, 114; classes of the people, 115; its government, 116 ; education and discipline. 117 ; head of the Peloponnesian League, 118: its position in Greece, 119; hostllity to Athens, 164 ; in Peloponnesian war, 178186 ; supremacy in Greece, 187190 ; conflict with the Achxan league, 241.

Spar'tacus, Roman gladiator, 377.

Sphactē'ria, 1sland, captured by Cleon, 182.

Stesieh'orus, Greek lyric poet, 139.

Stil'ieho, Vandal general in the service of Honorius, 487.

Sto'ic philosophy, 246; at Rome, $350,448,475$.

sto'la, Roman dress, 432.

Stra-te'gi.. Athenian generals, 127, 174,175 .

Sueto'nius, Roman biographer, 447.

Sué'vi, kingdom of, 492 .

Suffragium, 294.

Sul'la, L. Cornelius, Roman general and statesman, in Social war, 368: given command against Mithridates, 369 ; marched upon Rome, 370 ; in the first Mithridatic war, 371 ; war with the Marian party, 372; his proserintions, $373 ;$ his constitution, 373 , 374.

Sulpician (sul-pǐsh'l-an) laws, 370.

Sy-ä'grius, Roman governor of Gaul, 488, 493.

Sympo'sium, Greek, 223.

Syr'acuise, Dorian colony in Sicily, resists the Carthaginlans, in the Persian war's, 157, 158; besleged by the Athenians in the Peloponnesian war, 183, 184: its supremacy in western Hellas, 194. 195 ; in the first Punic war, 317, 318 ; in the second Punic war. 328 ; joined to the province of Sicily, 331 .

Syr'ia, early meeting ground be- tween the Babylonians and Egyptlans, 20 , 21 ; oceupled by the Pnœenicians and Hebrews, 41; conquered by the Assyrians, 53, 54 ; by the Perslans, 65 ; by Alexander, 235 ; kingdom of the Seleucidx, 239 ; war with Rome, 335 ; reduced to a Roman province, 379 .

Tac'itus, emperor, 453.

'Tacitus, Roman historian, 447.

Tan'agra, battle of, 166 .

Ta'nis, city of Fgypt, 30, 31 .

Taren'tum, Greek colony in Italy, war with Rome, 304; surrendered to Hannibal, 327 ; recaptured by Rome, 328.

Tar'quins, kings of Rome, 268.

Taxes, Roman, under the republic, 348, 358; under Cæsar, 390; under Augustus, 413.

Tel-el-Amarna tablets, 31 note.

Tel'lo, city of Babylonia, 22 .

Tem'pe, vale in 'Thessaly, 77 ; occupied by Xerxes, 153.

Temples, Babylonian, 26 : Egyptlan, 35: Greek, 134, 200 ; Roman, 282, 350, 404, 414.

Ten Thousand, march of the. 188.

Ter'ence. Roman dramatist, 351 .

Terentil'ius Irarsa, tribune, 291.

'Teu'toberg Forest. battle at. 413.

'Teu'tonēs. See Cimbric war.

Thā'lēs, Greek philc, opher, 140.

Thap'sus, battle of, 389 .

Tha'sos, island of the Agean, revolt of, 163 .

Theater, Greek, 205; Roman, 433.

Thēbes, city of Bœotia, 78; seized by Sparta, 190; liberated by Pelopidas. 191; supremacy of, 192; decline, 193; destroyed by Alexinder, 231.

Thebes, city of Egypt, 30.

'Themis'tocies, Greek statesman, his naval programme, 149 ; at the Congress of Corinth, 150 ; at the battle of Salamis, 154 ; rebuilds Athens, 160 ; character and exile, 161

Theoc'ritus, Greek pastoral poet, 225.

Theodo'ra, wife of Justinian, 449.

The'odore of Tarsus, 495 .

Theŏd'oric, king of the Ostrogoths, 489.

Theodo'sius (-shǐ-us) I., emperor, 465.

Thermop'ylæ, battle of, 153, 154.

These'tum, temple at Athens, 199. The'señs. mythical king of Athens, $85,120$.

Thesmoth'eto at Athens, 121.

Thes'saly, district of Greece, 77 ; early seat of the Dorians, 93 .

The'tes at Athens, 123.

Thirty Tyrants at Athens, 187. 
Thirty Years' Truce, 171.

Thoth'mes III., Egyptian king, 31. Thrace, Roman province, $4: 24$.

Thrasybü'lus, Athenian patriot, 187.

Thucyd'idess, Greek historian, 212 .

Tibērius, emperor, 420.

Tibul'lus, Roman poet, 416.

Tig'lath-Pilē'ser I., Assyrian king, 52.

Tiglath-Pileser III., 53.

Ti'gris-Euphra'tēs valley, 21.

Timo'leon the Liberator, 195.

Ti'ryns, city of Argolis, 82; citadel of, 89.

Tissapher'nēs, Persian governor of Asia Minor, 189.

Tit'i-ēs, Sabine settlers at Rome, 273.

Ti'tus, emperor, 427.

To'ga, Roman dress, 432.

Tours (toor), battle of, 506 .

Tragedy, 206-210.

Trā'jan, emperor, 437.

Trasumē'nus, Lake, battle of, 326.

Treason, Roman law under Tiberius, 423.

Tribes, in the Greek city state, 103 : the four Ionian, 120, 123: the ten Attic of Clisthenes (local), 126: the Italic, 261: in the Roman city state, 276 ; the Servian (local), 280; relation to the ager Romanus, 307.

Tribo'nian, Roman jurist, 502.

Tri'bunes of the people, 290, 374, 378.

Trit'tys, Attic county, 126.

Trlum'virate, first, 382 ; second, 396.

Tro'jan war, 86.

Troy, clty of Asia Minor, 86 ; excavations at, 88-100.

Tul'lus Hostil'ius, king of Rome, 268.

Twelve Tables, Roman code, 292.

Tyrants in Greece, 106.

Tỹre, city of Phœuicia, 42 ; besieged by Alexander, 231.

Tyrtæ'us, Greek lyric poet, 138.

Cl'filas. Arian Christian, apostle of the Goths, 485.

v'plan, Roman jurist, 475.

Um'brians, people of Italy, 265.
Ur, city of Babylonia, 22, 45.

U'tica, city of Africa, 340 .

Vadimo'nis, Lake, battle of, 302.

Vì'lens, emperor, 465.

Valentin'ian, emperor, 465.

Valerio-Horatian laws, 293.

Valē'rius Poplic'ola, laws of, 28:

Van'dals, German tribe, settled in Africa, 488; conquered by Justinian, 499, 500.

Vaphïo cups, $90,91$.

Văr'ro, Teren'tius, consul, 326.

Và'rus, Roman general, 413.

Ve'li $(-y \overline{1})$, city of Etruria, slege of, 300.

Vercel'læ, battle of, 366 .

Vercinget'orix, Gallic chlef, 386 .

Ver'gil, Roman poet, 415.

Ver'rēs, impeachment of, 382 .

Vespa'sian (-zhĭ-an), emperor, 426.

Vestal virgins, 278 .

Vesu'vius, Mt., eruption of, 428.

Village community, German, 484 .

Vis'igoths, invasion under Alaric, 486: kingdom in Spain, 492 .

Vitel'lius, emperor, 427 .

Vol'scians, Italic tribe, 263 ; wars with Rome, 299,300 .

Walls, at Athens, of Themistocles, 160 ; of Pericles, 165 ; at Rome, of Servius, 283 ; of Aurelian, 453. See also Long Walls.

Women in Homeric times, 100 ; in time of Pericles, 321.

Writing, Babylonlan, 25 ; Egyptian, 37; Phœulcian, 43, 44.

Xanthip'pus (zan-), Spartan general, 319.

Xenoph'anēs (ze-) Greek philosopher, 141.

Xen'ophon (zen'-), Greek historian, $189,213$.

Xerxes (zerk'sēz), Persian king, invasions of Greece, 151-155.

Zā'ma, battie of, 331 .

Ze'la, battle of, 388 .

Ze'no. Greek philosopher, 246.

Zeno'bia, queen of Palmyra, 453.

Zeñs (Jupiter), 99.

Zeñx'1s, Greek painter, 205.

Zoro-as'ter, Perslan reformer, 69. 


$$
\begin{aligned}
& 2 \vdots 0 \\
& 247 \\
& -11 \\
& 31 \% \\
& 32 \\
& 290
\end{aligned}
$$






\section{UNIVERSITY OF CALIFORNIA LIBRARY BERKELEY}

Return to desk from which borrowed. This book is DUE on the last date stamped below.

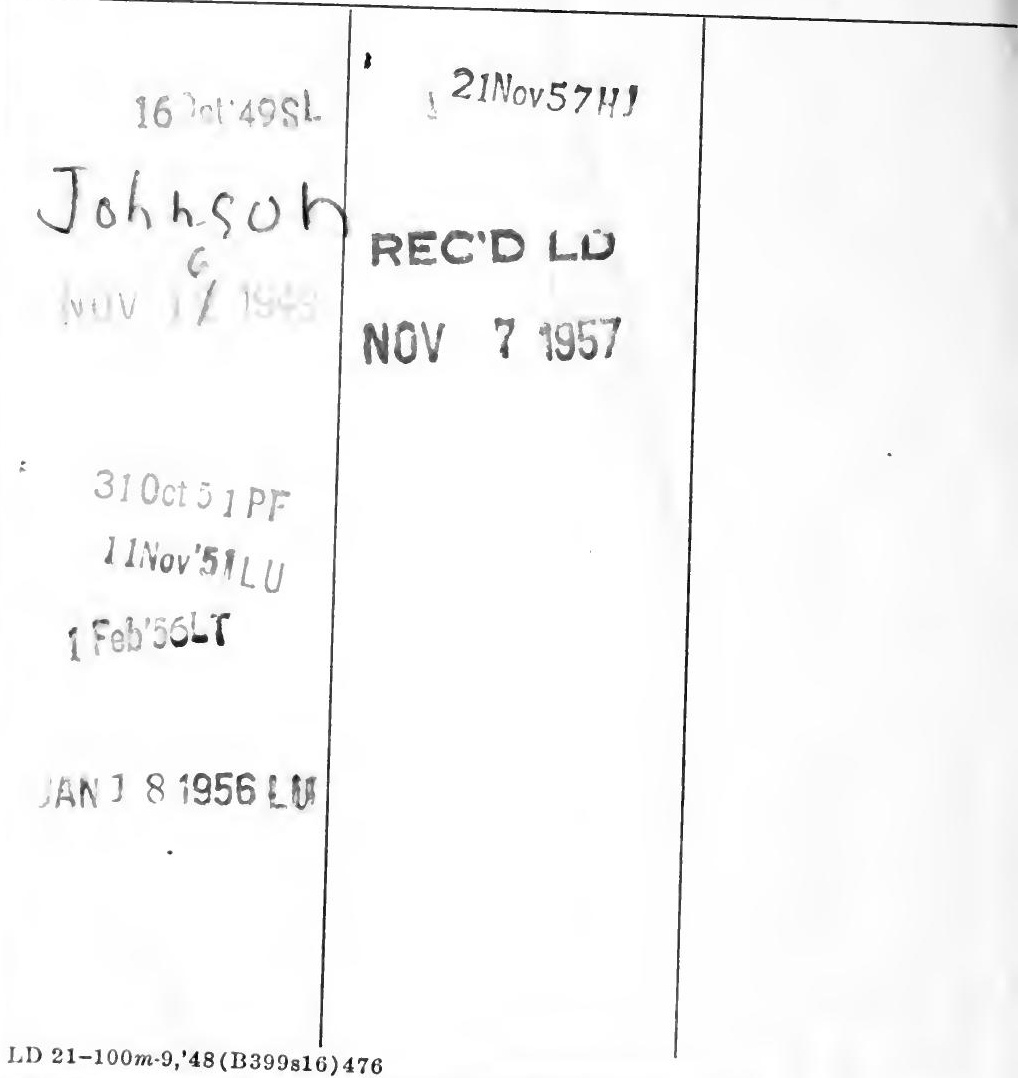




\section{YB 21560}

THE UNIVERSITY OF CALIFORNIA LIBRARY 

. 